UNIVERSIDADE DE SÃO PAULO

FACULDADE DE EDUCAÇÃ̃o

JOSÉ MOACIR DE AQUINO

\title{
EDUCAÇÃO, EMANCIPAÇÃO E CORRESPONSABILIDADE EM KARL OTTO APEL
}

São Paulo 


\section{JOSÉ MOACIR DE AQUINO}

\section{EDUCAÇÃO, EMANCIPAÇÃO E CORRESPONSABILIDADE EM KARL OTTO APEL}

Tese apresentada à Faculdade de Educação da Universidade de São Paulo para obtenção do título de Doutor em Educação.

Área de concentração: Linguagem e Educação.

Orientador: Prof. Dr. Nilson José Machado

\section{São Paulo}


AUTORIZO A REPRODUÇÃO E DIVULGAÇÃO TOTAL OU PARCIAL DESTE TRABALHO, POR QUALQUER MEIO CONVENCIONAL OU ELETRÔNICO, PARA FINS DE ESTUDO E PESQUISA, DESDE QUE CITADA A FONTE.

Catalogação na Publicação

Serviço de Biblioteca e Documentação

Faculdade de Educação da Universidade de São Paulo

37.01

A657e
Aquino, José Moacir de

Educação, emancipação e corresponsabilidade em Karl Otto Apel / José Moacir de Aquino; orientação Nilson José Machado. São Paulo: s. n., 2017. $378 \mathrm{p}$.

Tese (Doutorado - Programa de Pós-Graduação em Educação. Área de Concentração: Linguagem e Educação) - Faculdade de Educação da Universidade de São Paulo.

1. Linguagem 2. Emancipação 3. Corresponsabilidade 4. Semiótica transcendental 5. Ética do discurso I. Machado, Nilson José, orient. 
Nome: AQUINO, José Moacir de

Título: Educação, emancipação e corresponsabilidade em Karl Otto Apel

Tese apresentada à Faculdade de Educação da Universidade de São Paulo para obtenção do título de Doutor em Educação.

Aprovado em:

Banca Examinadora

Prof. Dr. Instituição:

Julgamento: Assinatura:

Prof. Dr. Instituição:

Julgamento: Assinatura:

Prof. Dr. Instituição:

Julgamento: Assinatura:

Prof. Dr. Instituição:

Julgamento: Assinatura:

Prof. Dr. Instituição:

Julgamento: Assinatura: 
Aos meus filhos, Nathan e Matheus.

Aos meus pais, Raimundo (in memoriam) e Maria. 


\section{AGRADECIMENTOS}

Este texto é uma chegada, fruto de muitas idas e vindas, em grande medida, só possível graças à generosidade e apoio de uma multidão de "cúmplices" e ao suporte de

algumas instituições. Particularmente, a todas as pessoas que colaboraram direta e indiretamente ao longo deste processo de estudos e formação, minha afeição e gratidão.

Por justiça, agradeço especialmente:

Aos meus familiares mais próximos: Raimundo, Maria, Claudionor, Valdeci, Lúcia, Aparecida, André, Socorro, Bia, Yasmim, Anna, Lara, Marcelo, Antônio, Nathan e Matheus.

À UFMS pela oportunidade de capacitação. Aos docentes da UFMS Antônio Hilário, Ricardo Melo e Wilson Gonçalves, que foram determinantes desde o início nesta trajetória. Também aos docentes José Paulo Gutierrez, Ana Paula Amaral, Weney Freitas, Luis Felipe e José Carlos pelo apoio inestimável.

Aos amigos Antônio Wardison, Junior Ribeiro e Alberto Marques pela acolhida, companheirismo e amizade verdadeira.

Às companheiras da UCDB Celeida, Gisela, Laurinda, Elaine e Regina, pelo apoio constante.

À comunidade da Paróquia São Domingos Sávio, em nome do Pe. José Carlos Spinola e Carlos Gouveia, pela acolhida e pelo testemunho de responsabilidade solidária.

Aos amigos José Ferreira Filho e Luís André Correia, agradeço imensamente a ajuda na finalização deste texto.

À Ana Paula Yamada, Josemar, Lorene, Felipe, Fran, Carlos Damasceno e Bárbara, pela companhia constante.

Ao Prof. Dr. José Sérgio, pelos recortes substanciais e pela interlocução virtual em minhas caminhadas.

Ao Prof. Dr. Nilson José Machado, minha gratidão pelo gesto inefável de acolhida, orientação e exemplo de vida. A sua contribuição em relação à parturição deste texto é de natureza transcendental.

Aos docentes que generosamente aceitaram compor a banca de avaliação deste trabalho. 
“Já que 'um único alguém e uma única vez' não se pode seguir a uma regra (...), estamos condenados $a$ priori a um acordo intersubjetivo" (Karl Otto Apel). 
AQUINO, José Moacir de. Educação, emancipação e corresponsabilidade em Karl Otto Apel. 2017. 317 p. Tese (Doutorado - Programa de Pós-Graduação em Educação. Área de Concentração: Linguagem e Educação) - Faculdade de Educação, Universidade de São Paulo, São Paulo, 2017.

Este trabalho aborda, por meio de uma revisão bibliográfica analítico-reflexiva, a possível contribuição da filosofia de Karl Otto Apel no sentido de fundamentar no a priori da comunidade de comunicação para uma perspectiva de educação intencionada na emancipação e na corresponsabilidade. Estruturalmente, este trabalho abrange três partes. Na primeira parte, procura-se compreender a problemática da transformação da filosofia apeliana como abertura para repensar a fundamentação filosófica da educação. São considerados aspectos referentes à retranscendentalização da filosofia no marco do paradigma da linguagem, à recuperação da dimensão pragmática da linguagem na semiótica transcendental de Apel e à pretensão de superação do solipsismo metódico pressuposto na concepção de ciência unitária. Em razão da aparente invisibilidade da questão da educação na filosofia de Apel, inclusive em suas publicações relativas ao campo ético-político, a hipótese guia dessa primeira parte é a suspeita de um déficit de abordagem da filosofia de Apel em relação ao campo da pedagogia e da filosofia da educação. $O$ foco da segunda parte é a especulação acerca de possíveis pontos de desdobramentos da semiótica transcendental, a concepção filosófica original como paradigma de prima philosophia no que tange à razão teorética, para o âmbito da educação. Para tanto, explicita-se o itinerário analítico-crítico de Apel em redor do linguistichermeneutic-pragmatic turn e, em seguida, como contribuição especulativa depreendida da semiótica transcendental, tematiza-se sobre a educação no sentido de uma formação que visa à elevação da humanidade e à autoria do sujeito. A terceira parte trata do entrelaçamento colateral dos conceitos de emancipação, apresentado com a pretensão de esboçar um novo viés da Teoria Crítica ligada à Escola de Frankfurt, e de corresponsabilidade, tematizado no âmbito da ética do discurso de Apel, com a compreensão geral da educação como ciência social da mediação entre teoria e práxis em vista do interesse cognitivo emancipador e da responsabilidade solidária. Com base no a priori da comunidade de comunicação, pretende-se demonstrar que a filosofia de Apel representa uma contribuição relevante para a reflexão de natureza filosófica em meio às abordagens das ciências da educação, à medida que ela fornece a pressuposição última racional dos fundamentos do campo da educação. Como elemento original desse trabalho, defende-se a ideia de que, de modo suplementar à filosofia prática de Apel, a esfera da educação possa figurar, transversalmente aos subsistemas coercitivos da responsabilidade ligados à política, ao direito e à economia, como uma mediação institucional contraestratégica responsável pela formação para a emancipação e corresponsabilidade histórica do homem pelo mundo. A educação pode, então, constituir-se, no sentido da formação que eleva à humanidade e desenvolve o primado judicativo do sujeito com base nos mínimos éticos universais implícitos no jogo hermenêutico-pragmático transcendental de linguagem. Tal via é fundamental para reduzir paulatinamente a diferença radical entre as condições ideais de uma comunidade ilimitada de comunicação e as condições históricas e contingentes da situação da comunidade real de comunicação. Enquanto mediação contraestratégica, a educação pode contribuir na criação das condições sociais suficientes para possibilitar a efetivação da resolução consensual-argumentativa dos problemas teóricos e práticos na sociedade.

Palavras-chave: Linguagem. Educação. Corresponsabilidade. Emancipação. Semiótica transcendental. Ética do discurso. Pragmática. Hermenêutica. 
AQUINO, José Moacir de. Education, emancipation e corresponsability in Karl Otto Apel. 2017. 317 p. Thesis (Doutorado - Programa de Pós-Graduação em Educação. Área de Concentração: Linguagem e Educação) - Faculdade de Educação, Universidade de São Paulo, São Paulo, 2017.

This work addresses, through an analytical-reflexive bibliographical revision, the possible contribution of Karl Otto Apel's philosophy with the intent of substantiating in the a priori of the communication community a purposeful education perspective in emancipation and corresponsability. Structurally, this work encompasses three parts. In the first part, we seek to comprehend the Apelian philosophy transformation issue as an opening to rethink the philosophical basis of education. We will consider aspects referred to the retranscendentalization of philosophy on what is referenced to the languages paradigm, the recuperation of the pragmatic dimension of language in the transcendental-semiotic of Apel, and to the desire of the surpassing of the methodic solipsism in the conception of unitary science. Because of the apparent invisibility of education in Apel's philosophy, even in his publications in the ethical-political field, the guide-hypothesis is the idea of a deficit in the approach of Apel's philosophy relating to the field of pedagogy and education philosophy. The second part's focus concerns the speculation on possible unfolding points in transcendental-semiotics, the original philosophical concept as a paradigm of prima philosophia in terms of theoretical reason in the context of education. For that, we clarify Apel's analytical-critical itinerary around the linguistic-hermeneutic-pragmatic turn and, following that, as speculative contribution taken from transcendental-semiotics, we argue about education in the sense of a formation that seeks to elevate mankind and the subject's authorship. The third part is about the collateral interweaving of the emancipation concepts, presented with the intent of outlining a new view of Critical Theory, connected to the Frankfurt School, and of corresponsability, in the context of Apel's discourse ethics, with the general comprehension of education as a social science of theory and practice mediation, considering the cognitive emancipatory interest and of solidary responsibility. Supported on the communication community a priori, we intend to demonstrate that Apel's philosophy represents a relevant contribution to the philosophical reflection in the midst of educational sciences' approaches, as it provides the final reasoning of the educational science field. As an unique element in this work, we defend the idea that, in addition to Apel's practical philosophy, the educational sphere can appear transversally to the coercive responsibility subsystems, connected to politics, law and economy, as an anti-strategic institutional mediation that results in the formation towards emancipation and historical corresponsability of men throughout the world. Therefore education can be constituted in the sense of formation that elevates to humanity and develops the priority to form a critical opinion of the subjects with a basis on the basic universal ethics implicit in the hermeneutic-pragmatic transcendental game of language. This view is fundamental to slowly reduce the radical differences between an unlimited communication community's ideal conditions and the eventual situations in a real communication community. As an anti-strategic mediation, education can contribute in creating enough social conditions to make possible the establishing of the consensualargumentative resolution of the theoretical and practical problems in society.

Keywords: Language. Education. Corresponsability. Emancipation. Transcendental semiotics. Ethics of discourse. Pragmatism. Hermeneutics. 


\section{SUMÁRIO}

INTRODUÇÃO

PARTE I - A PROBLEMÁTICA DA TRANSFORMAÇÃO DA FILOSOFIA PELA SEMIÓTICA TRANSCENDENTAL COMO ABERTURA PARA REPENSAR A FUNDAMENTAÇÃO FILOSÓFICA DA EDUCAÇÃO ....

1. A problemática da transformação da filosofia pela semiótica transcendental como abertura para repensar a fundamentação filosófica da educação

1.1 A retranscendentalização da filosofia no marco do paradigma da linguagem 16

1.2 A recuperação e reconstrução da dimensão pragmática da linguagem na pragmática transcendental

1.3 A pretensão de superação do solipsismo metódico pressuposto na concepção de ciência unitária

2 A pergunta pela contribuição da semiótica transcendental de Apel à educação: a aparente invisibilidade da questão da educação em Apel

2.1 A suspeita do déficit da educação na filosofia de Apel ............................................ 41

2.2 A transição prenunciada da filosofia de Apel à educação ........................................ 51

PARTE II - SEMIÓTICA TRANSCENDENTAL E EDUCAÇÃO.................................. 77

$3 \mathrm{O}$ giro hermenêutico como contraponto à redução cientificista do conhecimento e a perspectiva de uma hermenêutica normativa ............................................................ 79

3.1 A fenomenologia hermenêutica como contraponto à redução cientificista e ao solipsismo metódico.

3.2 A crítica de Apel à hermenêutica de Heidegger e Gadamer como contraponto para uma hermenêutica normativa

$4 \mathrm{O}$ giro pragmático-semiótico como contraponto à redução instrumental-designativa da concepção de linguagem

4.1 Da reviravolta linguística ("linguistic turn") da filosofia analítica da linguagem para o giro pragmático ("pragmatic turn")

4.2 Transformação semiótica da filosofia transcendental por Peirce .............................. 134

4.2.1 A dimensão transcendental da moderna logic of science .................................... 136

4.2.2 A transformação semiótica de Kant por Peirce ................................................. 140

4.2.3 A relevância da semiótica de Peirce para a transformação da filosofia de Apel.... 155

5 A semiótica transcendental em Apel como paradigma de prima philosophia do coentendimento e da ação ética ............................................................................ 160

5.1 A semiótica transcendental em Apel como paradigma de prima philosophia............ 160 
5.2 A estrutura performativo-proposicional do discurso argumentativo como fundamentação filosófica

$5.3 \mathrm{O}$ enfoque dialético da semiótica transcendental como mediação da razão teórica e da ação ética.

6 Possíveis desdobramentos especulativos para pensar a educação a partir da semiótica transcendental.

6.1 Educação como formação à elevação da humanidade.

6.2 Educação como processo de autoria do sujeito: o primado judicativo do sujeito e a dimensão transpositiva do compreender na formação

6.2.1 A importância da capacidade de pensar na formação: os exemplos de Sócrates,

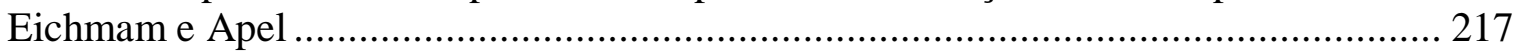

6.2.2 O lugar do sujeito no comunitarismo transcendental: formação da autonomia ..... 233

6.2.3 Suspensão parcial e temporária do pressuposto da simetria da competência comunicativa em razão da autoridade na educação.

\section{PARTE III - EDUCAÇÃO, EMANCIPAÇÃO E CORRESPONSABILIDADE EM APEL255}

7 Educação e emancipação em Apel.

7.1 O debate sobre a função da ciência e a dimensão antecipativa da filosofia em vista da emancipação na educação

7.2 A questão da emancipação como distintivo da Escola de Frankfurt .....

7.3 A caracterização da teoria crítica como "nova esquerda"

7.4 A compreensão de emancipação na teoria crítica de Habermas retomada por Apel... 286

7.5 Educação enquanto ciência social da mediação entre teoria e práxis em vista do interesse cognitivo emancipador.....

8 Educação e responsabilidade no marco da ética do discurso 326

8.1 A ética do discurso como ética da responsabilidade: fundamentação e estrutura. 326

8.2 A educação para a corresponsabilidade como complemento necessário para superar o problema da aplicação referenciada à história da ética do discurso ...... 345

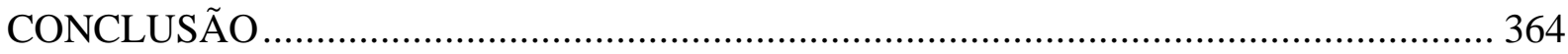

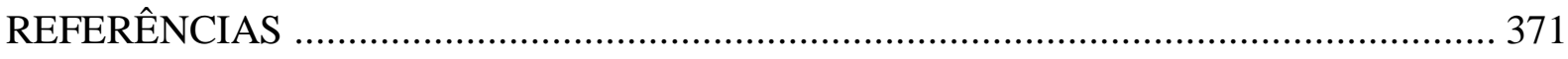

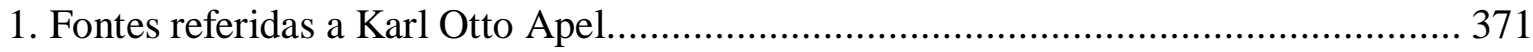

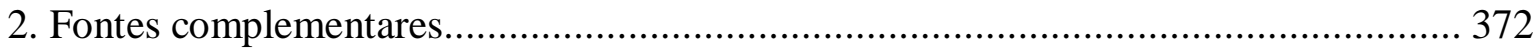




\section{INTRODUÇÃO}

Este trabalho investiga, por meio de uma revisão bibliográfica analítico-reflexiva, a possível contribuição da filosofia de Karl Otto Apel (1922-2017) no sentido de fundamentar no a priori da comunidade de comunicação uma perspectiva de educação intencionada na emancipação e na corresponsabilidade. Se não se pode refletir filosoficamente prescindindo de problemas, decerto, Karl Otto Apel, filósofo alemão ligado à tradição da teoria crítica da Escola de Frankfurt, parece estar no itinerário da filosofia, porquanto sua investigação referese à pretensão de reconstruir criticamente a tradição filosófica ocidental, em suas vertentes teórica e prática, à luz do paradigma da linguagem. Em seus contornos fundamentais, Apel desenvolve uma proposta filosófica, baseada no a priori do diálogo argumentativointersubjetivo, organizada arquitetonicamente ${ }^{1}$, que vem se compondo de uma antropologia do conhecimento, uma hermenêutica e uma pragmática transcendentais no sentido de uma semiótica transcendental como prima philosophia, uma teoria dos tipos de racionalidade, uma teoria consensual da verdade e uma ética discursiva. Apesar da amplitude dessa proposta, a obra apeliana não constitui propriamente um sistema filosófico. Apel desenvolve uma proposta filosófica para transformar a filosofia, a fim de que ela possa oferecer uma resposta à crise pós-moderna nos fundamentos (Begründungskrise) e, em tal medida, uma resposta filosófica para os dilemas afetos à fundamentação do conhecimento e da vida ética. Nessa arquitetônica, Apel une linguagem, história e filosofia, desde um ponto de vista filosófico cada vez mais enraizado nas tradições filosóficas continentais, particularmente, a filosofia transcendental, a fenomenologia, a hermenêutica e o pragmatismo. Por trás da transformação da filosofia elaborada por Apel se revela o intento de reabilitar a filosofia como ciência dos princípios intranscendíveis de todo discurso humano ${ }^{2}$.

A evolução do pensamento de Apel abrange três períodos. O primeiro período (1950-1969) corresponde ao momento em que Apel se dedica à transformação históricohermenêutica da filosofia transcendental, por meio da confrontação entre a hermenêutica do ser e a crítica analítico-linguística do sentido. Influenciado em grande medida por Heidegger, o foco predominante desse período situa-se na questão da autocompreensão do sujeito na história, como herdeiro de tradições e gerador de projetos que constituem seu sentido.

\footnotetext{
${ }^{1}$ Cf. CORTINA, A. Karl Otto Apel Verdad e Responsabilidad (introducción). In: APEL, Karl Otto. Teoría de la verdad y ética del discurso. Trad. Norberto Smilg. Barcelona: Paidós Ibérica, 1991, pp. 9-10.

${ }^{2}$ OLIVEIRA, Manfredo A. Sobre a fundamentação última. Porto Alegre: Edipucrs, 1994, p. 14.
} 
Também é nesse período que inicia a elaboração de uma concepção intersubjetiva de sujeito ${ }^{3}$. O segundo período (1970-1987) marca o intento de Apel no sentido de propor uma transformação semiótico-pragmática da filosofia transcendental kantiana, sob a inspiração principal da filosofia de Peirce. O ponto de fascínio do primeiro período, a questão do sentido, em razão do acontecer do sentido na abertura linguística do mundo, decepciona o segundo Apel, pois se mostra inoperante para afrontar os dois grandes desafios herdados da Ilustração: o progresso no conhecimento e a emancipação da humanidade. Em vista de apresentar um critério para o progresso e para a reflexão intencionada na emancipação da humanidade, Apel realiza o giro dentro de sua proposta filosófica. Esse giro concerne à transformação da filosofia do sujeito privado e peculiar à posição teórica do solipsismo metódico (filosofia da consciência), em uma filosofia transcendental da intersubjetividade, referenciada pelo horizonte da comunidade de comunicação ${ }^{4}$. No terceiro período (a partir de 1988), paulatinamente, Apel desloca seus interesses para o âmbito prático (razão prática), com o fim de aplicar sua teoria, a pragmática transcendental, à realidade histórica. As elaborações teóricas das fases anteriores são retomadas para fundamentar uma proposta de ética da responsabilidade (universal-intersubjetiva e atenta às diferenças culturais) aplicável à diversidade de esferas da vida social do direito, da economia e da política. Desse modo, o terceiro período pode ser considerado com uma síntese dos dois primeiros ${ }^{5}$.

Estruturalmente, este trabalho abrange três partes. Na primeira parte, procura-se compreender a problemática da transformação da filosofia apeliana como abertura para repensar a fundamentação filosófica da educação. Os pontos que considerados aqui como eixos dessa problemática são a retranscendentalização da filosofia no marco do paradigma da linguagem, a recuperação da dimensão pragmática da linguagem na semiótica transcendental de Apel e a pretensão de superação do solipsismo metódico pressuposto na concepção de ciência unitária. Em razão da aparente invisibilidade da questão da educação na filosofia de Apel, inclusive em suas publicações relativas ao campo ético-político, a hipótese guia dessa primeira parte é a suspeita de um déficit de abordagem da filosofia de Apel em relação ao campo da pedagogia e da filosofia da educação.

\footnotetext{
${ }^{3}$ APARISI, Juan Carlos Siurana. Una brújula para la vida moral: a idea de sujeto en la ética del discurso de Karl Otto Apel. Granada: Editorial Comares, 2003, pp. 9-22.

${ }^{4}$ APEL, Transformação da filosofia, v. II, pp. 277-297; Transformation der Philosophie, Band II, pp. 245-263. APARISI, Una brújula para la vida moral: a idea de sujeto en la ética del discurso de Karl Otto Apel, pp. 2351.

${ }^{5}$ APARISI, Una brújula para la vida moral: a idea de sujeto en la ética del discurso de Karl Otto Apel, pp. 53101.
} 
O foco da segunda parte é a especulação acerca de possíveis pontos de desdobramentos da semiótica transcendental, a concepção filosófica original como paradigma de prima philosophia no que tange à razão teorética, para o âmbito da educação. Em sua obra, Apel mostra que filosofar implica assumir uma postura crítico-dialética diante das perguntas fundamentais e respectivas soluções apresentadas no âmbito dos paradigmas de prima philosophia, os quais são, na visão dele, a metafísica, a filosofia transcendental e a filosofia da linguagem. Refletir filosoficamente implica pensar "com", "contra" e "para além" do pensado. Filosofar, para além da repetição exegética do conhecimento legitimado, exige um processo de reconstrução cognitiva autoral. Em razão disso, a arquitetura do pensamento apeliano emerge de forma gradual, respeitando o compasso de depurações das próprias convicções, em grande parte, auferidas em meio ao contínuo processo de interlocução com adversários teóricos. Ela se constrói, paulatinamente, em meio ao debate argumentativo. Até mesmo a estratégia de publicar preferencialmente em artigos, que ulteriormente são recolhidos em livros, é indicativa da pretensão de manter a reflexão filosófica como diálogo argumentativo. Na filosofia de Apel, o emprego do modo dialógico denota bem mais que uma espécie de estilo do autor ou apenas um viés metodológico. Pois, fundamentalmente, ele é um modus operandi que decorre do que Apel considera como ponto arquimédico da filosofia, a saber, a situação da argumentação como metainstituição ${ }^{6}$ constitutiva de tudo o que pertence ao sentido intersubjetivamente válido. Nessa etapa, explicita-se o itinerário analítico-crítico de Apel em redor do linguistic-hermeneutic-pragmatic turn e, em seguida, como contribuição especulativa depreendida da semiótica transcendental, tematiza-se sobre a educação no sentido de uma formação que visa à elevação da humanidade e à autoria do sujeito.

A terceira parte trata do entrelaçamento colateral dos conceitos de emancipação, apresentado com a pretensão de esboçar um novo viés da Teoria Crítica ligada à Escola de Frankfurt, e de corresponsabilidade, tematizado no âmbito da ética do discurso de Apel, com a compreensão geral da educação como ciência social da mediação entre teoria e práxis em vista do interesse cognitivo emancipador e da responsabilidade solidária. Com base no $a$ priori da comunidade de comunicação, pretende-se demonstrar que a filosofia de Apel representa uma contribuição relevante para a reflexão de natureza filosófica em meio às abordagens das ciências da educação, à medida que ela fornece a pressuposição última racional dos fundamentos do campo da educação. Como elemento original desse trabalho,

\footnotetext{
${ }^{6}$ Sprachliche Bedeutung, Wahrheit und normative Gültigkeit. Die Soziale Bindekraft der Rede im Lichte einer transzendentalen Sprachpragmatik. In: Archivio di Filosofia, v. 55, n. 1-3, pp. 51-88, 1987, cf. p. 52.
} 
defende-se a ideia de que, de modo suplementar à filosofia prática de Apel, a esfera da educação possa figurar, transversalmente aos subsistemas coercitivos da responsabilidade ligados à política, ao direito e à economia, como uma mediação institucional contraestratégica responsável pela formação para a emancipação e corresponsabilidade histórica do homem pelo mundo. A educação pode, então, constituir-se, no sentido da formação que eleva à humanidade e desenvolve o primado judicativo do sujeito com base nos mínimos éticos universais implícitos no jogo hermenêutico-pragmático transcendental de linguagem. Tal via é fundamental para reduzir paulatinamente a diferença radical entre as condições ideais de uma comunidade ilimitada de comunicação e as condições históricas e contingentes da situação da comunidade real de comunicação. Como mediação contraestratégica, a educação pode contribuir para a criação das condições sociais suficientes para possibilitar a efetivação da resolução consensual-argumentativa dos problemas teóricos e práticos na sociedade.

Por fim, aponta-se aqui uma observação de teor metodológico. Mais que uma esquematização linear ao estilo lógico-semântico dos conceitos de educação, emancipação e corresponsabilidade, busca-se mapear em cada uma das três partes desse texto os aspectos específicos do pensamento de Apel, nos campos da filosofia teórica e da filosofia moral, como ponto de partida para provocar a reflexão no rumo da educação, particularmente em relação à fundamentação filosófica da educação. A escolha desse viés metodológico parece ter ocorrido intuitiva e gradativamente, por força da percepção de que, na filosofia de Apel, a ciência da educação se define como ciência social da mediação entre teoria e práxis. Trata-se de uma mediação concebida, do ponto de vista epistemológico, sob a perspectiva do interesse cognitivo emancipador de uma teoria crítica capaz de uma fundamentação última da racionalidade e, do ponto de vista da filosofia moral, sob o horizonte de uma ética de princípios referida à história, portanto, capaz de fundamentar uma ação autônoma e corresponsável. 


\section{PARTE I - A PROBLEMÁTICA DA TRANSFORMAÇÃO DA FILOSOFIA PELA SEMIÓTICA TRANSCENDENTAL COMO ABERTURA PARA REPENSAR A FUNDAMENTAÇÃO FILOSÓFICA DA EDUCAÇÃO}

\section{Consideração inicial}

Esta primeira parte tem por objetivo investigar em que medida a problemática da transformação da filosofia transcendental moderna pela semiótica transcendental contempla o questionamento sobre a tarefa da educação, tanto no sentido da pedagogia quanto da filosofia da educação. O ponto de partida dessa investigação é uma interpretação acerca das questões multifacetadas e interligadas - que Apel enfrenta, no contexto do giro hermenêutico e do giro pragmático-semiótico (linguistic-hermeneutic-pragmatic turn), em vista de superar os obstáculos relativos à fundamentação filosófica última do conhecimento e da ação ética e à mediação entre teoria e práxis. A interpretação proposta aqui é que essa problemática se liga, fundamentalmente, ao seguinte propósito de Apel: a) retranscendentalizar a filosofia e, com isso, viabilizar a reflexão sobre a validade no marco do paradigma da linguagem; b) enfrentar teoricamente o solipsismo metódico, por ele compreendido como pressuposto transcendental da concepção de ciência unitária e como suporte teórico que impede a fundamentação da razão prática (ética); c) recuperar a interpretação adequada da dimensão hermenêuticopragmática da linguagem, a fim de compor uma semiótica filosófica (transcendental) como prima philosophia da verdade consensual e da ética discursiva, peculiarmente marcada pela capacidade de oferecer uma fundamentação racional última. Em seguida, interpela-se acerca do lugar e do significado da educação no projeto filosófico de Apel. A suspeita inicial é que Apel não incorpora na semiótica transcendental, nem na ética do discurso, a questão da educação de modo suficiente. Então, sob a suspeita de uma aparente invisibilidade da questão da educação na filosofia de Apel, pergunta-se sobre a possível contribuição de sua filosofia à educação, sobremaneira nos termos de uma filosofia da educação como reflexão radical sobre os pressupostos da educação. 


\title{
1. A PROBLEMÁTICA DA TRANSFORMAÇÃO DA FILOSOFIA PELA SEMIÓTICA TRANSCENDENTAL COMO ABERTURA PARA REPENSAR A FUNDAMENTAÇÃO FILOSÓFICA DA EDUCAÇÃO
}

\begin{abstract}
Este primeiro capítulo tematiza os pontos nucleares da problemática da transformação da filosofia em Apel: a) a retranscendentalização da filosofia no marco do paradigma da linguagem; b) recuperação e reconstrução da dimensão pragmática da linguagem na pragmática transcendental; c) a pretensão de superação do solipsismo metódico pressuposto na concepção de ciência metódica.
\end{abstract}

\subsection{A retranscendentalização da filosofia no marco do paradigma da linguagem}

O paradigma da linguagem irrompe no século XX como última dimensão de base do logos filosófico ${ }^{7}$. Tal decorre do fato de que a linguagem se torna, a partir do movimento de reviravolta linguística hermenêutico-analítica e do giro pragmático, o interesse comum (talvez o único) de quase todas as escolas e disciplinas. Ela deixa de ser apenas um objeto empírico das ciências referente a um entre outros objetos intramundanos e, ao mesmo tempo, adquire o status de grandeza transcendental, na medida em que se torna a nova instância de fundamentação ou de negação dos fundamentos. Em torno da linguagem se circunscreve, assim, a problemática acerca dos fundamentos da ciência e da filosofia. Nesse campo, a linguística empírica passa a dominar de maneira metódica os aspectos filosoficamente relevantes do fenômeno da linguagem, concernentes à sintaxe, semântica e pragmática da comunicação. Quase todas as ciências humanas - psicolinguística, sociolinguística, hermenêutica, semântica textual, e assim por diante - redescobrem seus aspectos linguísticos

\footnotetext{
${ }^{7}$ Para Apel, o aparecimento do paradigma da linguagem no século XX, e nele o que considera como o terceiro paradigma de filosofia primeira, a semiótica transcendental, já se insinua em várias antecipações modernas. Faticamente, constam entre essas antecipações, por exemplo, a filosofia da linguagem de Hamann, Herder e Wilhelm von Humbold; a teoria latente da intersubjetividade na filosofia kantiana do assentimento, orientada de modo psicológico e político à opinião pública; a concepção de uma linguagem-cálculo universal da lógica matemática proveniente de Leibniz. Não obstante, essas antecipações não se mostraram capazes de questionar profundamente a prioridade filosófico-transcendental da subjetividade da consciência. E somente após a conformação em Husserl de um tipo pós-metafísico de filosofia transcendental da consciência, decididamente pré-linguística e solipsista, é que irrompe a perspectiva de um novo paradigma, referenciado pela análise da linguagem (cf. APEL. Karl Otto. Paradigmas de filosofía primera. Trad. Andrés Crelier e Miguel Mailluquet. Buenos Aires: Prometeo Libros, 2013, p. 173).
} 
objetuais, bem como seus pressupostos metodológicos. Contudo, em meio à pluralidade e à convergência das tematizações filosóficas e científicas relativas à linguagem, a filosofia vê-se compelida a determinar o conceito de linguagem próprio da filosofia que, distintamente das tematizações das ciências particulares, venha a explicitar a especificidade da atividade do logos filosófico ${ }^{8}$.

Apel se insere no paradigma da linguagem, porém de um modo bastante peculiar. Em um breve esclarecimento autobiográfico ${ }^{9}$, Apel afirma que sua trajetória filosófica, inicialmente devotada a fazer a ponte entre a abordagem fenomenológica e o giro pragmático da análise linguística, tem se inserido no circuito de um movimento mais amplo de reflexão que afeta a filosofia e a teoria da ciência. Contemporaneamente, esse movimento é designado de reviravolta linguística hermenêutico-pragmática da filosofia atual. Trata-se de um movimento de convergência de tendências filosóficas, cujo pano de fundo concerne ao intento de levar o pragmatismo a assumir os pontos de vista, referentemente à concepção de linguagem e suas implicações para a fundamentação da racionalidade teórica e prática, do segundo Wittgenstein, Heidegger e, em uma segunda onda, Gadamer e Derrida. Ocorre que, no momento mais avançado de cruzamento dessas tendências, desse movimento deriva a exigência de "destranscendentalização" da filosofia. Nesse contexto, predomina a ideia de que a destranscendentalização do pensar constitui o único caminho válido para a superação radical da metafísica, uma tarefa não realizada pela filosofia transcendental nem pela dialética. Retranscendentalizar a filosofia significa, nesse âmbito, regressar ao marco das condições apriorísticas da metafísica da subjetividade, em vez de superá-la ${ }^{10}$.

\footnotetext{
${ }^{8}$ APEL, Karl Otto. Transformação da filosofia: o a priori da comunidade de comunicação. Trad. Paulo Astor Soethe. São Paulo: Loyola, 2000, v. II, pp. 375-378. APEL, Karl Otto. Transformation der Philosophie: das Apriori der Komnunikationsgemeinschaft. 5. Aufl., Frankfurt am Main: Surhkamp, 1993, Band II, pp. 331-333.

9 APEL, Karl Otto. Le problème de l'évidence phénomenologique à la limière d'une sémiotique transcendantale. In: Critique, n. 464-465, 1986, pp. 79-113, cf. pp. 79-80. Ver ainda o relato texto autobiográfico de Apel (aos 68 anos): APEL, Karl Otto. Processo de análisis e investigación - autopercepción intelectual de un processo histórico, retrospectiva autobiográfica. In Antropos: Karl Otto Apel - uma ética del discurso o dialógica, Barcelona, n. 183, pp. 12-19, marzo-abril 1999, cf. pp. 15-18.

${ }^{10}$ APEL, Le problème de l'évidence phénomenologique à la limière d'une sémiotique transcendantale. In: Critique, p. 80. Sobre a questão acerca da Aufhebung ("morte da filosofia" ou "decadência da filosofia") ou da transformação da filosofia (cf. APEL, Transformação da filosofia, v. I, pp. 11-15; Transformation der Philosophie, Band I, pp. 09-12). O apregoamento da destranscendentalização se desdobra na discussão em torno da questão consenso versus dissenso, bem como na defesa da tese da impossibilidade de uma fundamentação última. Aqui, defensores do consenso e da fundamentação última, como Apel, cujas raízes se fundam na transformação semiótica da filosofia transcendental kantiana operada por Peirce, travam uma batalha com teóricos, sobremaneira Lyotard, Rawls e Rorty, que criticam a idéia do consenso universal. Lyotard, partindo da distinção entre a modernidade (homogeneizadora, universalizadora e não estabelece diferenças entre os homens) e a pós-modernidade (fomentadora do pluralismo, do singular diante do universal e o sujeito descentrado), considera que "o consenso tem se convertido em um valor articulado e suspeito", porque o saber avança graças a lances revolucionários. Rawls e Rorty defendem concepções de consenso situacional, tal como o consenso por
} 
Porém, em continuação à linha de uma metodologia orientada normativamente ao discurso ontológico como "jogo" da "fusão de horizontes", iniciada por Gadamer, Apel empreende um itinerário próprio no interior do movimento de reviravolta linguística hermenêutico-pragmática, propondo justamente o inverso: a "retranscendentalização" da filosofia ${ }^{11}$. Apel sustenta a tese de que a "pré-estrutura" do ser-no-mundo, que determina a pré-compreensão de todo compreender efetivo não contém apenas pressuposições históricas e contingentes, mas pressuposições pragmáticas e transcendentais da argumentação. A tarefa de inventariar e explicitar essas pressuposições transcendental-pragmáticas da argumentação constitui, no marco do método transcendental, a especificidade da atividade de fundamentação filosófica. E, por isso, o movimento da reviravolta hermenêutico-pragmático não se desenvolve somente como crítica do logicismo e do cientificismo abstratos que caracterizam a primeira fase da filosofia analítica, mas também pode tomar a direção de uma crítica das pretensões à validade universal que eleva o logos filosófico. Mas, seguindo esse rumo, a retranscendentalização conduz Apel a defender, originalmente, a tese segundo a qual o falibilismo, teoria consensual da verdade e fundamentação última são conceitos ou posições da filosofia atual que se pressupõem e se exigem reciprocamente ${ }^{12}$. Com esse posicionamento, o próprio Apel reconhece seu deslocamento e contraposição em relação aos racionalistas críticos, pragmatistas e até partidários da pragmática-transcendental. Tal mostra o quanto a

superposição, baseadas nos pressupostos do common sense da tradição liberal-democrática ocidental. Para Rawls, o consenso só é aceitável por superposição desde uma concepção política da justiça, abarcando o pluralismo, a argumentação publicamente correta e as virtudes cooperativas da vida política, a saber, razoabilidade, sentido de equidade, espírito de compromisso e disposição para soluções. Para Rorty, porém, a base fática de consenso não está aberta nem à formação democrática e cosmopolita de consensos nem ao progresso nesta direção. O consenso deve ser mediatizado pela via da persuasão, isto é, convencimento não pela força, mas mediante razões ("todo o demais" é uma metafísica pernoitada!). Em face desses teóricos do dissenso, Apel levanta a questão de teor "transcendental", no sentido de indicar argumentos e critérios que possam fundamentar a priori o consenso, um consenso intercultural em condições de simetria (cf. APARISI, Juan Carlos Siurana. Consenso. In: VILLA, Mariano Moreno [coord.]. Diccionario de pensamiento contemporâneo. San Pablo, Madrid: 1997, pp. 239, 241 e 243).

${ }^{11}$ Ressalta-se que, na sua hermenêutica da finitude, Gadamer tematiza a compreensão como um constitutivo fundamental do ser histórico. Além de radicalizar a crítica metafísica por causa de sua pretensão de verdade absoluta e autonegação da finitude, a preocupação de Gadamer é superar a filosofia da subjetividade, vinculando o sujeito que compreende a história à precedência da história em todo conhecimento humano no ser finito. Nesse sentido, a hermenêutica não é um problema de metodologia, mas de ontologia, na medida em que pergunta pela historicidade da compreensão, a forma originária de ser do "ser-no-mundo". Uma ontologia hermenêutica concerne à experiência histórica e à interpretação dessa experiência: "o ser que pode ser compreendido é linguagem" (mediação da experiência interpretativa e da experiência do mundo). Por isso, ela não é a base metodológica das ciências do espírito, mas um aspecto universal da filosofia enquanto tal (cf. OLIVEIRA, M. A. de. Reviravolta lingüístico-pragmática na filosofia contemporânea. São Paulo: Loyola, 1996, pp. 225-248).

${ }^{12}$ Esta é a tese central da concepção de verdade de Apel (cf. APEL, Karl Otto. Fallibilismus, Konsenstheorie der Wahrheit und Letztbegründung. In: Philosophie und Begründung. Org. Forum Philosophie Bad Homburg. Frankfurt am Main: Suhrkamp, 1987, p. 119. APEL, Karl Otto. Teoría de la verdad y ética del discurso. Trad. Norberto Smilg. Barcelona: Paidós Ibérica, 1991, pp. 38-39). 
perspectiva em vista de retranscendentalizar a reflexão filosófica se desdobra de maneira enviesada, mesmo no contexto em que o itinerário de Apel se encontra cruzado e na forma de problemática aberta à própria filosofia.

Vem ao encontro do apregoamento da destranscendentalização a própria situação de superação ("morte" ou "decadência") da filosofia na era das ciências. Aí, a filosofia transcendental está determinada pela circunstância de que ela não pode reclamar como seu objeto algum, nem a consciência, nem a linguagem, nem a sociedade como comunidade de comunicação. Curiosamente, nem mesmo Peirce, que procede a uma transformação semiótica da filosofia transcendental de Kant, da qual Apel se utiliza em sua proposta de transformação da filosofia, parece escapar ao dilema do esvaziamento da filosofia "impotente". Do ponto de vista filosófico, a primeira noção que permite uma transformação da filosofia dos grandes pensadores é oferecida pela concepção de Peirce acerca da formação de consensos na comunidade de experimentação e interpretação dos cientistas. Tal como pensada por ele, essa comunidade é representativa do método da ciência e, na época da ciência, aparece como uma terceira era da racionalidade metódica contraposta às eras do método apriorístico dos grandes pensadores individuais e do método de autoridade. Assim, essa comunidade cumpre a função, por um lado, de substituir a era do apriorismo solipsista de evidências e, por outro, de construir, de forma metodologicamente controlável e como concretização do sujeito transcendental de Kant, o consenso acerca da verdade, até então imposto pelo método da autoridade na era do método apriorístico. Contudo, ao conceber o problema da substituição da autoridade pública e privada pelo consenso alcançado metodicamente na esfera da ciência, mais especificamente do método experimental das ciências naturais, aporeticamente, a transformação preconizada por Peirce não escapa à redução cientificista da racionalidade metódica.

O problema da redução cientificista é que ela impossibilita deduzir a racionalidade moralmente relevante do comportamento humano. E, em tal medida, ela inviabiliza a efetivação da filosofia como mediação entre teoria e práxis na sociedade humana. Segundo Apel, o próprio Peirce reconhece tardiamente que não é possível deduzir a partir de uma normatização tecnológica do esclarecimento de ideias, no sentido da máxima pragmática, a racionalização moral (prática). Ao contrário, Peirce assinala que é necessário pressupor a racionalização moralmente relevante do comportamento humano para que se possa proceder à fundamentação de uma lógica científica normativa. De qualquer modo, a aporia do 
cientificismo peirceano, conforme Apel, põe a nu o problema central de uma transformação da filosofia na era da ciência ${ }^{13}$.

Como já mencionado, Apel pensa que o caminho para reabilitar o discurso filosófico exige a reatualização da tradição da filosofia transcendental moderna, sob o patamar das duas revoluções que marcam o pensamento no século XX: a virada hermenêutica e a virada linguístico-pragmática ${ }^{14}$. Conta a favor disso o fato de que essa tradição tem o mérito de ter colocado o problema da fundamentação no centro da atividade filosófica. E é nessa perspectiva, entende Apel, que se deve pensar a elevação do logos filosófico. Com efeito, há que considerar que a filosofia, apesar de não ter um objeto específico na era da ciência, virtualmente pode e deve investigar todos os objetos de conhecimento científico e précientífico, quanto ao seu status transcendental, isto é, às condições de possibilidade e validade do conhecimento. O que possui status transcendental pode ser distanciado e possivelmente relativizado pela filosofia. De tal modo, a filosofia assume a especificidade do discurso teórico sobre a validade do conhecimento e se torna, ela mesma, a instância administradora da reflexão sobre a validade transcendental. Deve ser assim, por exemplo, com a linguagem, com o corpo (como a priori material), com as "constantes naturais" da física (como paradigmas de jogos de linguagem científicos $)^{15}$. Daqui, pois, surge a posição peculiar do discurso teórico da reflexão filosófica sobre a validade. O resultado dessa empreitada se espelha na transformação da filosofia transcendental à luz do paradigma da linguagem, segundo termos do próprio Apel, por meio do desenvolvimento de uma hermenêutica transcendental e uma pragmática transcendental, que resultam por conformar os aspectos complementares de uma semiótica transcendental.

\subsection{A recuperação e reconstrução da dimensão pragmática da linguagem na pragmática transcendental}

O problema da linguagem emerge, propriamente, no momento de transição de uma epistemologia como crítica do conhecimento para uma epistemologia entendida como

\footnotetext{
${ }^{13}$ APEL, Transformação da filosofia, v. I, pp. 15-16; Transformation der Philosophie, Band II, pp. 12-13.

${ }^{14}$ OLIVEIRA, Sobre a fundamentação última, p. 14.

${ }^{15}$ APEL, Transformação da filosofia, v. I, pp. 83-84 (nota de rodapé 115); Transformation der Philosophie, Band I, pp. 72. Isso torna justificável e, em princípio, factível o interesse particular delimitado em torno do intento de investigar o status transcendental da educação, segundo a perspectiva teórica desenvolvida por Karl Otto Apel.
} 
análise da linguagem. Aqui, faz-se necessária uma digressão histórico-filosófica para explicitar o teor fundamental de uma epistemologia como crítica do conhecimento, que encontra em Kant sua principal referência. A partir do século XVII, ocorre uma revolução espiritual, da qual a ciência moderna é ao mesmo tempo a raiz e o fruto. Nessa revolução, três aspectos importantes sobressaem como características predominantes da modernidade: a) a secularização da consciência; b) a descoberta da subjetividade pela consciência humana; c) a modificação na relação entre teoria e práxis: o moderno deseja a dominação e a subjugação, porém são concomitantes e expressões de um processo mais profundo e fundamental: "a perda do próprio mundo" 16 . No contexto da modernidade, frente ao fundamento do cogito cartesiano, a crítica de Hume significa a ruína da ideia de fundamentação como ideal de certeza e completude, pois tal ideia presume um salto suspeito na cadeia indutiva tanto do passado ao futuro quanto do particular ao universal, que não se apoia nem na razão nem na experiência, mas em uma zona opaca e obscura que é a região da crença baseada no hábito ${ }^{17}$. Kant concorda com Hume em relação à posição de que a demonstração dos pressupostos do conhecimento científico não pode ocorrer nem por via empírica nem por meio de procedimentos da lógica formal. No entanto, em oposição às conclusões céticas de Hume, Kant articula um novo tipo de demonstração, denominada de transcendental, que se caracteriza como crítica radical da razão sobre si mesma, no sentido de interpelação acerca da validade dos próprios procedimentos da razão. Ela transmuta-se, nos termos de Kant, em um conhecimento que "se preocupa menos dos objetos do que do modo de os conhecer, na medida em que este deve ser possível a priori”" ${ }^{18}$. Para tanto, Kant opera uma reviravolta ("revolução copernicana") no saber filosófico, deslocando-o da natureza dos objetos para a estrutura a priori da subjetividade. Aí, o sujeito transcendental constitui a condição a priori da possibilidade do conhecimento baseado na experiência, com validade objetiva, porém limitado ao domínio da sensibilidade. Embora todo conhecimento tenha início na experiência, é a estrutura a priori do sujeito que torna possível a experiência. Com essa viragem, a filosofia deixa de ser ontologia, ultrapassa o ceticismo empirista e se transforma em filosofia transcendental ${ }^{19}$.

\footnotetext{
${ }^{16}$ KOYRÉ, Alexandre. Do mundo fechado ao universo infinito. Trad. Donaldson M. Garschagen. Rio de Janeiro: Forense-Universitário. São Paulo: Editora USP, 1979, pp. 13-14.

17 JONES, Peter. Hume, in: BUNNIN, Nicholas, TSUI-JAMES (org.). Compêndio de filosofia. Trad. Luiz Paulo Rouanet. São Paulo: Loyola, 2002, pp. 569-573.

${ }^{18}$ KANT, Immanuel. Crítica da razão pura. Trad. Alexandre F. Murujao. 8. ed., Lisboa: Fundação Calouste Gulbenkian, 2013, p. 53.

${ }^{19}$ OLIVEIRA, Sobre a fundamentação, pp. 26-28.
} 
A filosofia transcendental passa para o centro da atividade filosófica a questão da crítica do conhecimento e, com ela, a pretensão de alcançar seus fundamentos últimos e seguros. Precisamente, a ideia de uma fundamentação última é o que distingue a filosofia de outros tipos de conhecimento. Kant sustenta que a tarefa fundamental da filosofia consiste em demonstrar a universalidade e a necessidade do conhecimento científico ${ }^{20}$. Essa tarefa específica concerne a determinar a possibilidade, os princípios e a extensão de todos os conhecimentos a priori que possibilitam o conhecimento dos fatos do mundo. Desse modo, Kant compreende que a especificidade da filosofia não é a tematização direta sobre os entes (o homem, o mundo e Deus), mas, antes de tudo, a crítica reflexiva da razão, quer dizer, um conhecimento da própria racionalidade sobre si mesma (no caso da filosofia teórica, sobre o sujeito cognoscente e suas faculdades de conhecimento) como instância de possibilitação do conhecimento e da ação do homem no mundo. Como reflexão ${ }^{21}$ que visa a possibilitar o

\footnotetext{
${ }^{20} \mathrm{Na}$ Crítica da Razão Pura, o problema central é averiguar como são possíveis os juízos sintéticos a priori, como conhecimento que não repousa na experiência, nem é redutível à análise. Na Crítica, a "lógica transcendental" é a ciência que esclarecer a possibilidade do conhecimento a priori e o alcance da sua validade. A primeira parte da lógica transcendental, a "analítica transcendental" (cf. KANT, Crítica da razão pura, pp. 97, 99 e 101), limita-se aos conceitos - que podem ser extraídos da experiência, mas não são empíricos - e aos princípios a priori próprios do nosso entendimento. A síntese (o conceito), em tais juízos, é obra da faculdade do entendimento humano. Ele tem a função unificadora, que se traduz na faculdade de julgar. Para realizar a classificação dos juízos, o entendimento recorre às formas lógicas possíveis (tábua de categorias, diferentes pontos de vista) que permitem classificar e unir sujeito e predicado no juízo. Kant distingue os juízos entre: a) analíticos: são juízos a priori universais e necessários que esclarecem, mas não ampliam o conhecimento científico (tautológicos, pois o predicado pode ser extraído do sujeito). O fundamento deles é o princípio de identidade e não-contradição; b) juízo sintético a posteriori: juízos experimentais ampliadores do conhecimento, que facultam produzir generalizações, mas não a universalidade e a necessidade. $\mathrm{O}$ fundamento deles é a experiência; c) juízo sintético a priori: juízos constitutivos da ciência (matemática e física) dotados de aprioridade (universalidade e necessidade) e fecundidade (sinteticidade). As categorias não são propriedades gerais das coisas (Aristóteles), mas correspondem a funções do entendimento. O uso das categorias é imanente e não transcendente. Elas reduzem as percepções à unidade de um objeto, garantindo a objetividade do fenômeno. $\mathrm{Na}$ analítica transcendental, Kant pretende mostrar que as categorias fundam os juízos sintéticos a priori da física. A natureza é constituída pela aplicação das categorias aos fenômenos. Graças às formas a priori do entendimento (categorias), a inteligibilidade do fenômeno é possível. Contudo, o entendimento tem seus limites estabelecidos na sensibilidade. Sem os dados da intuição sensível, elas são formas vazias que não permitem o conhecimento. Na segunda parte da lógica transcendental, a Dialética, Kant explicita a faculdade da razão, responsável pela unificação dos conhecimentos dispersos. O conhecimento começa pelos sentidos, passa pelo entendimento e termina na razão. Enquanto o entendimento se liga à experiência, a razão, cujo ato próprio é o raciocínio, faz conexão com o entendimento para ligar os juízos e, subindo de condição em condição, elevá-los ao incondicionado. Vez que os conhecimentos do entendimento são condicionados, a razão, dirigida ao incondicionado, tem a função de dar ao entendimento uma unidade mais completa. Ver a respeito: KANT, Crítica da razão pura, pp. v-xxvi (prefácio de Alexandre F. Morujão). OLIVEIRA, Sobre a fundamentação, pp. 24-40.

${ }^{21}$ Para alguns críticos contemporâneos, caso de Kuhlmann, Kant intenciona, porém não distingue de modo eficaz uma fundamentação dedutiva e uma demonstração propriamente reflexiva. A filosofia transcendental se centra na autoconsciência, que exerce o papel de princípio transcendental de dedução. O cerne da demonstração transcendental é um raciocínio no modus pones: "se não $x$ (a validade objetiva das categorias), então também não $y$ (a dificilmente questionável possibilidade da experiência)". Esse argumento pretende demonstrar a base confiável do conhecimento, porém se baseia em pressupostos não-demonstrados. Tal concerne a uma circularidade que enfraquece o procedimento da demonstração de Kant, e se evidencia em três circunstâncias que
} 
autocontrole da razão, a filosofia se contrapõe diametralmente a toda atitude dogmática da consciência comum ou científica que não estabeleça os limites da própria racionalidade humana. A racionalidade significa o processo de autocrítica, autodemonstração e autocontrole por meio de um esclarecimento reflexivo da razão sobre si mesma, que visa ao controle e à segurança do conhecimento.

No fim do século XIX e início do XX, o neokantismo e a fenomenologia retomam a forma transcendental de pensar, tendo a questão da fundamentação sua problemática central. Acentuando o princípio de autonomia do pensamento - no sentido de que o pensamento deve ter origem somente em si mesmo -, os neokantianos se propõem a tematizar os princípios que asseguram a validade de todo e qualquer conhecimento. O fundamento de qualquer filosofia é uma crítica que levanta a questão da validade do conhecimento. A filosofia é reflexão, pensamento do pensamento, que reconhece a independência das ciências, porém se constitui como filosofia científica, na medida em que tematiza o pensamento como fundamento último de todo conhecimento. Fundamentalmente, o neokantismo pretende evitar uma ontologização das condições de possibilidade do conhecimento do ser, razão pela qual insiste que, na fundamentação, tais condições não se radicam em um ente psicológico-antropológico (ôntico) ou metafísico, mas em pressupostos de validade de caráter lógico (princípios, ideias, valores de validade transcendental). Posto que todo e qualquer conhecimento levanta pretensão à validade e para tal pressupõe princípios lógicos, que possibilitam essa validade, cabe à filosofia tematizar esses pressupostos de caráter lógico. Por isso, a filosofia, entendida como pensamento do pensamento puro, é distinta do pensamento empírico ou metafísico, justamente porque tematiza os pressupostos da validade referentes aos princípios "primeirosúltimos" que fundamentam ultimamente todo o conhecimento. E, ao explicitar a base de validade de sua pretensão à validade, a filosofia consegue fundamentar a si mesma. Nessa perspectiva, fundamentalmente, o tema da crítica da razão não diz respeito às coisas, mas à validade do conhecimento de coisas, visto que todo conhecimento do ser dos objetos depende de princípios em cuja validade se baseia o conhecimento dos entes. O tema da lógica da validade concerne aos princípios, que subjazem a todo conhecimento dos seres. É sob este

\footnotetext{
não escapam à objeção do Trilema de Münchhausen: a) quando pressupõe a validade das leis lógicas que ele utiliza; b) quando pressupõe a validade da experiência, para demonstrar a validade das sentenças sintéticas $a$ priori, apesar de serem essas sentenças que possibilitam a experiência; c) quando incorre no problema do regresso ao infinito, à medida que a tese "sem $\mathrm{x}$, y não é possível" requer uma fundamentação para ela. De tal modo, essas três objeções parecem mostrar que a concepção de fundamentação em Kant permanece sendo a dedutiva, cujo problema central, desde Aristóteles, é o regresso ao infinito diante da exigência de fundamentação (cf. OLIVEIRA, Sobre a fundamentação, pp. 26-30).
} 
patamar teórico, característico do idealismo transcendental, que o neokantismo concebe a fundamentação do conhecimento. Então, com todas as diferenças internas da especulação idealista, marca-se uma radicalização da virada copernicana iniciada por Kant, concebendo-se que é sempre no sujeito, no sentido de uma aprioridade da subjetividade, que reside o centro de gravidade da filosofia. O saber não consiste na recepção de dados por um "eu" tabula rasa, mas numa construção empreendida por um "eu" que se entende como atividade. O saber não é atribuído ao espírito humano finito, como tal, mas à razão e, assim, o mundo se converte em automanifestação do pensamento ${ }^{22}$.

Apel assinala que, no âmbito da crítica filosófica do conhecimento, como análise transcendental ou psicológico-empírica da consciência, a discussão em torno da linguagem é praticamente uma curiosidade à margem da consciência filosófica. Esse quadro se modifica, na primeira metade do século $\mathrm{XX}$, ao menos no espaço de influência anglo-saxão do positivismo lógico, onde se dá a transição da epistemologia para a análise da linguagem. Em princípio, três motivos explicam a transição da epistemologia da crítica da consciência à crítica da linguagem. O primeiro se liga aos resultados decorrentes da lógica leibniziana (como mathesis universalis) e à nova fundamentação da lógica e da matemática; desenvolvese aí uma simbologia construtiva e um conjunto de problemas e conceitos semióticos, tais como as "antinomias semânticas" e a problemática da hierarquia das metalinguagens. O segundo motivo decorre da fundamentação da lógica matemática, a partir da qual se erige a suspeita basilar do neopositivismo referente à ausência de sentido das proposições e questões filosóficas. Estas não são nem ao menos falsas, mas simplesmente carentes de sentido, em razão de não entendermos a lógica da nossa linguagem. Na sequência dessa suspeita, o Círculo de Viena formula o princípio de verificação: "o sentido de uma proposição é o método de sua verificação". Dessa forma, verificação indica o método de confirmação científica para comparar enunciados linguísticos e fatos observados. O terceiro motivo se deve à contribuição do pragmatismo à análise linguística neopositivista: primeiro, mediante a reformulação mais abrangente do princípio de verificação por Ch. S. Peirce, segundo a qual para se determinar o significado de um signo, é necessário determinar que hábitos (efeitos) ele produz; segundo, mediante a semiótica trivalente de Charles Morris, que delineia as três dimensões da ciência dos signos, a saber, a sintaxe (trata da relação intralingüística dos signos), a semântica (trata da relação dos signos com os fatos extralinguísticos designados) e a pragmática (trata da relação dos signos com os seres humanos como usuários da linguagem).

${ }^{22}$ OLIVEIRA, Sobre a fundamentação, pp. 37-40. 
A partir dessa contribuição, as três dimensões da semiótica científica passam a representar os motivos centrais da filosofia linguístico-analítica ocidental ${ }^{23}$.

No desenvolvimento da epistemologia da análise da linguagem como filosofia linguístico-analítica, o problema da linguagem se configura, segundo Apel, em torno da disjunção entre as concepções semióticas da sintaxe, da semântica e da pragmática, que resulta na aporia consoante à abstração da dimensão pragmática da linguagem. Em comum, essas concepções se regem pelo princípio de verificação, que funciona como o motivo unificador e condutor de estágios do método de confirmação científica das proposições com sentido (sinnvolle Sätze). Fora isso, em torno da formulação da concepção epistemológicofilosófica da linguagem vige, de maneira mais aguda, a problemática decorrente da cisão entre verdade lógico-formal e o corretismo factual da pragmática ${ }^{24}$. Essa cisão evidencia a aporia central da concepção semântico-referencial de linguagem, orientada exclusivamente à função representativa das proposições. O paradoxo se coloca no fato de que, sem a dimensão pragmática da linguagem, a qual põe em evidência a relevância do logos na linguagem natural, nada pode ser conhecido da dimensão semântico-referencial, à medida que a referência semântica dos signos tem que ser entendida ou interpretada de maneira atual como identificação do objeto. Muitas e diversas ações humanas nem sequer poderiam ser identificadas ou descritas como objetos sem o recurso à compreensão de intenções e regras (dos jogos de linguagem) que devem ser seguidas. Essa circunstância tem demonstrado que, ao menos no âmbito das ciências sociais e da linguística, não se pode prescindir da compreensão comunicativa das intenções de sentido, a qual é igualmente originária como a compreensão autorreflexiva de intenções ${ }^{25}$. O enfrentamento da aporia central da concepção semântico-referencial de linguagem, orientada exclusivamente à função representativa das proposições, decorrente da disjunção entre a verdade lógico-formal e a crítica da pragmática, inclusive transcendendo-o por meio do método transcendental (reflexão sobre a validade), constitui o campo próprio da pragmática transcendental, tal como um desdobramento da problemática da linguagem no campo da epistemologia da análise de linguagem.

A filosofia como sintaxe lógica da linguagem, cujo apogeu se dá com o formalismo da lógica simbólica, visa à apreensão nominalista (convenção) e instrumental da

\footnotetext{
${ }^{23}$ APEL, Transformação da filosofia, v. I, pp. 163-167; Transformation der Philosophie, Band I, pp. 138141.

${ }^{24}$ APEL, Transformação da filosofia, v. I, pp. 184-185; Transformation der Philosophie, Band I, pp. 155156.

${ }^{25}$ APEL, Karl Otto. Semiotica filosofica. Trad. Julio de Zan, Ricardo Maliandi e Dorando Michelini. Buenos Aires: Editorial Almagesto, 1994, p. 297.
} 
linguagem, isenta de qualquer arbítrio na combinação de signos. Isola-se aí, provavelmente pela primeira vez, a essência de "verdade" filosófica, na medida em que cabe a ela apenas esclarecer as relações sintáticas entre os signos, de acordo com a construção de uma determinada língua. Para Apel, essa perspectiva de regulamentação da linguagem cai em aporia, pois "todo cálculo sígnico formal e passível de ser apreendido faz uso de um significado metalinguístico das regras por ele observadas" 26 , isto é, qualquer regulamentação da linguagem (cálculo) já pressupõe o significado (Bedeutung) na linguagem cotidiana.

A filosofia do positivismo lógico desenvolve o programa de uma semântica lógica da linguagem, tendo por objeto a relação dos signos com o mundo extralinguístico designado por eles. O seu ponto de partida não é a linguagem cotidiana, mas uma linguagem de cálculo formalizada, a partir da qual constrói a função semântica da linguagem, na forma de regras de designação possível sobre o mundo como regras de verdade a priori. Na visão de Apel, a perspectiva da lógica semântica é uma moderníssima variante da "revolução copernicana" no campo da epistemologia. Assim, mutatis mutandis, aparece o aspecto nuclear da transição epistemológica de uma crítica da consciência para a análise da linguagem. Com Kant não é mais a natureza que dita as regras ao intelecto, mas o intelecto à natureza, no sentido de ela ser constituída a priori em juízos sintéticos pelo intelecto. Por sua vez, com a construção de uma semântica da linguagem, de um lado, a tese kantiana é descartada e, em seu lugar, confiase no procedimento de construção das regras de significação e da verdade, que devem valer como a priori dos significados judicativos possíveis, por meio de um método de verificação do sentido das proposições linguísticas.

Esse procedimento conduz, segundo a análise de Apel, a dois resultados problemáticos, inicialmente, inesperados. Primeiro, a lógica da linguagem não pode decidir $a$ priori sobre a verificação possível de proposições, tampouco sobre seu sentido possível. O sentido e a verdade das proposições são relativos às regras da forma e da designação de um sistema sintático-semântico, introduzidas por convenção. Sendo o sentido e verdade relativos à respectiva linguagem, em princípio, é possível construir uma linguagem em que também proposições metafísicas sejam vistas como sensatas. A razão disso é que as possibilidades da semântica lógica não estão restritas a regras de verificação de uma linguagem técnica ligada às ciências naturais. Segundo resultado, as regras de significação e de verdade, fixadas $a$ priori no sistema semântico, dependem mais da metalinguagem (linguagem corrente) em que as regras são introduzidas do que de um sistema puramente sintático. Ao mesmo tempo,

\footnotetext{
${ }^{26}$ APEL, Transformação da filosofia, v. I, p. 169; Transformation der Philosophie, Band I, p. 143.
} 
porque a legitimação da linguagem artificial da semântica se dá pela mediação de conceitos da linguagem corrente, o sistema semântico de regras prima pela precisão do significado da linguagem corrente por meio de definições científicas. O ponto de julgamento extralinguístico da verdade linguística possível é a correção factual das proposições linguísticas, a rigor, determinante para a ciência empírica ${ }^{27}$. Não obstante, a perspectiva semanticista do positivismo lógico resta, segundo Apel, fracassada quanto ao intento de resolver o problema do significado linguístico, visto que se abstrai, aporeticamente, da dimensão pragmática da linguagem.

Conforme a crítica de Apel, o problema do significado linguístico não pode ser resolvido, suficientemente, apenas recorrendo à relação dos signos linguísticos entre si e à relação deles com fatos extralinguísticos. "Nenhum teor universal de significado capaz de dizer algo a um usuário da linguagem pode ser entendido apenas por meio do sistema de regras da 'sintaxe lógica' e da 'semântica lógica'"28. Algo - por exemplo, a expectativa de algo proveitoso ligada a uma palavra - só pode vir ao encontro desse usuário porque a significância (Bedeutsamkeit) já está antecipada linguisticamente. O sentido da linguagem cotidiana não pode ser verificado apenas de maneira formal-lógica e em vista da correção dos fatos. Falta à análise linguística sintático-semântica incorporar na constituição do teor objetivo do significado da linguagem o fator pragmático referente ao uso intersubjetivo dos signos, sem o qual não se estabelece qualquer informação científica.

É bem verdade que o problema de uma semiótica pragmática remonta, segundo a leitura de Apel da tradição filosófica, aos primórdios da filosofia e à filosofia humanista da linguagem. Na Antiguidade ${ }^{29}$ e posteriormente junto ao aparato escolar medieval, predomina

\footnotetext{
${ }^{27}$ APEL, Transformação da filosofia, v. I, pp. 173-174; Transformation der Philosophie, Band I, pp. 146147.

${ }^{28}$ APEL, Transformação da filosofia, v. I, p. 174; Transformation der Philosophie, Band I, p. 147.

${ }^{29} \mathrm{Na}$ Antiguidade, o conceito de logos (significa razão, linguagem e discurso. Na expressão de Heráclito (koinòs lógos; common sense), logos é o que faz surgir o mundo comum entre os homens despertos. Supõe-se aí que a unidade entre razão e linguagem, diante da qual, a dessemelhança entre as línguas é reduzida à diversidade nomes e sinais. Aí se delineia o acobertamento do fenômeno linguístico por meio da sua redução à função designativa, que vem a ocorrer, em Platão, em favor das ideias. Os significados linguísticos são vistos a partir das "idéias", isto é, das "essências extra e supralinguísticas" (Sofista 263 d) que prescindem de um possível consenso dialógico acerca do significado ou da regra de uso das palavras. Por considerar que o pensamento é o "diálogo calado da alma consigo mesma", a concepção dialógica do pensamento de Platão não conduz a uma interpretação do pensamento como função intersubjetiva, mas opera a distinção radical entre pensamento e linguagem. A linguagem é órganon, instrumento secundário de designação das essências do pensamento. Por sua vez, com o conceito de common sense da linguagem, Aristóteles apresenta o segundo paradigma que reduz a linguagem a uma função convencional de designação. Ele leva em conta a intencionalidade objetiva do juízo para a lógica e epistemologia, ao custo de acobertar as funções "transcendental-hermenêuticas" da linguagem. Os significados são as representações anímicas (da alma) internas. Eles são algo psíquico idêntico às coisas que espelha, conferindo um substrato ao princípio lógico de identidade. Em sua procedurística, os elementos do
} 
a divisão teofrásica ${ }^{30}$ acerca das dimensões do discurso: de um lado, a poética e a retórica administram a dimensão pragmática do discurso com os ouvintes, em vista do uso seleto e valorativo das palavras para o convencimento; de outro, a filosofia, imbuída da prerrogativa de cuidar do logos - daquilo que é sempre válido e eterno, e por isso não tem como tema aquilo que é historicamente casual -, tem a ver com a correção instrumental-designativa do discurso para nomear as coisas (com a adequação semântica do uso dos signos). Por séculos, essa divisão insufla o embate - sem consequentes impactos teóricos, segundo Apel - do movimento espiritual chamado humanismo e dos poetas contra a astúcia dos lógicos na ciência do "julgar" a correção semântica dos signos. De todo modo, nesse embate, o topos epistemológico e linguístico-filosófico humanista traz a lume as bases da problemática relativa à dimensão pragmática da linguagem.

Esse topos remonta a Cícero - a sua formulação da "tópica", entendida por ele como a "arte de encontrar" mais útil e anterior na ordem da natureza que ciência, a denominada "dialética", que persegue os caminhos do "julgar" - e se estende ao longo da história do humanismo retórico, de Quintiliano a Vico, em defesa da tese central de que a tópica universal pré-reflexiva da linguagem corrente, no sentido de um fator constitutivo de verdade em vista da qualidade das coisas no mundo do ser humano, precede a crítica reflexiva da linguagem, feita pela semântica lógica ${ }^{31}$. Por trás dessa tese caminha a crítica da tradição humanista à tradição da análise lógica da linguagem, embasada na argumentação que reivindica a precedência dos estudos lógicos histórico-hermenêuticos ante a lógica formal ${ }^{32}$. Nessa linha, argumenta-se que existe uma disjunção entre a verdade lógico-formal e o corretismo factual, por conta do qual o lógico puro não pode garantir de maneira completa a verdade a respeito das coisas do mundo. Argumenta-se, tal como defendido por Giambattista

mundo chegam por meio dos sentidos, sendo capturada deles pelo intelecto a estrutura ontológica do mundo mediante abstração, em seguida, eles são designados mediante conexões de signos e, por fim, comunicados com auxílio instrumental dos signos. Pretende-se com isso garantir a "emancipação da onto-lógica filosófica enquanto onto-semântica dos anseios de verdade e de sentido vinculados à linguagem" (APEL, Transformação da filosofia, v. II, p. 383; Transformation der Philosophie, Band II, p. 337).

${ }^{30}$ Apel cita um trecho de um texto de Ammonius, comentador de Aristóteles, para exemplificar tal divisão: "Como o discurso (logos) possui uma dupla relação, tal como demonstrou o filósofo Teofrasto - uma com os ouvintes, para os quais significa algo, e outra com as coisas, sobre as quais o falante pretende transmitir uma convicção aos ouvintes -, surgem a poética e a retórica em vista da relação do discurso com os falantes; (...) já em vista da relação com as coisas, o filósofo privilegia a preocupação de refutar o que é falso e de comprovar o que é verdadeiro" (APEL, Transformação da filosofia, v. I, p. 182; Transformation der Philosophie, Band I, p. 154). Essa divisão indica, assim se presume, que o orador humanista detém uma sapientia específica do orador ilustrado, "valorativamente orientada e incitativa", cabendo-lhe revelar no fórum a verdade da situação prática a seus concidadãos (APEL, Transformação da filosofia, v. I, p. 187; Transformation der Philosophie, Band I, p. 158).

${ }^{31}$ APEL, Transformação da filosofia, v. I, p. 184; Transformation der Philosophie, Band I, p. 156.

32 APEL, Transformação da filosofia, v. I, p. 183; Transformation der Philosophie, Band I, p. 155. 
Vico, que a correção das proposições, no sentido da crítica reflexiva da linguagem representada pela lógica tradicional em suas teorias da verificação, pressupõe a apropriação da tópica da formação da histórica (isto é, de sua interpretação universal) de acordo com pontos de vista humanos; ou seja, pressupõe as "coisas no mundo" pensadas na determinação de seu ser-assim, em sua abertura da "imagem do mundo" por uma linguagem corrente (cotidiana, pré-reflexiva) antes de qualquer reflexão cientifica ${ }^{33}$. É pressupondo isso que Vico se posiciona em defesa da formação humanista e em contraposição ao ideal cartesiano da ciência - enquanto mathesis universalis - isenta de pressupostos ${ }^{34}$.

O primeiro passo em vista da solução do problema da integralização da descrição estrutural do fenômeno-linguagem é empreendido Morris e Peirce, por via do pragmatismo. Eles, por um lado, complementam a análise linguística e a teoria da verificação do positivismo lógico e, por outro, efetivam a integração das pretensões do topos humanista na construção do conceito filosófico de linguagem. Isso ocorre à medida que os parâmetros de julgamento da verdade conteudística, a relação sintática dos signos entre si e a relação semântica dos signos com os fatos, sem incorrer em abstração da dimensão pragmática da linguagem, remetem-se ao uso da linguagem em situação ambiente. Tais parâmetros ganham efetivo sentido quando se constituem como momentos concretos de mediação linguística no comportamento ambiente do ser humano. Em Morris, já no seu ponto de partida fundamental, a semiótica, como "ciência do comportamento humano mediado por signos", que é efetivamente uma pragmática ${ }^{35}$. Por isso, não cabe na pragmática uma distinção das dimensões do discurso, tal como na semântica e na sintaxe, entre um aspecto empíricodescritivo, e outro, puramente formal. $O$ uso da linguagem (pragmática) requer o entendimento acerca das regras operacionais da sintaxe lógica e da semântica lógica como regulamentações do comportamento humano determinadas por um fim $^{36}$. Paralelamente, segundo Apel, Morris vem ao encontro da pragmática dos jogos de linguagem do segundo Wittgenstein, na medida em que ambos se afastam em relação à construção linguística de inspiração lógico-matemática e científica e, ao mesmo tempo, empreendem um aprofundamento em meio à essência da linguagem cotidiana ${ }^{37}$.

\footnotetext{
${ }^{33}$ APEL, Transformação da filosofia, v. I, pp. 183; Transformation der Philosophie, Band I, p. 155.

${ }^{34}$ APEL, Transformação da filosofia, v. I, pp. 183-184 e 191-192; Transformation der Philosophie, Band I, p. $155-156$ e 161-162.

35 APEL, Transformação da filosofia, v. I, p. 178; Transformation der Philosophie, Band I, p.150.

${ }^{36}$ APEL, Transformação da filosofia, v. I, p. 178; Transformation der Philosophie, Band I, p.150.

${ }^{37}$ APEL, Transformação da filosofia, v. I, p. 179; Transformation der Philosophie, Band I, p.151.
} 
Com efeito, nem toda abordagem pragmática resolve o problema da abstração da dimensão pragmática da linguagem. Tal é a conclusão de Apel ao distinguir a sua proposta, a de uma interpretação semiótico-transcendental da linguagem, da interpretação empirista da semiótica, cujo esquema básico se encontra na fundamentação da teoria dos signos de Morris. Embora Morris avance em relação ao positivismo lógico, na avaliação de Apel a ampliação pragmática do conceito de verdade linguística de Morris resulta fracassada ${ }^{38}$, pois ele postula verificar os modi informativo-designativos de significação não apenas com o auxílio da função designativa - chamada por ele de "denotativa" - da linguagem, mas também recorrendo à teoria da adequação da verdade (teoria metafísica clássica) ${ }^{39}$. Como hipótese metafísica, ele concebe que os modos de significação dos signos, inclusive os valorativos e prescritivos pressupõem uma "denotação" das qualidades objetivas das coisas, independentemente de qualquer interferência humana. Contudo, analisa Apel, ao recorrer à blindagem metafísica de algo que ultrapassa os limites do mundo interpretado pela mediação da linguagem, ele se exime de qualquer discussão. O limite interno da concepção de Morris decorre de sua fundamentação como ciência natural generalizadora, cujo objeto é o comportamento humano mediado por signos. Essa ciência desconsidera as ocorrências de sentido, as quais só podem ser entendidas a posteriori, até certo ponto, por via hermenêutica. Ele ignora o interesse específico das ciências humanas, que não é o comportamento humano passível de generalização, mas as ocorrências de sentido que refundam e evidenciam a historicidade do ser-aí humano ${ }^{40}$.

A alternativa pragmática, ao mesmo tempo, desviante da recaída na metafísica de Morris e inspirada no marco da filosofia transcendental, de modo a permitir avançar no sentido da transformação da filosofia transcendental, é a semiótica trivalente de Ch. S. Peirce $^{41}$. É dela que Apel parte em vista de mostrar a linguagem como uma grandeza transcendental no sentido kantiano, quer dizer, como uma condição de possibilidade e validade do entendimento e autoentendimento e, com isso, do pensamento conceitual, do

\footnotetext{
${ }^{38}$ A respeito da contraposição entre a semiótica-transcendental de Apel e a semiótica empirista de Morris, cf APEL, Paradigmas de filosofía primera, pp. 152-165; APEL, Transformação da filosofia, v. I, pp. 187-188; Transformation der Philosophie, Band I, pp. 158-159.

${ }^{39}$ Apel entende que a teoria fenomenológica repara, em parte, a limitação criteriológica da teoria da adequação, fazendo apelo ao critério da evidência fenomênica (cf. APEL, Teoría de la verdad y ética del discurso, pp. 4652. APEL, Karl Otto. Fallibilismus, Konsenstheorie der Wahrheit und Letztbegründung. In: Philosophie und Begründung, pp.125-129) Mas para-além da fenomenologia, por se tratar de um critério baseado na estrutura monológica (privada; “eu”) pré-linguística, ele recorre à semiótica tridimensional de Peirce para elaborar a sua proposta de teoria da verdade. Tratar-se-á disso na segunda parte deste trabalho.

${ }^{40}$ APEL, Transformação da filosofia, v. I, pp. 189-190; Transformation der Philosophie, Band I, p. 160.

${ }^{41}$ APEL, Paradigmas de filosofia primeira, pp. 17-18.
} 
conhecimento objetivo e do agir com sentido. O ponto de vista a ser considerado, segundo Apel, é o de que as qualidades possíveis das coisas só são constituídas como unidades de sentido à luz da "imagem de mundo conteudística" da linguagem corrente. Mais que isso, é preciso levar em conta a circunstância de significância que transcende, de algum modo, em cada referência situacional entre o ser humano e seu entorno, a interpretação de mundo convencional dada por meio da linguagem e que parece clamar ainda por conceitos novos. Ademais, é necessário considerar que o já conhecido sobre a qualidade das coisas e das carências dos seres humanos possa ser visto como algo questionável. Isso indica que a linguagem não possui apenas a função de designar corretamente qualidades já conhecidas. De modo mais original, porém unida a esta função, a linguagem possui outra função, a saber, "a de descerrar, antes de tudo, e a partir das referências vitais de uma situação, as 'qualidades' do meio ambiente (principalmente as qualidades 'valorativas')" ${ }^{42}$. Tais funções indicam, no interior do uso da linguagem, a distinção quanto ao uso linguístico: quer como instrumento de designação de coisas conhecidas que pressupõe as qualidades das coisas como "patentes" e subsume os fatos sob conceitos convencionais; quer como uso que torna patentes as qualidades das coisas, libera o ente em seu próprio ser-assim e coloca em cena as palavras como potências de encarnação de sentido, na expectativa de que não tenha sido ainda revelado por completo ${ }^{43}$.

Considerar a linguagem desde tal perspectiva requer, em primeiro lugar, compreender criticamente as tematizações metódico-abstrativas da linguagem, demonstrando a insuficiência filosófica da concepção de linguagem como função de designação e comunicação. Em segundo lugar, implica reconstruir o conceito de razão mediante o conceito de linguagem ${ }^{44}$, no sentido de um conceito transcendental-hermenêutico de linguagem, a partir do qual venha a ser possível refletir sobre os próprios pressupostos linguísticos da filosofia e, juntamente, possa fundamentar as pretensões de sentido e validade do pensar e agir humano. O enfrentamento da aporia central da concepção semântico-referencial de linguagem, orientada exclusivamente à função representativa das proposições, decorrente da disjunção entre a verdade lógico-formal e a crítica da pragmática, inclusive transcendendo-o por meio do método transcendental (reflexão sobre a validade), constitui o campo próprio da pragmática transcendental, tal como um desdobramento da problemática da linguagem no

\footnotetext{
${ }^{42}$ APEL, Transformação da filosofia, v. I, p. 188; Transformation der Philosophie, Band I, p. 159.

${ }^{43}$ APEL, Transformação da filosofia, v. I, pp. 188-189; Transformation der Philosophie, Band I, pp. 159160.

${ }^{44}$ APEL, Transformação da filosofia, v. II, pp. 396-405; Transformation der Philosophie, Band II, pp. 349357.
} 
campo da epistemologia da análise de linguagem. Eis parte da tarefa de Apel que se descortina como desafio-problema referente a desenvolver um programa de uma teoria da ciência que, reconstituindo transcendentalmente a dimensão pragmática da linguagem, fundase no $a$ priori da comunidade de comunicação.

\subsection{A pretensão de superação do solipsismo metódico pressuposto na concepção de ciência unitária}

O obstáculo para o desenvolvimento de uma teoria da ciência a partir da comunidade de comunicação reside no pressuposto do solipsismo metódico presente na concepção objetivista da ciência unificada. A tese de Apel é que a ciência unificada retrocede ao pressuposto do solipsismo metódico, que é compartilhado pelo neopositivismo, como abordagem linguístico-analítica, e pela filosofia tradicional da consciência moderna ${ }^{45}$. Esse pressuposto se refere ao reconhecimento da sociedade humana como um sujeito-objeto da ciência e concerne, ademais, à ideia de que, em princípio, um só indivíduo possa conhecer algo como algo e, assim, fazer ciência. Esse pressuposto se fundamenta na distinção metodológica, operada no seio da metodologia neopositivista, defensora da ciência unificada, entre o "compreender" (Verstehen) das ciências humanas e o "explicar" (Erklären) das ciências da natureza. Com base nesse pressuposto, na metafísica tradicional do sujeito e no neopositivismo, ignora-se que o conhecimento baseado na observação, ocorrido na relação sujeito-objeto, já pressupõe o conhecimento do acordo mútuo sobre o sentido, no plano da

\footnotetext{
${ }^{45} \mathrm{Na}$ filosofia moderna, com a radicalização nominalista e a dissolução do aristotelismo da baixa Idade Média, emerge o pressuposto do solipsismo metódico. Descartes, supondo que o pensamento possa refletir à margem dos vínculos da linguagem e da tradição, preconiza a ideia da evidência pré-linguística do conhecimento ou certeza. Ele não se dá conta que o pensamento com sentido está já mediado por uma comunidade real de comunicação referida ao mundo. John Locke pretende superar a obscuridade e mal-entendidos na filosofia e na ciência por meio da exatidão metódico-solipsita (introspecção pré-linguística no common sense) dos significados das palavras mediante uma redução definidora a "noções simples" (APEL, Transformação da filosofia, v. II, pp. 385-387; Transformation der Philosophie, Band II, pp. 339-341). Para Apel, Husserl é o último clássico da filosofia transcendental da consciência e do correspondente solipsismo metódico. Ele vê na pura evidência prélinguística da autodoação dos fenômenos, sobretudo na evidência apodítica da "esfera residual do ser" do "ego cogito" que sobrevive a toda "epochê", a base indubitável de certeza da filosofia crítica (APEL, Fallibilismus, Konsenstheorie der Wahrheit und Letztbegründung. In: Philosophie und Begründung, pp. 126-127). A respeito da crise da fenomenologia na contemporaneidade quando confrontada pelos fundamentos da evidência fenomenológica na forma da linguagem e na intuição de uma contextualidade da pré-compreensão dos fenômenos (cf. APEL, Le problème de l'évidence phénomenologique à la limière d'une sémiotique transcendantale. In: Critique, pp. 90-92).
} 
relação sujeito-sujeito. E, mais que isso, o neopositivismo desloca e subordina o interesse hermenêutico pelo compreender para o horizonte transcendental do saber objetivo disponível, reduzindo-o a hipóteses elucidativas dos comportamentos ${ }^{46}$.

Em relação ao solipsismo metódico, Apel vê com perplexidade o fato de que o neopositivismo não tenha notado a contradição entre os pressupostos do método linguísticoanalítico, como método de reconstrução sintática e semântica da linguagem científica, e os pressupostos da metodologia objetivista ${ }^{47}$. De um lado, paradoxalmente, a lógica da ciência neopositivista se ocupa, por via temática, com o acordo mútuo subjetivo. De outro, a metodologia unitária da ciência tem que unir entre si o interesse hermenêutico do compreender e o interesse analítico pelo acordo mútuo metacientífico, porém acaba subordinando aquele a este (elucidação objetiva). Ora, isso configura uma contradição entre o programa do neopositivismo e o programa da metodologia da ciência. Contudo, a contradição ainda mais fundamental entre a abordagem linguístico-analítica e o solipsismo metódico da epistemologia moderna se evidencia, segundo Apel, na irreflexão acerca dos pressupostos transcendentais da lógica da ciência neopositivista. Eles simplesmente não são reconhecidos pelo empirismo lógico. A primeira resposta à questão sobre os pressupostos últimos da lógica da ciência neopositivista é que o único pressuposto a priori aí incluído se refere à validação da lógica formal, com a qual se deriva a cognição científica a partir dos dados observados. Para Apel, entretanto, há aí outros pressupostos apriorísticos inconfessados, tais como: a pressuposição da existência de fatos, independentemente do pensamento humano, porém suscetíveis de serem conhecidos de maneira intersubjetivamente válida mediante observação; a pressuposição de uma linguagem científica ideal para superar a metafísica (ainda que apegada à metafísica secreta de Leibniz referente à linguagem de cálculo universal para ciência) e se aproximar da lógica dos fatos.

Por trás das contradições supramencionadas, aparece uma metaproblemática da linguagem cálculo. Ora, na esteira de Leibniz, as linguagens científicas formalizadas não se prestam ao interesse cognitivo do acordo mútuo, pois lhes cabe justamente torná-lo supérfluo, como pressuposto transcendental do conhecimento. Elas visam a substituir a problemática hermenêutica da intelecção recíproca de intenções subjetivas de sentido por um sistema de signos que a priori apenas libera "estados de coisas" como conteúdo de proposições ${ }^{48}$. Daí

\footnotetext{
${ }^{46}$ APEL, Transformação da filosofia, v. II, pp. 264-265; Transformation der Philosophie, Band II, p. 234.

${ }^{47}$ APEL, Transformação da filosofia, v. II, p. 265; Transformation der Philosophie, Band II, pp. 234-235.

${ }^{48}$ Nos começos do século XX, a lógica matemático-simbólica concebe as palavras como "elementos de cálculo" (Leibniz) de uma linguagem-cálculo intersubjetiva a priori. Para Apel, a radicalização transcendental da ideia da
} 
resulta o problema quanto à expressão de declarações (com identificadores pessoais) ou "atos de fala" (tais como asserções, perguntas, pedidos) que demonstrem a competência comunicativa do ser humano, que precisam tornar-se objeto da referência semântica em uma linguagem científica fisicalista (behaviorista e artificial) ${ }^{49}$. Tal exigência revela, decerto, o que é efetivamente irrefletido na ideia neopositivista de uma ciência unificada objetivista. Aí, na medida em que se pressupõe que um só cientista pode reduzir todos os seres humanos empiricamente existentes a objetos de descrição e da elucidação do comportamento deles, o solipsismo metódico da filosofia linguístico-analítica "não nega a existência de outros sujeitos, mas sim a pressuposição transcendental-pragmática e transcendental-hermenêutica de uma comunidade com outros sujeitos, no que diz respeito ao entendimento de mundo por parte do ser humano e ao seu autoentendimento humano" ${ }^{50}$. Ao negar essa pressuposição, o solipsismo metódico, além de dar sustentação à cisão entre razão teórica e razão prática, colabora na desmobilização da razão prática, impedindo-a de responsabilizar-se pelas consequências da ciência e técnica exigem uma ética universal ${ }^{51}$. Ironicamente, nessa

linguagem unificada se encontra no Wittgenstein do Tractatus. Aí, segundo Wittgenstein, sob a superfície da linguagem ordinária está oculta a "forma lógica" da linguagem universal, a qual possibilita a afiguração intersubjetivamente válida de "estados de coisas elementares" mediante "proposições elementares". Com a atribuição lógica de proposições sensatas a proposições elementares, ele supõe resolvido o problema da comunicação de teores particulares do significado ou validação objetiva de enunciados experienciais. Os significados estão pressupostos no sistema linguístico, que corresponde à "substância" objetual do mundo. A estrutura da linguagem não é nem exprimível, nem passível de discussão pública; ela "se mostra". Como a "forma" da linguagem e do mundo (estado de coisas) é a priori idêntica para todos os usuários da linguagem todo usuário se confronta com o mesmo mundo linguisticamente descritível. Uma vez forma lógica é a condição de transcendental de afiguração linguística do mundo e de qualquer discurso sobre o mundo, não pode haver qualquer discurso metalinguístico (por exemplo, uma reflexão sobre a linguagem em uma pragmática transcendental da comunicação). Assim, por esse viés, resolve-se o problema do solipsismo independentemente da eventual troca de experiências via comunicação ou acordo mútuo quanto ao sentido. Para Apel, essa solução elimina, paradoxalmente, a problemática da subjetividade e da comunicação intersubjetiva e limita a problemática da linguagem aos aspectos sintático-semânticos, separados da dimensão pragmática, considerando apenas a função designativa da linguagem no processo do conhecimento. Problematicamente, a abordagem analítica focaliza a linguagem como um objeto, sem considerar que ela é também, fundamentalmente, condição de possibilidade de conhecer os objetos e, nessa medida, algo não objetivável. Ademais, a linguagem é sempre intersubjetiva, ou melhor, a objetividade da linguagem é garantida pela intersubjetividade, na medida em que não se reduz à relação de um sujeito com objetos mediante sinais, mas consiste sempre num mútuo entendimento de diversos sujeitos a propósito de objetos (APEL, Transformação da filosofia, v. II, pp. 269-270 e 387-395; Transformation der Philosophie, Band II, pp. 238-239 e 341-348).

${ }^{49}$ APEL, Transformação da filosofia, v. II, pp. 265-269 e 278-279; Transformation der Philosophie, Band II, pp. 234-238 e 246-247.

${ }_{50}$ APEL, Transformação da filosofia, v. II, p. 273; Transformation der Philosophie, Band II, p. 242.

${ }^{51}$ APEL, Karl Otto. Necesidad, Dificultad y Posibilidad de una fundamentación filosófica de la ética en la época de la ciência. In: Estudios Éticos. Trad. Carlos Santiago. México: Distribuciones Fontamara, 2004, pp. 126-138. Ver ainda: OLIVEIRA, Sobre a fundamentação' p. 96; HERRERO, F. Javier. Desafios éticos no mundo contemporâneo. In: Síntese, Belo Horizonte, v. 26, n. 84, pp. 5-11, 1999, passim. O cientificismo positivista compreende que a neutralidadde axiológica é conditio sine qua non do saber racional. Por isso, preconiza a separação entre ser-dever, fatos-normas, teoria-práxis, a partir da qual culmina a atribuição de racionalidade ao discurso sobre fatos e de irracional ao discurso sobre normas. Ao ver de Apel, vigora um "maniqueísmo epistemológico" nas democracias ocidentais, que cumpre a função ideológica de legitimar a separação e 
irrefletida negação aparece a questão "fundamental-filosófica": se o conceito de racionalidade é definido no sentido da lógica da ciência, ou para além dos seus limites existe apenas a irracionalidade de decisões discricionárias, ou se trata de um conceito limitado de racionalidade (a ser superado, assim postula Apel).

Curiosamente, a aporia peirceana do cientificismo mostra a encruzilhada do problema-tarefa a ser enfrentado por Apel, a fim de apresentar uma solução filosófica alternativa à redução da racionalidade metódica cientificista - inclusive em relação à sua fonte de inspiração inicial, a semiótica trivalente de Peirce - e, assim, edificar sua proposta de transformação da filosofia. Para Apel, do ponto de vista filosófico, a concepção peirceana relativa à formação de consensos na comunidade de experimentação e interpretação dos cientistas é a primeira noção que permite uma transformação da filosofia dos "grandes pensadores" individuais. Para Peirce, a comunidade dos cientistas cumpre a função de substituir a era do apriorismo solipsista de evidências privadas (filosofias do "eu"), como concretização metodologicamente controlável do sujeito transcendental kantiano, e de construir o consenso acerca da verdade, até então imposto pelo "método de autoridade" que antecede o "método apriorístico" dos grandes pensadores individuais. Em tal medida, essa comunidade de investigação retrata a terceira era da racionalidade metódica da ciência e o âmbito próprio do método experimental das ciências naturais. Com efeito, ao conceber o problema da substituição da autoridade pública e privada pelo consenso alcançado metodicamente no campo da comunidade dos cientistas vinculada ao método experimental das ciências naturais, segundo Apel, a transformação semiótica de Kant preconizada por Peirce não escapa à redução cientificista da racionalidade metódica. A consequência direta dessa redução repercute no problema da fundamentação da moralidade. O próprio Peirce reconhece que, no marco dessa redução, não é possível deduzir a racionalização moralmente (ética) relevante do comportamento humano a partir de uma normatização tecnológica do “esclarecimento de ideias", no sentido da "máxima pragmática". A fim de solucionar o

complementação da vida pública, na qual as justificações morais são substituídas por argumentos pragmáticos de peritos, e da vida privada, na qual reina um "politeísmo axiológico", pois as decisões morais e religiosas estão instauradas na consciência privada. A esse respeito Cortina, citando Conill, esclarece: "esta situação é dilemática porque implica uma alternativa entre: 1) liberdade pessoal e ciência livre, porém sem compromisso intersubjetivo com normas éticas, valores e fins; e 2) uma mediação institucionalizada e fixada dogmaticamente entre teoria e práxis, porém sem oportunidade de mediação baseada na livre decisão da consciência individual" (CORTINA, Adela. Razón comunicativa y responsabilidad solidaria: ética y política em K.-O. Apel. 2. ed., Salamanca: Ediciones Sígueme, 1988, p. 34). Ora, sem a validade intersubjetiva das normas, a obrigatoriedade das convenções pela livre aceitação pode sujeitar-se à manipulação externa (causal) do comportamento, como um poder que impõe seu cumprimento mediante gratificações ou sanções, porque não distingue entre a livre aceitação baseada em convenções democráticas e, por exemplo, um compromisso voluntário entre os membros de uma máfia. 
problema da razão prática na era da ciência, resta aí inverter o caminho: pressupor a racionalidade moral para que se possa proceder à fundamentação de uma lógica científica normativa. De tal modo, a aporia do cientificismo peirceano, segundo Apel, põe a nu o problema central de uma transformação da filosofia na era da ciência ${ }^{52}$.

No entender de Apel, a solução para o problema da filosofia na era da ciência é, duplamente, malograda. Tal fracasso se evidencia tanto em relação à pretensão de superar a filosofia mediante a sua redução à ciência ou à lógica científica, quanto em relação à insistência de recorrer à "grande filosofia", ignorando o paradigma do método científico e a sua racionalização parcial da comunicação humana. Ironicamente, o regresso à "grande filosofia", passando ao largo da ciência na epocalidade da ciência, tende a perder-se em meio ao irracional ou em um descomprometimento privado à causa do progresso da ciência ${ }^{53}$. Já as tentativas de superar a filosofia pela via da redução cientificista incidem em falácias abstrativas, tal como se mostra no caso da concepção de "sociedade aberta" desenvolvida por Karl R. Popper no âmbito do racionalismo crítico. O exemplo contemporâneo mais nítido da revitalização da aporia peirceana na filosofia é a concepção de "sociedade aberta" de Karl R. Popper, orientada pela metodologia científica. Popper, como Peirce, pretende extrapolar o paradigma normativo do método científico em vista de uma filosofia da sociedade e do progresso histórico ética e politicamente relevante. Mas, diferentemente do percurso de Peirce (a transformação semiótico-pragmática de Kant), o enfoque metodológico de Popper derruba, em grande medida, a reflexão sobre os pressupostos transcendentais do conhecimento. Na avaliação de Apel, na estratégia popperiana de extrapolação do paradigma científico coexistem, lado a lado, dois tipos de falácias abstrativas, que surgem sem qualquer explicação ${ }^{54}$.

A primeira delas é a falácia cientificista-tecnicista, em que Popper tenta converter a um tempo o ideal metódico da ciência unitária e a tecnologia social (social engineering) em fundamento da racionalidade crítica na política social de uma "sociedade aberta". Não se pode ser ingênuo a ponto de prescindir, na sociedade industrial moderna, de uma tecnologia social baseada nas ciências empírico-analíticas. O que é problemático, mesmo do ponto de vista científico-teorético, afirma Apel, é supor que o pressuposto ideal da tecnologia social está no modelo da "sociedade aberta", na qual o maior número possível de cidadãos responsáveis, sob a égide de um convencionalismo crítico, participa da discussão bem informada sobre os fins e

\footnotetext{
52 APEL, Transformação da filosofia, v. I, p. 16; Transformation der Philosophie, Band I, p. 13.

${ }^{53}$ APEL, Transformação da filosofia, v. I, p. 16; Transformation der Philosophie, Band I, p. 13.

${ }^{54}$ APEL, Transformação da filosofia, v. I, pp. 17-20; Transformation der Philosophie, Band I, pp. 14-16.
} 
as normas. De todo modo, supondo a estabilidade da relação entre sujeito e objeto, Popper pensa que o modelo repetível de "tentativa e erro" é suficiente para direcionar todos os processos bem-sucedidos de aprendizagem dos seres humanos, "bem como os avanços obtidos no trabalho intelectual pré-científico, na ciência, na técnica e na política social" ${ }^{55}$, por meio do controle prognóstico do feedback de objetos sociais bem-informados ou espontâneos.

Criticamente, Apel vê esse modelo como uma ficção. Ele ignora que o pressuposto ideal da tecnologia social só pode ser a sociedade em sua real faticidade, tal como ela se compõe em suas estruturas de dominação, com "indivíduos informados e desinformados, manipuladores e manipulados, sujeitos e objetos da ciência e da tecnologia"56. Ironicamente, sob tais circunstâncias, o melhor funcionamento de uma tecnologia social aparece quando se pode reduzir, da maneira mais ampla possível, os efeitos de uma ciência que converte os sujeitos em meros objetos "sem voz" da elucidação empírico-analítica do comportamento. Em face do "sem voz" surge, efetivamente, um problema mais complexo: “organizar a comunicação e interação - em princípio irrepetíveis - dos cidadãos como sujeitos do progresso rumo à 'sociedade aberta', no sentido do princípio da racionalidade crítica"57. Entre outras coisas, isso implica organizar o acordo mútuo intersubjetivo sobre a inevitável objetivação técnico-científica do comportamento humano a serviço de medidas sociotecnológicas. Ressalta-se que essa organização não é ela mesma uma medida sociotecnológica, tampouco pode apoiar-se sobre os resultados da "ciência que tenha, desde o início, feito dos sujeitos desse entendimento mútuo meros objetos da Elucidação empíricoanalítica do comportamento" ${ }^{58}$. Afinal, essa organização trata de fixar em conjunto, sob a base do discurso argumentativo, o sentido e os limites de todas as medidas sociotecnológicas. Para Apel, isso parece indicar a necessidade de recorrer a filosofias da ciência ou teorias epistemológicas que, por não estarem fixadas apenas no problema tecnológico de controle de feedback dos sujeitos e objetos da ciência (e da tecnologia), miram um problema de princípio, consoante à reflexão transcendental sobre as condições de possibilidade e validade de um conhecimento não restrito às ciências naturais e de uma práxis não meramente técnica ${ }^{59}$. Ora, tal necessidade prenuncia, novamente, o horizonte da proposta filosófica de Apel.

A segunda falácia abstrativa se liga à substituição da fundamentação filosófica última por um postulado da crítica virtualmente universal. Para Apel, Popper utiliza esse

\footnotetext{
55 APEL, Transformação da filosofia, v. I, pp. 18-19; Transformation der Philosophie, Band I, p. 15.

${ }^{56}$ APEL, Transformação da filosofia, v. I, p. 17; Transformation der Philosophie, Band I, p. 14.

${ }^{57}$ APEL, Transformação da filosofia, v. I, p. 18; Transformation der Philosophie, Band I, p. 15.

${ }^{58}$ APEL, Transformação da filosofia, v. I, p. 18; Transformation der Philosophie, Band I, p. 15.

${ }^{59}$ APEL, Transformação da filosofia, v. I, pp. 18-19; Transformation der Philosophie, Band I, p. 15.
} 
postulado para dar a impressão de que o ponto de partida da extrapolação do ideal científico do método por parte do racionalismo crítico se situa menos nos métodos das ciências naturais e da tecnologia ligados ao objeto, porém muito mais no método da argumentação crítica, que eleva a comunidade de cientistas à condição de uma "sociedade aberta". Para Apel, o que o racionalismo crítico ignora com facilidade é que, no momento em que a argumentação crítica é elevada à condição de paradigma da "sociedade aberta", já se tem "instituído um interesse cognitivo" e pressuposto o "estabelecimento prático de certos fins como parâmetro (Maßstab) para a argumentação crítica" 60 .

$\mathrm{Na}$ interpretação de Apel, o racionalismo crítico incorpora a ideia de autorrendição (selfsurrender) de Peirce, justamente para indicar o fator de distinção da comunidade científica, e a partir dela passa a defender o programa de uma transformação da filosofia ligada à ciência (uma filosofia metódica), empenhada na ampliação do conceito de racionalidade pela via do exercício metódico do diálogo. A ideia de autorrenúncia peirceana preconiza que cada cientista se apropria por meio de exercícios sistemáticos da capacidade de se abstrair de necessidades e interesses individuais, ao mesmo tempo em que se coloca "como sujeito substituível de experimentos repetíveis e de operações conceptuais lógicomatemáticas, à disposição do progresso institucionalizado rumo à verdade, no âmbito de uma "comunidade ilimitada de pesquisadores""61. Procedendo assim, pressupõe-se que a "crítica" realizada na comunidade argumentativa dos cientistas (da natureza) se refere unicamente às operações conceituais e cognitivas tuteladas pelo interesse cognitivo das ciências naturais, portanto, isenta da contaminação em relação às necessidades e interesses concretos dos seres humanos socializados que, de qualquer modo, constituem a base do interesse cognitivo das ciências naturais.

Concebida de tal modo, segundo Apel, a perspectiva da filosofia metódica configura uma segunda forma de cientificismo, que se manifesta como falácia abstrativa típica da posição do cientificismo tecnocrático. Essa posição pressupõe que a produção e a validade da argumentação e do conhecimento se vinculam a um sujeito elitista da ciência e da tecnologia social, do qual é exigido - eis o núcleo dessa falácia - a abstração daquilo que perfaz a dificuldade do acordo mútuo interhumano (Verständingung) e da emancipação (Emanzipation) almejadas na sociedade concreta. Consequentemente, em vez de o

\footnotetext{
${ }^{60}$ APEL, Transformação da filosofia, v. I, p. 20; Transformation der Philosophie, Band I, p. 16.

${ }^{61}$ APEL, Transformação da filosofia, v. I, p. 20; Transformation der Philosophie, Band I, p. 16.
} 
cientificismo tecnocrático produzir uma sociedade aberta, contraditoriamente, ele concebe a sociedade como objeto de medidas planificadas e reformas tecnológicas ${ }^{62}$.

Frente ao limite imposto pelo paradigma do método científico, Apel propugna a extrapolação da ideia de argumentação crítica referida à validade na comunidade científica. De tal modo, por uma parte, Apel marca sua rejeição à solução malograda dos que pretendem superar a filosofia por meio de sua redução à ciência ou à lógica científica, ou dos que insistem em recorrer à "grande filosofia". Por outra parte, Apel vê que o estreitamento da validade na racionalidade metódica da comunidade científica, longe de sentenciar o fim da filosofia, constitui um campo de possibilidade efetiva para a filosofia, desde que aí ela possa marcar seu autoentendimento (especificidade da atividade filosófica) e extrapolar a ideia de argumentação crítica responsável pela redução cientificista do conhecimento. Em uma perspectiva alargada, a argumentação crítica deve ser institucionalizada "na sociedade real sob a forma de uma comunidade de comunicação, no sentido de um 'devir filosófico do mundo"; o que significa, dessa maneira, "tratar a própria sociedade real - sujeito das necessidades e interesses materiais - ao mesmo tempo como sujeito ideal do conhecimento e da argumentação (do ponto de vista normativo)"63. Em consequência a isso, em primeiro lugar, a sociedade real deixa de ser tratada como mero objeto da ciência e da técnica, tal como ocorre no cientificismo tecnocrático, que pressupõe sorrateiramente um sujeito elitista da ciência e da tecnologia social. Em segundo lugar, a sociedade real, embora não alcance ainda o status de sujeito efetivo da ciência, ao menos na filosofia e nas ciências sociais críticas, passa a constituir-se agora como um objeto que é concomitantemente o sujeito virtual da ciência ${ }^{64}$.

Na contramão do limite interno de uma filosofia orientada pela racionalidade metódica voltada à ciência unitária (e respectiva metodologia unitária), Apel defende que somente a partir da ampliação não-cientificista da ideia de racionalidade metódica, parece razoável pensar os horizontes relativos à concepção de uma "sociedade aberta" e à possível transformação da própria filosofia. Com a extrapolação da ideia da comunidade científica argumentativa, segundo Apel, em vez da filosofia ser entendida apenas como crítica, ela passa a ser concebida como crítica capaz de se assegurar dos parâmetros próprios à crítica, isto é, de suas condições de possibilidade e validade ${ }^{65}$.

\footnotetext{
${ }^{62}$ APEL, Transformação da filosofia, v. I, pp. 21-22; Transformation der Philosophie, Band I, p. 18.

${ }^{63}$ APEL, Transformação da filosofia, v. I, p. 21; Transformation der Philosophie, Band I, p. 17.

${ }^{64}$ APEL, Transformação da filosofia, v. I, p. 21; Transformation der Philosophie, Band I, p. 17.

${ }^{65}$ APEL, Transformação da filosofia, v. I, p. 22; Transformation der Philosophie, Band I, p. 18.
} 
Para Apel, isso é possível a partir de uma filosofia transcendental transformada semioticamente que reflete, primeiramente, sobre o sentido e, por conseguinte, também sobre as implicações do sentido, da argumentação em geral. Essa filosofia preconiza que a situação do discurso argumentativo - na comunidade real de comunicação pressupondo uma comunidade ideal e ilimitada de comunicação - constitui o último, o intranscendível (das letzte, nichthintergehbare). O metodicamente nichthintergerbar (ineliminável, intransponível) na filosofia não é a consciência solitária reflexiva do "eu penso" (Descartes, Husserl), que extrai seus princípios da pura reflexão fora do contexto do ser-no-mundo e da comunicação pública através da linguagem. Ele não é tampouco o pré-reflexivo ser-no-mundo (Heidegger, Merleau-Ponty), ou a práxis da ação comunicativa no mundo da vida. Ele é a praxis da ação da comunicação consensual que compreende a si mesma, no nível do discurso argumentativo, como aquilo detrás do qual não se pode retroceder mais mediante a reflexão ( "als reflexiv nichthinterbehbar”). E nisso, precisamente, reside a legítima transformação do solipsismo metódico 66 .

\footnotetext{
${ }^{66}$ Sobre a tradução de Unhintergehbarkeit, ver o estudo introdutório I (Filosofia e Pragmática da Linguagem) de
} Julio De Zan em: APEL, Semiotica filosofica, pp. 16-17. 


\section{A PERGUNTA PELA CONTRIBUIÇÃO DA SEMIÓTICA TRANSCENDENTAL DE APEL À EDUCAÇÃO: A APARENTE INVISIBILIDADE DA QUESTÃO DA EDUCAÇÃO EM APEL}

Este segundo capítulo analisa o enfoque da educação na obra de Apel. A hipótese inicial é que tal abordagem é deficitária, porém relevante do ponto de vista da reflexão sobre a função ético-política da educação.

\subsection{A suspeita do déficit da educação na filosofia de Apel}

A tentativa de investigar sobre o que a filosofia de Apel afirma ou pode sustentar teoricamente a respeito da educação, em vista de explicitar uma possível contribuição teórica da semiótica transcendental para a fundamentação filosófica da educação, tem como ponto de partida a suspeita de que a filosofia de Apel é deficitária em relação à temática da educação. Essa suspeita emerge à medida que se procede, do ponto de vista da educação, a um inventário dos interesses temáticos tratados nas publicações de Apel. O resultado básico desse levantamento é, por uma parte, a verificação que não há na obra de Apel, ao menos nos principais textos da obra de Apel relacionados à semiótica transcendental e à ética do discurso, uma publicação dedicada específica e sistematicamente à tematização da educação; e, por outra, a identificação de algumas referências avulsas à educação, a princípio, feitas colateralmente ou em apoio à exposição de algum assunto.

A meu ver, esse inventário evidencia uma situação de ambivalência em relação aos interesses de investigação e reflexão circundados nessas publicações, em que vem à tona a percepção inicial de que o objeto educação é quase invisível ou é abordado insuficientemente na obra de Apel. Ele faculta a hipótese interpretativa geral de que a questão da educação "aparece" na filosofia de Apel de maneira colateral e enviesada, porque ligada à elaboração de uma teoria crítica no marco da Escola de Frankfurt dos interesses do conhecimento e à tentativa de resolução do problema da parte $\mathrm{B}$ da ética do discurso em referência à história. $\mathrm{O}$ fator gerador dessa percepção é a constatação de que a obra de Apel não dispõe, até então, de um texto específico para tratar estritamente da problemática da educação e da sistematização de uma compreensão filosófica do significado intersubjetivamente válido da educação à luz da semiótica transcendental. Por certo, esta lacuna não obsta a tentativa de investigar a 
pergunta acerca da possível contribuição da semiótica transcendental no sentido de uma fundamentação filosófica da educação. Com efeito, é preciso considerar que, em alguma medida, essa lacuna constitui um fator limitador para o objetivo que visa a correlacionar semiótica transcendental e educação. Ante tal constatação, não se pode menosprezar a dificuldade de averiguar o grau de importância dispensada por Apel à educação e de inteligir o porquê de ele não ter desenvolvido suficientemente na arquitetônica de sua proposta filosófica uma análise sistemática da questão da educação.

Interessantemente, essa suspeita de déficit é reforçada quando se observa, por contraste, a diversidade de focos temáticos circundados nas publicações de Apel. Vários ensaios visibilizam o empenho de Apel no sentido de participar do debate teórico afeto a assuntos da nossa contemporaneidade, tratando de questões políticas, econômicas, jurídicas, ecológicas, desportivas, entre outras ${ }^{67}$. Nessas publicações, ele procura repercutir, em sua vertente de aplicação, a fundamentação filosófica da semiótica transcendental, justamente por supor que essas questões demandem uma resolução consensual dos conflitos fundamentada em uma ética da "corresponsabilidade" (reciprocity responsability) ${ }^{68}$. Quanto a isso, é presumível que, junto com a falta de um texto específico para tratar da educação, a constatação da abordagem seletiva de alvos teóricos específicos sobreleva a suspeita de uma possível invisibilidade ou insuficiência teórica da questão da educação na filosofia de Apel. Por seu turno, essa suspeita suscita um questionamento que parece consignar a hipótese de que a proposta filosófica de Apel comporta uma limitação indevida. A meu ver, esse questionamento reflete a suposição de que, por trás desse possível déficit, parece subsistir o problema do descolamento (fissura) entre a problemática filosófica da semiótica transcendental, suposta por Apel como tarefa primeira em função da natureza antecipativa do saber da filosofia, e a problemática concernente a pensar o significado público da educação, a ser enfrentada em um momento subsequente com base filosófica.

\footnotetext{
${ }^{67}$ Os seguintes textos - publicados como artigos e depois reunidos em um livro - exemplificam a importância conferida por Apel à tematização de assuntos diversos e a outras áreas do conhecimento: "Kant, Hegel e o problema actual dos fundamentos normativos de moral e direito" (1986), "Significado ético do desporto na perspectiva de uma ética do discurso universalista" (1986) e "Solução de conflitos na era atômica enquanto problema de uma ética da responsabilidade" (1987), "De regresso à normalidade? Ou poderíamos nos ter aprendido algo de especial a partir da catástrofe nacional? O problema da passagem da história (universal) para a moral pós-convencional a partir de uma perspectiva especificamente alemã" (1988). Ver: APEL, Karl Otto. Ética e responsabilidade: o problema da passagem para a moral pós-convencional. Trad. Jorge Telles Menezes. Lisboa: Instituto Piaget, 2007, respectivamente, pp. 39-66, 163-188, 189-208 e 259-341.

${ }^{68}$ APEL, Karl Otto. The response of discourse ethics: to the moral challenge of the human situation as such and especially today. Louvain: Peeters, 2001, pp. 90-94.
} 
Vale ressaltar que aqui se levanta essa hipótese de fissura, mesmo tendo em conta o entendimento de Apel a respeito da natureza específica da filosofia. Ora, Apel entende que a forma do discurso teórico é o modo próprio da contribuição "impotente" da filosofia ao mundo. Em sua "impotência", a filosofia, até que ocorra sua "superação" por meio da sua "realização" na história, reflete o momento da antecipação contrafática do consenso ideal de todos os seres humanos. Em sua especificidade, cabe à filosofia manter-se na posição de um "discurso teórico" "capaz de antecipar, como instância de justificação e validação, o consenso ideal [idealer Konsensus] da humanidade emancipada e de contrapor esse consenso, a título de experiência, a todo tipo de dogmatização" ${ }^{69}$. Aqui, a tomada de partido da razão prática deve ser no sentido de "suprassumir a contradição entre o risco do dogmatismo, que a práxis emancipadora tem que tomar para si, e a vontade de emancipação no sentido da maioridade da razão"70. Para isso, ela deve ser reduzida por intermédio da "reflexão teórica ao status da sugestão hipotética", que, em seu anseio crítico, "representa a tentativa de antecipar a posição ocupada pela comunidade ilimitada e ideal de comunicação na comunidade dos argumentantes, e de conferir validação a essa posição, opondo-se às idiossincrasias do presente" ${ }^{\prime 71}$. O "discurso teórico" da filosofia engajado do ponto de vista prático implica, portanto, um engajamento na direção da realização histórica da comunidade ilimitada de comunicação.

O aspecto surpreendente dessa suspeita de déficit em relação à educação é que tal suspeita parece estar presente mesmo nos desdobramentos em que Apel procura solucionar as dificuldades referentes à aplicação de sua proposta de filosofia prática, ou seja, nas tentativas empreendidas em vista de resolver o problema de uma aplicação referenciada à história da ética do discurso (parte B) como ética da responsabilidade. Sabe-se, conforme atesta o próprio Apel em seu relato autobiográfico, que ele tem canalizado "desde muito tempo"72 suas preocupações teóricas fundamentais no rumo do campo ético-político, sob o objetivo de elaborar e aperfeiçoar uma proposta de filosofia prática (ética), particularmente, uma versão da ética do discurso provida de fundamento último. Ocorre que, justamente aí, na exposição ${ }^{73}$ de Apel sobre a questão da aplicação da fundamentação abstrata da ética do discurso à história

\footnotetext{
${ }^{69}$ APEL, Transformação da filosofia, v. I, p. 13; Transformation der Philosophie, Band I, p. 10.

${ }^{70}$ APEL, Transformação da filosofia, v. II, p. 263; Transformation der Philosophie, Band I, pp. 232-233.

${ }^{71}$ APEL, Transformação da filosofia, v. II, p. 263; Transformation der Philosophie, Band I, p. 233.

72 APEL, Antropos, p. 19.

${ }^{73}$ Sobre essa exposição, ver: APEL, The response of discourse ethics, pp. 77-115 (capítulos 7 e 8). APEL, Karl Otto. Ética do discurso e as coerções sistêmicas da Política, do Direito e da Economia: uma reflexão filosófica sobre o processo de globalização. Trad. F. Javier Herrero. In: HERRERO, F. J. e NIQUET, Marcel (Ed.). Ética do discurso - novos desenvolvimentos e aplicações. Minas Gerais: FAFICH-UFMG, 2000, pp. 201-223.
} 
e à comunidade real de comunicação em sua urdidura com as coerções sistêmicas da política, do direito e da economia, a lacuna da problemática da educação parece ser mais notória e, até certo ponto, incompreensível. Aqui, delimitadamente, a referência que embasa essa consideração hipotética é a exposição de Apel sobre a ética do discurso e as coerções sistêmicas da política, do direito e da economia, em que ele trata do complemento da fundamentação última da ética do discurso por meio das coerções objetivas, restritivas da moral, das instituições ou subsistemas da sociedade. Aqui, presume-se que o teor dessa consideração se aclara à medida que se toma em consideração a concepção da ética do discurso como ética da responsabilidade, a fundamentação pragmático-transcendental e a estruturação da ética do discurso nas partes A e B. Como esses elementos descritivos da filosofia moral de Apel compõem o objeto do oitavo capítulo deste trabalho, nesse tópico, considera-se suficiente assinalar o teor geral do problema da suplementação ${ }^{74}$ da ética do discurso por meio de discursos práticos nas esferas do direito, política e economia para viabilizar a corresponsabilidade e, nisso, contextualizar a hipótese da ausência da esfera da educação no tocante à proposta de superação desse problema.

Apel concebe a ética do discurso tendo como pano de fundo a tese de que a atual situação de crise da humanidade, em função das consequências tecnológicas promovidas pela ciência e das ameaças à sobrevivência de todas as formas de vida no planeta, constitui um problema ético $^{75}$. Para Apel, essa crise traz consigo a situação paradoxal da ética na época da ciência $^{76}$, ao passo que a razão prática é marcada a um só tempo pela necessidade e pela impossibilidade de fundamentar ultimamente uma filosofia prática com validade universal. Em nossa época, aporeticamente, é cada vez mais notória a carência de uma ética vinculadora para toda a humanidade e, ao mesmo tempo, é cada vez mais complexa a tarefa filosófica de uma fundamentação racional da ética. Por uma parte, a necessidade de uma ética universal se apresenta em razão da circunstância em que, pela primeira vez e em escala mundial, a humanidade se defronta com o risco comum de autodestruição (causada por conflitos bélicos, fome, crise ecológica) das condições naturais e culturais de existência. Tal necessidade representa, segundo Apel, a exigência de macroética da humanidade. Por outra, no campo epistemológico, a compreensão de uma ciência valorativamente neutra obsta a fundamentação racional da ética, uma vez que, nessa era, a ideia de validade intersubjetiva é reduzida à ideia

\footnotetext{
${ }^{74}$ APEL, The response of discourse ethics, 2001, pp. 83-90.

${ }^{75}$ APEL, Karl Otto. Estudos de moral moderna. Trad. Benno Dischinger. Petrópolis: vozes, 1994, pp. 193-197.

76 APEL, Estudos de moral moderna, pp. 72-75. OLIVEIRA, Manfredo A. de. Ética e Racionalidade Moderna. São Paulo: Loyola, 1993, pp. 9-39.
} 
cientificista da objetividade. Ante essa situação totalmente nova criada pelo homem com base na racionalidade técnico-instrumental, torna-se cada vez mais urgente, com a ajuda da "razão prática", a "responsabilidade da razão". Em geral, considera-se que a cultura ocidental é uma cultura da razão, pois a razão constitui o foco ordenador de todos os discursos. Na sociedade moderna, a razão se torna essencialmente teórica; ela submete todos os âmbitos da vida a uma teorização. Ocorre que aí a ciência do ethos, isto é, a ciência que visa a confrontar o agir humano (práxis) com as exigências universais da razão, aliás, elaborada desde os primórdios da cultura ocidental, não logra o mesmo êxito que a ciência da natureza. E é precisamente em virtude do desenvolvimento atual das ciências e da técnica que emerge o problema da responsabilidade da razão, ou seja, a exigência de fundar uma responsabilidade pelo alcance de dimensões planetárias que a ciência e a técnica estão dando à atividade humana ${ }^{77}$.

Conforme Lima Vaz, o contexto de crise cultural e espiritual traz duas consequências problemáticas para o "bem-estar moral" da civilização ocidental. O pano de fundo dessa crise é o fenômeno cultural e espiritual da "desrealização" que atinge os paradigmas éticos transmitidos pela tradição. Isso ocorre porque aí os problemas de forma alcançam uma primazia mais ampla sobre os problemas de conteúdo. Vê-se isso na distinção vigente entre ciências formais (metaciências), que têm por objeto as formas do saber e sua articulação em formas de linguagens puras (domínio da lógica e da matemática) ou aplicadas (domínio da lógica e da epistemologia das diversas ciências), e ciências reais, que têm por objeto a realidade investigada e formalizada numa linguagem específica. No caso das ciências formais, o objeto e a forma se identificam; no das ciências reais, o objeto e a forma se distinguem. A primeira consequência, em decorrência da instrumentalização da forma em nossa época, isto é, da feição tecnológica e do domínio operatório, é a vigência de uma filosofia prática em termos de uma metaética, no sentido de uma instrumentalização da lógica e da linguagem éticas que, indiferentes a seu conteúdo real, servem "à expressão de um universal relativismo dos valores, de acordo com as necessidades e fins subjetivos ou com os interesses ideológicos dos agentes éticos"78. Ligada à primeira, a segunda consequência dessa crise concerne à renúncia da tradição da busca de uma concepção filosófica para a fundamentação e explicação da conduta ética. No lugar dessa busca, a ética é derivada do âmbito das ciências humanas e, por isso, considerada em termos de padrões culturais ou de

\footnotetext{
${ }^{77}$ HERRERO, F. Javier. A ética do discurso de K.-Otto Apel. In: HERRERO, F. J. e NIQUET, Marcel (Ed.). Ética do discurso: novos desenvolvimentos e aplicações. Minas Gerais: FAFICH-UFMG, 2000, p. 10.

${ }^{78}$ VAZ, Henrique C. de Lima. Escritos de filosofia IV: introdução à ética filosófica 1. São Paulo: Loyola, 1999, p. 36.
} 
categorias psicológicas e sociológicas. Por conseguinte, essa derivação resulta em corroborar o pressuposto de um relativismo ético ${ }^{79}$.

Apel concebe a ética do discurso como uma ética da responsabilidade. No rumo desse sentido, Apel preconiza a ideia de responsabilidade em um duplo sentido ${ }^{80}$ : a responsabilidade decorrente da força coercitiva dos subsistemas sociais da política, do direito e da economia, quer dizer, a responsabilidade imputável ao indivíduo no marco das instituições; e a responsabilidade como corresponsabilidade ou responsabilidade solidária pelas consequências e efeitos colaterais das ações humanas coletivas. Esse duplo sentido se justifica em razão do intento apeliano de elaborar uma filosofia prática capaz de fazer a transição de uma moralidade convencional (responsabilidade) para uma moralidade pósconvencional (corresponsabilidade). Apel entende a passagem para uma moral pósconvencional em termos de uma macroética ${ }^{81}$, ou seja, de uma filosofia prática fundamentada pragmático-transcendentalmente capaz de oferecer uma resposta à crise de fundamento válido intersubjetivamente que atinge a ética na época da ciência ${ }^{82}$. A convicção de Apel é que a resolução dos problemas ético-políticos contemporâneos passa pela mediação entre a fundamentação abstrata da ética do discurso para a corresponsabilidade e a responsabilidade imputada à sociedade pelos subsistemas funcionais da política, do direito e da economia de mercado $^{83}$. Nesse rumo, ele procura concatenar a fundamentação contrafática da semiótica transcendental, em nível de uma macroética relativa à corresponsabilidade intersubjetiva pelas consequências das ações humanas coletivas, com o viés da fundamentação fática desses subsistemas, em nível institucional.

Como contraponto à paradoxalidade da ética na época da ciência, Apel defende a concepção de uma fundamentação pragmático-transcendental última, de caráter especificamente filosófico e derivada por autorreflexão do a priori do discurso argumentativo, como fundamento universal da ética. Apel considera que a fundamentação do a priori do discurso argumentativo representa a possibilidade de mediação entre razão teorética e razão prática, sendo que: a) no plano da filosofia teórica, o a priori do discurso argumentativo funda uma teoria fenomenológica da correspondência (ou da "evidência da correspondência") como

\footnotetext{
${ }^{79}$ VAZ, Escritos de filosofia IV, pp. 36-37.

${ }^{80}$ APEL, The response of discourse ethics, pp. 100-101. APEL in: Ética do discurso: novos desenvolvimentos e aplicações, pp. 201-202.

81 APEL, Ética e responsabilidade: o problema da passagem para a moral pós-convencional, pp. 12-14. CORTINA, Razón comunicativa y responsabilidad solidaria: ética y política em K.-O. Apel, pp. 25-35.

${ }^{82}$ APEL, The response of discourse ethics, pp. 101-102. APEL in: Ética do discurso: novos desenvolvimentos e aplicações, pp. 201-202.

83 APEL, The response of discourse ethics, pp. 95.
} 
parte de uma teoria consensual da verdade, que visa a alcançar uma mediação entre a evidência referida à consciência (filosofia da subjetividade moderna) e a intersubjetividade relativa ao uso linguístico (hermenêutica e pragmática da linguagem) ${ }^{84}$; b) no plano da razão prática, Apel apregoa que a autorreflexão sobre a estrutura a priori do discurso fornece as normas que, sendo pressupostas como condições (fundamentos últimos) de possibilidade dos discursos práticos e compartilhadas universalmente pelos parceiros do discurso em absoluta igualdade de direitos, engendram a corresponsabilidade primordial de todos os seres humanos pelas consequências das atividades coletivas. Essas normas devem ser entendidas no sentido de uma macroética, cumprindo uma função pública acima das instituições ou subsistemas de coerção social, posto que ela fornece o marco normativo intranscendível para o funcionamento racional das instituições e subsistemas da sociedade. Na solução de Apel, a fundamentação desenvolvida no horizonte da semiótica transcendental, ao passo que configura uma espécie de metainstituição do discurso filosoficamente relevante, a rigor, uma fundamentação já sempre pressuposta (idealmente) pela racionalidade teórica e pela ação ética, representa a contribuição primordial da reflexão filosófica para a resolução dos problemas da humanidade, particularmente nos âmbitos institucionais da política, do direito e da economia.

\footnotetext{
${ }^{84}$ NICOLÁS, Juan A. Teoría de la verdad consenso-evidencial y teoría de la verdad fenomenológico-real. In: FERNÁNDEZ, Domingo Blanco et al. (Ed.). Discurso y realidad: en debate con K. - O. Apel. Madrid: Editorial Trotta, 1994, pp. 144-156. Sobre a teoria da verdade em Apel, retoma-se aqui o esclarecimento de que Apel atribui ao termo consenso dois sentidos diferente: a) consenso (Verständigung) enquanto pressuposto transcendental ou condição de possibilidade a priori do sentido e da compreensão linguísticos. O consenso concerne ao acordo em relação ao qual os seres humanos já se encontram sempre enquanto dotados de competência comunicativa; b) consenso enquanto telos último que se pretende alcançar em todo processo comunicativo. Nesse sentido, o consenso conota o caráter normativo e crítico de uma ideia regulativa, em sentido kantiano, ou seja, como um princípio procedimental discursivo, à universalização dos interesses in the long run. $\mathrm{O}$ consenso cumpre a função criteriológica à medida que, em seu caráter regulador, ele promete tomar em consideração ("zu tragen verspricht", cf. APEL, Teoría de la verdad y ética del discurso, p. 64. APEL, Fallibilismus, Konsenstheorie der Wahrheit und Letztbegründung. In: Philosophie und Begründung, p. 138) incorporar todos os distintos critérios fáticos disponíveis de verdade (por exemplo, correspondência, coerência, evidência, êxito, entre outros) e, ao mesmo tempo, exige uma síntese entre eles, tanto para cada consenso fático quanto para o consenso ideal in the long run. No sentido concebido por Apel, o consenso exige que se mantenha aberta a possibilidade de consensos fáticos ulteriores, para que possam - em sua reserva falibilista, porém no patamar de uma perspectiva "melhorista" - ser complementados em vista de alcançar a referência última do consenso ideal. Procedento assim, só é possível esperar disso, a meu ver, aproximações assintóticas à verdade, sem possuir a verdade de uma vez por todas (cf. AQUINO, José Moacir de. O problema da verdade: a aporia criteriológica da teoria metafísico-ontológica da verdade como correspondência segundo Karl Otto Apel. In: AQUINO, J. M. de; NUNES, Marcelo A.; MELO, Ricardo Pereira (orgs.). Filosofia contemporânea em debate. Campo Grande: UFMS, 2013, pp. 60-61).
} 
Há que se ter em conta que o hibridismo ${ }^{85}$, ou seja, a dualidade de planos, constitui a marca principal da ética do discurso de Apel. Essa dualidade de planos se explica em função da estruturação da ética do discurso num a priori dialético. De um lado, a razão prática se consubstancia pela ideia de que existe um fundamento filosófico último, portanto, uma base de fundamentação não volátil. Aqui, o a priori diz respeito ao princípio fundamental ideal concernente a uma fundamentação pragmático-transcendental final e contrafática da ética, que é fruto da autorreflexão sobre as condições implícitas do discurso argumentativo e, como tal, refletem as normas de interação de uma comunidade de comunicação ideal. De outro lado, em seu campo de aplicação, a razão prática se encontra limitada pelas condições históricas, contra as quais deve reajustar-se e lançar contraestratégias para efetivar a razão na história. Aqui, trata-se do a priori da faticidade, isto é, das formas de vida históricas da comunidade de comunicação real. A característica desse a priori é a diferença, posto que nele já estão pressupostas as condições de aplicação da ética do discurso - no sentido de uma ideia regulativa, uma "moralidade substancial" representando o "racional moral como real", porém, ao mesmo tempo, nunca estão inteiramente realizadas as condições de aplicação reais e ideais da ética do discurso. Em meio à dialeticidade da ética do discurso, a possibilidade do universalismo ético se enraíza na parte $\mathrm{A}$ da ética discursiva, referente à estrutura transcendental da argumentação constituinte da fundamentação universal da moralidade, que se projeta na história, em sua parte $\mathrm{B}$, como meta a ser atingida in the long run na comunidade real de comunicação ${ }^{86}$.

Para projetar a descoberta da fundamentação pragmático-transcendental última na história, como dito, Apel tem buscado suplementar a ética do discurso. Fundamentalmente, ele pensa que a resolução dos problemas ético-políticos passa pela mediação entre a fundamentação abstrata da ética do discurso para a corresponsabilidade e a responsabilidade imputada à sociedade pelos subsistemas funcionais da política, do direito e da economia de mercado ${ }^{87}$. E para viabilizar essa mediação, ele tem procurado resolver o problema da aplicação da fundamentação abstrata da ética do discurso "no mundo real" ${ }^{88}$ (parte B da ética do discurso referente à história) por meio da suplementação ${ }^{89}$ da ética do discurso com a

\footnotetext{
${ }^{85}$ NIQUET, Marcel. Ética do discurso como teoria moral realista. O que isso significa? In: HERRERO, F. J. e NIQUET, Marcel (Ed.). Ética do discurso: novos desenvolvimentos e aplicações. Minas Gerais: FAFICHUFMG, 2000, pp. 75-76.

${ }^{86}$ APEL, Teoría de la verdad y ética del discurso, pp. 147-184.

${ }^{87}$ APEL, The response of discourse ethics, pp. 107-115.

${ }^{88}$ APEL, The response of discourse ethics, pp. 77-78.

${ }^{89}$ APEL, The response of discourse ethics, pp. 83 e 92.
} 
dimensão de responsabilidade exigida pelos subsistemas funcionais da política, do direito e da economia de mercado. Nessa solução, Apel vislumbra tanto a interdependência entre os subsistemas funcionais de coerção social da política, do direito e da economia, quanto a necessidade de que tais subsistemas sejam suplementados, filosoficamente, pela fundamentação última da ética do discurso, ou seja, pelos pressupostos intranscendíveis do discurso argumentativo. $\mathrm{Na}$ arquitetura híbrida da ética do discurso, tal suplementação representa a saída para superar o problema da implementação do ideal normativo da moralidade da corresponsabilidade, correspondente à parte da fundamentação abstrata da ética do discurso (parte A), na história (parte B da ética do discurso concernente à comunidade real de comunicação). Basicamente, Apel pensa a ideia de suplementação no sentido de uma vinculação entre a responsabilidade exigida por esses subsistemas e a corresponsabilidade decorrente dos pressupostos do diálogo ideal da comunidade de comunicação.

O foco central dessa suplementação é a pretensão de assegurar as condições históricas que possam factibilizar uma ética da comunicação responsável, precisamente porque as condições de aplicação do princípio fundamental ideal - "age assim como se fosse membro de uma comunidade de comunicação ideal" - não estão historicamente realizadas. Apel entende que exigir o cumprimento do princípio ideal de uma ética do discurso sem tratar do problema das condições de aplicação da ética à história pode levar: a) ou à adoção de uma regra ético-opinativa, cuja responsabilidade fica a critério de Deus, tal como em relação ao cumprimento incondicional do imperativo categórico de Kant; b) ou à irresponsabilidade, se se imputa como dadas as condições de aplicação do princípio do discurso, o que depende de negociações entre sistemas de autoafirmação. Salienta-se que, para Apel, o problema da aplicação responsável da ética do discurso não se equipara ao conhecido problema da aplicação de normas universais a situações concretas, que acaba sendo conduzido pela “capacidade de julgar" (phronesis). Pelo contrário, o problema da parte fundamentadora B (relativo à história) da ética do discurso trata do problema da aplicação conveniente da moral universalista a partir da circunstância em que a regulação consensual de todos os conflitos de interesses não é, em princípio, possível mediante "discursos práticos". Apel vê a diferença entre o problema da aplicação de normas morais e o da aplicação relativa à história da ética do discurso como o ponto central em que se demarca a passagem da moral convencional para a pós-convencional. No tocante ao problema da aplicação de normas morais, as condições sociais de aplicação das regras se formam simultaneamente com a moral convencional e a partir das formas de existência (jogos linguísticos ou costumes). Já o problema da aplicação relativa à história da ética do discurso implica desenvolver a perspectiva de uma ética pós- 
convencional, posto que se trata de produzir, antes de tudo, as condições sociais para a prática de "discursos práticos", ou seja, colaborar responsavelmente na sua realização em longo $\operatorname{prazo}^{90}$.

Na direção da constatação hipotética de uma invisibilidade da esfera da educação na ética da responsabilidade de Apel, provocativamente, é possível afirmar que causa perplexidade - quer dizer, o espanto do qual se nutre o ato de filosofar, a vontade de conhecer a razão mais fundamental do existente velado $-o$ fato de que Apel incorpora suplementarmente os âmbitos do direito, da política e da economia de mercado em sua solução para o problema da aplicação da ética do discurso na história, porém não trata sobre a produção das condições para a realização de discursos práticos (éticos) especificamente relacionados ao campo da educação. Vendo isoladamente o teor dessa solução, é possível especular vagamente sobre a possibilidade de entender que, para Apel, a esfera da educação pode ser entendida como um campo de necessidade social dissolvido e subsumido pelos subsistemas funcionais de coerção da sociedade do direito, da política e da economia de mercado, que são incumbidos da função de regular a responsabilidade pública em sua dimensão fática. Como tal, o âmbito da educação configura uma esfera da sociedade sem autonomia específica em relação a tais subsistemas; assim, presume-se que educação se define na esteira desses subsistemas sociais. A supor isso, é possível imaginar que a suposta invisibilidade da educação na filosofia de Apel pode ser entendida como um reflexo do lugar colateral que cabe à educação em meio a esses sistemas de coerção social. Pelo que parece, essa especulação tende a ficar em aberto neste trabalho, por falta de elementos para um posicionamento preciso.

É possível assinalar duas razões para a perplexidade em virtude da solução presente na referida exposição: não se observa uma referência direta e sistemática a respeito de qual instância social compete a função de "transformar didaticamente" a trama da normatividade ideal da comunidade de comunicação com a normatividade fática dos subsistemas da política, do direito e da economia. Igualmente, nota-se que não se trata aí acerca de qual instância social cabe a função de conduzir a formação para a corresponsabilidade, seja em nível de uma macroética (corresponsabilidade), seja em nível institucional (responsabilidade fática fundada nas coerções dos subsistemas da sociedade). Quanto a essas observações, importa salientar que o fator que dimensiona tal perplexidade é o

\footnotetext{
${ }^{90}$ APEL, Ética e responsabilidade: o problema da passagem para a moral pós-convencional, respectivamente, pp. 11-15.
} 
alcance prático pretendido por Apel em sua solução para o problema da aplicação da ética do discurso na história. Em Apel, essa solução ultrapassa o caráter de uma proposta meramente especulativa, ao passo que se projeta como contribuição para o enfrentamento dos problemas institucionais da política, do direito e da economia. Por isso, resulta questionável que Apel desenvolva a semiótica transcendental como um paradigma de prima philosophia, pretendendo com ela solucionar o problema das condições de validade intersubjetiva do conhecimento teórico e da ação ética, porém, justamente em razão do alcance dos possíveis desdobramentos envolvidos em tal pretensão, passe ao largo de uma abordagem direta e aprofundada da problemática da educação, que é constitutiva da realidade do sujeito e da coletividade.

\subsection{A transição prenunciada da filosofia de Apel à educação}

A verificação preliminar e hipotética de uma lacuna na obra de Apel no que tange à educação, em um primeiro momento, abre espaço para um questionamento sobre a relevância e o significado da educação na filosofia de Apel. Dito com certo exagero alegórico, a tentativa de identificar o loco da educação na filosofia de Apel se assemelha à tentativa de entrecruzar os picos de duas montanhas contíguas, porém tendo que amarrar por conta própria os fios condutores entre elas para tanto. A propósito do exposto, o ponto de partida desse questionamento pode ser suposição sobre o déficit no campo da razão prática, perguntando: se Apel reflete sobre a conexão entre a "fundamentação filosófica última", no sentido de uma "metainstituição" das normas já pressupostas como condições de possibilidade dos discursos práticos, e o problema das coerções objetivas das instituições ou subsistemas da política, do direito e da economia de mercado, entendendo-o como um problema específico da cultura (da parte B da ética do discurso), então por que não integra aí o campo da educação? A fundamentação filosófica última é aplicável à educação? Se ela for aplicável, tal aplicação constitui uma tarefa posterior, a ser assumida na dimensão de uma filosofia da educação, como reflexão sobre os pressupostos e fundamentos irrecusáveis de todo processo educativo?

Indaga-se ainda o seguinte. É possível tratar do problema da cultura sem tratar da problemática da educação? Ou seja, é possível esperar a efetivação da moralidade - isto é, das pretensões de validade do pensar e agir humanos (verdade, veracidade, correção normativa e sentido) - prescindindo de uma abordagem teórica prioritária que trate da formação nos valores que engendram a responsabilidade recíproca no âmbito da vida pública? Por que a 
educação não figura como um possível subsistema responsável pela formação da responsabilidade para a vida pública? É o caso de supor-se que as funções da educação, tais como, socialização, formação humana e capacitação profissional, possam ser diluídas difusamente dentro do circuito dos subsistemas de coerção da sociedade da política, do direito e da economia? Acaso Apel pensa que a esfera da educação constitua uma espécie de dispositivo colateral e secundário da sociedade, cuja efetividade possa ser levada a reboque da política, do direito e da economia? Ademais, considerando os múltiplos focos temáticos dos ensaios de Apel, o fato de Apel não privilegiar a tematização da questão da educação em suas publicações é suficiente para indicar que a esfera da educação "ocupa", em seu programa filosófico de teoria crítica, uma posição de relevância secundária, portanto, menos premente em relação a outras demandas da sociedade (questões políticas, econômicas, jurídicas, ecológicas, desportivas)? Ante este labirinto de indagações, é preciso assinalar que elas cumprem a função de espelhar, de forma exemplificativa, a hipótese de um possível vácuo na filosofia de Apel. Mais que isso, é concomitante a ela a consideração de que esse suposto vácuo não faz jus ao horizonte da problemática da transformação semiótica da filosofia transcendental preconizada por Apel e tampouco à relevância da problemática da educação para a humanidade. A análise do transfundo dessas problemáticas demonstra que elas se entrelaçam e, por isso, parece ilógica a tentativa de escalonar para um segundo momento, tal como algo posterior à elaboração das bases filosóficas do conhecimento, exigência de fundamentação da responsabilidade no âmbito da educação.

Quando se considera que a esfera da educação perpassa todo o âmbito históricocultural, logo se constata que ela concerne a uma questão fundamental para toda a humanidade. De modo essencial, a educação não apenas condiciona todas as facetas da existência propriamente humana, mas é, graças a ela, que o homem se torna efetivamente humano. Desde a transmissão dos costumes tribais até a utilização da cibernética, a humanidade se defronta com a discussão relativa ao processo educativo, buscando a adequação dos meios (por exemplo, adestramento, aprendizagem, iniciação) para alcançar os fins desse processo (por exemplo, formar o cidadão ideal, o profissional, o conformista, o revolucionário, o crítico $)^{91}$. Nos termos de Dussel, a educação é constitutiva da ontologia do homem. Nesse sentido ontológico do processo formativo, a educação conota "a arte de tornar o homem ético" (sittlich), isto é, conforme o costume de um povo. A educação reflete o cuidado perante a novidade ontológica (prole, criança) que renova o mundo velho, que deve

${ }^{91}$ GILES, Thomas Ransom. Filosofia da educação. São Paulo: EPU, 1983, pp. 01, 11 e 28. 
ser integrada aos costumes (ethos) e indústrias de um povo, quer dizer, educada na cultura ${ }^{92}$. Em sentido lato, a problemática da educação, cujo teor diz respeito à vida humana em sua integralidade, trata do processo que objetiva promover a integração do singular, como membro crítico e responsável, em meio à intersubjetividade dos homens e ao mundo ${ }^{93}$.

Em uma compreensão geral, educar significa "alcançar a pessoa naquilo que lhe é mais específico, no seu ser humano, isto é, na sua intelectualidade, na sua afetividade, nos seus hábitos, para levá-la à realização de um ideal"94. A educação lida com os "recémchegados" ao mundo e sua efetiva possibilidade de iniciar algo novo no mundo ${ }^{95}$. A atividade educativa é marcada pela tensão entre a responsabilidade pela formação da singularidade "livre desenvolvimento de qualidades e talentos pessoais"; "singularidade que distingue cada ser humano de todos os demais, a qualidade em virtude da qual ele não é apenas um forasteiro no mundo, mas alguma coisa que jamais esteve aî" 96 - e a responsabilidade pela conservação e transformação do mundo comum. Concretamente, o processo educativo tem início no seio da

${ }^{92}$ DUSSEL, Enrique D.. Para uma ética da libertação latino-americana III: erótica e pedagógica. Trad. Luiz João Gaio. São Paulo: Loyola \& Ed. Unimep, [s.d; original de 1977], p. 157.

${ }^{93}$ ARENDT, Hannah. Entre o passado e o futuro. Trad. Mauro W. Barbosa. 7. ed., São Paulo: Perspectiva, 2011, p. 247. "A educação é o ponto em que decidimos se amamos o mundo o bastante para assumirmos a responsabilidade por ele e, com tal gesto, salvá-lo da ruína que seria inevitável não fosse a renovação e a vinda dos novos e dos jovens. A educação é, também, onde decidimos se amamos nossas crianças o bastante para não expulsá-las de nosso mundo e abandoná-las a seus próprios recursos, e tampouco arrancar de suas mãos a oportunidade de empreender alguma coisa nova e imprevista para nós, preparando-as em vez disso com antecedência para a tarefa de renovar um mundo comum".

${ }^{94}$ GILES, Filosofia da educação, p. 27.

${ }^{95}$ Para Hans Jonas, a educação tem um fim determinado como conteúdo: "a autonomia do indivíduo, que abrange essencialmente a capacidade de responsabilizar-se; ao alcançá-lo (ou supor-se que foi alcançada), ela termina no tempo. O término ocorre de acordo com sua própria lei, e não de acordo com a concordância do educador - nem sequer na medida do seu êxito -, pois a natureza concede apenas uma só vez um determinado lapso de tempo, no qual a educação precisa realizar sua tarefa. Depois disso, o objeto de responsabilidades anteriores se torna, ele mesmo, um sujeito de responsabilidades" (JONAS, Hans. O princípio responsabilidade: ensaio de uma ética para a civilização tecnológica. Trad. Marijane Lisboa e Luiz Barros Montez. Rio de Janeiro: Contraponto - Ed. PUC-Rio, 2006, p. 189). Jonas distingue a responsabilidade parental e a responsabilidade política. A responsabilidade paterna tem a ver com o devir individual (com seres que se tornarão homens), especificamente com a tarefa relativa ao crescimento orgânico e pessoal da criança - de modo que historicidade e natureza se interpenetram profundamente nela (criança) - até tornar-se adulto. A responsabilidade paterna cessa quando a criança se torna um adulto autônomo e responsável. Mas, somente com a continuidade da existência emancipada é possível, retrospectivamente, aos pais perguntar se desempenharam bem ou mal sua tarefa. A responsabilidade política pelo devir da história (da humanidade) é distinta dos fenômenos do devir individual, que vai do embrião ao adulto. Pois, "a história das sociedades, nações ou Estados - ou seja, "a História" - não tem nenhum fim predeterminado para o qual tenda ou deva ser conduzida; não faz sentido falar em infância, maturidade ou senilidade da história. Toda comparação orgânica, particularmente com o crescimento, por mais tentadora que seja, está fora de lugar e é enganosa. Desde as origens, todas as sociedades foram formadas por pessoas de diferentes idades, mas os adultos é que sempre exercem o poder e, especialmente nas sociedades mais antigas, os "mais velhos', que reúnem maior experiência, conhecimento e sabedoria" (cf. JONAS, O princípio responsabilidade, p. 190). Para Arendt, a essência da educação é a natalidade, "o fato de todos nós virmos ao mundo ao nascermos e de ser o mundo constantemente renovado mediante o nascimento" (cf. ARENDT, Entre o passado e o futuro, p. 247).

${ }^{96}$ ARENDT, Entre o passado e o futuro, pp. 238-239. 
família e é ampliado na instituição escolar, à qual cumpre a função de integrar os recémchegados em uma realidade diante da qual devem desenvolver a capacidade de avaliar e fazer opções fundamentais. Em um sentido geral, cabe ao educador o ofício de servir como mediador entre o velho e o novo ${ }^{97}$. Concretamente, a escola ultrapassa o papel educativo da família, na medida em que ela "formaliza o papel educativo da própria coletividade, a fonte mais ampla de onde procede a imagem-ideal que se imprime no processo educativo"98. A tarefa da escola transcende a função de transmitir conhecimentos, pois cabe à escola “capacitar a pessoa para que possa assumir um papel ativo e responsável dentro da coletividade"99. Educar é um processo de construção que, ao mesmo tempo, concretiza e impulsiona a imagem-ideal do projeto de homem e de sociedade. Como tal, esse processo não se limita à constatação da trama da realidade do eu, dos outros e do mundo, mas deve levar à compreensão e à disposição de transformar essa trama graças à liberdade criativa por ele ativada.

Decerto, não se pode afirmar que a filosofia de Apel abstrai de uma compreensão do fim (teleologia, sentido) essencial da educação no sentido da autonomia, socialização e responsabilidade do sujeito pelo mundo. Isso se mostra por meio de algumas escassas e ocasionais referências feitas à educação nas publicações de Ape $^{100}$, delimitadamente nos textos principais que se ligam à organização teórica da semiótica transcendental e da ética do discurso. Dessas referências, em princípio, provavelmente são as mais importantes o ensaio "Ciência como Emancipação? Uma apreciação crítica da concepção de ciência da 'Teoria Crítica", que compõe a obra Transformação da Filosofia, e o relato autobiográfico de Apel. Há ainda uma referência à educação por analogia, em que Apel trata do problema já contido na pedagogia e na psicoterapia, isto é, o problema da mediação arriscada entre teoria e prática. Nessa passagem, ele discute sobre o problema relativo à exigência de "impedir a manipulação elitista por parte dos manipuladores", ao mesmo tempo em que cogita, para os campos da

\footnotetext{
${ }^{97}$ ARENDT, Entre o passado e o futuro, pp. 235-239. Para Jonas, a responsabilidade dos pais para com o filho, no âmbito da moral tradicional, constitui o único caso de responsabilidade e obrigação elementar não recíproca, que é reconhecido e praticado espontaneamente. Sem essa responsabilidade, os filhos sucumbiriam, se a procriação não prosseguisse por meio da precaução e assistência. A expectativa de recompensa pelo amor e esforços despendidos para com o filho não é precondição para a responsabilidade dos pais, que é incondicional. É a relação com a progenitura não-autônoma, própria do fato biológico da procriação, que dá origem à ideia de responsabilidade. O dever de cuidado com o filho gerado e posto no mundo, mesmo sem o concurso de sentimento, justifica-se com a responsabilidade de autoria dos pais pela existência dos filhos e com o direito que agora pertence a essa existência (JONAS, O princípio responsabilidade, pp. 89-90).

${ }_{98}^{8}$ GILES, Filosofia da educação, p. 28.

${ }^{99}$ GILES, Filosofia da educação, p. 27.

${ }^{100}$ Respectivamente, ver: APEL, Transformação da filosofia, Band II, pp. 162-166; Transformation der Philosophie, Band II, pp. 141-145. Ver ainda: APEL, Antropos, pp. 13-15.
} 
pedagogia e da psicoterapia, a possibilidade de suspensão temporária da pressuposição idealmente implícita de simetria da comunicação interpessoal na situação do acordo mútuo (produção do coentendimento) para a mediação da tradição ${ }^{101}$.

Ocorre que, em face dessas referências ocasionais, faz-se necessário empreender uma guinada dentro deste texto, antes focado na suposição do déficit (invisibilidade), no sentido de um movimento analítico-reflexivo voltado a levantar algumas hipóteses interpretativas que possam caracterizar, no plano de problematização deste tópico da tese, o modo pelo qual a educação se encontra na filosofia de Apel. Isso implica reexaminar, do ponto de vista lógico, a hipótese de déficit suscitada neste texto. Trata-se de considerar que as alusões à educação, ainda que colateralmente, mitigam a suspeita de vacuidade do objeto da educação na filosofia de Apel. Pode parecer até paradoxal o modo enviesado de aludir sobre a educação em Apel, se se cogita que de tal modo essa perspectiva filosófica possa iluminar uma problemática e oferecer uma pista de solução para um objeto (fenômeno da educação) quando, tal como parece ser, nem o problema nem a solução transparecem suficientemente nela mesma, em sua arquitetônica filosófica. Ora, se elas mitigam, então é possível levantar a objeção de que a perplexidade perante a lacuna da educação na obra de Apel resulta, ela mesma, aparente e exacerbada. Assim, é preciso avaliar se essa perplexidade não ecoa apenas uma queixa pela carência de um momento em que Apel rompesse com sua situação de "fora da educação para pensar a educação" ${ }^{" 102}$.

Pois bem, a primeira hipótese interpretativa, a partir das referências ocasionais à educação nas publicações de Apel, é que a proposta de transformação da filosofia apeliana não prescinde da inteligibilidade do núcleo e da possível superação da problemática da educação. Ora, essa interpretação se patenteia, ainda que de maneira enviesada, na alusão à própria educação que Apel faz em seu relato autobiográfico de autopercepção intelectual ${ }^{103}$. Aí, ao retratar a própria experiência de formação, ele pontua o que lhe parece ser o aspecto central da problemática da educação: as dificuldades e riscos decorrentes de uma ciência manipuladora e de uma educação que não desenvolve a capacidade crítica. $O$ traço mais forte que emerge desse relato é a autopercepção de Apel do tipo de experiência formação que ele internaliza e compartilha socialmente durante sua infância e juventude: uma educação típica

\footnotetext{
${ }^{101}$ APEL, Transformação da filosofia, v. I, pp. 64-67; Transformation der Philosophie, Band I, pp. 55-58. A meu ver, se extrapolada para o campo da educação, mutatis mutandis, essa questão sugere, entre outras questões, a tematização acerca da autoridade na educação à luz da semiótica transcendental.

102 ARENDT, Hannah; WEIL, Eric; RUSSELL, Bertrand; ORTEGA y GASSET. Quatro textos excêntricos. Trad. Olga Pombo. Lisboa: Relógio D’Água Editores, 2000, pp. 8-9.

${ }^{103}$ APEL, Antropos, pp. 13-15.
} 
dos "tempos de guerra", marcada pelo caráter instrumental e pelo viés (supostamente) apolítico, movida fundamentalmente pelo dever "patriótico" e conformista à engrenagem "nacional-socialista" de vontade de domínio absoluto ${ }^{104}$. Quando à alternativa de superação de uma educação acrítica, o relato informa sobre a caminhada pessoal e intelectual de Apel em vista de construir teoricamente uma hermenêutica crítica ${ }^{105}$, ou seja, uma teoria filosófica normativa para formar a capacidade crítica e combater a irreflexão, sob a esperança de que o pensar reflexivo funcione como antídoto para evitar a repetição de Auschwitz ${ }^{106}$, ou de algo que analogamente favoreça a subjugação e a destruição humana. Por via tortuosa, o relato autobiográfico de Apel acaba sugerindo que a irreflexão e a reflexão formam o binômio nuclear da problemática da educação.

Para ilustrar a dramaticidade da fenomenologia da espécie de educação típica "anos de guerra" relatada por Apel, em que aparece a ligação entre o problema do pensar e a questão moral, ou melhor, em que a incapacidade de pensar deságua na incompreensão da atividade crítica inerente ao julgamento moral, é interessante trazer aqui o enfoque deflagrado por Hannah Arendt a propósito do julgamento do oficial nazista Adolf Karl Eichmann, realizado em Jerusalém no ano de 1961. Para Hannah Arendt, o julgamento de Eichmann ${ }^{107}$ é emblemático, porque nele se afigura o contorno da crise moral na contemporaneidade. Eichmann encarna, ainda que tipificado pelas autoridades religiosas e médicas como pessoa “mediana/normal”, a crise entre o dever e a consciência, à medida que se mostra incapaz de

\footnotetext{
${ }^{104}$ APEL, Antropos, p. 14.

105 APEL, Transformação da filosofia, v. I, p. 52; Transformation der Philosophie, Band I, pp. 43-44.

106 CORTINA, A. Karl Otto Apel Verdad e Responsabilidad (introducción). In: APEL, Teoría de la verdad y ética del discurso, pp. 14-15.

107 ARENDT, Hannah. Responsabilidade e julgamento. Tradução de Rosaura Eichenberg. São Paulo: Companhia das Letras, 2004, pp. 160 e 212. Ver ainda: CORREIA, Adriano. O pensamento pode evitar o mal? In: Revista Educação: Hannah Arendt pensa a educação. São Paulo: Segmento, n.4, 2006, p.46-55, cf. pp. 48 e 50. Em Eichmann, o mal é banal porque, caracteristicamente, é desprovido de explicação convincente e de motivação ideológica, patológica ou demoníaca. Ao declarar a banalidade de Eichmann, Arendt não pretender negligenciar a sua imputabilidade, mas compreender o tipo de mentalidade que pode contribuir para o surgimento de indivíduos como ele. Para além do caso Eichmann, há comentadores que sustentam que Arendt abandona a formulação kantiana de mal radical e, contrapartida, traz a noção de que o mal é algo banal. Nesse sentido, o mal não é uma fatalidade ou questão ontológica, mas uma possibilidade da liberdade humana e, como tal, uma questão da ética e da política. O mal banal pode ser extremo, porém é superficial. Contudo, banalidade não significa normalidade. Arendt distingue os fenômenos típicos do lugar-comum, aqueles que acontecem com regularidade e constância, e os do mal banal. O mal banal é o fenômeno que não é comum, mas ocupa indevidamente o lugar (como se fosse) da normalidade. O mal pôde ocupar o lugar da normalidade e esconder o próprio horror, graças à superficialidade e superfluidade. Arendt entende que, quanto mais alguém é superficial, mas tendente a ceder ao mal. Já a superfluidade diz respeito ao fenômeno decorrente do sentido utilitário da sociedade de massa. Urdindo esses aspectos, "o mal se torna banal porque os seus agentes são superficiais e suas vítimas são supérfluas". "Para o réu, tudo não passava de um golpe de azar, pois tinha sido um bom cidadão, porém num Estado assassino. Sorte teria, em sua lógica, um bom cidadão num Estado justo" (cf. ANDRADE, Marcelo. A banalidade do mal e as possibilidades da educação moral: contribuições arendtianas. In: Revista Brasileira de Educação, Rio de Janeiro, v. 15, n. 43, pp. 109-125, jan. /abr. 2010, cf. p. 111-115).
} 
distinguir o certo do errado. No julgamento, Eichmann alega a obediência à "engrenagem" como virtude e, ademais, reivindica para si o status de vítima do regime totalitário Para Arendt, contudo, Eichmann não é um "Mefisto" (o ser diabólico no sentido de Goethe), nem um antissemita. Ele é um "ninguém", um burocrata que repete um jargão administrativo. Como fiel cumpridor da lei, ele não assume a responsabilidade. Por isso, personifica uma existência irrefletida que, no entender de Arendt, significa uma recusa à própria consciência e à singularidade (pessoalidade). Eichmann não simboliza um caso de estupidez, mas de irreflexão. Longe de afigurar a patologia de um ou de poucos, o sacrifício do pensamento e da singularidade que ele representa sinaliza o ponto fundamental do problema moral.

Em seus contornos e implicações, o caso Eichmann se torna relevante para a filosofia moral, porque nele também se evidencia a fenomenologia da banalidade do mal: um mal que não é radical, porém é incompreensível. O aspecto dramático é que esse mal se espraia não pela mão dos "maldosos" e "pecadores", assim comumente descritos na literatura e na religião, mas justamente pela atuação de indivíduos comuns e inofensivos que foram “educados" (acostumados) a não-pensar. Se o perigo é intrínseco à atividade do pensamento, assim pensa Arendt, muito mais desastroso é a ausência de reflexão. Arendt pensa que a consciência moral resulta da experiência da atividade do pensamento; em contraste, a irreflexão impede a constituição e exercício da moralidade como singularidade. Porque nunca pensam na questão, os malfeitores nunca se confrontam consigo próprios, tampouco se lembram do mal perpetrado ou refletem antes de cometer um dano irreparável. Sem a lembrança, e tal constitui um aspecto fundamental da problemática moral e também na educação dos valores, a dimensão do passado corre o risco de esquecimento. Isso significa descuidar da dimensão de profundidade na existência humana. Pois a "memória e profundidade são o mesmo, ou antes, a profundidade não pode ser alcançada pelo homem a não ser através da recordação", de forma que a tarefa da moralidade dá conta das dimensões da memória e da profundidade humana ${ }^{108}$.

Aqui convém esclarecer melhor a ligação entre o problema do pensar e a questão moral. No pensamento de Arendt, a perda dos tesouros da tradição se deve ao lapso de memória das testemunhas (dos vivos) e dos herdeiros; e sem a continuidade consciente do tempo, impera a sempiterna mudança do mundo e o ciclo das criaturas. Ocorre que, assim concebe Arendt, a memória é um dos modos do pensamento. Como tal, ele é impotente fora de um quadro de referência, pois se desprovê de significação, e passa a repisar velhas

${ }^{108}$ ARENDT, Entre o passado e o futuro, p. 131. 
verdades que já perderam qualquer relevância concreta. Nos termos de Arendt, "a ação que possui sentido para os vivos somente tem valor para os mortos e só é completa nas mentes que a herdam e questionam" ${ }^{109}$. Com a quebra da tradição, Arendt afirma, seguindo Tocqueville, o passado deixa de lançar luz sobre o futuro, condenando a mente humana a vaguear na obscuridade. Arendt é cônscia de que o desenraizamento e a perda de autoridade da tradição impactam, dramaticamente, a educação, alijando-a da "atitude conservadora" que lhe é inerente ${ }^{110}$. Sem essa atitude conservadora, a "solução" que visa a traduzir e moldar a moralidade e a educação à convencionalidade constituída pela imposição do critério de funcionalidade, longe de resolver o problema da fonte do conhecimento moral e da educação dos valores, encobre os aspectos da crise da tradição. De forma nefasta, por detrás desse velamento, porém em favor da preservação do ethos consuetudinário, postula-se como "natural" não somente a morte da autoridade moral intrínseca ao uso dos valores tradicionais, mas também da responsabilidade pela formação da singularidade (que, segundo Arendt, é o âmbito da moralidade). Em consequência da quebra da tradição, o pensamento se aparta da realidade e a realidade se torna opaca à luz do pensamento. Em contrapartida, segundo Arendt, a solução dessa problemática relativa aos fenômenos mentais (não ao tempo históricobiográfico), está na atividade do pensamento. Nesse plano, a função da mente é compreender o acontecido, de forma a reconciliar o homem com a realidade e estabelecer a paz com o mundo. Contudo, "o problema é que, se a mente é incapaz de fazer a paz e de induzir à reconciliação, ela se vê de imediato empenhada no tipo de combate que lhe é próprio" ${ }^{111}$. Para Arendt, o surgimento do existencialismo ilustra essa "rebelião do filósofo contra a filosofia", à medida que se tenta escapar do pensamento para a ação (política).

Analogamente, mutatis mutandis, Apel e Eichmann são figuras atravessadas pela experiência de uma educação típica dos “tempos de guerra". Acontece que, arriscando aqui uma especulação, um deles alcança a autopercepção de que a incapacidade de pensar desemboca na incompreensão da atividade crítica inerente ao julgamento moral. Trata-se de uma incompreensão que segue em duas direções, em parte desdenhando dos giros dialéticos, reflexivamente abertos e próprios do discernimento pessoal acerca do certo e do errado, em

\footnotetext{
${ }^{109}$ ARENDT, Entre o passado e o futuro, p. 31.

${ }^{110}$ Nos termos de Arendt, "a crise da autoridade na educação guarda a mais estreita conexão com a crise da tradição, ou seja, com a crise de nossa atitude face ao âmbito do passado. É sobremodo difícil para o educador arcar com esse aspecto da crise moderna, pois é de seu ofício servir como mediador entre o velho e o novo, de tal modo que sua própria profissão lhe exige um respeito extraordinário pelo passado" (ARENDT, Entre o passado e o futuro, pp. 243-244).

${ }^{111}$ ARENDT, Entre o passado e o futuro, p. 34.
} 
parte fortalecendo uma cultura cuja pretensão fundamental é encontrar resultados doutrinários que tornem o pensamento ulterior desnecessário. A incapacidade de pensar despoja a ação humana de sentido e incute o absurdo $^{112}$ na dinâmica da vida e, em tal medida, tornando-a irredutível à razão ou contraditória em suas expectativas lógicas, ontológicas e axiológicas. Ora, a busca de uma mediação intelectual para superar a incapacidade reflexiva presente na procedurística do pensar e do agir dos campos de concentração - que faz com o mal seja perpetrado por preposto da engrenagem que não objetiva a punição de um delito e sim tornar todos os homens supérfluos - e na sociedade que se torna cúmplice da dominação totalitária, à medida que compartilha as mentiras do sistema não por ser enganada, mas por se recusar a perscrutar a verdade dos fatos ${ }^{113}$, é o que marca, no caso de Apel, a "lenta" reviravolta de uma experiência formativa típica "dos tempos de guerra" para um contexto de trabalho intelectual comprometido com a busca de fundamentos para a ação humana emancipada e responsavelmente solidária. A trajetória de Apel reflete o movimento autorreflexivo da razão agindo em meio aos escombros produzidos pela irreflexão. Em seu relato, as escassas descrições fáticas que ele faz sobre a educação dos "anos guerra" é uma quebra do "silêncio"114 em relação a fatos que não podem ser silenciados e repetidos, representados por Auschwitz. Aí não há análises de como deve se organizar a educação contra Auschwitz, mas apenas a indicação de que é no movimento autorreflexivo da razão que a educação deve se enraizar para tanto.

A segunda hipótese interpretativa, depreendida das alusões colaterais à educação na filosofia de Apel, é que Apel não desdenha da importância e função essencial da educação na sociedade. Nas duas referências principais à educação, o texto "Ciência como emancipação?" e o relato autobiográfico, aparece o pano de fundo contra o qual a filosofia de Apel se mobiliza, isto é, os dois grandes desafios herdados da Ilustração: o progresso no conhecimento e a emancipação da humanidade. Nelas, as menções à educação se ligam à pretensão de superar esses desafios. No relato, Apel fala do compromisso de sua atividade intelectual com a organização filosófica e epistemológica intencionada na emancipação e na responsabilidade solidária. E isso após ter internalizado duas perspectivas formativas marcadas pela heteronomia: a da infância, baseada no "fato sociológico" da diferença social conforme diferenças confessionais, segundo Apel, nos moldes da diferença entre católicos e protestantes retratada por Max Weber na obra Ética protestante e o espírito do capitalismo; a

${ }_{112}$ NICOLA, Abbagnano. ABSURDO. In: Dicionário de Filosofia. 5. ed., SP: Martins Fontes, 2007, pp. 6-7.

${ }^{113}$ ANDRADE, Revista Brasileira de Educação, p. 116.

${ }^{114}$ APEL, Antropos, pp. 13-14. 
da juventude, a educação dos "anos guerra" recebida no Instituto de Humanidades, nas Juventudes Hitleristas e na formação militar, baseada nos propósitos de domínio e ideologia do Reich alemão ${ }^{115}$.

A meu ver, o que permite depreender que a suposta invisibilidade da educação na obra de Apel é aparente é o ponto em que Apel assinala que existe um ponto de interseção entre a problemática filosófica enfrentada pela semiótica transcendental e a problemática da educação, na medida em que ambas, cada qual em sua especificidade, convergem para o propósito de realizar a mediação (Vermittlung) entre teoria e práxis ${ }^{116}$. Esta ideia é ligeiramente enunciada dentro do texto "Ciência como emancipação?" - em meio ao objeto principal, que é a crítica à instrumentalização da razão e a preponderância do interesse técnico-científico no âmbito do saber e sua propagação no mundo -, mas, mesmo assim, parece denotar que Apel é cônscio da relevância e função essencial da educação na sociedade.

Ademais, chama a atenção o fato de que o texto "Ciência como emancipação?", objeto de uma conferência proferida por ocasião dos "Kieler Univesitätstage" (de 1969), com o tema geral "Tarefas da universidade no presente e no futuro", portanto, fruto de sua atividade acadêmica e inserção no universo da educação. Esse texto, se visto à luz das publicações posteriores, é provavelmente o pronunciamento mais direto e principal de Apel para o campo da educação. Nesse texto, ele inicia uma reflexão político-acadêmica sobre as funções da ciência e a exigência de uma função emancipadora. É importante salientar que esse texto não traz uma análise minuciosa das possíveis funções histórico-sociais da educação ${ }^{117}$. Aí, a função da educação é avistada em sua colateralidade com a discussão principal relativa à função da ciência, no contexto de uma mediatização entre teoria e práxis, que Apel julga ser o "ponto culminante da filosofia enquanto teoria da ciência em potencial"118. É em torno dessa discussão principal e, mais especificamente, no interior do debate sobre as funções das ciências humanas no âmbito da ciência, que Apel enuncia o papel emancipador da educação.

A terceira hipótese interpretativa desde as menções colaterais à educação na obra de Apel, em decorrência lógica das duas anteriores, concerne à ideia de que a lacuna da educação na filosofia de Apel parece ocorrer em alguma medida em dois níveis, seja no da

\footnotetext{
115 Respectivamente, ver: APEL, Transformação da filosofia, v. II, pp. 162-166; Transformation der Philosophie, Band II, pp. 141-145. APEL, Antropos, pp. 13-15.

${ }^{116}$ APEL, Transformação da filosofia, v. II, pp. 147 e 149; Transformation der philosophie, Band II, pp. 128 e 130).

${ }^{117}$ HORTA, José S. Baia. Planejamento educacional. In: MENDES, Durmeval Trigueiro (coord.). Filosofia da educação brasileira. 6. ed., Rio de Janeiro: Civilização Brasileira, 1998, pp. 233-234.

118 APEL, Transformação da filosofia, v. II, p. 148; Transformation der philosophie, Band II, p. 129).
} 
pedagogia, seja no da filosofia da educação. Assim, no nível referido à pedagogia, observa-se que a obra de Apel não desenvolve uma tematização hermenêutico-conceitual da problemática concernente ao processo pedagógico. Esclarecendo, ele não desenvolve uma reflexão filosófica específica correlacionada à problemática que subsume a significação, em um sentido amplo, da expressão "pedagogia". Conceitualmente, o termo pedagogia designa não apenas as práticas de transmissão na escola, mas também de toda a atividade social que abrange "a seleção dos saberes a serem transmitidos pela escola, sua organização, sua distribuição em uma instituição diferenciada e hierarquizada, sua transmissão por agentes especializados e sua avaliação por métodos adequados"119. Nesse sentido da expressão pedagogia, as escassas alusões à fenomenologia da educação feitas por Apel não tematizam, de forma direta e aprofundada, as questões concernentes às práticas de transmissão na escola e ao referido conjunto de atividade social inerentes ao processo educativo. O texto do relato não é de todo incipiente quanto a isso. Nele, Apel pontua alguns aspectos da organização social presentes na dinâmica da instituição escolar frequentada por ele durante a infância: a separação das aulas (conteúdos) e dos serviços prestados pela instituição escolar em virtude da confessionalidade; a reprodução no pátio interconfessional, espaço supostamente interconfessional, do conflito entre protestantes e católicos; c) o viés confessional das escolas evangélicas (luteranas) e católicas delineando atividades artístico-pegagógicas (Apel cita o caso do desenho). Em relação à formação no Instituto de Humanidades, o relato testemunha a manipulação e instrumentalização dos conteúdos em vista de forçar uma interpretação e assimilação de uma "visão de mundo típica da época", "patriótica" e entusiasmada pelo domínio do antigo império romano-germânico ${ }^{120}$. No texto "Ciência como emancipação?”, ao tratar da função da ciência e do interesse cognitivo emancipador da teoria crítica, Apel enuncia o termo "pedagogia" (Pädagogik $)^{121}$. Nessa passagem, ele não explicita o conceito filosófico de pedagogia, ou melhor, um conceito de educação em conformidade com a semiótica transcendental, mas se refere a ela como uma ciência à qual cabe cumprir a função de mediação entre teoria e práxis. Sem maiores esclarecimentos, ele parece sugerir que é dessa função geral que se deve depreender a inteligibilidade dos problemas e das possíveis soluções para o campo pedagógico. Fora isso, no tocante ao nível em questão, as ditas

\footnotetext{
119 TANGUY, L. Racionalização pedagógica e legitimidade política. In: ROPÉ, F.; TANGUY, L. Saberes e competências. Campinas: Papirus, 1997, pp. 25-26.

${ }^{120}$ APEL, Antropos, pp. 13-14.

${ }^{121}$ APEL, Transformação da filosofia, v. II, p. 162; Transformation der philosophie, v. II, p. 141.
} 
referências não aprofundam qualquer discussão sobre os contornos epistemológicos, as funções e a procedurística do processo pedagógico.

Nesse ponto, provocativamente, é possível afirmar que falta ao pensamento de Apel um envolvimento em questões afetas ao processo pedagógico, tal como ocorre, por exemplo, com Adorno e Hannah Arendt. O exemplo de Theodor W. Adorno aqui é sugestivo, porque ele exemplifica, dentro da Escola de Frankfurt e anteriormente a Apel, uma abordagem direta da problemática relativa à necessidade de uma educação política, que tematiza a possibilidade de atribuir à educação um sentido emancipatório. Apel reconhece ter ingressado na Escola de Frankfurt desconhecendo por completo seus fundadores, Horkheimer e Adorno ${ }^{122}$. Mas, a despeito disso, o fato é que ele (Apel) incorpora - ao menos em "Ciência como emancipação?" - o "para quê" dessa abordagem. A obra Educação e emancipação de Adorno constitui uma referência de tal abordagem. Nela, uma coletânea de oito textos, produzidos no decênio entre 1959 e 1969, sendo quatro palestras e quatro transcrições de debates radiofônicos realizados em parceria com a Divisão de Educação e Cultura da Rádio do Estado de Hessen, Adorno trata de questões referentes à pedagogia prática e ao sentido teleológico (para quê) de uma educação para a autonomia “após Auschwitz".

Adorno pensa a relação entre educação e emancipação a partir da tese de que a meta primordial da educação é fazer com que "Auschwitz não se repita". Essa tese é reiterada por ele em seus textos. No texto Educação após Auschwitz, ele afirma que Auschwitz representa a barbárie, justamente "a barbárie contra a qual se dirige toda a educação"123. Em "Educação contra a barbárie", ele reafirma a tese de que desbarbarizar a cultura constitui a questão mais urgente da educação hoje em dia, justamente porque a "tentativa de superar a barbárie é decisiva para a sobrevivência da humanidade" 124 . A meta de evitar a repetição de Auschwitz, ao passo que corresponde ao "para onde a educação deve conduzir" ultimamente, é preponderante frente à discussão dos diversos campos e veículos da educação. Ela é prioridade em torno da qual é necessário reordenar todos os outros objetivos da educação ${ }^{125}$. Segundo Adorno, por trás da postulação dessa prioridade e da aparente obviedade de contraposição imediata à barbárie subsiste uma situação paradoxal, a qual concerne ao fato de que a fenomenologia da barbárie perdura, sem a visibilidade atual dos infortúnios, na medida em que persistem no capitalismo tardio as condições materiais fundamentais que geram a

\footnotetext{
122 APEL, Antropos, p. 17.

${ }^{123}$ ADORNO, Theodor W. Educação e emancipação. Trad. Wolfgang Leo Maar. 4. Ed., Rio de Janeiro: Paz e Terra, 1995, p. 119.

${ }^{124}$ ADORNO, Educação e emancipação, p. 156.

${ }^{125}$ ADORNO, Educação e emancipação, p. 155.
} 
regressão anticivilizatória simbolizada por Auschwitz. Efetivamente, a barbárie existe em toda parte e ninguém está inteiramente livre dos seus traços. O problema em relação a isso é que prevalece a obscuridade da sociedade em relação ao significado de Auschwitz e aos fatores subjetivos e objetivos que precisam ser enfrentados mediante a educação para evitar a barbárie. Na verdade, a essa situação paradoxal se justapõe o problema de saber se por meio da educação é possível transformar algo de decisivo em relação ao fenômeno da barbárie ou atuar profilaticamente para evitá-lo.

Os textos dessa obra espelham o combate de Adorno em uma dupla frente, a um só tempo contra a "falsa cultura" e a favor da "cultura" a ser emancipada. Eles transparecem o teor fundamental da análise irradiada pela Escola de Frankfurt - ao menos, até antes de Habermas - sobre a crise da educação em face da dinâmica do "trabalho formador", em que se considera essa crise como a referência mais desenvolvida da crise social da sociedade moderna ${ }^{126}$. Em linhas gerais, a raiz dessa crise é a dissolução da dimensão ética na formação pelo trabalho, em virtude do descompasso entre processo da civilização material (trabalho produtivo) e processo de formação cultural (interação), da deformação da subjetividade pela forma concreta do trabalho social alienado. Com Adorno, a teoria crítica (teoria social) toma a forma de uma abordagem formativa que alerta insistentemente sobre os "aspectos sombrios" da crise da educação na sociedade moderna, para assim, segundo ele, veicular que "o perigo é objetivo" (político-social) e não localizado em primeira instância nos indivíduos. Para ele, a reflexão educacional constitui uma educação política contra a barbárie representada por Auschwitz, cuja continuidade precisa ser rompida em suas condições sociais e objetivas.

Adorno trata de uma série de fatores subjetivos e objetivos que subsistem na sociedade, potencializando a sobrevivência do princípio Auschwitz na atualidade. Em um apanhado sintético, esses fatores dizem respeito a questões, tais como: a lógica da sociedade burguesa como uma das condições objetivas da liquidação da memória na sociedade moderna; o problema da autoridade no contexto da barbárie ligado aos traços das personalidades autoritárias, típicos do comportamento convencional, da identificação com o poder (independentemente do conteúdo), da ausência de reflexão e falta de aptidão à experiência, que devem ser superados no horizonte de uma educação após Auschwitz; a indústria cultural como cultura convertida em mercadoria; a interface entre nazismo e nacionalismo, refletindo sobre o narcisismo coletivo ("orgulho nacional”, a satisfação substitutiva na identificação com

\footnotetext{
${ }^{126}$ MAAR, W. Leo. À guisa de introdução: Adorno e a experiência formativa. In: ADORNO, Educação e emancipação, pp. 11-28.
} 
o todo), isto é, as fantasias coletivas de poder dos indivíduos impotentes, que só se imaginam "sendo alguma coisa" quando se agregam a um poder coletivo; o problema do travamento do esclarecimento sobre o passado na educação em razão da força de dominação e manipulação da indústria cultural e da semiformação sobre os indivíduos; o reforçamento do potencial totalitário pela imposição à adaptação a uma "consciência da época" deficitária culturalmente; o fracasso da democracia em cumprir sua promessa de felicidade e da própria experiência da democracia, que assim reforça o potencial totalitário hoje. Esses fatores, aqui exemplificados, entretecem a situação paradoxal da educação após Auschwitz, posta entre a exigência de uma "pedagogia do esclarecimento" para contrapor a destruição da memória (princípio Auschwitz) e a insuficiência da "educação política" (esclarecimento) frente à necessidade de combater as causas objetivas da dominação existente $\mathrm{e}^{127}$.

Para Adorno, o que está em jogo na tentativa de superar a barbárie é, decisivamente, a sobrevivência da humanidade. Contudo, por trás da urgência imperiosa dessa meta vem à tona a situação paradoxal da educação. A constatação de Adorno é que existem elementos de barbárie no conceito de educação, inclusive no conceito de educação pretensamente culta. Os textos A filosofia e os professores, publicado em 1963, e Tabus acerca do magistério, publicado em 1965, pontuam aspectos que constituem os momentos opressivos e repressivos presentes na educação. As concepções educacionais vigentes - na Alemanha e, por suposição, no mundo inteiro - estão permeadas por fatores psicológicos, os momentos repressivos aos homens singulares, e fatores objetivos, os momentos sociais opressivos não-acidentais do processo de desenvolvimento da sociedade em suas bases materiais, que geram a barbárie. Esses fatores estão presentes em concepções de educação direcionadas à preparação de pessoas para que venham a orientar-se segundo valores objetivamente válidos e dogmaticamente impostos, assumir compromissos coletivos irrefletidamente, enfim, adaptar-se ao sistema dominante ${ }^{128}$. Problematicamente, segundo Adorno, a racionalidade reflexiva não constitui por si só prova contra a barbárie. É fundamental que as reflexões sejam transparentes em sua finalidade humana, e não simplesmente reflexões em abstrato. Afinal, a "reflexão pode servir tanto à dominação cega como ao seu oposto", a emancipação ${ }^{129}$. Com efeito, isso implica a dificuldade de educar jovens para que façam reflexões sobre fins transparentes e humanos, quando a competição, no mundo inteiro e em sistemas políticos diversos, sendo promovida conscientemente por

${ }^{127}$ ADORNO, Educação e emancipação, respectivamente, pp. 29-49, 119-138 e 155-168.

${ }^{128}$ ADORNO, Educação e emancipação, p. 156.

${ }^{129}$ ADORNO, Educação e emancipação, pp. 158, 160-161. 
professores e alunos, permeia o ensino e o sistema educacional como um princípio pedagógico supostamente saudável. A opinião de Adorno, a competição - possivelmente adequada para educar esportistas, mas não pessoas desbarbarizadas -, na verdade, é "um princípio no fundo contrário a uma educação humana"130.

$\mathrm{Na}$ visão de Adorno, o único poder efetivo capaz de contrapor o "princípio Auschwitz", é a autonomia, entendida no sentido de Kant, como o poder para a reflexão, a autodeterminação, a não-participação. No caso, a não-participação significa autonomia na medida em que conota a resistência à heteronomia - seja pela assimilação de compromissos coletivos, convertidos em passaporte moral e fator de identificação do "cidadão confiável", seja pela substituição da consciência moral por "autoridades exteriores sem compromissos intercambiáveis" - que caracteriza a "índole dos algozes", em sua disponibilidade em ficar do lado do poder, tomando como norma o "curvar-se ao que é mais forte"131. Para Adorno, a exigência de emancipação não é apenas uma condição necessária para elaborar o passado e criticar permanentemente o presente prejudicado, de modo a evitar que este perdure e que aquele se repita, mas é também fundamental para a democracia. Ele pontua essa exigência, novamente à luz do programa de Kant, em seu texto Educação e emancipação (1969). A democracia exige o esclarecimento, como saída dos homens de sua autoinculpável menoridade; nesse sentido, ela repousa na formação da vontade de cada um em particular. Para Kant, o estado de menoridade é autoinculpável quando seu fator gerador não é a falta de entendimento, mas a falta de decisão de servir-se do entendimento sem a orientação de outrem. Pressupor a aptidão e a coragem de cada um em se servir de seu próprio entendimento constitui a condição indispensável para "evitar um resultado irracional"132.

Ainda em relação ao nível de um evolvimento da filosofia com a reflexão sobre o processo pedagógico, provocativamente, é possível assinalar que falta à filosofia de Apel uma análise de questões pedagógicas e políticas implicadas na crise da educação contemporâna semelhante à de Hannah Arendt. O posicionamento de Arendt sobre medidas pedagógicas que que passaram a orientar os projetos educacionais nas primeiras décadas do século XX, por ela consideradas como desastrosas, por contraste, confirma essa lacuna em Apel. Pois bem, Hannah Arendt concebe que a educação é uma das atividades humanas mais elementares e necessárias da sociedade humana, "que jamais permanece tal qual é" ${ }^{133}$. O campo da educação

\footnotetext{
${ }^{130}$ ADORNO, Educação e emancipação, p. 161.

131 ADORNO, Educação e emancipação, pp. 124-125.

${ }^{132}$ ADORNO, Educação e emancipação, p. 169.

${ }^{133}$ ARENDT, Entre o passado e o futuro, p. 247.
} 
reflete a encruzilhada, complexa e instável, das intencionalidades e possibilidades concernentes à responsabilidade pela formação da pessoalidade, pela conservação e transformação do mundo (ação política) e, ademais, pela própria compreensão do sentido da existência e da história. É da natureza da esfera da educação ser urdida pela permanente tensão, sujeitar-se à crise e à exigência de se repensar continuamente. Em nossa epocalidade, a crise na educação assume os contornos da crise geral da modernidade, que se refere à inviabilidade do passado iluminar o presente e das gerações passadas apresentarem o mundo como legado aos recém-chegados. Em sua especificidade, a crise na educação se vincula à “destruição de uma parte do mundo, alguma coisa comum a todos nós", cujo sinal mais evidente é o desaparecimento do senso comum e da capacidade de julgar nos dias atuais ${ }^{134}$. Apesar dessa perda da tradição, para Arendt, a crise não impede a reflexão acerca da crise na educação, tampouco denota o mero reflexo de mais uma época de crises. Às avessas, a crise na educação constitui a oportunidade privilegiada à reflexão na direção do retorno às questões mesmas, à medida que exige respostas velhas ou novas, livres de preconceitos e fundamentadas em julgamentos diretos. Como tal, ela é a oportunidade de explorar e investigar a essência da educação, que é a natalidade ${ }^{135}$, o fato de que os seres nascem para o mundo e o renovam continuamente porque seguem suas trajetórias vitais em estado de vir-aser, bem como trazer à luz as responsabilidades e valores implicados na atividade educativa.

Em sua tese basilar, Arendt afirma que a crise na educação contemporânea não concerne simplesmente a uma questão técnico-pedagógica, mas também envolve um problema político de primeira grandeza. De um lado, parte da crise na educação se deve à crise do mundo político, da autoridade e da tradição em meio à sociedade de massas e suas demandas ininterruptas. De outro lado, o agravamento da crise da educação decorre da associação entre educação e psicologia, ligada às "modernas teorias educacionais originárias da Europa Central" sob a divisa da educação progressista, para promover "uma radical revolução em todo o sistema educacional" ${ }^{136}$. Prescindir das questões políticas aí implicadas e tal é o alerta que se pode depreender da leitura conjunta dos dois escritos de Arendt "A crise na educação" e "Que é autoridade" -, supondo a suficiência da abordagem exclusiva e funcional das questões pedagógicas, ao invés de esclarecer o fenômeno da crise na educação e facultar o seu enfrentamento, mitiga, oculta e agrava sua problemática, à proporção que as soluções, por negligenciarem a importância do "jogo" afeto à pluralidade dos homens e seu

${ }^{134}$ ARENDT, Entre o passado e o futuro, p. 227.

${ }^{135}$ ARENDT, Entre o passado e o futuro, p. 223.

${ }^{136}$ ARENDT, Entre o passado e o futuro, pp. 226-227. 
agir livre e, ademais, das implicações políticas relativas ao cuidado do mundo (amor mundi), tendem a ser tornar complicadores futuros da crise. Em sua reflexão, Arendt analisa, inicialmente, os aspectos educacionais relativos à crise na educação. Esses dizem respeito e se agravam, segundo Arendt, devido à adoção desastrosa de medidas pedagógicas, pautadas em três pressupostos fundamentais, que passaram a orientar os projetos educacionais nas primeiras décadas do século XX. A despeito da "tentativa de reformar todo o sistema educacional", esses pressupostos têm contribuído para o fracasso da função mediadora que a escola e a educação deveriam cumprir entre o ambiente familiar e o mundo público dos adultos. À medida que tais pressupostos delineiam os traços orientadores de uma educação psicologizada e tutelada pela "natureza íntima da criança e suas necessidades", vislumbra-se uma educação apartada do mundo adulto, que leva à infantilização e à perda da responsabilidade pelo mundo.

O primeiro desses pressupostos diz respeito à insurgência, no campo educacional, de métodos pedagógicos oriundos da psicologia do desenvolvimento centrados na ideia de individualidade da criança e do adolescente, conformando "mundos" supostamente próprios nos quais prevalecem substratos psíquicos naturais alheios ao mundo e à história. Na sua origem, as práticas educacionais orientadas pelas abordagens 'psi' emergiram com o repúdio a todos os desmandos, castigos, punições e violências físicas e psíquicas contra jovens e crianças no interior dos muros escolares ${ }^{137}$. Porém, quando aplicadas à educação, essas abordagens fornecem elementos para a criação de novos métodos pedagógicos que tornam a "criança e o mundo infantil do brinquedo e da brincadeira como centro e foco praticamente exclusivos das ações pedagógicas e de educação" ${ }^{138}$. Criticamente, Arendt pensa que essa aplicação finda por infantilizar a educação e a política (o mundo dos adultos). De forma fictícia, esse pressuposto põe em suspensão a faticidade das relações reais e normais entre crianças e adultos, alicerçadas na evidência de que todas as idades já se encontram simultaneamente reunidas no mundo. Longe de libertar a criança do mundo do adulto, a aceitação desse pressuposto implica concordar, segundo Arendt, com o abandono da infância à mercê da própria sorte, vez que estão banidas do mundo adulto; ou com a subjugação da criança à tirania da maioria do seu grupo, que tende a desviá-la para o conformismo e a delinquência. $\mathrm{O}$ adulto, antes incumbido da autoridade para formar a criança, torna-se impotente para orientá-la, por isso acaba fazendo aquilo que agrada à criança, enquanto espera

137 CÉSAR, Maria R. de Assis; DUARTE, André. Hannah Arendt: pensar a crise da educação no mundo contemporâneo. In: Educação e Pesquisa, São Paulo, v. 36, n.3, pp. 823-837, set./dez. 2010, cf. p. 830.

${ }^{138}$ CÉSAR, Educação e Pesquisa, p. 830-831. 
evitar que o pior lhe aconteça ulteriormente. Assim, à medida que esse pressuposto deixa à margem o vínculo indissociável entre o homem e o mundo, ele deixa à margem o princípio educacional do cuidado e da responsabilidade para com o mundo ${ }^{139}$.

O segundo pressuposto refere-se à implicação da fusão entre psicologia moderna, princípios do pragmatismo e pedagogia em relação ao ensino. Com essa fusão, assinala Arendt, a pedagogia adquire o status de ciência do ensino em geral, ou seja, ciência da aprendizagem. Essa emancipação se fez, contudo, à custa da perda da importância do conteúdo a ser ensinado e do negligenciamento da formação dos professores. Pressupondo que a formação do professor deva ser na arte de ensinar e não no domínio de qualquer assunto particular, imagina-se que ele possa "simplesmente ensinar qualquer coisa". Desse modo, para Arendt, os educadores também restam abandonados à própria sorte, vez que são alienados de sua fonte legítima de autoridade, o domínio intelectual da área de conhecimento a ser ensinada. Em contraposição ao vazio de autoridade decorrente desse pressuposto, Arendt afirma que "não se pode educar sem ao mesmo tempo ensinar; uma educação sem aprendizagem é vazia e, portanto, degenera, com muita facilidade, em retórica moral e emocional" ${ }^{140}$. Na base dessa degeneração educacional e moral, empreendida em nome do estatuto da ciência da aprendizagem, segundo Arendt, sacrifica-se o professor não-autoritário, justamente aquele intencionado em abster-se de métodos de compulsão, porque confia na eficácia de sua própria autoridade; e, paradoxalmente, em virtude da falta de autoridade na educação, tolera-se o recurso de expedientes de coação e manipulação na atividade educativa.

O terceiro desses pressupostos concerne à aplicação do princípio do pragmatismo, segundo o qual só é possível conhecer e compreender aquilo que nós mesmos fazemos, no âmbito da educação, com o objetivo substituir o aprendizado pelo fazer. Neste pragmatismo educacional também se pressupõe a autonomia do mundo da infância, porém com o fim de substituir a aprendizagem pelo fazer e o trabalho intelectual pelo brincar (jogar). Por esse viés, o peso da responsabilidade pelo conhecimento cai sobre os ombros da criança e o conhecimento passa a depender exclusivamente das habilidades ligadas ao fazer e ao brincar desenvolvidas por ela. Todavia, para Arendt, aí subsiste a artificial retenção da infância e o abandono da responsabilidade educacional, pois não considera a infância como uma etapa temporária e preparatória para a vida pública adulta, em relação à qual os adultos devem reivindicar o papel de autoridade para conduzir as crianças até o mundo, suas regras e

\footnotetext{
${ }^{139}$ ARENDT, Entre o passado e o futuro, pp. 229-231.
}

${ }^{140}$ ARENDT, Entre o passado e o futuro, pp. 246-247. 
instituições. Outro aspecto problemático desse pressuposto se refere ao fato que não intenciona ensinar conhecimentos, mas moldar alguma habilidade. Daí, as instituições de ensino se transformam em instituições vocacionais, mais preocupadas com o êxito relativo ao domínio e instrumentalização de recursos tecnológicos do mundo do que com a capacitação da criança em relação aos pré-requisitos normais de um currículo padrão ${ }^{141}$.

Agora, pensando em termos de uma interseção entre filosofia e educação, no patamar do discurso próprio da filosofia da educação como questionamento radical sobre os pressupostos e sentido da educação, a partir das referências colaterais à educação na obra de Apel, é possível afirmar que Apel se ocupa, mesmo sem desenvolver ulteriores aprofundamentos, de "parcela" daquilo que compete à reflexão de natureza filosófica em meio às abordagens das ciências da educação ${ }^{142}$. Do ponto de vista da educação, essa parcela inclui diretamente o tipo de reflexão que Apel faz em "Ciência como emancipação" de Apel, à medida que aí se explicita o debate teórico sobre os interesses cognitivos do conhecimento conforme a especificidade das ciências. Esses interesses são o interesse das ciências naturais empírico-analíticas (science), o das ciências humanas hermenêuticas (ciências do espírito) e da "teoria crítica"143. Nesse debate, já integrado à Universidade de Frankfurt (1973) e ao entorno teórico da teoria crítica, Apel se posiciona em relação ao binômio conhecimento e emancipação, em parte, incorporando da abordagem epistemológica de Habermas dos três interesses cognitivos subjacentes aos conceitos de ciência, em parte, de modo paralelo e próprio, procurando se afastar de Habermas, para complementá-la em relação a "um ponto": a diferença entre a versão de reformulação da teoria crítica proposta por ele e Habermas é, respectivamente, a "diferença entre o apriori experimental dos interesses cognitivos constitutivos do sentido e o apriori do discurso argumentativo reflexivamente válido"144.

Nessa "parcela" se inclui também, a meu ver, a possibilidade de desdobrar da "arquitetura" da concepção de verdade como consenso ${ }^{145}$ e da ética discursiva como ética da

\footnotetext{
${ }^{141}$ ARENDT, Entre o passado e o futuro, pp. 231-233.

142 GILES, Filosofia da educação, p. 29. Sobre a distinção entre filosofia da educação e ciências da educação (pedagogia, psicologia da educação, sociologia da educação), ver pp. 29-31.

${ }_{143}$ APEL, Transformação da filosofia, v. II, pp. 156-158; Transformation der Philosophie, Band II, pp. 136137.

${ }^{144}$ APEL, Antropos, p. 18.

${ }^{145}$ Em "Falibilismo, teoria consensual da verdade e fundamentação última" (1986), texto em que Apel apresenta sua proposta de uma teoria da verdade, ele procura dá uma resposta a essa problemática. Para tanto, ele desdobrada essa problemática em dois problemas: a) o problema da complementação da teoria consensual da verdade das ciências empíricas da natureza, tal como concebida por Peirce, em relação às ciências sociais (hermenêuticas); b) o problema de uma teoria consensual da verdade compatível com os enunciados universais e autorreflexivos da filosofia. A tese de Apel, em relação ao segundo problema, é que é essencialmente próprio dos enunciados da filosofia é a reflexão sobre as pretensões de validade (pretensão de sentido, de verdade, de
} 
responsabilidade as implicações para a fundamentação da educação e, de modo específico, da educação dos valores (formação ética) ${ }^{146}$. Com efeito, é fundamental assinalar que dessa arquitetônica Apel não desdobra efetivamente uma elucidação do significado da educação em conformidade com as concepções da semiótica transcendental e da ética do discuso que, por consequinte, ponha em discussão questões referentes ao conteúdo fundamental, às práticas de transmissão e às instituições que a educação representa. Por outra parte, essas concepções concernem uma contribuição potencial, na medida em que estabelecem um marco criteriológico rigoroso (e último, segundo Apel) para a realização de discursos práticos (acordo recíproco) no campo da educação. Nesse marco, em tese, estão presentes as condições (pressupostos) para a correlação entre filosofia e educação no sentido de uma filosofia da educação. Apel chega ao limite de apontar esse marco; mas a tarefa de comprovar a possibilidade dessa correlação é algo que ele, conforme a terminologia apeliana, parece legar à comunidade real de comunicação. Não obstante, mesmo com essa lacuna conceitual e não mencionando propriamente a terminologia "filosofia da educação", na prática, Apel não se furta a levantar a questão sobre os alicerces (fundamentação) que podem se estender, em princípio, para outras áreas de conhecimento. Trata-se de uma possibilidade suposta, a despeito da ausência de replicação sistemática da semiótica transcendental e da ética do discurso à educação. A meu ver, ele parece esboçar os primeiros passos na direção de uma reflexão típica de uma filosofia da educação, ao circunscrever a compreensão própria do núcleo do problema da educação e, em contrapartida, indicar o ponto de ancoragem (fundamento) e o horizonte de superação do problema da educação na direção de uma "teoria crítica" da "ciência como emancipação"147.

veracidade e de correção normativa; "Reflexion auf Geltungansprüche: Sinn, Wahrheit, Wahrhaftigkeit, Richtigkeitsanspruch"). Há que observar, contudo, que a posição de Apel preconiza a distinção desses enunciados em relação aos enunciados das ciências empíricas da natureza, aos da ciência hermenêutica social e, em tal medida, também em relação aos de uma "teoria crítica". A posição de Apel representa uma inovação teórica dentro do âmbito da "teoria crítica". Essa inovação se refere à concepção da natureza dos enunciados típicos da filosofia. Para Apel, esses enunciados intentam dizer algo verdadeiro acerca do sentido da verdade dos enunciados, quer dizer, acerca das pretensões de verdade e condições de realização das diferentes classes de enunciados. Essa reflexão radica sob a compreensão de que os enunciados da filosofia são reflexivos em relação a sua própria pretensão de validade e dotados de pretensão universal de validade. A diferença entre a pretensão universal de validade dos enunciados da filosofia e a pretensão empírico-geral de validade dos enunciados de leis nas ciências da natureza, assim como da pretensão universal a priori de validade dos enunciados matemáticos, é que esses não podem ser autorreflexivos. Autorreflexividade e universalidade são as qualidades típicas dos enunciados da filosofia (cf. APEL, Teoría de la verdad y ética del discurso, pp. 103-104. APEL, Fallibilismus, Konsenstheorie der Wahrheit und Letztbegründung. In: Philosophie und Begründung, pp. 166-167).

${ }_{146}$ APEL, Teoría de la verdad y ética del discurso, pp. 147-184.

147 APEL, Transformação da filosofia, v. II, p. 166; Transformation der Philosophie, Band II, p. 145. 
Na linha dessa interpretação, Apel parece crer ter posto o pilar que toca à filosofia nesse questionamento radical sobre os pressupostos e sentido da educação, no momento em que reabilita a via de reflexão filosófica e científica em sua dimensão pragmáticohermenêutica da linguagem. Nesse sentido, o contributo da filosofia é a ampliação da noção de ciência, até então restrita às ciências empírico-analíticas, mediante a incorporação do âmbito relativo à experiência comunicacional e ao interesse cognitivo das ciências humanas hermenêuticas (hermeneutischen Geisteswissenschaften) frente ao problema da "mediatização da tradição"148. Esse pilar se liga à função antecipativa e fundamentadora da hermenêutica transcendental concebida por Apel, a qual subsume a normatividade a priori (intranscendível) do discurso para o acordo intersubjetivo-consensual e para a interpretação e reflexão crítica. $\mathrm{O}$ pilar da filosofia em meio ao questionamento da educação é a hermenêutica crítica ampliada pela dimensão perspectiva transcendental da pragmática, portanto, uma semiótica transcendental capaz de legitimar o contínuo refletir sobre o processo educativo por intermédio do acordo intersubjetivo possível e orientado para a ação. Pode-se supor que a orientação de sentido e as decisões em vista de formar o homem para assumir-se integralmente na existência, cujos desdobramentos impactam o presente e o futuro de toda a coletividade $^{149}$, na linha da reabilitação hermenêutico-pragmática mencionada, passam necessariamente pela intermediação do acordo hermenêutico-dialógico. Em tal medida, é possível supor que a peculiaridade do contributo da semiótica transcendental à educação é oferecer, em sua função antecipativa e implícita, os fundamentos e critérios contrafáticos (presentes no a priori do discurso argumentativo) da crítica com sentido e validade para o enfrentamento dos dilemas fáticos na educação.

Mesmo prescindindo da discussão concernente ao conteúdo fundamental, às práticas de transmissão e às instituições que a educação representa, bem como de um texto particularmente típico da filosofia da educação, se se considera o transfundo das breves referências que Apel faz em torno da educação, é possível depreender que ele é cônscio dos riscos, das implicações teóricas e das consequências inerentes ao processo educativo. Isso se patenteia no posicionamento crítico e propositivo de Apel. Visto que, por um lado, ele denuncia os riscos de uma ciência manipuladora ${ }^{150}$, que tem sua origem na vedação imposta pelo cientificismo positivista à reflexão hermenêutica e crítica. Sem se ater à tarefa de

\footnotetext{
${ }^{148}$ APEL, Transformação da filosofia, v. II, pp. 156-157; Transformation der Philosophie, Band II, p. 136. ${ }^{149}$ GADOTTI, Moacir. Concepção dialética da educação: um estudo introdutório. 10.ed., São Paulo: Cortez, 1997, pp. 93 e 107. GILES, Filosofia da educação, p. 11.

${ }^{150}$ APEL, Transformação da filosofia, v. II, p. 162; Transformation der Philosophie, Band II, p. 142.
} 
elaborar um conceito da "educação", ele direciona o foco de sua mirada à educação sobre os distintos significados (sentidos) e consequências que ela pode alcançar a depender do seu ponto de partida epistemológico, no caso, desde a perspectiva positivista da ciência ou desde a ótica da semiótica transcendental. Para ele, se vista pela perspectiva positivista, a educação assume o viés de "pura tecnologia de adestramento em sua referência prática"151. Como já dito, o próprio Apel atesta ter encarnado essa vedação em sua trajetória intelectual pessoal e profissional durante "os anos de guerra", levando-o à irreflexão e suposta apoliticidade (isenção ético-política) ${ }^{152}$. Por outro lado, como contraponto à ciência manipuladora, ele suscita a exigência de conceber filosoficamente a função emancipadora da ciência ${ }^{153}$ por meio de uma cognição complementar (Komplementärerkenntnis), o conhecimento das ciências humanas hermenêuticas ${ }^{154}$. Na solução metodológica vislumbrada por Apel, a ciência deve ser compreendida como investigação que comporta, simultaneamente, o interesse cognitivo de objetivação e instrumentalização teórico-analítica do mundo e o interesse cognitivo de realização da emancipação humana. Do ponto de vista da educação, este último interesse, se dimensionado à educação, pode ser entendido como o interesse hermenêutico-comunicativo referente ao "acordo mútuo engajado dos pedagogos quanto aos objetivos da formação integral e da instrução formal"155 em vista de uma intenção prática (político-ética) ${ }^{156}$.

Por seu turno, em uma interpretação mais rigorosa, é possível suspeitar que Apel não costure um "discurso teórico" característico da filosofia da educação. Fundamentalmente, falta à semiótica transcendental autoaclarar-se quanto a uma concepção de educação. A caminhada reflexiva iniciada nesse sentido em "Ciência como emancipação?", do ponto de vista da educação, não recebe ulteriores acréscimos substanciais. Estranhamente, pelo exposto antes, outros focos e assuntos da contemporaneidade se mostraram mais emblemáticos e urgentes para o projeto filosófico de Apel que o enfrentamento desse autoesclarecimento quanto à educação. Nisso, por sua vez, há que se considerar que não cabe a hipótese da

\footnotetext{
${ }^{151}$ APEL, Transformação da filosofia, v. II, p. 162. APEL, Transformation der Philosophie, Band II, pp. 141-142. Tal perspectiva parece encontrar guarida no modelo reativo de Skinner, para o qual a ação humana não é livre e pode ser descrita em termos de uma tecnologia sujeita à manipulação externa (causal) do comportamento, como um poder que impõe seu cumprimento mediante gratificações ou sanções. Sob tal perspectiva, a validade do comportamento moral é proporcional à sua eficácia, em vista de adestrar os indivíduos às demandas organizacionais (ver: SKINNER, B.F. O Mito da Liberdade. Trad. Elisane Reis Barbosa Rebelo São Paulo, Summus, 1983, cap. 1 - Uma tecnologia do comportamento).

${ }^{152}$ APEL, Antropos, pp. 14-15.

${ }^{153}$ APEL, Transformação da filosofia, v. II, p. 149; Transformation der Philosophie, Band II, p. 130 ("Die Forderung nach einer emanzipatorischen Funktion der Wissenschaft").

${ }^{154}$ APEL, Transformação da filosofia, v. II, p. 162; Transformation der Philosophie, Band II, p. 142.

${ }^{155}$ APEL, Transformação da filosofia, v. II, p. 162; Transformation der Philosophie, Band II, p. 141.

${ }^{156}$ APEL, Transformação da filosofia, v. II, p. 163; Transformation der Philosophie, Band II, p. 142.
} 
cegueira de Apel em relação à educação, mas a de uma insuficiência por descontinuidade da abordagem da "educação como emancipação" em razão do deslocamento dos interesses de Apel, em seu terceiro período (a partir de 1988) ${ }^{157}$, para o âmbito prático (ética do discurso como ética da responsabilidade), com o fim de aplicar sua teoria, a semiótica transcendental, à realidade histórica. Em meio a esse deslocamento, aposta-se aqui na hipótese de que os conceitos de emancipação e responsabilidade constituem os conceitos-chave de uma possível reflexão sobre os pressupostos da educação no marco da semiótica transcendental.

A propósito dessa interpretação mais rigorosa, por analogia e também provocativamente, é possível cogitar que a filosofia de Apel carece de um discurso teórico que realiza a interseção entre filosofia e educação, de modo semelhante ao da "pedagógica" de Enrique Dussel, um dos interlocutores vivos de Apel. Falta a Apel, mutatis mutandis, organizar o âmbito filosófico próprio de reflexão sobre a problemática da educação. Em Dussel, a pedagógica diz respeito à parte da filosofia que trata do ponto de convergência e passagem recíproca da erótica à política. A pedagógica não se confunde com a pedagogia, sendo esta última a ciência do ensinamento ou aprendizagem. Conceitualmente, a pedagógica é a parte da filosofia que pensa e trata do ponto de convergência e passagem mútua da erótica à política ${ }^{158}$. Nela, o pedagógico diz respeito a uma "ampla significação de todo tipo de 'disciplina' (o que se recebe do outro) em oposição à 'invenção' (o que se descobre por si mesmo)"159. A pedagógica de Dussel é concebida no interior da ética da libertação latinoamericana como uma "meta-física" da pedagógica ontológica da dominação, uma "antipedagogia" do sistema que se define como "arte de tornar o homem não-instalado (unsittlich)"160. Cabe a essa "meta-física" descobrir a exterioridade (alteridade) do filhodiscípulo educável numa "pedagógica analética da libertação histórica" 161 , a qual deve superar a dominação do "ser" pedagógico imperante, que é a reprodução de "o Mesmo" pai-mestre.

\footnotetext{
${ }^{157}$ APARISI, Una brújula para la vida moral: a idea de sujeto en la ética del discurso de Karl Otto Apel, pp. 53-101.

${ }^{158}$ DUSSEL, Para uma ética da libertação latino-americana III: erótica e pedagógica. Trad. Luiz João Gaio. São Paulo: Loyola \& Ed. Unimep, [s.d; original de 1977], p. 154.

${ }_{159}$ DUSSEL, Para uma ética da libertação latino-americana III: erótica e pedagógica, pp. 153-154. A pedagógica reflete sobre o face-a-face de vários tipos de relações pedagógicas (por exemplo, pai e filho, mestre e discípulo, médico e doente, político e cidadão) abrangidas pelo seguinte esquema quadridimensional: a) da pedagógica-erótica à pedagógica-política: o mundo se renova com a criança nascida no lar erótico (erótica germinal) é educado para ser um dia pai ou mãe (erótica terminal) e, ao mesmo tempo, cidadão adulto (política terminal); ou, b) da pedagógica-política à pedagógica-erótica: a criança é disciplinada na instituição políticopedagógica (política germinal) para ser um dia parte responsável pela cidade (política terminal) e, ao mesmo tempo, adulto no nível erótico (erótica terminal).

${ }^{160}$ DUSSEL, Para uma ética da libertação latino-americana III: erótica e pedagógica, pp. 184-185.

${ }^{161}$ Idem, p. 197.
} 
A pedagógica não é um ato ôntico de domesticação ou preparação funcional dentro do sistema, mas um momento do ser humano pelo qual se transcende "metafisicamente" para instaurar "alguém dis-tinto"162. "A pedagógica se desenvolve essencialmente na bipolaridade palavra-ouvido, interpretação-escuta, acolhimento da Alteridade para servir o Outro como outro" 163 . "O a priori de toda pedagógica é o 'ouvir-avoz-do-discípulo', sua história nova, sua revelação, aquilo que a geração traz sem repetição possível, porque é única"164. Em suma, é a partir da concepção de uma pedagógica que Dussel reflete sobre a eticidade do projeto pedagógico do sistema de totalidade da cultura imperial do "centro", quase exclusivamente europeu-norte-americana ${ }^{165}$, e a práxis de libertação pedagógica ${ }^{166}$. Por certo, cabe ponderar que a expectativa de uma filosofia da educação apeliana, com base no exemplo da "pedagógica" de E. Dussel, denota apenas uma provocação à problematização aqui pretendida. Ela é, por assim dizer, uma expectativa fraca, porque extrínseca (e talvez, de algum modo, ressentida) aos limites fáticos da arquitetônica conceitual da proposta filosófica de Apel. Ressalta-se de todo modo que a pedagógica de Dussel bem exemplifica claramente a premência, o lugar, a estrutura conceitual e a teleologia relativa ao enfrentamento filosófico da questão da educação.

A despeito de Apel propor-se a "transformar" filosoficamente o modelo de teoria do conhecimento para a produção de verdades científicas e universais e, ademais, a fundamentação da formação dos valores na era das ciências, efetivamente, ele não se detém na tarefa de tematizar, de modo direto e aprofundado, a correlação e as possíveis implicações entre a semiótica transcendental e a fenomenologia da educação. Decerto, Apel até esboça a linha condutora de uma possível "intervenção filosófica na educação"167, a qual deve ser possibilitada à luz do a priori da comunidade ilimitada de comunicação ${ }^{168}$. Com isso, ele prenuncia o traço fundamental de um questionamento radical e crítico acerca dos pressupostos e do sentido "último" da educação no tocante à singularidade, à intersubjetividade e à conservação do mundo, na linha de uma discussão teórica própria da filosofia da educação ${ }^{169}$. No final das contas, ao menos em tese, a suspeita de déficit faculta a suposição de que, em

\footnotetext{
${ }^{162}$ DUSSEL, Para uma ética da libertação latino-americana III: erótica e pedagógica, p. 197.

163 Idem, p. 191.

164 Idem, p. 194.

165 Idem, p. 213.

166 Idem, p. 236.

167 GILES, Filosofia da educação, p. 30.

168 APEL, Transformação da filosofia, v. II, p. 171-72; Transformation der Philosophie, Band II, pp. 150151.

${ }^{169}$ GILES, Filosofia da educação, pp. 29-30.
} 
face da tarefa central da filosofia de Apel, que consiste em ajustar o ponto de partida filosófico-transcendental de Kant, isto é, a resposta à pergunta pelas condições de possibilidade da validade do conhecimento, ao nível crítico-linguístico de reflexão de uma teoria crítica das ciências naturais e humanas (ou do espírito), a temática da educação acaba sendo relegada a um possível momento de reverberação ulterior, cuja efetivação permanece carente de aplicação sistemática. Enfim, à primeira vista, nisso parece ficar pendente o salto reflexivo da semiótica transcendental na direção da educação e, por conseguinte, a possibilidade de uma contribuição original de Apel que faculte repensar, dentro da tradição da teoria crítica da Escola de Frankfurt, a perspectiva da educação direcionada à emancipação e à responsabilidade solidária ${ }^{170}$.

Frente ao exposto, fica a dúvida quanto à possibilidade efetiva de uma contribuição da semiótica transcendental e da ética do discurso à fundamentação filosófica da educação. A meu ver, essa dúvida pode ser sugerida em duas perspectivas. Em uma direção, desde a perspectiva de uma possível expectativa de contribuição advinda da esfera da educação, pode-se indagar o seguinte: se as escassas referências diretas à educação na filosofia de Apel parecem ser colaterais, porquanto que ligadas ao projeto de elaboração teórica de uma antropologia do conhecimento (gnoseoantropologia) ${ }^{171}$ como superação do solipsismo metódico e do cientificismo do positivismo e, ao mesmo tempo, à problemática da aplicação da fundamentação pragmático-transcendental abstrata da ética do discurso na história, o campo da educação pode esperar alguma contribuição emanada da pragmática transcendental para iluminar seus fundamentos e seus processos de organização e funcionamento? Se a novidade fundamental da semiótica transcendental, a fundamentação filosófica última, parece não ter alcançado uma exterioridade mais consequente para a reflexão sobre o processo educativo com o próprio Apel, por que então o campo da educação precisa se ocupar com novidade da pragmática transcendental? Aqui, ironicamente, por trás da dúvida parece residir uma recusa implícita à intencionalidade unilateral de uma mera

\footnotetext{
${ }^{170}$ APEL, Transformação da filosofia, v. II, p. 149; Transformation der Philosophie, Band II, p. 130.

${ }^{171} \mathrm{O}$ esboço da antropologia do conhecimento de Apel, pensado a partir de Rothacker e Plessner, compõe o programa para a transformação da filosofia transcendental kantiana. Em sua composição, essa antropologia contém "um apriori corporal cêntrico, os aprioris de reflexão e dos interesses do conhecimento excêntricos, junto com a significatividade do mundo que eles proporcionam e, finalmente, também com o apriori linguístico de Humboldt e Weisgerber" (cf. APEL, Antropos, p. 15). Ver: CORTINA, A. Karl Otto Apel Verdad e Responsabilidad (introducción). In: CORTINA, Razón comunicativa y responsabilidad solidaria: ética y política em K.-O. Apel, pp. 16-18. Sobre a gnoseoantropologia em Apel, ver: CONILL, Jesus. El crepúsculo de la metafísica. Barcelona: Anthropos, 1988, pp. 295-310.
} 
“intervenção filosófica na educação" ${ }^{172}$. Em outra direção, desde a perspectiva da pretensão de superação da problemática filosófica enfrentada por Apel, a dúvida quanto à possibilidade de entrecruzamento entre semiótica transcendental e educação parece pôr a nu um problema mais profundo, o qual concerne à interpelação sobre as condições de possibilidade de efetivação (factibilidade) ${ }^{173}$ do próprio projeto filosófico de Apel. Neste caso, pergunta-se: pode a transformação da filosofia postulada por Apel, no sentido da passagem da ilha isolada de comunicação dos "grandes pensadores" à integração de todos os cossujeitos na tarefa de fundamentação e resolução dialógico-consensual dos problemas afetos à existência ${ }^{174}$, consumar-se historicamente, se tal projeto não incorporar uma ampliação da autocompreensão da comunidade de comunicação como sendo simultaneamente uma comunidade de formação (educativa)? Decerto, quando se considera a dimensão e a teleologia da problemática da educação e o propósito nuclear da semiótica transcendental de Apel, a transformação da filosofia moderna do conhecimento centrada na consciência (sujeito isolado) em uma filosofia da intersubjetividade ${ }^{175}$ capaz de dotar a razão prática de responsabilidade ${ }^{176}$, parece absurdo presumir que se possa transformar a sociedade e a cultura, a partir de uma perspectiva semiótico-dialógica, sem o devido cuidado fundamental para com a atividade formativa por intermédio da qual a postulada transformação pode deitar suas raízes no mundo. Apel concebe a filosofia como ciência dos princípios intranscendíveis de todo discurso humano ${ }^{177}$. Cabe, portanto, investigar em que medida os princípios da semiótica transcendental e a exigência de responsabilidade da ética do discurso podem ser depreendidos e direcionados à educação.

\footnotetext{
172 GILES, Filosofia da educação, p. 30.

173 A razão estratégico-instrumental se ocupa dos "meios-fins" da ação humana. O critério de factibilidade concerne às condições de possibilidade da realização objetiva, material, formal empírica, técnica econômica, política etc., de "maneira que o ato seja possível levando em conta as leis da natureza em geral e humanas em particular. Trata-se de escolher as mediações adequadas ou eficazes para determinados fins", para que o ato seja possível (DUSSEL, Enrique D.. Ética da libertação: na idade da globalização e da exclusão. Trad. Ephraim F. Alves et al.. Petrópolis: Vozes, 2000, p. 268).

174 APEL, Transformação da filosofia, v. I, p. 15; Transformation der Philosophie, Band I, p.12.

175 APEL, Transformação da filosofia, v. II, p. 186; Transformation der Philosophie, Band II, pp. 163-164.

176 Quanto à fundamentação do ideal normativo e o postulado de um progresso eticamente possível, Apel afirma que "há motivos para supor que não se pode pensar o progresso normativamente relevante do acordo mútuo no sentido da hermenêutica sem que se pense também um progresso eticamente relevante na conformação social da humanidade enquanto comunidade de interpretação e interação" (cf. APEL, Transformação da filosofia, v. II, p. 441; Transformation der Philosophie, Band II, p. 390). CORTINA, Razón comunicativa y responsabilidad solidaria: ética y política em K.-O. Apel, pp. 155-177.

${ }^{177}$ OLIVEIRA, Sobre a fundamentação, p. 14.
} 


\section{PARTE II - SEMIÓTICA TRANSCENDENTAL E EDUCAÇÃO}

\section{Consideração inicial}

Esta parte visa a tematizar a possível interseção entre a semiótica transcendental de Apel e o campo da educação. Em vista de alcançar tal propósito, essa parte se estrutura em quatro capítulos: os dois primeiros enfocam o itinerário analítico-crítico de Apel em face da reviravolta linguístico-hermenêutica (primeiro capítulo) e linguístico-pragmática (segundo capítulo), ou seja, diante do movimento linguistic-hermeneutic-pragmatic turn da filosofia atual. Esses dois capítulos tematizam essas reviravoltas dentro do paradigma da linguagem, as quais representam o contraponto à redução instrumental designativa da concepção de linguagem. Essas reviravoltas, sob a pressuposição de que linguagem (comunicação) tem o status de última dimensão de base da racionalidade filosófica ${ }^{178}$, procuram sanar o vazio quanto à problemática da constituição do sentido, legado pela filosofia analítica em sua fase inicial lógico-matemática. No século XX, a hermenêutica e a pragmática encarnam o projeto de promover a despedida tanto da metafísica como da filosofia transcendental como filosofia primeira $^{179}$. Nesse itinerário, no que tange à hermenêutica, pontua-se a proposta apeliana de uma hermenêutica filosófica normativa como contraponto à hermenêutica de Heidegger e Gadamer. E, no que concerne à pragmática, sublinha-se a transformação semiótica da filosofia transcendental de Kant por Peirce, a qual constitui o ponto de partida de Apel no rumo de uma filosofia transcendental da intersubjetividade. A virada pragmática da semiótica de Peirce constitui a principal fonte de inspiração para a retranscendentalização da filosofia como reflexão sobre a validade no âmbito do paradigma da linguagem elaborada por Apel.

O terceiro capítulo caracteriza o núcleo, do ponto de vista da razão teorética, da proposta de transformação pragmático-transcendental da filosofia de Apel, a semiótica (ou hermenêutica-pragmática) transcendental. O desafio fundamental desse capítulo concerne à

\footnotetext{
178 APEL, Paradigmas de filosofía primera, p. 17.

179 APEL, Paradigmas de filosofía primera, pp. 174-177. Na filosofia analítica da linguagem, o projeto da crítica à metafísica é um motivo compartilhado desde o início. E no caso do primeiro e do último Wittgenstein, o repúdio também se dá em relação à transformação da filosofia transcendental orientada pela linguagem. (Para Apel, o segundo Wittgenstein se perde no relativismo e no soft naturalism (naturalismo suave) das formas de vida, às quais pertencem os diversos e incomensuráveis jogos de linguagem). Algo semelhante ocorre na fenomenologia proposta por Heidegger, quando aí se concebe a linguagem pelo viés da faticidade e se preconiza a destranscendentalização da filosofia.
} 
tentativa interpretativa de delinear a semiótica transcendental como paradigma de filosofia primeira capaz de estabelecer uma solução para a mediação entre razão teórica e a razão prática. A especificidade e novidade desse paradigma é que ele descobre um fundamento último presente no a priori (estrutura performativo-proposional) do discurso argumentativo como medium instranscendível do acordo recíproco relativo à razão teórica e à ação ética responsável. O enfoque desse capítulo tem como pano de fundo o segundo período (19701987) da evolução do pensamento de Apel $^{180}$, em que ele procura enfrentar teoricamente os dois grandes desafios herdados da Ilustração: o progresso no conhecimento e a emancipação da humanidade. Com essa mirada, tanto quanto possível, procura-se conectar a problemática enfrentada por Apel em sua busca por um critério para o progresso e para a reflexão intencionada na emancipação da humanidade com o campo da educação. Sob o propósito dessa conexão, o último capítulo dessa parte, em uma tentativa de reflexão especulativa e de forma exemplificativa, procura desdobrar alguns aspectos gerais da semiótica transcendental que, em tese, podem contribuir na tarefa de pensar a educação no sentido da autonomia do sujeito, da construção de uma cultura dialógica e consensual, da formação baseada na complementação dos saberes do "explicar" (ciências naturais) e do "compreender" (ciências humanas e hermenêuticas), enfim, no rumo da elevação da humanidade.

${ }^{180}$ APARISI, Una brújula para la vida moral: a idea de sujeto en la ética del discurso de Karl Otto Apel, pp. 04-05 e 23-51. 


\section{O GIRO HERMENÊUTICO COMO CONTRAPONTO À REDUÇÃO CIENTIFICISTA DO CONHECIMENTO E A PERSPECTIVA DE UMA HERMENÊUTICA NORMATIVA}

Este capítulo aborda a compreensão de Apel acerca do giro hermenêutico da linguagem no pensamento contemporâneo. Fundamentalmente, enfocam-se dois pontos: a) o resgate apeliano da crítica da fenomenologia hermenêutica de Heidegger e Gadamer à concepção de ciência metódica baseada na concepção logicista de linguagem e da descoberta da pré-estrutura do compreender (do sentido); b) a crítica de Apel à hermenêutica de Heidegger e Gadamer como contraponto para uma hermenêutica normativa (filosófica), que restitui o predicado judicativo do sujeito no processo do compreender.

\subsection{A fenomenologia hermenêutica como contraponto à redução cientificista e ao solipsismo metódico}

Com base na filosofia de Apel, esta exposição principia por desnudar o preconceito da noção de ciência e metodologia unitárias contra a hermenêutica, que é notório já nas raízes da história do cientificismo. A rigor, esse é o ponto da polêmica de Apel com Hans Albert, representante da escola do racionalismo crítico popperiano. Essa escola tende a considerar, do ponto de vista teórico-científico, o paradigma das ciências naturais e da tecnologia, representativo da racionalidade metódica, como mais esclarecido que outros paradigmas cognitivos da tradição filosófica, como o da hermenêutica das ciências humanas (designadas de ciências do espírito; Geisteswissenschaften) ou o da dialética sócio-crítica, sendo esses inclusive tachados de metodologias irrelevantes ou "obscurantistas". Para Apel, a falácia que subjaz a essa polêmica contra a hermenêutica estabelece a distinção entre a esfera da experiência experimental, do saber operativo e das ciências naturais, representativa da racionalidade livre de ideologia, e a esfera da "alta cultura", representativa dos legados trazidos da teologia, da filosofia e das ciências humanas. A esfera da "alta cultura", contraditoriamente, vê-se aprisionada pela coação a uma legitimação ideológica por parte dos sistemas de dominação e impedida de avançar rumo a uma racionalidade simultânea à da científica. Curiosamente, em torno do preconceito contra a hermenêutica se esconde, segundo Apel, a falácia relativa à própria a formulação acerca do fenômeno de não-simultaneidade no 
desenvolvimento sócio-cultural das "formas de saber". A princípio, aí transparece a intenção de transferir os métodos tecnicamente comprovados da racionalidade científica para a esfera da tradição cultural e da educação (socialização) normativamente relevantes. Não obstante, o que está em jogo, por trás do cultivo da crítica à metafísica, à cultura e à sociedade, é o interesse da racionalidade técnico-científica, intentando consumar o "esclarecimento" (Aufklärung) pela redução de todas as formas de saber à do setor técnico-científico ${ }^{181}$.

Por duas razões fundamentais, segundo Apel, essa falácia é insustentável. Primeiro, porque as ciências naturais e a tecnologia podem ser postas a serviço da legitimação prática das relações de dominação; e provavelmente de forma mais eficiente do que o fariam as ciências humanas ${ }^{182}$. Isso revela que não é autossuficiente a conclusão de que a manifestação de racionalidade livre de ideologia ocorre no campo do saber científicotecnológico. Segundo, porque os propagandistas da racionalidade técnico-científica, como Popper e sua escola, não aplicam quaisquer métodos "isentos de valor". Contudo, pretendendo estabelecer uma continuidade entre a epistemologia e a história da ciência, eles se envolvem com problemas afetos às ciências humanas histórico-hermenêuticas, ou seja, com a problemática metodológica do compreender normativo-racional concernente à reconstrução normativamente relevante de uma "história interna" da ciência. Na verdade, faticamente, não há isenção de valor na manifestação da racionalidade técnico-científica; ao contrário, ela sempre é suscetível de novas ideologizações, enquanto não for complementada por meio de uma reconstrução correspondente no campo das instituições sociais e da tradição normativamente relevantes. Tal implica romper, em conformidade com o programa de uma teoria dos tipos de racionalidade ${ }^{183}$ baseado na tese da complementaridade das ciências

${ }^{181}$ APEL, Transformação da filosofia, v. I, pp. 23-25; Transformation der Philosophie, Band I, pp. 19-21.

182 Para ilustrar, no campo da história da filosofia, a possibilidade da perversão da razão (moderna), ver: DELACAMPAGNE, Christian. História da filosofia no século XX. Trad. Lucy Magalhães e Carlos Nelson Coutinho. Rio de Janeiro: Zahar, 1987, pp. 11-20, 135-143.

${ }^{183}$ Esquematicamente, é possível distinguir os seguintes tipos de racionalidade na unidade da razão humana: a) racionalidade lógico-matemática enquanto "racionalidade mínima abstrata no sentido do princípio de nãocontradição entre proposições ou funções proposicionais"; b) racionalidade técnico-científica enquanto "pressuposição recíproca entre a intervenção instrumental efetiva e a análise causal experimental"; c) racionalidade estratégica enquanto "aplicação da racionalidade instrumental à interação e comunicação humanas, levada a cabo de forma reciprocamente reflexiva"; d) racionalidade consensual-comunicativa enquanto "possível coordenação comunicativa das ações, em virtude da força vinculante das quatro pretensões universais de validade dos atos de fala"; e) racionalidade discursiva enquanto "questionamento crítico e revalidação reflexiva das pretensões de validade da racionalidade consensual-comunicativa, mediante a racionalidade consensualcomunicativa liberada da ação, e conforme o princípio de não-autocontradição performativa dos que argumentam" (cf. CORTINA, Razón comunicativa y responsabilidad solidaria: ética y política em K.-O. Apel, pp. 255-256). 
proposto por Apel ${ }^{184}$, com a diferenciação metodológica entre "compreender" (Verstehen, consoante às ciências histórico-hermenêuticas) e "elucidar" (Erklären, referente às ciências explicativas) ${ }^{185}$.

Como ponto de partida desse programa, Apel tematiza acerca da necessidade de romper com o preconceito relativo aos paradigmas cognitivos da tradição filosófica ligados à hermenêutica. A razão fundamental para isso é que esses paradigmas podem fornecer recursos conceituais, cujo auxílio pode colaborar na explicação dos problemas de uma autoexperienciação da sociedade (Selbsterfahrung der Gessellschaft), talvez não repetível experimentalmente, porém reconstruível como história ${ }^{186}$. Segundo Apel, a confirmação prática dessa explicação não reside na factibilidade permanente, mas no progresso histórico da interação social, cuja validade ou eficácia é imensurável com parâmetros cientificistas. Diferentemente do que ocorre no campo do método da racionalidade científico-tecnológica, em que a proposição ou não de problemas em cada área da vida se dá em razão dos métodos disponíveis, a explicação no campo da hermenêutica exige a racionalidade dos métodos filosófico-científicos, que é mensurada com base no grau de complexidade e no tipo de problemas que se apresentam a nós, e não no inverso. O fato é que propor ou deixar de propor problemas em cada área da vida não deve depender dos métodos disponíveis; e isso tanto mais quando a situação de interação social se mostra inconciliável com o método de racionalidade científico-tecnológica. Daí, é necessário incorporar as contribuições de filosofias hermenêutico-dialéticas na produção da "sociedade aberta" e crítica (segundo a terminologia do racionalismo crítico de Popper), o que pode, segundo Apel, fazer progredir o processo de transformação de uma filosofia voltada à ciência. Faticamente, a tarefa da construção da sociedade aberta não constitui um problema em relação ao qual é possível se dedicar apenas na mesma medida em que for possível solucioná-lo com base nos recursos conceituais de disposição cientificista e de produção tecnológica adequados a processos já em andamento. Disso resulta a importância do contributo das filosofias hermenêutico-dialéticas, tematizando, ainda que de modo insuficiente, "o problema central das ciências humanas e da filosofia social modernas: a identidade e não-identidade de sujeito e objeto do conhecimento comunicativo, e da ação como interação em uma 'sociedade aberta"" 187.

\footnotetext{
184 APEL, K. A. O desafio da crítica total da razão e o programa de uma teoria filosófica dos tipos de racionalidade. Trad. Márcio Suzuki. In: Novos Estudos - CEBRAP, n. 23, pp. 67-84, março de1989, p. 77.

185 APEL, Transformação da filosofia, v. I, pp. 25-26; Transformation der Philosophie, Band I, pp. 21-22.

186 APEL, Transformação da filosofia, v. I, p. 22; Transformation der Philosophie, Band I, p. 19.

${ }^{187}$ APEL, Transformação da filosofia, v. I, p. 23; Transformation der Philosophie, Band I, p. 20.
} 
A convicção fundamental de Apel é que a fenomenologia hermenêutica, iniciada por Heidegger e depois desenvolvida por Gadamer com a designação de Verdade e Método, não apenas constitui o contraponto à posição reducionista da racionalidade da filosofia orientada metodologicamente no caminho da ciência, mas também delineia o caminho inicial determinativo para a transformação da filosofia transcendental por ele postulada. $\mathrm{Na}$ interpretação de Apel, o modo de pensar fenomenológico, aproveitando-se das discrepâncias entre o conceito moderno de método e a experiência pré-científica de vida (Leben) e de mundo (Welt), pode requerer para si a vantagem teórica de emancipar-se tanto da metafísica ocidental quanto do distanciamento crítico da ciência e da técnica modernas. Ao tematizar a experiência pré-científica do mundo da vida como uma experiência que não chega a ser metódico-abstrativa, a fenomenologia hermenêutica tem o mérito de estabeler o liame entre duas emancipações, tanto a emancipação em relação à experiência da metafísica dogmática e da filosofia das visões de mundo, quanto a emancipação em relação às restrições cientificistas. E isso justifica a vinculação semiótica transcendental com a forma do pensar fenomenológico ${ }^{188}$.

Para Apel, essas duas emancipações são explicitadas na filosofia tardia de Heidegger. Aí, de modo singular, elas são entendidas como um contínuo entre a reconstrução e a destruição crítica da metafísica ocidental ${ }^{189}$ e o distanciamento crítico da ciência e da técnica modernas, nas quais imperam o método da disponibilização matemática e experimental do ente. Nesse ponto, para entender o significado dessas emancipações, faz-se necessário esclarecer em que consiste, fundamentalmente, o projeto da fenomenologia hermenêutica de Heidegger, designado de "hermenêutica da faticidade", em relação ao qual Gadamer reconhece que dá prosseguimento. Na interpretação de Gadamer, a hermenêutica heideggeriana traz à luz um fundamento diferente, sendo o único a possibilitar a compreensão do ser: o fundamento se refere ao fato de que existe um "pré" (" $D a$ "), uma clareira do ser, isto é, a diferença entre ente e ser. Na hermenêutica heideggeriana, a pergunta pelo fato de "que 'há' tal coisa" é a indagação pelo ser, porém numa direção até então impensada e esquecida,

\footnotetext{
${ }^{188}$ APEL, Transformação da filosofia, v. I, p. 27; Transformation der Philosophie, Band I, p. 23.

${ }^{189}$ Para Heidegger, apesar de todo o interesse pela "metafísica", é necessário concretizar a questão do ser, cujo caminho passa pela destruição do acervo legado pela tradição da antiga ontologia, à luz da problemática da temporalidade. Trata-se, portanto, de buscar uma interpretação do ser não mais a partir do mundo e da natureza (ontologia grega e suas filiações), mas a partir do "tempo". O tempo constitui o "horizonte da compreensão do ser a partir da temporalidade, como ser da presença, que se perfaz no movimento de compreensão de ser" (cf. HEIDEGGER, Martin. Ser e tempo. Trad. Márcia de Sá Cavalcante Schuback. 2. ed., Petrópolis: Vozes e Ed. Universitária São Francisco, 2007, p. 55). Não se trata de arrasar a tradição ontológica, mas de demonstrar que a problemática central de toda ontologia se fundamenta e lança suas raízes no fenômeno do "tempo". É na exposição da problemática da temporalidade do ser que se dá a resposta à questão sobre o sentido do ser.
} 
porque velada pela metafísica. Nela, concebe-se que a compreensão humana se orienta a partir de uma pré-estrutura da compreensão que emerge da situação existencial (do ser-aî), antes (por detrás) de qualquer locução ou enunciado, porém demarcando o enquadramento temático e o limite de validade de cada tentativa de interpretação. Essa compreensão é, fundamentalmente, "um entender sobre algo", que indica menos um saber (um modo de conhecimento) do que um "como" existencial por força do qual é possível "situar-se" no mundo. Daí, compreender teoricamente uma coisa (pragma, práxis) significa estar apto para ela, estar em condições de "ter-que-haver" no cuidado com algo (habilidade, poder, mestria ou "arte" que permanece inexpresso) ${ }^{190}$.

Conforme Grondin, o conceito de hermenêutico se refere à estrutura prélinguística (pré-predicativa) do "como" que pertence à nossa "conduta" ("caminho do costume”). Na compreensão pré-predicativa, de início, o que existe é a relação humana com o mundo, no "modus" de pré-esboços de compreensão, em relação ao qual, sem escolha, o ser humano é primariamente lançado (jogado) na faticidade. A consideração teórica do mundo constitui uma explícita suspensão desses esboços que, ao mesmo tempo, testemunha a inaudita universalidade da pré-estrutura fática. A compreensão epistemológica do cientista do espírito constitui, ela mesma, uma modalidade de tal mestria. Contudo, ressalta-se que esse novo conceito de compreensão não implica colocar-se à mercê da pré-estrutura de explanação induzida e seus correspondentes preconceitos, pois, contrariamente, a hermenêutica existencial de Heidegger visa a um explícito esclarecimento (interpretação) da pré-estrutura da compreensão historicamente dada. Essa hermenêutica inverte a relação teleológica tradicional, na qual a interpretação funciona como meio à compreensão (intelligere); no caso, a compreensão constitui o elemento primário e a interpretação, instância de elaboração da compreensão. Assim, a interpretação constitui um desmembramento e uma autoapropriação do implicitamente já pré-entendido, em vista da autotransparência do ser-aí (da faticidade) ${ }^{191}$.

A faticidade do Dasein constitui a base ontológica do questionamento fenomenológico ${ }^{192}$, e nele a ideia de fundamentação experimenta uma "inversão total". A

190 GADAMER, Hans-Georg. Verdade e método I: traços fundamentais de uma hermenêutica filosófica. Trad. Ênio Paulo Giachini. 14. ed., Petrópolis, RJ: Vozes e Ed. Universitária São Francisco, 2014, p. 345.

191 GRONDIN, Jean. Introdução à hermenêutica filosófica. Trad. Benno Dischinger. São Leopoldo: UNISINOS, 1999, pp. 156-174.

${ }^{192}$ HEIDEGGER, Ser e tempo, pp. 66- 79. A expressão fenomenologia significa um conceito de método, que não caracteriza a quididade dos objetos da investigação filosófica, mas o como dos objetos, isto é, refere-se exclusivamente ao modo como se demonstra e se trata o que deve ser tratado nela. A fenomenologia exprime o retorno "para as coisas elas mesmas", por oposição à inapreensão de conceitos só aparentemente verificados ou às pseudoquestões apresentadas como problemas por gerações. A expressão fenômeno abrange dois significados, 
expressão "hermenêutica da faticidade" 193 denota a tendência de "conceber a partir da vida", isto é, de uma posição anterior à objetividade da ciência, e por isso não pode ser fundamentada nem deduzida. Não se busca aí uma solução para o problema do historicismo, apesar de tal ontologia fundamental colocar em primeiro plano o problema da história, tampouco uma fundamentação original para as ciências. Trata-se de uma análise do mundo da vida e da fundação anônima de sentido, que constitui o terreno de toda experiência humana. $\mathrm{O}$ que fica superado no redespertar da questão do ser é a carência de uma base ontológica da subjetividade transcendental, pois, inversamente, é a estrutura da temporalidade que aparece como determinação ontológica da subjetividade e do ser. Na verdade, essa estrutura é mais que isso, à medida que o próprio ser é tempo. Nela, quanto à fundamentação, a estrutura do ser-aí - pelo fato de estar às voltas com seu ser e diferenciar-se de qualquer outro ente por sua compreensão do ser - se desfaz do subjetivismo da filosofia moderna, que postula um fundamento último a partir de um questionamento transcendental, e do horizonte da metafísica, que compreende o ser como o presente. A analítica transcendental do ser-aí visa a esclarecer a estrutura fundamental da vida humana sobre a qual repousa toda a compreensão, que é o movimento da ascensão acima do ente (transcendência) ${ }^{194}$.

Salientando, Gadamer entende que a hermenêutica fenomenológica de Heidegger delineia uma nova direção para o compreender (Verstehen), pois, em Heidegger, o

\footnotetext{
a saber, fenômeno como o que se revela e se mostra em si mesmo e fenômeno como aparecer, parecer e aparência, que se interrelacionam em sua estrutura. O sentido formal da pesquisa designada de fenomenologia é o de "deixar e fazer ver por si mesmo aquilo que se mostra, tal como se mostra a partir de mesmo" (HEIDEGGER, Ser e tempo, p. 74). Quanto ao seu conteúdo, a fenomenologia é ontologia (ciência do ser dos entes). Quanto ao sentido metodológico da descrição fenomenológica, a fenomenologia da presença (Dasein, ser-aí; dependendo da tradução) é hermenêutica (interpretação). Conjuntamente, ontologia e fenomenologia caracterizam a filosofia em seu objeto e em seu modo de tratar. "A filosofia é uma ontologia fenomenológica e universal que parte da hermenêutica da presença, a qual, enquanto analítica da existência, amarra o fio de todo questionamento filosófico no lugar de onde ele brota e para onde retorna" (HEIDEGGER, Ser e tempo, p. 78). “"Atrás' dos fenômenos da fenomenologia não há absolutamente nada. Contudo, aquilo que deve tornar-se fenômeno pode velar-se" (HEIDEGGER, Ser e tempo, p. 75). Daí a importância da fenomenologia, enquanto hermenêutica, que é anuncia o sentido próprio do ser e as estruturas fundamentais da presença encoberta (velada, obstruída). Enquanto tema fundamental da filosofia, o ser, embora referente a todo e qualquer ente, não corresponde ao gênero dos entes. $\mathrm{O}$ ser, cuja "universalidade" se eleva acima de qualquer ente e de toda determinação ôntica possível de um ente, é o "transcendens pura e simplesmente". De forma privilegiada, é na transcendência do ser da presença que "reside a possibilidade e necessidade da individuação mais radical". Assim, "toda e qualquer abertura de ser enquanto transcendens é conhecimento transcendental. A verdade fenomenológica (abertura do ser) é veritas transcendentalis" (HEIDEGGER, Ser e tempo, p. 78).

${ }^{193}$ Heidegger designa de facticidade "o caráter de fatualidade do fato da presença em que, como tal, cada presença sempre é. À luz da elaboração das constituições existenciais básicas da presença, a estrutura complexa desta determinação ontológica só poderá ser apreendida em si mesma como problema. O conceito de faticidade abriga em si o ser-no-mundo de um ente "intramundano", de maneira que este ente possa ser compreendido como algo que, em seu 'destino' está ligado ao dos entes que lhe vêm ao encontro dentro de seu próprio mundo" (HEIDEGGER, Ser e tempo, p. 102).

${ }^{194}$ GADAMER, Verdade e método I, p. 348.
} 
compreender não diz respeito a "um ideal resignado da experiência de vida na idade avançada do espírito" (Dilthey), ou a um "ideal metodológico último da filosofia frente à ingenuidade do ir vivendo", mas concerne à forma originária de realização do ser-aí, que é o ser-nomundo, na medida em que ele é possibilidade ${ }^{195}$. De tal modo, o conceito da compreensão não é um conceito metodológico para fundamentar hermeneuticamente as ciências do espírito, tal como uma "operação posterior e na direção inversa, que segue o impulso da vida rumo à idealidade. Compreender é o caráter ontológico da própria vida humana" ${ }^{196}$. A compreensão de expressões não diz respeito somente à captação do conteúdo da expressão, mas também se refere ao descobrimento do que há oculto para além da interioridade oculta. Daí que, "todo compreender acaba sendo um compreender-se", e por isso "aquele que compreende projeta-se rumo a possibilidades de si mesmo"197. Desse direcionamento resulta que, para legitimar espistemologicamente a especificidade metodológica das ciências históricas, a compreensão do ser histórico não precisa destacar-se em face do ser da natureza, tal como ocorre na forma de conhecer das ciências da natureza. O conhecimento histórico recebe sua legitimação da estrutura prévia do ser-aí que, como tal, não espelha um projetar planejador, como extrapolação de metas da vontade e acomodação das coisas aos desejos, mas uma adequação à coisa ("mensuratio ad rem"). Porém, essa coisa não é um factum brutum, um dado simplesmente constatável e mensurável, mas algo que possui o modo de ser da historicidade da presença humana que, em sua mobilidade do relembrar e do esquecer, constitui a condição de possibilidade de atualização do passado em geral ${ }^{198}$.

$\mathrm{Na}$ interpretação de Apel, Heidegger critica a racionalidade metódica cientificista, tanto porque ela leva o ser humano a dispor do mundo e, retroativamente a partir do próprio mundo, de si mesmo, quanto por suas possíveis implicações quando aplicada à esfera social,

\footnotetext{
195 GADAMER, Verdade e método I, p. 347.

196 Idem, p. 348.

197 Idem, p. 349.

198 Para Heidegger, porque só se faz história na medida em que somos "históricos", então o conhecedor e o conhecido não estão dados "onticamente", mas se dão "historicamente". Para a realização da compreensão que se dá nas ciências do espírito, a adequação do conhecedor ao conhecido não se fundamenta no postulado de que ambos possuam o mesmo modo de ser, mas que recebam seu sentido da especificidade do modo de ser histórico comum a ambos. A estrutura universal da compreensão se concretiza na compreensão histórica, uma vez que os vínculos concretos de costume e tradição e suas correspondentes possibilidades de futuro operam na própria compreensão. De tal maneira, a pertença a tradições, antes vista como barreira para o conceito tradicional de ciência e método ou como condição subjetiva de acesso ao conhecimento histórico, agora de forma central, constitui uma condição para o sentido originário do interesse histórico, porque ela faz parte da finitude histórica da presença originária e do seu "estar-projetado" para possibilidades futuras de si mesma. Assim, mesmo quando o conhecedor pretende apenas ler "o que está aí" ou extrair das fontes "como realmente foi", toda compreensão (ou interpretação) implica a totalidade da estrutura existencial. E demonstrar o sentido da pertença do intérprete ao seu objeto é a tarefa da hermenêutica (GADAMER, Verdade e método I, pp. 348-353).
} 
em que ela pode tornar-se "um instrumento de dominação cuja modulação funcional é praticamente imperscrutável ou impassível de sofrer crítica" ${ }^{199}$. O fato é que Heidegger vê a ciência, enquanto atitude do homem, como um modo de ser do ente como ser-aí (Dasein). Ela emerge do Dasein, e só a partir do Dasein é possível compreender criticamente a atividade científica e suas implicações ${ }^{200}$. Como contraponto à redução cientificista do conhecimento, a fenomenologia hermenêutica de procedência heideggeriana proporciona, em lugar das coações categoriais de pensamento e comportamento que partem da disponibilização técnicocientífica - porém não em substituição das coações sócio-econômicas associadas possivelmente a isso -, o desvendamento da experiência cotidiana, em que o sentido do ser torna-se disponível, mesmo sem considerar a disponibilização ${ }^{201}$.

Apel assinala que, no contexto da crítica à racionalidade metódica cientificista, a fenomenologia tem sido vista frequentemente como oposição metódica à crítica semiótica do conhecimento, exercida pelo neopositivismo. Precisando, com exceção à escola inglesa do Wittgenstein tardio, essa oposição se refere à semiótica da filosofia analítica da linguagem em sua fase pré-pragmática. A questão por trás dessa oposição é a ambiguidade que determina a relação entre humanismo e pragmatismo, pensada a partir do ideal retórico de linguagem e verdade. Ocorre que, segundo Apel, a filosofia da linguagem heideggeriana reflete essa ambiguidade de uma maneira particularmente elucidativa, em sua virada (Kehre) que parte da "análise do ser-aí" para a "história do ser". De início, essa concepção trata da oposição entre a "eidética" ou "intuição imediata" e o método, que parte da "mediatidade" do conhecimento do mundo e desenvolve proposições para verificá-las com base no "mundo exterior". Contudo, bem mais que uma oposição, importa para Heidegger é evidenciar o caráter da historicidade da linguagem. Em Ser e Tempo (1927), a eidética corresponde a uma "hermenêutica da antecipação" linguística no mundo. A hermenêutica ontológica de Heidegger, que "pensa com a linguagem", distingue-se do método semiótico, não por tratar a linguagem como um

\footnotetext{
${ }^{199}$ APEL, Transformação da filosofia, v. I, p. 27; Transformation der Philosophie, Band I, p. 23.

${ }^{200}$ HEIDEGGER, Ser e tempo, p. 47. A guinada de Heidegger, em sua análise do mundo da vida e da fundação anônima de sentido, que constitui o terreno da experiência humana, pontua Gadamer, estabelece o pano de fundo a partir do qual é reorientado o rumo do problema consoante à objetividade das ciências do espírito. Aí, o conceito de objetividade da ciência aparece como um caso excepcional; a ciência, cuja tarefa é esclarecer a idealização já posta por ela, não constitui um factum do qual deve partir, pois ela não é a primeira tarefa. Antes, "tanto as ciências do espírito como as da natureza deverão derivar-se dos desenhos da intencionalidade da vida universal, portanto, de uma historicidade absoluta. Essa é a única forma de compreender que pode satisfazer a autorreflexão da filosofia" (cf. GADAMER, Verdade e método I, p. 347).

${ }^{201}$ APEL, Transformação da filosofia, v. I, pp. 27-28; Transformation der Philosophie, Band I, p. 23. Na linha desta crítica à racionalidade metódica cientificista, segundo Apel, é possível estabelecer uma correlação entre o pensamento de Heidegger e a crítica neomarxista da "razão instrumental" e do "homem unidimensional" empreendida por Horkheimer, Adorno e sobremaneira H. Marcuse.
} 
medium quod do conhecimento - no sentido instrumental de um sistema objetualmente disponível -, mas por mobilizar, desde o início, "a função apriorística medium quo da linguagem corrente, em favor da pré-compreensão ontológica do mundo (ou seja, em favor do pensamento historicamente essencial" 202.

Esclarecendo, a referida oposição reflete a distinção no âmbito do chamado "uso da linguagem", isto é, da compreensão que não necessita recorrer metafisicamente a algo além dos limites do mundo interpretado linguisticamente, entre dois tipos de uso das palavras. Em um tipo, entende-se o uso da linguagem como instrumento de designação de coisas conhecidas a serviço de objetivos e necessidades já conhecidos. Por pressupor que as qualidades das coisas e dos seres sejam "patentes", a linguagem subsume os fatos sob conceitos convencionais. Em outro, concebe-se que o uso da linguagem torna patente ("põe em cena") as qualidades das coisas e dos seres humanos e, como tal, "libera" o ente em seu próprio ser-assim (Sosein) mediante "percepções verdadeiras" autênticas ("ocorrências de sentido"). Neste último, as palavras são "potências de encarnação de sentido", na expectativa de que os objetivos e as carências do ser humano não tenham sido desvelados na essência do seu momento presente. $\mathrm{Na}$ interpretação de Apel, essa diferença reflexiona o fato de que a semiótica positivista-pragmática considera o condicionamento imposto pelos objetivos e as carências do ser humano a toda significância do mundo, mas não leva em conta as "ocorrências de sentido" - postas em relevo pela fenomenologia hermenêutica - que, junto com as coisas, evidenciam as verdadeiras carências humanas. Além disso, o que se põe em questão é que a compreensão das "ocorrências de sentido" talvez seja possível apenas $a$ posteriori e por via hermenêutica, e até certo ponto ${ }^{203}$.

O mistério da linguagem, ou seja, a ideia de que não é possível falar propriamente sobre a forma intrínseca da linguagem e sim, em última instância, mostrá-la por meio de sua "coprojeção", segundo Apel, fundamenta o segredo metodológico da fenomenologia hermenêutica heideggeriana ${ }^{204}$. Para Heidegger, o logos é um "deixar e fazer ver algo como algo, na medida em que se dá em conjunto com outro", podendo ser verdadeiro ou falso.

\footnotetext{
202 APEL, Transformação da filosofia, v. I, p. 193; Transformation der Philosophie, Band I, p. 163. "O homem fala. Falamos quando estamos acordados e em sonho. Falamos continuamente. Falamos mesmo quando não deixamos soar nenhuma palavra. (...) Falamos porque falar nos é natural. (...) Costuma-se dizer que por natureza o homem possui linguagem. Guarda-se a concepção de que, à diferença da planta e do animal, o homem é o ser vivo dotado de linguagem. (...) Nela se diz que a linguagem é o que faculta o homem ser o ser vivo que ele é enquanto homem" (cf. HEIDEGGER, Martin. A caminho da linguagem. Trad. Marcia Sá Cavalcante Schuback. Petrópolis, RJ: Vozes e Ed. Universitária São Francisco, 2014, p. 7).

${ }^{203}$ APEL, Transformação da filosofia, v. I, p. 188-189; Transformation der Philosophie, Band I, pp. 159160.

${ }^{204}$ APEL, Transformação da filosofia, v. I, p. 194; Transformation der Philosophie, Band I, p. 164.
} 
Verdadeiro quando descobre do seu velamento o ente sobre que se fala, e falso quando o encobre, pondo-o como algo que não é. E porque ele pode ser verdadeiro ou falso, a ideia de concordância não expressa a ideia primária de verdade (alétheia como "des-velar", "descobrir"). Somente quando o logos cumpre a função de deixar e fazer perceber o ente, ele pode significar razão (ratio), isto é, aquilo que, em todo dizer e em toda discussão, já está presente como "fundo e fundamento"205. Segundo Grondin, no tocante à compreensão e à interpretação de natureza linguística, o olhar hermenêutico não se direciona contra a linguagem, tampouco seu objeto paira "antes" da linguagem. Na hermenêutica, o discurso (falar) é a autointerpretação do ser-aí; a linguagem, como "morada do ser", assume a precedente e insuperável revelação do ser. A crítica de Heidegger se dirige à visão restritiva da lógica, que reduz a linguagem à predicação objetivante (constructo lógico) e exclui o ser-aí que também se expressa. Nela, até se supõe que o sofrimento da finitude possa ser expresso em sentenças locucionais autossuficientes. Contudo, a suspeita de Heidegger ante o enunciado deságua no risco que a funcionalização da linguagem - oferecida pela técnica que tudo pode expressar e calcular - representa à questão da verdade, quando se enxerga em sentenças locucionais a plena expressão da verdade filosófica. Para a hermenêutica, a questão da verdade se estabelece a partir da situação existencial humana, elaborando a própria estrutura preconceitual como estrutura ontológica da compreensão e assim ocorre o dar-se do ser-aí com base nas possibilidades que estão à sua disposição. Por isso, perseguir uma verdade absoluta ou um último fundamento (atemporal) significa encobrir a realidade da compreensão, reprimir ou esquecer a própria temporalidade ${ }^{206}$.

Importa considerar que o mistério da linguagem na fenomenologia hermenêutica heideggeriana, assim pontua Apel, não obsta a interpretabilidade pública. Nos escritos de juventude de Heidegger, em As categorias e doutrina do significado de Duns Scotus, ainda predomina a visão de Husser ${ }^{207}$, em que a problemática da verdade é ainda pensada em

\footnotetext{
${ }^{205}$ HEIDEGGER, Ser e tempo, pp. 72-74.

${ }^{206}$ GRONDIN, Introdução à hermenêutica filosófica, pp. 174-177.

${ }^{207}$ Em Husserl, esse método faz parte da tarefa de transformação da ontologia em uma "filosofia transcendental", porém não a partir do "método construtivo-regressivo de Kant". Husserl crê que o método kantiano impossibilita a realização da tarefa básica da filosofia transcendental, ou seja, a apresentação das condições de possibilidade do conhecimento objetivo. Segundo Husserl, Kant procura apresentar as condições de possibilidade do conhecimento objetivo por meio de suposições construídas pelo espírito e, desse modo, a subjetividade é simplesmente construída no pensamento vazio. Com isso, o idealismo não tem conseguido se liberar de pressuposições secretas de natureza objetivista, ou tem omitido de pôr em questão, em razão de seu caráter especulativo, de maneira concreta e analítica, a subjetividade em ato, aquela que confere valor no plano da intuição a um mundo em ato, fenomênico. Em contrapartida, distinguindo o dado enquanto simplesmente pensado e enquanto dado-em-si-mesmo, Husserl responde à questão das condições de possibilidade do conhecimento por meio da intuição. Diferentemente do pensamento que é abstrato, porque tem apenas intenções
} 
termos de uma verdade lógico-formal e semântica de uma "consciência em geral". Para Apel, já o Heidegger da obra Ser e tempo se aproxima da filosofia linguístico-terapêutica de Wittgenstein em sua fase tardia, que intenta encontrar o critério para o pensamento sensato no ajuste interno da filosofia ao uso contextual da linguagem. Em Ser e tempo, Heidegger parece privilegiar a dimensão pragmática do significado em detrimento da dimensão lógico-formal e concernente à correção factual ${ }^{208}$. Não obstante, é preciso atentar-se para a peculiaridade do entendimento sobre a interpretabilidade pública referenciada em Ser e tempo. Aí, a interpretabilidade pública é a verdade que decorre do desvelamento (alétheia) do ser-aí em sua "cotidianidade mediana". A interpretabilidade pública é continuamente determinada a partir dos objetivos de "deferência" ("cuidado") pelo outro, posto que somente as carências do ser humano (voluntariedade da preocupação) possibilitam a interpretação linguística do mundo e um acordo mútuo inter-humano. Nessa interpretabilidade, o ente se coloca de acordo com sua "circunstância explicativa" ("significância", Bedeutsamkeit), perante a constatação do puro "estar-de-antemão" dos fatos e de suas relações formais. Heidegger entende que a relação, inclusive a relação dos signos, em razão do seu caráter formal-geral, tem sua origem

não realizadas, a intuição é a revelação plena do ser, e por isso só nela está realmente a coisa no seu ser próprio. A filosofia deve retroceder à intuição das próprias coisas, uma vez que a intuição constitui a "forma mais originária do dar-se do dado" e significa simplesmente a maneira suprema segundo a qual algo pode ser dado ao sujeito, à sua consciência. Segundo ele, a fundamentação do conhecimento só é possível a partir de uma análise fenomenológica, ou seja, de uma descrição da estrutura específica do fenômeno, do fluxo imanente de vivências que constitui a consciência. A atitude fenomenológica se pauta pela investigação "puramente imanente" do psíquico (fenomenal). Tal é possível porque, em seus passos básicos, a reflexão fenomenológica parte da significação das palavras e, ulteriormente, retrocede dessas às próprias coisas. $\mathrm{E}$ assim procedendo, o mundo psíquico manifesta-se como instância à qual os objetos são dados à consciência do homem em "atos intuitivos" (vivências) de diferentes modos. Sob esse horizonte, ele entende esta filosofia transcendental qua movimento de transcendência dos dados mutáveis para a estrutura imutável da subjetividade, como condição última de possibilitação da validade intersubjetiva do conhecimento (ver: OLIVEIRA, Manfredo A.. A filosofia na crise da modernidade. São Paulo: Loyola, 1989, pp. 29-40; STEGMÜLLER, Wolfgang. A Filosofia Contemporânea. São Paulo: Ed da Universidade de São Paulo, 1977, v. 2, p. 73; HUSSERL, Edmund. La filosofia como ciencia estricta. Trad. Elsa Tabernig. Bueno Aires: Editorial Nova, 1962, pp. 72-73). É no contexto do preenchimento, viabilizado por meio das intuições cumpridoras, que Husserl levanta a questão da evidência e, ligado a ela, a questão do sentido da verdade. A evidência é a síntese de preenchimento que dá à intenção a plenitude do próprio objeto, o qual não é meramente visado, mas dado. Nela se realiza o ser no sentido da verdade, da 'concordância' corretamente entendida, da adequatio rei ad intelectus. A verdade é diretamente dada, ela própria, à intuição e à apreensão (cf. HUSSERL, Edmund. Investigações lógicas: sexta investigação (elementos de uma elucidação fenomenológica do conhecimento). Seleção e trad. Zeljko Loparié e Andréa M. A. de C. Loparié. São Paulo: Abril Cultural, 1975, pp. 10 e 91-94 (col. Os Pensadores). Em sua análise da da crise da fenomenologia contemporânea, Apel (cf. APEL, Le problème de l'évidence phénomenologique à la limière d'une sémiotique transcendantale. In: Critique, p. 81) aponta os motivos condutores dessa a crise: em parte, em em função do confronto com lógica fregeana da linguagem que interpela pelos fundamentos da evidência fenomenológica, considerando-a como um sentimento subjetivo de evidência que não satisfaz as exigências dos argumentos científicos; em parte, porque ela parte da intuição de uma contextualidade da pré-compreensão dos fenômenos. Esses dois motivos põem em descrédito a pretensão husserliana de fundar a filosofia como ciência rigorosa baseada na evidência apodítica de uma intuição das essências.

${ }^{208}$ APEL, Transformação da filosofia, v. I, p. 194; Transformation der Philosophie, Band I, p. 164. 
ontológica em uma remissão. Onticamente, o signo é algo que está à mão e funciona como instrumento revelador da estrutura ontológica do mundo operante e da mundicidade ${ }^{209}$.

No entanto, diferentemente da pragmática, o ponto de vista último da analítica do ser-aí de Heidegger não é proceder a uma relativização pragmática da significância do mundo em relação aos objetivos da práxis humana. "A voluntariedade última do ser-no-mundo é apenas aparentemente uma referência objetiva fixa, que relativiza o mundo como mundo instrumental", posto que o autoentendimento pragmático "predomina apenas na cotidianidade mediana dos afazeres do cuidar" ${ }^{210}$. Heidegger pensa que o ser-aí é histórico somente na voluntariedade de sua práxis. Para ele, assim assinala Apel, as carências últimas do ser humano podem se transformar em "ocorrências" históricas, nas quais, por um lado, "os objetivos humanos quanto à circunstância explicativa das coisas como 'instrumentos' não estejam decididos de antemão", porém, "pelo contrário, as coisas revelem-se ao ser humano de modo que o ser-aí do homem venha alterar-se, sob a luz de uma nova significância"211. Para Apel, exemplos dessa "virada" histórica da aparente pragmática antropológica de Ser e tempo são dados por Heidegger em suas interpretações de Hölderlin e em seu texto A origem da obra de arte. Na linha dessa virada, por exemplo, Heidegger pensa que a poesia desvela a essência mais profunda da linguagem; e que a relação da linguagem com a verdade é “determinada mais profundamente pelo caráter de 'obra' das palavras literárias do que pelo caráter pragmático “instrumental' dos signos linguísticos”212. Em Heidegger, toda correção dos enunciados, mediada pelo uso instrumental de palavras ou juízos formados a partir delas, não trata ainda de verdade ${ }^{213}$, mas de descerramento de sentido como condição

\footnotetext{
209 APEL, Transformação da filosofia, v. I, p. 195; Transformation der Philosophie, Band I, p. 165.

${ }^{210}$ APEL, Transformação da filosofia, v. I, p. 195; Transformation der Philosophie, Band I, p. 165.

211 APEL, Transformação da filosofia, v. I, p. 195; Transformation der Philosophie, Band I, p. 165.

212 APEL, Transformação da filosofia, v. I, p. 196; Transformation der Philosophie, Band I, p. 166.

${ }^{213}$ A teoria metafísico-ontológica da verdade delineia a definição tradicional da verdade como correspondência, isto é, como adequação ou conformidade do pensamento com a coisa. O significado de "ser verdadeiro" e "verdade" é o acordo sob duas maneiras: a concordância entre uma coisa e o que dela previamente se presume ("veritas est adaequatio rei et intellectus") e a conformidade entre o que é significado pela enunciação e a coisa ("veritas est adaequatio intellectus ad rem"). O "verdadeiro" designa um enunciado exato, se ele concorda com o fato. A verdade da proposição só é possível quando fundada na verdade da coisa, pois a verdade de uma proposição consiste em sua correspondência (acordo, Übereinstimmung) ao fato ("cópia exata"). O conteúdo do conhecimento verdadeiro não depende da consciência, vontade ou preferência; o conteúdo do conhecimento, aquilo que é refletido na consciência, tem caráter objetivo, isto é, existe fora e independente de nós. Sendo assim, pôr-se em concurso à verdade é investigar os objetos e fenômenos e descobrir as verdades e as leis naturais pelas quais elas se regem, refletindo corretamente na nossa mente aquilo que existe na realidade (ver: RESCHER, Nicolas. Die Kriterien der Warhheit In: Wahrheitstheorien. Gunnar Skirbekk (Org.). Frankfurt am Main: Suhrkamp, 1996, pp. 341 e 344; HEIDEGGER, Martin. Sobre a essência da verdade: a tese de Kant sobre o ser. Trad. Ernildo Stein. SP: Duas Cidades, 1970, pp. 22-24; BAZARIAN, Jacob. O problema da verdade teoria do conhecimento. SP: Alfa-Omega, 1985, pp. 133-135). Vale salientar que, a teoria da correspondência desenvolvida no quadro da tradição aristotélico-tomista, comporta nuances. Aristóteles compreende a definição
} 
transcendental-hermenêutica de verdade. A correção do designar, "pressupõe, de sua parte, a verdade como desvelamento do ser em geral no ser-aí". Tal desvelamento, ele mesmo, é constituído novamente na linguagem. Isso parece indicar que todo uso verificável da linguagem de maneira pragmática já pressupõe que o ser humano "habita como inquilino na 'morada do ser', a qual nasce em ocorrências de sentido humanisticamente relevantes ao longo da história da linguagem" 214.

Para Apel, a radicalização existencial-ontológica da ideia de hermenêutica introduzida por Heidegger delineia um dos principais méritos da fenomenologia hermenêutica em geral, que é ter reagido, em meio à "lógica científica" moderna, ao processo de atrofia sofrido pela teoria e crítica do conhecimento de origem kantiana. Esse mérito, em razão da relevância epistemológica ligada a ele, é ulteriormente incorporado por Apel em seu projeto de transformação da filosofia. A fenomenologia hermenêutica, ao radicalizar o interesse em apropriar-se do "compreender", não apenas revela os pressupostos transcendentais da lógica científica, mas também descobre as estruturas semitranscendentais (quasitranszendentalen) pressupostas no compreender que não podem ser tematizadas a partir da relação sujeitoobjeto, ou seja, segundo o esquema cartesiano-kantiano. Entre as estruturas semitranscendentais, destaca-se a "pré-estrutura existencial" do compreender descoberta por Heidegger, a qual se desdobra nas várias implicações ${ }^{215}$ : a) como estrutura do "ser-nomundo", ela implica, ao mesmo tempo, a superação do idealismo epistemológico; b) como estrutura do "ser-com" (Mitsein), ela possibilita simultaneamente a superação do solipsismo metódico; c) como estrutura do pré-entendimento, marcada sempre linguística e historicamente, ela implica questionar, por meio da figura de pensamento do "círculo

de verdade no sentido de uma "Entsprechung", uma correspondência (cf. PUNTEL, Lorenz Bruno. Wahrheitstheorien in der neueren Philosophie. 3. ed., Darmstadt: Wiss. Buchgesellschaft, 1993, pp. 26-28). Conforme Puntel, a fórmula da verdade é a seguinte: "\{wahr [verdadeiro] $\} \mathrm{p}=\mathrm{df}$ Üb (p, SVp)", isto é, a expressão lingüística "p" está conforme com o estado-de-coisa (Sachverhalt), então refere-se a "p". A relação de correspondência pode ser representada em distintos modos e graus, tais como, "anima-ens", "sujeito-objeto", "consciência-mundo", "conhecimento-realidade", "linguagem-mundo", a partir da qual se chega da forma mais abstrata à forma mais concreta. Já os escolásticos, conforme assinala Manfredo de Oliveira, "vão considerar a verdade um 'transcendental', isto é, algo que compete à realidade enquanto tal. O fundamento último do conhecimento da verdade de nosso conhecimento". E segundo Tomás de Aquino, "é a autopresença da razão a si mesma. A razão sabe de seu próprio exercício, sabe de sua correspondência à realidade. Para essa perspectiva, o homem só pode saber do erro na base de um saber da realidade em si, que ele compara com o seu saber atual" (cf. OLIVEIRA, Reviravolta lingüístico-pragmática, nota 1, p. 35). Sobre o conceito de verdade e a tríplice divisão da verdade e do verdadeiro, bem como a respeito da verdade primeira (a inteligência de Deus), ver: AQUINO, Tomás de. Questões Discutidas Sobre a Verdade. Trad. Luiz João Baraúna. São Paulo: Abril Cultural, 1973, pp. 23-59, especificamente os artigos I, II, IV, V, VI, VII e VIII).

${ }^{214}$ APEL, Transformação da filosofia, v. I, p. 196; Transformation der Philosophie, Band I, p. 166.

215 APEL, Transformação da filosofia, v. I, p. 29; Transformation der Philosophie, Band I, p. 25. 
hermenêutico" 216 , a alternativa abstrata entre apriorismo e empirismo; d) como estrutura do "ser-que-se-antecipa" do ser-aí, no modo da preocupação (Sorge) voltada ao futuro, ela implica pôr em questão também a ideia do conhecimento livre de interesses de algo como algo. Relevantemente, em torno da descoberta da pré-estrutura do compreender se assinala, desde o início, a possibilidade de elaborar os pressupostos semitranscendentais de uma teoria do conhecimento inédita. Daí se desdobra, entre outras tematizações, o ineditismo teórico com a tematização da linguagem como um a priori ineludível (intranscendível, nicht hintergehbare) do compreender, cujo mistério talvez não seja passível de reconstrução. Semelhante originalidade também ocorre com a tematização da fundamentação da verdade como correção dos juízos ou das asserções mediante o desvelamento acobertante de sentido, em vista da "síntese hermenêutica de algo como algo" em sua circunstância de significância ${ }^{217}$.

A relevância epistemológica da radicalização existencial-ontológica da hermenêutica se mostra, segundo Apel, na superação da ideia do compreender o sentido (Verstehens, atividade hermenêutica) como um método concorrente ao explicar (Erklärung), como método da explicação analítico-causal e formalizada dos aspectos naturais dos fatos que visa a responder cientificamente a perguntas referentes ao “por quê?”. Enquanto a lógica científica neopositivista tende a ver o compreender como um método com função psicológico-heurística auxiliar da interpretação no contexto de descoberta da explicação de comportamentos, a hermenêutica mostra que a compreensão, como modo peculiar do humano ser-no-mundo, já é pressuposta pela epistemologia na constituição dos dados da experiência,

\footnotetext{
${ }^{216}$ Conceitualmente, o círculo hermenêutico não é um dispositivo metodológico; não é de natureza formal. Ele descreve como se dá a compreensão como jogo decorrente do intercâmbio entre o movimento da tradição e o movimento do intérprete. Nele, a compreensão do texto se encontra determinada pelo movimento de concepção prévio da pré-compreensão (antecipação de sentido). O círculo não se dissolve com a compreensão, mas alcança com ela sua realização mais autêntica. Ele não é subjetivo, pois a antecipação de sentido não é um ato da subjetividade, mas se determina a partir da comunhão dos sujeitos com a tradição em continua formação. Não é objetivo ou uma pressuposição dada, mas se instaura a partir da participação no acontecer da tradição. Ele descreve o "momento estrutural ontológico da compreensão". O sentido desse círculo que forma a base do compreender é a "concepção prévia da perfeição", isto é, compreender as expectativas de sentido presentes no texto (GADAMER, Verdade e método I, pp. 388-389). O "círculo hermenêutico" prima pelo conhecimento mais originário. Nele se revela que a "tarefa primordial, constante e definitiva da interpretação" é "não permitir que a posição prévia, a visão prévia e a concepção prévia (Vorhabe, Vorsicht, Vorbegriff) lhe sejam impostas por intuições ou noções populares. Sua tarefa é, antes, assegurar o tema científico, elaborando esses conceitos a partir da coisa, ela mesma" (GADAMER, Verdade e método I, p. 355). Para compreender o sentido diante da multiplicidade do opinável, o empreendimento hermenêutico adota o critério referente à coisa mesma. Assim, a tarefa hermenêutica se converte num questionamento pautado na coisa em questão, e já se encontra codeterminada por esta. A consciência formada hermeneuticamente deve ser receptiva à alteridade do texto, deixando que ele lhe diga alguma coisa. Essa receptividade não implica em neutralidade em relação à coisa, mas na apropriação das opiniões prévias e preconceitos pessoais a fim de que o texto possa apresentar-se em sua alteridade.
}

${ }_{217}$ APEL, Transformação da filosofia, v. I, pp. 29-30; Transformation der Philosophie, Band I, p. 25. 
bem como na resposta a perguntas relativas ao "o quê?" da teoria do conhecimento. Desse modo, por uma parte, ao juntar a problemática da compreensão, como problemática transcendental da constituição, com a problemática heideggeriana da verdade, como desvelamento de sentido, a hermenêutica se posiciona na retaguarda da problemática semitranscendental da constituição dos dados por meio de teorias científicas. Por outra parte, fica patente que a questão específica referente à compreensão nas chamadas ciências humanas só pode ser posta de forma adequada se não estiver subordinada, de antemão, à problemática da explicação científica analítico-casual. Adequadamente, a questão da compreensão das ciências humanas deve ser vista “em conjunto com o 'acordo mútuo' (Verständigung) metacientífico entre os cientistas, já pressuposto em todo anseio elucidativo, e que se dá acerca dos objetos a ser tematizados e da abordagem metodológica de seu respectivo programa de pesquisa" ${ }^{218}$.

No entender de Apel, o compreender das ciências humanas assume a função semitranscendental de esclarecer o pré-entendimento categorial da experiência. Esse préentendimento ocorre mediante um "pré-acordo mútuo" (Vorverständigung) intersubjetivo em relação à linguagem científica, aos modelos teóricos, ao processamento de teorias e aos programas de pesquisa, conforme medidas estabelecidas pelo "círculo hermenêutico" entre a "antecipação apriorística" e de uma correção empiricamente condicionada do compreender "algo como algo". A função semitranscendental desempenhada por esse esclarecimento transporta a problemática hermenêutica para perto da problemática da reconstrução linguística e da explicação dos conceitos. E essa aproximação, a exemplo da abordagem da Escola de Erlang, indica a possibilidade de complementaridade entre a filosofia linguístico-analítica (ligada à pragmática) e a filosofia linguístico-hermenêutica, tendo em vista uma reconstrução do acordo mútuo mediado pela linguagem na dimensão pragmática de uso dialógico da linguagem. Para Apel, o que confere suma importância a essa função é que por meio dela se explicita a dimensão do acordo intersubjetivo, que é significativa para a constituição e validade do conhecimento ${ }^{219}$.

Gadamer, partindo da radicalização ontológica de Heidegger, que libera a ciência das inibições ontológicas do conceito de objetividade, pretende construir uma hermenêutica histórica própria para as ciências do espírito, alicerçada na historicidade da estrutura prévia da

\footnotetext{
${ }^{218}$ APEL, Transformação da filosofia, v. I, pp. 30-31; Transformation der Philosophie, Band I, p. 26.

219 APEL, Transformação da filosofia, v. I, p. 31; Transformation der Philosophie, Band I, pp. 26-27.
} 
compreensão ${ }^{220}$. Para ele, a historicidade não é uma limitação ou um abismo devorador à compreensão, mas constitui um princípio de compreensão, "o fundamento que sustenta o acontecer, onde a realidade finca suas raízes" ${ }^{221}$. Em seu ponto de partida, a hermenêutica histórica abole a oposição abstrata entre a ação da tradição que perdura e a investigação histórica, ao conceber que, inversamente ao pretendido pelo historicismo, entre elas subsistem relações recíprocas que não implicam algo radicalmente novo, mas em um momento novo dentro do que sempre tem sido a relação humana com o passado. Nessa perspectiva hermenêutica, a investigação histórica não se restringe aos ditames em vista do progresso científico e de resultados assegurados, mas é "também mediação da tradição", que faculta a realização de experiências históricas, desde que aí se escute "cada vez uma nova voz em que ressoa o passado". A essência da tradição se mostra na forma de "uma pluralidade de vozes nas quais ressoa o passado. E o passado aparece na diversidade dessas vozes" ${ }^{222}$, porque a compreensão se sustenta no movimento histórico em que se encontra a própria vida, segundo Gadamer, os resultados da investigação feita pelas ciências do espírito quase não envelhecem. Nelas, a motivação do questionamento é decisiva para estabelecer o tema e o objeto da própria compreensão a respeito do "Ser histórico" que nunca se esgota no saber-se. Isso, a rigor, é o que distingue as ciências do espírito (humanas e hermenêuticas) em relação às da natureza, cujo objeto é determinado idealiter como aquilo que pode ser conhecido em um conhecimento completo da natureza ${ }^{223}$. Assim, as ciências do espírito se caracterizam por desenvolver a concepção de compreensão que "deve ser pensada menos como uma ação da subjetividade e mais como um retroceder que penetra num acontecimento da tradição, onde se intermedeiam constantemente passado e presente"224.

É bem verdade que, para Gadamer, o questionamento hermenêutico não apenas figura a base metodológica das ciências do espírito, mas também constitui um aspecto

\footnotetext{
${ }^{220}$ Gadamer é cônscio da dificuldade relativa à construção de uma hermenêutica histórica a partir da radicalização ontológica de Heidegger. Em Heidegger, a analítica existencial da presença reivindica para si uma validade a priori e neutra e, como tal, não inclui nenhum ideal histórico determinado. E extrair da estrutura da temporalidade da cura (Sorge) um determinado ideal existencial implica em perder o sentido do que Heidegger denomina de "existencial". Para Gadamer, parece subsistir um problema em aberto: se a analítica da presença não permite o desenvolvimento positivo do modo de ser da vida, parece que a existência humana é sustentada por algo extra-histórico, natural (GADAMER, Verdade e método I, pp. 351-353). Noutra passagem, Gadamer assinala o impulso decisivo de Heidegger, em razão de ter proposto a mudança de rumo ontológico à compreensão como um existencial e aplicado a interpretação temporal ao modo de ser da presença, permitindolhe elaborar a ideia da distância temporal como fator da produtividade hermenêutica (GADAMER, Verdade e método I, p. 393).

${ }^{221}$ GADAMER, Verdade e método I, p. 393.

222 Idem, p. 377.

${ }^{223}$ Idem, pp. 377-378 e 399.

${ }^{224}$ Idem, p. 385.
} 
universal da filosofia e sua preocupação central. Isso, na medida em que a filosofia hermenêutica, como realidade da finitude, procura autointerpretar a faticidade humana e prestar contas da sua finitude como a do horizonte universal. Nesse caminho, o fenômeno hermenêutico se revela em seu próprio caráter de linguagem como mediação de um significado universal, posto que todo entendimento necessita tornar-se acessível à compreensão e à interpretação. A linguagem não se limita a uma linguagem específica, caso da lógica dos enunciados que tende a fragmentar a linguagem em unidades significativas e busca expressão para tudo, mesmo sem jamais esgotar o enunciável. O fenômeno hermenêutico reflete o caráter universal da linguagem, porque ambas, compreensão e linguagem, não podem ser tomadas como um objeto de investigação empírica, mas "abrangem, antes, tudo o que, de um modo ou de outro, pode chegar a ser objeto"225. A dimensão hermenêutica da linguagem é universal e forma o universum da vida (o elemento ou o todo), no qual se realiza toda a compreensão e toda a existência humana. Nessa perspectiva, a hermenêutica da finitude se dedica à exploração do caráter universal e especificamente hermenêutico da consciência histórica na sua experiência de mundo ${ }^{226}$.

A tarefa da hermenêutica, afirma Gadamer, é explicar o "milagre da compreensão, que não é uma comunhão misteriosa das almas, mas uma participação num sentido comum" 227 . Essa tarefa se desenrola no entremeio (Zwischen) da tensão entre a estranheza e a familiaridade que a tradição ocupa junto aos homens, entre a objetividade da distância, pensada historicamente, e a pertença a uma tradição. A compreensão é o acontecer de uma conversação com a tradição. Nesse acontecimento, em sua alteridade em relação à tradição, a consciência histórica se introduz no campo da fusão de horizontes do novo e do velho - não um horizonte único, nem horizontes destacados - para experimentar a "relação de tensão entre texto e o presente" ${ }^{\text {228 }}$. Em razão dessa posição intermediária, o fim dessa tarefa não é desenvolver um procedimento ou método compreensivo (disciplina técnica), mas esclarecer as condições sob as quais surge a compreensão e corrigir a autocompreensão que se exerce no compreender, livrando-a de adaptações inadequadas. Para isso, é necessário "reabilitar" a estrutura pré-conceitual da compreensão - os pré-conceitos (antecipações), pois eles valem como "condições de compreensão" transcendentais - por meio de esboços adequados à realidade, para que o texto se apresente em sua diversidade a partir das coisas mesmas e

${ }^{225}$ GADAMER, Verdade e método I, p. 523.

${ }^{226}$ GADAMER, Verdade e método I, pp. 395-396 e 516. GRONDIN, Introdução à hermenêutica filosófica, pp. 200-205.

${ }^{227}$ GADAMER, Verdade e método I, p. 387.

${ }^{228}$ Idem, p. 387. 
possibilite jogar sua verdade objetiva contra o seu pré-entendimento. Pensando de tal maneira, Gadamer pretende marcar o meio termo entre uma autoextinção positivista do compreender e um perspectivismo universal (Nietzsche). Na falta de critérios seguros para diferenciar os verdadeiros preconceitos, sob os quais se dá o compreender, dos que produzem os malentendidos (falsos), deve-se nortear pelos indícios que o olhar histórico retrospectivo (distância temporal) pode fornecer, mediante a descoberta dos "princípios artísticos" valiosos de seu tempo, para basilar o juízo mais seguro 229 .

Gadamer considera que a historicidade não é uma limitação, mas um princípio de compreensão. No compreender, a verdade, concebida como abertura de sentido, ocorre apenas no decurso da aplicação histórico-efeitual. A historicidade dessa aplicação exclui a representação de um ponto zero da compreensão ou de um progresso no decurso da história ou de uma compreensão melhor. Nos termos de Gadamer, "basta dizer que, quando se logra compreender, compreende-se de um modo diferente" ${ }^{230}$. A compreensão é menos a captação de um sentido noético, no sentido de uma captação intelectual por um sujeito de um contexto

\footnotetext{
${ }^{229}$ A distância temporal, simultaneamente, filtra os preconceitos de natureza particular e faculta o surgimento daqueles "princípios artísticos" que levam a uma objetividade nas ciências do espírito e a crítica interpretativa. O olhar histórico retrospectivo fornece os indícios para basilar o juízo mais seguro acerca de "um questionamento de história efeitual", isto é, um o questionamento sobre o real significado (tematizado secundariamente) dos fenômenos históricos e das obras transmitidas. $\mathrm{O}$ interesse histórico não se dirige somente aos fenômenos históricos ou às obras transmitidas, mas tem como temática secundária os efeitos dos mesmos na história. Segundo Gadamer, por princípio, a compreensão é um processo da "história efeitual", que implica em trazer à luz a relação formada tanto pela realidade da história "efetuada" (que condiciona a consciência humana em suas valorações e conhecimentos) como pela realidade do compreender histórico (que exige o esclarecimento da situação hermenêutica). Gadamer assinala o caráter intransponível e ambíguo do condicionamento históricoefetual. De modo intransponível, a história efetual é mais ser (substância) que consciência (subjetividade); o homem pertence mais à história do que ela lhe pertence. Ambiguamente, de um lado, a consciência humana (valorações e conhecimentos) se mostra "efetuada" pela retaguarda da história; de outro, essa consciência exige um esclarecimento dessa historicidade histórico-efetual (situação hermenêutica). Com efeito, o esclarecimento dessa historicidade histórico-efetual é inconclusivo, pois a história efetual está em ação como horizonte, e esse não pode ser questionado retroativamente até a última nitidez e distância. Na verdade, "ser histórico quer dizer não se esgotar nunca no saber-se". Nisso se coloca a mais unívoca expressão filosófica do reconhecimento do horizonte universal da finitude humana. (GADAMER, Verdade e método I, pp. 395-399). Para Grondin, o problema da crítica hermenêutica permanece sem solução. Pois, faticamente, a História também atua de modo encobridor, quando se rege por princípios de interpretação que obstruem o acesso às coisas ou às fontes. Em tais circunstâncias, o que é hermeneuticamente valioso é, justamente, "o salto para trás das interpretações historicamente poderosas". Ademais, limitadamente, a distância temporal praticamente nada informa acerca do domínio de interpretações contemporâneas (cf. GRONDIN, Introdução à hermenêutica filosófica, pp. 186192).

${ }^{230}$ Para Gadamer, a superioridade da compreensão posterior face à produção originária, no sentido de um "compreender melhor", não se deve a conscientização posterior capaz equiparar o intérprete com o autor (Schleiermacher), mas em razão da diferença entre eles, que é dada pela distância histórica. O verdadeiro sentido de um texto, na medida em que cada época o compreender a seu modo, "supera seu autor não ocasionalmente, mas sempre". A compreensão não é um comportamento reprodutivo, mas produtivo. Mas, "compreender não é compreender melhor, nem sequer no sentido de possuir um melhor conhecimento sobre a coisa em virtude de conceitos mais claros, nem no sentido da superioridade básica que o consciente possui com relação ao caráter inconsciente da produção" (GADAMER, Verdade e método I, p. 392). Este é um ponto de controvérsia de Apel com Gadamer, a ser retomado mais adiante.
} 
objetivável e isolado, do que a pertença e continuação a uma relação de conversação já iniciada antes de nós e em permanente formação, a partir da qual, unicamente, o "colóquio que somos nós" adquire para nós consistência e significado. A condição hermenêutica suprema dessa conversação é a estrutura da pergunta ${ }^{231}$, pois o compreender começa onde algo (nos) interpela acerca do universum relativo à faticidade humana. De forma reprodutiva e produtiva, o diálogo se concretiza pela dialética da pergunta e da resposta, com vistas a abrir e manter abertas as possibilidades da pergunta pela compreensão num processo, em princípio, infinito. Esse é o rumo da ultrapassagem da hermenêutica tradicional, de caráter científicoespiritual, em direção a uma hermenêutica filosófica, em princípio, projetada para liberar o fenômeno hermenêutico em toda sua amplitude ${ }^{232}$.

O mérito da hermenêutica de Gadamer ${ }^{233}$, segundo Apel, consiste em ter aplicado criticamente a radicalização existencial-ontológica da ideia de hermenêutica introduzida por Heidegger à autocompreensão filosófica das ciências humanas e, por conseguinte, ter delineado o campo originário da hermenêutica. Nela, o pensamento fenomenológico ingressa em uma relação mais estreita e crítica com a problemática do método, confrontando-se com o posicionamento oriundo dos neopositivistas ou das metodologias histórico-hermenêuticas, especialmente do historicismo semipositivista do século XIX. Esse posicionamento se caracteriza por reduzir o "compreender" a um acontecimento pertinente à transmissão da tradição, em relação ao qual não pode haver qualquer conscientização definitiva, tampouco uma objetivação metódica da pré-estrutura existencial do pré-entendimento constitutivo do sentido. Como ponto de partida, Gadamer critica a tendência "objetivisticamente" restrita de conceber o fenômeno da compreensão do sentido como equivalente à tematização descritiva ou explicativa de processos e atos psíquicos no outro, supondo assim que o compreender se dá possivelmente por assimilação emocional ou por vivência posterior. Ele desmascara tal concepção, revelando-a como deformação abstrativa e fenomenologicamente secundária do

\footnotetext{
231 Toda experiência pressupõe a estrutura da pergunta. Pois, sem a atividade de perguntar, não se faz experiência. A forma lógica da pergunta e a negatividade que lhe é inerente deságuam numa negatividade mais radical, o "saber que não sabe" (a docta ignorantia socrática). Na docta ignorantia, prelineia-se a verdadeira superioridade da pergunta na negatividade extrema da aporia. A essência da pergunta mostra o modo peculiar de realização da experiência hermenêutica. O essencial a toda pergunta é o sentido de orientação que a resposta deve adotar para que tenha sentido e pertinência. "Com a pergunta, o interrogado é colocado sob determinada perspectiva. O surgir de uma pergunta rompe de certo modo o ser interrogado. Nesse sentido, o logos que desenvolve esse ser assim aberto já é sempre resposta, e só tem significado no sentido da pergunta" (GADAMER, Verdade e método I, pp. 473). Sobre a primazia hermenêutica da pergunta em Gadamer, cf. GADAMER, Verdade e método I, pp. 473-493.

${ }^{232}$ GRONDIN, introdução à hermenêutica filosófica, pp. 194-197. GADAMER, Verdade e método I, p. 396. ${ }^{233}$ APEL, Transformação da filosofia, v. I, pp. 28, 31-32; Transformation der Philosophie, Band I, pp. 24 e 27.
} 
problema hermenêutico original. Na contramão dessas reduções, o caminho de Gadamer é o de incorporar os fenômenos das condições existenciais - "esquecidos" pelas metodologias histórico-hermenêuticas - ao desvendamento da experiência hermenêutica, tomando-os como fatores constituintes da compreensão, por ele entendida como teoria da arte (Kunstlehre) da interpretação.

De forma propositiva, Gadamer reconfigura o âmbito original e central da problemática hermenêutica. Ele circunscreve que o problema hermenêutico original concerne à questão do acordo mútuo (interpessoal) acerca do sentido e da verdade linguística sobre o mundo como objeto (de algo como algo ${ }^{234}$. Originalmente, o problema hermenêutico diz respeito ao acordo realizado em uma conversação sobre um assunto, que se dá no medium da linguagem, cuja função diz respeito a deixar o objeto falar, ao mesmo tempo, sendo a própria linguagem do intérprete ${ }^{235}$. De tal modo, a tarefa da hermenêutica é explicitar a compreensão como participação em um entendimento inter-humano já linguisticamente constituído, portanto de um estar "já sempre de acordo" que constitui a condição de possibilidade da tarefa interpretativa. Quanto à sua função originária e específica, o compreender o outro (mit den Anderen) só representa um ato hermenêutico se a relação linguístico-cognitiva entre sujeitosujeito, relativa ao acordo intersubjetivo acerca de algo e por meio do qual se deposita a confiança no outro quanto à verdade ou à correção normativa de questões práticas, não for substituída por uma objetivação descritiva ou explicativa de seu comportamento, pautada pela relação (linguístico-cognitiva) entre sujeito-objeto ${ }^{236}$.

Para Apel, tendo demarcado o objeto original da hermenêutica como contraponto à "abstração metódica" cientificista, em um passo adiante em relação ao procedimento de validação normativa de textos empregados pela hermenêutica tradicional, Gadamer propõe uma hermenêutica filosófica. Nela, ele preconiza que também as regras metódicas da hermenêutica partem sempre do contexto prático de acordo mútuo, quer dizer, da compreensão de um sentido comunitário linguisticamente já constituído e compartilhado, que se dá no tipo de relação linguístico-cognitiva sujeito-sujeito. Nessa perspectiva, por extensão, Gadamer relativiza a distinção metodológica entre hermenêutica "histórica" e hermenêutica “dogmática" (normativa), posicionando-se em favor de uma hermenêutica filosoficamente neutra em relação à normatividade. De maneira fundamental, essa hermenêutica estabelece que, em todo e qualquer caso do compreender, subsiste a mesma estrutura de "fusão de

\footnotetext{
${ }^{234}$ APEL, Transformação da filosofia, v. I, pp. 31-32; Transformation der Philosophie, Band I, p. 27. ${ }^{235}$ GADAMER, Verdade e método I, pp. 499 e 503.

${ }^{236}$ APEL, Transformação da filosofia, v. I, pp. 31-32; Transformation der Philosophie, Band I, p. 27.
} 
horizontes", que é própria à história, e de "mediação" do presente com o passado, seja como pressuposto, seja como sua aplicação prática $^{237}$.

$\mathrm{Na}$ avaliação de Apel, o caminho trilhado pela fenomenologia hermenêutica de Heidegger e Gadamer retorna à problemática de uma filosofia da ciência normativamente relevante, cuja circunstância remete ao problema de uma transformação da filosofia ligada às ciências $^{238}$. Nessa direção, nota-se que o significado filosófico fundamental da maioria das descobertas semitranscendentais da fenomenologia hermenêutica é confirmado pelo fato de que receberam ora uma elaboração mais exata, ora uma aplicação mais eficiente, nas filosofias do século XX não restritas à lógica científica. Em consequência dessas relações teóricas postas também em virtude da descoberta da pré-estrutura da compreensão pela fenomenologia hermenêutica, observa-se a seguinte mudança de orientação no contexto da problemática da validade do conhecimento: o chamado "contexto de descoberta", anteriormente abordado como tema empírico-psicológico de uma ciência particular (psicologia empírica) e de modo separado do "contexto de justificação" metacientífico, passa a ser "tematizado em meio ao conjunto transcendental-hermenêutico de problemas referentes à constituição de novos jogos de linguagem ou horizontes de sentido" 239 . Apel entende que, ao passo que a filosofia linguístico-analítica moderna deixa para trás a fase da abstração lógico-científica ligada à construção sintático-semântica dos sistemas sentenciais, é possível reconstituir as evidências da hermenêutica transcendental sobre o acordo mútuo interpessoal. Segundo Apel, constituem abordagens que corroboram essas descobertas, por exemplo, a análise dos jogos de linguagem de Wittgenstein em sua fase tardia, a problemática da formação de consensos na ideia de comunidade interpretativa, na semiótica pragmática de Peirce, e na teoria dos "atos de fala" da ordinary language philosophy de Austin e Searle ${ }^{240}$.

Criticamente, Apel pondera que a alternativa exposta por Gadamer entre "verdade" e "método", em face da separação que perdura por décadas entre "lógica científica" e "fenomenologia hermenêutica", não aparenta ser tão plausível e unívoca. De qualquer modo, isso não mitiga a importância da fenomenologia hermenêutica, na medida em que ela pode cumprir a função corretiva diante do estreitamento científico-metodológico quanto à problemática da verdade, contanto que ela mesma possa ser considerada relevante do ponto de vista normativo-metodológico. Em relação a isso, Apel sustenta a tese, incorporada em sua

\footnotetext{
237 APEL, Transformação da filosofia, v. I, pp. 32-33; Transformation der Philosophie, Band I, pp. $27-28$.

238 APEL, Transformação da filosofia, v. I, pp. 31-37; Transformation der Philosophie, Band I, pp. 27 e 32.

${ }^{239}$ APEL, Transformação da filosofia, v. I, p. 35; Transformation der Philosophie, Band I, p. 30.

240 APEL, Transformação da filosofia, v. I, pp. 33-34; Transformation der Philosophie, Band I, pp. 28-29.
} 
concepção da teoria da verdade ${ }^{241}$, que a fenomenologia hermenêutica cumpre tanto essa relevância normativo-metodológica quanto a função de correção da redução cientificista. Ainda segundo Apel, isso fica demonstrado através da atual irrupção de uma problemática fenomenológico-hermenêutica em meio à dimensão histórica da teoria normativa da epistemologia ${ }^{242}$. No entender de Apel, a discussão dessa problemática resulta no delineamento de um relevante marco normativo-metodológico para a compreensão de todas as formas de conhecimento. Basicamente, essa discussão torna visível que as descrições empíricas e as explicações referentes a fatos na história das ciências se mostram, quando consideradas em si mesmas, irrelevantes à compreensão filosófica das ciências. Porém, elas se tornam relevantes à medida que podem ser entendidas como "complementos externos de reconstruções internas", isto é, "de reconstruções racionais, normativamente relevantes" direcionadas a "elucidar" (explicar) exatamente aquilo que não se pode "compreender" no sentido de uma reconstituição metodológico-racional ${ }^{243}$.

No entender de Apel, tal perspectiva implica a tese de que o sentido da história da ciência reside, de maneira complementar ${ }^{244}$, tanto na validação da elucidação empíricoanalítica dos acontecimentos naturais quanto na correção da ratio normativo-metodológica da epistemologia filosófica, utilizando-se, para tal, de um compreender mais profundo da ratio dos clássicos, no sentido do "círculo hermenêutico". A tese da complementaridade traz a proibição quanto à redução da problemática hermenêutica do acordo mútuo metódico, na era do progresso científico-tecnológico, a uma problemática elucidativa. A tese de Apel que justifica tal proibição é que, a rigor, mesmo o interesse cognitivo técnico de disposição e explicação, enquanto um a priori da constituição de sentido para as ciências naturais, já pressupõe a legitimação normativa do campo de sentido aberto por meio do próprio interesse no acordo mútuo. Trata-se de reconhecer que o compreender as ações humanas deve ter em conta, ao contrário do elucidar dos acontecimentos naturais, uma reivindicação normativa de justificação, precisamente para revelar o engajamento normativo no sentido mediante a

\footnotetext{
${ }^{241}$ APEL, Fallibilismus, Konsenstheorie der Wahrheit und Letztbegründung. In: Philosophie und Begründung, p. 126. APEL, Fundamentación semiótico-trascendental de la filosofía pragmática del lenguaje" in: Semiotica filosofica, p. 172.

${ }^{242}$ APEL, Transformação da filosofia, v. I, p. 37; Transformation der Philosophie, Band I, p. 32.

${ }^{243}$ APEL, Transformação da filosofia, v. I, pp. 37-38; Transformation der Philosophie, Band I, p. 32.

${ }^{244}$ Trivializando esta tese da complementaridade, Hans Albert afirma "o progresso epistemológico, em si ilimitado, que ocorre na dimensão sujeito-objeto da descrição e elucidação, não pode jamais substituir a melhora metódica do acordo mútuo na dimensão sujeito-sujeito, pois ele justamente a pressupõe" (APEL, Transformação da filosofia, v. I, p. 32; Transformation der Philosophie, Band I, pp. 27-28). Albert sugere a redução da problemática hermenêutica do acordo mútuo metódico, na era do progresso científico-tecnológico, a uma problemática elucidativa (típica dos acontecimentos naturais).
} 
participação no acordo interpessoal em todo compreender. Isso fica claro quando se considera que qualquer pretensão de descrição das coisas "sem qualquer juízo de valor é incapaz de se conectar cognitivamente, por exemplo, a algo como a história ${ }^{245}$. Então, supondo que a relevância normativo-metodológica do compreender se refere ao compreender filosófico de todas as formas de cognição, inclusive à de autocompreensão, Apel considera pertinente a expectativa de que a problemática da hermenêutica se ramifique na direção de novas ciências do acordo mútuo, voltadas à ciência no âmbito da teoria da ciência, da história, da sociologia, das políticas relacionadas à pesquisa científica e da educação ${ }^{246}$.

\subsection{A crítica de Apel à hermenêutica de Heidegger e Gadamer como contraponto para uma hermenêutica normativa}

Feito o inventário no tópico anterior acerca da contribuição e do mérito da fenomenologia hermenêutica, Apel desenvolve uma crítica às filosofias de Heidegger e Gadamer como ponto de partida de um aprimoramento normativo da abordagem da fenomenologia hermenêutica, a ser empreendido por ele (Apel) como uma hermenêutica transcendental. A crítica de Apel às filosofias hermenêuticas assinala o que ele pretende, pari passu, recuperar e ultrapassar nessas filosofias em razão do seu horizonte de transformação da filosofia. Basicamente, essa crítica se desdobra em torno de três teses ${ }^{247}$. Contudo, o núcleo dela concerne ao "fracasso" da fenomenologia hermenêutica quanto à resolução do problema da verdade e, consequentemente, quanto ao da validação. Para Apel, tal decorre do fato de que a hermenêutica se equivoca ao não separar a problemática da constituição do sentido - que é onde ela presta uma inegável contribuição - da problemática da justificação (fundamentação) e da verdade (validade). Do ponto de vista da recuperação do ganho teórico das filosofias hermenêuticas, Apel reconhece que não se pode subestimar a relevância fenomenológica para a problemática da constituição do sentido, cuja ênfase na "ocorrência" (o acontecer) do sentido em todos os processos "criadores" e "criativos" constitui o fator indisponível e cofundador da história do mundo. Do ponto de vista da pretensão de superar o déficit relativo ao problema da validade, ele sustenta que não se pode deixar de perceber o caráter unilateral e

\footnotetext{
245 APEL, Transformação da filosofia, v. I, pp. 38-39; Transformation der Philosophie, Band I, pp. 33-34.

246 APEL, Transformação da filosofia, v. I, p. 32; Transformation der Philosophie, Band I, pp. 27-28 (aqui, vale observar que tal ideia é apenas mencionada no final da nota de rodapé 27 e não recebe explicitação ulterior).

${ }^{247}$ APEL, Transformação da filosofia, v. I, p. 41; Transformation der Philosophie, Band I, p. 35.
} 
vacilante dessa filosofia, ao pensar a verdade como o descerramento de sentido da ontologia do "estar-presente", cuja legitimação é deduzida do "kairos ligado à sina do ser"248.

$\mathrm{Na}$ óptica de Apel, em vez de essa nova filosofia suplantar a metafísica da era moderna, fundamentada na "autonomia" do sujeito (que pensa, quer e age) e conquistada por meio do esclarecimento da razão, corre-se aí o risco de dissipá-la em uma nova credulidade no destino, possivelmente uma nova alienação ${ }^{249}$. Por isso, com boas razões, pode-se colocar em dúvida a necessidade intrínseca da virada heideggeriana referente à separação entre o problema da constituição do sentido do compreender e o problema da validação do sentido. $\mathrm{O}$ transfundo que autoriza essa dúvida, segundo Apel, é o fato de que Heidegger avalia erradamente sua descoberta relativa ao conceito de verdade. Por sua vez, o ponto de partida para superar isso, ainda com e para-além de Heidegger e Gadamer, é distinguir o âmbito dessas duas questões, concebendo que elas não se excluem nem podem ser confundidas. Mas, para isso, é necessário que a filosofia novamente retroceda à filosofia transcendental, porém transformando à luz dos horizontes das hermenêuticas de Heidegger e Gadamer, de modo que aí venha a se realizar em uma ampliação transcendental da hermenêutica ${ }^{250}$. A crítica de Apel se desdobra, enfim, no projeto filosófico de uma hermenêutica normativa, cujo núcleo reside em torno da pretensão de incorporar concomitantemente a pergunta pela verdade e pela validade e, desse modo, abordar o que é propriamente específico da filosofia, a questão da justificação do sentido, cuja gênese é tematizada nas sociedades históricas pela hermenêutica $^{251}$.

$\mathrm{Na}$ primeira tese, Apel contesta a Gadamer em razão de ele se referir erroneamente a Kant e à filosofia transcendental. De modo análogo a Kant, Gadamer recorre ao questionamento transcendental ao interpelar as condições de possibilidade de todo o compreender. Ocorre que Gadamer rechaça a pretensão relativa à justificação filosófica da validade do conhecimento (quaestio iuris), sob o argumento de que Kant não impõe com seu questionamento transcendental qualquer prescrição de comportamento à ciência natural moderna. Segundo Apel, o que parece reforçar esse abandono referente à justificação da validação do conhecimento é a própria autocompreensão da hermenêutica defendida por Gadamer, uma vez que a questão “como é possível compreender?" precede a todo comportamento da subjetividade compreensiva e de todo comportamento metódico das

\footnotetext{
${ }^{248}$ APEL, Transformação da filosofia, v. I, pp. 47-48; Transformation der Philosophie, Band I, pp. 40-41.

${ }^{249}$ APEL, Transformação da filosofia, v. I, p. 48; Transformation der Philosophie, Band I, p. 41.

${ }^{250}$ APEL, Transformação da filosofia, v. I, p. 41; Transformation der Philosophie, Band I, p. 45.

${ }^{251}$ Cf. Estudio introductorio I (Júlio Zan) in: APEL, Semiotica filosofica, p. 39. OLIVEIRA, Reviravolta lingüístico-pragmática na filosofia contemporânea, nota 31, p 262.
} 
ciências compreensivas, às suas normas. Em relação a essa autocompreensão da hermenêutica, Gadamer afirma não propor método algum, mas apenas descrever o que é, em vez de partir daquilo que deveria ser (segundo o viés normatizado pelo método da ciência moderna). A hermenêutica descreve o modo do que sempre acontece na experiência do mundo referente à moção fundamental do ser-aí que perfaz sua finitude e historicidade ${ }^{252}$. Em contraposição, Apel argumenta que é indevida a invocação da Crítica da razão pura (1787), sem que se queira propor e responder, a exemplo do que pretende fundamentar Kant com base em uma dedução transcendental, à pergunta sobre as condições de possibilidade e validade do conhecimento em geral. Kant difere dos modernos representantes de uma "filosofia metodológica" não por rejeitar uma resposta à questio iuris metodologicamente relevante, mas por buscar fundamentá-la com base na dedução transcendental das condições de possibilidade e validade do conhecimento em geral. O problema é que, procedendo como reflexão ex post factum, tal como preconiza Gadamer, a hermenêutica abdica da pretensão à justificação normativamente relevante da validade do conhecimento. Ora, sem tal justificação não é possível aprender nada novo (nichts mehr) sobre a essência da ciência ao refletir filosoficamente sobre o que faz a ciência, tampouco distinguir entre o que é válido e o que se passa factualmente despercebido ${ }^{253}$.

Enfaticamente, Apel afirma não se pode renunciar à crítica normativamente relevante em prol da mera descrição do que sempre acontece. Por isso, é necessário dar o salto de uma hermenêutica filosófica, que deixa "tudo como está" e procura se eximir de pretensões crítico-normativas, para uma reflexão transcendental-hermenêutica, caracteristicamente capaz de responder à pergunta acerca das condições de possibilidade de todo compreender. Decerto, essa crítica não descredencia o ganho auferido com a correção fenomenológico-hermenêutico em face dos prejuízos normativo-metodológicos, por exemplo, do cientificismo, tampouco mitiga o mérito da fenomenologia hermenêutica ligado ao desvendamento reflexivo das condições de possibilidade do conhecimento. Trata-se, antes, de considerar que a fenomenologia hermenêutica deve ir além, projetando-se na direção de uma hermenêutica transcendental, com a função de aclarar, mediante o "círculo hermenêutico", o modo pelo qual é possível manter e corrigir uma pré-compreensão normativamente relevante por meio da

${ }^{252}$ GADAMER apud APEL, Transformação da filosofia, v. I, pp. 40-41 (nota 44); Transformation der Philosophie, Band I, p. 34.

${ }^{253}$ APEL, Transformação da filosofia, v. I, pp. 41-42; Transformation der Philosophie, Band I, pp. 35-36. 
elucidação de fenômenos, tais como o do compreender em todos os âmbitos científicos e précientíficos $^{254}$.

Na segunda tese, Apel avalia que Gadamer se refere a Heidegger de maneira historicamente correta. No caso, essa referência ocorre tanto em relação ao conceito heideggeriano de pré-estrutura do compreender (concebida não como um dos modos de agir do sujeito, mas um modo do próprio ser-aí no mundo), quanto no tocante à ideia aí implícita de verdade, entendida como "abertura" do ser-aí. Com isso, Gadamer faz valer a reação levantada pela análise do ser-aí heideggeriana contra a redução gnoseológica da lógica, graças a qual é possível refletir sobre estruturas humanas fundamentais em sua função semitranscendental, tais como, o atrelamento ao corpo, o trabalho, a linguagem. Graças ao mérito da reflexão heurística de Ser e Tempo, voltada ao "perfeito a priori" do "ser-que-seantecipa já de antemão" do "ser-aí" como "ser-no-mundo" compreendente e sensível, vem à tona um novo estilo de reflexão transcendental. Há que se atentar para o fato de que no giro linguístico de Heidegger que se opera no modo de pensar, o que vige como transcendental (nichthintergehrbar) é a situação fundamental do "ser-que-se-antecipa", na qual se inscrevem os fatores semitranscendentais da pré-estrutura do compreender. Ocorre que, como essa situação constitui o a priori linguístico, do ponto de vista transcendental-hermenêutico proposto por Heidegger, é efetivamente falso explicar o problema da constituição do sentido como um ato resultante das "conquistas" subjetivas de uma "consciência pura" (como em Husserl), pois, para Heidegger, os fenômenos constituem-se, ou já estão constituídos desde sempre para a consciência, e os atos subjetivos, em resposta ao mundo desde já sempre constituído, realizam o esclarecimento do "aí" 255 .

Ao invocar a Heidegger de forma historicamente correta, Gadamer acaba mostrando que a consciência humana é determinada pela história. Posto que o "eis-ser-ẫ" não pode superar sua própria faticidade (que é inescapável, um transcendental), a constituição do sentido não é obra de uma subjetividade isolada e apartada da história, porém somente explicável a partir da pertença e vinculação a costumes e tradições que codeterminam sua experiência de mundo. Efetivamente, a subjetividade não é dona do sentido, porque apenas no horizonte da tradição de um todo é possível compreender qualquer coisa ${ }^{256}$. Para Apel, o ponto crítico da posição de Gadamer é que, na medida em que a verdade do compreender depende, em última instância, da "pré-compreensão" pertencente à história, o homem se

\footnotetext{
${ }^{254}$ APEL, Transformação da filosofia, v. I, pp. 43-44; Transformation der Philosophie, Band I, pp. 37-38. ${ }^{255}$ APEL, Transformação da filosofia, v. I, pp. 41 e 45; Transformation der Philosophie, Band I, pp. 35 e 39. ${ }^{256}$ OLIVEIRA, Reviravolta lingüístico-pragmática na filosofia contemporânea, p 227.
} 
encontra a mercê da vitória da história do ser ou do tempo sobre o logos. Isso explica porque Gadamer não está em condições de admitir a possibilidade um "compreender melhor", condicionado pela reflexão e referenciado pela autoridade da tradição. Diferentemente, em Gadamer, a causa da supremacia da história do ser sobre o logos não decorre da pretensão de um compreender melhor, mas do princípio segundo o qual é possível no horizonte da historicidade sempre compreender de "outra maneira". Perplexamente, Apel assinala a estranheza de ver Gadamer sustentar tal posicionamento com base contraditória, ou seja, alicerçado na suposta vitória do a priori fático da linguagem, porém com pretensão de validade universal $^{257}$.

Na terceira tese, Apel afirma que Heidegger traz uma contribuição inédita para o problema transcendental-hermenêutico da constituição do sentido, porém falha quanto ao problema da verdade e da validação do conhecimento. Ao colocar a pergunta ontológica fundamental relativa às condições da compreensão do ser como pergunta transcendental, no sentido da "Crítica da razão pura" como "razão finita", ele equipara a pergunta pela verdade com a pergunta pela abertura do Dasein finito e, em seguida, com a pergunta pela iluminação e pelo ocultamento do sentido do ser, condicionados pela historicidade deste último. Não obstante, Apel pensa que Heidegger avalia erradamente sua descoberta relativa ao conceito de verdade. Heidegger define a verdade como abertura de sentido que precede à correção das declarações, na perspectiva do estar-aberto hermenêutico do ser-aí ou dos horizontes específicos de significância. Conforme os estudos de E. Tugendhat, a definição de verdade declarativa heideggeriana é uma reconstrução da definição herdada originalmente de Husserl, para o qual a declaração é verdadeira “quando ela revela e 'des-cobre' o ente de maneira tal como ele é em si mesmo" ${ }^{258}$. Aí, tacitamente, Heidegger modifica essa definição, no rumo do seu conceito do "estar-aberto" do ser-aí ou de "clareação" do ser, mediante recurso ao artifício de se fixar pela determinação mais simples, segundo a qual a "declaração é verdadeira quando ela 'des-cobre"'. Assim, a abertura de sentido é equiparada à verdade, no sentido original de alétheia, como desocultamento. O "erro" de Heidegger, segundo Apel, reside em ele não perceber a distinção essencial entre a verdade como abertura de sentido (desocultamento) e a verdade referente à sentença declarativa. A verdade como abertura de sentido - que é também ocultamento de sentido - constitui a condição de possibilidade da verdade do enunciado, porém nela inexiste o diferencial entre sujeito e objeto e, ademais, a possibilidade de

257 APEL, Paradigmas de filosofía primera, pp. 178-179.

258 APEL, Transformação da filosofia, v. I, p. 49; Transformation der Philosophie, Band I, p. 43. 
justificação imediata. Apenas a verdade declarativa tem sua medida no ser-em-si do ente demonstrado e expresso, e também somente nela subsiste o diferencial entre as instâncias subjetiva e objetiva, por intermédio do qual é possível refutar ou justificar asserções acerca das coisas. Por conseguinte, o risco que decorre a propósito desse erro, analisa Apel, é tomar a verdade, aí equiparada à clareação de sentido, como objeto de um destino pelo qual não se pode mais assumir responsabilidades ${ }^{259}$.

Para Apel, Heidegger se aparta da pergunta kantiana pela validade a priori universal e intersubjetiva dos juízos do conhecimento. De início, a expressão "ser-que-seantecipa" como "preocupação" (Sorge) parece evidenciar que Heidegger não rompe por completo sua ligação com a filosofia transcendental da subjetividade. Contudo, ele não estabelece relação entre a pré-estrutura do compreender e uma subjetividade pré-consciente. Efetivamente, do factum apriorístico do "estar aberto do ser-aí", Heidegger depreende uma virada (Kehre): partindo da análise semitranscendental-filosófica do ser-aí, ele segue em direção a um pensamento que, peculiarmente, provém do fato de pertencer à história do ser e se manifesta insubmisso a qualquer ligação normativo-metodológica para a validação conceitual. Heidegger sustenta que a iluminação histórico-destinal do sentido do ser constitui a condição de possibilidade dos juízos verdadeiros e falsos; e, filosoficamente, é mais fundamental que a verdade priorizada pela filosofia transcendental clássica como validade intersubjetiva para todos os seres racionais. Como um desdobramento de uma abordagem transcendental-fillosófica não-kantiana, o "estar aberto do ser-aî" pode ser entendido como um acontecimento anônimo da "clareação" da pré-estrutura do ser-aí, eximida da disponibilidade subjetiva. De tal modo, por um lado, Heidegger desenvolve apenas a problemática da constituição do sentido do mundo mantida na pré-estrutura do compreender; por outro, lega a problemática da validação do sentido a uma filosofia transcendental subjetiva, que é incluída na metafísica a ser suplantada. Em consequência, ele negligencia a possibilidade de que as iluminações epocais do destino do ser não só podem estar condicionadas pelo destino do ser, senão que também pelos processos de aprendizagem no sentido da verificação e falsificação dos juízos do conhecimento. Ao fazer depender do destino do ser toda a filosofia ocidental, avalia Apel, Heidegger projeta a vitória do "evento" temporal e sua pretensão de validade universal sobre o $\log o s^{260}$.

\footnotetext{
${ }^{259}$ APEL, Transformação da filosofia, v. I, pp. 48-50; Transformation der Philosophie, Band I, pp. 41-43. ${ }^{260}$ APEL, Paradigmas de filosofía primera, pp. 177-178. APEL, Transformação da filosofia, v. I, pp. 47-48; Transformation der Philosophie, Band I, pp. 40-41.
} 
A partir das críticas à filosofia hermenêutica, de maneira avaliativo-propositiva, Apel extrai as consequências ligadas ao significado das contribuições de Heidegger e Gadamer no marco da filosofia contemporânea, em princípio, suscetíveis de aplicação em uma transformação da filosofia que se mantenha ligada às ciências. Em relação a Heidegger, Apel depreende as seguintes consequências ${ }^{261}$ : a primeira delas concerne à falta de uma concepção de verdade consistente. A descoberta de Heidegger amplia a problemática da constituição do sentido averiguada por Husserl, porém ela não estabelece um novo conceito de verdade ${ }^{262}$. O que Heidegger faz é desvendar a pré-estrutura problemática da verdade, que é idêntica à do compreender como "estar-aberto do ser-aí" e, como tal, precede a todas as operações cognitivas da subjetividade. O "estar-aberto do ser-aí” descoberto por Heidegger não é a verdade em si mesmo, mas corresponde a um "espaço de manobra" que permite préjulgar possíveis verdades ou inverdades. Em consequência dessa primeira, segundo Apel, resulta impossível seguir Heidegger em sua virada concernentemente ao conceito de verdade. Pois, como já exposto, essa virada finda por separar totalmente a problemática relativa às condições de possibilidade do compreender (constituição do sentido) e a questão sobre a justificação metodologicamente relevante dos resultados do compreender o sentido (problema da validade em sentido kantiano). Ante tal impossibilidade, a terceira consequência se desdobra como a "guinada" (de Apel) dentro da virada hermenêutica, em que aparece a tarefa do itinerário de Apel referente à transformação da filosofia transcendental em uma hermenêutica transcendental.

Como desdobramento da terceira consequência e do giro hermenêutico aí postulado, em lugar de seguir na perspectiva de superação da filosofia transcendental kantiana por meio de uma filosofia do destino do ser, Apel procura aprofundar e ampliar a filosofia transcendental kantiana a partir da dimensão de historicidade da pré-estrutura hermenêutica do compreender. De uma parte, a realização dessa guinada implica, quanto à hermenêutica, ultrapassar a visão de que a pré-compreensão é um pressuposto da constituição do sentido presa ao destino do ser; e, quanto à filosofia transcendental, incorporar a ela a dimensão

\footnotetext{
${ }^{261}$ APEL, Transformação da filosofia, v. I, pp. 50-52; Transformation der Philosophie, Band I, pp. 43-44.

${ }^{262}$ Segundo Apel, Heidegger compreende inicialmente sua pergunta ontológica fundamental relativa às condições da compreensão do ser como pergunta transcendental, no sentido da "Crítica da razão pura" enquanto "razão finita". Mas, posteriormente, Heidegger acaba confundindo a pergunta kantiana pelas condições de possibilidade da validade objetiva (intersubjetiva) do conhecimento com a pergunta, possivelmente inspirada em Husserl, pela constituição de sentido da compreensão do ser. Desse modo, ele equipara a pergunta pela verdade com a pergunta pela abertura do Dasein finito e, em seguida, com a pergunta ao mesmo tempo pela iluminação (Lichtung) e pelo ocultamento do sentido do ser, condicionados pela historicidade deste último. O aspecto problemático é que, desse modo, ele se aparta da pergunta kantiana pela validade a priori universal e intersubjetiva dos juízos do conhecimento (APEL, Paradigmas de filosofía primera, pp. 177-178).
} 
fenomenológica dos acontecimentos históricos de sentido, na qual desde sempre se configura a interpretação pública - pode-se dizer, em certo sentido, a dimensão pragmática da linguagem - do ser-aí como pré-estrutura de nosso entendimento acerca do mundo e de nós próprios. De outra, essa guinada implica desenvolver uma concepção de verdade que leve em conta a exigência da validade do conhecimento. A resposta para essa exigência se encontra no cruzamento da tradição hermenêutica com a tradição da filosofia como análise da linguagem, tendo como ponto de partida mais específico a teoria do consenso como acordo mútuo sobre o sentido linguístico e verdade possível, procedente da semiótica de Peirce.

Em seu núcleo, essa teoria do consenso preconiza que o alcance da consciência cognitiva sobre algo como algo requer, necessariamente, a participação em um processo de acordo mútuo linguístico e interpessoal mediado no âmbito da comunidade ilimitada de investigação. Criteriologicamente, ela estabelece que qualquer evidência só pode valer como verdade no âmbito do consenso intersubjetivo. Nela, vantajosamente, reside a superação do solipsismo metódico presente na teoria filosófica do conhecimento, segundo Apel, ao menos de Ockham, Descartes, Husserl e B. Russell. Ulteriormente, em sua teoria da verdade, Apel amplia o conceito de consenso, antes restrito ao âmbito da comunidade ilimitada de investigação (Peirce), concebendo-o como o acordo mútuo a ser alcançado por todos os afetados na comunidade de comunicação, em sua dialeticidade fática (comunidade real de comunicação, sociedade) e contrafática (instância apriorística, comunidade ideal de comunicação). É na comunidade real de comunicação que surge a exigência de que o indivíduo possa discernir acerca da necessidade do acordo mútuo; entretanto, ao realizar tal discernimento, concomitantemente, ele já tem antecipado contrafaticamente o ponto de vista de uma comunidade ideal de comunicação em seu autoconhecimento pensante, a qual representa o sujeito da verdade consensual ${ }^{263}$.

Fundamentalmente, Apel pensa que a filosofia transcendental hermeneuticamente transformada parte do a priori de uma comunidade real de comunicação ${ }^{264}$. Essa transformação se configura como "uma crítica transcendental do sentido", sob a pressuposição da tese que a validação do sentido do discurso depende da pressuposição de um jogo de linguagem transcendental, que é o jogo semiótico-hermenêutico do a priori da comunidade de comunicação. A “figura fundamental”, que resulta dessa transformação, é a

\footnotetext{
${ }^{263}$ APEL, Transformação da filosofia, v. I, pp. 69-70; Transformation der Philosophie, Band I, p 60. Tratarse-á do tema da teoria da verdade mais adiante, inclusive explicitando a retomada de Kant por Peirce e, em continuação, a incorporação crítica de Peirce por Apel.

${ }^{264}$ APEL, Transformação da filosofia, v. I, pp. 70; Transformation der Philosophie, Band I, p 60.
} 
"pré-estrutura" (Vorstruktur) transcendental-hermenêutica do compreender. Ela corresponde à pré-estrutura hermenêutica do compreender (de pré-entendimento) de uma filosofia transcendental que, diferentemente do idealismo transcendental de Kant, não parte da hipostasiação do "sujeito" ou de uma "consciência em geral" como garantia metafísica à validação do conhecimento, mas da pressuposição de que, pelo fato de "um único alguém e uma única vez" não pode seguir uma regra (no sentido do Wittgenstein tardio), os seres humanos, por participarem do "jogo de linguagem transcendental" da comunidade de comunicação ilimitada, estão condenados a priori a um acordo intersubjetivo. Em razão desse pré-entendimento acerca do sentido (quanto à pretensão de verdade, veracidade, correção normativa e sentido), os seres humanos estão obrigados a entender-se no mundo e alcançar, em princípio, conhecimentos válidos sobre as coisas e sobre a sociedade ${ }^{265}$.

Continuando, para Apel, já que esse indivíduo pertence automaticamente a uma comunidade ilimitada de argumentação, ele deve dar conta da reflexão transcendental, ou seja, da reflexão sobre a validade (e o sentido, do ponto de vista hermenêutico) do pensar e agir humanos. Quer dizer, todo ser humano que tenha aprendido uma linguagem no processo de socialização - e, com isso, tiver adquirido competência comunicativa e se tornado capaz de responder por si -, em razão da referida pertença, deve ser "capaz de estar com a verdade" consensual e de se assegurar dessa circunstância, por meio de reflexão transcendental ${ }^{266}$. Contudo, pondera Apel, esse autoasseguramento da verdade só tem validade a priori, na medida em que o discernimento consensual reconhece alguns pressupostos para a fundamentação de conhecimentos substancialmente consistentes. Esses pressupostos são: a) o pressuposto relativo à necessidade de considerar a experiência empírica e o acordo ilimitado e intersubjetivo quanto ao sentido e à validação da verdade da experiência; b) o pressuposto de que o discernimento consensual só é valido como verdade, na medida em que ele mesmo possa embasar as discussões e os critérios de verdade de todos os participantes do "discurso teórico" da filosofia - no horizonte deste trabalho, da educação -, se tiver que fazê- $\mathrm{lo}^{267}$; c) o

\footnotetext{
${ }^{265}$ APEL, Transformação da filosofia, v. I, pp. 69; Transformation der Philosophie, Band I, pp. 59- 60. 266 APEL, Transformação da filosofia, v. I, p. 70; Transformation der Philosophie, Band I, p 60.

267 Apel postula uma explicação possível do sentido da verdade que promete tomar em consideração todas as teorias criteriologicamente relevantes da verdade, exceto a teoria metafísico-ontológica da correspondência, que ele vê como criteriologicamente inutilizável. O realismo crítico do sentido e a teoria consensual da verdade, teoria normativo-procedimental aplicável a todo critério de verdade, são os maiores atrativos do programa da semiótica transcendental. Mediante ambas as teorias são possíveis evitar qualquer forma de realismo acrítico "externo" ou "metafísico" e fixar um princípio regulativo que force relacionar, desde o postulado de uma comunidade ideal e ilimitada de argumentação-interpretação-experimentação, todos os critérios relevantes de verdade, ainda quando nunca suficientes, com uma síntese da interpretação possível, o "ponto supremo" da teoria semiótica do conhecimento. Sobre isso, ver: APEL, Fallibilismus, Konsenstheorie der Wahrheit und
} 
pressuposto de que convenções tácitas, aquelas que determinam a pré-compreensão do mundo segundo as regras dos distintos jogos de linguagens, só podem ser concebidas como convenções, sob a pressuposição transcendental-hermenêutica do a priori do acordo mútuo ilimitado. Assim, no a priori da comunidade de comunicação que busca o consenso, todo o gênero humano, como sujeito semitranscendental da verdade em face das ocorrências de sentido na história do ser, reassume sua autonomia de responsabilidade solidária pela verdade $^{268}$. Nisso, enfim, consiste o sentido de uma filosofia transcendental transformada hermeneuticamente.

Em um passo adiante, Apel aplica as consequências extraídas da filosofia de Heidegger à hermenêutica de Gadamer, tencionado a ir além de Gadamer e alinhavar os contornos elementares de uma hermenêutica filosófica normativa e metodologicamente relevante. Ao fazer essa aplicação, Apel constata a limitação da hermenêutica de Gadamer, em razão de ela não responder de maneira suficiente (metodologicamente relevante) à questão sobre a validade do compreender, ou seja, à questão acerca do marco criteriológico de distinção entre o mal-entendido e o compreender adequado. Para Apel, Gadamer até parte da pergunta sobre a possibilidade do compreender (“como é possível compreender?”), entendendo-a como uma questão extensível ao todo da experiência de mundo e da prática de vida humana. A rigor, afirma Apel, essa é a pergunta basilar de uma hermenêutica transcendental. Ao respondê-la, Gadamer recorre à demonstração da estrutura da ocorrência do ser na fusão de horizontes e na mediação do presente com o passado, afirmando que ela se realiza, como estrutura de ocorrência, de igual modo no mal-entendido e compreensão adequada. No entender de Apel, parece quase impossível extrair da obra Verdade e método uma resposta inequívoca para a questão dos pressupostos do compreender adequadamente ou do progresso da compreensão. Assim, Gadamer passa ao largo de uma exigência fundamental: a resposta à pergunta sobre a possibilidade do compreender implica suscitar, necessária e concomitantemente, a interpelação sobre a validade do compreender, de modo a cumprir com as exigências normativas que possibilitem definir um critério de progresso possível no compreender ${ }^{269}$.

Decerto, pensa Apel, as exigências consoantes aos critérios devem ser cumpridas de forma clara e independentemente dos limites, se de modo estreito ou amplo, referentes à

Letztbegründung. In: Philosophie und Begründung, p. 138. APEL, Karl Otto. El camino del pensamiento de Charles S. Peirce. Trad. Ignacio Olmos \& Gonzalo de Puerto y Gil. Madrid: Visor, 1997, p. 16. ${ }^{268}$ APEL, Transformação da filosofia, v. I, p. 71; Transformation der Philosophie, Band I, p 61.

269 APEL, Transformação da filosofia, v. I, p. 52; Transformation der Philosophie, Band I, pp 44-45. 
possibilidade do compreender. Em caso contrário, consequentemente, resulta impossível diferenciar o discernimento transcendental-hermenêutico, no sentido de uma "filosofia transcendental que reflita a 'pré-estrutura' do compreender de todas as formas de conhecimento, científica e pré-científica", de uma explicação empírico-analítica, que possa elucidar a realização de qualquer ação causal (ou estatística, desde que atrelada a condições naturais) e, nisso, indicar as condições suficientes para o insucesso do compreender e as condições necessárias, conforme as leis da natureza, para o compreender bem-sucedido ${ }^{270}$.

Mais que uma imprecisão, a resposta de Gadamer à questão sobre as condições de possibilidade da compreensão é marcada por uma dificuldade intrínseca à sua hermenêutica. $\mathrm{Na}$ análise de Apel, a resposta de Gadamer traz à luz aspectos não suficientemente claros de sua proposta, posto que: a) ou a resposta à pergunta que ele propôs é normativa e metodologicamente irrelevante. Nessa situação, por conseguinte, ela se caracteriza tanto por não responder a qualquer pergunta transcendental, como por configurar, conforme a terminologia utilizada por Apel, um caso de naturalistic fallacy; b) ou as constatações sobre o que “sempre ocorre' quando se entende", indicando tacitamente pressupostos do compreender adequado, são minimamente incompletas ${ }^{271}$. A reflexão de Gadamer sobre o conceito hegeliano de compreensão como "autoprevalecimento do Espírito" evidencia, para a decepção de Apel, a ambiguidade da resposta de Gadamer quanto às condições de possibilidade do compreender adequado. Para Apel, Gadamer parece seguir inicialmente a Hegel $^{272}$, em face da concepção do compreender como reconstituição idêntica de experiências, difundida por Dilthey e Schleiermacher ${ }^{273}$, pretendendo com isso defender implicitamente a concepção de uma hermenêutica metodologicamente relevante de progresso. Todavia, ao reduzir o princípio "entender um autor melhor do que ele mesmo compreende a si mesmo" à constatação do sempre e tão somente "entender de outra maneira", consequentemente, ele reduz a automediação progressiva hegeliana do conceito de

\footnotetext{
${ }^{270}$ APEL, Transformação da filosofia, v. I, pp. 52-53; Transformation der Philosophie, Band I, p. 45.

271 APEL, Transformação da filosofia, v. I, pp. 53-54; Transformation der Philosophie, Band I, p. 46. Embora Apel não esclareça o sentido da aplicação da expressão naturalistic fallacy a Gadamer, tal parece conotar a posição que tende a reduzir e descaracterizar a normatividade ao âmbito descritivo de fatos em sua produtividade temporal. (Sobre a expressão naturalistic fallacy, ver: CHEDIAK, Karla. O problema da falácia naturalista para o projeto de uma ética evolucionista. In: Kriterion, Belo Horizonte, no 113, Jun/2006, p. 147157 , passim).

272 "Todo saber-se procede de um dado histórico prévio, que com Hegel chamamos de 'substância', porque suporta toda opinião e comportamento do sujeito e, com isso, prefigura e delimita toda possibilidade de compreender uma tradição em sua alteridade histórica. A partir disso, a tarefa da hermenêutica filosófica pode ser caracterizada do seguinte modo: deve refazer o caminho da Fenomenologia do espírito hegeliana, até o ponto em que, em toda subjetividade, se mostre a substancialidade que a determina" (cf. GADAMER, Verdade e método I, p. 399).

${ }^{273}$ GADAMER, Verdade e método I, pp. 388 e 391.
} 
compreensão - que, em Hegel, é reflexivamente transpositiva - a um acontecimento de mediação normativamente neutro, derivado da "produtividade do tempo"274.

Sob essa ambiguidade, Gadamer sustenta que o compreender não significa "entender melhor", no sentido de um saber objetivamente melhor, mediado por conceitos mais claros. A compreensão é um contínuo "entender diferente", sendo seu processo de produção consciente ou inconsciente. Ela é assim e não um "entender melhor", porque a finitude do ser-aí impede a comprovação definitiva de um "entender melhor". Daí, "basta, se acaso se entenda", expressar que se "entende de outra maneira". Pois bem, é em torno desse entendimento do compreender que brota a oposição de Apel à concepção fundamental de "hermenêutica" gadameriana. Para Apel, ressoa absurdo que uma "hermenêutica filosófica" possa sustentar que "se entende de outra maneira, quando afinal se entende". Ora, efetivamente, tal evidencia a perda da problemática normativo-transcendental de Kant. Gadamer negligencia que, assim afirma Apel, só é possível preservar o pressuposto de que "afinal se entende" quando - e apenas nessa condição se entende efetivamente - o postulado de "entender melhor" também é preservado. E considerando isso, então é possível recuperar os dois critérios (ou condições) tradicionais do "entender melhor" rejeitados por Gadamer, a saber: o de "entender um autor melhor do que ele mesmo compreende a si mesmo" e do “autoprevalecimento do Espírito" hegeliano, os quais estão mais relacionados um ao outro do que pensa Gadamer 275 .

Para Apel, a justificativa da renúncia de Gadamer ao ponto de vista hegeliano da compreensão como automediação progressiva da razão reflexivamente transpositiva é, por assim dizer, um caso de "meia verdade". O argumento de Gadamer é que a hermenêutica, ao abandonar a perspectiva do "saber absoluto" - peculiar à concepção de que a história é dotada de um fim - e ao reconhecer a insuperável pertinência de cada intérprete à história, vê-se obrigada a restituir ao interpretandum (autor, texto) tanto o privilégio do "compreender-se melhor", quanto o seu status de "superioridade", em razão da "antecedência heurística de plenitude", em face do intérprete. Contudo, a insustentabilidade do ponto de vista hegeliano ("saber absoluto") por causa da superioridade do interpretandum, para Apel, é uma "meia verdade", porque o próprio pressuposto de que o interpretandum possui a verdade, seja qual for seu tempo, representa a possibilidade de conduzir a atividade hermenêutica por uma “instância superior". No fundo, diz Apel, ao estabelecer a inferioridade constitutiva "de quem

\footnotetext{
${ }^{274}$ APEL, Transformação da filosofia, v. I, pp. 54-55; Transformation der Philosophie, Band I, pp. 46-47. ${ }^{275}$ APEL, Transformação da filosofia, v. I, pp. 54-55 (nota de rodapé 70); Transformation der Philosophie, Band I, pp. 46-47.
} 
compreende" em face "daquele que afirma e se dá a entender", mediante a remissão a uma mensagem salvífica (suposta vontade divina) ou às obras dos clássicos, Gadamer valida a característica normativa de uma hermenêutica mitológica, teológica ou clássico-humanística anterior ao Iluminismo. Curiosamente, ironiza Apel, quando Gadamer transcende de modo normativo à característica valorativamente neutra da estrutura formal do compreender como mediação da tradição, ele o faz, de forma conservadora, para reabilitar e validar a autoridade e a normativa de alguma hermenêutica (mitológica, teológica ou clássico-humanística) anterior ao Iluminismo ${ }^{276}$.

A fim de superar a dita "meia verdade" e a dificuldade intrínseca quanto à normatividade da hermenêutica de Gadamer, Apel assinala o ponto de ancoragem e os elementos constitutivos a serem conservados (ou retomados) na urdidura de uma hermenêutica normativa derivada do princípio regulativo do progresso do conhecimento. Por normatividade entende-se o campo de indicação do marco criteriológico do progresso possível do compreender. A hermenêutica "normativa" corresponde a uma "hermenêutica filosófica", fundamentalmente, empenhada em responder adequadamente à pergunta sobre a possibilidade do compreender. Como tal, ela se contrapõe a uma hermenêutica "devota do ser", valorativamente neutra e desvinculada da reflexão crítica ${ }^{277}$, em razão de estar implicada com a aplicação de pressupostos dogmáticos inevitáveis, tal como é o caso do princípio da subordinação unilateral do intérprete à superioridade do interpretandum. Não obstante, mais que a distinção e confrontação com o conceito de um método valorativamente neutro e objetivo do compreender, o que essencialmente caracteriza a hermenêutica normativa é que ela se funda sob a exigência da ideia transcendental-filosófica do compreender, quer dizer, “ela está envolvida na resposta adequada à pergunta sobre a possibilidade do compreender" ${ }^{278}$. Por conseguinte, tal implicação já é indicativa do ponto de ancoragem da hermenêutica normativa, o legado do Esclarecimento.

\footnotetext{
${ }^{276}$ APEL, Transformação da filosofia, v. I, p. 55; Transformation der Philosophie, Band I, p. 47.

277 Optando por uma linha crítica, Apel pensa que a hermenêutica não pode negligenciar o enfrentamento da problemática, por exemplo, referente ao rol de deformations professionelles dos especialistas históricohermeneutas. Afinal, mesmo dispondo de pontos de vistas críticos, a "análise objetiva" desses especialistas sempre está condicionada pelas transações intersubjetivas, pela inserção na tradição e pela tendência a validar preconceitos do passado em face do presente. Isso, todavia, não implica em supervalorizar essa problemática sintomática da diversidade lugares de pertença à história, pois tal não constitui, segundo Apel, um fator decisivo para vedar a possibilidade de uma hermenêutica normativa. A hermenêutica normativa não se funda nessa problemática, mas decorre de uma exigência transcendental-hermenêutica do compreender (cf. APEL, Transformação da filosofia, v. I, pp. 56-57; Transformation der Philosophie, Band I, p. 48).

${ }^{278}$ APEL, Transformação da filosofia, v. I, p. 57; Transformation der Philosophie, Band I, p. 48.
} 
Apel parte do pressuposto que a hermenêutica normativa deve conservar criticamente o legado racional do Iluminismo, posto que aí se efetiva o momento normativamente relevante da reflexão sobre a validação de todo compreender. Supondo isso, evidencia-se que a hermenêutica normativa se alicerça e se efetiva a partir da crença na própria razão, isto é, no potencial autorreflexivo da razão para responder à pergunta acerca do critério de validade e do fundamento do conhecimento, pressupondo que ambos, o critério e o fundamento, constituem as chaves para toda interpretação com sentido ${ }^{279}$. Enquanto exigida na reflexão transcendental sobre a validade de todo compreender, segundo Apel, a crença na razão não é apenas uma crença dogmática entre outras e, por isso, reduzível a um dentre outros lugares de pertença na história, tal como em Heidegger. Fundamentalmente, conservar o legado do Iluminismo significa incorporar a definição do compreender como “autoprevalecimento do Espírito e autoconhecimento por meio do outro", proposta pelo idealismo alemão hegeliano, na constituição da hermenêutica normativa ${ }^{280}$. Ao contrário de Gadamer, que abandona essa definição por julgá-la inconciliável com a circunstância de finitude e historicidade do intérprete e a possível superioridade do interpretandum, Apel entende que essa definição evita a queda em uma representação puramente "temporal" da "mediação" que reside no compreender ("ocorrência" de verdade ou de sentido). O viés dessa retomada do conceito hegeliano do compreender, como salienta Apel, não conota uma proposta de um retorno à dialética idealista de Hegel na hermenêutica filosófica. Trata-se de resgatar para o âmbito da hermenêutica a exigência de identificação, pensada na perspectiva hegeliana, referente à "dialética" da identidade e da alteridade que é sempre pressuposta na síntese do compreender como mediação temporal fundamentada no pensamento, no sentido do acordo mútuo. E, a partir daí, ele objetiva moldar um princípio regulativo normativamente relevante para toda compreensão bem-sucedida, ao qual cabe a função de nortear a mediação

\footnotetext{
${ }^{279}$ CORTINA, Verdad y responsabilidad (Introducción) in: APEL, Teoría de la verdad y ética del discurso, p. 15.

280 'Em face de uma teoria científica que reconhece a mera sistematização externa de dados ('descrição' ou 'elucidação' com auxílio de regras trazidas de fora para junto do objeto, e testáveis somente pela observação), trata-se hoje, primeiro, de fixar a concepção do Idealismo Alemão do saber-se do Espírito a si mesmo na Alteridade como condição de possibilidade para algo próximo ao Compreender-o-sentido; e, segundo, de conferir a tal concepção uma validação teórico-científica e metodológica. Isso terá êxito - assim espero - no momento em que a autorreflexão da teoria científica analítica tiver a clareza de que ela mesma, como análise da linguística e semântica, não procede de modo algum no sentido de sua metodologia, mas apreende, sim, de maneira reflexivo-hermenêutica, relações internas de sentido" (cf. APEL, Transformação da filosofia, v. I, p. 57, nota 73; Transformation der Philosophie, Band I, p. 49).
} 
linguística dos momentos de "espírito e matéria" (o ideal e o material) presentes na fenomenologia dialética do compreender ${ }^{281}$.

Para enfatizar a relevância desse resgate, convém evidenciar a diferença entre a perspectiva heideggeriana e gadameriana e a perspectiva hegeliana quanto à concepção do compreender. Heidegger e Gadamer conferem validade à finitude e à pertinência à história. Por isso, eles substituem a exigência idealista do "autoprevalecimento reflexivo do espírito e autoconhecimento por meio do outro" por conceitos temporais de ocorrência. Para Apel, como inexiste aí a mediação efetuada por meio do que há de idêntico no pensamento, por via da qual se dá a ponte para o acordo mútuo entre os seres humanos, essa perspectiva resulta incapaz de favorecer o entendimento. Na perspectiva hegeliana, a "dialética" da identidade e da alteridade está sempre pressuposta na síntese do compreender como mediação temporal fundamentada no pensamento. A mediação linguística é concebida no pensamento como instrumento de identificação. Cabe à mediação linguística identificar os atos intencionais separados espacial e temporalmente no pensamento, ou seja, a mediação visa a identificar $o$ que há de idêntico no pensamento (relações internas de sentido), de modo a suplantar a distância espaço-temporal e alcançar o acordo linguístico mútuo compartilhado por autor e intérprete e, em geral, por todos os seres humanos. Por isso, afirma Apel, a abordagem heideggeriana não suplanta a concepção do idealismo, que tem o mérito de ter possibilitado, pela primeira vez, conceber filosoficamente a experiência comunicativa e o conhecimento próprio das ciências humanas ${ }^{282}$.

Quanto à sua constituição, Apel estrutura sua hermenêutica normativa justapondo três elementos. Tal hermenêutica deve conservar os seguintes elementos: a) a "suposição da superioridade virtual do interpretandum", defendida por Gadamer; b) o "discernimento hegeliano quanto à exigência precípua, no Compreender, de um autoprevalecimento reflexivo do Espírito"; c) e, derivado do autoprevalecimento do Espírito, "como princípio", o "primado

\footnotetext{
${ }^{281}$ APEL, Transformação da filosofia, v. I, pp. 60-61; Transformation der Philosophie, Band I, pp. 52-53. Para além de Hegel, Apel pensa que a "dialética" da identidade e da alteridade pressuposta na síntese do compreender não pode ser fundamentada unicamente a partir do pensamento. Afinal, o pensamento não cai por si só na temporalidade, mas sim por meio da sua mediação com a natureza. Na linha de uma correção do jogo de linguagem dialético hegeliano, Apel pensa que a fenomenologia do compreender, além de ser sistematizada de maneira dialética, pode ter início, também dialeticamente, no ponto da mediação dos momentos "equiprimordiais" de "espírito" (o momento dos atos intencionais separados espácio-temporalmente no "pensamento") e "matéria" (o momento materialista da motivação de interesses dos atos humanos). Concebida de tal modo, tal fenomenologia, segundo Apel, corresponde à "pré-estrutura do compreender" descoberta por Heidegger, e permite concretizar a "produtividade do distanciamento temporal" que condiciona, no âmbito da hermenêutica filosófica, a orientação fundamental de "entender de outra maneira".

${ }^{282}$ APEL, Transformação da filosofia, v. I, pp. 60-61; Transformation der Philosophie, Band I, pp. 51-52.
} 
judicativo do intérprete"283. Em contraposição à suposição da inferioridade do intérprete, Apel idealiza o princípio do "primado judicativo do intérprete" justamente para facultar ao intérprete a possibilidade de atribuir a si mesmo o direito de julgamento crítico acerca do que existe para entender, e assim poder confiar a verdade a si mesmo. Tal princípio marca a passagem de uma hermenêutica a serviço de crenças dogmáticas para uma hermenêutica propriamente filosófica, constitutiva da autonomia hermenêutica do intérprete e, por conseguinte, de todos os envolvidos no processo argumentativo ${ }^{284}$.

A hermenêutica normativa preconizada por Apel subsume uma solução inusitada, a fim de conciliar os referidos elementos constitutivos. Em princípio, o quadro se mostra aparentemente insolúvel, pois, do ponto de vista da sua constituição, a hermenêutica normativa, tendo que fazer valer para toda compreensão a reflexão transcendental sobre a validade, não pode rechaçar o conceito de compreensão do idealismo alemão, em favor da validade conferida à finitude e à historicidade do intérprete e da possível superioridade do interpretandum. Não obstante, Apel apresenta uma solução à questão, considerada por ele “inevitável”. A solução concerne a resgatar o conceito hegeliano de autoprevalecimento substancial do espírito - quer dizer, resgatar a exigência de identificação da identidade e da alteridade sempre pressuposta na síntese do compreender -, porém na forma reduzida de um princípio regulativo, no sentido kantiano, "passível de conciliar-se com a 'antecedência' hermenêutica da superioridade virtual do interpretandum" (autor). Conforme Apel, o princípio normativamente relevante do progresso do conhecimento e do compreender bemsucedido (adequado) que corresponde ao topos central da tradição hermenêutica é: "entender o autor melhor do que ele compreende a si mesmo"285.

Para Apel, esse postulado decorre do caráter reflexivamente transpositivo da atividade do compreender, sendo que aí a auto-compreensão (Selbstverständnis), "tal como sua transposição reflexiva como 'compreender-se no mundo', sempre pressupõe o "compreender as coisas de que se trata",286. Gadamer alega em contraposição a esse postulado a referência à distância temporal, já que esta faz a exigência de uma "identificação com o autor", no sentido da reconstituição de atos cognitivos em sentido psicológico, parecendo algo utópico. Por sua vez, Apel entende que a ideia de um compreender transpositivo é inevitável

\footnotetext{
${ }^{283}$ APEL, Transformação da filosofia, v. I, p. 56; Transformation der Philosophie, Band I, p. 47.

${ }^{284}$ APEL, Transformação da filosofia, v. I, p. 56; Transformation der Philosophie, Band I, pp. 47-48.

285 APEL, Transformação da filosofia, v. I, p. 58; Transformation der Philosophie, Band I, p. 49. Hipoteticamente, presume-se que, em princípio, todo processo educativo pode ser entendido como um compreender transpositivo, um processo necessariamente autoral. A respeito disso, tratar-se-á adiante.

${ }^{286}$ APEL, Transformação da filosofia, v. I, p. 58; Transformation der Philosophie, Band I, p. 49.
} 
precisamente em decorrência da superação da teoria psicologista de Schleiermacher e Dilhey $^{287}$. Para Apel, a aplicação desse princípio regulativo alcança inclusive o caso limite das teorias matemáticas. Assim, pode-se supor que a compreensão da geometria euclidiana alcançada pelos muitos matemáticos que não se limitaram a repeti-la, na medida em que a entenderam e vieram a relativizá-la, é melhor ("mais completa") que a compreensão do próprio Euclides e a dos matemáticos que se limitaram a reproduzi-la. Na mesma linha, também é possível presumir que as ciências humanas modernas e a filosofia, mediante a reconstituição da argumentação à luz da história da lógica ou da história das culturas euroasiáticas, sejam capazes de entender Homero e Platão, em muitos aspectos, melhor do que eles mesmos puderam compreender-se a si próprios como filhos do seu tempo. Agora, para que se tenha certeza de que tal aplicação se refere ao compreender, é necessário pôr em questão "apenas os aspectos em que se possa falar ao mesmo tempo de transposição"288.

Por fim, com base no princípio regulativo "entender o autor melhor do que ele compreende a si mesmo", Apel reorienta teoricamente a compreensão relativa à ocorrência do pressuposto da superioridade do interpretandum. Problematicamente, a preponderância desse pressuposto parece obstruir o alcance universal desse postulado e, por conseguinte, a pretensão de universalidade da hermenêutica. De início, Apel reconhece que tal pressuposto continua existindo nas situações em que os autores conservam algum segredo para si e, em tal medida, sempre precedem seus intérpretes posteriores como interpretandum. Esse pressuposto também subsiste enquanto o intérprete tiver à sua frente a tarefa do compreender; no entanto, nesse caso, não se pode dar por suposto que o intérprete tenha entendido suficientemente o autor, tampouco depreender desse postulado que o autor seja incapaz de entender-se melhor do que o compreendem seus intérpretes. À medida que o sentido a ser compreendido não se explicita em estruturas lógico-matemáticas, surge daí uma dificuldade adicional, que é discernir em que medida o complexo semântico - por exemplo, referente a uma obra de arte, uma lei ou uma instituição -, é mais bem entendido pelos intérpretes do que pelos próprios autores. Tomando isso em relevo e em posição diversa à do hermeneuta puro aferrado ao referido pressuposto, Apel parece defender a ideia do "funcionamento concomitante" 289 do pressuposto da superioridade do autor e do referido princípio regulativo

\footnotetext{
${ }^{287}$ GADAMER, Verdade e método I, pp. 388 e 391.

288 APEL, Transformação da filosofia, v. I, pp. 58-59; Transformation der Philosophie, Band I, pp. 49-50.

${ }^{289}$ Apel não utiliza esta terminologia. É apenas uma tentativa para decodificar o "nó" do argumento brevemente explicitado na seguinte passagem do texto: "Ao mesmo tempo, no entanto, continua existindo, em decorrência disso [o pressuposto da superioridade do autor], a exigência de que o entendamos melhor do que ele compreende a si mesmo" (cf. APEL, Transformação da filosofia, v. I, p. 58; Transformation der Philosophie, Band I, p.
} 
na estrutura do compreender. Ele afirma que, em decorrência do pressuposto da superioridade do autor, ao mesmo tempo, perdura a exigência de compreender melhor o autor do que ele compreende a si mesmo, no sentido de um princípio regulativo aplicável a todo compreender hermenêutico ${ }^{290}$.

Tendo isso em conta, Apel pensa que a hermenêutica normativa deve conservar, tal como defendido por Gadamer, a suposição da superioridade virtual do interpretandum. Contudo, além disso, ela deve incorporar as relações internas de sentido, mediante a reconstituição hermenêutica interna das intenções de sentido inteligíveis, as quais são apreensíveis por autorreflexão (de maneira reflexivo-hermenêutica) e pressupostas a um só tempo na síntese do compreender. A exigência hermenêutica universal de entender o autor melhor do que ele mesmo se fundamenta e é assegurada pelo pressuposto da simetria idealmente implícita na situação de acordo mútuo quanto à mediação da tradição ${ }^{291}$. Esse pressuposto assegura não só para autor e intérprete, mas para todos os seres humanos, uma vez que todos estão condenados ao coentendimento em razão de compartilharem transcendentalmente as relações internas de sentido, a validade intersubjetiva do conhecimento. Segundo Apel, a argumentação em favor dessa solução se encontra no topos da tradição hermenêutica. Aí, tal exigência perdura em razão do caráter reflexivo-transpositivo do compreender, por via do qual todo compreender sempre implica compreender-se no mundo e não somente em reconstituir os atos cognitivos do autor. O alcance universal dessa exigência se justifica, normativa e metodologicamente, porque o próprio compreender implica aprimorar o processo cognitivo, entendendo-o de forma autoral. Delineia-se de tal maneira o traço fundamental de uma hermenêutica filosófica normativa ${ }^{292}$ exigida pela ideia transcendental-filosófica do compreender e, por isso, exigida na resposta adequada à pergunta sobre a possibilidade do compreender.

50). A meu ver, parece ser difícil falar em conciliação entre tais elementos, pois o argumento de Apel parece ser ex post factum. Ele retrocede ao pressuposto da simetria entre os interlocutores, que é próprio da sua pragmática transcendental, para contrapor a unilateralidade da superioridade do interpretandum. A questão é se isso caracteriza ou não o uso do próprio argumento para justificar o próprio argumento. Talvez um hermeneuta puro não reconheça nessa passagem um argumento forte para demovê-lo da sua posição típica).

${ }^{290}$ APEL, Transformação da filosofia, v. I, p. 58; Transformation der Philosophie, Band I, p. 50.

${ }^{291}$ APEL, Transformação da filosofia, v. I, pp. 64-65; Transformation der Philosophie, Band I, pp. 49-50.

${ }^{292}$ APEL, Transformação da filosofia, v. I, p. 57; Transformation der Philosophie, Band I, p. 48. 


\section{O GIRO PRAGMÁTICO-SEMIÓTICO COMO CONTRAPONTO À REDUÇÃO INSTRUMENTAL-DESIGNATIVA DA CONCEPÇÃO DE LINGUAGEM}

Este capítulo trata da compreensão de Apel acerca do giro pragmático-semiótico da linguagem em sua contraposição à redução instrumental-designativa da concepção de linguagem. Fundamentalmente, abordam-se dois pontos: a) a compreensão da reviravolta linguística ("linguistic turn") da filosofia analítica da linguagem no sentido do giro pragmático (“pragmatic turn"), que resgata a dimensão pragmática da linguagem abstraída pela logic of science; b) a incorporação da transformação semiótica de Kant por Peirce no projeto de transformação da filosofia de Apel. Busca-se demonstrar a relevância da semiótica tridimensional de Peirce para a transformação semiótico-transcendental de Apel.

\subsection{Da reviravolta linguística ("linguistic turn") da filosofia analítica da linguagem para o giro pragmático ("pragmatic turn")}

Na contemporaneidade, o movimento de reviravolta linguística tem seu lugar no contexto da legitimação das ciências empíricas modernas, que modifica a noção de racionalidade e, por conseguinte, desloca a problemática da fundamentação para o âmbito da metodologia usada pelas ciências. Nesse contexto, passa a entrar em jogo uma racionalidade procedurística que difere da racionalidade "do que é conhecido", pretendida pela tradição filosófica. Trata-se da racionalidade do método do conhecimento científico, que combina a dimensão teorética com a dimensão experimental, tendo em vista a solução exitosa de problemas. Ocorre aí um estranhamento entre a pretendida totalidade de sentido da filosfia ao tematizar seja o ser das coisas, como entre os antigos, seja o que é constituído pela subjetividade transcendental, como na tradição moderna da filosofia transcendental - e as ciências que se ocupam com a linguagem. Com isso desaparece o aspecto característico da filosofia clássica: a determinação do lugar ocupado pelo singular no todo, o que pressupunha a tematização do princípio de unificação de toda a realidade. Essa reviravolta traz consigo a seguinte mudança: a filosofia primeira não é a ontologia ou teoria do conhecimento, senão a 
análise da linguagem ${ }^{293}$. A filosofia primeira deve ser entendida como reflexão sobre o significado ou o sentido das manifestações linguísticas e, como tal, mediatizar-se metodicamente por uma análise filosófica do uso da linguagem. Esse entendimento se mostra ainda mais amplo, se se considera que ele não aponta apenas para mais um objeto empírico das ciências, em meio a outros objetos intramundanos, mas para o fato de que a filosofia vê-se confrontada com a problemática da linguagem, ou seja, com a "problemática dos fundamentos da formação teórica e conceitual e de seus próprios enunciados, isto é, das formulações sensatas e intersubjetivamente válidas da cognição em geral" ${ }^{294}$. De tal modo, a reviravolta linguística significa, ao mesmo tempo, ruptura, pois faz a passagem da análise do entendimento puro ou da consciência da filosofia transcendental para a análise da forma da linguagem, e aprofundamento, na medida em que direciona a questão da fundamentação para o âmbito da análise da linguagem e torna a filosofia uma crítica da linguagem. A questão que se impõe a partir daí é a tarefa de conceber um conceito filosófico de linguagem que, de modo independente (sem ignorar os resultados das ciências particulares), torne criticamente inteligíveis todas as tematizações linguísticas metódico-abstrativas das ciências particulares, dê conta dos próprios pressupostos linguísticos da filosofia e, assim, inspire as ciências a empreenderem uma reflexão crítica" ${ }^{295}$.

O deslocamento de uma epistemologia como crítica do conhecimento para uma epistemologia como análise da linguagem, que é decisivo para os rumos da questão da fundamentação, tem seu ponto de partida em uma tese comum levantada pelos teóricos do Círculo de Viena ${ }^{296}$. Eles preconizam a necessidade de aproximar as exigências de

\footnotetext{
293 APEL, Semiotica filosofica, pp. 275-276. OLIVEIRA, Sobre a fundamentação, p. 44-51.

${ }^{294}$ APEL, Transformação da filosofia, v. II, pp. 378-379; Transformation der Philosophie, Band II, pp. 332.

295 APEL, Transformação da filosofia, v. II, pp. 377-379; Transformation der Philosophie, Band II, pp. $332-$ 333.

${ }^{296}$ Para uma visão resumida sobre o neopositivismo lógico e seus principais expoentes (Ernst Mach, Moritz Schlick, L. Wittgenstein, Rudolf Carnap, Hans Reichenbach, Karl Popper), bem como sobre a distinção entre o neopositivismo e a filosofia analítica (George Moore, Alfred J. Ayer, Friedrich Waismann, Gilbert Ryle, John Wisdom, John L. Austin, Peter F. Strawson, entre outros), ver os cap. 20 e 21 in: ROVIGHI, Vanni Sofia. História da filosofia contemporânea do século XIX à neoescolástica. Trad. Ana Pareschi Capovilla. São Paulo: Loyola, 1999 respectivamente, pp. 473-502 e 503-540. A filosofia analítica ("análise filosófica" ou "filosofia da linguagem") tem seu ponto de partida na diversidade de enfoques do neopositivismo do Círculo de Viena. Em comum, o neopositivismo lógico e a filosofia analítica têm o interesse pela linguagem, por suas condições de significação e por sua estrutura fundamental. Porém, há aspectos que distinguem em profundidade as duas correntes. O neopositivismo reserva seu interesse para a linguagem (e metodologia) das ciências, e por isso se propõe a reduzir todas as outras linguagens à linguagem, científica, a única correta e significante. Para tanto, segue a filosofia do atomismo lógico - Russell e o primeiro Wittgenstein são seus expoentes mais conhecidos - segundo a qual, partindo de poucas fórmulas primitivas da lógica, é possível reduzir todas as proposições significantes às fórmulas fundamentais de uma linguagem ideal (não equívoca e com sentido). Diferentemente, os filósofos analistas, inspirados no último Wittgenstein, pensam a linguagem pelo viés do princípio de uso. Em vez de apenas um modelo linguístico capaz de oferecer a única representação do real, eles
} 
fundamentação e as discussões críticas entre os filósofos com a metodologia utilizada pelas ciências. Para tanto, a filosofia deve abandonar seu caráter especulativo e metafísico e submeter suas sentenças aos critérios de verificação empírica. Por trás dessa mudança se eleva a rejeição a todo tipo de metafísica, ou seja, à tentativa de conhecer a constituição e as leis do mundo real por meio da pura reflexão e sem qualquer controle empírico, unida à valorização das ciências experimentais e da lógica formal. Em lugar da filosofia especulativa, projeta-se um novo saber alicerçado no princípio do empirismo, tendo a experiência sensível como única base do conhecimento humano, e no princípio de verificabilidade, considerando que o sentido de uma sentença se define no processo que permite verificar sobre sua verdade ou falsidade. Por conseguinte, esses princípios delineiam os dois critérios fundamentais para a superação dos vícios da filosofia especulativa: a referência à experiência do ponto de vista do conteúdo; e, do ponto de vista formal, a isenção de contradições, mediante a sequência lógica das sentenças. Conjuntamente, esses princípios e critérios constituem o remédio para pôr fim à disputa indefinida das escolas filosóficas que dificulta alcançar o consenso nas questões filosóficas mais essenciais, bem como para desmistificar o suposto acesso privilegiado e superior à verdade pelo filósofo em relação à compreensão das ciências particulares ${ }^{297}$.

A vinculação da filosofia à metodologia das ciências experimentais e à lógica formal impacta a problemática da fundamentação duplamente. De uma parte, a questão relativa à verificabilidade das sentenças se torna central para a pretensão de uma filosofia científica, uma vez que ela, analogamente à racionalidade procedurística das ciências, deve considerar que somente o dado empírico, cujo enunciado é verificado, fornece um conteúdo ao conhecimento. De outra, o neopositivismo transforma o papel do dado. Este não mais constitui o ponto de partida do conhecimento, nem seu objeto único, mas a instância de controle para a validação das sentenças. Numa sociedade regida pela lógica da ciência, tal representa uma guinada quanto ao objeto das pesquisas filosóficas, que não concernem mais a coisas e eventos do mundo, mas aos enunciados e conceitos científicos, à análise da linguagem. Concebida assim, a reviravolta linguística afeta, inicialmente, a própria tradição

analisam as diferentes formas linguísticas, como elas aparecem nos vários contextos da linguagem comum. Nessa perspectiva, a linguagem não é parâmetro último de juízo, mas ponto de partida para uma terapia do conceito, olhando para as semelhanças e diferenças entre suas diversas aplicações e a trama de relações que resultam em sua constituição. O limite de sentido do conceito depende das ações e do contexto de uso do conceito em questão (cf. ROVIGHI, História da filosofia contemporânea do século XIX à neoescolástica, pp. 504-506; MORENO, Arley R.. Introdução a uma pragmática filosófica: de uma concepção de filosofia como atividade terapêutica a uma filosofia da linguagem. Campinas, SP: Unicamp, 2005, p. 255).

${ }^{297}$ OLIVEIRA, Sobre a fundamentação, pp. 44 e 47, respectivamente, notas 83 e 92. ROVIGHI, História da filosofia contemporânea do século XIX à neoescolástica, p. 473. 
empirista em que se situam os teóricos articuladores do giro linguístico. Isso se mostra, por exemplo, em relação à compreensão da tarefa básica da ciência. Comparativamente, antes do giro linguístico, a tarefa teórica é realizar a descrição exata do que é dado imediatamente pela experiência. A partir do giro, adquire-se consciência de que a ciência só principia onde as observações são articuladas linguisticamente. De tal modo, a análise da linguagem assume a perspectiva de uma teoria das ciências como teoria das sentenças científicas, que não se amolda à referência imediata do campo respectivo das ciências particulares, porém procura pesquisar esses campos na medida em que eles são articulados na linguagem. Contudo, sem se limitar à tradição empirista, a guinada linguística se difunde por toda a tradição do pensamento filosófico contemporâneo, caracterizando assim uma reviravolta no pensamento filosófico como tal; levada adiante pela logic of science aplicada não só ao campo das ciências naturais, mas também no das ciências humanas, em busca dos fundamentos do conhecimento científico $^{298}$.

O giro linguístico (linguistic turn) da filosofia analítica da linguagem (positivismo lógico) faz valer a concepção semântico-referencial da linguagem como instrumental da logic of science para a análise linguística orientada às proposições. Em um primeiro momento, o giro linguístico se reduz ao paradigma semântico-referencial da linguagem (do empirismo lógico), para o qual o problema da fundamentação se liga à questão do significado das proposições. Por primar pela perspectiva lógico-matemática no plano da teoria do conhecimento, esse paradigma se alicerça nas dimensões sintático-semânticas da linguagem, porém sem pressupor o significado na linguagem cotidiana. De tal modo, ele impõe uma dupla redução sobre o sentido da linguagem natural: de um lado, a redução semânticoreferencial e empírica; de outro, a redução lógico-matemática. Nessa redução, prevalece a análise semântica que se define como análise das formas de sentenças, sobremaneira das sentenças assertivas, porém abstraindo da situação ou do contexto de fala, referente à dimensão pragmática da linguagem como práxis social. Na linha da análise semântica, o positivismo lógico distingue dois tipos de sentenças com sentido: as sentenças da lógica e da matemática, que não são portadoras de conteúdo empírico e estabelecem as determinações formais para todas as ciências; as sentenças das ciências, que são testáveis na experiência. Com isso, a semântica lógico-formal e matemática intenta expurgar metodicamente a reflexividade autorrefencial da linguagem, pragmaticamente mediada, justamente por

\footnotetext{
${ }^{298}$ APEL, Transformação da filosofia, v. II, p. 255; Transformation der Philosophie, Band II, p. 225.
} OLIVEIRA, Sobre a fundamentação, pp. 45-47. 
considerar que o sentido pragmático decorrente do uso subjetivo da linguagem conduz a inconsistências semânticas e discussões inconclusivas. Sempre que se trata da dimensão pragmática da semiosis, isto é, do uso e interpretação dos signos por um sujeito humano, põese em juízo a intencionalidade do sentido que é autorreflexiva. É autorreflexiva porque trata não somente da significação de algo outro, mas também de um saber reflexivo acerca do sentido da própria significação subjetiva. Contra isso, o positivismo lógico preconiza que as explicações científicas se desenvolvam unicamente com o auxílio da semântica lógica das linguagens artificiais, sem a consideração de fatores pragmáticos ${ }^{299}$. Tal é, segundo Apel, a estratégia de Russell e Tarski ao proporem a substituição da problemática relativa ao sentido pragmático autorreferencial da linguagem cotidiana (natural, ordinária) no âmbito da semântica, mediante a separação entre linguagem-objeto e metalinguagem ${ }^{300}$.

Em consequência dessa redução, o conceito de "pragmática" é operado como indicador de problemas psicológicos residuais da semântica lógica e da lógica da ciência; um "cesto de resíduos" fora do contexto de justificação lógica do sentido intersubjetivamente válido da linguagem, cujos problemas são unicamente relevantes a partir de um ponto de vista meramente psicológico-subjetivo. Para superar isso, preconiza-se que as explicações científicas se desenvolvam unicamente com o auxílio da semântica lógica das linguagens artificiais, sem a consideração de fatores pragmáticos ${ }^{301}$. Caracteriza-se como sentença com sentido aquela que é logicamente coerente e testada na experiência. E o que está fora dessas condições conota proposições pseudo-objetuais da filosofia, disparates linguísticos de caráter metafísico que, no máximo, pode ter a função de expressar sentimentos, que podem ser alvo de uma elucidação empírico-analítica do comportamento. Isso explica o porquê do paradigma semântico referencial, orientado às proposições, cobrar o veredicto de psicologismo contra toda reflexão linguística referida ao sujeito, precisamente por pressupor que as funções linguísticas comunicativas e expressivo-subjetivas devam ficar excluídas da tematização do logos filosófico.

Na tradição filosófica, a posição da semântica referencial das proposições, no sentido de uma estrutura lógico-formal objetivável de dedução das proposições, contra a "mera pragmática" das funções comunicativas da linguagem no plano psico-social constitui a referência do paradigma clássico (tradicional) da relevância do logos na linguagem. É possível constatar as raízes históricas desse paradigma na Antiguidade. Na ilustração grega, o

\footnotetext{
299 APEL, Semiotica filosofica, p. 289.

300 APEL, Semiotica filosofica, p. 296.

${ }^{301}$ APEL, Semiotica filosofica, p. 289.
} 
termo logos carrega os significados de exposição em prosa (verdadeira), de razão como fundamento (em oposição a mito), de argumento que se expõe a exame (no contexto dos diálogos com Sócrates). Em Platão, o logos indica, como linguagem e discurso, um "órganon", no sentido de um instrumento de designação, para comunicar aos outros "algo" sobre as coisas. O logos tem lugar no diálogo; e o pensamento é inclusive concebido como “diálogo da alma consigo mesma". É com Platão, contudo, que o significado de logos se torna mais preciso, limitando-o e objetivando-o no sentido do enunciado ou proposição verdadeira ou falsa, até adquirir o sentido de definição, conceito, argumento ou conclusão racional. Por sua vez, Aristóteles distingue entre o logos semântico da linguagem simbólica convencional, como logos do significado linguístico, e o logos da verdade significativa, como logos da afirmação e do exame argumentativo que cumpre a função expositiva das orações proposicionais, que portam valores de verdade. Nessa distinção, o primeiro é mais amplo que o segundo, pois contém o significado de um enunciado, verdadeiro ou falso. O modelo aristotélico compreende a função dos signos linguísticos conforme o tipo dos signos da escrita. Em razão disso, pressupõe que os conteúdos da significação, os quais têm que ser meramente designados, já estão na alma como reproduções pré-linguísticas de coisas idênticas para todos os homens. Sem levantar o problema da validade intersubjetiva dos significados, Aristóteles desenvolve, sobre a base da identidade intersubjetiva dos significados a serem designados, a lógica do conceito e dos enunciados. Na opinião de Apel, essa semântica lógica - determinante para o logos da ciência, como doutrina virtualmente formalizável do silogismo e da demonstração - deixa em segundo plano, por dois milênios, a problemática de uma teoria da argumentação informal ou do discurso, baseada no diálogo ${ }^{302}$.

As tendências dominantes da filosofia semanticista da linguagem dos gregos, no período pós-socrático, se opõem à ampliação da problemática do logos semântico. Tal como já exposto anteriormente, embora existissem outras ciências do logos junto à lógica semântica, tais como a gramática, a retórica, a poética e a hermenêutica, com efeito, a luta de Platão contra os poetas e os retóricos da sofística impede que essas disciplinas se tornem determinantes para a problemática filosófica do logos. Na tradição, passa a prevalecer a divisão do logos proposta por Teofrasto, discípulo de Aristóteles, que distingue as funções meramente pragmáticas da linguagem e o objeto da semântica lógica. Nessa separação, à filosofia cabe refutar o que é falso e provar o que é verdadeiro, podendo abandonar a relação de expressão subjetiva, relativa aos ouvintes e à persuasão, para a poética e a retórica. A

\footnotetext{
${ }^{302}$ APEL, Semiotica filosofica, pp. 276-279.
} 
filosofia do humanismo retórico (Isócrates, Cícero, humanistas do renascimento italiano, G. B. Vico) e a tradição hermenêutica, em nome da sabedoria do filósofo-orador e baseada no sensus communis, no sentido da compreensão do mundo da vida, historicamente, protestam contra essa divisão entre, por um lado, a filosofia como semântica lógica e, por outro, a retórica e a poética. Contudo, essa demarcação permanece decisiva, segundo Apel, para a tradição da lógica escolástica da linguagem e para a tradição da lógica simbólica, iniciada com Leibniz, bem como para a fundamentação antifenomenológica (antipsicologista) da semântica lógica (metalógica) de Gottlob Frege ${ }^{303}$.

A tese de Apel é que o giro linguístico da filosofia analítica da linguagem desenvolve, na linha da concepção de linguagem predominante desde Teofrasto, a tachativa separação entre a problemática do significado referente à verdade das proposições e a força psicossocial das expressões nas situações comunicativas. Por conta disso, eles fazem valer a concepção tradicional de linguagem, para a qual a linguagem é um instrumento secundário do conhecimento humano. O mundo conhecido se mostra tal como ele é valendo-se do caráter designativo da linguagem. Sendo a designação a função principal da linguagem, a significação de uma palavra decorre do que é por ela designado. A concepção tradicional de linguagem pressupõe uma isomorfia entre realidade e linguagem, porque considera que há uma essência comum (protótipo comum) a vários objetos individuais (a uma classe, não a coisa individual) que pode ser designada pela palavra. As palavras têm sentido porque existem objetos (coisas singulares ou essências) que elas designam. Para Apel, as ideias de Frege e do primeiro Wittgenstein constituem referências modelares, segundo Apel, desse tipo de posicionamento. Para Frege, a semântica lógica deve abstrair dessa força, pois ela não determina o conteúdo proposicional ("pensamento") de uma oração. As orações da linguagem não conotam a expressão comunicativa de um sentido intencional, como na vida cotidiana, mas funções matemáticas objetivas. No sentido preconizado por Leibniz, a filosofia e a ciência devem se reger pelo "calculemus", em lugar do diálogo argumentativo do uso da cotidiano da linguagem. Por isso, deve-se excluir do conceito lógico-semântico do sentido de linguagem toda expressão semântico-convencional e sintática de intencionalidade e subjetividade ${ }^{304}$.

Partindo de uma concepção de linguagem semelhante à de Frege, o primeiro Wittgenstein, no Tractatus logico-philosophicus, concebe uma linguagem ideal, construída 
(artificial) segundo o modelo de um cálculo lógico ${ }^{305}$. Ele preconiza a correspondência estrutural entre frase (linguagem, pensamento) e fatos (mundo), assegurada pela "forma de afiguração" ("forma lógica", "forma de realidade"). Nela, a linguagem figura o mundo (Bild, imagem, cópia) quando existe identidade estrutural entre a proposição (estrutura interna) e o real (estrutura externa). As orações são funções de verdade das orações elementares ou, como no caso dessas configurações de nomes que representam estados de coisas. A função da linguagem consiste em reproduzir (afigurar) as relações externas dos objetos (estados de coisas), sobre a base de uma ordem do mundo cujas "relações internas" se mostram na forma lógica da linguagem. Essa forma concerne à estrutura profunda sintático-semântica da lógica de todas as linguagens, fixada lógica e transcendentalmente e já programada em todos os homens. Nessa concepção de linguagem, a qual conjuga o "solipsismo" com o "realismo puro", segundo Apel, a dimensão de comunicação linguística, como entendimento intersubjetivo sobre o sentido e dimensão constitutiva para o conteúdo semântico de significação das palavras da linguagem, é tido como desnecessária para a autocompreensão do sujeito e do mundo dos fatos. Entendendo que tal comunicação diz respeito à codificação, transmissão e decodificação de intenções de sentido pré-linguísticas e privadas, a concepção de linguagem preconizada pelo Wittgenstein do Tractatus concebe que a afiguração do mundo dos fatos se faça livre de interpretação ${ }^{306}$.

O ponto culminante do paradigma clássico da concepção de linguagem semânticoreferencial pode ser constatado na proposta de uma semiótica trivalente de Charles Morris e Rudolf Carnap. Nela, a dimensão pragmática, abstrativamente excluída pela semântica lógica, é tomada em consideração dentro de um programa que intenta fazer convergir a lógica da linguagem e ciência do positivismo lógico (Carnap) com a semiótica tridimensional do pragmatismo norte-americano de Morris. Nessa linha, a versão da semiótica trivalente proposta por eles abrange tanto as dimensões sintática e semântica da linguagem, quanto a dimensão pragmática da linguagem, a qual tematiza o uso comunicativo dos signos pelo emissor e receptor no contexto situacional do comportamento prático. Porém, o entendimento atribuído à pragmática aí não permite extrair nenhuma significação relevante para a constituição do logos da linguagem. Efetivamente, ela resulta irrelevante não somente para a problemática da verdade da ciência formal e empírica, mas também para a problemática

\footnotetext{
${ }^{305}$ Ver proposições 1.1, 2.17, 2.18, 4.05 e 4.12, in: WITTGENSTEIN, Ludwig. Tractatus logico-philosophicus. Trad. José Arthur Giannotti. São Paulo: Companhia Editora Nacional \& Editora da Universidade de São Paulo, 1968. OLIVEIRA, Reviravolta lingüístico-pragmática na filosofia contemporânea, pp. 101-111 e 119-121. 306 APEL, Semiotica filosofica, pp. 283-284. WITTGENSTEIN, Tractatus logico-philosophicus, ver proposições 4.122 e 5.64 .
} 
referida ao sentido intersubjetivamente válido dos signos convencionais da linguagem. A razão disso se assenta no fato de essa semiótica se nortear por uma concepção de pragmática meramente empírica, que impõe uma restrição lógico-semântica à problemática do sentido pragmático das intenções subjetivas do uso dos signos. Essa restrição se expressa no postulado de que o sentido das orações deve ser definido exclusivamente mediante os conceitos de suas possíveis condições referenciais de verdade. De tal modo, o conteúdo intencional dos conceitos, na ciência e na filosofia, deve ser redutível à referência extensional dos objetos no mundo, isto é, à representação de estados de coisas por meio de proposições. Por conseguinte, todo sentido pragmático resulta meramente subjetivo. De tal modo, ele somente pode ser tematizado empiricamente pela psicologia empírica behaviorista, como componente de um estado de coisas, por exemplo, ocupando as funções de expressão e apelação dos signos linguísticos como sintomas ou sinais. Nem mesmo, analisa Apel, quando Carnap e Morris cotejam passar de uma concepção de pragmática empírica para uma pragmática formal-construtiva, aí se abandona a restrição lógico-semântica sobre o sentido do sentido. Sob o título de "pragmática formal", Carnap constrói uma "metalinguagem" que continua considerando o sentido pragmático como objeto de referência semântica das proposições. Presa à referida restrição, essa concepção de pragmática não tematiza o que, do ponto de vista da pragmática, é fundamental. Tal vem a ser a dimensão comunicativa da linguagem, que expressa o sentido reflexivo e autorreferencial das intenções subjetivas de significação ${ }^{307}$.

Na avaliação de Apel, a abstração da dimensão comunicativa da linguagem pelo giro linguístico da filosofia analítica da linguagem se fundamenta em uma aporia ${ }^{308}$ produzida pelo próprio linguistic turn. Se, por um lado, o linguistic turn representa uma importante contribuição para a filosofia contemporânea, cujo mérito decorre de ter destacado a relevância do logos da linguagem como condição de possibilidade do sentido intersubjetivamente válido, por outro, ao desenvolver seu programa, o movimento do linguistic turn (Carnap, o jovem Wittgenstein, Tarski, racionalismo crítico) se caracteriza pelo rechaço lógico-linguístico à

\footnotetext{
${ }^{307}$ APEL, Semiotica filosofica, pp. 284-289.

308 APEL, Semiotica filosofica, p. 293-298. Para Apel, a aporia central do paradigma semântico-referencial se torna mais nítida à luz da semiótica trivalente de Peirce. Na semiótica de Peirce, a função dos signos (semiosis) para mediar o conhecimento é uma relação triádica entre: a) o objeto real do conhecimento, que é conhecido como algo; b) o signo que, mediante a interpretação do seu significado, transmite o conhecimento de algo como algo, e enquanto signo da linguagem da linguagem pertence a um sistema linguístico; c) o usuário do signo ou intérprete, como sujeito do conhecimento simbolicamente (por signos) mediado, o qual, como sujeito da interpretação dos signos tem que pertencer, em princípio, a uma comunidade ilimitada de interpretação, a única que tem a possibilidade de ser o sujeito transcendental do conhecimento verdadeiro.
} 
apelação metódica da evidência dos fenômenos como evidência fundacional. O rechaço decorre da distinção adotada pelo positivismo lógico entre "o que pode ser dito", referente à fundamentação empírica das "proposições elementares" por meio de "fatos" (proposições logicamente verdadeiras), e o que "simplesmente se mostra", concernente aos fenômenos. Essa distinção configura a arquitetônica bipolar do positivismo lógico, orientada à forma lógica da linguagem e, fundamentalmente, antifenomenológica. Para Apel, esse rechaço constitui o transfundo da posição abstracionista em relação à dimensão comunicativa da linguagem no giro linguístico da filosofia analítica da linguagem. Contudo, segundo Apel, o rechaço é uma aporia, na medida em que supõe dispensar o que é imprescindível na fundamentação dos enunciados, a evidência fenomênica objetiva. Essa aporia surge quando o positivismo lógico deixa de buscar postulados elementares evidentes de maneira empíricofenomênica (enunciados protocolares) e, em outra direção, passa a considerar o princípio lógico-linguístico segundo o qual os enunciados podem ser fundamentados somente por enunciados e não por evidências fenomênicas. Para evitar esse paradoxo, segundo Apel, a ciência empírica deve considerar, seguindo a Brentano, que não há somente sentimentos subjetivos (psicológicos) da evidência, senão que uma evidência objetiva dos fenômenos, com base na qual a evidência dos sentimentos subjetivos pode ser corrigida. Perante essa evidência objetiva dos fenômenos, até os enunciados ou teorias compatíveis entre si podem fracassar. De outra maneira, a ciência, ao menos a empírico-experimental, perde o próprio sentido, pois não teria como diferenciar as teorias coerentes de um mundo meramente possível ${ }^{309}$. Com essa crítica, por um lado, Apel resgata a relevância criteriológica da evidência fenomênica objetiva, a fim de superar a arquitetura bipolar do positivismo lógico em sua concepção de verdade consensual. Por outro, ele preconiza que a superação da aporia do paradigma do logos semântico depende de levar a efeito a tese segundo a qual o linguistic turn, como teorias do significado referidas à linguagem, e o pragmatic turn, como teorias da intenção referentes à ação comunicativa, são compatíveis e se pressupõem reciprocamente ${ }^{310}$. Contudo, para Apel, o giro pragmático significa a inserção da tematização autorreflexiva das intenções subjetivas de significação, não para reduzir o significado linguístico às intenções prélinguísticas da ação, mas em vista de uma ampliação pragmaticamente integrada do conceito de semântica linguística ${ }^{311}$.

\footnotetext{
309 APEL, Karl Otto. Le problème de l'évidence phénomenologique à la limière d'une sémiotique transcendantale. In: Critique, pp. 83-84.

${ }^{310}$ APEL, Semiotica filosofica, p. 316.

${ }^{311}$ APEL, Semiotica filosofica, p. 290-292.
} 
A virada pragmática delineia uma nova perspectiva para a concepção de linguagem, à medida que explicita o caráter prático, intersubjetivo e histórico da linguagem humana. Nessa nova perspectiva, o pensamento do segundo Wittgenstein constitui uma referência fundamental a partir da qual, posteriormente, pensadores ligados à Escola de Oxford, tais como Austin e Searle, fazem avançar a empreitada da virada pragmática. Precisamente, tal inovação tem por referência inicial o conceito de jogo de linguagem desenvolvido pelo último Wittgenstein ${ }^{312}$. Esse jogo expressa uma espécie de unidade funcional da linguagem e das atividades a ela ligadas como práxis linguística de uma forma de vida social. Tal conceito se desenvolve sob o pressuposto de que a linguagem se apoia sobre um sistema de normas e convenções sociais, que permite o acordo prévio entre os falantes - o consenso a respeito da eficácia do emprego das regras estabelecidas - e determina a estrutura subjetivo-intersubjetiva do agir dos indivíduos no interior das comunidades linguísticas. A linguagem é a mediação de um processo de interação, socialização e internalização de normas e papéis. Daí, a compreensão da significação de uma expressão linguística não depende de uma explicação ou fundamentação especulativa, mas de sua constatação em um jogo fático de linguagem, bastando para tanto recorrer a seu uso e às normas e práticas sociais que subjazem a seu uso. O traço característico dessa nova compreensão da linguagem é que ela se define como uma atividade humana, uma espécie de ação tal como andar, correr, passear, entre outras. Supondo a íntima relação entre linguagem e ação, não é possível separar a consideração da linguagem da consideração do agir humano, tampouco a consideração do agir pode ignorar a linguagem. Enfim, por esse viés, a virada pragmática modifica a concepção

\footnotetext{
312 Ao propor o conceito de jogo de linguagem, Wittgenstein critica, ao mesmo tempo, o essencialismo e o ideal de exatidão linguística. Nas Investigações, Wittgenstein abandona o ideal da exatidão a priori da linguagem, tese que é fundamental no Tractatus. Essa tese pressupõe que no mundo há uma estrutura ontológica em relação à qual a linguagem é apenas uma cópia fiel. Ela pressupõe, portanto, uma essência comum entre as coisas, funcionando como base ontológica da designação. Nas Investigações, ele assinala que esse ideal é um mito filosófico, uma ilusão metafísica. Em razão disso, metodologicamente, ele se nega a explicitar aí uma definição de jogo de linguagem; isso seria uma recaída no essencialismo. Os conceitos da linguagem comum são estabelecidos por "semelhanças de família entre os conceitos"; semelhanças e parentescos entre os diversos tipos de jogo. Não há uma propriedade comum capaz de estabelecer fronteiras definitivas para uma definição acabada relativa ao uso de palavras, mas apenas elementos comuns que se interpenetram. Por isso, os conceitos são abertos, ao passo que admitem a possibilidade de sua aplicação a casos não previstos. Não é possível afastar o campo de vaguidade dos conceitos, mas apenas diminuí-lo por meio das regras do jogo. Os possíveis limites da linguagem são a posteriori, ligados às situações concretas do uso da linguagem. Se se pretende saber o que é linguagem, basta olhar seus diferentes usos. Daí o convite: "não pense, veja" (cf. fragmentos 23, 65, 66, 67, 71, 79 e 80 in: WITTGENSTEIN, Ludwig. Investigações filosóficas. Trad. José Carlos Bruni. São Paulo: Abril Cultural, 1975 (col. Os Pensadores).
} 
tradicional de linguagem, concebendo-a como práxis comunicativa mediadora de intersubjetividade ${ }^{313}$.

De forma relevante, a virada pragmática amplia e complementa o horizonte da mudança de paradigma defendida pelo paradigma da linguagem. Em seu traço fundamental, a virada pragmática concretiza uma nova concepção da constituição do sentido, o qual deixa de ser pensado como algo produzido por uma consciência para si independentemente de um processo de comunicação. O sentido conota algo que nós sempre comunicamos reciprocamente, como participantes de uma práxis real e de comunidades linguísticas. O horizonte a partir de onde se pensa a linguagem não é o sujeito isolado (esfera da subjetividade), mas a comunidade de sujeitos em interação, cuja práxis comum é realizada de acordo com regras determinadas. Tais regras não são convenções arbitrárias, mas originadas historicamente a partir do uso compartilhado pelas comunidades linguísticas. Elas são costumes que se tornam fatos sociais reguladores (instituições). Sendo o falar um ato social que implica assumir uma práxis social em uma determinada configuração sócio-histórica, aprender a falar uma língua não é aprender a repetir símbolos, mas aprender (dominar e agir) as regras de um determinado tipo de comportamento regrado. As regras estabelecem a equivalência entre o agir e o dizer nas instituições sociais, onde o comportamento se realiza. Daí que, saber usar corretamente as palavras significa saber comportar-se corretamente. De tal modo, tantas são as formas de vida existentes, tantos são os modos de uso regrado da linguagem, os jogos de linguagem, podendo-se a partir daí estabelecer o sentido das expressões linguísticas ${ }^{314}$.

Em sua análise histórico-reconstrutiva do paradigma da linguagem, Apel entende que subsiste a compatibilidade e a recíproca pressuposição entre o linguistic turn das teorias do significado referidas à linguagem e o pragmatic turn das teorias da intenção referentes à ação comunicativa. Mais que isso, do ponto de vista da virada pragmática, constata-se que a semântica (linguistic turn) só atinge sua finalidade por via da pragmática, posto que o problema semântico relativo à significação das palavras só pode ser resolvido pela explicação dos contextos pragmáticos. De forma geral, a virada pragmática, mediante a incorporação da dimensão de interação social simbólica de acordo com diferentes modos de sua realização, parece resolver o problema do paradigma semanticista da linguagem. Com efeito, nem toda

\footnotetext{
${ }^{313}$ OLIVEIRA, Sobre a fundamentação, pp. 52-53 e 55. OLIVEIRA, Reviravolta lingüístico-pragmática na filosofia contemporânea, p. 138. WITTGENSTEIN, Investigações filosóficas, fragmentos 7, 19 e 23.

314 OLIVEIRA, Sobre a fundamentação, pp. 52-55. OLIVEIRA, Reviravolta lingüístico-pragmática na filosofia contemporânea, pp. 120 e 139-143.
} 
abordagem pragmática resolve o problema da abstração da dimensão pragmática da linguagem. Tal é a conclusão de Apel ao contrapor $^{315}$ a sua proposta de uma interpretação semiótico-transcendental da linguagem da interpretação empirista da semiótica, cujo esquema básico se encontra na fundamentação da teoria dos signos de Morris.

O esquema semiótico de Morris tem determinado até hoje a problemática básica da filosofia analítica da linguagem e da epistemologia analítica e, ademais, o desenvolvimento do giro pragmático ${ }^{316}$. Para Apel, Morris acaba por abstrair a dimensão comunicativa da linguagem, ao introduzir a pragmática meramente como uma disciplina suplementar da sintaxe e semântica lógicas fundadas por Carnap, no marco de uma interpretação empirista da semiótica. A interpretação empirista da semiótica, possivelmente por receio de incorrer em antinomias semânticas, proíbe todo falar autorreferencial (autorreflexivo). Efetivamente, segundo Apel, a semiótica concebida de modo empirista-behaviorista não dá conta de tematizar o saber autorreflexivo e performativo de intenções ilocucionárias (e eventualmente perlocucionárias), que liga o falante aos seus atos de fala. Isso mostra, então, que a concepção empírica da semiótica é inapropriada para cumprir com os propósitos hermenêuticonormativos da compreensão dos signos ${ }^{317}$.

Para Apel, a exigência de retranscendentalizar a filosofia a partir da virada pragmática ultrapassa os limites da compatibilidade e pressuposição recíproca entre as concepções sintático-semântica e pragmática de linguagem. Isso implica a exigência de pensar uma concepção de linguagem referenciada no pragmatic turn, contudo "para-além" do linguistic turn e do pragmatic turn. Tal concepção deve superar, segundo Apel, a abstração relativa à dimensão hermenêutico-transcendental e pragmático-transcendental da interpretação autorreflexiva dos $\operatorname{signos}^{318}$. Para tanto, ela deve ir além do linguistic turn, porque a

\footnotetext{
315 APEL, Paradigmas de filosofía primera, pp. 152-165; APEL, Transformação da filosofia, v. I, pp. 187189; Transformation der Philosophie, Band I, pp. 158-160.

${ }^{316}$ APEL, Paradigmas de filosofía primera, pp. 152-153.

317 APEL, Paradigmas de filosofía primera, pp. 164-165.

318 Hipoteticamente, a situação de um intérprete de um texto que se interessa pelo ajuizamento correto das pretensões de validade ligadas aos signos do texto, segundo Apel, configura um caso paradigmático de uma hermenêutica normativa. Aqui, o intérprete não permanece na posição da observação e descrição dos fatos da conduta mediada por signos. Com efeito, ele produz, em relação aos signos que devem ser interpretados (expressões atuais ou textos), uma relação de comunicação. Nessa relação de comunicação, o intérprete já tem reconhecido, na prática, os pressupostos intranscendíveis para a interpretação atual e autorreflexiva dos signos. Pois, ela está determinada pela referência antecipada ao consenso intersubjetivo possível de todos os possíveis intérpretes de signos acerca das pretensões de validade concernentes aos atos de fala (sentido, verdade, veracidade, correção normativa). Por tal razão não se pode abstrair da dimensão hermenêutica-transcendental e pragmático-transcendental da interpretação atual e autorreflexiva dos signos. Essa dimensão, configurada na relação entre sujeito e co-sujeito, é constitutiva para a ilimitada comunidade de comunicação. E a comunidade de comunicação, enquanto mediação na qual se processa a interpretação normativamente correta do significado dos
} 
concepção de linguagem aí concebida, como um instrumento intersubjetivo a priori da representação de estados de coisas isenta de reflexões, no sentido de uma estrutura universal formalizada de todas as linguagens, parece incompatível com a estrutura do discurso humano e da comunicação. No entender de Apel, pesa "contra" o linguistic turn o fato de que a linguagem ordinária natural comporta a autorreflexibilidade (natürliche Umgangssprache Selbstreflexivität) que, como tal, constitui sua própria metalinguagem ${ }^{319}$. O uso comunicativo da linguagem humana não pode ser concebido de modo suficiente, seja como pura transmissão de informações factuais, imune à compreensão do sentido do mundo dos interlocutores, seja como atualização privada do sistema linguístico, que deixe intacta a estrutura semântica, pois subsiste a possibilidade e a necessidade de renovação do acordo mútuo quanto ao sentido humano dos "objetos" do mundo experimental, bem como quanto ao sentido (significação) dos sinais linguísticos (palavras).

Para Apel, essas duas constatações são expressão de um mesmo factum, a autorreflexividade da razão humana. A reflexividade não está alojada em um mundo circundante de sinais, mas desenvolve, com o auxílio da linguagem, uma interpretação do mundo. Por conseguinte, com a ajuda dessa interpretação alcançada, ela desenvolve um sistema semântico de linguagem. Disso decorre que não se pode conceber o sistema linguístico natural, pressuposto para todo acordo mútuo, como produto (invenção) da convenção humana. Para Apel, na medida em que o linguistic turn, como modelo metódicosolipsita que parte da designação arbitrária de noções instrumentais, não consegue explicar como o sistema da língua se conserva na comunidade (e funda essa comunidade), tampouco como se dá a validação intersubjetiva das regras do uso da linguagem, ele não pode ser considerado como um modelo linguístico intersubjetivamente válido a priori, independente do uso comunicativo da linguagem e das funções subjetivas dos usuários da linguagem. $\mathrm{O}$ paradoxo do linguistic turn reside em supor o uso comunicativo da linguagem apenas como atualização particular e isenta de reflexão de um sistema linguístico já previamente dado e, em decorrência disso, desconsiderar que a possibilidade da construção linguística artificial possa ser compreendida como um caso da tematização reflexiva da linguagem ${ }^{320}$.

No sentido de avançar "com" e "para-além" do pragmatic turn, Apel propõe uma ampliação da pragmática. Isso se desdobra em torno da exigência de pensar "com" e "para-

signos - ainda que possivelmente nunca em definitivo -, é o sujeito transcendental da interpretação dos signos (APEL, Paradigmas de filosofía primera, pp. 164-167).

319 APEL, Transformação da filosofia, II, p. 390; Transformation der Philosophie, Band II, p. 343.

${ }^{320}$ APEL, Transformação da filosofia, II, pp. 390-391; Transformation der Philosophie, Band II, pp. 343- 
além" de Wittgenstein ${ }^{321}$. Para Apel, o segundo Wittgenstein, ao contrapor o modelo dos jogos de linguagem ao modelo atomismo lógico e ao solipsismo metódico da tradição, sustenta a tese da impossibilidade de uma linguagem privada, em razão do caráter precipuamente público do cumprimento de regras consoantes às "formas de vida". Não obstante, segundo Apel, não basta substituir o modelo designativo de linguagem pela exigência de "descrever" as múltiplas funções e regras de uso dos jogos de linguagem, pois isso implica, contra Wittgenstein, a exigência de que o descritor do jogo de linguagem participe do jogo linguístico, de modo que tenha certeza que as regras descritas por ele são idênticas às que efetivamente se seguem no jogo de linguagem. Na visão de Apel, ocupar-se com a descrição de jogos de linguagem subsistentes e as "formas de vida" com que estão "entretecidos", ao mesmo tempo, implica refletir sobre eles sob pontos de vista críticonormativos. A crítica terapêutica da linguagem implica recorrer a um jogo linguístico específico, que está relacionado reflexiva e criticamente a todos os jogos linguísticos possíveis. A partir dele é possível, em princípio, participar de todos os jogos linguísticos e estabelecer comunicação com as respectivas comunidades linguísticas. Decerto, admite Apel, isso contradiz a tese de Wittgenstein acerca da inexistência de qualquer traço essencial (comum) contínuo aos muitos e diversos jogos de linguagem, existindo entre eles apenas certa "semelhança de família".

Para Apel, os traços comuns a todos os jogos de linguagem decorrem da circunstância de que, com o aprendizado de uma língua - com o aprendizado de uma "forma de vida" socializada com o uso da linguagem -, aprende-se "o" jogo de linguagem ou "a" forma de vida humana, que faculta "a competência para a reflexão sobre a própria língua e para a comunicação com todos os jogos de linguagem"322. Nessa direção, é preciso considerar que a tese de Wittgenstein sobre a impossibilidade de uma linguagem privada exige, contra ele mesmo, o jogo linguístico transcendental, uma vez que, para além do caráter público de todo segmento de regras, segundo Apel, é necessário que seja possível para o indivíduo introduzir novas regras que eventualmente não possa provar faticamente em uma comunidade, justamente por causa dos "paradigmas" dos jogos de linguagem subsistentes. Tal é o caso de todos os inventores e autores de novas descobertas na ciência, bem como revolucionários voltados ao futuro, que pretendem transformar normas sociais e ficam incompreendidos em seu tempo. Aqui, tais casos não figuram uso de uma "linguagem particular", mas uso de um

${ }^{321}$ APEL, Transformação da filosofia, II, p. 393-395; Transformation der Philosophie, Band II, pp. 346-348.

${ }^{322}$ APEL, Transformação da filosofia, II, p. 395; Transformation der Philosophie, Band II, p. 348. 
jogo de linguagem ideal - em sentido normativo, como instância de controle de cumprimento de regras em geral - de uma comunidade ideal de comunicação. Apel designa o jogo de linguagem ideal como "jogo de linguagem transcendental”, justamente porque ele se antecipa a qualquer jogo de linguagem factual (subsistente). O jogo de linguagem transcendental é antecipado, por todo aquele que segue uma regra, como possibilidade real do jogo de linguagem ao qual faticamente ele está vinculado. Ele é antecipado, implicitamente, por aquele que segue a regra de maneira sensata; e, explicitamente, por aquele que argumenta.

A exigência de retranscendentalizar a filosofia a partir da virada pragmática, sob o viés do jogo de linguagem transcendental, concerne a um saber pragmático-reflexivo acerca das intenções e pressupostos exigidos na ação comunicativa. Sem esse saber não é possível constituir o saber sobre as pretensões de validade dos próprios atos de fala, tampouco uma compreensão hermenêutica da conduta dos interlocutores mediada pelos signos, no sentido de atos ilocucionários com suas correspondentes pretensões de validade. Para elaborá-lo, no sentido de propor algo "com" e "para-além" do pragmatic turn, inclusive para superar a redução empirista da dimensão transcendental da semiosis, Apel toma como ponto de partida a pragmática da semiótica trivalente de Peirce. Sob a inspiração da virada pragmática de Peirce, Apel se propõe a ampliar o giro da virada pragmática, demonstrando a dimensão hermenêutico-transcendental e pragmático-transcendental constitutiva do paradigma da linguagem como prima philosophia.

\subsection{Transformação semiótica da filosofia transcendental por Peirce}

A fonte de inspiração possivelmente mais importante para a semiótica de Apel, ao menos no contexto da obra Transformação da Filosofia, é a semiótica trivalente da linguagem de Ch. S. Peirce. Apel parte da transformação semiótica da filosofia transcendental kantiana realizada por Peirce e incorpora dele o programa relativo a uma teoria consensual da verdade e à interpretação da crítica do sentido, pragmática e normativo-semiótica. Para Apel, o programa de Peirce se mostra mais vantajoso em comparação com Kant, Hegel e programas analíticos e hermenêuticos da linguagem no século $\mathrm{XX}^{323}$. Nesse ponto, seguindo a Apel, é possível apontar a vantagem do programa de Peirce, na linha do realismo crítico do sentido, frente à crítica a Kant feita por Hegel. Mesmo ciente da aporética da Crítica da razão pura kantiana entre realismo empírico e realismo transcendente da coisa-em-si, diferentemente de

${ }^{323}$ APEL, Paradigmas de filosofía primera, pp. 180-182. 
Hegel, Peirce continua com o programa kantiano da crítica do conhecimento. Essa é, segundo Apel, a primeira grande vantagem do programa de Peirce. De uma parte, como Hegel, Peirce preconiza que é necessário ter a capacidade de conhecimento da verdade acerca da realidade, e não apenas acerca do mundo fenomênico, sob pena de resultar sem-sentido ou contraditória a própria pretensão de conhecimento da crítica do conhecimento. Por outra, diferentemente de Hegel, Peirce não concebe ser possível um conhecimento filosófico-apriorístico da realidade em seu conjunto. Por isso, Peirce estabelece a diferença entre a lógica filosófica da investigação, chamada por ele de normativa e semiótica, e a ciência empírica da modernidade, aplicando a esta última o princípio do falibilismo. Ademais, Peirce entende que, diferentemente do conhecimento puramente conceitual filosófico (autorreflexão), o conhecimento empírico depende da informação mediada por dois tipos de signos conceituais, os indexicais e os icônicos, correspondentes em Kant à "afecção dos sentidos" e à "intuição".

Segundo Apel, ao manter a diferença entre ciência empírica e filosofia transcendental apriorística - sendo esta última restringida à fundamentação última reflexiva, às condições inelimináveis da argumentação -, vantajosamente, Peirce soluciona a aporia central da arquitetônica sistemática de Hegel. Essa aporia consiste em que, por uma parte, Hegel se encontra em um "ponto de vista absoluto" da história a partir do qual é possível compreender retrospectivamente a alienação histórica e o regresso do espírito para si mesmo e, desse modo, justificar o real como racional. Desde esse ponto de vista absoluto, Hegel tem que "superar" na filosofia teorética a dimensão de futuro, assim como o dever da filosofia prática. Por outra, tal pretensão se contradiz com a tese histórico-relativista de Hegel, conforme a qual uma filosofia só pode captar conceitualmente sua época.

Continuando, segundo Apel, Peirce soluciona essa aporia, na medida em que apresenta uma instância correspondente à pretensão (do idealismo absoluto) de poder "superar", na autorreflexão de um sujeito da consciência, o saber possível, porém incompleto: a comunidade ilimitada de investigação, própria da ciência empírica. Ademais, a transformação peirceana de Kant é mais vantajosa que a restituição da metafísica filosófica hegeliana, pois ela estabelece o princípio de autoalcance, como postulado relativo aos intentos hermenêuticos internos da reconstrução da evolução cultural por parte das ciências empíricas. Por esse princípio, as hipóteses fundamentais da reconstrução da evolução cultural têm que dar conta do fato de que suas próprias condições de possibilidade, como pressupostos históricos das ciências do espírito ou sociais, constituem também um factum da evolução cultural. Esse factum deve ser alcançado (tornar-se compreensível) na reconstrução da evolução cultural, e inclusive ampliado à evolução natural, ao passo que esta corresponde à 
pré-história da evolução cultural humana. À medida que submete as ciências empíricas ao princípio de autoalcance, a transformação semiótica de Kant por Peirce não cai no reducionismo cometido por teorias naturalistas, que pretendem explicar externamente e por completo as pretensões racionais (fenômenos espirituais, individuais ou coletivos, tais como os relacionados aos pressupostos da argumentação científica), recorrendo aos mecanismos da natureza. As explicações externas e naturalistas, embora desqualificadas a priori em relação ao princípio de autoalcance, exercem uma função secundária como complemento dos intentos internos hermenêuticos de reconstrução.

Precisamente, o programa de Peirce apresenta três vantagens. A primeira vantagem se liga à recuperação da dimensão transcendental da moderna da lógica da ciência. A segunda decorre da transformação semiótica da filosofia transcendental de Kant. A terceira decorre do fato de que Peirce esboça, ao apresentar uma definição do "real", junto com uma teoria consensual da verdade, um novo paradigma da filosofia primeira. Essas determinações referentes ao real e à verdade estabelecem as bases, segundo Apel, para ir além dos paradigmas tradicionais da ontologia e da teoria do conhecimento. E com base nessas vantagens, além de defender o programa de Peirce, Apel procura radicalizá-lo e ultrapassá-lo no rumo de uma semiótica (pragmática) transcendental da linguagem ${ }^{324}$. A seguir, tratar-se-á dos dois ganhos teóricos de Peirce que são incorporados por Apel, programaticamente, em sua semiótica transcendental, a saber, da recuperação (demonstração) da dimensão transcendental oculta na moderna lógica da ciência e da transformação semiótica de Kant por Peirce. Por fim, neste tópico, trata-se da relevância de Peirce para a transformação da filosofia transcendental de Apel.

\subsubsection{A dimensão transcendental da moderna logic of science}

Para Apel, Peirce realiza de forma exitosa o programa de transformar semioticamente a filosofia transcendental de Kant. Isso se explica, em parte, porque se encontram em Peirce todas as características principais da moderna lógica analíticolinguística da ciência: a diferenciação do problema da validade ou da justificação na pergunta pelos critérios de sentido e a pergunta pelos critérios de confirmação dos enunciados científicos, bem como a substituição da crítica da metafísica como crítica do conhecimento pela crítica da metafísica como crítica do sentido. Em outra parte, esse êxito decorre porque,

\footnotetext{
${ }^{324}$ APEL, Paradigmas de filosofía primera, pp. 179 e 184.
} 
diante da moderna lógica da ciência, Peirce mostra que não é possível esclarecer as condições de possibilidade e validade do conhecimento científico mediante a formulação sintática das teorias e a análise semântica da relação diádica (zweistelligen) entre teorias e fatos, mas mediante um elemento intersubjetivo, análogo à "unidade transcendental da consciência" kantiana, na tríplice dimensão pragmática da interpretação dos signos ${ }^{325}$. Nesse sentido, o primeiro passo da transformação semiótica de Kant por Peirce é a recuperação da dimensão transcendental da moderna lógica da ciência.

Iniciando a exposição sobre essa recuperação, Apel pontua que a diferença mais acentuada ao se comparar a Crítica da razão pura kantiana, como epistemologia, com a atual lógica da ciência reside na distinção metodológica entre análise da consciência e análise da linguagem. O propósito de Kant é tornar compreensível a validade objetiva da ciência para toda consciência em geral. Com tal propósito, ele substitui a psicologia empirista do conhecimento de Locke e Hume por uma lógica "transcendental" do conhecimento, embora seu método de investigação permaneça relacionado ao "ponto supremo" ("höchsten Punkt"), por ele mesmo assim designado, da unidade da consciência na "síntese transcendental da apercepção". Nela, ele situa, no lugar de leis psicológicas de associação (Hume), as regras a priori que instituem uma unidade objetiva e que são regras de faculdades psíquicas, tais como “intuição", "imaginação", "entendimento" e "razão". Do ponto de vista histórico-filosófico, a partir da reconstrução sintático-semântica da epistemologia, considera-se que a "consciência em geral" (o sujeito transcendental da ciência) não é mais necessária. A justificativa oficial para tal é que: a) enquanto ser humano como sujeito, o sujeito da ciência se reduz a um objeto desta última; b) como condição lógica da possibilidade e validade da ciência, a função transcendental do sujeito é substituída pela lógica da linguagem científica. Quer dizer, a lógica da linguagem e a comprovação empírica ocupam, conjuntamente, o lugar da lógica transcendental da experiência objetiva kantiana. Com isso, o discurso acerca de faculdades (Vermögen) psíquicas e o problema da consciência como sujeito do conhecimento científico em oposição aos objetos, tratados como requisitos da "lógica transcendental" de Kant, são quase por completo eliminados. Em lugar desses requisitos, não se recoloca a lógica formal em sua renovação matemática, mas a sintaxe lógica e a "semântica" das linguagens científicas. As linguagens científicas, como "semantical frameworks", constituem o novo substrato das regras a priori que determinam a possível descrição e explicação das coisas, na medida em que elas formam uma conexão regida por leis. Assim, o problema kantiano da

${ }^{325}$ APEL, Transformação da filosofía, II, p. 187; Transformation der Philosophie, Band II, p. 164. 
validade objetiva do conhecimento científico para uma "consciência em geral" é resolvido na moderna lógica da ciência mediante a justificação lógico-sintática e lógico-semântica de proposições (hipóteses) científicas ou teorias, ou seja, mediante a garantia de sua consistência lógica e de sua verificabilidade (confirmabilidade) empírica ${ }^{326}$.

Não obstante, segundo Apel, a autocompreensão oficial da moderna lógica da ciência do empirismo lógico não corresponde à situação real do problema. Pois, ela implica um momento ideológico, que encobre o fracasso do programa original da moderna lógica da ciência, desde o qual se defende a esperança de garantir a intersubjetividade da possível validade de toda ciência empírica mediante a sintaxe e a semântica de uma linguagem acerca de "coisas" ou "fatos". Contrariamente, o que se tem constatado é que a consistência lógica e a comprovação empírica e intersubjetiva da ciência não podem ser asseguradas mediante a sintaxe e a semântica de uma linguagem sobre as "coisas" ou "fatos". Em razão disso, assim pensa Apel, em dois lugares faz-se necessário introduzir, sob a denominação de convenções práticas, a denominada dimensão pragmática da interpretação humana dos signos, como condição de possibilidade e validade dos enunciados científicos ${ }^{327}$.

O primeiro lugar de introdução da dimensão pragmática da linguagem é o do problema da verificação, no qual se conecta a linguagem científica, reconstruída logicamente, com os "fatos". A forma analítico-linguística da moderna teoria da ciência só pode confrontar teorias científicas com os denominados enunciados básicos. Porém, para proporcionar validade a eles, precisa de um acordo intersubjetivo (Verständigung) dos investigadores como intérpretes pragmáticos da ciência, isto é, como sujeitos da ciência, que não podem ser reduzidos, em princípio, a objetos da ciência empírica. A linguagem desse acordo sobre enunciados básicos não pode ser idêntica, no sentido da semântica lógica, à linguagem reconstruída pela ciência. Antes, ela deve coincidir com a linguagem não-formalizada, na qual os construtores da linguagem e os investigadores empíricos devem poder colocar-se em acordo sobre a interpretação pragmática da própria linguagem científica ${ }^{328}$.

O segundo momento, ainda mais fundamental, é o fracasso da substituição da função transcendental do sujeito pelas regras sintático-semânticas de uma linguagem sobre coisas ou fatos. Pois, a linguagem formalizada da ciência não pode fazer uso, conforme postula o primeiro Wittgenstein, da forma lógica não-reflexiva (nicht mehr reflektierbaren)

\footnotetext{
${ }^{326}$ APEL, Transformação da filosofía, II, pp. 179-180; Transformation der Philosophie, Band II, pp. 157158.

${ }^{327}$ APEL, Transformação da filosofía, II, pp. 180-182; Transformation der Philosophie, Band II, pp. 158159.

${ }^{328}$ APEL, Transformação da filosofía, II, p.182; Transformation der Philosophie, Band II, pp. 160-161.
} 
"da" linguagem ou "do" mundo. Em contrapartida, ela deve ser estabelecida e legitimada como "semantical framework" convencional pelos investigadores que a interpretam, pragmaticamente, em uma metalinguagem. Por sua vez, isso demonstra que não é possível conceber a dimensão pragmática dos signos, introduzida por Ch. Morris na moderna lógica da ciência, como um tema da psicologia empírica, tal como acontece no empirismo lógico. Antes, a dimensão pragmática representa na moderna lógica da ciência o análogo semiótico da "síntese transcendental da apercepção", postulada por Kant. Como Kant é obrigado a postular, com anterioridade a toda crítica do conhecimento, que é possível alcançar algo semelhante à unidade entre a consciência e o ser do objeto, os modernos lógicos da ciência, que partem de uma base semiótica ou analítico-linguística, segundo Apel, devem postular a possibilidade de alcançar algo semelhante a uma interpretação do mundo, intersubjetivamente unitária, desde a interpretação dos $\operatorname{signos}^{329}$.

Para Apel, a recuperação da dimensão transcendental da lógica da ciência moderna passa pela compreensão de que o "convencionalismo crítico" não exclui o postulado de uma interpretação de mundo unificada de maneira intersubjetiva, mas a pressupõe. A ressalva quanto a isso é que a diferença entre a filosofia de Kant e a da ciência moderna reside na impossibilidade de exigir uma unidade transcendental da interpretação do mundo. Em razão disso, segundo Apel, é possível supor por parte dos representantes da filosofia "analítica" moderna (por exemplo, Popper, Wittgenstein tardio e Carnap da última fase) a restrição aos limites do "convencionalismo crítico". Contrapondo essa restrição, Apel afirma que reduzir a cognição a uma mera convenção é um equívoco, pois o convencionalismo crítico apenas pode diferenciar entre as convenções dos especialistas (dentro de uma reserva falibilista) e o consenso intersubjetivo sobre a validação de proposições científicas, buscado desde sempre.

Exemplificativamente, Apel procura mostrar o status transcendental presente em Popper e no Wittgenstein tardio. No caso de Popper, Apel destaca que, porque o "falibilismo é sempre meliorismo", em que a exigência por uma falsificabilidade de princípio não decorre da "pressuposição metafísica da inutilidade de todos os esforços cognitivos do ser humano", mas da "pressuposição metodológica da corrigibilidade de todas as proposições ou teorias científicas factualmente alcançáveis", é preciso reconhecer que nessa pressuposição metodológica já se esconde, como "princípio regulativo" da pesquisa, o postulado "quase-

${ }^{329}$ APEL, Transformação da filosofía, II, pp. 182-183; Transformation der Philosophie, Band II, p. 160-161. 
kantiano da interpretação do mundo unificada" ${ }^{330}$. À medida que Wittgenstein entende que a regra é dependente das convenções dos jogos de linguagem dos que a utilizam, não é admissível hipostasiar um princípio regulador como "unidade ideal do ser"; ademais, se for o caso de pressupor um jogo de linguagem que se pressupõe para o uso não arbitrário da regra, para ele, esse status transcendental precisa ser relativizado, no sentido de um pluralismo de jogos de linguagem como fatos últimos descritíveis.

Para além de Wittgenstein, Apel argumenta que os jogos de linguagem (faticamente subsistentes, diversos e inconsistentes) não estão em condições de delinear o contexto determinante para o cumprimento de uma regra. Para tanto, é necessário o jogo de linguagem transcendental (universal e consistente), ou seja, o jogo de linguagem já pressuposto em todos os jogos de linguagem como condição de possibilidade e de validade do acordo mútuo ${ }^{331}$. Para Apel, esses exemplos demonstram que a filosofia transcendental kantiana perpassa a moderna lógica da ciência pelo caminho da pragmática dos signos e a problemática implícita da intersubjetividade da interpretação do mundo. Ressalta Apel que aqui não se reporta ao Kant histórico, nem sequer ao neokantismo do século XIX, mas a uma transformação analítico-linguística ou semiótica da filosofia transcendental. Trata-se de uma transformação da crítica kantiana do conhecimento, como análise da consciência, em uma crítica do sentido, como análise dos signos, cujo "ponto supremo" não se assenta em uma unidade objetiva das representações, que é acessível agora mesmo em uma "consciência em geral", supostamente intersubjetiva, mas em uma unidade do acordo intersubjetivo que alguma vez deva alcançar-se mediante a interpretação consistente dos signos em um consenso intersubjetivo ilimitado ${ }^{332}$.

\subsubsection{A transformação semiótica de Kant por Peirce}

A tese central de Apel é que a abordagem desenvolvida por Peirce, na linha do realismo crítico do sentido, pode ser entendida como uma transformação semiótica da lógica transcendental kantiana ${ }^{333}$. Para Apel, antes que se comprovasse a insuficiência da base bivalente sintático-semântica própria da ciência moderna, Peirce desenvolve a base trivalente

\footnotetext{
${ }^{330}$ APEL, Transformação da filosofía, II, pp. 183-184; Transformation der Philosophie, Band II, p. 161.

${ }^{331}$ APEL, Transformação da filosofía, II, pp. 183-185; Transformation der Philosophie, Band II, p. 161-163.

332 APEL, Transformação da filosofía, II, p. 186; Transformation der Philosophie, Band II, p. 163-164.

333 APEL, Transformação da filosofía, II, p. 189; Transformation der Philosophie, Band II, pp. 165-166. PEIRCE, Charles S. Sanders. Escritos coligidos. Trad. Armando M. D’Oliveira e Sérgio Pomerangblum. São Paulo: Abril Cultural, 1974, (col. Os Pensadores), p. 130.
} 
de uma lógica científica da interpretação dos signos, entendendo-a como que uma reconstrução crítica da Crítica da razão pura de Kant. Peirce instaura, a partir da semiótica trivalente que Morris introduz na moderna logic of science ${ }^{334}$, uma semiótica trivalente como fundamento triádico de uma logic of inquiry. Peirce continua com o programa kantiano da crítica do conhecimento, mesmo tendo em conta a aporética da Crítica da razão pura kantiana entre realismo empírico e realismo transcendente da coisa-em-si. Coerente com a virada copernicana, Peirce recorre ao "princípio supremo dos juízos sintéticos" de Kant tendo em vista sua própria teoria da realidade, que pretende responder à pergunta de como são possíveis os juízos sintéticos em geral. Contudo, Peirce não concebe possível um conhecimento filosófico-apriorístico da realidade em seu conjunto. Em sua teoria, o rechaço ao transcendentalismo não se refere, em absoluto, a uma concepção de um "ponto supremo" da “dedução transcendental”, mas ao modelo psicologista e circular do procedimento kantiano. Peirce julga necessário ter a capacidade de conhecimento da verdade acerca da realidade e não apenas acerca do mundo fenomênico, sob pena de resultar sem-sentido ou contraditória a própria pretensão de conhecimento da crítica do conhecimento. Então, a partir e além de Kant, Peirce estabelece a diferença entre a lógica filosófica da investigação, chamada por ele de normativa e semiótica, e a ciência empírica da modernidade, aplicando a esta última o princípio do falibilismo. Ademais, Peirce entende que, diferentemente do conhecimento puramente conceitual filosófico (autorreflexão), o conhecimento empírico depende da informação mediada por dois tipos de signos conceituais, correspondentes em Kant à "afecção dos sentidos" e à "intuição", os indexicais e os icônicos ${ }^{335}$. A expressão unity of consistency, que Peirce utiliza em sua crítica a Kant, indica a direção desde a qual ele procura o ponto supremo de sua dedução transcendental. Não se trata da unidade objetiva das representações (Vorstellungen) e um "eu-consciência", mas da consistência semântica de uma "representação" (Repräsentation) ${ }^{336}$ válida intersubjetivamente dos objetos mediante signos,

\footnotetext{
${ }^{334}$ Apel entende a sintaxe, a semântica e a pragmática como dimensões da verdade lingüística, seguindo a evolução histórica da filosofia analítica da linguagem desde o Tractatus de Wittgenstein, a Logische Syntax der Sprache de Carnap até a "semiótica tridimensional de Morris. A tríplice dimensão da linguagem quer dizer: a) do ponto de vista sintático, as proposições da argumentação devem cumprir as regras intersubjetivas do uso linguístico de uma determinada comunidade linguística; b) do ponto de vista semântico, as proposições devem ser compreensíveis para mediatizar o significado do objeto da argumentação; c) do ponto de vista pragmático, as proposições devem ser compreensíveis sintática e semanticamente para os sujeitos da argumentação. Ver: HERRERO, F. J. O Problema da fundamentação última. In: Kriterion, Belo Horizonte, v. XXXV, n. 91, pp. 716, Jan/95-Jul/95, cf. pp. 10-11.

${ }^{335}$ APEL, Paradigmas de filosofía primera, p. 180.

${ }^{336} \mathrm{O}$ termo Vorstellungen é expressivo do conteúdo kantiano e o termo Repräsentation, por sua vez, alude à transformação semiótica realizada por Peirce. Em sua conferência sobre a realidade da terceiridade, Peirce afirma que terceiridade é sinônimo de representação. A terceiridade é compreendida como operatória na
} 
que só pode ser determinada na dimensão da interpretação dos signos, designada de "pragmática" por Morris. O "ponto supremo" em Peirce, então, vem a ser entendido como unidade semiótica da interpretação consistente. Com efeito, Peirce não considera a lógica dedutiva formal dos símbolos conceituais e proposicionais como um substituto suficiente para a "lógica transcendental" kantiana, mas funda uma "lógica sintética da investigação" com a ajuda de Kant.

Segundo Apel, Peirce resolve de um modo completamente novo o problema central dos fundamentos de validade do conhecimento no sentido de uma lógica semiótica normativa da investigação. De uma parte, ele evita a fixação de princípios sintéticos a priori da ciência e, de outra parte, confia a fundamentação de validade das inferências sintéticas a uma lógica transcendental, que é uma lógica normativa de interpretação dos signos. No entanto, o processo de interpretação e inferência está sujeito a priori a idéias regulativas e a postulados normativos, os quais evidenciam que tal processo só tem sentido quando se pressupõe que o consenso último (ultimate opinion) de uma comunidade ilimitada de investigadores constitui tanto a meta da interpretação dos signos do ultimate logical interpretant (correspondente a um habit do comportamento), quanto a meta da construção de hipóteses científicas como ideia regulativa da verdade. Mediante esse deslocamento do ponto de gravidade do apriorismo da lógica transcendental da investigação, Peirce fundamenta, ao menos indiretamente, o conceito de uma lógica semiótica transcendental que precede metodicamente, como prima philosophia, a toda construção hipotética, empírica e falível. Desse modo, segundo Apel, Peirce lega uma alternativa, ao menos para a filosofia teorética, à superação da metafísica e da filosofia transcendental que aspira a uma total destranscendentalização de toda condição imaginável de validade intersubjetiva ${ }^{337}$. Contudo, a autêntica base da transformação da lógica transcendental ocorre, fundamentalmente, quando Peirce (1867) deduz, a partir da relação-signo (semiosis), como ponto supremo provisório de

\footnotetext{
natureza: "um princípio geral operatório no mundo real tem natureza de representação e símbolo porque o seu modus operandi é o mesmo pelo qual as palavras produzem efeitos físicos". Peirce afirma preferir o termo representação porque suas sugestões são menos estreitas (PEIRCE, Escritos coligidos, p. 37).

${ }^{337}$ APEL, El camino del pensamiento de Charles S. Peirce, pp. 12-14. A semiótica transcendental baseada na transformação da "lógica transcendental" de Kant abre, segundo Apel, uma terceira via. Esta via é capaz de ultrapassar, por um lado, a versão semanticista do giro lingüístico e a posição da ontologia pré-linguística e da filosofia transcendental (kantismo e fenomenologia husserliana); e, por outro lado, de operar a mediação entre essas filosofias (APEL, Significado linguiístico e intencionalidad in: Semiotica filosofica, p. 229.)
} 
sua filosofia transcendental, os três tipos de inferência de sua lógica da investigação e também os três tipos de signos como ilustrações de suas três categorias fundamentais ${ }^{338}$.

A relação-signo ou representação pode ser explicitada, segundo Peirce, mediante o seguinte esquema de definição: um signo é algo que representa alguma outra coisa para um interpretante em algum aspecto ou qualidade ${ }^{339}$. Para Peirce, a função essencial do signo "é tornar eficientes relações ineficientes, não pô-las em ação, mas estabelecer um hábito ou regra geral, a que se subordinarão na ocasião própria" ${ }^{340}$. À questão se é possível pensar sem signos, cuja resposta é que o pensamento precede o signo, Peirce afirma que o único pensamento que se pode conhecer é o pensamento-em-signos. Todo pensamento existe, necessariamente, em signos ${ }^{341}$. No tocante a signo-pensamento, um signo possui três referências: 1) "é signo para algum pensamento que o interpreta"; 2) "é signo para algum objeto que se lhe equivale nesse pensamento"; 3) "é signo sob algum aspecto ou qualidade que o liga ao seu objeto". Isto é, “o pensamento tem três elementos: a função representativa que o torna representação; a aplicação denotativa, ou ligação real, que põe um pensamento em relação com outro; a qualidade material, que dá ao pensamento sua qualidade ${ }^{\text {342 }}$. No signo, portanto, são implícitas três categorias: primeiridade, segundidade e terceiridade ${ }^{343}$.

A categoria do firstness, denominada de primeiridade ${ }^{344}$, é a qualidade isenta de relação, em virtude da qual algo se expressa como algo em seu ser-assim (presentidade, Sosein). A essa categoria corresponde o tipo de signo do "ícone”. O ícone é um representamen (signo) que preenche a qualidade de sensação, mesmo que o seu objeto não

\footnotetext{
338 APEL, Transformação da filosofía, II, p. 194; Transformation der Philosophie, Band II, p.170. Peirce conceitua semeiosis como "uma ação ou influência, que consiste em, ou envolve, a cooperação de três sujeitos, o signo, o objeto e o interpretante, influência tri-relativa essa que não pode de forma alguma ser resolvida em ações entre pares. (...) Tudo o que se comportar a denominação de "signo"' (PEIRCE, Escritos coligidos, pp. 149-150). A palavra categoria possui, segundo Peirce, substancialmente o mesmo significado em todos os filósofos, isto é, significa "um elemento dos fenômenos com uma generalidade de primeira ordem" (PEIRCE, Escritos coligidos, p. 23). As categorias cenopitagóricas (primeiridade, segundidade e terceiridade), assim designadas por Peirce, constituem uma outra tentativa para caracterizar o que Hegel quis caracterizar como os três estágios do pensamento. Elas correspondem também às três categorias de cada uma das quatro tríades da tábua de Kant. Em Hegel vigora, por exemplo, a idéia de que o absoluto é uno e, por isso, a existência de três absolutos vem a ser uma ridícula contradição in adjecto. Em Hegel, as três categorias não têm posições independentes e irrefutáveis no pensamento; a primeiridade e a segundidade devem ser de alguma forma aufgehoben. Diferentemente, a perspectiva de Peirce é no sentido da irredutibilidade e interdependência das categorias (PEIRCE, Escritos coligidos, pp. 34, 119-120).

${ }^{339}$ APEL, Transformação da filosofía, II, p. 194; Transformation der Philosophie, Band II, p. 170.

${ }^{340}$ PEIRCE, Escritos coligidos, p. 123.

${ }^{341}$ PEIRCE, Escritos coligidos, pp. 73-74.

${ }^{342}$ PEIRCE, Escritos coligidos, pp. 79-81.

${ }^{343}$ Sobre as três categorias, vide: APEL, Transformação da filosofía, II, pp. 194-195. PEIRCE, Escritos coligidos, pp. 31-33.

344 APEL, Transformação da filosofía, II, p. 194; Transformation der Philosophie, Band II, pp. 170-171. APEL, Significado linguístico e intencionalidad in: Semiotica filosofica, pp. 227-228.
} 
exista, como é o caso da estátua de um centauro. Fundamentalmente, ele deve estar implícito em todo predicado de um juízo de experiência para integrar na síntese da representação o conteúdo da imagem de uma qualidade do mundo experimentada. A categoria secondness, designada de segundidade ${ }^{345}$, é a relação diádica do signo com os objetos por ele denotados. A essa categoria concerne o tipo sígnico do "índice". O índice é um representamen em função de uma característica pertinente à existência de seu objeto, que continuará tendo quer seja interpretado como signo, quer não. $O$ índice deve estar presente, por exemplo, como função dos pronomes ou advérbios, em todo juízo de experiência para garantir a identificação espaçotemporal dos objetos, os quais são determinados mediante predicados. A categoria do thirdness, denominada de terceiridade ${ }^{346}$, vem a ser a relação triádica dos signos como mediação de algo para um interpretante. Ela corresponde ao tipo de signo do "símbolo" convencional. O símbolo é um representamen que preenche sua função sem qualquer similaridade ou analogia com o seu objeto, sendo independente de qualquer ligação fatual. Ele tem a principal função da síntese como "representação" em conceitos de algo como algo.

No tocante à relação dessas três categorias, segundo Peirce, os conceitos resultam vazios sem a integração das funções do ícone e do índice, bem como, inversamente, as funções do ícone e do índice são cegas sem sua integração à função de representação ${ }^{347}$. Nos três tipos de representamen, o ícone é o qualitativamente degenerado, na medida em que representa o que representa (o ícone puro não traça distinção entre si e o objeto), seja como for, pelo fato de ser o que é. O índice é um signo de reação, envolve uma relação efetiva com o objeto. O símbolo é o gênero de representamen relativamente genuíno ${ }^{348}$. Nos termos de Peirce: "o objeto da experiência como realidade é segundo. Mas o desejo que busca ligar um ao outro é terceiro, ou medium" "349. Só a interpretação logra tornar plena de sentido a função do índice (por exemplo, de uma placa na rua ou da pulsação sanguínea) ou a função do ícone (por exemplo, de um diagrama, uma imagem). E é precisamente isso, segundo Apel, que a construção linguística da sintaxe e da semântica deve (sollen) levar em consideração ${ }^{350}$.

No momento em que, à luz de Peirce, os três tipos fundamentais de inferência são coordenados com as três categorias ou três tipos de signo, segundo Apel, percebe-se em que

\footnotetext{
${ }^{345}$ APEL, Transformação da filosofía, II, p. 194; Transformation der Philosophie, Band II, p. 171. APEL, Significado linguístico e intencionalidad in: Semiotica filosofica, p. 226.

${ }^{346}$ APEL, Transformação da filosofía, II, p. 195; Transformation der Philosophie, Band II, p. 171.

${ }^{347}$ APEL, Transformação da filosofía, II, p. 195; Transformation der Philosophie, Band II, p. 171.

${ }^{348}$ PEIRCE, Escritos coligidos, pp. 33-34.

${ }^{349}$ PEIRCE, Escritos coligidos, p. 100.

${ }^{350}$ APEL, Transformação da filosofía, II, p. 195; Transformation der Philosophie, Band II, p. 171.
} 
medida a dedução semiótica das três categorias fundamentais e dos três tipos de signos contribui realmente para explicar as condições de possibilidade e validade da experiência ${ }^{351}$. Em seu ordenamento, a terceiridade é coordenada à dedução, enquanto mediação racionalmente necessária. A dedução parte de um estado de coisas hipotético definido abstratamente por certas características. Nela, a inferência é válida quando existe relação entre o estado de coisas suposto nas premissas e o da conclusão. A segundidade é coordenada à indução, enquanto confirmação do que é geral mediante os fatos mostráveis aqui e agora. Trata-se de um processo de investigação experimental. No sentido de Peirce, o experimento é uma interrogação posta à natureza e, por isso, baseia-se numa suposição. A primeiridade é coordenada, por sua vez, à abdução, como conhecimento de novas qualidades do "ser-assim" (chamada também retrodução ou hipótese). A abdução é a única operação lógica a introduzir ideias novas e formar hipóteses explicativas. Então, quanto aos três tipos de inferência, "a dedução prova que algo deve ser; a indução mostra que algo atualmente é operatório e a abdução faz uma mera sugestão de algo que pode ser" ${ }^{352}$. Constata-se assim que a dedução e a indução não podem dar origem a uma nova ideia, pois todas as ideias da ciência procedem através da abdução ${ }^{353}$.

O ponto-chave da transformação semiótica do transcendentalismo por Peirce reside, segundo Apel, em sua capacidade de considerar os fatos empíricos ${ }^{354}$. "Todo conhecimento é, para Peirce, inferencial, mediato, articulado no tempo e processual. Todo processo de conhecimento faz-se mediante signos e no decorrer da experiência" ${ }^{355}$. As funções dos tipos de signos não conceituais da linguagem, índices e ícones, que estão estreitamente ligadas com o contexto da situação perceptiva, são capazes de fundamentar semioticamente a base de evidência do conhecimento humano. Quer dizer, elas testemunham a relação diádica (segundidade) do $e u$ volitivo com o efeito causal do não-eu e, desse modo, a doação resultante do ser-assim monádico (isento de relações) dos fenômenos. É nesse sentido que se entende que, para Peirce, é o descobrimento da abdução ou hipótese que resulta frutífero para a lógica pragmática da investigação. Peirce enuncia que o problema do pragmatismo é o problema da lógica da abdução, pois ela é a inferência que amplia a

\footnotetext{
${ }^{351}$ APEL, Transformação da filosofía, II, p. 195; Transformation der Philosophie, Band II, p. 171. APEL, Significado linguístico e intencionalidad in: Semiotica filosofica, p. 231.

${ }^{352}$ PEIRCE, Escritos coligidos, p. 52.

${ }^{353}$ PEIRCE, Escritos coligidos, pp. 46-52.

${ }^{354}$ APEL, Significado linguístico e intencionalidad in: Semiotica filosofica, p. 207.

${ }^{355}$ SILVEIRA, Lauro Frederico Barbosa da. O caráter dialógico do signo e do pensamento em Peirce. In: Trans/Form/Ação, São Paulo, v. 11, p. 23-29, 1988, cf. p. 24.
} 
cognição, em sentido kantiano, e já se encontra inconscientemente no juízo de percepção. Como toda abdução ou hipótese, ao menos tentativamente, pressupõe uma premissa geral (universal) e, ademais, necessita ser empiricamente testada pela indução, conjuntamente, a abdução e a indução fornecem a resposta à questão de Kant, ainda que não feita explicitamente, acerca de como é possível e válida a experiência em geral ${ }^{356}$.

Explicando mais, a abdução elucida a possibilidade da experiência, posto que ela "faz que a verdadeira síntese como redução do que há de múltiplo nos estímulos sensórios e nas qualidades sentimentais tenha êxito como unidade da consistência no juízo experimental" 357 . A elucidação da abdução exige mediatizar, em primeiro plano, a função de ícone dos predicados proposicionais com o significado "intensional" (intensionalen, no sentido de intensão como sentido inerente, o conceito que ela evoca) dos predicados como símbolos. Por sua vez, a indução elucida a validade empírica dos pressupostos universais da experiência, estejam eles implícitos em juízos perceptivos, estejam explícitos como hipóteses normativas. A elucidação da indução exige mediatizar, em primeira linha, a função de índice da linguagem "como identificação dos objetos apresentáveis aqui e agora com o significado extensional dos predicados como símbolos de classe" ${ }^{\text {358. }}$. Peirce concebe que, no caso de haver um juízo que contenha uma hipótese que possa ser testada empiricamente mediante indução, é possível constar "isso" (no sentido de um "batismo original" ${ }^{359}$ ) experimentalmente, mesmo antes da validação empírica do juízo, questionável por meio da dedução de consequiências experimentáveis a partir do sentido universal e nomológico (legal) de um predicado, em forma de prognósticos condicionados operacionalmente. É o caso, por exemplo, na proposição básica: “aqui (ou isto) é um caso de peste”. Então, supondo um procedimento

\footnotetext{
${ }^{356}$ APEL, Transformação da filosofía, II, p. 196; Transformation der Philosophie, Band II, p. 172. PEIRCE, Escritos coligidos, pp. 52-62. Peirce explicita três "proposições afiadoras" que conferem fisionomia própria ao pragmatismo. Vem a ser: 1) "Nihil est in intellectu quod non prius fuerit in sensu". Contudo, Peirce emprega a frase em um sentido diferente ao de Aristóteles. Ele entende por intelllectus o significado da representação em qualquer espécie de cognição, virtual, simbólica ou outra. E, ademais, utiliza o termo in sensu na acepção de um juízo perceptivo (ponto de partida ou premissa primeira de todo o pensamento crítico e controlado); 2) os juízos perceptivos contêm generalidade, e nesse sentido as proposições universais são dedutíveis deles; 3) a inferência abdutiva se dissolve gradualmente nas sombras do juízo perceptivo, sem uma linha nítida de demarcação entre ambos. A inspiração abdutiva é um ato de insight (lampejo), embora extremamente falível (mesmo os elementos da hipótese estando antes na mente, é a idéia de associar o que antes não fora pensado em associar que faz lampejar a inspiração abdutiva). Curiosamente, não se pode fornecer nenhuma razão para justificar a abdução, mesmo porque não é necessário, segundo Peirce, uma vez que ela somente oferece sugestões. Ou melhor, "a sua única justificação é que da sugestão a dedução pode tirar uma predição testável pela indução, e que para apreender ou compreender os fenômenos só a abdução pode funcionar como método" (PEIRCE, Escritos coligidos, p. 52).

357 APEL, Transformação da filosofía, II, p. 196; Transformation der Philosophie, Band II, p. 172.

${ }^{358}$ APEL, Transformação da filosofía, II, p. 196; Transformation der Philosophie, Band II, p. 172.

${ }^{359}$ APEL, Significado linguístico e intencionalidad in: Semiotica filosofica, p. 224.
} 
como esse que Peirce desenvolve uma reflexão metacientífica intencionada em explicitar a conexão entre as fases analítica e sintética da lógica da investigação. Isso é explicado por Peirce em sua "máxima pragmática" como método de aclaração e crítica do sentido ${ }^{360}$.

Em seu programa filosófico do pragmatismo crítico de sentido, segundo Apel, Peirce formula uma definição do "real", junto com uma teoria da verdade consequente a ela, que esboça um novo paradigma da filosofia primeira. Vantajosamente, nisso se demonstra, para Apel, o caráter inovador e fecundo desse programa em duas perspectivas, a perspectiva da "máxima pragmática" aplicada aos conceitos de realidade e verdade e a perspectiva da transformação de Kant no sentido das ideias regulativas. Salientado esse aspecto mencionado anteriormente, Peirce concebe que o real não é o incognoscível, tal como supõe Kant, mas o cognoscível "in the long run" que nunca pode ser conhecido. O "real" é, de um lado, independente de todo conhecimento fático por parte de um indivíduo ou de uma comunidade limitada, porém, por outro, não é independente do conhecimento possível em geral, isto é, não é independente do conhecimento possível de uma comunidade ilimitada de investigadores. O real é e permanece sempre cognoscível, ainda que não possa ser conhecido. De início, tal determinação consoante ao real parece ser em si mesma contraditória, pois aquilo que nunca pode ser conhecido parece ser incognoscível. E isso, quando se leva em conta a infinitude potencial dos processos temporais de investigação, parece implicar mudança na própria significação de cognoscível, de modo a diferenciar entre a possibilidade fática (aquilo que está dado) e a possibilidade do princípio (de cognoscibilidade). Contudo, essa aparente contradição é esclarecida ao aplicar a máxima pragmática da explicação do sentido aos conceitos de real e verdadeiro ${ }^{361}$.

\footnotetext{
${ }^{360}$ APEL, Transformação da filosofía, II, pp. 196-197; Transformation der Philosophie, Band II, pp. 172173.

${ }^{361}$ É bastante controversa a resposta à questão acerca de como deve ser entendida em Peirce a teoria da realidade e sua correspondente teoria da verdade como crítica do sentido conforme o realismo. Conforme Apel, há muitas vacilações entre os intérpretes de Peirce em relação a essa questão, caracterizando a posição de Peirce entre idealismo, fenomenalismo e realismo empírico. Contudo, assinala Apel, é possível uma posição mais clara quando se parte da máxima pragmática do esclarecimento dos conceitos, formulada em 1878, a qual caracteriza o pragmatismo crítico de sentido (cf. APEL, Significado linguístico e intencionalidad in: Semiotica filosofica, pp. 207, 226-230). Conforme Peirce, o pragmatismo comporta duas funções. Na primeira, ele é um método de reflexão que objetiva tornar claras as ideias, determinando o verdadeiro sentido de qualquer conceito, doutrina, proposição, palavra ou outro tipo de signo. Pragmatismo é a opinião segundo a qual a metafísica será amplamente clarificada pela aplicação da seguinte máxima: "para determinar o sentido de uma concepção intelectual devem-se considerar as consequências práticas pensáveis como resultantes necessariamente da verdade da concepção; e a soma dessas consequências constituirá o sentido total da concepção". Na Segunda, ele visa assumir uma atitude satisfatória em relação à terceiridade. A terceira categoria é aquela cuja realidade é negada pelo nominalismo. Aqui, o idealismo pragmatístico assinala, na medida em que afirma que a realidade consiste no futuro, a necessidade de abandonar o nominalismo. Nesse sentido, Peirce define o pragmatismo como "uma espécie de atração instintiva por fatos vivos". Assim, quem aceita as "proposições do pragmatismo"
} 
A máxima pragmática de Peirce estabelece a exigência de "considerar os efeitos práticos que possam pensar-se como produzidos pelo objeto de nossa concepção. A concepção desses efeitos é a concepção total do objeto"362. Em seu núcleo, essa máxima preconiza que é preciso representar-se, em um experimento mental, as consequências experimentáveis que sucederiam se acaso se empreendesse operações deliberadas com as coisas cujas propriedades se caracterizam mediante predicados. E compreendendo que os experimentos mentais postulados sempre se referem ao futuro, Peirce designa o método concebido com o termo de "mellorization" (meliorismus) $)^{363}$. O conceito não tem nenhum sentido se não puder aplicar o método da explicação do sentido mediante melonização. Assim, por exemplo, se se pretende aplicar o método de melonização e esclarecer o predicado "(algo) é pesado", pode-se explicitar seu sentido mediante proposições do tipo "se-então", tal como "se lhe remove o apoio, então cai". Do mesmo modo, também uma possível diferença entre conceitos tem que poder explicitar-se mediante melonização; do contrário, só existe aparência $^{364}$.

Aplicando a noção da máxima pragmática da explicação do sentido aos conceitos de real (teoria da realidade) e verdade (teoria consensual da verdade), esclarece-se a definição do real como o cognoscível in the long run. O real consiste em uma síntese extremamente concisa da melonização possível faticamente. Aprende-se a entender o significado de real, diferentemente de não-real, ao buscar distinguir, em um discurso contínuo, o crido de modo idiossincrático do que se prova como existente (tal como é) não apenas para um sujeito ou

sustenta que a lógica fica limitada ao que se pode controlar, ainda que no futuro seja provável a ampliação do controle. Para Peirce, "não há mostras, no entanto, de que o conteúdo do juízo perceptivo que não é controlável agora o venha a ser alguma vez. Pode ser que dependa obscuramente (...). Mas a soma de tudo isso é que os nossos pensamentos logicamente controlados compõem uma pequena parte da mente, mera florescência de um vasto complexo que podemos chamar a mente instintiva, e no qual não se tem fé, pois isso implica a possibilidade de suspeita, mas sobre o qual é edificada, afinal, toda a verdade da lógica" (cf. PEIRCE, Escritos coligidos, pp. 11-13, 29-30 e 65-66).

${ }^{362}$ Cf. PEIRCE, Escritos coligidos, p. 11. Ver ainda no texto "Como tornar nossas ideias claras", in: PEIRCE, Charles Sanders. Ilustrações da lógica da ciência. Trad. Renato R. Kinouchi. São Paulo: Ideias \& Letras, 2008, p. 73.

363. Para Peirce, um dos mais maravilhosos traços do raciocínio e um dos mais importantes filosofemas da ciência consiste em que a "razão tende a corrigir-se a si mesma". E ela faz isso tanto melhor quanto mais bem trabalhado estiver o esquema. Ela deve corrigir não só as conclusões, mas também suas premissas. Daí, é um caminho errado pensar que ciência se faz por empilhamento de inferência após inferência (PEIRCE, Escritos coligidos, p. 134). Afirma Peirce: "por melonização (do grego, méllon, o ser, o estar para fazer, o há de ser, o futuro), refiro-me àquela lógica pela qual o que concebemos como tendo sido (concebido como paralelythose) é imaginado como repetido ou estendido indefinidamente àquilo-que-será-sempre (ou àquilo que será-um-dia, quer dizer, cuja ausência não-existirá-sempre, o que igualmente envolve melonização, que nada asserta e é apenas um modo de conceber (mode of conceiving). A concepção do real deriva de uma melonização do lado-coação da consciência. Portanto, dizer que é o mundo do pensamento que é real significa, bem entendido, afirmar enfaticamente a realidade do mundo público, a realidade do futuro indefinido frente a nossas opiniões passadas, realidade daquilo-que-havia-de-ser" (PEIRCE, Escritos coligidos, p. 114).

${ }^{364}$ APEL, Paradigmas de filosofía primera, p. 185. 
uma comunidade em particular, mas para uma comunidade ilimitada de investigadores. Em referência ao método do conhecimento, Peirce considera que é necessário promover a ampliação do mero discurso acadêmico dos filósofos mediante o discurso de laboratório do cientista experimental. Decerto, assim pensa Apel, somente um discurso ampliado pode ter em conta o que efetivamente é possível se fazer na prática em referência à experiência da realidade do real. Como discurso, essa ampliação se dá mediante o uso não apenas de signos "simbólicos", mas também de signos indexicais e icônicos (por exemplo, diagramáticos). Ora, para Apel, o discurso espelha precisamente a tridimensionalidade da função dos signos explicitada na semiótica normativa de Peirce. É essa estrutura trivalente dos signos que faz valer diretamente o voto da realidade, integrando continuamente este último em processo conceitual de interpretação ${ }^{365}$.

Peirce define o real a partir de uma teoria consensual da verdade. Nessa teoria, a verdade da ciência da natureza ${ }^{366}$ consiste na opinião última consensuada ("ultimate opinion") que deve ser atingida pela comunidade ilimitada de investigadores, sob condições normativamente ideais. Tal como no conceito de real, também se aplica a perspectiva da melonização ao conceito de verdade. Assim, para averiguar o sentido do predicado "verdadeiro" é preciso determinar, em um experimento mental, o que se pode fazer na prática em referência a um enunciado ou uma convicção que devem ser verdadeiros. Desse ponto decorre uma questão-chave para uma teoria "pragmática" da verdade, que é saber (explicitar) o que se pode realizar, na prática, para determinar a verdade de um enunciado ou uma convicção. No âmbito da teoria pragmática da verdade norte-americana, William James procura responder a essa questão afirmando que, em certa medida, é possível tentar provar uma convicção mediante a crença manifesta na própria vida pela ação; e nisso, na medida em que a convicção dá bom resultado e se mostra satisfatória, conveniente ou útil, tal significa que é ela verdadeira. Entretanto, por coerência ao seu realismo crítico de sentido, Peirce ${ }^{367}$ não concorda com a aplicação da máxima pragmática feita por W. James. Além disso, em seu itinerário crítico, Peirce constata também a irrelevância da teoria tradicional metafísica (ontológica) da verdade, porque é incapaz de fornecer uma resposta criteriologicamente suficiente. Para ele, é preciso considerar que não se pode tratar um enunciado como se fosse uma coisa real, tal como uma pedra à qual é possível lhe atribuir a propriedade de ser dura ou

\footnotetext{
365 APEL, Paradigmas de filosofía primera, p. 186.

366 APEL, Paradigmas de filosofía primera, p. 183.

367 APEL, Karl Otto. El camino del pensamiento de Charles S. Peirce. Trad. Ignacio Olmos \& Gonzalo de Puerto y Gil. Madrid: Visor, 1997, resumidamente pp. 35-40.
} 
pesada. Por isso, nada pode ser feito, na prática, se se parte da orientação da teoria da adequação realista, visto que ela não possibilita comprovar "de fora" (externamente) ${ }^{368}$ a concordância de um enunciado ou de uma convicção com a realidade, a menos que se pressuponha uma inteligência divina.

Para Peirce, a aplicação da máxima pragmática tem que corresponder à exigência básica, a ser facultada em longo prazo, de uma separação entre as opiniões ideocráticas de indivíduos e comunidades particulares e as convicções universalmente válidas, sendo estas últimas as únicas que correspondem com o cognoscível in the long run. Aqui vale observar que Apel leva em conta essa separação, o que o faz limitar a perspectiva da melonização da filosofia pragmática, considerando como relevante apenas a versão de Peirce em sua aplicação ao conceito de verdade. A partir dessa versão, Apel entende a pretensão de verdade, de acordo com a fundamentação última pragmático-transcendental, como um pressuposto inevitável do discurso argumentativo. Entretanto, além dessa separação, Peirce considera que a aplicação da máxima pragmática também deve ser compatível com a noção de racionalidade científica, que se alicerça no pressuposto de que o indivíduo deve se identificar a priori com a comunidade ilimitada dos investigadores da verdade. Em vista dessa identificação, o indivíduo deve efetuar a autorrenúncia (self-surrender) de seus interesses e crenças particulares. Por esse viés, ele estabelece a implicação moral em relação à teoria consensual da verdade: para ser racional, a busca da verdade possível exige que o investigador se identifique também moralmente, desde o primeiro momento, com uma comunidade ilimitada de investigadores. Assim concebendo, segundo Apel, de modo vantajoso, Peirce não somente procura eliminar a cisão moderna entre o campo teórico (fundamentação racional filosófico-científica) e o campo prático (ética), mas também estabelece exigência de correlacionar esses campos para a própria determinação da verdade ${ }^{369}$. Aqui, previamente, é importante destacar que é nesse ponto que se alicerça o horizonte da mediação entre razão teórica e razão prática defendida por Apel em sua semiótica transcendental.

$\mathrm{Na}$ interpretação de Apel, Peirce se refere à opinião última, tendo em vista a possível aplicação do princípio do falibilismo a todo consenso faticamente esperável, como um pressuposto contrafático, uma necessidade de sentido ao modo de um "seria" ("would

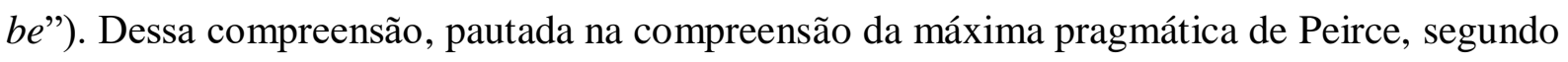

\footnotetext{
${ }^{368}$ APEL, Paradigmas de filosofía primera, p. 187. Apel desenvolve praticamente a mesma crítica em relação à teoria da verdade ontológico-metafísica (cf. APEL, Teoría de la verdad y ética del discurso, pp. 47-48. APEL, Fallibilismus, Konsenstheorie der Wahrheit und Letztbegründung. In: Philosophie und Begründung, p. 125).

${ }^{369}$ APEL, Paradigmas de filosofía primera, pp. 183 e 188.
} 
Apel, é possível extrair duas consequências. Em uma delas, depreende-se que se o homem se julga capaz de chegar à verdade - algo que é ineliminável, quando se pretende que o discurso filosófico não careça de sentido -, então também parece razoável considerar possível, e inclusive necessário, que a verdade possa ser explicitada como a meta possível de um processo discursivo epistêmico. Considerando isso, uma primeira consequência é a de que é injustificável distinguir entre uma teoria da verdade epistêmico ou pragmático-discursiva e uma realista, sob a suposição de que a verdade é algo que ultrapassa, como conhecimento possível, toda afirmação fundamentada e sua justificação. Afinal, admitir essa suposição, pragmaticamente sem sentido, é o mesmo que aceitar o pressuposto de que as coisas em si são, por princípio, incognoscíveis ${ }^{370}$.

A outra consequência decorre do fato que, na explicação da verdade mediante os conceitos de uma teoria epistemológica do discurso, para fazer justiça à reserva falibilista, é necessário introduzir idealizações. Isso significa que as idealizações das condições do discurso e do conhecimento, por um lado, devem conservar a conexão com as condições indiscutíveis de um discurso atual possível, e, por outro, têm que ser suficientemente fortes para provar como carente de sentido toda possível aplicação do princípio do falibilismo aos resultados contrafaticamente pressupostos do conhecimento ou da justificação discursiva do conhecimento. A conclusão de Apel é que a teoria consensual da verdade de Peirce cumpre com essas condições de idealização, ao menos em relação à realidade progressivamente investigável tal como se supõe no discurso das ciências naturais. Efetivamente, ela parte do pressuposto indiscutível de um discurso possível e atual sobre o verdadeiro e o falso. Segundo esse pressuposto, chega-se "idealiter" (idealmente) a um consenso que já não pode mais ser questionado com base em todos os critérios de verdade epistêmicos e todas as possibilidades de argumentação. Sob o patamar da reserva falibilista, esse pressuposto amplia o postulado do consenso, imprescindível no discurso atual, a um processo discursivo e de investigação que faticamente não pode ser encerrado. Mediante a ampliação do postulado de consenso, o processo investigativo chega a uma transição, que vai do pressuposto de um consenso faticamente possível, ao qual se deve aspirar em cada caso, ao pressuposto contrafático de um consenso insuperável. Apel pontua que é em relação a essa transição que se focaliza o ponto nuclear da objeção à teoria de Peirce, pois implica transpor a fronteira entre o finito e o infinito, tornando inaplicável a teoria consensual e, junto com ela, toda definição epistêmica do sentido da verdade. De forma central, a crítica sobre a teoria de Peirce subjaz precisamente

\footnotetext{
${ }^{370}$ APEL, Paradigmas de filosofía primera, p. 189.
} 
em relação à quebra dos limites entre o fático e o contrafático, o que a torna incapaz de fornecer orientação ao processo de investigação ${ }^{371}$.

A "ultimate opinion" da "indefinite Comunity of investigators" constitui o "ponto supremo" da transformação peirceana da lógica transcendental kantiana. Aplicando seu método de aclaração do sentido ao conceito de "real", Peirce chega à concepção de que o sujeito transcendental do conhecimento pode ser somente a comunidade ideal ilimitada da interpretação dos signos que, no nível do discurso argumentativo, pode chegar à "compreensão definitiva" do real. Nesse "ponto supremo" converge o postulado semiótico da unidade supraindividual da interpretação e o postulado da lógica da investigação de uma confirmação experimental da experiência "in the long run". O sujeito quase-transcendental dessa unidade postulada é a comunidade ilimitada de experimentação que é, ao mesmo tempo, a comunidade ilimitada de interpretação. Para Apel, isso pode ser postulado mediante uma "idéia regulativa", independentemente dos fatos no futuro. $\mathrm{O}$ real, tomado em sua referência a esse sujeito da interpretação dos signos, é definido como o infinitamente cognoscível que, faticamente, nunca pode ser conhecido em sua forma definitiva. Essa definição assinala para o centro da "superação" do realismo comum, em que o real é independente do pensamento de alguém sobre ele, por uma semiótica transcendental, em que o real é o identificável e o apreensível que deve ser objeto da interpretação dos signos. Em razão disso, Apel designa essa posição de Peirce como realismo crítico de sentido ${ }^{372}$.

Apel entende que sob o pressuposto da "ultimate opinion" da "indefinite Comunity of investigators", Peirce deduz a validade universal das inferências sintéticas, isto é, das inferências do procedimento metódico da abdução e da indução in the long run, como transcendentalmente necessárias. Nisso, Peirce não realiza nenhuma dedução transcendental de princípios da ciência como juízos sintéticos a priori em sentido kantiano, mas aclara que os princípios a priori "não-relativos" são desnecessários, pois a afirmação deles conduz a um resíduo de dogmatismo metafísico. O que Peirce faz é aplicar analogamente, segundo Apel, o princípio supremo kantiano dos juízos sintéticos. Nessa aplicação, o lugar dos "princípios constitutivos" da experiência de Kant é ocupado pelos "princípios regulativos", sob a pressuposição de que os princípios regulativos venham a ser princípios constitutivos in the long run. Com essa transposição da necessidade e universalidade da validade das proposições científicas para a meta do processo de investigação, segundo Apel, Peirce evita o ceticismo de

${ }^{371}$ APEL, Paradigmas de filosofía primera, pp. 189-190.

372 APEL, Transformação da filosofía, II, pp. 197-198; Transformation der Philosophie, Band II, pp. 173174. APEL, Significado lingüístico e intencionalidad in: Semiotica filosofica, pp. 235-236. 
Hume, sem se prender (com Kant) à necessidade ou à universalidade das proposições científicas atualmente válidas. Assim, a verdade das proposições científicas pode ser concebida, em princípio, como falíveis (corrigíveis). Diferentemente da concepção kantiana que permanece ligada ao conceito platônico de ciência como episteme, Peirce pensa a concepção da verdade das proposições científicas como falibilista e meliorista, ainda que nãocética. Em relação à concepção kantiana, salienta Apel, a maioria dos epistemólogos modernos prefere a concepção das proposições científicas de Peirce ${ }^{373}$.

A transformação da lógica transcendental kantiana por Peirce é, segundo Apel, consequente e legítima por três motivos. O primeiro motivo concerne ao ponto de vista do conceito semiótico de conhecimento (cognição): Peirce não aceita a distinção kantiana entre objetos cognoscíveis do mundo fenomênico (phainomena) e coisas-em-si (noumena), que são incognoscíveis, ainda que pensáveis como existentes, inclusive afetando os sentidos ${ }^{374}$. Em contraposição ao sentido do conceito de coisa-em-si incognoscíveis ${ }^{375}$, Peirce realiza uma transformação positiva da distinção kantiana. Quer dizer, em vez de distinguir entre objetos cognoscíveis e incognoscíveis, ele distingue entre o real cognoscível in the long run e o conhecido (Erkannten) faticamente em um momento determinado sob uma reserva falibilista. A problemática das coisas-em-si incognoscíveis é transformada na problemática da aproximação indefinida à verdade, segundo Apel, certamente também acometida de paradoxos, como no caso da suposta convergência entre os princípios constitutivos e os regulativos. Disso resulta que a pretensão por conhecimento se equipara ao anseio de verdade

${ }^{373}$ APEL, Transformação da filosofía, II, p. 198; Transformation der Philosophie, Band II, p. 174. Sobre os estudos kantianos do jovem Peirce, cf. APEL, El camino del pensamiento de Charles S. Peirce, pp. 63- 67. Na interpretação de Apel, a exposição da transformação peirceana de Kant é unilateral, na medida em que aponta a substituição dos "princípios constitutivos" kantianos pelos "princípios regulativos" para os métodos da conclusão sintética e da construção interpretativa do consenso in the long run. Na direção dessa transformação, cuja consequência é o "fallibilismus" radical e o "meliorismus" ilimitado na construção de teorias, Peirce dá início a uma transformação pragmático-transcendental das condições constitutivas de possibilidade da experiência experimental; condições essas que não estão sujeitas a nenhum "falibilismo", pois são pressupostas para a falsificação de teorias. Essa transformação não se apóia no reconhecimento de "juízos sintéticos a priori, como em Kant, mas sobre a concepção da remissão precípua do sentido da realidade ao contexto das experiências experimentáveis, comprováveis mediante a práxis ("interesse cognitivo técnico"). Então, diferentemente do sentido das "proposições sintéticas a priori”, para Peirce, as proposições devem estar sujeitas ao falibilismo, como exige a construção semiótica do consenso in the long run (APEL, Transformação da filosofía, II, p. 188 (nota de rodapé 12); Transformation der Philosophie, Band II, pp. 165-166).

374 APEL, Transformação da filosofía, II, p. 199; Transformation der Philosophie, Band II, p. 175.

375 APEL, Karl Otto. Sprachliche Bedeutung, Wahrheit und normative Gültigkeit. Die Soziale Bindekraft der Rede im Lichte einer transzendentalen Sprachpragmatik. In: Archivio di Filosofia, pp. 51-88, 1987, pp. 55-56. PEIRCE, Escritos coligidos, pp. 74 e 86. Mesmo diante de possíveis perguntas referentes às proposições universais e hipotéticas, a resposta de Peirce delineia-se afirmativamente em contraposição ao incognoscível. Pois, ainda que a verdade não possa ser conhecida com certeza absoluta, ela é possível mediante a indução. Ademais, as concepções são obtidas por abstração e combinação de cognições ocorridas em juízos de experiência. Uma vez que o incognoscível não ocorre na experiência, o absolutamente incognoscível é absolutamente inconcebível. 
das hipóteses sensatas. Por conseguinte, todo conhecimento deve ter o caráter explícito ou implícito de uma inferência (conclusão) hipotética.

O segundo motivo é que Peirce não recorre à virada copernicana para o entendimento como patrimônio dos princípios (Vermögen der Grundsätze), mas a reivindica para o entendimento como patrimônio das inferências (das conclusões) sintéticas. Em Kant, o idealismo transcendental, baseado na distinção entre coisas em si incognoscíveis (que afetam os sentidos) e fenômenos, que são pré-determinados pelo entendimento, é o pressuposto da reviravolta copernicana. Supondo o patrimônio das conclusões sintéticas no entendimento, segundo Apel, Peirce pode manter a principal conquista de Kant, que é a fundamentação transcendental da objetividade possível da ciência em geral, e, ainda assim, postular a possibilidade de correção empírica de todas as proposições como hipóteses a partir do encontro com o ser-assim qualitativo do real aqui e agora (categoria da primeiridade) ${ }^{376}$.

O terceiro motivo é que a transformação pragmática do kantismo por Peirce se evidencia na rejeição da distinção kantiana entre razão teórica e prática ${ }^{377}$. Peirce defende a tese da fusão dos princípios da ciência em uma crença (Glauben) prática. Aí, tal transformação se alicerça na ideia de que a fundamentação de princípios da ciência se baseia em uma "fé prática". Ele rejeita tal distinção, porque concebe que o processo histórico do conhecimento, cuja meta se encontra no futuro, "implica um compromisso social e moral de todos os membros da Community of Ivestigators, justamente por causa do falibilismo ou meliorismo de todas as convicções" ${ }^{378}$. Com a supressão da distinção entre noumena e phainomena em sentido kantiano, assim pensa Peirce, descarta-se também a distinção entre princípios regulativos e postulados morais, na medida em que o mesmo processo ilimitado do conhecimento é, simultaneamente, como processo social real, cujo êxito fático é incerto, objeto da lógica e da ética.

A transformação semiótica de Kant operada por Peirce alcança seu "ponto mais alto", segundo Apel, no postulado de um "socialismo lógico". Segundo esse postulado, comportar-se de maneira lógica, no sentido da lógica sintética da experiência possível,

\footnotetext{
${ }^{376}$ APEL, Transformação da filosofía, II, p. 200; Transformation der Philosophie, Band II, pp. 175-176.

377 APEL, Transformação da filosofía, II, pp. 200-202; Transformation der Philosophie, Band II, pp. 176177.

378 APEL, Transformação da filosofía, II, p. 201; Transformation der Philosophie, Band II, p. 176. A infalibilidade em matérias científicas é irresistivelmente cômica para Peirce. Ninguém que se respeite apresenta os seus resultados sem atribuir-lhes um erro provável. Deve atentar-se para o adágio "humanum est errare" (sic!). Ele diz: "recuso-me a ser guia de rebanho. Meu livro é para pessoas que querem descobrir; e quem queira filosofia às colheradas deve ir a outro lugar. Durante anos, no decurso deste processo de amadurecimento, acostumei-me a reunir minhas idéias sob a designação de falibilismo" (PEIRCE, Escritos coligidos, p. 129).
} 
implica identificar-se com o interesse da "indefinite community". Do ponto de vista da práxis postulada como logicamente necessária, exige-se que o indivíduo sacrifique seus interesses particulares e existenciais em prol do interesse científico da comunidade ilimitada de investigação na direção da aproximação in the long run à verdade. A rigor, sem esse sacrifício da "própria alma para salvar o mundo", o indivíduo se comporta de modo ilógico em todas as suas inferências, coletivamente. O princípio social está intrinsecamente enraizado na lógica de investigação em vista da meta de aproximação in the long run à verdade. O socialismo lógico se funda sob a expectativa de que o processo ilimitado de investigação científica, no qual os homens devem engajar-se, produza também a racionalização das condutas humanas ("habits"). E esses "habits", como complemento das leis da natureza, de sua parte, possam consumar a racionalização do universo. A conjunção entre lógica da pesquisa e ética resulta, segundo Apel, em uma nova formulação do imperativo categórico: "age tal como se a máxima de tua ação devesse tornar-se mediante tua vontade lei universal da natureza" ${ }^{\text {379 }}$. Esse postulado do socialismo lógico representa o ápice da transformação semiótica do "ponto mais alto" da lógica transcendental de Kant. E por ele se preconiza que o processo ilimitado do conhecimento se constitui em objeto simultâneo da lógica e ciência, em princípio, alcançável no horizonte da comunidade ilimitada de investigação, que é "a única que pode alcançar a verdade como meta" 380 .

\subsubsection{A relevância da semiótica de Peirce para a transformação da filosofia de Apel}

Para finalizar este tópico, cabe aqui assinalar a relevância da semiótica trivalente de Peirce para a semiótica transcendental de Apel. A meu ver, tal relevância se evidencia à medida que Apel, no marco da reconstrução pragmático-transcendental da explicação peirceana do sentido dos signos linguísticos em geral, retoma e amplia a concepção da teoria consensual da verdade de Peirce ${ }^{381}$, bem como as implicações no campo da razão prática que o "socialismo lógico" peirceano preconiza. Inspirado em Peirce, particularmente, em sua explicação do sentido da verdade concebida simultaneamente como explicação semântica e

\footnotetext{
379 APEL, Transformação da filosofía, II, p. 202; Transformation der Philosophie, Band II, p. 177.

${ }^{380}$ APEL, Transformação da filosofía, II, p. 201; Transformation der Philosophie, Band II, p. 177. APEL, Karl Otto. Husserl, Tarski oder Peirce? Für eine transzendentalsemiotische Konsentheorie der Wahrheit In: Manuscrito Inédito, Frankfurt am Main, pp. 1-12, 1995, p. 11.

${ }^{381}$ APEL, Teoría de la verdad y ética del discurso, pp. 63-80. APEL, Fallibilismus, Konsenstheorie der Wahrheit und Letztbegründung. In: Philosophie und Begründung, p. 138-150. APEL, El camino del pensamiento de Charles S. Peirce, pp. 14-16.
} 
pragmática da verdade, Apel reelabora a compreensão de consenso no marco do a priori da comunidade de comunicação, concebendo-o desde uma base de fundamentação pragmáticotranscendental aplicável ao campo ético-político para a resolução dos conflitos humanos. Vendo por esse prisma, é possível afirmar que a pragmatic turn da teoria da ciência de Peirce compõe os alicerces filosófico-epistemológicos da ética do discurso como ética da responsabilidade de Apel. Em Peirce vem à tona o vínculo fundamental entre epistemologia e ética, do qual Apel se serve e amplia no sentido de uma filosofia primeira que é a base teórica do coentendimento capaz de fornecer os pressupostos últimos para o agir humano com sentido e validade.

A explicação do significado, no sentido da "máxima pragmática" de Peirce, não aclara apenas o uso linguístico estabelecido, senão que eleva tendencialmente à consciência o "transfundo" - já pressuposto no uso e na compreensão linguísticos normais, porém indisponível - da pré-compreensão do mundo. Basicamente, essa máxima estabelece que a necessidade de representar em um experimento mental as consequências experimentáveis que poderiam se suceder caso fossem empreendidas operações deliberadas com as coisas, cujas propriedades se caracterizam mediante predicados. Compreendendo que os experimentos mentais postulados sempre se referem ao futuro, Peirce designa o método concebido com o termo de "mellorization" (meliorismus) $)^{382}$. Desse modo, essa explicação permite, em princípio, modificar o uso linguístico, ou ao menos o da ciência. Por não se prender ao aclaramento do uso linguístico fático e por conta do posicionamento de caráter contrafático e normativo $^{383}$ (vinculado ao interesse da "indefinite community"), segundo Apel, o método

\footnotetext{
382. Para Peirce, um dos mais maravilhosos traços do raciocínio e um dos mais importantes filosofemas da ciência consiste em que a "razão tende a corrigir-se a si mesma". E ela faz isso tanto melhor quanto mais bem trabalhado estiver o esquema. Ela deve corrigir não só as conclusões, mas também suas premissas. Por isso, é errado pensar que ciência se faz por empilhamento de inferência após inferência (PEIRCE, Escritos coligidos, p. 134). Afirma Peirce: "por melonização (do grego, méllon, o ser, o estar para fazer, o há de ser, o futuro), refirome àquela lógica pela qual o que concebemos como tendo sido (concebido como paralelythose) é imaginado como repetido ou estendido indefinidamente àquilo-que-será-sempre (ou àquilo que será-um-dia, quer dizer, cuja ausência não-existirá-sempre, o que igualmente envolve melonização, que nada asserta e é apenas um modo de conceber (mode of conceiving). A concepção do real deriva de uma melonização do lado-coação da consciência. Portanto, dizer que é o mundo do pensamento que é real significa, bem entendido, afirmar enfaticamente a realidade do mundo público, a realidade do futuro indefinido frente a nossas opiniões passadas, realidade daquilo-que-havia-de-ser" (PEIRCE, Escritos coligidos, p. 114).

${ }^{383}$ No sentido de Peirce, o problema da ética é determinar um fim possível. A definição do fim não pode ser reduzida a um mero formalismo, mas ela constitui um assunto importante para o pragmatismo. $\mathrm{E}$ isso porque a significação de um símbolo consiste em como ele pode levar os homens à ação; e esse 'como' deve se a referir uma descrição da ação que tem este ou aquele fim, um fim que possa ser perseguido indefinidamente. Aqui, o segredo do pragmatismo consiste na relação entre lógica, ética e estética: "Quem raciocina ipso facto virtualmente sustenta uma doutrina lógica [cujo centro reside na classificação dos argumentos]. Esta classificação não é mera qualificação do argumento. Envolve uma aprovação qualitativa. Ora, tal autoaprovação supõe autocontrole. (...) Trata-se de atos voluntários que a nossa lógica (...) aprova. Ora, o aprovar
} 
peirceano de clarificação do significado se mostra superior frente aos métodos descritivos da Ordinary Language Philosophy ${ }^{384}$. Em certa medida, pode-se presumir que Apel, à proporção que subsume a reconstrução pragmático-transcendental de Peirce em sua proposta de transformação da filosofia, intenciona estender tal relevância criteriológica para todo o âmbito do paradigma da linguagem.

A superioridade da semiótica de Peirce, segundo Apel, consiste em tornar compreensível a conexão interna entre os processos internos de raciocínios e a interpretação linguística do mundo. Desse modo, ela abrange, por um lado, a conexão da formação inovadora de hipóteses com a nova interpretação linguística dos fenômenos no contexto de raciocínios abdutivos. Por outro lado, ela contempla também a possível explicação do sentido linguístico, inclusive as pressuposições de fundo do mundo da vida pressupostas nele, mediante a aplicação da "máxima pragmática" e a teoria correspondente da ideia dos últimos “intérpretes lógicos", reguladora e normativamente reitora em toda interpretação dos signos. Esses dois teoremas da semiótica normativa de Peirce prometem, diz Apel, uma superação da separação conceitual atualmente predominante entre, por uma parte, os processos racionais de raciocínio e também os processos de aprendizagem, e, por outra, os processos de interpretação linguística do mundo. A teoria do raciocínio abdutivo torna possível essa superação, na medida em que faculta a realização de novas interpretações linguísticas do mundo junto com raciocínios sintéticos que se confirmam. As "iluminações" linguísticas do ser (Heidegger), à luz dos raciocínios abdutivos, podem ser concebidas tanto como condição de possibilidade como resultados de processos de aprendizagem (Ergebnisse von Lernprozessen $)^{385}$.

A reconstrução pragmático-transcendental da linguagem em Peirce reconfigura o âmbito de validade do conhecimento e da razão prática (ética). Peirce entende que a pergunta pelo sentido da "verdade" não pode ser esclarecida ultimamente mediante recurso ao uso fático da palavra "verdade" em uma determinada língua, mas mediante o uso adequado

um ato voluntário é algo de moral. A ética é o estudo dos fins de ação que estamos deliberadamente preparados para adotar. Um raciocinador lógico é aquele que exerce grande autocontrole nas operações intelectuais; 'a excelência-lógica' é uma espécie do moralmente-excelente. A ética (...) é a ciência normativa par excellence; nela um fim, objeto essencial da ciência normativa, está ligado a um ato voluntário de maneira primária. (...) Um fim derradeiro de ação (...) deve ser um estado de coisas que se recomenda razoavelmente por si próprio, sem qualquer outra consideração. Deve ser um ideal admirável (...); excelência estética. A excelência moral depende do excelente estético" (PEIRCE, Escritos coligidos, pp. 43-44; ainda sobre esse ponto ver na p. 110 a correspondência de Peirce [1902] a William James).

${ }^{384}$ APEL, Teoría de la verdad y ética del discurso, p. 66. APEL, Fallibilismus, Konsenstheorie der Wahrheit und Letztbegründung. In: Philosophie und Begründung, p. 140.

${ }^{385}$ APEL, Teoría de la verdad y ética del discurso, p. 79. APEL, Fallibilismus, Konsenstheorie der Wahrheit und Letztbegründung. In: Philosophie und Begründung, p. 149. 
empreendido pelos denominados "intérpretes lógicos" "386, em relação aos quais se supõe o uso adequado dessa palavra existente para o conceito em qualquer idioma que disponha de uma palavra correspondente. Desse modo, ele estabelece o marco para a comprobabilidade da verdade teórica e prática: o da comunidade de interpretação e experimentação dos investigadores, em princípio, ilimitada. O pano de fundo dessa reconstrução reside em que a comprobabilidade prática da verdade, que nada tem a ver com explicações "pragmatistas vulgares", deve ser primariamente uma questão pública e não subjetivo-privada ${ }^{387}$. Como representante de uma lógica normativa e semiótica da ciência, Peirce pensa que o contexto de comprovação prática para os enunciados ou opiniões verdadeiras não é o do êxito na vida individual ou social, mas o da comunidade ilimitada "dos apaixonados por aprender" 388 . Isso explica a exigência normativa de autorrenúncia ("Selfsurrender") moral, no sentido da subordinação dos interesses individuais e sociais ao interesse da busca pela verdade. Com efeito, ressalta-se que a comprovação de opiniões ou hipóteses em tal contexto somente pode ser cogitada como prova da capacidade de consenso mediante argumentos ${ }^{389}$.

\footnotetext{
386 PEIRCE, Escritos coligidos, pp. 145-149. Peirce propõe o nome interpretante do signo para o significado resultado de um signo. O interpretante é "tudo aquilo que é explícito no signo extraído do contexto e das circunstâncias da verbalização". São três as classes de interpretantes (ou dos efeitos significados de signos): a) interpretante emocional ("o primeiro efeito significado de um signo é o sentimento por ele provocado". É o caso da execução de uma peça de música de concerto); b) interpretante energético (um esforço mental); c) interpretante lógico (efeito mental de aplicação geral que é uma mudança-de-hábito, isto é, "uma modificação nas tendências de uma pessoa para a ação, que resulta de exercícios prévios da vontade ou dos atos, ou de um complexo de ambas as coisas. Exclui disposições naturais; ou alteração de associações, e inclui até dissociação").

387 APEL, Fallibilismus, Konsenstheorie der Wahrheit und Letztbegründung. In: Philosophie und Begründung, pp. 140-141. Apel esclarece: uma explicação da comprovação pública das convicções, no sentido empíricopragmático quase sociológico (caso de John Dewey e Richard Rorty ao retomar a teoria da verdade de William James, para o qual a teoria verdadeira é aquela na qual se crer e se obtém experiências satisfatórias, isto é, uma teoria da verdade como satisfação, utilidade ou produtividade, que é aplicada absolutamente a experiências puramente subjetivo-individuais), está equivocada em relação à idéia normativa vinculante da comprovação concebida por Peirce. Esse equívoco pode ser constatado através do entendimento de alguns popperianos hoje em dia, segundo os quais a teoria pragmático-transcendental da verdade como consenso, que recorre a Peirce, realiza uma redução sociologista da pretensão absoluta de validade da verdade. Vista assim, ela representa um perigo para a busca da verdade científica livre da tutela social.

388 "Se pensamento por signos, este estruturalmente dialógico e por isso jamais individualista; se articulado num contínuo temporal tencionado para o futuro para o qual, pelo presente, recupera todo o passado - o pensamento gerando pensamento -, o pensamento pertence antes de tudo ao âmbito do social e só encontraria sua plenitude na totalidade da comunidade dos apaixonados por aprender" (SILVEIRA, O caráter dialógico do signo e do pensamento em Peirce in: Trans/Form/Ação, p. 27).

${ }_{389}$ APEL, Fallibilismus, Konsenstheorie der Wahrheit und Letztbegründung. In: Philosophie und Begründung, pp. 141-142. Em uma correspondência de 1897, Peirce diz que o grande tema dos primeiros escritos (1877), a saber, que tudo deve ser aferido (tested) pelos resultados práticos, está em consonância no principal com William James. Já nos escritos mais recentes (The Monist, 1891), diz ele, "vi melhor do que costumava que não é a mera ação como exercício bruto da força que é o objetivo de tudo, mas, digamos, a generalização, ação que tende à regularização e à atualização do pensamento, que sem ação permanece 'impensamento' ("unthought")". Outra referência ainda é sua carta a James em 1902, na qual Peirce escreve: "foi só depois que obtive a prova de que a lógica deve estar fundada na ética, da qual é um desenvolvimento mais elevado. (...) Mesmo então, fiquei estupidamente sem ver que a ética assenta no alicerce da estética (...). A verdadeira natureza do pragmatismo não
} 
Continuando, em Peirce, o contexto da comprovação prática para as pretensões de verdade está formado, de certo modo, por uma quase-instituição que não representa nenhum sistema social ou individualmente limitado de autoafirmação; todavia, está constituído a priori por uma ideia regulativa da formação ilimitada e intersubjetiva do consenso sobre os critérios de verdade disponíveis. Nessa linha, presume-se que também a formação do dissenso, por meio da falsificação (Popper) ou de teorias alternativas, pode ser posta a priori a serviço da formação do consenso. Para Apel, a formação do consenso constitui, fundamentalmente, o sentido do discurso argumentativo. É possível, assim reconhece Apel, sob a pressuposição empírico-pragmática de uma formação do consenso via pressões sociais do sistema, usar emancipatoriamente a formação do dissenso contra a formação do consenso $^{390}$. A pergunta sobre o sentido da verdade científica pressupõe, como ideia regulativa, uma comunidade científica ilimitada que trabalhe em condições ideais para alcançar in the long run opinião intersubjetivamente válida sobre a representação adequada do real e do seu equivalente normativo (ético). Nesse sentido, a realização fática de um consenso não pode valorar-se como um critério de verdade. Antes, o ponto de partida fundamental peirceano, que Apel entende como pragmático-transcendental ou crítico do sentido, consiste em que o sentido que pode ser entendido como verdade, de forma pragmaticamente relevante, tem que estar em qualquer caso na opinião que possa ser alcançada, sob condições ideais, por todos em geral, e que já não possa ser discutida mais (portanto, intranscendível). Se não se supõe isso desde o princípio, afirma Apel, não há nenhum sentido pragmaticamente relevante da verdade e, tampouco, a discussão do tema "teorias da verdade" 391 .

\footnotetext{
pode ser compreendida sem elas [as três categorias]; o pragmatismo não toma a reação como sendo o tudo da coisa; mas considera o fim como o ser-tudo e o fim é algo que dá a sua sanção à ação. É da terceira categoria. Não se deve assumir uma visão nominalista do pensamento como se fosse algo lá na consciência do homem. Se consciência referir pensamento, existe mais fora que dentro de nós" (cf. PEIRCE, Escritos coligidos, pp. 109110).

${ }^{390}$ APEL, Fallibilismus, Konsenstheorie der Wahrheit und Letztbegründung. In: Philosophie und Begründung, p. 142.

${ }^{391}$ APEL, Fallibilismus, Konsenstheorie der Wahrheit und Letztbegründung. In: Philosophie und Begründung, pp. 142-143.
} 


\section{A SEMIÓTICA TRANSCENDENTAL EM APEL COMO PARADIGMA DE PRIMA PHILOSOPHIA DO COENTENDIMENTO E DA AÇÃO ÉTICA}

Este capítulo aborda a concepção de uma semiótica transcendental em Apel como paradigma de prima philosophia capaz de fundamentar o coentendimento e a ação racional ética. Este capítulo trata dos seguintes aspectos dessa concepção: a) a caracterização históricoreconstrutiva da semiótica transcendental como paradigma de prima philosophia; b) a caracterização da estrutura performativo-proposicional do discurso argumentativo como fundamento filosófico último desse paradigma; c) o fator de inovação desse paradigma em função de resolver o problema da mediação da razão teórica e da razão prática (ação ética).

\subsection{A semiótica transcendental em Apel como paradigma de prima philosophia}

Apel pensa que, em razão do alcance paradigmático da linguagem na contemporaneidade, aí se encontra a referência basilar para a fundamentação tanto teórica quanto prática de uma filosofia primeira (erste Philosophie) ${ }^{392}$. Essa diretiva é claramente enunciada na obra Transformação da Filosofia (1973), quando pontua que a filosofia primeira deve ser entendida como reflexão sobre o significado ou o sentido das manifestações linguísticas e, como tal, mediatizar-se metodicamente por uma análise filosófica do uso da linguagem. A respeito disso, é interessante salientar que, em geral, a ideia de prima philosophia (ciência primeira) conota a pretensão de prioridade epistemológica, à medida que tem como fim o objeto de todas as ciências, e como postulado um princípio que condiciona a validade de todos os outros princípios. Ela pressupõe que o saber já está organizado e dividido em ciências; e estas, relativamente independentes e capazes de estabelecer sua integração com base em um fundamento comum ${ }^{393}$. Na Antiguidade, Platão e Aristóteles estabelecem distintas concepções de filosofia primeira. No interior da tradição filosófica contemporânea, mutatis mutandis, Apel pleitea a propriedade de paradigma e de filosofia primeira para a sua

\footnotetext{
${ }^{392}$ APEL, Transformação da filosofia, v. II, p. 378; Transformation der Philosophie, Band II, p. 333. Segundo Abbagnano, a ideia de ciência primeira conota a pretensão de prioridade epistemológica, à medida que tem como objeto o objeto de todas as ciências, e como princípio um princípio que condiciona a validade de todos os outros princípios. Ela pressupõe que o saber já está organizado e dividido em ciências; e estas, relativamente independentes e capazes de estabelecer sua integração com base em um fundamento comum (cf. ABBAGNANO, Nicola. Verbete Metafísica, in: Dicionário de filosofia. Trad. Alfredo Bosi. 2. ed., São Paulo: Martins Fontes, 1998, pp. 660-661).

393 ABBAGNANO, Dicionário de filosofia, pp. 660-661.
} 
semiótica transcendental. No caso deste último, chama a atenção o fato de que a semiótica transcendental, além de ser articulada sob o intento de reconstruir a tradição filosófica ocidental a partir do paradigma da linguagem como filosofia primeira, também se desenvolve em torno da noção de paradigma. A princípio, esse intento coloca a perspectiva filosófica de Apel no rumo de dois conceitos, o de filosofia primeira (Platão e Aristóteles) e de mudanças de paradigmas, introduzido por Thomas Kuhn desde os anos 60 (século XX) no debate sobre história da ciência. Acontece que Apel ressignifica esses conceitos a seu modo, na medida em que, paradigmaticamente, propõe um novo modelo de filosofia primeira essencialmente intersubjetivo e semiótico.

Em Platão, a ciência primeira é a dialética, cuja tarefa fundamental é criticar e selecionar as hipóteses que cada ciência adota como fundamento, mas que não ousam tocar, porque não estão em condições de explicá-las. Platão parte de uma distinção primeira, fundamental depois para o pensamento Ocidental, entre o mundo da percepção (kósmos aisthetós) e mundo do pensável (kósmos noetós). Dessa distinção ele estabelece, por meio de uma comparação com o conhecimento da matemática (dianóia), o que é próprio da atividade filosófica na esfera do pensamento. O conhecimento matemático se dá por demonstração dedutiva como inferência a partir dos axiomas postos como premissas. Tal como vislumbrado por Platão, o conhecimento filosófico não apela para hipóteses fora dele mesmo, mas é um conhecimento que fundamenta a si mesmo e a todos os outros. Trata-se de um conhecimento que é conhecimento do conhecimento (episteme epistemes). A dialética é o conhecimento filosófico de princípios, pois atinge o que não é eliminável do pensamento humano. Cabe à dialética chegar ao começo, ou seja, alcançar a um princípio não-condicional que não pode ter mais pressupostos em razão de ser ele mesmo o pressuposto de tudo, trabalhando exclusivamente com conceitos. A dialética constitui uma ciência primeira na medida em que é pressuposta mesmo pelos que tentam negá-la. No sentido de filosofia primeira vislumbrado por Platão, o reconhecimento da estrutura reflexiva do conhecimento delineia a especificidade do paradigma do conhecimento filosófico. A dialética é a demonstração reflexiva do que "necessariamente já se reconheceu como condição de possibilidade da argumentação, ou seja, em última instância, do discurso humano como tal" ${ }^{394}$. A reflexividade do saber fundamenta a absolutidade da razão, posto que tematiza uma estrutura de conhecimento que não pode ser abstraída. A razão, para Platão, é "sinônimo da possibilidade de uma conhecimento

\footnotetext{
${ }^{394}$ OLIVEIRA, Sobre a fundamentação, p. 19.
} 
sistemático, ontologicamente fundado, com uma fundamentação última (não-condicional, não-hipotética)"395.

Em Aristóteles, a metafísica é a ciência primeira e, como tal, tem o status de ciência das ciências. Trata-se de uma ciência que, indo além da física, a primeira das ciências particulares, deve chegar ao fundamento comum para todas as ciências, bem como estabelecer o lugar de cada qual na hierarquia do saber. A metafísica como ontologia é a teoria daquilo que o ser enquanto ser é ou implica. A metafísica como ontologia preconiza que: a) existem determinações necessárias do ser, presentes em todas as formas e modos de ser particulares; b) existem ciências que têm por objeto um modo de ser particular e existe uma ciência, precedente às particulares, cujo objeto trata das determinações necessárias do ser já implícitas nos objetos de todas as outras ciências e, por isso, condiciona a validade de todas as outras ciências $^{396}$. A ciência primeira, como saber último, pergunta pela essencialidade do ente como ente não no singular, mas naquilo que é comum a todas as coisas e, por isso, captável em todas elas. $\mathrm{O}$ ente comum a tudo é condição de possibilidade do discurso humano e da comunicação humana. Cada ciência possui um corpo de axiomas, isto é, aquilo a partir de que e por meio de que se demonstra e, assim, assegura e justifica a coerência do discurso humano, porém o discurso humano pressupõe axiomas comuns de que todos os homens se servem. Esses axiomas comuns são os princípios mais cognoscíveis, os pressupostos últimos de todos os outros axiomas, e constituem o objeto da ciência primeira. Como ciência dos fundamentos últimos e universais, a ciência primeira tematiza esses princípios, reconhecendo-os como condição de possibilidade do diálogo entre os homens. Por tematizar esses princípios que constituem o horizonte sempre pressuposto da comunicação, a ciência primeira explicita as condições do discurso sensato e intersubjetivo ${ }^{397}$.

Para Aristóteles, o princípio de todo pensar é o princípio de não-contradição, através da mediação da refutação. A refutação é uma prova indireta; toda tentativa de demonstrar esse princípio leva à contradição. Pelo procedimento da refutação, uma tese é posta à prova através da mediação da falsidade da proposição antitética, quer dizer, por meio da sua passagem pelo negativo. A refutação de uma afirmação conduz à aceitação de um suposto impossível em contradição com a primeira afirmação. Na refutação, o princípio de não-contradição é fundamentado em uma circularidade que se expressa de duas maneiras: "à circularidade negativa de quem nega o princípio de não-contradição corresponde uma

\footnotetext{
395 OLIVEIRA, Sobre a fundamentação, p. 20.

396 ABBAGNANO, Dicionário de filosofia, pp. 660-667.

${ }^{397}$ OLIVEIRA, Sobre a fundamentação, pp. 19-21.
} 
circularidade positiva e, assim, autoconstitutiva de quem o afirma e mantém" ${ }^{398}$. A própria contradição faz emergir o princípio de não-contradição como pressuposto ineliminável de todo e qualquer discurso humano. Como princípio primeiro-último de todo pensar, ele é condição insubstituível para que na fala algo seja designado, razão pela qual constitui o fundamento do diálogo. E por isso ele é o primeiro e mais seguro princípio da ciência primeira, a que estuda o ente enquanto ente ${ }^{399}$.

Thomas Kuhn caracteriza, em A estrutura das revoluções científicas, o termo paradigma "um modelo ou padrão aceitos" 400 , uma realização universalmente reconhecida fornecedora de problemas e soluções modelares ${ }^{401}$. Do ponto de vista conceitual, Kuhn assinala, no posfácio de 1969 dessa obra, ter sido admoestado por fazer uso do termo em cerca de vinte e duas maneiras diferentes ${ }^{402}$. Ainda nesse posfácio, ele caracteriza o termo paradigma como "constelação dos compromissos de grupo" e "exemplos compartilhados" 403 . A ideia de paradigma se relaciona à ideia de ciência normal, que consiste na resolução dos "quebras-cabeças" supostos e peculiares ao modelo teórico adotado. E adotar um paradigma significa igualmente adquirir um critério para a escolha de problemas preexistentes, sob a suposição de que o desacordo e debate constante acerca dos fundamentos são inerentes à préciência $^{404}$. Não cabe à ciência normal produzir novidades, seja no domínio dos conceitos, seja no dos fenômenos ${ }^{405}$. No tocante à educação científica, Isso implica uma espécie de identificação (praticamente uma sintonia acrítica) entre o cientista e a ciência normal (modelo investigado). No âmbito da ciência normal, os problemas que resistem são considerados anomalias $^{406}$. Entre os paradigmas vigora certa incomensurabilidade, caracteristicamente um "diálogo de surdos ao debaterem os méritos relativos dos respectivos paradigmas" ${ }^{407}$. Nisso, a escolha de paradigmas concorre para a escolha entre "modos incompatíveis de vida

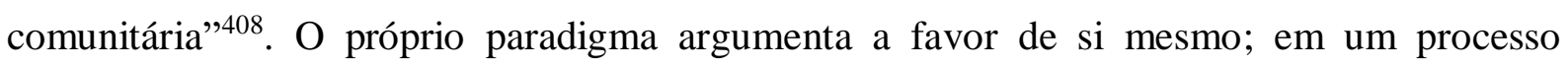

\footnotetext{
398 CIRNE-LIMA apud OLIVEIRA, Sobre a fundamentação, p. 23 (nota de rodapé 21).

${ }^{399}$ OLIVEIRA, Sobre a fundamentação, pp. 21-24.

${ }^{400}$ KUHN, Thomas. A estrutura das revoluções científicas. Trad. Beatriz Vianna Doeira e Nelson Boeira. 2. ed., São Paulo: Perspectiva, 1978, p. 43.

${ }^{401}$ KUNH, A estrutura das revoluções científicas, p. 13.

402 Idem, p. 226.

${ }^{403}$ Idem, pp. 225-236.

${ }^{404}$ Idem, p. 60.

${ }^{405}$ Idem, p. 57.

${ }^{406}$ Idem, p. 77.

${ }^{407}$ Idem, p. 144.

408 Idem, p. 127.
} 
circular e de modo apologético, ele força a aceitação de sua imagem-programa. O critério para tal escolha, por fim, é o do consentimento da comunidade científca relevante ${ }^{409}$.

Apel procura aplicar o pensamento da mudança de paradigmas de Kuhn à reconstrução da história da filosofia e à perspectiva de uma filosofia primeira assumida por Aristóteles como concepção de base da filosofia. Não obstante, é possível depreender que Apel atribui a esses conceitos uma significação diversa das suas formulações originais; tal parece ser mais uma apropriação terminológica que de seus respectivos conteúdos específicos. Quanto a T. Kuhn, Apel se reporta ao conceito de mudança de paradigmas, tendo-o como uma fonte de inspiração para elaborar uma reconstrução histórico-hermenêutica das épocas da história da filosofia. O próprio Apel assinala que logo se afasta de Kuhn por estar em desacordo quanto à ideia de uma mudança de paradigmas incomensuráveis ${ }^{410}$, cuja fundamentação se processa apenas nos limites histórico-contingentes. Apel rechaça a ideia de incomensurabilidade dos paradigmas porque ela inviabiliza, à medida que atesta a irredutibilidade e o fechamento dos jogos de linguagem ou paradigmas em si mesmos, produzindo um "diálogo de surdos" entre eles, a possibilidade de consenso (ainda que permaneça como ideia regulativa) e, no campo da razão prática, remete a posturas céticas ou relavistas. Já no horizonte de uma filosofia primeira, Apel não defende um retorno à metafísica clássica (ontologia) de Aristóteles. Em uma direção oposta, ao explicitar sua concepção de verdade, Apel toma como ponto de partida a problemática da irrelevância criteriológica da teoria metafísica da verdade como correspondência ${ }^{411}$. O paradigma de filosofia primeira preconizado por Apel, a semiótica transcendental, parte da pressuposição de um esquema de desenvolvimento racional que contempla uma fundamentação última, obtida por estrita autorreflexão sobre a estrutura do discurso argumentativo. Essa fundamentação se contrapõe ao caráter dogmático da metafísica, concebida a partir de um ponto de vista quase divino de uma visão externa do mundo como totalidade limitada ${ }^{412}$.

Efetivamente, Apel evoca a noção de paradigma como um instrumento metodológico empregado para interpretar e reconstruir criticamente as principais épocas do pensamento ocidental ${ }^{413}$. Apel se refere aos paradigmas epocais que impregnam o pensamento

\footnotetext{
${ }^{409} \mathrm{KUNH}$, A estrutura das revoluções científicas, p. 128.

${ }^{410}$ APEL, Paradigmas de filosofía primera. Buenos Aires: Prometeo Libros, 2013, p. 15

411 APEL, Teoría de la verdad y ética del discurso,, pp. 47-48. APEL, Fallibilismus, Konsenstheorie der Wahrheit und Letztbegründung. In: Philosophie und Begründung, p. 125.

${ }^{412}$ APEL, Karl Otto. Paradigmas de filosofía primera. Buenos Aires: Prometeo Libros, 2013, p. 15.

413 CRELIER, Andrés, Introducción a "Paradigmas de filosofía primeira" in: APEL, Paradigmas de filosofía primera, pp. 9-10.
} 
filosófico e determinam os parâmetros normativos para o pensar e o agir humanos. No singular, o termo paradigma designa a perspectiva histórico-normativa que configura cada marco filosófico; ele se refere ao modo específico de abordar os problemas e pressupostos inelimináveis reunidos em torno de noções centrais como o ser, a divindade, o conhecimento ou a linguagem. A noção de paradigma corresponde a uma mirada histórico-normativa. É histórica, na medida em que seu objeto de análise é a tradição do pensamento ocidental. Apel assinala que a sequência de posições entre os paradigmas não conforma uma ordem histórica plausível, mas uma dialética (uma lógica do desenvolvimento) da possível radicalização da autorreflexão crítica do pensamento filosófico. É normativa, porque essa reconstrução produz uma avaliação das virtudes e falências de cada paradigma. Essa normatividade se enlaça com a tese do possível progresso do conhecimento filosófico, que se dá pela superação de um paradigma epocal pelo seguinte. Assim, por exemplo, o paradigma moderno da consciência destaca aspectos inelimináveis para o pensamento, porém não é capaz de resolver os problemas da separação dualista entre sujeito e objeto do conhecimento.

No sentido dessa normatividade, segundo Andrés Crelier, a intenção de Apel que transparece na coletânea de textos reunidos em Paradigmas de filosofia primeira - é destacar o próprio marco filosófico, situando-o historicamente e justificando-o como uma "melhor visão" dos problemas centrais da filosofia" 414 . Tal justificativa põe em evidência que a semiótica filosófica transcendental consegue combinar duas relevantes dimensões do logos filosófico: a reflexão transcendental e o giro pragmático da linguagem da filosofia atual. Nisso, trata-se de considerar que mesmo que a lógica proposicional tenha tratado de problemas linguístico-analíticos desde o início, somente depois da pergunta kantiana relativa às condições de possibilidade do conhecimento objetivamente válido parece resultar pertinente, com o efetivo significado crítico, a pergunta pelas condições semióticas de possibilidade da mediação intersubjetivamente válida do conhecimento intersubjetivamente válido $^{415}$. Ao mesmo tempo, a semiótica transcendental, como reconstrução da última base do logos filosófico tematizado na tradição hermenêutica (Heidegger e Gadamer) e no giro linguístico da filosofia analítica (Frege, Russell, Wittgenstein, e mais tarde, Austin e Searle), que é a linguagem e a comunicação, subsume a vantagem de ser uma perspectiva filosófica que deixa para trás problemas e pressupostos anteriormente tidos como incontornáveis, tais como a divisão sujeito-objeto e os problemas ligados ao solipsismo metódico moderno. Para

${ }^{414}$ CRELIER, Andrés, Introducción a "Paradigmas de filosofía primeira" in: APEL, Paradigmas de filosofía primera, p. 11.

${ }^{415}$ APEL, Karl Otto. Paradigmas de filosofía primera. Buenos Aires: Prometeo Libros, 2013, p. 16. 
Apel, a semiótica transcendental pode ser entendida como uma unidade do giro linguístico referido à linguagem no século XX nos enfoques hermenêuticos, analíticos e pragmáticos. Nisso parece residir a vantagem teórica semiótica transcendental ${ }^{416}$.

Em sua reconstrução da mudança de paradigmas de filosofia primeira, essencialmente, Apel trata da sequência de três paradigmas principais: o da metafísica, o da filosofia transcendental e o da semiótica transcendental ${ }^{417}$. O ponto de partida de Apel é a análise do paradigma da metafísica. Para ele, a característica principal desse paradigma é a tematização do ente objetivado. Nele não se tematiza a tripla relação sígnica (sintática, semântica e pragmática, ou seja, a dupla estrutura proposicional-performativa), nem a relação gnoseológica sujeito-objeto, entendida como condição de possibilidade e validade do conhecimento do ente. Decerto, assim pontua Apel, isso não significa que esse paradigma não tem uma teoria do conhecimento ou teoria da linguagem. Ocorre que, nesse paradigma, a relação de conhecimento e a relação de signos que media a relação cognitiva não são tematizadas na perspectiva reflexiva como pré-condição da objetividade, mas como relações objetivas entre entidades no mundo ${ }^{418}$.

Para Apel, o paradigma metafísico tem um déficit de reflexão. Esse déficit decorre de dois fatores problemáticos ${ }^{419}$, que se ligam, em primeiro lugar, à aporética da teoria clássica da correspondência, e, em segundo lugar, à aporética do problema da fundamentação última de princípios. A aporética da teoria clássica da correspondência se apoia na circunstância de que a correspondência entre a mente (ou o enunciado) e as coisas (ou estado de coisas) deve ser representada e correlativamente examinada como uma relação entre coisas objetiváveis no mundo. Contudo, tal como Kant já tem demonstrado, isso não é possível, pois a relação sujeito-objeto do conhecimento, que precede a todo conhecimento de objetos como condição de sua possibilidade, não pode ser reduzida, por princípio, a uma relação objetoobjeto intramundana. Aporeticamente, toda tentativa de realização do exame criteriológico da

\footnotetext{
${ }^{416}$ APEL, Karl Otto. Paradigmas de filosofía primera. Buenos Aires: Prometeo Libros, 2013, p. 18.

${ }^{417}$ APEL, Karl Otto. Paradigmas de filosofía primera. Buenos Aires: Prometeo Libros, 2013, pp. 71-75. Em uma classificação mais sofisticada, Apel trata de sete paradigmas de filosofia primeira, sendo: a) a sequência teleológica de três paradigmas de filosofia primeira, os quais constituem a coluna vertebral da história interna da filosofia três paradigmas (I - metafísica; II - teoria do conhecimento; III - semiótica transcendental); b) quatro subparadigmas derivados dos três paradigmas principais: o semanticismo, o onto-semântico, o do idealismo subjetivo, o idealismo semiótico. Para Apel, na relação interna entre os sete paradigmas e o esquema triádico dos signos (sintática, semântica e pragmática), exceto o paradigma da semiótica transcendental - que considera reflexivamente as três posições da relação de signos como condições constitutivas de um mundo significativo -, os outros seis tipos estão marcados por abstrações de uma ou duas dimensões da semiosis, e por isso se baseiam em algum tipo de falácia abstrativa (cf. Paradigmas de filosofía primera, p. 75).

${ }^{418}$ APEL, Paradigmas de filosofía primera, pp. 157-158.

419 APEL, Fundamentacion semiotico-trascendental de la filosofia pragmatica del lenguaje in: Semiotica filosofica, pp. 170-171. APEL, Paradigmas de filosofía primera, pp. 157-158.
} 
correspondência entre o intelecto e a coisa conduz a um regressus ad infinitum. Por sua vez, a aporética relativa à problemática da fundamentação última se baseia no fato de que no plano das relações objetiváveis da lógica dos enunciados, o qual corresponde à ontologia, nunca se pode arrolar um princípio último, sem que o mesmo tenha que ser novamente fundamentado por inferência a partir de algo distinto. E nisso consiste o peculiar caráter dogmático de toda metafísica, visto que parte de axiomas não suscetíveis de questionamento.

No entanto, assim pontua Apel, ao questionar a ontologia em sua crítica da razão, Kant introduz a diferenciação entre transcendental e transcendente (o "exaltado"), justamente para marcar seu distanciamento crítico em relação à metafísica dogmática. Kant considera a “crítica da razão" (transcendental) como estágio transitório para uma metafísica criticamente depurada que deve poder aparecer como ciência. Contudo, conforme Apel, pesa contra Kant o fato de ele recair numa metafísica de fundo; que se fundamenta na concepção da "coisa-emsi” incognoscível, porém funcionalmente imprescindível, e se desenvolve na filosofia prática de Kant como o dualismo da "doutrina dos dois reinos" 420. Ainda segundo Apel, depois da recaída metafísica do idealismo alemão, no século XIX, os neokantianos regressam à filosofia “crítica" de Kant e, a partir de então, entendem que a filosofia primeira metodológica corresponde à teoria do conhecimento.

O segundo paradigma da filosofia primeira, o da reflexão transcendental, diz respeito às condições subjetivas intranscendíveis do conhecimento referido ao mundo objetivamente dado ${ }^{421}$. O aspecto decisivo no paradigma da reflexão transcendental se define em razão de que a objetividade do ente é entendida reflexivamente, como correlato da subjetividade transcendental da consciência em geral. De tal modo, esse paradigma constitui uma saída ao dilema do primeiro paradigma. É interessante observar que apesar da tendência dominante de crítica à metafísica presente no empirismo britânico e no positivismo, ele ainda não se apresenta aí com a pretensão de filosofia primeira. Já com Descartes se evidencia que a

\footnotetext{
${ }^{420}$ APEL, Paradigmas de filosofía primera, pp. 169-170. Kant afirma que a filosofia passa por três fases: a dogmática (modelo da metafísica), a cética (Hume) e a crítica (dele mesmo). Contra a metafísica se opõem outras filosofias dogmáticas, daí a luta entre sistemas. Mas como não é possível se desinteressar da metafísica já que se encontra radicada na natureza humana -, Kant procura princípios adequados ao pensamento metafísico. Por isso classifica sua filosofia como crítica (tribunal da razão), cuja tarefa fundamental consiste em levantar as exigências da própria razão que são justificadas e eliminar as pretensões sem fundamento. "Previamente à constituição de um sistema metafísico, conhecimento pela razão pura das coisas em si, dever-se-á investigar - o que será tarefa da Crítica da Razão Pura - o que pode conhecer o entendimento e a razão, independentemente de toda a experiência. Trata-se de criticar, de encontrar os limites de todo conhecimento puro, a priori, isto é, independentemente de qualquer experiência. Deste modo se abrirá um caminho certo para a metafísica, que lhe obtenha o consenso dos que se ocupam de filosofia, pois se encontram garantidas a necessidade e universalidade desse saber; estaremos em face de uma ciência" (cf. KANT, Crítica da razão pura, 2013, p. x).

${ }^{421}$ APEL, Paradigmas de filosofía primera, pp. 157-158.
} 
consciência (ou os dados da consciência) funciona como o intranscendível na reflexão filosófica sobre os fundamentos, porém esse paradigma surge de forma explícita em Kant e de uma maneira relativamente pura, em uma fase de consumação do segundo paradigma, em Edmund Husserl. Em correspondência com o paradigma anterior, a autorreflexão da subjetividade transcendental em Kant e no idealismo pós-kantiano pode assumir a função da fundamentação última. Não obstante, a solução mais contundente para os problemas da verdade e da fundamentação última, concernentes ao paradigma da metafísica, é apresentada por Husserl, o último clássico do segundo paradigma.

Husserl concebe que o conhecimento se realiza por meio de intenções preenchidas por essências universais. Supondo isso, ele propõe o método da redução fenomenológica (epoché), justamente como caminho às evidências de essências. A epoché é, fundamentalmente, uma contraposição ao naturalismo, à ideia de que o sujeito está no mundo como algo que o contém ou como uma coisa entre outras coisas, já encontradas no mundo independentemente de si mesmo. A epoché é um "pôr entre parênteses" dos componentes históricos (teorias e opiniões), existenciais (abstração dos juízos de existência), bem como dos componentes merecedores de redução eidética (passagem espiritual do fático à essência) ou redução transcendental (os dados da consciência ingênua tornam-se fenômenos transcendentais da consciência pura, a esfera absoluta do eu puro), para que a coisa mesma dada "fale" (manifeste sua essência). Essa essência não corresponde a um mundo inteligível (Platão), nem se confunde com fenômenos de consciência (psicologia). Ela é uma forma pura do pensamento, uma categoria lógica e gramatical que nos permitem pensar o "objeto em geral", porém que não tem existência fora do ato intencional da consciência que as visa e do modo puro sob o qual ela o apreende na intuição ${ }^{422}$. A teoria fenomenológica de Husserl não trata de uma relação de correspondência ontológica, que é objetivável externamente, mas de uma relação de cumprimento (Erfüllungs-Beziehung) ${ }^{423}$ examinável, a partir da perspectiva do sujeito do conhecimento, entre a intenção noemática do juízo e a autodoação (Selbstgegebenheit) do fenômeno em cada caso. Ao introduzir o critério da evidência fenomênica, assinala Apel, vantajosamente Husserl evita as aporias do primeiro paradigma que resultam da ilícita objetivação da relação do sujeito-objeto de conhecimento na forma do

\footnotetext{
${ }^{422}$ STEGMÜLLER, A filosofia contemporânea, pp. 73-76.

${ }^{423}$ HUSSERL, Investigações lógicas: sexta investigação (elementos de uma elucidação fenomenológica do conhecimento), pp. 10 e 91-94.
} 
regressus ad infinitum. Porém, também em Husserl se evidencia a aporia fundamental do paradigma da filosofia transcendental da consciência ${ }^{424}$.

Ao avaliar criticamente a solução de Husserl, à luz do terceiro paradigma, o da semiótica transcendental, Apel observa que essa solução supõe uma cláusula condicional, que leva à aporia típica do segundo paradigma de filosofia primeira ${ }^{425}$. Essa cláusula expressa a seguinte exigência: a evidência fenomênica funciona como critério de verdade para a correspondência, "contanto que" se pressuponha no mundo da vida em geral uma compreensão intersubjetivamente compartilhada do significado da proposição e, correspondentemente, do fenômeno que se quer identificar. Ocorre que, aporeticamente, de uma parte, a evidência fenomênica já é sempre evidência linguisticamente interpretada; ou seja, no plano da ciência, ela é equiparável à verdade somente na medida em que a validade intersubjetiva da interpretação linguística, que no mundo da vida é simplesmente pressuposta, pode ser discursivamente fundamentada. Por outro lado, ao contrário da garantia de preenchimento da evidência fenomênica, a evidência linguisticamente interpretada nunca pode ser objeto de uma consciência individualizada ("minha consciência). No entender de Apel, a tarefa que se desdobra a partir dessa aporia, no campo do terceiro paradigma de filosofia primeira, consiste em recuperar a correspondente pretensão de validade referente à evidência fenomênica no contexto da interpretação ("inferências sintéticas"), considerando-a, juntamente com outros critérios de verdade não referidos à evidência empírica, como suscetível de consenso na comunidade de interpretação dos intérpretes dos signos. Entre esses critérios se encontra, primariamente, o da coerência que, na formação de consenso discursiva realizada na comunidade de investigação, tem que ser mediado com a interpretação das evidências empíricas.

A teoria evidencial da verdade de Husserl ilustra essa aporia. Husserl concebe a verdade como cumprimento das intenções noemáticas que são a base das pretensões mentais de verdade mediante o dar-se a si mesmo dos fenômenos. No sentido de uma teoria da verdade fenomenológica da evidência para a correspondência, aí se preconiza que, para atestar a adequação entre o pensado e o fato percebido, basta voltar à coisa mesma e comprovar tal correspondência. Aí não se fala de uma interpretação linguística dos fenômenos dados, porém se pressupõe, em regra, uma interpretação comum (intersubjetiva) e linguística do mundo. Com efeito, o principal déficit das operações intencionais de constituição de

\footnotetext{
${ }^{424}$ APEL, Paradigmas de filosofía primera, pp. 171-172.

425 APEL, Paradigmas de filosofía primera, pp. 158-159.
} 
sentido do mundo decorre de justamente abstrair a dimensão de interpretação linguística dos fenômenos dados. Isso se aclara, por exemplo, quando se pensa na comprovação científica da verdade ou no intento de compreensão entre membros de culturas diferentes. Em tais casos, assinala Apel criticamente, a superação desse déficit exige o reconhecimento da condição cognoscitiva transcendental da interpretação linguística do mundo, seja como pressuposto do caráter impregnado de teoria das verificações ou falsificações de hipóteses, seja como précompreensão linguística do mundo da vida. Por conseguinte, esse reconhecimento implica a necessidade sistemática e histórica de uma transição desse paradigma pré-linguístico da filosofia transcendental do sujeito da consciência, orientado em um solipsismo metódico, a um novo paradigma ${ }^{426}$.

O terceiro paradigma de filosofia primeira, segundo Apel, é o semiótico transcendental. Esse paradigma alcança sua constituição completa no momento em que, no âmbito do paradigma da linguagem, a relação triádica do conhecimento mediada pela linguagem (signos) substitui a relação dual sujeito-objeto do segundo paradigma, tematizada reflexivamente como condição de possibilidade e validade do conhecimento ${ }^{427}$. A rigor, ele se completa quando se extraem dessa substituição as consequências consoantes à transformação semiótica da filosofia transcendental clássica. Há que se considerar, afirma Apel, que essa substituição não é assegurada pelo "linguist turn" da filosofia contemporânea, mas somente na medida em que o segundo paradigma é complementado pelo "pragmatic turn". Entretanto, também aí é necessário delimitar a concepção de pragmática adequada a tal complementação. Problematicamente, nem toda incorporação da noção de pragmática no logos filosófico implica efetiva superação do solipsismo metódico típico do segundo paradigma de filosofia primeira. Aí, o solipsismo deita raiz, precisamente em sua desconsideração do compartilhamento dos significados linguísticos dos signos como uma condição de possibilidade da validade intersubjetiva do conhecimento válido. Isto se mostra, por exemplo, no caso da noção de pragmática empírica e pragmática formal (metalinguisticamente semantizada) de Morris e Carnap. Em contrapartida, a noção de pragmática que permite essa complementação e enfrentamento do solipsismo metódico, como ponto de partida, é a da triplicidade da relação sígnica desenvolvida por Peirce. Nela, o giro pragmático se processa por meio de uma pragmática reflexivo-transcendental da linguagem, no horizonte da transformação semiótica da filosofia transcendental.

\footnotetext{
426 APEL, Paradigmas de filosofía primera, pp. 172-173.

${ }^{427}$ APEL, Paradigmas de filosofía primera, pp. 159-160. APEL, Semiotica filosofica, pp. 173-174.
} 
Para explicar a reconstrução desses paradigmas à luz da semiótica transcendental, Apel lança mão da tese segundo a qual os três possíveis tipos de paradigmas da filosofia primeira podem ser alinhados às três funções dos signos (semiosis), que são a sintática, a semântica e a pragmática. Conjuntamente, essas funções dos signos constituem a mediação necessária da interpretação do mundo e, em tal medida, a condição de possibilidade de todo saber sobre a realidade. No quadro das funções dos signos, a sintática se ocupa da relação entre os signos, os quais constituem a estrutura gramatical de uma linguagem como sistema de signos. A semântica trata da relação entre o signo e seu denotatum efetivo. A pragmática se ocupa da relação entre o signo e seu usuário ou intérprete, seja um falante ou ouvinte ${ }^{428}$. Em relação ao ente, os paradigmas de filosofia primeira assumem posicionamentos distintos. A metafísica geral ou ontologia (no sentido aristotélico) considera o ente, a partir de um ponto de vista externo ao mundo, unicamente como é designado e denotado mediante signos nomeadores (nomes próprios e conceitos universais). O paradigma da filosofia transcendental da consciência ou crítico da razão, no sentido kantiano, considera o ente como tema da filosofia como um possível objeto cognitivo do sujeito ou consciência transcendental, porém sem dar conta da linguagem ou da função sígnica como uma condição transcendental de possibilidade da interpretação intersubjetivamente válida do mundo e da constituição do objeto. Já a semiótica transcendental, como um terceiro paradigma da filosofia primeira, considera o ente como possível objeto (denotatum e designatum) da interpretação do mundo mediada por signos ${ }^{429}$.

Com efeito, em relação à tese supramencionada, surge a questão referida à problemática da fundamentação. Se a semiótica filosófica aparece, ao mesmo tempo, como um dos paradigmas da filosofia primeira e como ideia básica a partir da qual se deriva a possibilidade dos três paradigmas de filosofia primeira, então tal não configura um caso de petitio principii? Respondendo, Apel afirma que essa dupla função da semiótica transcendental se deve ao fato de que ela ocupa o lugar, em uma sequência passível de justificação, de uma síntese possível dos dois paradigmas precedentes da filosofia primeira. Nisso se consubstancia a posição de que a semiótica transcendental não é mera e simplesmente um terceiro tipo em enumeração dos possíveis paradigmas. Diferentemente da concepção de paradigmas conforme Kuhn, Apel entende que essa dupla função é possível na medida em que considera a sequência de distintos paradigmas que revolucionam o

\footnotetext{
${ }^{428}$ APEL, Paradigmas de filosofía primera, p. 63.

${ }^{429}$ APEL, Paradigmas de filosofía primera, p. 71.
} 
pensamento à luz da ideia de progresso possível na história do pensar. Essa sequência não implica, contudo, sustentar a pretensão de um progresso necessário, que possa ser explicado casualmente e em tal medida capaz de predizer. O que ela implica é a pretensão de que os três paradigmas de filosofia primeira conformam uma ordem hierárquica de níveis de reflexão crítica, compreensível ex post, porém sem uma garantia prévia de sua realização ${ }^{430}$. Essa dedução esquemática dos paradigmas da filosofia primeira não implica, esclarece Apel, uma suposição interpretativa segundo a qual o paradigma da ontologia exclua completamente a temática da epistemologia e/ou da filosofia da linguagem, ou que o segundo paradigma exclua completamente a filosofia da linguagem, pois interpretar desse modo seria o mesmo que fraudar os fatos históricos e o ponto central da ideia dos paradigmas de filosofia primeira. Trata-se de considerar que sob o domínio do paradigma ontológico, as questões da epistemologia e da filosofia da linguagem são tratadas como questões do ente; sob o paradigma epistemológico transcendental, as questões de filosofia da linguagem são tratadas como possíveis problemas do conhecimento do objeto ${ }^{431}$.

No esquema de reconstrução da mudança de paradigmas defendido por Apel, o segundo paradigma de filosofia primeira determina a possibilidade do terceiro paradigma de filosofia primeira. Todavia, para isso, é necessário ocorrer antes uma transformação radical e inovadora da própria filosofia transcendental à luz das questões suscitadas nos séculos XIX e XX relativas à validade da ciência. Esse é o caso, por exemplo, de questões referentes à física não-clássica, à teoria da evolução e às ciências sociais, em relação às quais o apriorismo da relação sujeito-objeto da consciência transcendental não poderia responder, seja por ainda estar preso ao esquema tradicional de uma teoria ontológico-metafísica de dois mundos, concebida a partir de uma perspectiva divina, seja por estar livre da referência constitutiva da linguagem para a fundamentação do conhecimento e da razão prática ${ }^{432}$. Efetivamente, essa pressuposição norteia, de forma paradigmática, o próprio esquema de reconstrução da mudança de paradigmas pensado por Apel. No entender de Apel, é da combinação entre o segundo paradigma, o da filosofia transcendental, e o terceiro paradigma, especificamente no que se refere ao giro pragmático da linguagem empreendido por Charles S. Peirce, que resulta relevante a reconstrução da mudança de paradigmas para uma fundamentação inovadora no interior do terceiro paradigma de filosofia primeira.

\footnotetext{
${ }^{430}$ APEL, Paradigmas de filosofía primera, pp. 72-73.

${ }^{431}$ APEL, Paradigmas de filosofía primera, p. 72.

${ }^{432}$ APEL, Paradigmas de filosofía primera, p. 16.
} 


\subsection{A estrutura performativo-proposicional do discurso argumentativo como fundamentação filosófica}

Como dito, na contemporaneidade, a semântica, a hermenêutica e a pragmática da linguagem conformam o giro linguístico-hermenêutico-pragmático ("linguistic-hermeneuticpragmatic turn") da filosofia atual. Essas correntes marcam distintas perspectivas quanto à resolução do problema da significação da linguagem. Nesse contexto, a pragmática emerge, por uma parte, marcada pela contraposição ao modelo da análise semântica que, concebendo a linguagem como puro meio de descrição do mundo, faz abstração dos diversos contextos de usos das palavras; por outro, assinala a via necessária para resolver tal problemática, que é a explicitação de seus contextos pragmáticos (de uso). Decerto, tal perspectiva indica o núcleo da virada pragmática, do qual decorre uma tese fundamental e consequente para a mudança e configuração do paradigma da linguagem, à medida que aí promove sua ampliação e complementação. Trata-se da tese que a semântica só atinge sua finalidade chegando à pragmática, posto que o problema da significação das palavras só pode ser resolvido pela explicação dos contextos pragmáticos. A virada pragmática se assenta, fundamentalmente, na consideração de que o problema semântico (significação das palavras) não se resolve sem pragmática, o que implica em incorporar ao paradigma da linguagem a dimensão de interação social simbólica de acordo com diferentes modos de sua realização ${ }^{433}$.

Ocorre que, em relação à problemática da fundamentação, a virada pragmática limita o fundamento da linguagem à esfera fática do seu próprio uso. Para a pragmática, o fundamento não é algo exterior à linguagem concreta, mas a própria práxis do uso da linguagem. Isso veda, por princípio, qualquer intento de fundamentação última que ultrapasse o caráter prático, intersubjetivo e histórico da linguagem humana. Sendo uma ação comunicativa entre homens livres, a linguagem difere de processos mecânicos naturais. Por isso, o fundamento da linguagem não se confunde com o produto do modelo de explicação do fenômeno linguístico do behaviorismo linguístico ${ }^{434}$. No processo de fundamentação, a cadeia

\footnotetext{
433 OLIVEIRA, Sobre a fundamentação, pp. 53-54 e 55. OLIVEIRA, Reviravolta linguístico-pragmática na filosofia contemporânea, pp. 139-143.

${ }^{434}$ A linguagem é, em sua dimensão última, interação social. O poder de uso da linguagem é a capacidade, historicamente adquirida, de inserir-se em um processo de interação simbólica social de acordo com diferentes modos de sua realização. A linguagem se liga à práxis social e, por isso, o poder de usá-la é uma capacidade adquirida por adestramento, de um aprendizado das normas e dos papeis aí implicados. Obehaviorismo linguístico também relaciona linguagem e práxis social, porém compreende a linguagem como um fenômeno natural, interpretável por meio da categoria comportamentalista do estímulo-resposta (cf. OLIVEIRA, Reviravolta lingüístico-pragmática na filosofia contemporânea, p. 143).
} 
de provas, assim como toda dúvida, já acontece dentro de um sistema que possibilita a argumentação. Por isso, a cadeia de fundamentos chega a um fim, a um ponto (de verdades) para além do qual não pode haver mais provas. Problematicamente, tais verdades servem de prova para outras sentenças, porém não há provas para elas ${ }^{435}$.

Salientando essa questão, Wittgenstein resolve tal problema afirmando que não se pode aplicar o conceito de saber para aquilo que é pressuposto do saber. Esse pressuposto concerne a um pré-saber pressuposto que constitui uma práxis, que não se pode fundamentar. Trata-se do pressuposto dos jogos de linguagem, que a filosofia "olha", mas "não toca". Ele diz respeito a um sistema de sentenças, constituídas como um pré-saber e uma "pré-práxis", que estabelecem uma "forma de vida" (visão de mundo) - nem verdadeira, nem falsa -, porém somente a partir da qual se pode ter uma confrontação sobre a verdade. Somente no seio dessa forma de vida pode ter sentido as palavras dos interlocutores que se confrontam com a verdade das sentenças. Em tal medida, o fim (de um ponto de "segurança") a que se deve chegar a justificação da evidência, na perspectiva da pragmática, não se confunde com o de uma captação espiritual (ter-em-mente) e imediata do conteúdo das sentenças, mas diz respeito à segurança relativa à práxis (ação) que subjaz ao jogo de linguagem. Frente aos desentendimentos próprios do processo interativo, a filosofia assume uma função terapêutica, desmascarando o enfeitiçamento do nosso entendimento pelos meios da linguagem. Para tanto, cabe à filosofia tematizar a gramática profunda - a qual concerne ao conjunto de regras que constitui determinado jogo de linguagem; e se diferencia da gramática superficial, que trata do conjunto de normas para a construção correta das frases -, por via da qual vêm à tona os critérios para o uso correto das palavras em meio à pluralidade fática dos modos da linguagem humana ${ }^{436}$.

Para Apel, a equiparação do significado com uso fático da linguagem, tal como é sugerida pelo segundo Wittgenstein, resulta insatisfatória. A insuficiência de uma pragmática (ou semiótica empírica) que se liga à faticidade, assim como ocorre também na hermenêutica Heidegger e Gadamer, tal como já exposto, reside em sua "restrição" a responder acerca da validade universal da própria linguagem. Por sua vez, Apel entende que a superação do solipsismo metódico exige uma articulação dialética entre a perspectiva pragmática, que reclama o reconhecimento da dependência do pensar e do conhecer em relação às convenções de significado das linguagens "naturais" concretas (ou as regras dos distintos jogos de

\footnotetext{
435 WITTGENSTEIN, Investigações filosóficas, fragmentos 326 e 485.

${ }^{436}$ WITTGENSTEIN, Investigações filosóficas, fragmentos 109, 199 e 241.
} 
linguagem entendidos como incomensuráveis) e a pretensão de uma reflexão transcendental sobre a validade universal de sentido dos signos linguísticos, em que se supõe que cada discurso interlingual já sempre tem reconhecido a abertura de todas as linguagens naturais na direção de uma antecipação (contrafática) de significados intersubjetivos por antonomásia (quer dizer, interlinguisticamente válidos) ${ }^{437}$. Tal exigência se defronta, pois, com o impasse de articular a perspectiva pragmática (e hermenêutica) da linguagem com a reflexão transcendental em vista de responder à pergunta pelas condições de possibilidade da argumentação válida.

Frente a essa pergunta central para a compreensão da proposta filosófica de Apel, faz-se necessário expor aqui, já levando em conta a exposição sobre o "linguistic turn" (giro linguístico) e do "pragmatic turn" (giro pragmático) da filosofia contemporânea feita neste capítulo, a explicação apeliana do termo "intranscendível” (nichthintergehbar ${ }^{438}$. Para Apel, o recurso à intranscendibilidade de um ponto de vista, enquanto referência racional de certeza intuitiva indubitável ou fundamento metódico irrecusável, é peculiar do filosofar da modernidade, caracterizado pela reflexão metódica. Aí, o "cogito, ergo sum" de Descartes representa o primeiro paradigma dessa estratégia argumentativa, ainda que ele não tenha posto em relevo o caráter transcendental do pensamento em geral. Com efeito, a diferença entre esse caráter e todo possível auto-conhecimento empírico-introspectivo se dá em Kant, para o qual o pensar em geral deve acompanhar todas as representações da consciência transcendental do "eu". Contudo, na história da filosofia, essa intranscendibilidade metódica do "eu penso" ou da consciência transcendental não permanece inquestionável. A ela tem se contraposto uma intranscendibilidade "mais profunda", por ser pré-reflexiva, que é a do mundo da vida. Essa contraposição emerge em variadas versões, tais como o "ser-no-mundo" (Heidegger), a "vida" (Dilthey) ou a "praxis" social material (Marx). Segundo Apel, o caráter ineliminável préreflexivo da práxis da vida se mostra não somente no sentido popular do "primum vivere, deinde philosophari" (primeiro viver, depois filosofar), mas também, de modo fundamental, na perspectiva da problemática da constituição de sentido ("significatividade") do próprio mundo da vida. Em suma, o a priori da consciência, próprio da reflexão sobre a validade, vêse confrontado pelo a priori pré-reflexivo - referente à vida prática - da constituição do sentido $^{439}$.

\footnotetext{
${ }^{437}$ APEL, Paradigmas de filosofía primera, p. 161. APEL, Semiotica filosofica, p. 175.

${ }^{438}$ APEL, Paradigmas de filosofía primera, p. 143.

${ }^{439}$ APEL, Paradigmas de filosofía primera, p. 144.
} 
Na visão de Apel, esse confronto se apresenta de modo problemático. A pretendida prioridade dos pressupostos pré-reflexivos da práxis da vida para a compreensão da constituição do sentido do mundo, assim pensa Apel, não supera os pensamentos básicos da intranscendibilidade no sentido do a priori reflexivo da consciência. Neste último subsistem pressupostos que não podem ser negados pelo a priori da práxis pré-reflexiva. A intranscendibilidade do ego cogito se refere, essencialmente, à reflexão acerca da dúvida e da pergunta retrospectiva pelas condições de validade; e, em relação a isso não tem sido refutada. Com efeito, aí o que se modifica é a ideia, inaugurada por Kant e renovada por Husserl, de que a pergunta pelas condições de possibilidade e validade do conhecimento pode ser suficientemente respondida mediante recurso às operações constitutivas do objeto pela consciência pressuposta na reflexão sobre a validade. Nessa perspectiva, sustenta-se desde então a ideia de que a pergunta pelas condições de possibilidade e validade do conhecimento se responde mediante recurso à consciência, de certo modo, imanente à reflexão ${ }^{440}$. O núcleo desse problema reside no fato de que, para o a priori da práxis pré-reflexiva, a constituição de sentido, de forma compreensível e significativa, não pode dar-se pela efetuação intencional de uma consciência pura autorreflexiva. Em defesa da reflexividade, argumenta Apel que é a reflexão que possibilita inteligir a prioridade dos pressupostos pré-reflexivos da práxis da vida para a compreensão da constituição do sentido do mundo. Por uma parte, enquanto préestrutura da compreensão do mundo, o a priori do mundo da vida precede ao a priori da consciência do eu concernente à reflexão sobre a validade. Por outra, é essa reflexão que dá a medida da reconstrução racional e, ademais, da evidência de significatividade do mundo a que possivelmente está sujeito o a priori pré-reflexivo da faticidade e historicidade do ser-nomundo ${ }^{441}$.

O rival mais importante do a priori da consciência é o a priori semióticotranscendental da mediação do pensamento intersubjetivamente válido pelos signos. $\mathrm{O}$ aspecto distintivo do a priori da linguagem reside no fato de que ele está associado tanto ao primado pré-reflexivo (da vida prática) do a priori da constituição de sentido, como ao primado reflexivo do a priori da reflexão sobre a validade. Ele corresponde, enquanto condição principal da pré-compreensão do mundo, à pré-estrutura hermenêutica do mundo da vida. Além disso, ele se constitui como pressuposto da reflexão e do questionamento radical sobre os pressupostos da compreensão do mundo contidos no mundo da vida. A convergência

\footnotetext{
440 APEL, Paradigmas de filosofía primera, p. 145.

441 APEL, Paradigmas de filosofía primera, pp. 144-145.
} 
entre o a priori da consciência do eu e o a priori da práxis pré-reflexiva ocorre, pensa Apel, à medida que o a priori da linguagem possibilita a validade intersubjetiva do pensamento reflexivo no marco do discurso argumentativo. Aí, fundamentalmente, o primado metódico do a priori da linguagem condiciona também a intranscendibilidade da $\operatorname{argumentação~}^{442}$.

Do ponto de vista histórico-filosófico, o traço comum entre as propostas do movimento de reviravolta linguística e do giro pragmático é que, recorrendo ao a priori da linguagem, isto é, à implícita dependência do pensar e do conhecer em relação ao acordo intersubjetivo, elas coincidem quanto ao intento de superar um postulado que tem predominado, a partir de Santo Agostinho, no pensamento ocidental, o do solipsismo metódico. Em geral, essa expressão se refere à suposição de que um indivíduo, em princípio, pode chegar sozinho e por si mesmo - decerto, não prescindindo do processo de socialização - a resultados válidos do pensar e do conhecer. Esse ponto de vista se apresenta, por exemplo, também em Kant, quando afirma que uma faculdade regulativa pré-linguística, fundada na "consciência em geral", é capaz de assegurar a validade intersubjetiva do conhecimento, sem que seja necessário um compartilhamento intersubjetivo das significações linguísticas, isto é, um acordo comunicativo. Em vista de superar o solipsismo metódico, inclusive o que é próprio da filosofia transcendental clássica, paradigmaticamente, o movimento do giro linguístico pragmático-hermenêutico propugna a perspectiva segundo a qual o pensar e o conhecer dependem do acordo comunicativo, a ser alcançado no medium da linguagem histórica. Mas com isso, à medida que linguagem cultural própria de uma determinada forma de vida toma o lugar do logos universal da filosofia transcendental clássica, desloca-se a tarefa da fundamentação do pensar e do conhecimento para o âmbito do a priori contingente do mundo da vida ${ }^{443}$.

A alternativa na qual se apóia a tese da superação do solipsismo metódico, segundo Apel, desemboca no problema central da interpretação semiótico-transcendental intentada por ele no interior do movimento do giro linguístico pragmático-hermenêutico. As diversas tendências dentro do giro linguístico convergem, ressalta Apel, na linha de uma defesa da destrancendentalização da filosofia e do abandono de todas as pretensões de validade universal. Nesse sentido, o neo-pragmatismo de Rorty, juntamente com autores pósmodernistas, coincide com a relativização histórica do $\operatorname{logos}$ da filosofia e da ciência ocidentais que fazem Heidegger, Wittgenstein (o das Investigações) e Derrida, no sentido de

\footnotetext{
${ }^{442}$ APEL, Paradigmas de filosofía primera, pp. 145-146.

${ }^{443}$ APEL, Paradigmas de filosofía primera, pp. 148-149.
} 
uma possível superação do logos por meio do "desocultante-ocultante acontecer do ser" que o torna temporalizado como época. A necessidade da destranscendentalização e do abandono das pretensões de validade universais se afigura, nessa linha, como uma consequência do caráter contingente do a priori da linguagem. Por seu turno, em defesa de uma reinterpretação filosófico-transcendental específica, Apel se contrapõe a essa tendência, dentro do giro linguístico pragmático-hermenêutico. Para Apel, o entendimento de que a pretensão de validade do a priori da linguagem implica em uma destranscendentalização da filosofia atual, é sintomático de uma interpretação que incorre em autocontradição performativa. Contraditoriamente, os defensores da destranscentralização no giro linguístico, embora defendam um a priori da linguagem apenas contingente, em verdade, não podem renunciar a expor sua tese contra a possibilidade ou a necessidade das pretensões de validade universais e dos princípios universais na forma corrente do recurso à intelecção filosófica da validade universal dos argumentos. Vê-se essa contradição, por exemplo, quando se sustenta a tese sobre a incomensurabilidade dos jogos de linguagem e das formas de vida entretecidas com eles, porém sem que ela implique em abandonar a intencionalidade de que alcance validade universal. De modo contrário, essa renúncia implica em renunciar a filosofar. Em verdade, os referidos defensores nem podem mesmo fazer tal renúncia, pois mesmo que isso fosse possível, para que não ficasse infundada, essa "fuga do discurso filosófico" deveria explicitada na forma de uma tese com pretensão de validade universal ${ }^{444}$.

Enfatizando sua contraposição à destrancendentalização da filosofia, Apel assinala que exigência de destranscendentalização conduz ao mesmo tipo de contradição que ocorre em relação à pretensão de validade intransponível da práxis da vida (ou do mundo da vida). E nesta situação, enquanto convite a compreender a contingência do a priori da linguagem, a pretensão de validade ineliminável da práxis da vida corrobora, segundo Apel, tão somente o primado teórico e referido à validade da intranscendibilidade da consciência reflexiva. O que essa interpretação do a priori da linguagem não mostra é que a intelecção reflexiva da consciência, entendida como uma intelecção com pretensão de validade intersubjetiva, já pressupõe o a priori da linguagem enquanto a priori da argumentação. Efetivamente, esse é o ponto central a ser tomado em consideração, pois a possibilidade mesma do conhecimento e da ação ética se assenta sob o caráter intranscendível do priori da argumentação. O priori da argumentação constitui a condição de possibilidade da validade universal das intelecções filosóficas e epistemológicas. Daí que, não é possível determinar suficientemente o a priori da

\footnotetext{
${ }^{444}$ APEL, Paradigmas de filosofía primera, p. 150.
} 
linguagem próprio do pensar e conhecer unicamente recorrendo ao seu caráter contingente, posto que esse a priori é ineliminável para o argumentar filosófico ${ }^{445}$. Entao, para Apel, o giro linguístico da filosofia atual não implica a destranscendentalização da sua tarefa de fundamentação, mas em uma transformação crítica da filosofia transcendental clássica. É nessa direção que se deve enfrentar a problemática do solipsismo metódico, a qual implica em uma a alternativa a ele mais radical que a simples distinção entre pensar monológico e o dialógico. Afinal, o pensar monológico (por exemplo, na execução de operações aritméticas ou de inferências lógicas), à medida que tem que seguir regras compreensíveis e controláveis pelos outros, é dependente da "forma de vida" social. Ao mesmo tempo, tal alternativa também não pode ser conduzida ao beco sem saída relativista do a priori contingente do mundo da vida ${ }^{446}$.

Retomando, Apel considera que a alternativa para superar o impasse da articulação entre a perspectiva pragmática (e hermenêutica) da linguagem e a reflexão transcendental em vista de responder à pergunta pelas condições de possibilidade da argumentação válida se baseia em uma transformação pragmático-transcendental da concepção de linguagem, no horizonte do terceiro paradigma de filosofia primeira, a semiótica transcendental. Para Julio Zan, "o programa de Apel se define como o de fundamentação da possibilidade e da necessidade metodológica de uma transformação filosófico-transcendental da semiótica, que é, ao mesmo tempo, uma transformação semiótica da filosofia mesma, baseada em uma pragmática transcendental da linguagem" ${ }^{447}$. Essa transformação pragmático-transcendental da linguagem concerne, em princípio, à tarefa de complementar a insuficiência da convencionalidade linguística com uma doutrina pragmáticonormativa dos "logical interpretants" dos $\operatorname{signos}^{448}$, desenvolvida por Peirce. Nessa doutrina,

\footnotetext{
${ }^{445}$ APEL, Paradigmas de filosofía primera, p. 150.

446 APEL, Paradigmas de filosofía primera, pp. 148-149.

${ }^{447}$ ZAN, Julio de (prólogo) in: APEL, Semiotica filosofica, p. 11.

${ }^{448}$ Com o fim de explicitar a plasticidade (natureza evolutiva) da mente humana na aquisição de novos hábitos, Peirce concebe o interpretante lógico último como mudança de hábito ("modificação das tendências de uma pessoa em relação à ação"). O interpretante lógico último, localizado no cerne das ciências normativas, é o que possibilita integrar a teoria dos signos com a natureza evolutiva do pragmatismo. As ciências normativas (estética, ética e lógica) se alicerçam sob a convicção de que o fim ideal do pensamento só pode nascer por meio da experiência futura. Por isso, cabe a elas a examinar a conformidade das coisas aos fins em um futuro condicional, isto é, os ideais reguladores que atraem e guiam o sentimento, conduta e pensamento. Assim, a lógica lida com inferências e argumentos e, na medida em que supõe o autocontrole para aprovação do seu objeto, é um caso especial da ação ética. A ética, em posição ascendente sobre as ciências normativas, estuda os fins que estão deliberadamente preparados para serem adotados. Porém a ética depende de uma ciência mais básica, a estética, cuja tarefa consiste em discernir o fim último do empenho ético. A estética concerne a aquilo que é admirável em si mesmo, sem nenhuma razão ulterior, razão pela qual atrai a sensibilidade e captura a vontade. O ideal é estético, mas a adoção deliberada do ideal e o empenho para atingi-lo são éticos. A adoção do ideal e o empenho ético dão expressão à liberdade no seu mais alto grau (enquanto expressão do admirável
} 
os interpretantes lógicos dos signos correspondem a princípios regulativos, implícitos nos significados linguísticos de todas as linguagens naturais, da interpretação entendida como de validade universal de sentido. Com essa complementação, a linguagem se constitui como instância que articula, dialeticamente, a dependência linguística do pensar e agir humanos, à medida que nada escapa ao uso fático convencional (pragmático) da linguagem, com os seus pressupostos intranscendíveis de validade universal, presentes implicitamente em todo discurso argumentativo. É nessa articulação dialética entre a referida dependência linguística e a pretensão de validade universal que se caracteriza o contorno geral da transformação e fundamentação pragmático-transcendental da linguagem ${ }^{449}$.

Com efeito, o aspecto principal dessa dialética entre dependência linguística e a pretensão de validade universal reside na transformação pragmático-transcendental da função do sujeito do conhecimento mediado por signos. O núcleo dessa transformação pode ser resumido do seguinte modo: enquanto intérprete de signos, o sujeito do conhecimento tem que entender-se a priori como membro de uma comunidade de comunicação e de interpretação real e, ao mesmo tempo, de uma comunidade ideal, pressuposta por antecipação contrafática; e isso não somente em relação à interpretação do mundo linguisticamente mediada, mas também em relação à sua autocompreensão (à evidência já sempre linguisticamente interpretada do "eu penso") ${ }^{450}$. Levando-se a cabo as transformações postuladas da filosofia transcendental, no sentido da base triádica da semiótica transcendental, resultam as seguintes soluções, típicas para o terceiro paradigma de filosofia primeira, para o problema da explicitação da verdade e do problema da fundamentação última. A solução do primeiro problema é aclarada por Peirce mediante a ideia regulativa de um consenso último, suposto como já não mais questionável pela crítica, da comunidade ilimitada de investigadores acerca da aceitação de hipóteses falíveis. O núcleo dessa solução reside em que

estético que se consubstancia no ideal pragmático). Esse ideal se dirige aos propósitos humanos coletivos, não aos particulares. E enquanto "meta completamente satisfatória, o ideal deve ser evolutivo, estando seu significado pleno apenas em um futuro distante, sempre buscado, mas sempre concretamente adiado. Um futuro idealmente pensável, mas materialmente inatingível na sua plenitude, porque só é aproximável assintoticamente". Peirce caracteriza esse ideal como "o crescimento contínuo da corporificação da potencialidade da idéia". "As idéias não são pensamentos materializados; elas são "certa potencialidade, certa forma que pode ou não ser encarnada num signo externo ou interno" (cf. pp. 81-82). Em relação ao desenvolvimento desse ideal pragmático, o interpretante lógico desempenha o papel de autocrítica e autocontrole da razão, por meio da avaliação das conseqüências referentes aos hábitos de ação. Porém, como o ideal pragmatista está em permanente devir, a mudança de hábito é aquilo que produz o deslocamento constante dos interpretantes dinâmicos na direção do interpretante final, que é uma meta idealmente pensável, mas concretamente inatingível (cf. SANTAELLA, Lucia. O Papel da Mudança de Hábito no Pragmatismo Evolucionista de Peirce, in: Cognitio, São Paulo, v. 5, n. 1, p. 75-83, jan./jun. 2004, pp. 75-83). .

${ }^{449}$ APEL, Paradigmas de filosofía primera, p. 162. APEL, Semiotica filosofica, p. 176.

${ }^{450}$ APEL, Paradigmas de filosofía primera, p. 162. APEL, Semiotica filosofica, p. 176. 
ela transcende a priori todo consenso fático pensável, embora o expondo à contínua crítica, sob a pressuposição de que é possível estabelecer novamente um consenso argumentativodiscursivo na comunidade de investigados sobre a base dos critérios de verdade disponíveis, que possivelmente se encontram em conflito.

A solução do segundo problema se assenta sob o entendimento de que, a partir da transformação pragmático-transcendental da função do sujeito do conhecimento mediado por signos, o "eu penso" se converte em "eu argumento", no sentido da função interpretativa de signos por parte do sujeito. Como essa função no discurso argumentativo é intranscendível, Apel entende que a fundamentação última deriva da interpelação pelas pressuposições do argumentar, cuja impugnação conduz a uma autocontradição pragmática (performativa) do argumentante. De tal modo, não se dogmatiza, como ocorre no paradigma metafísico, uma premissa (evidente) de uma inferência lógica. Tampouco se entende o dar-se pré-linguístico e pré-comunicativo do "eu penso", no sentido de uma evidência independente da interpretação, como no paradigma da filosofia transcendental clássica. Propriamente, em relação à fundamentação última, trata-se de indagar reflexivamente acerca das "certezas paradigmáticas" do jogo de linguagem da argumentação filosófica. Contudo, cabe esclarecer que o lugar da fundamentação última não é o de um jogo de linguagem historicamente contingente entre muitos outros quaisquer. Trata-se de um jogo de linguagem transcendental autorreflexivo, no qual já sempre se postula que é possível sustentar enunciados com pretensão de validade universal a priori sobre todos dos jogos de linguagem, por mais distintos que estes sejam. E, dado que os discursos filosóficos devem em geral ter sentido, os participantes sempre têm que pressupor também que neste jogo de linguagem as pretensões de validade universal, mostradas como duvidosas em outros jogos de linguagem, podem ser fundamentadas em um sentido não apenas convencional. Em suma, os filósofos tem que destacar, sob pena de autocontradição performativa, o jogo de linguagem próprio do discurso argumentativo como jogo de linguagem transcendental (ineliminável) ${ }^{451}$.

Para aclarar sua posição frente ao impasse da articulação entre a perspectiva pragmático-hermenêutica da linguagem e a reflexão transcendental e, assim, responder à pergunta pelas condições de possibilidade da argumentação válida, Apel se remete à teoria dos atos de fala de Austin. Isso se faz necessário porque ainda se observa que a validade intersubjetiva do sentido linguisticamente articulado está limitada, de todo modo, ao sentido

${ }^{451}$ APEL, Paradigmas de filosofía primera, pp. 163-164. APEL, Semiotica filosofica, pp. 177-178. 
explicável de maneira semântico-referencial ${ }^{452}$. A dimensão pragmática da linguagem cumpre funções "meramente pragmáticas" de expressão e apelação referentes a sintomas e sinais. A respeito disso, Apel tem reiterado que a separação entre o sentido linguístico semântico e o sentido linguístico meramente pragmático se mostra inaplicável, em relação às expressões usadas para identificar objetos reais da referência semântica das proposições (expressões com o teor de "o isto", "Diesheit" - isto ali, aqui, abaixo e semelhantes) Sobre isso, como já assinalado, Peirce mostra que a ação conjunta de signos conceituais ("símbolos") com "índices" e "ícones" na organização linguística da experiência representa a solução semiótica do problema aludido no lema kantiano: "a intuição sem conceitos é cega, os conceitos sem intuição são vazios". Pois, ainda que essas expressões só possam ser usadas em dependência de uma situação, elas implicam também uma significação semântica já estabelecida para tal uso, independentemente do uso atual, por meio das convenções de um sistema linguístico (de uma língua). A superação dessa separação requer uma compreensão do sentido linguístico, ao mesmo tempo, revestida do significado pragmático (denotatum) e do caráter semântico convencional (designatum). Ora, segundo Apel, o descobrimento das expressões e orações performativas, por J. L. Austin, refuta completamente a separação entre semântica referencial e pragmática.

A descoberta de Austin preconiza que o sentido pragmático-comunicativo dos atos de fala pode ser estabelecido já antes da expressão de uma oração, por meio do sentido convencional da oração. Tal como Austin concebe, a força ilocucionária da expressão das orações pode estar convencionalmente predeterminada por orações performativas ou por componentes performativos das orações. De tal modo, a descoberta de Austin põe em relevo que o logos semântico da linguagem natural é mais amplo que o logos, filosoficamente destacado a da partir de Aristóteles e Teofrasto, da representação de estados de coisas mediante proposições. O logos da linguagem natural eleva, por meio das expressões performativas ou dos componentes performativos das orações, também as funções comunicativas da linguagem ao plano do sentido simbolicamente articulado e, como tal, intersubjetivamente válido. Ademais, diferentemente do logos da linguagem artificial (formalizada) de orientação matemática - que orienta as análises de Frege, Russell, o primeiro Wittgenstein, Tarski e Carnap - e é limitado à função de representação e dedução no sentido da funcionalidade veritativa do sentido das orações, o logos da linguagem natural não exclui a autorreferência plena de sentido da intencionalidade autoconsciente do homem. A descoberta 
da estrutura performativa da linguagem, feita por Austin em sua teoria dos atos de fala, na interpretação de Apel, conota um alcance filosófico revolucionário no paradigma na filosofia da linguagem. E, para Apel, Austin não é autoconsciente da mudança revolucionária que representa a teoria dos atos de fala fundada por ele ${ }^{453}$.

Em um primeiro momento, Apel toma em consideração os distintos estágios do pensamento de Austin. Para Apel, inicialmente, Austin distingue entre atos locucionários, os quais concernem aos enunciados (afirmações, "staments") teórico-representativos, e os atos de fala descobertos por ele (Austin), os atos ilocucionários, por meio dos quais se executam ações sociais. Os atos locucionários são expressos por meios dos enunciados constatativos, cujo significado consiste em explicitar se são ou não verdadeiros (true/untrue). Os atos ilocucionários são expressos por meio dos enunciados performativos, marcados pela "força" pragmática para tornar a expressão das orações exitosa ou não (happy/unhappy). Esquematicamente, segundo Apel, essa distinção reflete a dicotomia entre a semântica referencial, no sentido do paradigma clássico, e o conceito puramente pragmático de "força", sobre cuja base o ato ilocucionário pode ser exitoso ou não. Assim, no começo da elaboração do seu pensamento, Austin supõe que os atos ilocucionários abrangem determinadas fórmulas performativas, mediante as quais se realizam certas ações no marco de instituições sociais, como por exemplo: "eu te batizo", "eu o designo". Segundo Apel, posteriormente, Austin assinala que a dicotomia entre atos locucionários e atos ilocucionários é insustentável. Ele descobre que a possibilidade de realizar ações sociais por meio dos performativos não se limita ao marco de determinadas instituições sociais. Pois, as próprias convenções linguísticas existentes funcionam como instituições da pré-estruturação sintático-semântica dos atos de fala; assim é, por exemplo, no caso "eu te prometo (por este meio) que...". Por fim, Austin considera que todos os atos locucionários possuem a força potencial dos atos ilocucionários formulados performativamente. Isso se evidencia, por exemplo, no caso da expressão da seguinte oração: "eu asseguro (por este meio) que chove". Essa elucidação põe em evidência que o significado, estabelecido por convenções linguísticas, não se limita à representação potencialmente falsa ou verdadeira de estados de coisas. Além disso, enquanto ato ilocucionário da comunicação, o significado também regula, de forma intersubjetivamente válida, a possível força pragmática da expressão das orações. De tal modo, a expressão de

${ }^{453}$ APEL, Semiotica filosofica, pp. 300-302. 
uma oração semanticamente significativa em um ato locucionário comporta, por si mesma, um ato ilocucionário ${ }^{454}$.

Por sua vez, Apel considera que a distinção fundamental apontada por Austin é insustentável. Segundo Apel, Austin introduz a seguinte distinção, sob a influência da semântica referencial clássica: o significado semântico de todas as orações da linguagem, inclusive das orações formuladas de maneira performativa, consiste na representação verdadeira ou falsa de estados de coisas; além disso, todos os atos locucionários devem possuir, todavia, uma força ilocucionária potencial, que pode ser explicitada por meio dos componentes performativos das orações. Criticamente, Apel considera que essa distinção é uma recaída no antigo paradigma semântico referencial da linguagem, que finda por restringir o alcance dos passos significativos, ligados à descoberta da estrutura performativa da linguagem, na direção de um novo paradigma ampliado da semântica. A distinção introduzida por Austin, segundo Apel, conduz a uma aporia. Essa aporia se evidencia, por exemplo, quando se explicita performativamente uma oração afirmativa. Por um lado, para Austin, a oração "eu afirmo (por este meio) que chove" tem o mesmo significado que a oração "chove" (considerada como uma afirmação verdadeira). Aqui, à medida que a primeira oração apenas explicita a "força" potencial da segunda oração, nada varia quanto ao valor de verdade da oração afirmativa. Por outro lado, também o significado semântico da parte da oração "eu afirmo (por meio deste) que..." tem que residir em seu valor de verdade. Ora, segundo Apel, esses dois pressupostos não resultam compatíveis entre si. Pois, a oração "é o caso que eu afirmo (por este meio) que chove" tem um valor de verdade distinto que o da oração "chove", visto que uma das orações pode ser verdadeira sem que a outra o seja. O mais razoável, segundo Apel, é considerar a possibilidade de recusar a hipótese de que a potencial força ilocucionária possa se tornar explícita por meio de um componente performativo da oração sem alterar o seu significado ${ }^{455}$.

A solução da dificuldade de Austin reside, segundo Apel, no ponto de vista que considera a estrutura de complementaridade do significado preposicional e do significado performativo das funções comunicativas da linguagem. Essa perspectiva sustenta a tese de que as orações da linguagem natural têm, diferentemente das orações funcionalmente entendidas de uma linguagem artificial (lógico-matemática), a dupla estrutura performativoproposicional, que é sintático e semântico. Isto vale implicitamente para toda oração, contanto

\footnotetext{
${ }^{454}$ APEL, Semiotica filosofica, pp. 302-305.
}

455 APEL, Semiotica filosofica, pp. 305-307. 
que expressa como ato de fala; e vale explicitamente para orações da seguinte forma "eu afirmo (por este meio), que p". Sob o patamar dessa tese, a explicação clássica do significado linguístico no sentido da semântica referencial vale somente para o componente proposicional "p" de cada oração. Quanto ao componente performativo vale que nele, sobre a base das convenções do sistema linguístico, está semanticamente pré-estruturada a força potencial pragmática da oração (seu papel ou função ilocucionária no nível comunicativo). Com esta solução, mostra-se que o logos semântico da linguagem natural não pode ser definido, em seu conjunto e de maneira satisfatória, apenas com o significado proposicional, senão que mediante a estrutura complementária proposicional-performativo. Nisso se mostra que as duas funções comunicativas podem ser expressas mediante "símbolos" linguísticos e não meramente por meio de "sintomas" ou "sinais". A posse dessa dupla estrutura, que falta aos animais, é o que constitui precisamente a relevância do logos na linguagem humana ${ }^{456}$.

Entendendo que a ampliação da semântica para-além da semântica referencial só pode ser levada a cabo no marco de uma pragmática transcendental da linguagem, Apel explicita o conteúdo da dimensão performativa do discurso argumentativo. Para tanto, ele parte da ideia de que a existência de pretensões de verdade levantadas pelos homens, que podem ser explicitadas performativamente, constitui a condição de possibilidade pragmáticotranscendental do conceito abstrato de verdade (proposicional). E isso se mostra até no caso do predicado metalinguístico proposicional "é verdadeiro", o qual não resulta compreensível sem a pressuposição da existência de uma pretensão de verdade autorreferencial e performativa, que pode ser posta em questão e tematizada no discurso ${ }^{457}$. Então, partindo da dupla estrutura performativo-proposicional da linguagem explicitada por Austin, Apel inventaria as pretensões de validade transcendentais (implícitas e inelimináveis) relativas ao componente performativo do discurso, a saber, pretensão de verdade, pretensão de correção normativa eticamente relevante, pretensão de veracidade (sinceridade) e a pretensão de sentido $^{458}$.

$\mathrm{Na}$ compreensão de Apel, o componente performativo das orações, semanticamente autorreferencial, não concerne exclusivamente a uma pretensão de verdade. Isso se evidencia quando se considera a oração da forma "eu afirmo (por este meio) que p", por meio da qual se levanta não somente uma pretensão de verdade, mas também uma pretensão de correção normativa eticamente relevante. A pretensão de verdade é levantada em

\footnotetext{
456 APEL, Semiotica filosofica, pp. 311-312.

457 APEL, Semiotica filosofica, pp. 307-310.

458 APEL, Semiotica filosofica, p. 318.
} 
referência à proposição "p”, que é afirmada. Por sua vez, a pretensão de correção normativa é levantada em referência à própria pretensão de verdade das proposições; ela é formulada performativamente, na medida em que se dirige, enquanto pretensão, ao(s) interlocutor(es) da comunidade, cumprindo a função apelativa dos atos comunicativos. $\mathrm{O}$ aspecto característico da pretensão de correção normativa subsiste no fato de que essa pretensão é levantada somente de forma indireta. Mesmo quando se intenta levantá-la explicitamente, mediante a oração da forma "eu te exijo (por meio disto) que p" (por exemplo, "eu te exijo que aceite ou discuta com argumentos a pretensão de verdade da minha afirmação que p"), também aí o falante se compromete igualmente a fundamentar a pretensão de verdade de sua afirmação com argumentos. Finalmente, com a oração "eu afirmo (por este meio) que p" se levanta, implicitamente, uma pretensão de veracidade (sinceridade). Essa pretensão se torna clara quando a afirmação é questionada por um interlocutor (ou seja, "pensas seriamente assim a respeito do que está dizendo com isso?). Em tal caso, o falante pode tornar explícita sua pretensão de veracidade por meio de uma oração da forma "eu te asseguro que creio efetivamente que p é verdadeira" ${ }^{459}$.

De tal maneira, pontua Apel, é possível formular, por meio das orações autorrefenciais, explicitamente performativas, três pretensões de validade necessárias e universais dos atos de fala comunicativos, isto é, do discurso humano. Em síntese, essas pretensões ${ }^{460}$ são: 1) a pretensão de verdade intersubjetivamente válida das proposições; 2) a pretensão de correção normativa intersubjetivamente válida, em vista da justificação ou da legitimidade, dos atos de fala enquanto atos sociais de comunicação; 3) a pretensão de reconhecimento interpessoal da veracidade (sinceridade) referente à expressão das intenções subjetivas. De forma original, Apel concebe que essas três pretensões de validade universal do discurso (logos) são necessárias e inelimináveis (intranscendíveis), pois não podem ser impugnadas sem cometer uma autocontradição performativa. É por essa razão, assinala Apel, que ele as denomina não somente pragmático-universais (Habermas), mas também pragmático-transcendentais. Para Apel, a articulação linguística das três pretensões de validade pressupõe, por sua vez, a validade de sentido não apenas semântico referencial, mas intersubjetivamente vinculante da linguagem. Trata-se de uma quarta pretensão igualmente universal de validade intersubjetiva do discurso, que se encontra fixada no logos semântico da

\footnotetext{
${ }^{459}$ APEL, Semiotica filosofica, pp. 312-313.

${ }^{460}$ Sobre as pretensões de sentido e validade, ver: APEL, Significado lingüístico e intencionalidad in: Semiotica filosofica, p. 258. HABERMAS, Jürgen. Teorías de la Verdad. In: Teoría de la acción comunicativa: complementos y estudios previos. Trad. Manuel Jiménez Redondo. Madrid: Ediciones Cátedra, 1989, pp. 113158.
} 
linguagem. Essa última pretensão, salienta Apel, é a mais fundamental, pois constitui a condição de possibilidade das pretensões de validade universais do discurso referidas à verdade, à correção normativa e à veracidade. Em tal medida, ela não apenas possibilita a validade intersubjetiva das proposições verdadeiras, mas também a validade intersubjetiva das intenções humanas de sentido geral, tanto no sentido da afirmação de proposições verdadeiras, como no sentido da apelação comunicativa justificada e da auto-expressão $\operatorname{veraz}^{461}$.

Para Apel, à luz da reflexão pragmático-transcendental do discurso, demonstra-se que o logos semântico da linguagem natural, por expressar a intenção autorreferencial de sentido dos homens, é mais amplo que o logos abstrato da função representativa das proposições. Algumas razões demonstram essa ampliação. Primeira, esse logos traz à luz, além do sentido lógico-semântico, também o sentido criteriológico-pragmático do conceito metalinguístico de verdade das proposições. Vê-se isso quando se supõe performativamente a justificação discursiva da validade intersubjetiva da pretensão subjetiva de verdade, enquanto princípio regulativo da formação fundamentada do consenso sobre os critérios de verdade em uma comunidade de argumentação ilimitada e ideal. A formação do consenso, enquanto ideia regulativa, deve tomar em conta todos os critérios concebíveis de verdade, tais como o da correspondência, da evidência e da coerência. Em tal medida, no conceito consensual e pragmático transcendental de verdade se "superam" todos os conceitos tradicionais de verdade $^{462}$. Em Peirce, a verdade, como validade intersubjetiva do conhecimento, só pode ser assegurada definitivamente por meio de um processo, em princípio, ilimitado de reinterpretação e de formação de consenso na comunidade indefinida de investigadores. Segunda, esse logos, à medida que desvela as pretensões de sinceridade e de correção normativa, simultaneamente, põe em evidência a dimensão ética. Trata-se de uma dimensão que o sujeito carrega de forma implícita, como pretensão de validez performativa, em sua relação discursiva perante si mesmo e os cossujeitos participantes do discurso. Terceira, a função expressiva, simbolicamente articulável, do logos semântico do discurso incorpora, junto à função eticamente relevante da sinceridade, uma dimensão de validade que é esteticamente relevante. Essa dimensão concerne à possibilidade de autenticidade da

\footnotetext{
${ }^{461}$ APEL, Semiotica filosofica, p. 315.

${ }^{462}$ APEL, Semiotica filosofica, p. 316.
} 
expressão das vivências subjetivas, sob a expectativa de que possa ser representativa da abertura, formalmente alcançada, do sentido do mundo da vida ${ }^{463}$.

O logos do discurso, tendo ampliado a dupla estrutura da linguagem por reflexão pragmático-transcendental sobre o logos da linguagem, em sua pretensão de validade universal de sentido, remete-se sempre a cada uma das dimensões do mundo, a saber, o mundo objetivo, o mundo intersubjetivo e o mundo interior subjetivo. De tal modo, esse logos se remete sempre a três dimensões da validade universal. A pretensão de validade de sentido do discurso humana só pode ser explicitada e posta em questão, mediante uma "crítica do sentido", tendo em vista essas três dimensões do mundo e da validade (verdade, correção normativa e veracidade). A ampliação pragmático-transcendental do logos do discurso resulta também na ampliação nada trivial do critério de verificação ou falsificação das proposições afirmadas, ao passo que adiciona ao significado semântico-referencial três pretensões de validade dos atos de fala. Na perspectiva dessa ampliação, por exemplo, é possível compreender como pleno de sentido os testemunhos da crença humana, enquanto expressão sincera (veraz) das convicções vividas (caso da religião como "expressão de vida"), mesmo quando não é possível apresentar nenhuma condição de verificação ou falsificação relevante ${ }^{464}$.

$\mathrm{Na}$ linha da tese referente à dupla estrutura performativo-proposicional do discurso argumentativo, Apel afirma que a função representativa das proposições se fundamenta desde sempre na determinação interpretativa da validade do sentido dos símbolos por meio do uso comunicativo. Se, por um lado, a concepção clássica de linguagem como representação induz a pensar em uma reprodução puramente teórica de estado de coisas, por outro, há que se considerar que a abertura à significação, facultada pela função comunicativa da linguagem, já aparece testemunhada no conteúdo e valoração antropocêntrica dos significados das palavras na linguagem cotidiana, bem como nas categorias da ciência, que mostram uma pré-compreensão dos interesses cognitivos que dirigem internamente o conhecimento. Diferentemente de uma reprodução puramente teórica de estados de coisas, a fixação implícita e interpretativa do sentido dos símbolos conceituais no nível comunicativo do mundo da vida põe em evidência, sempre e ao mesmo tempo, uma relação prática e interessada dos homens com o mundo em suas três dimensões: o mundo objetivo, o mundo intersubjetivo e o mundo subjetivo. Em correspondência com isso, o sentido dos símbolos

\footnotetext{
463 APEL, Semiotica filosofica, p. 317.

${ }^{464}$ APEL, Semiotica filosofica, pp. 317-318.
} 
comporta o resultado de um entendimento intersubjetivo implícito sobre a interpretação do mundo nas dimensões do mundo objetivo, do mundo intersubjetivo e do mundo subjetivo.

No nível do discurso argumentativo é possível questionar, criticamente, tanto a verdade das proposições, quanto sua pretensão de validade de sentido. A argumentação não consta, em última instância, de proposições abstratas, senão que de atos de fala que podem ser explicitados semanticamente. Se isso não fosse assim, tampouco seria possível entender a razão pela qual o discurso argumentativo da ciência deve já sempre pressupor uma ética. No nível da derivação lógica das proposições, além de não ser possível qualquer fundamentação última racional das normas, também não resulta evidente em que medida ela seria necessária. Posto que, aí cada qual pode pensar por si mesmo, sem ter que assumir obrigações éticas para com os outros. Outra coisa é o que ocorre no nível do discurso argumentativo, que está ligado à dupla estrutura performativo-proposicional dos atos de fala. Nesse nível, o discurso, próprio da crítica e da virtual justificação das pretensões de sentido e verdade, depende de condições normativas que estão subordinadas, do mesmo modo que as pretensões de sentido e verdade dos atos de fala, ao critério da aptidão para um consenso ilimitado. A tentativa de negar isto, por conseguinte, conduz a uma autocontradição por parte de quem argumenta. Todavia, essa contradição não diz respeito a uma contradição lógico-matemática entre proposições puras (“A e não-A"). Trata-se de uma contradição pragmática, produzida quando o falante concretiza o descompasso entre a proposição enunciada por ele e a pretensão perfomativoreflexiva dessa proposição. Essa contradição, segundo Apel, tem o status de um critério negativo da racionalidade na fundamentação última do logos filosófico. Daí, somente a ampliação da relevância do logos na linguagem humana, no sentido da dupla estrutura performativo-proposicional, oferece a possibilidade de compreender reflexivamente a intranscendibilidade argumentativa da razão linguisticamente articulada e, assim, o próprio $\log o s^{465}$.

\subsection{O enfoque dialético da semiótica transcendental como mediação da razão teórica e da ação ética}

A "transformação da filosofia" desenvolvida por Apel no sentido da semiótica transcendental comporta a pretensão de ser uma perspectiva filosófica capaz de fazer a mediação entre teoria e práxis. Em Apel, essa pretensão se liga à discussão relativa à

\footnotetext{
${ }^{465}$ APEL, Semiotica filosofica, pp. 327-330.
} 
superação ou transformação da filosofia. Ao mesmo tempo, de uma maneira provocativa, ela se conecta à problemática da "agonia" ou "decadência" da própria filosofia, pois a expectativa de subordinar o bom êxito da "superação da filosofia" à sua "realização efetiva", quer dizer, ao momento em que o mundo se tornasse filosófico, fulgura na contemporaneidade como um horizonte longínquo. No tocante ao "engajamento total da filosofia, muito mais ainda há de se esperar hoje do que antes por tal superação da filosofia" ${ }^{466}$. Ocorre que, em face de esse distanciamento da "superação" bem-sucedida da filosofia, surge a discussão acerca da refuncionalização (e institucionalização) da filosofia "impotente", em que a filosofia aparece como uma ilha de comunicação "para aquém ou para além da política" 467 . Frente ao presságio do "fim" da filosofia, à primeira vista, a ideia de uma institucionalização da filosofia impotente insurge como uma perspectiva necessária e até consoladora à filosofia.

Mas, analisando a questão, Apel afirma que nessa aparição da filosofia impotente se revela uma face de aparência de identidade da própria atividade filosófica. Essa a ausência de identidade se perfaz por conta da suposta separação entre a ilha de comunicação filosófica, pretensamente quase livre de dominação e purificada do tipo de interação que tenta resolver os conflitos por via da violência, e a comunidade de comunicação de seres humanos. Junto a isso, tal identidade também não passa de aparência, porque cada um de nós, como seres humanos, permanece preso aos reais interesses da sociedade, ainda alienada e dividida em classes e partidos. Conforme pontua Apel, tal situação põe em cena um debate no qual interpela: a) se a institucionalização da comunicação humana, como filosofia, constitui um velamento da realidade e, como tal, tende a ser mera ilusão; b) se a determinação dos pensadores radicais e eloquentes deve substituir a "comunidade filosófica impotente e ilusória" por uma "comunidade real da solidarização total em meio ao engajamento político" 468. Com efeito, Apel entende esse debate se apoia em uma crença ilusória, qual seja a crença de supor-se capaz de "firmar e atualizar, no engajamento total de uma solidarização (Solidarisierung) efetiva, a identidade de comunicação humana e emancipada, apenas antecipada pela filosofia" 469 .

Em relação a esse debate, Apel defende uma tese de caráter duplo. Trata-se de que nem a comunidade de comunicação de filósofos pode considerar-se a si mesma como uma efetivação da filosofia, tampouco pode considerar-se uma realização política qualquer da

\footnotetext{
${ }^{466}$ APEL, Transformação da filosofia, v. I, p. 12; Transformation der Philosophie, Band I, p. 09.

${ }^{467}$ APEL, Transformação da filosofia, v. I, p. 12; Transformation der Philosophie, Band I, p. 10.

${ }^{468}$ APEL, Transformação da filosofia, v. I, pp. 12-13; Transformation der Philosophie, Band I, p. 10.

${ }^{469}$ APEL, Transformação da filosofia, v. I, p. 13; Transformation der Philosophie, Band I, p. 10.
} 
solidariedade humana como efetivação da filosofia. Isso deve de tal modo porque, do contrário, em virtude da realização política, a filosofia precisa abandonar "a posição de 'um discurso teórico' [Theoretischer Diskurs] que seja capaz de antecipar, como instância de justificação e validação, o consenso ideal [idealer Konsensus] da humanidade emancipada e de contrapor esse consenso, a título de experiência, a todo tipo de dogmatização" ${ }^{470}$. Não se pode desconsiderar que existe o risco de que a filosofia, em prol de uma dogmatização política, necessariamente abandone essa posição e venha a se identificar com o momento da práxis social "aqui e agora". O motivo pelo qual a filosofia tem de permanecer impotente é que, segundo Apel, na forma do discurso teórico, ela deve firmar, ao menos até que aconteça sua superação pela via da sua realização, o momento da antecipação contrafactual do consenso ideal de todos os seres humanos ${ }^{471}$.

$\mathrm{Na}$ visão de Apel, a perspectiva da filosofia como discurso teórico que antecipa contrafaticamente o consenso ideal entre os seres humanos não implica em uma distinção estático-ontológica entre política e filosofia, entre teoria e práxis. Há que se considerar que no âmbito da fragmentação das ciências particulares e da racionalidade metódica, uma das tarefas essenciais da filosofia consiste em fundamentar criticamente as abstrações da teoria das ciências particulares, levando em consideração os interesses cognitivos humanos. Apel entende que essa tarefa implica em que a filosofia busque novamente uma mediação entre teoria e práxis ${ }^{472}$. Ocorre que, pensar a filosofia em tal horizonte significa tematizá-la sob a perspectiva da exigência de uma "transformação da filosofia" em vista da sua "superação" (realização efetiva). O desafio duplo que se abre já no marco da discussão relativa à transformação da filosofia é o de fazer com que a comunidade de comunicação da filosofia seja capaz de organizar o discurso teórico de tal forma que ele, por uma parte, não mais se desintegre em antecipações solipsistas e perspectivistas da verdade definitiva por meio de visões de mundo dos "grandes pensadores" e, por outra, direcione o olhar à efetivação da filosofia como mediação entre teoria e práxis na sociedade humana ${ }^{473}$. Em consequência a esse desafio, surge a dificuldade de saber "como chegar" a isso por meio da transformação da filosofia. Depois de décadas dedicadas a tal tarefa, sabe-se agora que a tentativa de responder a esse desafio, em Apel, toma a forma da semiótica transcendental ${ }^{474}$.

\footnotetext{
${ }^{470}$ APEL, Transformação da filosofia, v. I, p. 13; Transformation der Philosophie, Band I, p. 11.

${ }^{471}$ APEL, Transformação da filosofia, v. I, p. 13; Transformation der Philosophie, Band I, p. 11.

${ }^{472}$ APEL, Transformação da filosofia, v. I, p. 14; Transformation der Philosophie, Band I, p. 11.

${ }^{473}$ APEL, Transformação da filosofia, v. I, pp. 14-15; Transformation der Philosophie, Band I, pp. 11-12.

${ }^{474}$ APEL, Transformação da filosofia, v. I, pp. 14-15; Transformation der Philosophie, Band I, pp. 11-12.
} 
Em sua caminhada pela transformação da filosofia, Apel parte da concepção da formação de consensos na comunidade de experimentação e interpretação dos cientistas de Peirce. Na ótica de Apel, o que justifica esse ponto de partida é o fato de que tal concepção constitui a "primeira noção" de como se deve conceber filosoficamente uma transformação da filosofia dos grandes pensadores. No sentido de Peirce, essa comunidade, enquanto representante da racionalidade metódica das ciências naturais, cumpre a função de construir, de forma metodologicamente controlável e como concretização do sujeito transcendental de Kant, o consenso acerca da verdade, até então imposto pelo método da autoridade na época que antecede o método apriorístico. Na linha da história da filosofia, essa concepção aparece como uma "terceira era" da filosofia, cuja marca fundamental é o "método da ciência" que vem substituir as eras do apriorismo solipsista de evidências dos grandes pensadores individuais e do método de autoridade. Não obstante, segundo Apel, o ponto problemático dessa concepção é que, ao conceber o problema da substituição da autoridade pública e privada pelo consenso alcançado pela comunidade de experimentação e interpretação dos cientistas, aporeticamente, a transformação preconizada por Peirce não escapa à redução da racionalidade metódica aos parâmetros do método experimental das ciências naturais, aliás, praticado por ele. Assim, Peirce chega a um patamar de transformação da filosofia ainda segundo a redução cientificista. Nisso, a aporia do cientificismo peirceano, na visão de Apel, põe a nu o problema central de uma transformação da filosofia na era da ciência ${ }^{475}$. Segundo Apel, o próprio Peirce reconhece tardiamente que não é possível deduzir a partir de uma normatização tecnológica do "esclarecimento de ideias" no sentido da "máxima pragmática" a racionalidade moralmente relevante do comportamento humano. E que, ao contrário disso, trata-se de pressupor uma racionalização moral relevante do comportamento humano para que se proceda à fundamentação de uma lógica científica normativa ${ }^{476}$.

Como dito, segundo Apel, a redução cientificista constitui o problema central da filosofia na época da ciência, posto que tal redução impossibilita uma fundamentação racional da razão prática e, com isso, inviabiliza a efetivação da filosofia como mediação entre teoria e práxis na sociedade humana. Em sua análise, Apel salienta que a solução para esse problema é igualmente malograda, seja por parte dos que pretendem "superar a filosofia" por meio da sua redução à lógica científica, seja por parte dos que insistem em recorrer à "grande filosofia" (dos “grandes pensadores"), "ignorando o grande paradigma do método científico e a

\footnotetext{
475 APEL, Transformação da filosofia, v. I, pp. 15-16; Transformation der Philosophie, Band I, pp. 12-13.

${ }^{476}$ APEL, Transformação da filosofia, v. I, p. 16; Transformation der Philosophie, Band I, p. 13.
} 
racionalização (parcial) da interação e comunicação humanas aí pressuposta" ${ }^{\text {"77 }}$. No caso destes últimos, do ponto de vista da racionalidade metódica da ciência, tal opção parece perder-se em meio ao irracional ou conotar apenas um descomprometimento privado.

Antes de apresentar sua proposta de solução ao problema da redução cientificista e assim delinear uma perspectiva de superação da distinção entre teoria e praxis, Apel procura indenticá-lo no contexto atual da filosofia. Na interpretação de Apel, contemporaneamente, a aporia peirceana do cientificismo surge de forma mais nítida na filosofia da "sociedade aberta” de Karl R. Popper, orientada pela metodologia científica ${ }^{478}$. Popper, como Peirce, extrapola o paradigma normativo do método científico, concebendo-o como uma filosofia da sociedade e do progresso histórico possível capaz de se mostrar ética e politicamente relevante. Contudo, há uma diferença fundamental entre ambos. Comparado à transformação semiótico-pragmática de Kant por Peirce, o enfoque metodológico de Popper derruba, em grande medida, a reflexão sobre os pressupostos transcendentais do conhecimento. Conforme Apel, "Popper considera menos que Peirce" a circunstância de que "não se pode conceber a ideia de uma filosofia crítica da sociedade", à qual importa o consenso interpessoal sobre as necessidades e fins, "simplesmente como uma generalização do ideal metódico das ciências naturais e de sua referência tecnológica à práxis" ${ }^{479}$. Ao analisar a estratégia de extrapolação da racionalidade crítica do paradigma científico adotada por Popper, em uma perspectiva crítica, Apel identifica nessa extrapolação a coexistência de dois tipos de falácias abstrativas que obstaculizam a mediação entre teoria e práxis.

Em sentido mais estrito, a primeira falácia abstrativa concerne à falácia cientificista-tecnicista $^{480}$. Ela consiste em agregar o ideal metódico da ciência unitária e a tecnologia social (social engineering), para fazer de ambos o fundamento da racionalidade crítica na política social de uma "sociedade aberta". Avaliando essa falácia, inicialmente, Apel observa que é ingênuo supor que se pode prescindir na sociedade industrial moderna de uma tecnologia social fundamentada sobre ciências empírico-analíticas; ao lado disso, do ponto de vista científico-teorético, que é um equívoco supor que o pressuposto ideal da tecnologia social se encontra no modelo da "sociedade aberta". No entender de Apel, efetivamente, esse pressuposto está presente na sociedade tal como ela se compõe em suas estruturas de dominação (estáveis e arcaicas) e com “indivíduos informados e desinformados,

\footnotetext{
477 APEL, Transformação da filosofia, v. I, p. 16; Transformation der Philosophie, Band I, p. 13.

478 APEL, Transformação da filosofia, v. I, p. 16; Transformation der Philosophie, Band I, p. 13.

479 APEL, Transformação da filosofia, v. I, p. 16; Transformation der Philosophie, Band I, p. 13.

480 APEL, Transformação da filosofia, v. I, pp. 17-19; Transformation der Philosophie, Band I, pp. 14-15.
} 
manipuladores e manipulados, sujeitos e objetos da ciência e da tecnologia"481 . Na contramão do que apregoa o racionalismo crítico de Popper, a tecnologia social não atinge seu melhor funcionamento quando o maior número possível de cidadãos responsáveis participa da discussão bem informada sobre os fins e as normas, procedendo assim segundo uma espécie de "convencionalismo crítico". Diversamente, Apel pensa que, sob tais circunstâncias, o melhor funcionamento de uma tecnologia social aliada à ciência unitária aparece "quando se pode reduzir", da maneira mais ampla possível, "os objetos comportamentais da tecnologia" à condição (status) de "meros objetos sem voz" ("den Status stummer Naturobjekte") da elucidação, "que se deixam pesquisar em experiências repetíveis, bem como se manipular de maneira instrumental, de acordo com fins estabelecidos de antemão" ${ }^{482}$.

Com base no exposto acima, Apel pondera que o modelo repetível de "tentativa e erro" da ciência unitária, sob o pressuposto da relação sujeito-objeto, tende a ser suficiente para conceber os processos bem-sucedidos de aprendizagem (Lernprozesse) dos seres vivos (“desde a ameba até Einstein"), assim como os avanços "no trabalho intelectual pré-científico, na ciência, na técnica e na política social" ${ }^{\prime 83}$. Mas, aceitando-se isso, problematicamente, fica evidente a impossibilidade de uma "sociedade aberta" de cidadãos responsavelmente engajados no processamento das informações técnico-científicas e no direcionamento éticopolítico da sociedade. Não se pode vislumbrar a "melhoria da tecnologia social" por meio do controle prognóstico do feedback de objetos sociais bem-informados, no sentido de uma estabilização prática da relação sujeito-objeto. Para Apel, por trás dessa impossibilidade que resulta do ideal metódico da ciência unitária emerge um problema muito mais complexo. Trata-se do problema de "organizar a comunicação e interação - em princípio, irrepetíveis dos cidadãos como sujeitos do progresso rumo à 'sociedade aberta', no sentido do princípio da racionalidade crítica" ${ } 484$. Isso implica, entre outras coisas, em organizar o acordo mútuo intersubjetivo relacionado à "inevitável objetivação técnico-científica do comportamento humano a serviço de medidas sociotecnológicas", que devem ser, simultaneamente, “controláveis em sua efetividade e assumidas pelos cidadãos enquanto sujeitos virtuais" 485 . E quanto a isso, Apel salienta que a organização desse acordo não é ela mesma uma medida sociotecnológica, e tampouco pode apoiar-se sobre os resultados de uma ciência que tenha tratado os sujeitos desse entendimento como meros objetos da elucidação empírico-analítica

\footnotetext{
${ }^{481}$ APEL, Transformação da filosofia, v. I, p. 17; Transformation der Philosophie, Band I, p. 14.

${ }^{482}$ APEL, Transformação da filosofia, v. I, p. 17; Transformation der Philosophie, Band I, p. 14.

${ }^{483}$ APEL, Transformação da filosofia, v. I, pp. 17-18; Transformation der Philosophie, Band I, p. 14.

${ }^{484}$ APEL, Transformação da filosofia, v. I, p. 18; Transformation der Philosophie, Band I, p. 15.

${ }^{485}$ APEL, Transformação da filosofia, v. I, p. 18; Transformation der Philosophie, Band I, p. 15.
} 
do comportamento. Concretamente, a organização desse acordo concerne à atividade de "fixar em conjunto, e com base em argumentos, o sentido e os limites de todas as medidas sociotecnológicas" ${ }^{486}$. Em positivo, Apel entende que essa atividade requer uma perspectiva de filosofia ou teoria epistemológica que trate o problema da organização da comunicação e interação não apenas como um problema de controle de feedback, mas repense tal problema a partir do reconhecimento que os homens são simultaneamente sujeitos e objetos da ciência e tecnologia. Procedendo assim, em lugar de um problema de controle de feedback, pensa-se sob o horizonte de um "problema de princípio", ou seja, um problema "afeto à reflexão transcendental sobre as condições de possibilidade e validade de um conhecimento não apenas relativo às ciências naturais e uma práxis não meramente técnica" ${ }^{487}$.

A segunda falácia se correlaciona à pretensão de substituição de uma fundamentação "filosófica" última por um postulado da crítica virtualmente universal. Aqui, a extrapolação do ideal científico do método no âmbito do racionalismo crítico tende a se situar no método da argumentação crítica, por meio do qual a comunidade dos cientistas é elevada à condição de paradigma de uma "sociedade aberta" 488 . Na suposição dessa elevação, o racionalismo crítico se deloca para perto de Peirce, segundo Apel, à medida que defende o programa de uma filosofia metódica empenhada na ampliação do conceito de racionalidade por meio do exercício metódico do diálogo. Com essa abordagem no plano da comunicação interpessoal, dá-se um passo essencial rumo à ampliação do programa de uma transformação da filosofia ligada à ciência. Entretanto, segundo Apel, nesse programa se manifesta uma segunda forma de cientificismo, que pode ser tipificada como falácia abstrativa. Apel entende que esse programa incorpora a perspectiva de autorrenúncia (selfsurrender), no sentido de Peirce, como fator de distinção da comunidade científica. Isso consiste na exigência de que cada cientista, por meio de exercícios sistemáticos, tenha se apropriado da capacidade de se abstrair de necessidades e interesses individuais, e que ele se coloque, "como sujeito substituível de experimentos repetíveis e de operações conceptuais lógico-matemáticas, à disposição do progresso institucionalizado rumo à verdade, no âmbito de uma 'comunidade ilimitada de pesquisadores" "489. Por conta dessa exigência de autorrenúncia, assim avalia Apel, a "crítica" realizada na comunidade argumentativa dos cientistas se refere unicamente às operações conceituais e cognitivas tuteladas pelo interesse cognitivo das ciências naturais.

\footnotetext{
${ }^{486}$ APEL, Transformação da filosofia, v. I, p. 18; Transformation der Philosophie, Band I, p. 15.

${ }^{487}$ APEL, Transformação da filosofia, v. I, pp. 18-19; Transformation der Philosophie, Band I, p. 15.

${ }^{488}$ APEL, Transformação da filosofia, v. I, pp. 19-26; Transformation der Philosophie, Band I, pp. 15-22.

${ }^{489}$ APEL, Transformação da filosofia, v. I, p. 20; Transformation der Philosophie, Band I, pp. 16-17.
} 
Além disso, ela se isenta de qualquer referência às necessidades e interesses concretos dos seres humanos socializados que, de qualquer modo, constituem a base do interesse cognitivo das ciências naturais. De tal modo, o cientificismo tecnocrático elimina precisamente o que perfaz a dificuldade do acordo mútuo inter-humano e da emancipação almejadas na sociedade concreta. Tal exigência resulta no seguinte paradoxo: sob o limite condicionado pelo axioma da "ciência unitária" e da "metodologia unitária", em lugar do cientificismo tecnocrático produzir uma "sociedade aberta", no sentido de uma sociedade compreendida como sujeito do acordo e da emancipação humanas, à medida que aí se prevê uma comunidade científica argumentativa já fixada em conformidade com os moldes dos métodos científico-tecnológicos voltados ao objeto e sob o pressuposto de que o saber disponível mediado por ela representa o interesse cognitivo da sociedade, contraditoriamente, ele trata a sociedade como objeto de medidas planificadas e reformas tecnológicas ${ }^{490}$.

Aqui, antes de explicitar a contraposição apeliana a essas falácias, em relação a essa segunda falácia, faz-se necessário esclarecer o ponto de vista de Apel em relação à questão da fundamentação última. Pois bem, a semiótica transcendental de Apel, empreendendo o encontro da tradição analítica e da tradição da filosofia transcendental kantiana, apresenta uma proposta de reformulação da problemática da fundamentação, a qual se delineia na direção de uma reflexão estrita sobre as condições de possibilidade e validade da argumentação. Nessa direção, a semiótica transcendental cumpre a função teóricocientífica de desenvolver uma reflexão sobre as condições não-contingentes do conhecimento contingente válido e também das convenções ${ }^{491}$ e, com isso, projetar uma alternativa de fundamentação universal e última, baseado nos pressupostos do jogo de linguagem da filosofia, que contrasta com a fundamentação da lógica formal, das ciências empíricas e da metafísica tradicional. Essa alternativa se contrapõe diretamente ao "programa de crítica racional ilimitada" defendido pelo racionalismo crítico da escola popperiana, que, com base no princípio epistemológico do falibilismo, sustenta a tese da impossibilidade de uma fundamentação última. Na linha da escola popperiana, Hans Albert preconiza a tese de que todas as teses devem ser consideradas como hipóteses ${ }^{492}$. Disso procede a necessidade de sacrificar a tendência à certeza, que é o fundamento da doutrina clássica, e conformar-se com

\footnotetext{
${ }^{490}$ APEL, Transformação da filosofia, v. I, pp. 21-22; Transformation der Philosophie, Band I, pp. 17-18.

491 APEL, Karl Otto. El Problema de la fundamentación última desde una pragmática transcendental del lenguaje. In: Estudios Filosóficos. Trad. Noberto Smilg. N. 102, pp. 251-299, 1987, cf. p. 264. Ver: OLIVEIRA, Sobre a fundamentação, pp. 57-60.

${ }^{492}$ APEL, Teoría de la verdad y ética del discurso, p. 114. APEL, Fallibilismus, Konsenstheorie der Wahrheit und Letztbegründung. In: Philosophie und Begründung, p. 174.
} 
a incerteza permanente de saber se as concepções serão confirmadas no futuro e, em tal caso, mantidas. Ele aceita inclusive a auto-aplicação da sentença "tudo é falível"; tal não produz antinomia nem leva à falsidade, pois nessa sentença emerge apenas a conseqüência de que ela mesma é, em princípio, sujeita a dúvidas e, portanto, compatível com sua retidão absoluta ${ }^{493}$. Na perspectiva de Hans Albert, o intento de uma fundamentação última conduz a um trilema, designado por ele como o trilema de Münchhausem. Neste sentido, Albert afirma que a pretensão de uma fundamentação última conduz a três alternativas inaceitáveis, quais sejam: a primeira, ou se cai num regresso ao infinito dada a necessidade de busca contínua do fundamento; a segunda, ou em um círculo lógico (petitio principii); a terceira, ou se interrompe o encadeamento de fundamentação adotando determinadas premissas como $\operatorname{dogmas}^{494}$.

Como contraponto a esse programa, Apel explicita que o problema da fundamentação última não pode ser concebido como um problema puramente lógico-formal. Para Apel, o trilema colocado por Hans Albert exemplifica o ponto de vista da abstração sintático-semântica que que prescinde previamente da dimensão pragmática do uso argumentativo da linguagem (da situação do sujeito que conhece e argumenta), ao passo que equipara a idéia de fundamentação suficiente filosófica e científica com o procedimento de dedução lógica de proposições a partir de proposições em sistemas axiomatizados. Para Apel,

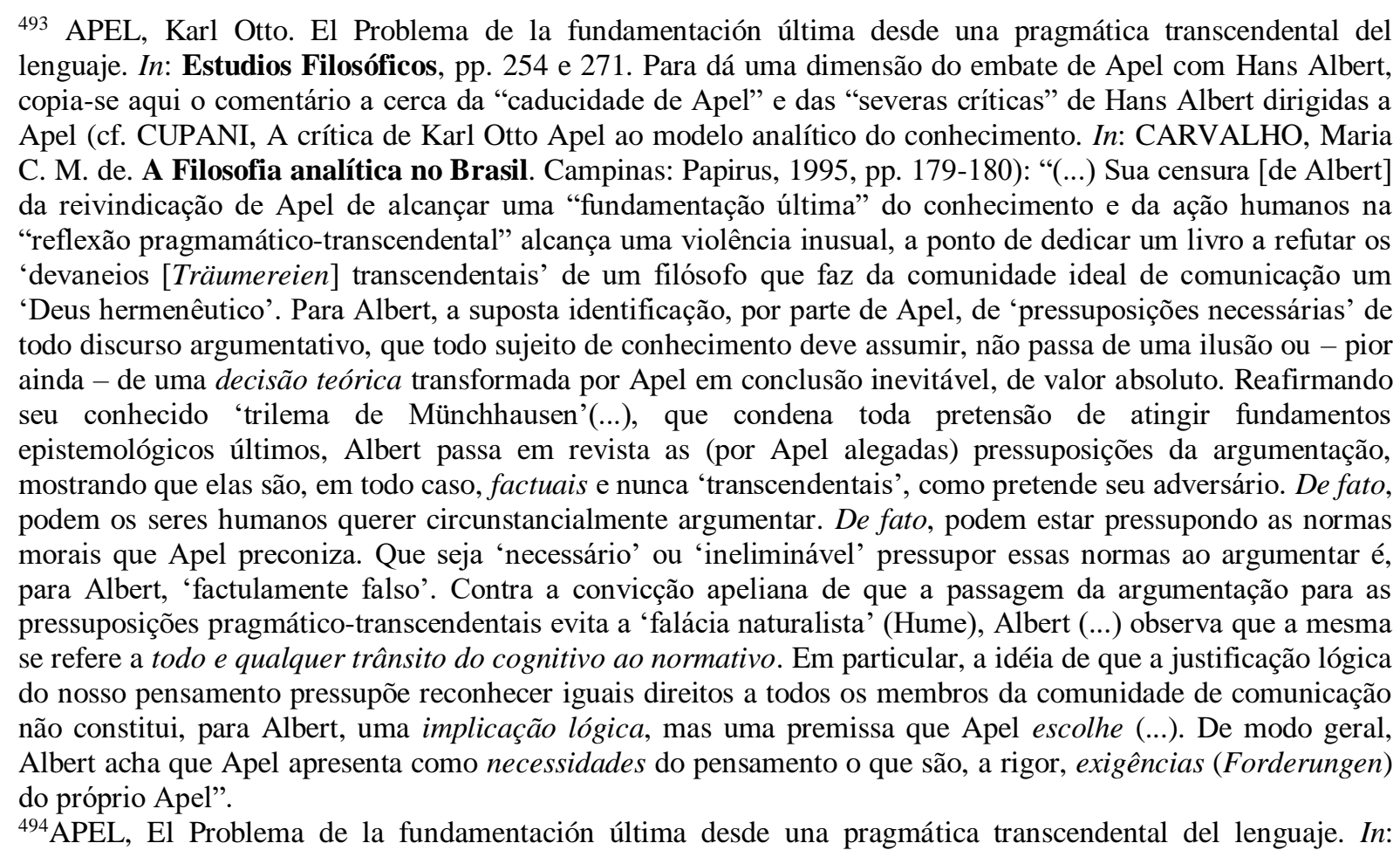

Estudios Filosóficos, pp. 252 e 258. 
o procedimento dedutivo da redução de proposições a proposições constitui um momento objetivável no contexto de fundamentação argumentativa de encunciados afirmados por evidência de conhecimento. Isso significa que a dedução lógica não é por si mesma a fundamentação da validade do conhecimento; ela é somente um momento no procedimento argumentativo de fundamentação que se caracteriza mediante evidência intersubjetiva $a$ priori $^{495}$. A fundamentação direcionada à validade do conhecimento e do agir humanos tem que simultaneamente apoiar-se "nas possíveis evidências de consciência dos sujeitos de conhecimento individuais competentes (como representantes autônomos do sujeito do conhecimento transcendental em geral)" e "nas regras intersubjetivas e $a$ priori de um discurso argumentativo, em cujo contexto as evidências de conhecimento, como testemunhos subjetivos de validade objetiva, devem chegar a obter validade intersubjetiva" ${ }^{496}$. Essa fundamentação depende, portanto, da urdidura pragmático transcendental entre evidências de conhecimento, interpretáveis em seu conteúdo "como algo", e regras do uso linguístico, um discurso linguístico como contexto de interpretação e coerência lógica. No horizonte da semiótica transcendental, o discurso de fundamentação pleno de sentido e argumentativo precisa contar com a presunção de determinadas evidências de conhecimento que introduzem cada um dos participantes no discurso, funcionando como critérios de verdade regulativo na formação argumentativa do consenso ${ }^{497}$.

Em contraposição ao racionalismo crítico, Apel afirma que o princípio do falibilismo ilimitado e aplicável a si mesmo, do qual se deriva a exigência contínua de crítica, conduz a uma antinomia semelhante ao paradoxo do mentiroso ${ }^{498}$. Trata-se do seguinte: se o princípio do 'falibilismo' é falível, então nesse sentido precisamente não é falível e viceversa; uma vez autoaplicado, ele interdita a negação de princípio da pretensão

\footnotetext{
${ }^{495}$ APEL, El Problema de la fundamentación última desde una pragmática transcendental del lenguaje. In: Estudios Filosóficos, pp. 265-266.

${ }^{496}$ APEL, El Problema de la fundamentación última desde una pragmática transcendental del lenguaje. In: Estudios Filosóficos, p. 269.

${ }^{497}$ APEL, Karl Otto. El Problema de la fundamentación última desde una pragmática transcendental del lenguaje. In: Estudios Filosóficos, p. 269.

${ }^{498}$ Segundo Apel, "o paradoxo do mentiroso não surge porque a linguagem é utilizada auto-referencialmente em enunciados como "Todos os homens mentem" ou "Eu sempre minto" ou "Estou mentindo agora", mas sim porque, através de tais enunciados, aquele que fala ao mesmo tempo nega e suprime sua atual exigência de veracidade - e com isso também sua exigência de verdade. A proibição da autocontradição performativa é introduzida não enquanto axioma de uma teoria da lógica, como por exemplo a proibição da contradição proposicional "a e não-a", mas resulta de uma compreensão reflexiva: a de que, ao introduzir qualquer teoria concebível, isto é, todos os axiomas concebíveis, já se pressupõe a autoconsistência performativa do discurso. Assim, a exigência de autoconsistência reside não numa posição ou decisão, mas é a condição de possibilidade de toda posição ou decisão inteligível enquanto portadora de sentido; tal exigência é, pois, incontornável para o pensar enquanto argumentar" (cf. APEL, O desafio da crítica total da razão e o programa de uma teoria filosófica dos tipos de racionalidade in: Novos Estudos/CEBRAP, p 70).
} 
autorreferencial à verdade e, desse modo, permanece imunizado. Para Apel, o ponto de vista do "racionalismo pancrítico" (falibilismo ilimitado e aplicado a si mesmo) é insustentável ou, minimamente, exacerbado, se se considera que aí não se estabelece a diferença de princípio entre hipóteses falsificáveis e as pressuposições e critérios não-falsificáveis da falsificação. $\mathrm{O}$ erro dos racionalistas críticos é não excluir da possível crítica justamente a dimensão pragmático-transcendental das condições de possibilidade não-criticáveis da crítica e da autocrítica filosóficas intersubjetivamente válidas ${ }^{499}$. Para Apel, o pensamento central do popperianismo avançado perde aquilo que ele tem de sensato, se não existe nenhum critério de verdade (não-falível) e nenhum parâmetro de medida normativa de procedimentos (nãofalível) que permite apreciar racionalmente o valor de uma teoria. Ocorre que, se os critérios de confirmação e de apreciação de teorias devem ter eles mesmos o caráter de hipóteses falíveis e concorrentes, então não existe, finalmente, nenhum parâmetro de medida para a ciência racional, tampouco para o conceito de ciência racional que é já sempre pressuposto no falibilismo, na medida em que ele é um "méliorisme" (enquanto formação de hipóteses e põe à prova metódica tais hipóteses). Sendo assim, o conceito de falibilismo perde todo o seu sentido. Todavia, o que ocorre é mais grave. Sob a pretensão de libertar a humanidade do dogmatismo, o pancriticismo chega ao contrário, a um dogmatismo mais radical ${ }^{500}$.

Para Apel, a estratégia dos racionalistas pancríticos consiste em universalizar extrapolativamente o princípio, aplicado por Peirce e Popper à ciência empírico-hipotética, aplicando-o também à filosofia. A questão que emerge disso é saber se é possível essa universalização extrapolizadora do princípio do falibilismo. Frente a isso, a censura de Apel se refere, muito mais, ao conteúdo do princípio estabelecido, ou mais exatamente, à sua carência de conteúdo. Segundo Apel, não é possível aplicar a combinação de pretensão de verdade (refutável, em princípio) e reserva de certeza (tese verdadeira sobre a base dos critérios disponíveis no momento), que é normativa para toda hipótese empírica, aos enunciados filosóficos-universais, aplicação mediante a qual se afirma precisamente a universalidade dessa combinação. O princípio do racionalismo pancrítico não pode prever, diferentemente das hipóteses empíricas, nenhum metavível (Metaebene) mais além da própria pretensão de validade em que poderia ter seu lugar a reserva de certeza. A alternativa para o

\footnotetext{
499 APEL, Karl Otto. El Problema de la fundamentación última desde una pragmática transcendental del lenguaje. In: Estudios Filosóficos, p. 285. APEL, Teoría de la verdad y ética del discurso, pp. 113-120. APEL, Fallibilismus, Konsenstheorie der Wahrheit und Letztbegründung. In: Philosophie und Begründung, pp. 177-179.

500 APEL, Karl Otto. El Problema de la fundamentación última desde una pragmática transcendental del lenguaje. In: Estudios Filosóficos, p. 285. Ver: OLIVEIRA, Sobre a fundamentação p. 96.
} 
paradoxo do pancriticismo, segundo Apel, é a limitação consciente quanto ao conteúdo do princípio do falibilismo, na perspectiva de um "falibilismo consequente" que inclui algo como a fundamentação última ${ }^{501}$. Nessa direção, Apel estabelece a diferença formal entre os enunciados cuja falsificação empírica é possível e aqueles que não podem, em princípio, ser falsificados, porque estão incluídos, como pressuposições, no conceito de falsificação empírica. Tal diferença conduz à distinção fundamental entre o conhecimento empírico, que não pode ter uma fundamentação última, porque é, em princípio, falível (o que mostra a verdade "relativa" do falibilismo para um campo do conhecimento no qual ele efetivamente vale, o campo do conhecimentos empírico), e o conhecimento sobre as condições de possibilidade do conhecimento empírico, que não é falível e possibilita detectar quando um conhecimento é falível ou não (ao passo que indica as condições de validade dos enunciados hipotéticos).

É em relação a este último tipo de conhecimento que corresponde o ponto de vista pragmático-transcendental apeliano ${ }^{502}$, em que se defende a possibilidade da reserva formal geral de certeza em razão da diferença transcendental entre todos os jogos linguísticos descritíveis e o jogo linguístico transcendental da filosofia. O elemento fundamental dos argumentos filosóficos é um jogo transcendental de linguagem, no qual se pressupõem, além das regras lógicas, a existência do mundo real e as regras pragmático-transcendentais da comunidade ideal (pretensões de validade do discurso: sentido, verdade, veracidade e correção normativa). Por conter esses pressupostos de certeza, o jogo de linguagem da

\footnotetext{
${ }^{501}$ APEL, Teoría de la verdad y ética del discurso, pp. 113-120. APEL, Fallibilismus, Konsenstheorie der Wahrheit und Letztbegründung. In: Philosophie und Begründung, pp. 174-179.

${ }^{502}$ Este é o ponto em que Apel afirma seguir além de Peirce. Em Peirce, a conexão entre falibilismo e progresso do conhecimento não consiste apenas na eliminação das hipóteses falsas, todavia significa que se deve esperar $a$ priori a convergência dos raciocínios sintéticos in the long run no sentido da aproximação da verdade. $\mathrm{O}$ falibilismo se fundamenta na lógica normativa da investigação, que deve fornecer uma "dedução transcendental" dos "fundamentos de validade" dos "processos sintéticos de raciocínio" e, nesta medida, do conhecimento da experiência. Neste sentido, Peirce pensa que todo conhecimento é mediado por signos, os quais só podem exercer sua função de representação para uma consciência em um mundo real cognoscível. Se não é possível fazer a representação de algo sem uma interpretação por parte de um intérprete real, a crítica do sentido exige supor uma comunidade ilimitada de investigadores, a qual atuará no sentido de dar conta do cognoscível em um processo indefinido do conhecimento. Para Peirce, esta comunidade assegura a objetividade e verdade daquilo que é acordado nos consensos fáticos mediante um consenso ideal, que funciona como idéia regulativa. E sendo assim, o único pressuposto completamente a priori e transcendental necessário é a validade do procedimento inferencial sintético in the long run e a distinção dar-se-á entre o efetivamente conhecido por uma comunidade finita de investigadores e o que pode ser conhecido por uma comunidade ilimitada em um processo indefinido de conhecimento. $\mathrm{O}$ entendimento dita, de certo modo, a lei à natureza (em longo prazo), sem impedir que a natureza, por sua parte, determine o conteúdo de todos os enunciados sintéticos possíveis, na medida em que obriga que eles venham a ser confirmados na experiência. Cf. APEL, Teoría de la verdad y ética del discurso, p. 121. APEL, Fallibilismus, Konsenstheorie der Wahrheit und Letztbegründung. In: Philosophie und Begründung, p. 180.
} 
filosofia permite falar a respeito de todos os jogos linguísticos com pretensão universal de validade $^{503}$

Na concepção de Apel, o critério de validade que atesta a vulneração desses pressupostos de certeza é fornecido pelo princípio pragmático-transcendental da não autocontradição performativa ${ }^{504}$. Ele exemplifica proposições de anomalias linguísticas que configuram casos de contradição performativa: a) tese de R. Rorty: "eu não tenho ("als Philosoph") nenhuma pretensão de verdade" (ou "afirmo com pretensão de compreensibilidade que eu não tenho nenhuma pretensão de compreensibilidade"); b) tese pós-mordenista: "eu defendo o dissenso como objetivo do discurso" (ou "represento, como susceptível de consenso, a proposta de que, em princípio, deveríamos substituir o consenso pela dissensão como meta do discurso". Em tais casos, a contradição performativa constitui o motivo da rejeição a priori dessas proposições. Contudo, salienta Apel, o conceito chave de fundamentação última pragmático-transcendental só é aplicável quando se reflete sobre os pressupostos pragmático-transcendentais do discurso dos sujeitos que elaboram a teoria; portanto, não é aplicável quando se trata de um exame probatório de fatos regulados empiricamente e tematizados como simples objetos de uma teoria, no caso, referentes aos "pressupostos básicos contingentes do mundo da vida". Acontece que, segundo Apel, essa taxativa distinção entre universais filosóficos e fatos regulados empírico-hipotéticos não obsta a possibilidade de um programa de cooperação complementária da filosofia e das ciências empírico-sociais (hermenêuticas) na reconstrução da evolução cultural. Nessa linha, pode-se vislumbrar, por exemplo, uma reconstrução do desenvolvimento da consciência moral. Decerto, nessa complementação, é preciso ter conta a independência desses âmbitos do saber quanto aos próprios métodos e critérios de exame da validade ${ }^{505}$.

Pontuando ainda quanto à fundamentação, Manfredo de Oliveira assinala que semiótica transcendental pretende tematizar a situação de argumentação não em uma postura teorética, onde ela seria somente objeto de hipóteses, mas tematizá-la em seu papel

503 APEL, Karl Otto. El Problema de la fundamentación última desde una pragmática transcendental del lenguaje. In: Estudios Filosóficos, p. 294. OLIVEIRA, Sobre a fundamentação, p. 96. APEL, Teoría de la verdad y ética del discurso, pp. 120-122. APEL, Fallibilismus, Konsenstheorie der Wahrheit und Letztbegründung. In: Philosophie und Begründung, pp. 179-180.

${ }^{504}$ APEL, Teoría de la verdad y ética del discurso, pp. 124-125. APEL, Fallibilismus, Konsenstheorie der Wahrheit und Letztbegründung. In: Philosophie und Begründung, pp.181-182. APEL, Sprachliche Bedeutung, Wahrheit und normative Gültigkeit. Die soziale Bindekraft der Rede im Lichte einer transzendentalen Sprachpragmatik. In: Archivio di Filosofia, pp. 63-64.

${ }^{505}$ APEL, Teoría de la verdad y ética del discurso, pp. 124-127. APEL, Fallibilismus, Konsenstheorie der Wahrheit und Letztbegründung. In: Philosophie und Begründung, pp.181-184. APEL, Sprachliche Bedeutung, Wahrheit und normative Gültigkeit. Die soziale Bindekraft der Rede im Lichte einer transzendentalen Sprachpragmatik. In: Archivio di Filosofia, pp. 63-64. 
transcendental enquanto condição irrecusável de validade da ação linguística, o que só é possível numa postura reflexiva. A estrutura do argumento pragmático-transcendental é marcada pela distinção entre a postura teorética e a postura reflexiva. Na postura teorética o saber é objetal. Nela, o sujeito, trabalhando a partir de hipóteses e esquecido de si mesmo e de sua práxis enquanto cognoscente de objetos, comporta-se como observador. O teorético diz: "se minha teoria é correta, então o problema está resolvido". A postura teorética compreende a fundamentação como conhecimento por derivação de algo a partir de alguma coisa diferente, como dedução lógica de setenças a partir de setenças num sistema de setenças sintático-semântico, sem considerar a dimensão pragmática. Por sua vez, na postura propriamente reflexiva o "saber explícito é sempre duplo", ou seja, o saber é ao mesmo tempo saber do tematizado e do tematizante. O reflexivo diz: "temos um problema e com isto a solução, pois a solução é condição de possibilidade do problema". Tal vem a ser a relação pragmático-transcendental entre a parte performativo-ilocucionária, nível da metacomunicação, e a parte proposicional-predicativa da sentença, nível da comunicação sobre objetos de referência. Perante a afirmação $p$, o argumento reflexivo confronta $p \operatorname{com} p$. Com isso, vem à tona um tipo de fundamentação que tematiza uma estrutura ineliminável, porque seu conteúdo somente explicita sua forma. Trata-se de uma fundamentação não por derivação, mas por reflexão estrita (autorreflexão, reflexão crítica sobre as condições de validade da argumentação que pretende certificar-se das pressuposições incontestáveis, sob pena de autocontradição performativa). Nessa fundamentação aparece o momento da transcendentalidade já conhecido pela filosofia transcendental na modernidade, porém com uma novidade: na semiótica transcendental, a instância fundante não é a razão interpretada subjetivamente, mas intersubjetivamente, sob o patamar da comunidade finita de comunicação ${ }^{506}$.

Em face do exposto, em que as formas abstracionistas da aporia do cientificismo constituem obstáculos à mediação entre teoria e práxis, Apel defende a tese de que é necessário "extrapolar a ideia de argumentação crítica", ligada à validade na comunidade dos cientistas (naturais), "de modo a institucionalizar-se na sociedade real sob a forma de uma comunidade de comunicação, no sentido de um 'devir filosófico do mundo"”,507. Para essa perspectiva alargada do programa da argumentação crítica, importa tratar a sociedade real, enquanto sujeito de necessidades e interesses materiais, "como sujeito ideal do conhecimento

\footnotetext{
506 OLIVEIRA, Sobre a fundamentação' pp. 77, 84-85.

${ }^{507}$ APEL, Transformação da filosofia, v. I, p. 21; Transformation der Philosophie, Band I, p. 17.
} 
e da argumentação (do ponto de vista normativo)", ou seja, como "um objeto que é simultaneamente o sujeito virtual da ciência" ${ }^{508}$. Nisso, a sociedade, antes tratada como mero objeto da ciência e da técnica, embora não alcance ainda o status de sujeito efetivo da ciência, ao menos na filosofia e nas ciências sociais críticas, agora se constitui como um objeto que é concomitantemente o sujeito virtual da ciência. No entender de Apel, somente a partir da ampliação não-cientificista da ideia de racionalidade metódica, que possibilita institucionalizar a argumentação crítica na sociedade real sob a forma de uma comunidade de comunicação, é possível pensar os horizontes relativos à concepção de uma "sociedade aberta", bem como a própria possibilidade da transformação da própria filosofia. Relevantemente, com a extrapolação da ideia da comunidade científica argumentativa, em vez da filosofia ser entendida apenas como crítica, ela passa a ser concebida como crítica capaz de se assegurar dos parâmetros próprios à crítica, isto é, de suas condições de possibilidade e validade $^{509}$. Nisso reside a um só tempo o motivo e o significado fundamental dessa extrapolação.

O ponto de ancoragem dessa extrapolação, em vista de facultar a mediação entre razão teórica e razão prática, se encontra na pré-estrutura (Vorstruktur) transcendentalhermenêutica do compreender (discurso argumentativo), alcançada como resultado da transformação da filosofia transcendental na direção semiótico-hermenêutica do a priori da comunidade de comunicação. Em Apel, é a comunidade a priori da argumentação, pressuposta desde o início, que legitima a missão da filosofia. Tal missão se desenvolve na forma do "discurso teórico" que antecipa contrafaticamente o consenso ideal entre os seres humanos, quanto à mediação entre teoria e práxis no mundo. Ressalta-se, mesmo as convenções "tácitas", que determinam a pré-compreensão do mundo segundo as regras dos jogos de linguagem humanos, só podem ser concebidas como convenções, sob o coentendimento pressuposto na comunidade institucionalizada. Os pressupostos materiais e existenciais do acordo mútuo real, mesmo quando intentam impor sua significação vital perante as regras transcendentais do jogo da argumentação, só podem ser discutidos ou reconhecidos sob a pressuposição deste último, o a priori da argumentação ${ }^{510}$. O ponto chave a respeito disso é que no a priori da comunidade de comunicação que busca o consenso, todo o gênero humano, enquanto "sujeito semitranscendental da verdade face às ocorrências de sentido na história do ser", "reassume sua autonomia de responsabilidade solidária pela

\footnotetext{
${ }^{508}$ APEL, Transformação da filosofia, v. I, p. 21; Transformation der Philosophie, Band I, p. 17.

${ }^{509}$ APEL, Transformação da filosofia, v. I, pp. 21-23; Transformation der Philosophie, Band I, pp. 18-19.

${ }^{510}$ APEL, Transformação da filosofia, v. I, pp. 68-69; Transformation der Philosophie, Band I, pp. 59-60.
} 
verdade" 511 . O a priori argumentação se manifesta por meio da solidariedade para com uma comunidade de comunicação real que, contrafaticamente e in the long run, incorpora a realização da comunidade de comunicação ideal.

Apel entende que, com base na estrutura aprioristicamente dialética da comunidade de comunicação é "possível fundamentar, de maneira propriamente transcendental-hermenêutica, a necessidade da mediação crítico-ideológica do acordo mútuo entre os seres humanos" ${ }^{\text {512. }}$. Nessa dialeticidade, de um lado, é forçoso considerar que não é possível retirar-se da tradição histórica para refletir, em estilo cartesiano; ou seja, é impossível chegar a um acordo mútuo sem pressupor um co-entendimento concreto em uma forma social já institucionalizada (o a priori do common sense, um jogo de linguagem em funcionamento). De outro, Apel concebe que o jogo de linguagem transcendental da comunidade de comunicação ideal (em princípio, já “antecipado" em todos os jogos de linguagem concretos) constitui o postulado da razão prática quando se vislumbra o paradigma do co-entendimento humano na comunidade real de comunicação. A supor isso, depreende-se que a mediação entre teoria e prática (ética) em Apel é intrínseca à dialeticidade estrutural da comunidade de comunicação. Em termos de concepção, essa mediação pode ser suposta como possível, contato que se leve em conta a especificidade da contribuição da argumentação filosófica, ao explicitar a estrutura do a priori da argumentação. Assim, a efetividade da mediação aparece quando se vislumbra um co-entendimento não apenas suficiente do ponto de vista pragmático, mas fundamentalmente um co-entendimento com recursos da argumentação filosófica ${ }^{513}$.

Apel concebe a semiótica transcendental como uma perspectiva filosófica "verdadeiramente dialética" capaz de empreender a mediação entre teoria e práxis na sociedade. Segundo ele, trata-se de uma mediação dialética que representa a tentativa de mediar o jogo dialético entre idealismo e materialismo, precisamente, "para aquém do idealismo e do materialismo" ${ }^{14}$. Em uma perspectiva histórico-filosófica, Apel vê sua proposta de mediação como uma continuidade ao processo de transformação da filosofia de Kant empreendido por duas abordagens filosóficas fundamentais, a concepção wittgensteiniana de jogo de linguagem e a concepção de "indefinite Community of investigators" (entendida como sujeito do consenso científico possível) de Ch. S. Peirce, posteriormente ampliada por J. Royce (como “Community of Interpretation”) e G. H. Mead

\footnotetext{
511 APEL, Transformação da filosofia, v. I, p. 71; Transformation der Philosophie, Band I, p. 61.

${ }^{512}$ APEL, Transformação da filosofia, v. I, p. 73; Transformation der Philosophie, Band I, p. 63.

${ }^{513}$ APEL, Transformação da filosofia, v. I, pp. 72-74; Transformation der Philosophie, Band I, pp. 62-64.

${ }^{514}$ APEL, Transformação da filosofia, v. II, p. 254; Transformation der Philosophie, Band II, pp. $224-225$.
} 
(como "Community of Universal Discourse"). Para Apel, a concepção wittgensteiniana de jogo de linguagem e a concepção peirceana de "Community" podem ser interpretadas, por um lado, como um equivalente à "síntese transcendental da apercepção" (o "ponto mais alto" da dedução transcendental) e ao "princípio superior dos juízos sintéticos" ("as condições de possibilidade da experiência são ao mesmo tempo condições de possibilidade dos objetos da experiência") ${ }^{515}$. Consideradas de tal modo, segundo Apel, essas concepções preservam o cerne do idealismo transcendental de Kant. Além disso, elas podem ser interpretadas como perpectivas que esboçam de maneira implícita uma mediação entre o idealismo transcendental de Kant e um realismo "voltado à sociedade pressuposta factualmente como 'sujeito-objeto' da ciência" ${ }^{" 516}$.

Na linha dessa segunda interpretação, Apel entende que a possibilidade de tal mediação se liga ao ponto de partida das concepções de Wittgenstein e Peirce. Para Apel, nessas concepções a "filosofia transcendental concebida de maneira senso-crítica" não tem como ponto de partida, como em Kant, o pressuposto metafísico da distinção entre coisa-emsi e mundo fenomenal, e com isso o pressuposto de um sujeito transcendental como limite do mundo fenomenal. Nelas, parte-se da pressuposição de que as normas ideais da comunicação, "qual seja o estabelecimento de consenso no conhecimento do mundo real e no acordo mútuo quanto a um prosseguimento do mundo real pela práxis histórica" ${ }^{\$ 17}$, em princípio, podem ser concretizadas na sociedade concreta. Trata-se de um pressuposto transcendental da ciência, sem o qual todo argumento perde seu sentido, que não é nem idealista, no sentido da filosofia consciencial tradicional, nem materialista, no sentido do materialismo dialético ou do objetivismo cientificista de origem positivista.

Conforme Apel, esse pressuposto se vincula à concepção "verdadeiramente dialética" do jogo de linguagem transcendental de uma comunidade ilimitada de comunicação, a qual, por possuir um duplo caráter, é postulada em cada argumento (palavra), porém precisa ser realizada na sociedade historicamente. Para Apel, já no seu ponto de partida, essa concepção se mostra dialética à medida que "medeia" a oposição entre o momento normativo-ideal (idealismo transcendental) e o momento material-factual ("materialismo histórico" de cunho social). O traço fundamental da filosofia da ciência resulta do antagonismo entre esses momentos. Esse traço emerge no instante em que a comunidade de comunicação, enquanto sujeito transcendental da ciência, torna-se objeto da ciência ("no

\footnotetext{
${ }^{515}$ APEL, Transformação da filosofia, v. II, pp. 253-254; Transformation der Philosophie, Band II, p. 224.

${ }^{516}$ APEL, Transformação da filosofia, v. II, p. 254; Transformation der Philosophie, Band II, p. 224.

${ }^{517}$ APEL, Transformação da filosofia, v. II, p. 254; Transformation der Philosophie, Band II, p. 224.
} 
plano das ciências sociais em sentido lato"). E aí se evidencia, de um lado, que o sujeito do consenso científico sobre a verdade é a sociedade real e histórica, e não uma consciência "em geral" (extramundana); de outro, que essa sociedade só pode ser compreendida adequada se for entendida como sujeito virtual da ciência e, ademais, se sua realidade histórica for continuamente reconstruída, de modo "empírico e normativo-crítico", em vista de concretizar em si mesma o ideal da comunidade ilimitada de comunicação ${ }^{518}$.

A consequência mais radical do reconhecimento epistemológico da sociedade como sujeito-objeto da ciência, segundo Apel, é a insustentabilidade da separação entre teoria e práxis. Mais precisamente, Apel entende que a distinção entre as razões teórica e prática, tal como estabelecida por Kant em vista da fundamentação das ciências naturais, é insustentável perante a fundação das ciências sociais críticas. Também aqui Apel marca uma diferenciação em relação às ciências sociais: a) ciências sociais que seguem o modelo da ciência empírico-analítica que mantém a separação entre sujeito e objeto da ciência e, ambiguamente, coloca-se a serviço da "tecnocracia" e da divisão da sociedade entre controladores e controlados (consumação do domínio do ser humano sobre o ser humano); b) ciências sociais críticas que, sob uma base de autorreflexão teórico-filosófica ("saber que se sabe de si mesmo", "mantêm sob controle seu engajamento emancipador, que precisa assegurar-se em tentativas de uma reconstrução normativa e ao mesmo tempo empírica da situação histórica" 519 . Com efeito, superar essa separação implicar em transpor o "abismo lógico" entre "ser" e "dever", que a lógica moderna da ciência preconiza ao defender o conceito de ciência isenta de valores. Tratando do contexto desse abismo, Apel pontua que Max Weber estende esse conceito para o âmbito das ciências sociais, quando afirma que os horizontes valorativos do "compreender" devem se restringir ao parâmetro normativo da racionalidade instrumental ("Compreender de acordo com a racionalidade de fins"). Os teóricos das ciências sociais neutras defendem que os parâmetros normativos (prescrições obrigacionais) devem ser derivados a partir da empiria (da descrição de fatos). Com efeito, essa derivação significa reduzir a valoração crítica do comportamento humano a uma elucidação causal de motivos. Em consequência à distinção lógica entre juízos de realidade e juízos de valor, desde Weber, é comum o discernimento de que os pressupostos normativos da

\footnotetext{
${ }^{518}$ APEL, Transformação da filosofia, v. II, pp. 254-255; Transformation der Philosophie, Band II, pp. $224-$ 225.

${ }^{519}$ APEL, Transformação da filosofia, v. II, p. 262; Transformation der Philosophie, Band II, p. 231. APEL, Transformação da filosofia, v. I, p. 25 (nota 14); Transformation der Philosophie, Band I, p. 21.
} 
valoração são subjetivos e se assentam em um "decisionismo intersubjetivamente nãoobrigatório" 520 .

Em uma direção oposta a Weber, Apel defende a tese da inevitabilidade de uma valoração crítica das ações humanas. Ao contrário das experiências empírico-analíticas e descritíveis da natureza e do "comportamento" humano (metodicamente reificado), as experiências históricas da sociedade "não podem ser obtidas ou verbalizadas, de modo algum, sem certo engajamento normativamente relevante no sentido do prosseguimento da história (possível ou indispensável), através da práxis subjetiva-objetiva"521. Se a ciência empíricoanalítica em relação ao comportamento observável ("proposições de observação"), tal como afirmam os defensores de uma ciência isenta de valores, apenas reconhece a pressuposição de "horizontes teoréticos" e julga desnecessário atribuir valores aos fins supostos, diversamente ocorre em relação ao campo de investigação da "auto-experiência" histórica da sociedade, que precisa reconhecer "horizontes valorativos" para proceder à sua "abertura de dados". É forçoso considerar que "sem atribuição de valor não se pode de modo algum reconhecer o agir humano como tal, ao contrário do que ocorre com o comportamento observável" ${ }^{522}$. O campo do "agir" humano "precisa ser valorado junto com seu entendimento, na mesma medida em que é preciso encontrar uma 'boa razão', no sentido do ideal da racionalidade dos fins. Isso mostra, a rigor, que não é possível haver experiência 'empírico-analítica' das ações humanas" 523 . Trata-se de pôr em relevo que "as ações humanas não podem ser descritas tal como são sem que se tenham entendido as normas de seu êxito, e sem que essas normas tenham sido reconhecidas como parâmetros de valoração" 524 . No tocante a isso, importa considerar que "juízos de realidade isentos de valor não podem ser o início da experiência histórica e não precisam ser tomados como ponto de partida para juízos históricos de valor"; e, além disso, que "juízos históricos de valor são resultado de um horizonte de sentido que possibilita a experiência histórica com auto-experiência (passível de reconstrução) de uma comunidade virtual de comunicação" ${ }^{\text {525. }}$.

Mais relevante que a indicação da invevitabilidade da valoração no horizonte experiencial da história, segundo Apel, é o discernimento de que os pressupostos normativos

\footnotetext{
${ }^{520}$ APEL, Transformação da filosofia, v. II, p. 258; Transformation der Philosophie, Band II, p. 228.

${ }^{521}$ APEL, Transformação da filosofia, v. II, pp. 258-259; Transformation der Philosophie, Band II, pp. 228229.

${ }^{522}$ APEL, Transformação da filosofia, v. II, p. 259; Transformation der Philosophie, Band II, p. 229.

${ }^{523}$ APEL, Transformação da filosofia, v. II, p. 259; Transformation der Philosophie, Band II, p. 229.

${ }^{524}$ APEL, Transformação da filosofia, v. II, p. 259; Transformation der Philosophie, Band II, p. 229.

${ }^{525}$ APEL, Transformação da filosofia, v. II, p. 259; Transformation der Philosophie, Band II, p. 229.
} 
dessa valoração correspondem a uma ética mínima (Minimalethik) intersubjetivamente obrigatória $^{526}$. Apel preconiza que ao menos a ética do "socialismo lógico" de Peirce, pressuposta pela própria ciência empírico analítica como condição normativa de possibilidade da formação de consensos e do estabelecimento de verdade, no sentido da superação da contradição entre as comunidades real e ideal de comunicação, pode ser tida como o ponto de partida fundamental para superar a distinção entre razão teórica e razão prática. $\mathrm{O}$ reconhecimento dessa ética mínima está implicado no reconhecimento da sociedade como sujeito-objeto da ciência. À medida que a realização da verdade a priori depende da realização da comunidade ilimitada de comunicação na sociedade que precisa organizar-se em um sistema funcional limitado, resulta que a "ciência social crítica, que concebe seu objeto ao mesmo tempo como sujeito virtual da sociedade, não pode renunciar a ainda atribuir valor, ela própria, aos objetivos das ações humanas" ${ }^{27}$. A consideração dessa ética mínima significa, para Apel, transpor o "abismo lógico" entre "ser" e "dever", que a lógica moderna da ciência preconiza ao defender o conceito de ciência isenta de valores. Para Apel, a contradição a ser superada entre o momento normativo-ideal (comunidade ideal de comunicação) e o momento material-factual (comunidade real de comunicação), que precisa ser reconhecida na pressuposição transcendental da ciência confere o ponto de partida para uma crítica ideológica valorativa $^{528}$.

Na visão de Apel, a superação da distinção lógica entre juízos de realidade e juízos subjetivos de valor se efetua em razão de uma ética mínima intersubjetivamente obrigatória que subsiste implicitamente no anseio de sentido de cada argumento como declaração dialógica. Apel entende essa ética como uma "metanorma" ${ }^{529}$ relativa ao a priori do discurso argumentativo. Trata-se de levar em conta que os interesses cognitivos da

\footnotetext{
${ }^{526}$ APEL, Transformação da filosofia, v. II, p. 260; Transformation der Philosophie, Band II, p. 230.

${ }^{527}$ APEL, Transformação da filosofia, v. II, p. 258; Transformation der Philosophie, Band II, p. 228.

${ }^{528}$ APEL, Transformação da filosofia, v. II, p. 260; Transformation der Philosophie, Band II, p. 230.

529. APEL, Sprachliche Bedeutung, Wahrheit und normative Gültigkeit. Die soziale Bindekraft der Rede im Lichte einer transzendentalen Sprachpragmatik. In: Archivio di Filosofia, pp. 86-87. Aqui é preciso ter em conta a concepção de linguagem em Apel, que possui um duplo caráter: a) a linguagem é "a 'instituição das instituições', normativamente obrigatória por si mesma"; b) a linguagem, como instrumento de autorreflexivo do acordo mútuo ilimitado, é "a 'metainstituição de todas as instituições estabelecidas de maneira firme e dogmática". Como metainstituição, ela é a "instância da crítica de todas as normas sociais irrefletidas", assim como "a instância normativamente obrigatória que não abandona os indivíduos ao arbítrio de seus próprios pensamentos, mas os obriga, enquanto queiram manter viva a comunicação, a um acordo intersubjetivo sobre as normas sociais". Ainda conforme os termos de Apel, "essa obrigatoriedade virtual da comunicação crítica como instituição da formação comunitária ilimitada só subsiste enquanto o sentido dos signos linguísticos aí utilizados permanecer referido à práxis possível e à experiência possível - em tal medida confirma-se a abordagem de uma semiótica pragmática expandida" (cf. APEL, Transformação da filosofia, v. II, pp. 238-239; Transformation der Philosophie, Band II, pp. 210-211).
} 
racionalidade teórica sempre já pressupõem as regras éticas - no sentido da dimensão da parte A da ética discursiva - para a formação da verdade consensual em longo prazo, regras essas que concernem aos pressupostos intranscendíveis da argumentação. Na argumentação, essa metanorma constitui o fundamento último de geração de normas e, como tal, cumpre a função de um princípio metódico-regulativo, na medida em que estabelece as condições ideais de comunicação para a possível formação do consenso sobre normas. Essa ética mínima constitui a instância última da reflexão, da crítica ou da legitimação em relação com todas as instituições concebíveis da interação ou comunicação humanas. Em uma perspectiva ampla do âmbito da razão prática, essa metanorma constitui também a condição de possibilidade da democracia, porquanto que entendida como processo que requer a participação de todos os "afetados" (cossujeitos) na construção de um consenso futuro, quer dizer, na construção da universalização dos interesses “in the long run”. Para Apel, é justamente essa pressuposição ideal e inalienavelmente normativa do a priori da argumentação de uma comunidade ilimitada de comunicação - já sempre reconhecida implicitamente por cada argumentante em seu anseio de sentido e, ademais, pela própria ciência empírico-analítica (supostamente neutra e isenta de valoração) como condição de possibilidade da formação de consensos e do estabelecimento de verdades - que deve ser tomada em consideração para a resolução do problema da mediação entre teoria e práxis.

Em suma, na semiótica transcendental, a superação da distinção entre razão teórica e razão prática se dá por meio da mediação dialética que se opera no âmbito da comunidade de comunicação, na qual se busca superar contradição dialética entre as comunidades real e ideal de comunicação. A semiótica transcendental se projeta como uma concepção verdadeiramente dialética situada "aquém" do idealismo e do materialismo, porém supondo-se capaz de mediar, já no seu ponto de partida, a oposição entre o idealismo transcendental e o materialismo de cunho social ${ }^{530}$. É possível depreender que, na semiótica transcendental, o problema da mediação entre teoria e práxis "é superado" (teoricamente) na dialeticidade entre os momentos normativo-ideal e material-fático contidos na pressuposição transcendental da comunidade de comunicação. Com efeito, do ponto de vista da razão prática, "não se pode pensar o progresso normativamente relevante do acordo mútuo no sentido da hermenêutica sem que se pense também um progresso eticamente relevante na conformação social da humanidade enquanto comunidade de interpretação e interação" 531 .

\footnotetext{
${ }^{530}$ APEL, Transformação da filosofia, v. II, p. 254; Transformation der Philosophie, Band II, p. 224.

${ }^{531}$ APEL, Transformação da filosofia, v. II, p. 441; Transformation der Philosophie, Band II, p. 390.
} 
Nesse sentido, Apel acredita que sua proposta de filosofia da intersubjetividade, baseada no $a$ priori da comunidade de comunicação, é capaz de dotar a razão prática de responsabilidade perante o consenso relacionado ao conhecimento do mundo real e o acordo mútuo referido a um prosseguimento do mundo real pela práxis histórica ${ }^{532}$.

Do ponto de vista teórico, a consequência possivelmente mais relevante que se depreende do reconhecimento do pressuposto transcendental da ciência é a exigência relativa ao programa de teoria dos tipos de racionalidade. O reconhecimento do pressuposto transcendental da ciência ("aquém", ética mínima) implica em superar a separação entre os interesses cognitivos dos juízos de realidade ("Erklären" qua método das ciências da natureza) e os juízos de valor ("Verstehen" qua método das ciências do espírito) ${ }^{533}$. Para Apel, essa superação consiste em ampliar o conceito de racionalidade por meio da complementaridade entre a relação de conhecimento sujeito-objeto de descrição das experiências passíveis de repetição e controle instrumental, típica da racionalidade do cientificismo e da filosofia do solipsismo, e a relação de conhecimento sujeito-cossujeito, típica da racionalidade das ações comunicativas ligada à experiência do interesse cognitivo hermenêutico e dialógico. Na perspectiva de uma racionalidade intersubjetiva e dialógica (ampliada), esse "aquém" fornece o acordo prévio entre os sujeitos do conhecimento quanto ao sentido dos conceitos a serem utilizados pela ciência objetivo-descritiva em suas explicações sobre os fatos. E, por isso, ele constitui o "parâmetro dos juízos de valor da ciência empírico-analítica, pelas mãos de uma ciência social crítica, à qual cabe reconstruir a auto-experiência histórica da espécie humana" ${ }^{234}$.

\footnotetext{
${ }^{532}$ CORTINA, Razón comunicativa y responsabilidad solidaria: ética y política em K.-O. Apel, pp. 155-177.

${ }^{533}$ Analisando a questão da suposta inconciliabilidade da concepção de jogo transcendental de linguagem com a separação de sujeito-objeto do cientificismo, Apel mapeia as abordagens teóricas que, desconsideradas de suas diferenças epistemologicamente relevantes, negaram de forma consciente a separação entre sujeito e objeto proposta pelo cientificismo. Essas abordagens - a filosofia do espírito histórico de Hegel, a fundação das ciências do espírito histórico-hermenêuticas (Schleiermacher, dos representantes da "Escola Histórica", W. Dilthey, Max Weber e Collingwood), o "materialismo histórico" de Karl Marx (no contexto da emancipação da práxis subjetivo-intersubjetiva e enquanto corretivo ideológico-crítico das ciências humanas burguesas) - concebem que "a sociedade é um "sujeito-objeto" - para dizer dialeticamente - com o qual é possível identificar-se intelectivamente, e não um objeto da observação ou elucidação que se dá de acordo com regras apostas de fora" (cf. APEL, Transformação da filosofia, v. II, p. 282; Transformation der Philosophie, Band II, pp. 249-250). ${ }^{534}$ APEL, Transformação da filosofia, v. II, p. 260. APEL, Transformação da filosofia, v. II, p. 260; Transformation der Philosophie, Band II, p. 224.
} 


\section{POSSÍVEIS DESDOBRAMENTOS ESPECULATIVOS PARA PENSAR A EDUCAÇÃO A PARTIR DA SEMIÓTICA TRANSCENDENTAL}

Este capítulo, à luz do conteúdo dos capítulos precedentes da segunda parte deste texto, em uma tentativa autoral, procura tematizar a possível interseção entre a semiótica transcendental de Apel e o campo da educação. Nessa direção, este capítulo apresenta dois exercícios especulativos: a) a compreensão da educação como formação à elevação da humanidade; b) a reflexão sobre a autonomia do sujeito em face do comunitarismo transcendental de Apel, abrangendo aí a discussão sobre a relação entre simetria e autoridade na educação. Esses exercícios pontuam ideias gerais que, em princípio, podem ser supostas como possíveis pontos de desdobramentos da semiótica transcendental para o campo da educação. Como Apel não efetiva tal desdobramento, os apontamentos que se seguem correspondem a uma tentativa de enunciar, no que tange ao conteúdo dos tópicos apresentados a respeito da semiótica transcendental, alguns aspectos que, em tese, podem indicar alguns pontos em torno dos quais parece ser possível deflagrar uma reflexão na direção da educação a partir de traços da sua filosofia teórica. Ressalta-se, esses apontamentos, de caráter exemplicativo e hipotético, carregam os limites peculiares de uma provocação inicial intencionada em inventariar possíveis tópicos que possam facultar a articulação entre a perspectiva filosófica da semiótica transcendental e a educação.

\subsection{Educação como formação à elevação da humanidade}

A ideia de uma educação como formação à elevação da humanidade pode ser desdobrada da concepção de uma hermenêutica crítica-normativa desenvolvida por Apel. No âmbito da semiótica transcendental, essa ideia tem sua raiz na hermenêutica de Gadamer. Aqui, a meu ver, cabe a hipótese de que Apel assimila essa ideia na medida em que ele reconhece o mérito da hermenêutica de Gadamer. Como exposto, esse mérito decorre do fato de Gadamer aplicar criticamente a radicalização existencial-ontológica da ideia de hermenêutica introduzida por Heidegger à autocompreensão filosófica das ciências humanas e, como isso, ter delineado o campo originário da hermenêutica. $\mathrm{O}$ ponto chave dessa ideia concerne à visão de Gadamer retomada por Apel, em que se vislumbra que o campo das ciências humanas, enquanto esfera do saber hermenêutico, tem a incumbência de lidar com a 
questão da formação ${ }^{535}$. Presume-se aqui que, se Apel assimila a compreensão gadameriana sobre o campo das ciências humans, ele admite também o que está implicado em tal compreensão. Fundamentalmente, isso pode significar que Apel incorpora em sua semiótica transcendental o viés da hermenêutica gadameriana que concebe que cabe às "ciências do espírito" (humanas) a função de cuidar da formação que eleva a humanidade.

A questão da "formação" em Gadamer se liga à autocompreensão filosófica das ciências humanas como campo originário da hermenêutica. Para marcar essa autocompreensão, Gadamer pontua que a autorreflexão lógica das "ciências do espírito", defendida pelo neopositivismo e pelo historicismo, está dominada pelo modelo das ciências da natureza, fundadas em métodos da indução lógica. Por isso, faz-se necessário estabelecer a distinção entre os âmbitos das ciências naturais e das ciências do espírito. Para Gadamer, caracteristicamente, estas últimas são procedentes de uma "sensibilidade instintiva", uma espécie de "indução artística" para a qual não existem regras definidas. Em razão de tal especificidade, as ciências do espírito devem elaborar seus próprios métodos para garantir a validade universal e, assim, gozar do status de ciência ${ }^{536}$. Gadamer critica essa "obsessão metodológica" e, ao mesmo tempo, evidencia o campo próprio das ciências do espírito. Para ele, elas têm mais a ver com o "emprego de um tato", portanto, algo não metodizável, que se encontra no seio da tradição humanística, do que com a adoção de quaisquer métodos da ciência moderna. O caráter científico das ciências do espírito pode ser compreendido com base na tradição do conceito de "formação que eleva à humanidade", em torno do qual, como conceito genuinamente histórico marcado pelo caráter da "conservação", a compreensão das ciências do espírito se movimenta.

Para Gadamer, o conceito de formação está ligado atualmente ao de cultura, designando a maneira humana de aperfeiçoar aptidões e faculdades pré-existentes, de cultivar algo dado, cuja apropriação instrumental serve para algum fim. Todavia, "formação" significa mais que cultura, pois denota algo mais elevado e mais íntimo, isto é, "o modo de perceber que vem do conhecimento e do sentimento do conjunto do empenho espiritual e moral, e que

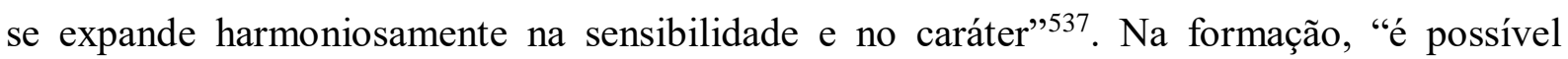
apropriar-se totalmente daquilo em que e através do que alguém é instruído". O que é assimilado na formação não é como um meio que perde sua função, pois nela nada desaparece, tudo é preservado. A natureza conceitual da formação, tal como formulada por

\footnotetext{
${ }^{535}$ APEL, Transformação da filosofia, v. I, pp. 28 e 31; Transformation der Philosophie, Band I, pp. 24 e 27. 536 GADAMER, Verdade e método I, pp. 37-44.

${ }^{537}$ GADAMER, Verdade e método I, pp. 45-46.
} 
Hegel, repousa na concepção de uma elevação à universalidade e um "distanciamento da imediatez da cobiça", que não se reduz à formação teórica ou à oposição desta ao comportamento prático, "mas cobre o conjunto da determinação essencial da racionalidade humana. A essência universal da formação humana é tornar-se um ser espiritual, no sentido universal (...), pelo qual paute sua particularidade com medida e postura"538. A formação teórica conduz à exigência de um alheamento daquilo que o homem sabe e vivencia de imediato, mantendo-o aberto para o diferente. Ela leva o homem a ocupar-se com o mundo estranho e remoto dos antigos que pertence à memória e ao pensamento, a fim de que ele encontre pontos de vista universais - não um padrão fixo de validade, mas pontos de vista de possíveis outros - e apreenda a coisa.

Gadamer sublinha que o que perfaz a essência da formação não é o alheamento como tal, mas é a familiarização com este mundo, já iniciado e precedente à nossa chegada nele, e o reencontro de si mesmo, agora segundo a essência universal do espírito. "Reconhecer no estranho o que é próprio, familiarizar-se com ele, eis o movimento fundamental do espírito, cujo ser é apenas o retorno a si mesmo a partir do ser-outro"539. O sentido universal e comunitário constitui a essência da formação, em que ressoa um amplo contexto histórico. Com efeito, esse conceito de formação deve ser reabilitado pelas ciências do espírito, mediante o retorno à tradição humanista, em sua tarefa de romper com a estreiteza artificial da ciência moderna ${ }^{540}$. Trata-se de enfrentar o estiolamento da tradição humanista e a dominação excludente do parâmetro do pensamento metódico da ciência moderna, segundo Gadamer, decorrentes da estetização e subjetivação dos conceitos básicos do humanismo, sobretudo o de juízo e de gosto (Crítica do Juízo de Kant), anteriormente providos de uma função de conhecimento. Na ciência moderna, o que não satisfaz aos parâmetros objetivos e metódicos das ciências naturais (uniformidade, regularidade e legalidade), vale agora como âmbito subjetivo ou estético do que é pré-concebido, portanto, afastado do reino do conhecimento seguro. Para Gadamer, o significado do abandono da tradição humanística, sobremaneira dos estudos histórico-filológicos, e do ingresso no caminho da estetização e subjetivação do juízo é "sobrestimável". Mas esse "desvio" deve ser contraposto por uma antiestética que reconquiste a compreensão do conhecimento acionado pelas ciências humanas, cujo ideal é compreender o fenômeno na sua concreção singular e histórica; isto é, compreendê-lo não como um caso de uma regra geral, segundo o processo indutivo das ciências da natureza, mas

${ }^{538}$ GADAMER, Verdade e método I, pp. 47-48.

${ }^{539}$ GADAMER, Verdade e método I, p. 50.

${ }^{540}$ GADAMER, Verdade e método I, p. 54. 
compreender o modo pelo qual algo "agora é assim" ou "veio a ser assim" 541 . Trata-se de combater o preconceito metodológico do século XIX, oriundo do Iluminismo, que exige para a objetividade científica a desarticulação da subjetividade, que compreende situadamente ${ }^{542}$.

Especulativamente, é possível supor que a ideia gadameriana de uma formação para a elevação da humanidade, em Apel, adquire o significado de uma educação direcionada à produção do acordo mútuo (interpessoal) acerca do sentido e da verdade linguística sobre o mundo enquanto objeto ${ }^{543}$. A princípio, a educação pode ser entendida como uma mediação que, estando ligada epistemologicamente ao interesse cognitivo das ciências hermenêuticas (humanas), contribui na formação do co-entendimento humano. A educação toma parte na função originária e específica do compreender (hermenêutico) no tocante ao entendimento com o outro (mit den Anderen) sobre o mundo enquanto objeto, quer dizer, sobre o sentido e a verdade da investigação intelectual linguística de algo como algo. De forma genérica, a atividade educativa que busca compreender ao outro pode ser vista como um ato hermenêutico, se ela, por um lado, não for reduzida à dimensão sujeito-objeto da descrição e elucidação e, por outro, for desenvolvida em uma relação sujeito-sujeito de "entendimento" sobre algo, na qual se deposita confiança no outro quanto à verdade e à correção normativa de questões práticas ${ }^{544}$.

Ainda a título de enunciação geral, é possível depreender que uma educação impactada pelo interesse cognitivo da hermenêutica (acordo mútuo metódico) poderia atuar em duas frentes. Em uma, pode-se inferir que caberia a essa educação colaborar na tarefa da explicação dos problemas de uma auto-experienciação da sociedade; uma auto-experienciação que possivelmente não é repetível experimentalmente, porém reconstruível como história ${ }^{545}$. A esse respeito, como já exposto, importa considerar que a confirmação prática de tal explicação não reside na factibilidade permanente, mas no progresso histórico da interação social, cuja validade ou eficácia é imensurável com os parâmetros analítico-causal das ciências naturais. Em outra, na linha da tese da complementaridade (ou seja, o progresso epistemológico que ocorre na dimensão sujeito-objeto da descrição e elucidação já pressupõe a melhora metódica do acordo mútuo na dimensão sujeito-sujeito ${ }^{546}$ ), caberia a essa educação

\footnotetext{
${ }^{541}$ GADAMER, Verdade e método I, pp. 38-39.

542 GRONDIN, Introdução à hermenêutica filosófica, pp. 181-186.

${ }^{543}$ APEL, Transformação da filosofia, v. I, pp. 31-32; Transformation der Philosophie, Band I, p. 27.

${ }^{544}$ APEL, Transformação da filosofia, v. I, pp. 31-32; Transformation der Philosophie, Band I, p. 27.

545 APEL, Transformação da filosofia, v. I, p. 22; Transformation der Philosophie, Band I, p. 19.

${ }^{546}$ APEL, Transformação da filosofia, v. I, p. 32 (nota 27); Transformation der Philosophie, Band I, pp. $27-$ 28.
} 
colaborar na produção da "sociedade aberta" (crítica). Presume-se que, à medida que a educação atrai para a sua esfera a problemática hermenêutica do acordo mútuo metódico, ela passa a tematizar, tal como já assinalado, "o problema central das ciências humanas e da filosofia social modernas: a identidade e não-identidade de sujeito e objeto do conhecimento comunicativo, e da ação como interação em uma 'sociedade aberta" ${ }^{547}$. Nessa segunda frente, a contribuição de Apel é sua proposta de uma hermenêutica crítica ("hermenêutica filosófica normativo-metodologicamente relevante") ${ }^{548}$, ou seja, uma teoria filosófica normativa para formar a capacidade crítica, movida pela esperança de que o pensar reflexivo possa funcionar como antídoto para evitar a repetição de Auschwitz ou de algo que analogamente favoreça a subjugação e a destruição humana ${ }^{549}$. Essa hermenêutica expressa a especificidade da racionalidade do discurso argumentativo, uma racionalidade simultaneamente referida à história (sociedade) e à idealização in the long run da vida racional.

Possivelmente, o aspecto mais relevante de uma educação impactada pelo "logos das ciências de compreensão hermenêutica", aqui entendida no sentido apeliano da dimensão reflexiva da racionalidade comunicativa, concerne ao fato de que ela pode se respaldar nos critérios normativos que estão contidos no $\log o s$ da racionalidade do discurso. Tal como concebido por Apel, esses critérios concernem a "princípios da razão ou logos" que podem orientar, normativamente, a reconstrução racional dos processos de aprendizagem relacionados à cultura. No conjunto desses critérios ${ }^{550}$, as quatro exigências (pretensões) universais de validação do discurso humano, isto é, as exigências de sentido, de verdade, de veracidade e de correção ética dos atos de fala comunicativos, perfazem uma ética mínima relativa aos pressupostos do discurso argumentativo. Agrega-se também a esses critérios a pressuposição de que essas exigências de validade, exceto a de veracidade, são passíveis de cumprimento racional (embora raramente de modo fático) mediante o auxílio do discurso argumentativo. Posto que Apel entende esses critérios como elementos constitutivos nãocontingentes da pré-estrutura do ser-no-mundo capaz de compreensão (fundamentação), aqui se presume que tais critérios, enquanto pressuposições concernentes a toda argumentação,

\footnotetext{
${ }^{547}$ APEL, Transformação da filosofia, v. I, p. 23; Transformation der Philosophie, Band I, p. 20.

548 APEL, Transformação da filosofia, v. I, p. 52; Transformation der Philosophie, Band I, p. 45.

${ }^{549}$ CORTINA, A. Karl Otto Apel Verdad e Responsabilidad (introducción). In: APEL, Teoría de la verdad y ética del discurso, pp. 14-15.

${ }^{550}$ APEL, O desafio da crítica total da razão e o programa de uma teoria filosófica dos tipos de racionalidade. In: Novos Estudos/CEBRAP, pp. 71 e 75. APEL, Significado linguístico e intencionalidad in: Semiotica filosófica, p. 258. HABERMAS, Teoría de la acción comunicativa, pp. 113-158 ((para uma síntese das pretensões de validade, cf. p. 124). NICOLÁS, Teoría de la verdad consenso-evidencial y teoría de la verdad fenomenológico-real. In: Discurso e realidade, pp. 150-151.
} 
valem como princípios reguladores da aprendizagem a serem considerados no âmbito da educação. Para Apel, toda tentativa na direção do progresso da verdade e dos juízos morais tem de admitir "como telos possível dos processos de aprendizagem a serem reconstruídos, as pressuposições necessárias de sua própria competência reconstrutiva" ${ }^{551}$, portanto, o logos da racionalidade do discurso. E isso significa que há nesses processos, proporcionalmente ao cumprimento das exigências de validade universal do $\log o s$, a possibilidade de aprender a viver de forma mais razoável, dialógica e solidária. Seguindo nesse rumo, com e para além de Gadamer, a versão hermenêutica de Apel tem o mérito de explicitar o marco normativo (condições transcendentais) de uma formação intencionada na elevação da humanidade.

\subsection{Educação como processo de autoria do sujeito: o primado judicativo do sujeito e a dimensão transpositiva do compreender na formação}

O intento deste tópico é destacar um aspecto, aparentemente nebuloso, do giro linguístico hermenêutico-pragmático de Apel, o qual diz respeito ao lugar da autonomia do sujeito na semiótica transcendental, tendo em conta que tal aspecto pode figurar como um pilar fundamental para o âmbito de uma compreensão de educação que se pretenda comprometida com a formação de um sujeito crítico e corresponsável perante a sociedade. Quanto a esse destaque, é preciso assinalar que a esse tópico não interessa resumir a tese do primado judicativo do sujeito alcançado por Apel em sua proposta de uma hermenêuticotranscendental, tal como se essa tese fosse um "produto" já disponível à intrumentalização no campo da educação. Decerto, não se pode desconsiderar que essa tese é nuclear para pensar a autonomia do sujeito desde um ponto de vista semiótico-transcendental. Ao estilo de uma provocação e de modo restrito, esse destaque visa chamar a atenção para a necessidade de ter em pauta o questionamento sobre a imbricação entre atividade do pensar e potencialização da autonomia do sujeito no contexto da educação. Em vista disso, partindo da semiótica transcendental de Apel, esse destaque procura pontuar três pontos interligados que ficam à volta de tal imbricação: a) com o auxílio de Hannah Arendt, o enfoque sobre o efeito depurativo do pensamento, recorrendo-se às figuras de Sócrates, Eichmam e Apel para ilustrar o risco decorrente da incapacidade de pensar, bem como o alcance liberador da capacidade de pensar à singularidade e ação humana; b) o aparente obscurecimento do lugar do sujeito na

${ }^{551}$ APEL, O desafio da crítica total da razão e o programa de uma teoria filosófica dos tipos de racionalidade. In: Novos Estudos/CEBRAP, p. 75. 
"comunitarismo transcendental" de Apel; c) novamente com o auxílio de Hannah Arendt, a relação entre o primado judicativo do sujeito (autoria) e autoridade em Apel. Aqui, o primado judicativo do sujeito, decorrente da dimensão transpositiva do compreender, aparece contributo filosófico nuclear do giro linguístico hermenêutico-pragmático para pensar a situação do sujeito crítico e corresponsável no campo da formação.

\subsubsection{A importância da capacidade de pensar na formação: os exemplos de Sócrates, Eichmam e Apel}

Para iniciar, convém explicitar a observação e a hipótese interpretativa por trás desse tópico. O ponto de partida desse destaque é uma observação, suscitada com a análise do relato de autopercepção autobiográfica de Apel, especificamente na parte que trata dos "anos de guerra”, que se desdobra na forma de uma pergunta. Na verdade, mutatis mutandis, trata-se de uma pergunta já iniciada na Antiguidade, quando Platão coloca em questão "se a virtude pode ser ensinada" 552 , assim como quando se tematiza no diálogo Górgias o alcance do poder do pensamento (razão) para evitar o "mal" (no caso, contra si mesmo). Pelo relato retrospectivo, é possível depreender que, para Apel, a pergunta sobre a autonomia racional do sujeito não é uma questão meramente especulativa; antes disso, de modo mais profundo, ela se enraíza e atravessa a trajetória intelectual e pessoal de Apel. A observação que impulsiona esse destaque consiste em que, no geral, a trajetória ilustra um caso - e não se pode precisa aqui em que medida tal ocorre - supreendente de reviravolta intelectual e existencial em virtude da atividade do pensar crítico-reflexivo. O relato qualifica esse processo de reviravolta como uma "lenta" conversão à filosofia ${ }^{553}$, no qual se expressa uma experiência de reconstrução da autonomia racional do sujeito, a do próprio Apel.

Dessa observação surge uma interrogação referente ao "entremeio" da irreflexão à reflexão. Aqui, entretecendo essa observação com o âmbito da educação tanto quanto possível, é possível afirmar que, mesmo enviesadamente, o relato de autobiográfico de Apel traz uma denúncia à instrumentalização acrítica e quase irracional da educação. Aí, Apel põe a nu, sobremaneira em relação à atmosfera de belicismo e rechaço ao "diferente" dos "anos de guerra" $" 554$, a própria experiência formativa que internaliza na infância e juventude. Trata-se de uma experiência marcada pela manipulação programada das consciências e pela supressão do

\footnotetext{
${ }^{552}$ PLATÃO, Mênon. Trad. Maura Iglesias. Rio de Janeiro: PUC-Rio - Loyola, 2001, 70a-71d.

${ }_{553}$ APEL, Antropos, p. 13.

${ }^{554}$ APEL, Antropos, pp. 12-14.
} 
diálogo argumentativo. Ao mesmo tempo, em uma autopercepção ampliada no sentido da consideração do contexto da maioria da população alemã, o relato testemunha uma experiência intersubjetiva de formação intencionada em forjar seres irreflexivos capazes de levar adiante práticas que mitigam a dignidade humana. Por seu turno, em alternativa a isso, o relato atesta a "lenta" reviravolta que se opera na trajetória de Apel. Lenta, em boa medida, porque a decretação do término da guerra (para Apel, um ex-oficial do exército alemão na Segunda Guerra Mundial), assim reconhece Apel, não significa o efetivo fim do espírito de guerra incutido em sua interioridade, em sua atitude espiritual perante o mundo.

Com efeito, vale observar que o relato é praticamente nulo quanto à elucidação do processo de passagem em que o "jovem Apel”, educado em conformidade com a heteronomia de uma engrenagem voltada ao domínio civilizatório, alcança o "Apel filósofo", pensador humanista vinculado à Teoria Crítica e engajado no projeto de uma teoria consensual da verdade e de uma ética do discurso como ética da responsabilidade. Basicamente, nele consta que Apel, em razão do gosto pelos estudos, imediatamente ao retorno da Guerra, ingressa na Universidade de Bonn. Aí estuda história, línguas clássicas e filosofia, por fỉm, concluindo o doutorado com uma tese sobre Martin Heidegger (1950). O relato informa ainda que, depois do doutorado, ele se dedica às ciências que permitem uma compreensão histórica dos acontecimentos e sua normalização, bem como a explicação sobre a verdade e a possibilidade do progresso ético-político da humanidade. Um aspecto que ilustra o lento percurso de "conversão" à filosofia, é o fato de que a primeira publicação sobre a ética do discurso (como texto programático) ocorre depois de mais de duas décadas após o doutorado. Continuando essa trajetória, surpreendentemente, Apel elabora Importa uma perspectiva teórica intencionada em reconstruir o "sujeito autônomo", no sentido de delinear os traços que caracterizam o "sujeito ideal". Em uma mirada na filosofia de Apel, em linhas gerais, esse sujeito ideal, em conformidade com o horizonte da transformação pragmático-transcendental da filosofia, corresponde a um sujeito crítico-reflexivo e, em consonância com o horizonte da ética do discurso, a um sujeito corresponsável.

A interrogação que surge quase inevitavelmente, se se pensa desde o ponto de vista do interesse de saber como tal passagem (salto) pode ser efetivar no âmbito público da educação, concerne à intenção de saber a respeito de como se opera o "entremeio" de tal reviravolta. O relato parece sugerir que esse salto principia em virtude de um traço idiossincrático de Apel, o gosto pelos estudos desde a infância. Decerto, tal traço (subjetivo, particular) não serve como critério suficiente - aliás, a semiótica transcendental afirma isso contra o solipsismo metódico - para basilar o salto de uma educação acrítica e heterônoma 
para uma postura que ruma, paulatinamente, na direção de uma perspectiva teórica intencionada em reconstruir o "sujeito autônomo", no sentido de delinear os traços que caracterizam o "sujeito ideal". No relato, Apel reconhece que a atuação junto com Habermas e o embate com o movimento estudantil são fatores decisivos para a constituição de sua postura político-filosófica ${ }^{555}$. De todo modo, ele não esclarece acerca do "entremeio" que retrocede (enquanto momento anterior) e possibilita a alguém migrar do domínio da irreflexão para o domínio em que seus pensamentos e atos contém a força do primado judicativo do próprio sujeito. O relato não retrata, didaticamente, esse entremeio; ele apenas o telos do processo de reconstrução da autonomia do sujeito, um sujeito formativamente, críticoreflexivo e corresponsável. A propósito de tal entremeio, a pergunta que se faz aqui é a seguinte: de que modo o sujeito "formatado" segundo os ditames de uma "formação" social (pública e intersubjetivamente) marcada pela heteronomia e pelo pensar acrítico pode migrar para uma situação em que ele se torna autônomo, isto é, adquire capacidade e direito para defender com argumentos racionais suas propostas perante a sociedade, ao memo tempo que busca o consenso in the long run? Curtamente, como alguém que supostamente não pensa por exemplo, por não ter aprendido ou por ser impedido ${ }^{556}$ - passa a pensar? Efetivamente, aqui não se alimenta a presunção de uma resposta a essa questão. Antes, no limite desse tópico e para manter em aberto essa questão, aqui se acrescenta a seguinte hipótese. A meu ver, a tese do primado judicativo do sujeito esclarece acerca do lugar e do princípio condutor à autonomia racional do sujeito na semiótica transcendental, porém não esclarece suficientemente sobre a inquietação relativa a saber acerca do "entremeio", como dito antes, do "intervalo" no processo em se efetiva o salto de um sujeito acrítico para o sujeito crítico e

\footnotetext{
${ }^{555}$ APEL, Antropos, p. 17.

${ }^{556}$ Há que considerar em relação a essa pergunta o seguinte problema: por um lado, Apel entende que o princípio de universalização da ética do discurso, a resolução consensual dos conflitos, pode ser aplicado ser aplicado a qualquer momento; por outro, desde o ponto de vista de uma ética da responsabilidade (isto é, que considera as consequências de tal aplicação), as condições de aplicação de uma ética da comunidade ideal de comunicação "ainda-não" estão realizadas na comunidade real e historicamente condicionada. Ver: APEL, Teoría de la verdad y ética del discurso, p. 177-180. Cf. epílogo: APEL, "Límites de la ética discursiva" in: CORTINA, Razón comunicativa y responsabilidad solidaria, pp. 254-262. Tal problema se torna mais complexo à medida que se postula, na comunidade concreta de argumentação do discurso prático, a consideração das pretensões virtuais dos não-participantes "do" discurso, porém afetados "pelo" discurso, como é o caso dos interesses insuficientemente representados dos membros de países em "desenvolvimento" (por exemplo, na América Latina ou da África). A respeito da discussão entre ética do discurso e ética da libertação, bem como, sobre a crítica ideológica do eurocentrismo: APEL, Karl Otto. A Ética do discurso em face do desafio da filosofia da libertação latino-americana. In: SIDEKUM, Antônio (org.). Ética do discurso e filosofia da libertação: modelos complementares. Trad. Ilson Kayser. São Leopoldo: UNISINOS, 1994, pp. 19-39. Dussel vê Apel positiva e criticamente: de um lado, "refugiado" em um puro e formal nível "transcendental"; de outro, necessitando dar um passo adiante, no sentido "da" pragmática à "econômica". Ver: DUSSEL, Enrique. Filosofia da libertação: crítica à ideologia da exclusão. Trad. Georges I. Maissiat. São Paulo: Paulus, 1995, cap. 2, pp. 43-78.
} 
corresponsável. Mais que afigurar nisso uma pendência da filosofia, a meu ver, em relação a esse entremeio se estabelece o limite da semiótica transcendental, à qual compete definir racionalmente o princípio do primado do sujeito, e à abertura ao campo próprio da educação.

Tratando agora do primeiro ponto, com o auxílio de Hannah Arendt, importa aqui aclarar acerca do poder do pensamento. A escolha de Arendt aqui não é acidental. Ainda que Arendt e Apel representem lados e momentos distintos quanto à lógica e política da Guerra, bem como posições teóricas distintas, a ambos (ao menos no momento tardio de Apel, se se considera seus dois momentos, o dos "anos de guerra" e o da transformação da filosofia) é comum o empenho em vista de uma filosofia moral fundamentada no conceito de responsabilidade. Obliquamente, presume-se que a compreensão do problema da irreflexão segundo a filosofia moral de Arendt se traduz, positivamente, na exigência de adoção princípio hermenêutico do primado judicativo do sujeito, reelaborado por Apel no contexto teórico de uma hermenêutica normativo, em todas as atividades humanas. Na suposição de que ambos refletem a preocupação com a dimensão da razão prática (ético-política), indiretamente, a exposição desse ponto tem como pano de fundo a expectativa de que tal aclaração possa ser suscetível de desdobramentos no campo da educação. Isso, decerto, fica aqui a título de sugestão para em ulteriores investigações, por exemplo, a respeito da formação moral (educação dos valores).

Para explicitar o poder do pensamento, Arendt extrai as implicações, não suficientemente percebidas por Kant, entre pensamento, faculdade da razão que busca o significado, e o conhecimento, faculdade do intelecto que visa a apreender a verdade situada na evidência dos sentidos, o dado verdadeiro. Para Arendt, o homem, como ser pensante e não simplesmente racional, tem a inclinação e necessidade de pensar além das limitações do conhecimento, enquanto atividade devotada ao fazer e à construção do mundo. A necessidade de pensar, diferentemente do desejo de conhecer, só pode ser satisfeita pela atividade do pensamento, pois não deixa nada tangível atrás de si, nem pode ser saciada por intuições supostamente definitivas. Os mais brilhantes pensamentos de ontem só podem satisfazer a necessidade de pensar hoje, à medida que são repensados novamente ${ }^{557}$. Já o desejo de conhecer, seja por necessidades práticas, perplexidades teóricas ou pura curiosidade, tende a se satisfazer quando se alcança o objetivo pretendido e deixa atrás de si um tesouro crescente de conhecimento, retido e armazenado por toda civilização como parte do seu mundo.

557 ARENDT, Hannah. Responsabilidade e julgamento. Trad. Rosaura Eichenerg. São Paulo: Companhia das Letras, 2004, pp. 230-231. 
Segundo Arendt, na ciência, a cognição pertence ao mundo das aparências e constitui um prolongamento refinado do raciocínio do senso comum, sob a regência do critério de evidência. Rege também a ciência a ilusão do progresso ilimitado do conhecimento em vista de uma verdade irrefutável e coercitiva, estribada na exigência de necessidade ditada pela natureza, o que acaba transformando a noção de verdade numa corrente de "veracidades provisórias". Acontece que, no horizonte da busca científica, a retirada para "pensar" em busca das manifestações do "invisível" se justifica em função de resultados específicos, da acumulação de saberes e especialização técnica. De tal modo, o pensamento tem o papel de um meio em relação a um fim, que é decidir sobre o que vale a pena conhecer. Para Arendt, não se deve desconsiderar que tal decisão não é científica.

Para exemplificar o exercício da atividade do pensamento, Arendt se remete a Sócrates. Ela toma como referência uma passagem no diálogo Górgias, em que Platão põe em relevo a concepção socrática de que a consciência moral resulta da experiência do pensamento enquanto atividade. No diálogo circula a convicção compartilhada de que ao se fazer o que é melhor para o próprio indivíduo, faz-se igualmente o melhor para a comunidade. Mas, como aí não aparece, explicitamente, a questão acerca do que fazer no caso de um conflito (desgraça), Sócrates propõe algumas afirmações paradoxais aos seus interlocutores. Mesmo sem convencer a ninguém, ele faz as seguintes afirmações: a) "é melhor sofrer o mal do que o cometer"; 2) "é melhor para o agente ser punido do que continuar impune"; 3) "o tirano que pode fazer com impunidade tudo que quiser é um homem infeliz" ${ }^{558}$. Mesmo "sozinho", Sócrates se mostra "incapaz de concordar" com seus interlocutores, afirmando ser preferível o desafino do "coro" regido por ele do que ele, "sendo um só", estivesse em contradição consigo mesmo (Górgias 482b-c) ${ }^{559}$. Essa afirmação de Sócrates, segundo Arendt, representa a noção-chave da crença no efeito depurativo do discurso para a fundamentação da moralidade: o "eu que sou um só" pensando é, na verdade, o "sou dois-em-um" "560, que pode entrar ou não em harmonia consigo mesmo.

Analisando essa passagem do Górgias, Arendt pontua que a consciência, peculiarmente presente naqueles que "vivem consigo mesmos", seja pelo temor do desprezo de si (no sentido de Kant), seja pelo receio de contradizer-se a si mesmo (no sentido de Sócrates), sustenta a moralidade. Arendt pensa que a obrigação moral (o imperativo "deves"

\footnotetext{
${ }^{558}$ ARENDT, Responsabilidade e julgamento, p. 146.

559 PLATÓN. Gorgias. Disponível em: http://www.dominiopublico.gov.br/download/texto/bk000468.pdf. Acesso em 10/09/2015.

${ }^{560}$ ARENDT, Responsabilidade e julgamento, pp. 155-157.
} 
ou "não deves") não é absolutamente evidente, tampouco pode ser provada sem que se ultrapasse o âmbito do discurso racional. Por conta disso, ela afirma que o imperativo de Kant poderia ter sido uma "afirmação categórica", como a de Sócrates: "é melhor sofre o mal do que o cometer”. Afinal, “por detrás da obrigação, do 'Deves', 'Não deves', está um 'senão', a ameaça de um sansão imposta por um Deus vingador, pelo consentimento da comunidade ou pela consciência, que é a ameaça de autopunição que comumente chamamos de arrependimento" 561 . No entender de Arendt, não é essa obrigação que sustenta a moralidade, mas a capacidade de resistir, sob o patamar de um padrão negativo (o "não posso"), em momentos de crise e exceção. Disso, o ponto fundamental é que, para quem reflexivamente vive em alerta contra o risco do autodesprezo ou de tornar-se má companhia para si próprio, as proposições morais são evidentes por si mesmas e, por isso, prescindem da obrigação. $\mathrm{O}$ mal significa entrar em contradição consigo próprio, mesmo quando - e essa é uma tese comum na tradição da filosofia moral que norteia as proposições morais desde Sócrates a Kant - não se acredita que se busca praticar deliberadamente atos cruéis, querer o mal pelo $\mathrm{mal}^{562}$. Enfim, a moralidade conota o cuidado zeloso do indivíduo consigo próprio, a partir do qual 'todos os padrões objetivos 'cedem a primazia ao critério 'subjetivo' do tipo de pessoa que desejo ser, e com quem desejo viver" ${ }^{563}$, que se traduz na definição do próprio caráter ou pessoalidade.

Arendt sublinha que é próprio do pensamento se retirar do mundo e de sua natureza evidencial para interpelar acerca do significado da existência e do mundo. $\mathrm{O}$ pensamento tem lugar quando se interrompe "tudo o mais" (do inter homines esse), todo fazer relativo às atividades comuns que impedem a atividade do pensar ${ }^{564}$. Para pensar, é necessário está liberado de interesses (instrumentalizações, acúmulos ou verdades) e desembaraçado de limites, no sentido de que a necessidade de pensar nunca pode ser exaurida pelos insights; o que lhe faculta produzir obras de arte e formular as questões sobre as quais se funda qualquer civilização $^{565}$. Quando mal-compreendida, toda reflexão que não serve ao conhecimento ou não é guiada por fins práticos e instrumentais aparece como forma de um modo de vida (bios theórétikos) "antinatural" e "fora de ordem". A despeito disso, há que se considerar que,

\footnotetext{
${ }^{561}$ ARENDT, Responsabilidade e julgamento, pp. 141-142.

562 ARENDT, Responsabilidade e julgamento, p. 136.

563 CORREIA, Adriano. O pensamento pode evitar o mal? In: Revista educação: Hannah Arendt pensa a educação, (Ed. Segmento - especial biblioteca do professor), São Paulo, n. 4, [201-], pp. 46-55, cf. p. 51.

564 ARENDT, Responsabilidade e julgamento, p. 232.

565 ARENDT, Hannah. A vida do espírito: o pensar, o querer, o julgar. Trad. Antonio Abranches, César Augusto R. de Almeida, Helena Martins. 3. ed., Rio de Janeiro, Relume Dumará, 1995, p. 48.
} 
segundo Arendt, "toda a história da filosofia", que retrata mais os objetos do pensamento que sobre o processo do próprio pensar, é transpassada pela luta interna entre o senso comum do homem, "esse sentido muito elevado que ajusta os nossos cinco sentidos a um mundo comum e nos torna capazes de nos orientarmos neste mundo, e a faculdade humana de pensar, pela qual se afasta voluntariamente de tal mundo" ${ }^{566}$. Se as questões formuladas pelo pensamento são irrespondíveis e sem significado, perante os olhos do senso comum e da ciência, é porque eles estão já comprometidos em "adequar-nos ao mundo das aparências e deixar-nos em paz"567. Por sua vez, "um objeto do pensamento é sempre uma representação, isto é, algo ou alguém que está realmente ausente e presente apenas para o espírito que, pela imaginação, pode torná-lo presente na forma de uma imagem"568. Essa distinção, que não implica em negar a conexão entre a busca de significado pelo pensamento e a busca da verdade pelo conhecimento, denota que o pensamento, mesmo sendo invisível e lidando com objetos ausentes e imperceptíveis aos sentidos (no sentido ontológico), é a atividade que dá significado ao que aparece e é. O significado propriamente está fora do mundo das aparências, e só é acessível pela atividade do pensamento.

Quanto à "arte" de pensar, conforme Arendt, Sócrates e Eichmann constituem, respectivamente, o modelo de educador para o pensar e o antimodelo da reflexão. O Sócrates histórico representa a real atividade do pensar, mesmo sem deixar atrás de si nenhum corpo doutrinário. Em seus traços, Sócrates é um pensador que permanece um homem entre os homens, um cidadão entre os cidadãos, sem pretensão de governar ou aconselhar os que estão no poder, mas que não se submete docilmente às regras. Sócrates é o modelo da experiência do que significa pensar, no sentido de uma atividade que tem a faculdade de degelar o significado original congelado dos conceitos. Em suas autocomparações, Sócrates se diz semelhante a um moscardo, uma parteira e uma arraia-elétrica, a despeito de afirmar que nada tinha a ensinar. Com efeito, é por meio delas que Sócrates mostra o único modo como o pensamento pode ser ensinado, a saber, verificando se as perplexidades percebidas por ele são compartilhadas também pelos seus interlocutores. Como um moscardo, Sócrates ferroa os cidadãos para despertá-los da letargia. Como uma parteira, Sócrates traz à luz os pensamentos alheios. Supondo que compartilha da esterilidade das parteiras, cabe-lhe checar a "gravidez" de conceitos alheia, depurando-a dos pré-julgamentos não examinados que impedem o pensar. Essa atividade, ao invés de tornar os pré-julgamentos bons ou convertê-los em suma verdade,

\footnotetext{
${ }^{566}$ ARENDT, Responsabilidade e julgamento, p. 233.

${ }^{567}$ ARENDT, A vida do espírito, p. 46.

568 ARENDT, Responsabilidade e julgamento, p. 232.
} 
resulta em novas aporias; tal como é peculiar à obstetrícia do pensamento. Resistente à ignorância indiferente - que sabe que não sabe, mas deixa tudo com estar - e paralisado pelas perplexidades, Sócrates, como uma arraia-elétrica, ferroa e paralisa seus interlocutores. Essa paralisia é a condição para sentir o vendaval invisível do pensamento, que varre destrutivamente todos os critérios estabelecidos, valores e medições do bem e do mal, na moral e na ética, deixando os afetados pela reflexão apenas vivos e despertos com as próprias perplexidades (sem doutrina) e a possibilidade de compartilhá-las ${ }^{569}$.

Para Arendt, Eichmann, em razão das implicações morais decorrentes de sua recusa a pensar diante das atrocidades implementadas pela política nazista, representa o antimodelo da reflexão que encarna a "banalidade do mal". É um antimodelo não em razão de ser portador de uma teoria ou doutrina, mas por representar, faticamente (quaestio facti), o subterrâneo dos atos malignos, cometidos em larga escala. Ele é um antimodelo não por causa de alguma maldade particular, patologia ou convicção ideológica do agente, mas por representar a superficialidade, "irreflexão" e "incapacidade de pensar". Escondido por detrás de clichês, lugares-comuns, códigos padronizados de expressão e conduta, Eichmann exemplifica a função socialmente reconhecida referente ao uso de convenções "morais" para imunizar-se contra as exigências que os acontecimentos e fatos cobram do pensamento ${ }^{570}$. Em seus contornos e implicações, o caso Eichmann é relevante para a filosofia moral, porque nele se torna patente a fenomenologia da banalidade do mal: um mal que não é radical, porém é incompreensível. No caso Eichmann, segundo Arendt, o mal é um mal banal porque, caracteristicamente, é desprovido de explicação convincente e de motivação ideológica, patológica ou demoníaca.

Ao declarar a banalidade de Eichmann, Arendt não pretender negligenciar a sua imputabilidade, mas compreender o tipo de mentalidade que pode contribuir para o surgimento de indivíduos como ele. Para entender o caso Eichmann, Arendt parece abandonar a formulação kantiana de mal radical e, em contrapartida, traz a noção de que o mal é algo banal. Nesse sentido, o mal não é uma fatalidade ou questão ontológica, mas uma possibilidade da liberdade humana e, como tal, uma questão da ética e da política. O mal banal pode ser extremo, porém é superficial. Contudo, banalidade não significa normalidade. Arendt distingue os fenômenos típicos do lugar-comum, aqueles que acontecem com regularidade e constância, e os do mal banal. O mal banal é o fenômeno que não é comum,

\footnotetext{
${ }^{569}$ ARENDT, Responsabilidade e julgamento, pp. 241-244; A vida do espírito, pp. 130-131.

${ }^{570}$ ARENDT, Responsabilidade e julgamento, pp. 226-228.
} 
mas ocupa indevidamente o lugar (como se fosse) da normalidade; ao fazer isso, ele esconde o próprio horror, graças à superficialidade e superfluidade. Arendt entende que, quanto mais alguém é superficial, mas tendente a ceder ao mal. Já a superfluidade diz respeito ao fenômeno decorrente do sentido utilitário da sociedade de massa. Urdindo esses aspectos, o mal se torna banal porque os seus agentes são superficiais e suas vítimas são supérfluas" ${ }^{\text {571 }}$. O aspecto dramático é que esse mal se espraia não pelas mãos dos "maldosos" e "pecadores", assim comumente descritos na literatura e na religião, mas justamente pela atuação de indivíduos comuns e inofensivos que foram "educados" (acostumados) a não-pensar. Se o perigo é intrínseco à atividade do pensamento, assim pensa Arendt, muito mais desastroso é a ausência de reflexão.

O problema que se liga à irreflexão é que ele, segundo Arendt, impede a constituição e o exercício da moralidade como singularidade. O próprio da esfera da moralidade é a constituição de personalidades morais; a transformação distintiva do ser meramente humano na "qualidade de ser uma pessoa". No sentido da filosofia moral, a "qualidade pessoal de um indivíduo" conforma precisamente a sua "qualidade moral", que não está "entre as propriedades, dons, talentos ou defeitos individuais congênitos e dos quais é possível usar e abusar" ${ }^{" 572}$. Para Arendt, o critério de moralidade não depende, em última análise, nem dos hábitos e costumes compartilhados nem de uma ordem de origem divina ou humana. Define-se o critério moral em razão daquilo que cada pessoa decide a respeito de si mesmo nos processos do pensamento, isto é, na atividade que faculta a toda pessoa a comunicação consigo mesma a respeito de tudo o que lhe diz respeito. Por esse viés, o padrão criteriológico da moralidade "não é nem o amor por algum próximo, nem o amor por si próprio, mas o respeito por si mesmo" ${ }^{573}$. Enfim, a preocupação com a dignidade humana torna a pessoa capaz de distinguir o certo do errado, assim como fazer o certo e evitar o errado. É nessa perspectiva que a moralidade diz respeito ao indivíduo na sua singularidade ${ }^{574}$. Acontence que, na situação de irreflexão, porque nunca pensam (refletem) sobre o que acontece, os malfeitores nunca se confrontam consigo próprios, tampouco se lembram do mal perpetrado ou refletem antes de cometer um dano irreparável. "Memória e profundidade são o mesmo, ou antes, a profundidade não pode ser alcançada pelo homem a não ser através da recordação", de forma que a tarefa da moralidade dá conta das dimensões

\footnotetext{
571 ARENDT, Responsabilidade e julgamento, pp. 160 e 212. ANDRADE, A banalidade do mal e as possibilidades da educação moral: contribuições arendtianas. In: Revista Brasileira de Educação, pp. 111-115. 572 ARENDT, Responsabilidade e julgamento, p. 143.

${ }^{573}$ ARENDT, Responsabilidade e julgamento, p. 131.

${ }^{574}$ ARENDT, Responsabilidade e julgamento, pp. 162-163.
} 
da memória e da profundidade humana"575. A incapacidade de pensar deságua na incompreensão da atividade crítica inerente ao julgamento moral. Essa incompreensão, à medida que desdenha dos giros dialéticos e abertos próprios do discernimento pessoal acerca do certo e do errado, acaba fortalecendo uma cultura cuja pretensão fundamental é encontrar resultados doutrinários que tornem o pensamento ulterior desnecessário. A incapacidade reflexiva está presente tanto na "procedurística" da engrenagem que tornar todos os homens supérfluos $^{576}$, como na sociedade que se torna cúmplice da dominação totalitária, à medida que compartilha as mentiras do sistema não por ser enganada, mas por se recusar a perscrutar a verdade dos fatos ${ }^{577}$.

Nesse ponto, para ilustrar a situação de irreflexão, é interessante interpor aqui também o caso de Apel. A esse respeito, a parte do relato autobiográfico de Apel sobre os "anos de guerra" é bastante esclaredora. Aí, Apel quebra o "silêncio" e desduda criticamente a dramaticidade da auto-experiência de irreflexão. A respeito desse ponto, tratar-se-á no terceiro capítulo deste trabalho. Aqui se adianta os aspectos que ilustram o envolvimento de Apel na "engrenagem" (para usar aqui a terminologia de Arendt); particularmente, aqui interessa a justificativa para prosseguir em estado de guerra que ele internaliza. Pois bem, em sua juventude, com a ascensão de Hitler ao poder, Apel participa das "Juventudes Hitlerianas" e, de 1940 a 1945, abandona os estudos e ingressa no exército alemão, participando da campanha da Rússia. Avaliando retrospectivamente (aos 68 anos), Apel reconhece que as atividades no Instituto de Humanidades, cujas aulas de história suscitavam o entusiasmo pelo antigo império romano-germânico, bem como as desenvolvidas nas "Juventudes Hitlerianas" e na formação de recrutas do exército, resultaram em lhe condicionar a agir em conformidade com uma visão doutrinária tipicamente patriótica e "nacional-socialista". A intensidade desse condicionamento ressoava, segundo Apel, nos campos de batalha. Ele narra que, no começo das campanhas da Polônia e da Rússia, teve dúvidas e inquietações (vagas e imaturas) sobre o direito dos alemães de submeter os eslavos e o "sem-sentido" da guerra, mas, em desterro destas, sobrevinha-lhe a resposta de que "a essência da história universal consiste na luta das nações pela hegemonia, que se justifica em vista da elevação cultural daqueles que se impõem"578.

\footnotetext{
575 ARENDT, Responsabilidade e julgamento, p. 131.

${ }^{576}$ CORREIA, O pensamento pode evitar o mal? In: Revista educação: Hannah Arendt pensa a educação, pp. 47 e 48.

577 ANDRADE, A banalidade do mal e as possibilidades da educação moral: contribuições arendtianas. In: Revista Brasileira de Educação, p. 116.

578 APEL, Antropos, p. 14.
} 
Sem minimizar quanto à circunstância de irreflexão, Apel reconhece: nem os episódios catastróficos para os alemães (como a morte de mais de cem mil soldados da infantaria por congelamento dos pés, na batalha do inverno de 1941, em Moscou), nem memo o acesso às inúmeras informações restritas entre o alto comando do exército e o quartel general do Führer (a partir de 1943, quando Apel já ocupava um posto de oficial do serviço de comunicações), cujo teor evidenciava tanto o fim da racionalidade (perversão da razão) e da crença na vitória militar alemã, quanto o propósito de Hitler de resolver definitivamente e de qualquer maneira (cruelmente) a questão judaica, trouxeram-lhe à razão. Nada disso, apesar de contribuir para uma "visão negativa" (termo de Apel, que parece um eufemismo para a catástrofe em escala mundial) do momento histórico, causara-lhe uma mudança de perspectiva rápida e radical. Em vez de superar logo essa "visão negativa" após seu regresso da guerra (aos 23 anos), depois de ter sido prisioneiro por seis meses em um cativeiro americano na França, a atitude espiritual de Apel é ressentir-se de pertencer à last generation e passar a adotar uma postura de retirada apolítica (no sentido de "estar por cima das coisas") $^{579}$. Para concluir essa parte do relato Apel explicita o saldo de sua experiência formativa: um déficit filosófico na dimensão da filosofia prática contra o qual só se insurge, de fato, a partir do seu reencontro com Habermas e ingresso, em 1973, na Escola de Frankfurt $^{580}$.

Descrevendo o contexto de justificação dos "anos de guerra", Apel aponta duas razões ${ }^{581}$ que o levaram ao "cumprimento do dever até o último dia" (enquadramento no "espírito do povo") e ao rechaço da insubordinação ou deserção. A primeira é o fato de que a maioria da população adulta se norteia pelo grau de convencionalidade em relação ao juízo moral e à valoração. Vendo isso do ponto de vista teórico da teoria de Lawreng Kolhberg sobre os graus de competência para o juízo moral, esse fato corresponde ao grau 4 (lei e ordem). A segunda é a existência de duas peculiaridades da sociedade alemã: a) a redução e incorporação do rigoroso conceito de dever universalista na ética profissional dos agentes e oficiais prussianos, preconizado no cumprimento convencional da lei e da ordem; b) a instrumentalização mística e racista do conceito de nação e Estado pelo nacional-socialismo, induzindo a uma solidariedade de ordem consanguínea. A mensagem que impulsiona essa indução é a seguinte: "você não é nada, a nação é tudo". Aqui, não se pode deixar de observar que o "expor-se" de Apel transcende o relato de uma experiência particular, à medida que ele

\footnotetext{
579 APEL, Antropos, p. 15.

${ }^{580}$ APEL, Antropos, p. 17.

${ }^{581}$ APEL, Antropos, pp. 14-15.
} 
chama a atenção - e nisto reside o aspecto que interessa à reflexão sobre o sentido públicosocial da educação - para uma experiência que é a um só tempo o ethos compartilhado pela maioria da população naquele momento histórico. Especulando a respeito dessa justificativa, parece possível assinalar o seguinte contraponto entre Apel e Arendt. Apel afirma que as catástrofes adjacentes à Guerra estavam sustentadas por uma moralidade convencional; e, ao recorrer a Kohlberg, parece sugerir algum grau de compatibilidade entre as atrocidades ocorridas e os níveis de formação da consciência moral. Mas vendo nisso um problema, no contexto da ética do discurso, defende a necessidade de refundamentar a moralidade, agora em um sentido pós-convencional capaz de assegurar a responsabilidade solidária. Arendt sustenta, por sua vez, que a consciência moral se fez presente, efetivamente, naqueles "poucos" que ousaram dizer "não posso" em relação às demandas do sistema, mesmo à custa da própria dignidade humana.

Retornando agora à comparação de Arendt, Sócrates e Eichmann evidenciam, distintivamente, os riscos inerentes à presença e à ausência da atividade do pensamento. Eichmann ilustra o risco da irreflexão e da superficialidade, a ponto de conduzi-lo ao servilismo e ao valor supostamente moral da obediência ${ }^{582}$. Por estar somente preocupado com a posse de regras, sem examiná-las e julgá-las, ele é um triste exemplo daquele mal que é praticado por pessoas que nunca decidiram ser boas ou más. Falta a Eichmann o elemento purificador do pensar, a maiêutica socrática ${ }^{583}$, que traz à luz as implicações dos valores, doutrinas, teorias e até convicções não examinadas (e com isso as destrói). Como ele se recusa a pensar, Eichmann também é incapaz de perceber que todo pensar é político por implicação e que se manifesta no mundo através da capacidade de julgamento ${ }^{584}$. Por sua parte, Sócrates põe a nu, mediante palavras e atos, que todo pensar, embora perigoso para todos os credos, não é uma questão marginal nas questões políticas. O pensar acompanha o viver, à medida que pela mediação da linguagem retrocede às coisas invisíveis, como os conceitos de justiça, felicidade, temperança e prazer, para expressar o significado de tudo que acontece durante a

\footnotetext{
${ }^{582}$ ARENDT, A vida do espírito, p. 133.

${ }^{583}$ Para Werner Jaeger, em contraposição aos sofistas, que ensinam aos filhos de cidadãos abastados sobre disciplinas ou artes específicas, as investigações de Sócrates se desdobram por meio de duas formas entrelaçadas de conversação, a exortação (protreptikos) e a indagação (elenchos), as quais constituem duas fases distintas do mesmo processo educativo. A missão educativa de Sócrates concerne ao "cuidado da alma", enquanto um cuidado através do conhecimento do valor e da verdade (phronesis e aletheia) (JAEGER, Werner. Paidéia: a formação do Homem Grego. Trad. Artur M. Parreira. São Paulo: Herder, [s.d.], pp. 486-491). Ainda sobre maiêutica e o método da procura da verdade por meio da refutação do adversário (elenchos), cf. REALE, Giovanni. História da filosofia antiga. Trad. Henrique Cláudio de Lima Vaz e Marcelo Perine. São Paulo: Loyola, 1984, v. II, p. 26-27.

${ }^{584}$ ARENDT, Responsabilidade e julgamento, p. 256.
} 
vida. O pensar parece beneficiar bem menos a sociedade que a sede de conhecimento, que é utilizado como um instrumento para outros fins. Ademais, além de não criar valores, o pensar traz consigo o risco de dissolver as regras de conduta aceitas. Contudo, a importância políticomoral do pensar aparece justamente nos momentos que é necessário exercer a faculdade de julgamento, relativa à capacidade de "julgar os particulares sem subsumi-los naquelas regras gerais que podem ser ensinadas e aprendidas até se tornarem hábitos que podem ser substituídos por outros hábitos e regras" ${ }^{\text {585 }}$. A manifestação do pensar, enquanto representação de coisas ausentes, no mundo das aparências não é o conhecimento, mas o julgar particulares e coisas próximas, a capacidade de distinguir o certo do errado, o belo do feio. Nesse sentido, o julgar é um como subproduto do efeito liberador do pensar. E importa que, ao emprestar realidade ao pensar, o julgar "pode impedir catástrofes, pelo menos para mim, nos raros momentos em que as cartas estão abertas sobre a mesa" ${ }^{286}$.

Para Arendt, é evidentemente mais plausível correr o risco que se liga à implicação política da maiêutica socrática do que acompanhar-se do anti-risco da reflexão de Eichmann. O próprio Sócrates sublinha que uma vida sem reflexão carece do próprio sentido de viver. Tal compreensão, entretanto, não elimina a perigo de o argumentante achar-se em meio a caminhos aporéticos, típicos da atividade maiêutica, e frustrar-se perante os nãoresultados doutrinários que são facultados pela investigação mediada pela atividade do pensamento. No Górgias, Platão alerta acerca das variações de um ressentimento referente a essa frustração, ora migrando para a licenciosidade e cinismo (tal é o caso de Alcibíades e Crítias, homens públicos que precisam vender resultados doutrinários), ora para o niilismo (entendido como o outro lado do convencionalismo que aposta numa verdade invertida, cujo resultado dispensa o próprio pensar ulteriormente). Ocorre que essa frustração é fruto da incompreensão da busca do pensamento pelo significado e, ironicamente, do único assunto que Sócrates se diz conhecedor, o amor ("eros"). O amor é a necessidade, o desejo daquilo que não se tem; o amor estabelece uma relação com o que não está presente. Para Sócrates, os homens amam a sabedoria e praticam a filosofia, porque não são sábios; amam a beleza e praticam o belo, porque não são belos. Porque a busca do pensamento é um tipo de amor desejante, os objetos do pensamento só podem ser coisas merecedoras de amor, justiça, beleza, sabedoria. Quando investidas de esse amor desejante, assim pensam Sócrates e Arendt, os homens são capazes de pensamento e incapazes de fazer o mal. A feiura e o mal

\footnotetext{
${ }^{585}$ ARENDT, Responsabilidade e julgamento, p. 257.

${ }^{586}$ ARENDT, Responsabilidade e julgamento, p. 257.
} 
são excluídos do interesse do pensamento, pois apenas indicam ausência, privação, algo sem raízes próprias que o pensamento possa apreender. $\mathrm{O}$ ato de pensar não possa oferecer garantias ou determinações absolutas - costuma desfazer "toda manhã o que tinha acabado na noite anterior" 587 -, mas sempre já pressupõe o patamar de um padrão negativo de moralidade (o "não posso"), a busca de evitar praticar o mal. Esse padrão, em que Sócrates aparece como modelo, é compartilhado por quem vive "consigo mesmo", teme o desprezo de si próprio ou autocontradizer-se ${ }^{588}$. Eis porque parece preferível aproximar-se de companhias ${ }^{589}$ que se buscam, a exemplo de Sócrates, como amantes das perplexidades.

Diferentemente da tentação da obediência irrefletida de Eichmann, em termos de educação, o risco inerente à investigação socrática é relativo à possibilidade de ser impactado pelo amor. À medida que o amor é o pré-requisito de todo pensar, pode-se cogitar que ele também o é de toda atividade educativa fundada na reflexão, inclusive moral. Para Arendt, dotada dessa pré-condição, a educação se manifesta como uma atividade em prol da singularidade (autoria de si) e do amor mundi. Na educação, a responsabilidade para com os filhos adquire novos contornos quando, pela primeira vez, a criança é introduzida no mundo

\footnotetext{
587. ARENDT, Responsabilidade e julgamento, p. 234.

588 ARENDT, Responsabilidade e julgamento, p. 136 (no texto "pensamento e considerações morais", pp. 247257).

${ }^{589}$ Para Arendt, no final das contas, a decisão acerca do certo e do errado depende da escolha da companhia e dos seus exemplos. A caminhada em busca da companhia e dos exemplos não pode ser marcada pela tautologia do olhar, seja pela camuflagem emanada e difundida pelo establishment, seja pela adesão irrefletida dos portavozes do Zeitgest (expoentes da História). Parece ser esse o transfundo da obra "Homens em tempos sombrios" de Arendt. A obra é uma coletânea de relatos exemplares, ensaios escritos ao longo de doze anos, referentes "basicamente a pessoas" (Lessing, Rosa de Luxemburgo, Angelo Giuseppe Roncalli, Karl Jaspers, Isak Dinesen, Hermann Broch, Walter Benjamin, Bertolt Brecht, Randall Jarrell e Martin Heidegger), caracteristicamente, diferentes entre si quanto às convicções, profissões ou ambientes, porém compartilhando o mesmo tempo histórico, os "tempos sombrios". Não interessa a Arendt narrar mundos interiores (a introspecção, a discussão do íntimo transposto para o domínio público que se reduz à trivialidade do mexerico), mas falar das pessoas no mundo e realçar o predomínio e a importância do mundo público. Aos tempos sombrios dizem respeito não às monstruosidades do século XX, mas à opacidade do âmbito público que não consegue mais iluminar a vida dos homens: "as sombras chegam quando essa luz se extingue por 'fossos de credibilidade' e 'governos invisíveis', pelo discurso que não revela o que é, mas varre para sob o tapete, com exortações, morais ou não, que, sob o pretexto de sustentar antigas verdades, degradam toda a verdade a uma trivialidade sem sentido" (ARENDT, Hannah. Homens em tempos sombrios. Trad. Denise Bottmann. São Paulo: Companhia das Letras, 2008, p. 8). Mas, para Arendt, subsiste o "direito de esperar alguma iluminação". E essa iluminação, mesmo em tempos sombrios, pode "provir, menos das teorias e conceitos, e mais da luz incerta, bruxuleante e frequentemente fraca que alguns homens e mulheres, nas suas vidas e obras, farão brilhar em quase todas as circunstâncias e irradiarão pelo tempo que lhes foi dado na Terra" (ARENDT, Homens em tempos sombrios, p. 9). Por sua vez, o sentido da companhia em Apel remete sempre ao outro ((mit den Anderen), pois o compreender ao outro só figura um ato hermenêutico se a relação linguístico-cognitiva entre sujeito-sujeito, relativa ao acordo intersubjetivo acerca de algo e por meio da qual se deposita a confiança no outro quanto à verdade ou à correção normativa de questões práticas, não é substituída por uma objetivação descritiva ou explicativa de seu comportamento, pautada pela relação (linguístico-cognitiva) entre sujeito-objeto (cf. APEL, Transformação da filosofia, v. I, pp. 31-32; Transformation der Philosophie, Band I, p. 27).
} 
pela mediação da escola, uma esfera pré-política ${ }^{590}$. Sem ser o mundo, ainda que represente isso para a criança, a escola é uma instituição interposta entre o domínio privado do lar e o mundo público, com o propósito de operar a transição da família para o mundo. No contexto escolar, o Estado (o mundo público dos adultos representado pela escola), e não a família, é requisitado a comparecer como responsáveis pela tarefa educativa. Nesse campo, essa responsabilidade novamente se desdobra de forma tensa, porém sem privilegiar tanto o "bemestar vital de um ser em crescimento". O foco de tensão se conflui entre a responsabilidade pelo "livre desenvolvimento de qualidades e talentos pessoais", consoante à formação da "singularidade que distingue cada ser humano de todos os demais, a qualidade em virtude da qual ele não é apenas um forasteiro no mundo, mas alguma coisa que jamais esteve aí" ${ }^{591}$, e, ao mesmo tempo, a responsabilidade coletiva ${ }^{592}$ pelo mundo, que é implícita em toda atividade educativa e fator constitutivo da autoridade do educador ${ }^{593}$. Também pela natureza crítica da reflexão, quanto pela essência da educação - que, em Arendt, é a natalidade, "o fato de todos nós virmos ao mundo ao nascermos e de ser o mundo constantemente renovado mediante o nascimento" $" 594$-, presume-se que a tarefa educativa permeada pela atividade do pensar (razão) deve facultar novas experiências de ressignificação do mundo.

Para Arendt, sob o estatuto do pensamento, a educação impulsiona a formação da singularidade e passa a mirar o significado do mundo, enquanto se desnuda da tentação de modelar valores absolutos ou códigos moralizantes instrumentais. A faculdade do pensamento não delineia "nenhuma proposição ou mandamento moral, nenhum código final de conduta da atividade de pensar, muito menos uma nova definição, agora supostamente final, do que é

\footnotetext{
${ }^{590}$ ARENDT, Entre o passado e o futuro, p. 238

${ }^{591}$ ARENDT, Entre o passado e o futuro, pp. 238-239.

592 A noção de responsabilidade coletiva se liga aos dilemas políticos. A responsabilidade coletiva é sempre política, porque decorre da pertença a um grupo que nenhum ato voluntário pode dissolver. A culpa, ao contrário da responsabilidade, sempre é pessoal e se refere a um ato. Para Arendt, "nenhum padrão moral, individual e pessoal de conduta será capaz de nos escusar da responsabilidade coletiva. Essa responsabilidade vicária por coisas que não fizemos, no sentido de assumir as consequências por atos de que somos inteiramente inocentes, é o preço que pagamos pelo fato de levarmos a nossa vida não conosco mesmos, mas entre nossos semelhantes, e de que a faculdade de ação, que, afinal, é a faculdade política par excellence, só pode ser tornada real numa das muitas e múltiplas formas da comunidade humana" (ARENDT, Responsabilidade e julgamento, p. 225).

593 "A educação vive a tensão de ter de salvaguardar a singularidade que renova o mundo por meio da ação e, simultaneamente, salvar o mundo do estranhamento da condição de estrangeiro; e vive também a tensão de convidar à responsabilidade do amor mundi e ter de evitar a ameaça do conformismo e da doutrinação. A educação, como esfera pré-política, está para a novidade assim como, no domínio político, a fundação está para a ação: no interstício entre a conservação e a renovação, entre o zelo e a transformação" (cf. CORREIA, Adriano. Natalidade e amor mundi: sobre a relação entre educação e política em Hannah Arendt. In: Educação e Pesquisa, São Paulo, v.36, n.3, p. 811-822, set./dez. 2010, cf. p. 819).

${ }^{594}$ ARENDT, Entre o passado e o futuro, p. 247.
} 
bom e do que é o mau" 595 . À medida que o ato de pensar é desinteressado e aberto - tanto do fim e dos resultados de uma verdade neutra e objetiva, quanto da tentação de acumular significados, pois esses são experiências únicas e irreproduzíveis -, ele é uma mirada relação ao mundo, e não por critérios morais ou normativos extra-mundo (metafísico). Ele não é normativo porque não é código de conduta, tampouco critério de conhecimento ou de manipulação para a vida prática ${ }^{596}$. A atividade do pensamento é a possibilidade de ver o mundo "desde fora", para ressignificá-lo e, assim, reconciliar-se com o próprio mundo. Como tal, embora não possa fundamentar o agir moral, o pensamento tem um caráter reparador, o que parece ser essencial para a educação dos valores. Na perspectiva desse caráter reparador com o mundo, educar por meio da atividade do pensamento implica em cultivar relações educativas e processos pedagógicos que favoreçam o diálogo interno ("silêncio ${ }^{597}$ ), enquanto atividade inerente à própria vida comprometida com novos significados e a reconciliação com o mundo, apesar das injustiças, violências e intolerâncias.

Finalizando esse primeiro ponto com uma observação, Arendt projeta sua reflexão acerca da filosofia moral "para-além" de Sócrates e Kant. Porém, de modo semelhante a Apel, ela é cônscia de que os seres humanos, enquanto seres dotados de logos, não dialogam apenas sozinhos (pensar consigo mesmo), mas também com a pluralidade dos seres singulares. Para Arendt, a ação e o discurso são os modos pelos quais os seres humanos se revelam uns aos outros na teia das relações intersubjetivas. Com efeito, a interação entre os seres singulares e a esfera da pluralidade é atravessada pela cisão entre moral e política ${ }^{598}$ : quando se coloca em relevo o padrão do "eu", reivindica-se a primazia dos princípios morais relativos ao cuidado com o eu; se o padrão é o cuidado com o mundo, então a prevalência é dos princípios políticos. Em relação a essa separação entre moral e política, seguindo Maquiavel ${ }^{599}$, Arendt

\footnotetext{
595 ARENDT, Responsabilidade e julgamento, p. 234.

596 ANDRADE, A banalidade do mal e as possibilidades da educação moral: contribuições arendtianas. In: Revista Brasileira de Educação, p. 123.

597 "Privilegia-se a fala, a leitura, o trabalho em grupo. (...) Toda conversa dialógica - entre educador/a e educando, educando e texto e educandos entre si - deveria levar ao silêncio, isto é, deveria instigar o educando para o diálogo consigo mesmo. (...) Toda aula, texto, pesquisa ou trabalho de grupo deveria colocar-se no campo das possibilidades que propiciam, naquele e naquela que se educa, uma reflexão pessoal e interna, desinteressada e capaz de dar significados ao mundo que habitamos" (ANDRADE, A banalidade do mal e as possibilidades da educação moral: contribuições arendtianas. In: Revista Brasileira de Educação, p. 124).

${ }^{598}$ Segundo Vásquez, a dissociação entre moral e política implica em sacramentar duas posições redutoras: o moralismo abstrato (abstração da política pela moral, consequente sacrifício da política) e realismo político (abstração da moral pela política, consequente sacrifício da moralidade), optando pelo (cf. VÁZQUEZ, Adolfo Sanchez. Ética. Trad. João Dell'Anna. 25. ed., Rio de Janeiro: Civilização Brasileira, 2004, capítulo 4).

599 Para Arendt, na soleira da modernidade, Maquiavel retorna às experiências políticas dos romanos, considerando-as dependentes de sua experiência política central, a fundação, em vista de repeti-la através de uma Itália unificada como um novo organismo político (nação-estado). No marco do realismo, Maquiavel pensa que os conceitos tradicionais de bem, a saber, o conceito grego de "bom para" (adequação) e o conceito cristão de
} 
considera a primazia dos princípios políticos. Acima do bem pessoal (ou da prisão da subjetividade de uma existência singular) está a pluralidade entre os homens. O amor mundi tende a exigir que os indivíduos se coloquem em desacordo consigo próprios, justamente para evitar a privação da pluralidade do mundo. Para Arendt, sendo as forças da vida íntima de existência incerta e obscura, entre elas, os pensamentos do espírito, é necessário que "sejam 'transformadas', 'desprivatizadas' e 'desinvidualizadas', por assim dizer, de modo que assumam um aspecto adequado à aparição pública". Afinal, "a presença de outros que vêem (sic!) o que vemos e ouvem o que ouvimos garante-nos a realidade do mundo e de nós mesmos"600. Esse é, aliás, o sentido que se depreende da polis grega e da res publica dos romanos enquanto espaço protegido contra a futilidade da vida individual e, ao mesmo tempo, reservado à permanência dos mortais (imortalidade).

\subsubsection{O lugar do sujeito no comunitarismo transcendental: formação da autonomia}

Depois de expor sobre o estatuto do pensamento, o segundo ponto aqui em destaque trata sobre o lugar do sujeito na filosofia da intersubjetividade de Apel. À primeira vista, é possível supor algum contrassenso em relação à pretensão de elevar o sujeito em face do "comunitarismo transcendental" 601 defendido por Apel. Em linhas gerais, entende-se a semiótica transcendental de Apel como uma filosofia da intersubjetividade que "corrige" o erro do solipsismo metódico presente na filosofia da subjetividade moderna. Ela corrige na medida em que reabilita a dimensão do uso intersubjetivo (pragmática) da linguagem,

uma bondade absoluta que não é deste mundo, são válidos apenas para a esfera privada e não para o âmbito público da política. No mundo público da política, a harmonia entre os homens não decorre da sabedoria do político, da excelência moral do indivíduo ou da competência dos peritos, mas da interação entre virtù e fortuna. A virtù é a qualidade humana especificamente política, sem conotação de caráter moral (virtus romana) ou excelência moralmente neutra (areté grega); é a resposta que o homem dá à constelação da fortuna em que o mundo se apresenta. Mas Maquiavel, assim como Robespierre no contexto da Revolução Francesa, ao presumir a conexão entre fundação e ditadura, diferentemente dos romanos (mesmo porque para eles a fundação era um evento do passado), justifica a necessidade da violência para fundar novos estados ou restaurar os degenerados. Compreendendo o ato de fundar à imagem do fazer, Maquiavel reinterpreta a fundação em termos da justificação de meios (violentos) para atingir o fim (República). No entender de Arendt, salvo a Revolução Americana, pela qual os "pais fundadores" fundaram um organismo político novo sem o recurso da violência e com o auxílio de uma Constituição, as revoluções modernas não se pautaram pela noção de autoridade dos romanos (cf. ARENDT, Entre o passado e o futuro, p. 180-186).

600 ARENDT, Hannah. A condição humana. Trad. Roberto Raposo. 11. ed., Rio de Janeiro: Forense Universitária, 2010, p. 61. Essa transformação não implica em anulação da moralidade: "Pois, embora o mundo comum seja o local de reunião de todos, os que estão presentes ocupam nele diferentes posições, e assim como se dá com dois objetos, o lugar de um não pode coincidir com o de outro. A importância de ser visto e ouvido por outros provém do fato de que todos veem e ouvem de ângulos diferentes" (cf. A condição humana, p. 70).

601 APEL, Las Aspiraciones del Comunitarismo Anglo-Americano desde el Ponto de Vista de la Ética Discursiva; comunidade como a priori de la facticidad y como antecipación contrafáctica de la razón. In:

Discurso e realidade, p. 25. 
abstraída na filosofia do sujeito (isolado). Para essa filosofia da intersubjetividade, o pensar não surge dos fenômenos, mas é efetivamente seu a priori. O pensar é um modo modo de "ser-uns-com-outros" "602. Esse modo estabelece o diálogo argumentativo em condições de igualdade entre as pessoas afetadas por um problema comum como uma ideia regulativa para a resolução de todos os conflitos que atingem a humanidade e o mundo. Nisso, aparentemente, o lugar do sujeito na filosofia de Apel parece ter sido obscurecido por um comunitarismo transcendental, cujo fundamento não é o apriori da faticidade da pré-formação do compreender e valorar, ou seja, a pertença à tradição particular de uma comunidade linguística e cultural, mas a tese do "apriori da comunidade de comunicação".

O critério defendido por Apel para a reconstrução do sujeito crítico é o critério da comunidade ideal de comunicação. Esse critério se torna tangível no conteúdo da norma ética fundamental, que obriga a todos os portadores de competência comunicativa a procurar na comunidade real de comunicação um entendimento (acordo) para alcançar a formação solidária da vontade. Vale observar que a comunidade ideal de comunicação apeliana não representa "outro mundo" (um "não-lugar" ao estilo das utopias renascentistas, como em Tomás Moro) ou mesmo uma utopia com conteúdo (utopia social concreta), tampouco corresponde à expectativa de algo como uma "revolução mundial". A comunidade real de comunicação é pensada como uma "ideia regulativa de uma "aproximação metódica", ou seja, "como o objetivo ideal de uma possível formação argumentativa do consenso" ${ }^{603}$, que serve como referência para a crítica e a organização dos consensos fáticos de todos os afetados em uma situação de comunicação ideal. Esse critério, no sentido de uma ética formaldeontológica, só estabelece um marco universal do correto (condições ideais da possível formação do consenso sobre normas), dentro do qual pode conviver as distintas concepções da vida feliz. Enfim, Apel não propõe uma utopia com conteúdo, mas uma idéia regulativa para avaliar as sociedades atuais, ainda muitas marcadas pelo "diálogo de surdos" e por desigualdades (em que todos são iguais, porém, na prática cotidiana, alguns mais iguais que outros $)^{604}$.

Apel define o "perfil" do sujeito crítico a partir do critério da "opinião última" em longo prazo peirceano. Para Peirce, a resolução das dúvidas e a definição da convicção acertada precisam ser determinadas pela "conclusão última de cada homem", portanto, por

\footnotetext{
${ }^{602}$ APEL, Transformação da filosofia, v. I, pp. 31-32; Transformation der Philosophie, Band I, p. 27.

${ }^{603}$ APEL, Teoría de la verdad y ética del discurso, p. 73. APEL, Fallibilismus, Konsenstheorie der Wahrheit und Letztbegründung. In: Philosophie und Begründung, p. 144-145.

${ }^{604}$ APEL, Transformação da filosofia, v. II, p. 58; Transformation der Philosophie, Band II, pp. 223-225.
} 
algo com certa permanência externa, algo que o pensamento (individual) não exerça influência. Peirce renova a pergunta kantiana sobre as condições de possibilidade e validade do conhecimento científico como pergunta pela possibilidade do acordo intersubjetivo sobre o sentido e validade dos enunciados. Na transformação da crítica kantiana do conhecimento em uma crítica do sentido, realizada por Peirce e assumida por Apel, o novo ponto supremo é a "opinião última", entendida como o consenso alcançado pela comunidade ilimitada de investigadores. Peirce atribui ao acordo intersubjetivo universal in the long run a função de um "princípio regulativo", ao qual cabe assegurar a possibilidade da objetividade frente ao relativismo. Para alcançar a unidade do acordo intersubjetivo, segundo Peirce, o investigador movido pelo interesse na verdade e consciente dos limites de seus interesses e convicções subjetivos, obriga-se a adotar quatro atitudes (traços), que caracterizam o posicionamento designado de "socialismo lógico". Essas atitudes são: a) autorrenúncia dos próprios interesses e convicções que tendem a obscurecer a busca da verdade; b) reconhecimento quanto ao direito de expor e à obrigação de justificar as descobertas perante os membros da comunidade de investigação; c) compromisso da comunidade real, ainda que falível, com a busca da verdade; d) esperança no consenso definitivo, enquanto antecipação contrafática e garantia dos consensos fáticos ${ }^{605}$.

Apel reforça, transcendentalmente, o compromisso de Peirce com a objetividade e a verdade no sentido não relativista, à medida que amplia a compreensão acerca do sujeito ao qual cumpre empreender o discurso para alcançar o acordo universal em longo prazo. Em Peirce, esse sujeito quase-transcendental é a comunidade ilimitada de investigação e experimentação. Em Apel, de forma ampliada, esse sujeito é a humanidade em seu conjunto. Como bem assinala Cortina, nessa distinção reside o ponto em que Apel transforma o socialismo lógico-científico de Peirce em um "socialismo pragmático e hermenêutico" ${ }^{606}$. No horizonte do socialismo pragmático de Apel, a idéia do consenso último (como ideia regulativa) incorpora as seguintes implicações normativas: a) quem argumenta seriamente, levanta uma pretensão de verdade e, por isso, pressupõe a capacidade intersubjetiva ilimitada de chegar a um consenso sobre a verdade da proposição afirmada; b) como idéia regulativa, a

\footnotetext{
${ }^{605}$ CORTINA, Razón comunicativa y responsabilidad solidaria: ética y política em K.-O. Apel, pp. 75-76. APARISI, Juan Carlos Siurana. Una brújula para la vida moral: a idea de sujeto en la ética del discurso de Karl Otto Apel. Granada: Editorial Comares, 2003, p 33.

${ }^{606}$ CORTINA, Razón comunicativa y responsabilidad solidaria: ética y política em K.-O. Apel, p. 77. APARISI, Juan Carlos Siurana. Una brújula para la vida moral: a idea de sujeto en la ética del discurso de Karl Otto Apel. Granada: Editorial Comares, 2003, pp 29-33. APARISI, Consenso. In: Diccionario de Pensamiento Contemporâneo, pp. 239-241.
} 
exigência do consenso busca todos os critérios possíveis e nunca suficientes de verdade para chegar a um consenso fático (falível e provisório) realizado no discurso argumentativo da comunidade real de investigadores; c) com a exortação à construção fática do consenso, a idéia regulativa da busca de um consenso último exige que se ponha em questão cada consenso fático de uma comunidade real de investigadores, por meio de contra-argumentos, ao considerar novos critérios de verdade. Para Apel, essas implicações são enunciados tipicamente filosóficos, que versam sobre princípios indiscutíveis e universais, descobertos no plano da autorreflexão.

Pois bem, como dito, em face do critério do comunitarismo transcendental apeliano, emerge a suspeita de redução da esfera do sujeito na filosofia de Apel. Curiosamente, ele parece ser cônscio de que existe algum obscurecimento da subjetividade, pois ele mesmo levanta o problema referente a saber "de onde reside propriamente as condições comunitárias da identidade pessoal" de um homem moderno, isto é, autônomo ${ }^{607}$. Trata-se da seguinte questão: é possível um "cidadão" alcançar sua identidade de homem autônomo somente por meio de uma síntese ex-post de uma tradição cultural concreta, ainda que muito ampla? Ora, a resposta de Apel a essa pergunta é negativa. A justificativa é que, se o universal dessa síntese for "concreto" (fático), ele deixa de fora a situação da mediação comunicativo-discursiva referida ao futuro (o "ainda-não" a ser realizado) do princípio de justiça por meio do consenso com o "outro", por exemplo, com as culturas não-ocidentais ${ }^{608}$.

Não obstante, a suposição de tal redução parece cair por terra à medida que se leva em consideração que o "socialismo pragmático" de Apel, enquanto prolongação do socialismo lógico de Peirce, mostra que os indivíduos, em nível empírico e transcendental, são necessariamente "sociais" porquanto que "dialógicos". Os indivíduos mesmo quando dialogam "sozinhos" (em companhia de si mesmos, no sentido socrático), efetivamente dialogam com a pluralidade dos indivíduos singulares. Isso significa que a validade, tanto teórica quanto prática (ética), não é definida monologicamente por meio de uma intuição peculiar de cada indivíduo, mas cada indivíduo, sob a pressuposição da igualdade universal de direitos (simetria) de todos os afetados em relação a alguma questão comum, deve participar no diálogo argumentativo para realizar sua possibilidade de ser autônomo e, simultaneamente,

\footnotetext{
${ }^{607}$ APEL, Teoría de la verdad y ética del discurso, pp. 177-180. APEL, Las Aspiraciones del Comunitarismo Anglo-Americano desde el Ponto de Vista de la Ética Discursiva; comunidade como a priori de la facticidad y como antecipación contrafáctica de la razón. In: Discurso e realidade, pp. 16-17 e 26.

608 APEL, Las Aspiraciones del Comunitarismo Anglo-Americano desde el Ponto de Vista de la Ética Discursiva; comunidade como a priori de la facticidad y como antecipación contrafáctica de la razón. In: Discurso e realidade, p. 25.
} 
aproximar-se de um acordo intersubjetivo último, contrafaticamente postulado na horizonte de uma comunidade ideal de argumentação. Essa suposição se mostra equivocada, ao passo que se considera que o critério da comunidade ilimitada de argumentação não é apenas abstratotranscendentalista (um apriori regulativo da comunidade ideal de comunicação), mas também dialético e referido à história (um apriori da faticidade da pertença a uma comunidade real de comunicação). Decerto, a autonomia da consciência do indivíduo é compreendida a partir do paradigma da intersubjetividade. Nisso, o postulado da formação do consenso tende a uma solução procedimental, mas é no contexto deste último apriori que o indivíduo exerce a autonomia, empenhando-se para o entendimento definitivo de uma comunidade ideal de comunicação. À luz da semiótica transcendental, a autonomia não se confunde com idiossincrasia em seu aspecto cognitivo e voluntarista, quando o indivíduo renuncia ou interrompe por razões subjetivas o discurso para a formação real do consenso. A situação que se depreende do "socialismo pragmático" é que o sujeito, para realizar sua possibilidade de ser autônomo, necessita desenvolver a autonomia em solidariedade ${ }^{609}$.

A transformação semiótica hermenêutico-transcendental não prima, conforme a interpretação de Cortina e Aparisi, apenas pela perspectiva do "diálogo intersubjetivo", mas também, complementarmente, pela perspectiva de aprofundamento em um "diálogo intrasubjetivo" ${ }^{\prime 10}$. A esse respeito, vale observar que, em seu giro hermenêutico-pragmático transcendental, a filosofia de Apel enfrenta a negação de uma filosofia do sujeito, no caso, ao se contrapor diretamente à teoria da afiguração do primeiro Wittgenstein. Aí, este sustenta a objeção em relação a uma filosofia do sujeito, em razão de considerar que a "consciência em geral” coincide com a forma a priori da linguagem. Para ele, já que só existe fatos reais tal como os que são representados (afigurados) por meio da linguagem, resulta desnecessária toda reflexão do sujeito sobre seu projeto linguístico do mundo. A linguagem ao representar o mundo descarta toda reflexividade da linguagem e, com isso, toda a relação do sujeito transcendental consigo mesmo ${ }^{611}$. Não obstante, como bem assinala Cortina, a semiótica transcendental coloca em cena um novo tipo de ser autônomo, designado por Apel como "pessoas"612 de competência comunicativa. Os falantes competentes (interlocutores válidos)

\footnotetext{
${ }^{609}$ APARISI, Una brújula para la vida moral: a idea de sujeto en la ética del discurso de Karl Otto Apel, p. 34. ${ }^{610}$ APARISI, Una brújula para la vida moral: a idea de sujeto en la ética del discurso de Karl Otto Apel, p. 03 e 34-48.

${ }^{611}$ WITTGENSTEIN, Tractatus logico-philosophicus, ver proposição 5.62 (os limites da linguagem signifam os limites do "meu" mundo). APARISI, Una brújula para la vida moral: a idea de sujeto en la ética del discurso de Karl Otto Apel, pp. 21-22.

${ }^{612}$ CORTINA, Razón comunicativa y responsabilidad solidaria: ética y política em K.-O. Apel, pp. 108-109. APARISI, Una brújula para la vida moral: a idea de sujeto en la ética del discurso de Karl Otto Apel, p. 39.
} 
são reconhecidos como "pessoas", porque "em todas suas ações e expressões são interlocutores válidos, e a justificação ilimitada do pensamento não pode renunciar a nenhum interlocutor e a nenhuma de suas contribuições virtuais à discussão" ${ }^{613}$. A categoria básica no paradigma comunicativo não é propriamente a categoria de sujeito, mas a de "subjetividade/intersubjetividade", que emerge no reconhecimento recíproco da autonomia de falante e ouvinte ${ }^{614}$. Distintamente da competência gramatical (semântico-sintática), por meio da qual ocorre o "explicar-se", a competência comunicativa (pragmática) visa ao “compreender-se". Na visão de Apel, a competência comunicativa é adquirida dentro de uma língua particular, porém ela a transcende como condição de possibilidade e validade da "tradução", da "compreensão hermenêutica" e da "construção linguística". A competência comunicativa representa "o momento de distanciamento reflexivo e soberania dos seres humanos em relação a cada língua determinada" ${ }^{615}$. Esse novo ser autônomo são as pessoas dotadas de capacidade (de reflexão, pensar) e de direitos para defender com argumentos racionais suas propostas. Não se trata de uma autonomia que induz o sujeito a responder sozinho, de forma irresponsável e enganosa - metaforicamente falando, como o titã Atlas por todos os homens e pelo mundo. Em vez disso, trata-se de uma noção de autonomia, cuja efetivação exige o engajamento do sujeito em um processo crítico e corresponsável in the long run de aproximação da verdade e do cuidado zeloso de si, dos outros e do mundo. Nesse sentido, parece pertinente afirmar, juntamente com Aparisi, que na semiótica transcendental de Apel, "subjetividade e intersubjetividade confluem", "em uma proposta que não pode abandonar a irrenunciável conquista que supõe a autonomia"616.

6.2.3 Suspensão parcial e temporária do pressuposto da simetria da competência comunicativa em razão da autoridade na educação

O terceiro ponto dessa provocação reflexiva enfoca a dificuldade de correlacionar a tese do primado judicativo do sujeito apeliana com a questão da autoridade na educação. Parece existir uma suspeita de que a exigência de autoridade na educação pode mitigar o princípio hermenêutico-transcendental que faculta a autonomia e reconstrução autoral do sujeito. Aqui, à vista de enfocar tal suspeita, esse ponto conta novamente com a análise de

\footnotetext{
${ }^{613}$ CORTINA, Adela. Ética aplicada y democracia radical. Madrid: Editorial Tecnos, 1993, p. 136.

${ }^{614}$ CORTINA, Adela. Ética aplicada y democracia radical, pp. 136-137.

${ }^{615}$ APARISI, Una brújula para la vida moral: a idea de sujeto en la ética del discurso de Karl Otto Apel, p. 40.

${ }^{616}$ Idem, pp 33-34.
} 
Arendt sobre a crise de autoridade na educação. Como ponto de partida, aqui se retoma o teor básico da tese apeliana do primado judicativo do sujeito. Apel entende que essa se baseia no caráter transpositivo de todo o compreender (atividade hermenêutica). Essa tese compõe o marco da alternativa teórica que ele elabora no sentido de capacitar o sujeito para a crítica e corresponsabilidade e, assim, potencializar a autonomia racional do sujeito. Em sua concepção de hermenêutica pragmático-transcendental normativa, Apel procura conciliar o "primado judicativo do intérprete" com o princípio da "antecedência" hermenêutica da superioridade virtual do interpretandum" (autor). Apel entende o "primado judicativo do intérprete" como um princípio derivado autoprevalecimento substancial do espírito (razão) que permite ao intérprete a possibilidade de atribuir a si mesmo o direito de julgamento crítico acerca do que existe para entender, e assim poder confiar a verdade a si mesmo ${ }^{617}$. Nessa conciliação, o pressuposto da superioridade interpretandum continua existindo nas situações em que os autores conservam algum segredo para si e, em tal medida, sempre precedem aos seus intérpretes posteriores como interpretandum. Ao mesmo tempo, para Apel, perdura a exigência de compreender melhor o autor do que ele compreende a si mesmo, no sentido de um princípio regulativo aplicável a todo compreender hermenêutico. Como já assinalado, Apel entende que essa exigência hermenêutica universal é assegurada pelo pressuposto da simetria idealmente implícita na situação de acordo mútuo quanto à mediação da tradição ${ }^{618}$.

O resultado dessa conciliação é o princípio normativamente relevante do progresso do conhecimento e da compreensão adequada. Esse princípio, segundo Apel, correspondente ao topos central da tradição hermenêutica, preconiza que é "entender o autor melhor do que ele compreende a si mesmo"619. Para Apel, esse postulado decorre do caráter reflexivamente transpositivo da atividade do compreender, posto que todo compreender sempre implica em compreender-se no mundo e não somente em reconstituir os atos cognitivos do autor. O alcance universal dessa implicação se justifica, normativa e metodologicamente, porque o próprio compreender implica em aprimorar o processo cognitivo, entendendo-o de forma autoral. Para Apel, essa conciliação consiste no traço fundamental de uma hermenêutica filosófica normativa exigida pela ideia transcendentalfilosófica do compreender e, por isso, implicada na resposta adequada à pergunta sobre a possibilidade do compreender ${ }^{620}$. Tal princípio caracteriza a perspectiva de uma hermenêutica

\footnotetext{
${ }^{617}$ APEL, Transformação da filosofia, v. I, p. 56; Transformation der Philosophie, Band I, p. 47.

${ }^{618}$ APEL, Transformação da filosofia, v. I, pp. 64-65; Transformation der Philosophie, Band I, pp. 49-50.

${ }^{619}$ APEL, Transformação da filosofia, v. I, p. 58; Transformation der Philosophie, Band I, p. 49.

${ }^{620}$ APEL, Transformação da filosofia, v. I, p. 57; Transformation der Philosophie, Band I, p. 48.
} 
propriamente filosófica que visa a autonomia interpretativa do intérprete e, por conseguinte, de todos os envolvidos no processo argumentativo ${ }^{621}$. E, em tal medida, é possível depreender que inclusive todo processo educativo deve ser entendido como um compreender transpositivo, um processo necessariamente autoral ${ }^{622}$.

Em continuação a esse terceiro ponto, para apresentar a questão da autoridade, em um primeiro momento, recorre-se aqui ao conceito de autoridade que Arendt desenvolve em sua análise sobre a crise na educação. Para ela, a crise da autoridade na educação se liga estreitamente à crise da tradição ${ }^{623}$. Para contrapor teoricamente essa crise, ela desenvolve uma análise que passa pelo entroncamento ${ }^{624}$ da especificidade do campo moral, que é a constituição da singularidade, e do realinhamento dos conceitos de educação, autoridade e responsabilidade, tendo em vista a perspectiva que a escola, como instância pré-política, possa servir de ponte entre o mundo privado da casa e o mundo público. Resumidamente, nessa análise, Arendt sustenta os seguintes pressupostos e diretrizes teórico-práticos: a) quanto à função da escola, cabe-lhe "ensinar às crianças como o mundo é, e não instruí-las na arte de viver" ${ }^{625}$. No tocante ao ensino dos "conteúdos" do mundo, deve-se considerar que a criança é semelhante a um forasteiro que não tem familiaridade com o mundo, razão pela qual deve ser introduzida "aos poucos" e, assim, chegar à "fruição em relação ao mundo como ele é" ${ }^{626}$; b) é necessário estabelecer uma linha limítrofe entre a infância e o mundo adulto ${ }^{627}$, sem separar as crianças dos adultos, em um mundo supostamente autônomo, ou tratá-las como um adulto em tamanho reduzido, como se fosse já um adulto amadurecido, porém considerando as peculiaridades da infância em razão da idade, espaço geográfico e cultural e as diferenças de indivíduo para indivíduo. O critério para esse limite se alinha à função mesma da atividade educativa, que é introduzir o jovem no mundo como um todo, e não em um segmento especializado dele, caso do mundo do trabalho; c) não se pode educar sem, simultaneamente,

\footnotetext{
${ }^{621}$ APEL, Transformação da filosofia, v. I, p. 56; Transformation der Philosophie, Band I, pp. 47-48. ${ }^{622}$ APEL, Transformação da filosofia, v. I, pp. 58-59; Transformation der Philosophie, Band I, pp. 49-50. ${ }^{623}$ ARENDT, Entre o passado e o futuro, pp. 243-244.

${ }^{624}$ No momento da introdução da criança ao mundo através da educação, os adultos devem se responsabilizar tanto pelo bem-estar vital de um ser em crescimento, quanto pelo "livre desenvolvimento de qualidades e talentos pessoais", que conforma "a singularidade que distingue cada ser humano de todos os demais, a qualidade em virtude da qual ele não é apenas um forasteiro no mundo, mas alguma coisa que jamais esteve aí" (ARENDT, Entre o passado e o futuro, pp. 238-239). É a autoridade que faz a ponte entre o ato da fundação e a novus ordo saeculorum, de modo a legitimar a comunidade política e preencher a lacuna entre o passado e o futuro (ARENDT, Entre o passado e o futuro, p. 24).

${ }^{625}$ ARENDT, Entre o passado e o futuro, p. 246.

${ }^{626}$ ARENDT, Entre o passado e o futuro, p. 239.

${ }^{627}$ Para Arendt, a educação adulta pode ser importante para o enriquecimento da personalidade, porém irrelevante politicamente; a menos que seja para adquirir requisitos técnicos necessários à sua participação nos problemas públicos (ARENDT, Entre o passado e o futuro, p. 160).
} 
ensinar. Em contraposição direta à concepção da pedagogia como uma ciência em geral, tal como já expresso, importa que a educação sem aprendizagem é vazia; d) é necessário atentarse ao risco de pretender ensinar sem educar. É possível aprender muito acerca de algo sem que isso constitua educação (responsabilidade pelo mundo); e) fundamentalmente, por concernir a todos e não à ciência específica da pedagogia, a relação entre adultos e crianças em geral, que é "nossa atitude face ao fato da natalidade", é indelegável ${ }^{628}$.

Nessa análise, ela considera que há uma onda de mal-entendidos ${ }^{629}$, tanto do ponto de vista prático quanto teórico, em torno do conceito de autoridade. Para superar isso, Arendt retoma a experiência romana de fundação, segundo ela, a única experiência política que trouxe a autoridade como vocábulo, conceito e realidade. Nela, a palavra auctoritas é derivada do verbo "augere" (aumentar) e, por isso, o termo autoridade indica aquele que aumenta a fundação, mesmo sem possuir poder. A palavra auctores tem o sentido de "autor", de fundador da obra. Na interpretação de Arendt, o Senado romano ilustra essa compreensão da autoridade, na medida em que o "caráter autoritário do acréscimo dos anciães repousa em sua natureza de mero conselho, prescindindo, seja da forma de ordem, seja de coerção externa, para fazer-se escutado"630. No contexto da experiência romana, os exemplos e os feitos dos antepassados, bem como o costume desenvolvido a partir deles, são sempre “coercivos", tornando-se os modelos autoritários para o comportamento efetivo e os padrões políticos e morais, precisamente porque evidenciavam um crescimento em direção às raízes, à fundação. A autoridade não decorre da suposição de maturidade, no sentido de um crescimento para o futuro auxiliado pela sabedoria e experiências acumuladas, mas se liga à idade provecta, que cresce no sentido da proximidade aos antepassados e do passado. Relevantemente, a autoridade, ao passo que se assenta sobre o alicerce do passado, cumpre a função de dá ao "mundo a permanência e a durabilidade de que os seres humanos necessitam precisamente por serem mortais" 631 .

Abordando o conteúdo do conceito de autoridade, Arendt pontua que é comum, já que a autoridade supõe obediência, confundir a autoridade com poder ou violência. Todavia, a autoridade exclui o uso de meios externos de coerção; a rigor, onde a força é usada, a autoridade em si mesmo já tem fracassado ${ }^{632}$. A autoridade também é incompatível com a persuasão, que pressupõe a igualdade entre os agentes e opera mediante a argumentação. Se

\footnotetext{
${ }^{628}$ ARENDT, Entre o passado e o futuro, p. 247.

${ }^{629}$ Idem, p. 128.

${ }^{630}$ Idem, p. 165.

${ }^{631}$ Idem, p. 131.

${ }^{632}$ Idem, p. 129.
} 
for necessário argumentar, então a autoridade já está efetivamente suspensa. A autoridade se define em contraposição tanto à coerção pela força como à persuasão através de $\operatorname{argumentos}^{633}$. A relação de autoridade entre quem manda e quem obedece assenta-se na hierarquia legitimamente reconhecida pelos envolvidos; a hierarquia define o lugar estável predeterminado de ambos. Para Arendt, a fonte da autoridade é uma força externa e superior ao próprio poder, ou seja, o caráter sagrado da fundação, do qual as autoridades derivam sua legitimidade. É relevante observar que, no caso da educação, a hierarquia é temporária. Politicamente, a autoridade adquire caráter educacional quando "os antepassados representam o exemplo de grandeza para cada geração subsequente, que eles são os maiores, por definição" ${ }^{34}$. Sem essa convicção fundamental, a noção de autoridade na educação pode servir, às avessas, para obscurecer pretensões de poder, fingindo-se educar quando se objetiva dominar 635 .

Para esclarecer sobre a essencialidade da educação, o fato da natalidade, e o sentido da autoridade na educação, Arendt delineia os traços característicos e qualificadores dos educandos (recém-chegados) e dos educadores (adultos do mundo público, pais e mestres) face ao fato da natalidade. Na educação, a infância não constitui um espaço autônomo ${ }^{636} \mathrm{em}$ relação ao mundo dos adultos. A criança é um novo ser humano em um mundo que lhe é estranho e, ao mesmo tempo, um ser humano em processo de formação ${ }^{637}$, que se relaciona com o mundo e com a vida. A criança é o recém-chegado (o estrangeiro, o novo) que deve ser familiarizado a um mundo velho que a precede e possivelmente perdurará após sua morte; é o estrangeiro que deve perder a condição mesma de estrangeiro e ser convidado a cuidar do mundo enquanto transcorre sua vida. Na educação, a criança chega ao mundo na condição de

\footnotetext{
${ }^{633}$ ARENDT, Entre o passado e o futuro, p. 128.

634 Idem, p. 161.

635 Idem, p. 161.

${ }^{636}$ Arendt assinala o paradoxo entre a defesa do "século da criança", que preconiza a emancipação da criança em relação aos padrões de um mundo adulto, e o menosprezo danoso em relação às condições elementares de desenvolvimento da criança. No entender de Arendt, esse estado de coisas não tem a ver com educação, mas com os juízos e preconceitos acerca da natureza da vida privada, do mundo público e da sua relação mútua, que foram incorporados irrefletidamente na atividade educativa. A sociedade moderna tende a promover a emancipação do ocultamento da privacidade dos indivíduos e da família, por meio da sua exposição à luz do mundo público, enquanto espaço de direito de verem e serem vistos, a falar e serem ouvidos. No mundo público se leva em conta o trabalho com que cada indivíduo contribui para com o mundo comum, mas não a vida qua vida. Ocorre que, assim pensa Arendt, expor a criança ao mundo público é o mesmo que "abandono e traição". Às avessas, é supor que o fator personalidade é mais relevante que a vida e o desenvolvimento da criança. Quanto mais a sociedade moderna "introduz entre o privado e o público uma esfera social na qual o privado é transformado em público e vice-versa", tanto maior é o risco para a criança, que perde a segurança do ocultamento. Por isso, a criança deve ser protegida do mundo, que não pode lhe dar atenção. Ela precisa da "segurança da escuridão para poder crescer" (ARENDT, Entre o passado e o futuro, pp. 236-238).

${ }^{637}$ ARENDT, Entre o passado e o futuro, p. 235.
} 
estrangeira e pagã e, desde então, passa a viver com o risco de doutrinação (batismos) que sufocam sua capacidade de iniciar novos eventos, quando os adultos lhe ditam sua aparência futura à sua própria imagem e semelhança. Vez que se concebe a criança como um recémchegado ao mundo que está em processo de formação e tem a possibilidade de iniciar algo novo no mundo, a educação não é apenas uma função da vida e o treinamento na prática de viver, tal como ocorre com os animais ${ }^{638}$.

Em regra, os educadores (pais e professores) são os representantes de todos os adultos e do mundo. E por terem empreendido o itinerário da autoria (pessoalidade) com "os olhos grudados no passado", os educadores são (ou devem ser) os "companheiros de luta" e as autoridades legítimas que testemunham a responsabilidade pelo mundo público por meio da própria atividade educativa. Os pais se tornam responsáveis por introduzirem os filhos no mundo, ao trazê-los à vida pela concepção e nascimento. A autoridade dos pais tem origem na responsabilidade da autoria dos pais por trazerem ao mundo sua criação (as crias recriantes). O professor, face à criança, é o representante do mundo investido da intrínseca e não arbitrária responsabilidade pelo mundo. E para exercer a função de professor, pressupõe-se que ele congregue qualificação e autoridade. A qualificação consiste em conhecer o mundo como ele é e ser capaz de instruir os outros acerca dele; a autoridade diz respeito à responsabilidade que o educador assume perante o mundo. A qualificação, por si, não engendra a autoridade. Com efeito, na educação, a responsabilidade pelo mundo, tal como pensa Arendt, assume a forma de autoridade ${ }^{639}$. A autoridade tem origem na responsabilidade pelos riscos inerentes às ações de quem inicia algo em alguém ou aponta novos caminhos, tendo por base o conhecimento, os valores compartilhados e as qualidades pessoais (autoria, singularidade). Na educação, a autoridade se manifesta na responsabilidade de formar para a ação, crítica e pessoal (com projetos novos), que oscila entre a conservação e a transformação do mundo ${ }^{640}$. Mas, porque

\footnotetext{
${ }^{638}$ Tal perspectiva parece encontrar guarida no modelo reativo de Skinner, para o qual a ação humana não é livre e pode ser descrita em termos de uma tecnologia sujeita à manipulação externa (causal) do comportamento, como um poder que impõe seu cumprimento mediante gratificações ou sanções. Sob tal perspectiva, a validade do comportamento moral é proporcional à sua eficácia, em vista de adestrar os indivíduos às demandas organizacionais (SKINNER, O Mito da Liberdade, cap. 1 - Uma tecnologia do comportamento, passim).

${ }^{639}$ ARENDT, Entre o passado e o futuro, p. 239.

${ }^{640} \mathrm{Em}$ certo sentido, a autoridade do professor comporta as dimensões de mediar, tecer, mapear e fabular, transformando-o em "um mediador de relações, um tecelão de significações, um cartógrafo de relevâncias e, sobretudo, contador de histórias, não quaisquer histórias, mas as de natureza fabulosa" (cf. MACHADO, Nilson José. Educação e autoridade: responsabilidade, limites, tolerância. Petrópolis, RJ: Vozes, 2008, p. 73). No sentido do fabular, junto com Eduardo Galeano, pode-se dizer que o mundo não é feito de átomos, mas de histórias (narrativas). Pois, as histórias permitem converter o passado em presente, o distante em algo próximo, possível, visível, e assim revelar a existência. Em sentido metafórico, Segundo Machado, a ação do professor é análoga à atividade do Sol e da Lua. "Os dois pares de ações - mediar/mapear, tecer/fabular - apresentam certa similaridade com o par Lua/Sol: o primeiro elemento representa a suavidade, a ternura, a humildade; o segundo,
} 
os educadores foram mitigados em parte da sua autoridade relativa ao domínio intelectual dos conteúdos por força da intervenção de uma ciência geral do ensino e, além disso, tendo que atuar em meio aos escombros do "colapso total de todos os padrões morais tradicionais na vida pública e privada durante as décadas de 1930 e 1940"641, eles se recusam a assumir atualmente a autoridade na educação, o "perfill" de educador resulta esvaziado de significado.

Faticamente, a recusa da autoridade na educação pelos educadores é um fator nuclear da crise na educação moderna. Tal recusa denota que os educadores abrem mão do ofício de educador, que é "servir como mediador entre o velho e o novo" ${ }^{642}$, bem como da atitude conservadora, sem a qual a educação não é possível, tampouco a profissão de educador, que exige um respeito extraordinário pelo passado. A crise de autoridade na educação é correlata à crise da tradição do mundo moderno, em torno da qual transcorre um fenômeno ambíguo relativo à autoridade na vida pública e política (campo das relações entre os homens). É ambíguo porque se culmina, em quaisquer das formas de compreensão da autoridade, em semelhante resultado, a perda da autoridade, seja ao inflá-la por meio da suposta atribuição de igual responsabilidade para todos, seja ao esvaziá-la mediante o repúdio à autoridade, quando ninguém efetivamente assume a responsabilidade coletiva. Em sua irradiação, a expressão mais radical dessa crise se manifesta na esfera pré-política ${ }^{643}$, mediante a recusa dos educadores a assumirem a responsabilidade e o cuidado do mundo, ironicamente, em razão do sintomático desgosto e insatisfação (desencantamento e estranhamento) com o mundo atual.

Perante a recusa do amor mundi pelos educadores, à primeira vista, parece inevitável não suspeitar de uma possível paralisia (ou "agonia") em relação à tarefa de conservação e transformação do mundo ${ }^{644}$. Em certa medida, parte dessa suspeita é suscitada

o calor, o alimento, a orientação. É preciso mediar, sem abdicar de mapear; é necessário tecer, sem evitar o comprometimento e o risco da fixação de mensagens que a proposição de uma fábula representa. As ações do professor, como se vê, são tanto solares como lunares, abrangendo um espectro vital que inclui simultaneamente a disciplina e o afago, o dar e o receber, o emitir e o absorver, a razão e a emoção, a autoridade e a tolerância" (MACHADO, Educação e autoridade, p. 85).

${ }^{641}$ ARENDT, Responsabilidade e julgamento, p. 116. No entender de Arendt, a quebra entre o passado e o futuro resulta no desmoronamento dos fundamentos tradicionais da moralidade na contemporaneidade. A ruptura significa, por um lado, a ruína daqueles fundamentos "permanentes e vitais" que serviam de regras e padrões para discernir acerca do certo e do errado, bem como para julgar ou justificar as ações humanas, e cuja validade se supunha razoável e evidente tal como se fosse parte da lei divina ou natural. Mas, a empresa iconoclasta da modernidade não instaura uma "nova" tradição, tampouco propõe a asserção de "novos valores". De forma aporética, aí se preconiza um único princípio moral novo: a negação da moralidade, à medida que é estigma de algo vergonhoso e sem-sentido.

${ }^{642}$ ARENDT, Entre o passado e o futuro, p. 244.

${ }^{643}$ ARENDT, Entre o passado e o futuro, p. 239-240.

${ }^{644}$ Por detrás do temor relacionado à aparente falta de saída perante a crise, subsiste uma preocupação exagerada em relação ao modo por meio do qual a educação deveria cumprir sua destinação. Efetivamente, isso se 
em face da admoestação que, em meio à crise, nem se pode ir simplesmente em frente, pois tal poderia levar à ruína ou aprofundar o processo de estranhamento do mundo; tampouco se pode "voltar para trás", porque a intenção do retorno ao início poderia recair na repetição da origem $^{645}$. Todavia, ao se considerar essa suspeita de paralisia na educação à luz do pressuposto da natalidade, não parece plausível supor que a crise de autoridade na educação implique no fracasso definitivo das tarefas educativas, por certo, ao menos enquanto subsistir o esforço humano para iniciar algo novo no mundo e ser autor de novos projetos. À medida que o pressuposto antropológico basilar da educação é a condição humana de seres natais, é de se esperar que qualquer crise na educação venha a ser enfrentada, de alguma forma e em algum momento, pois é da essência humana e da educação instaurar a possibilidade de novas possibilidades formativas. Decerto, olhar por esse prisma não significa mitigar, levianamente, a extensão e impactos da crise na educação moderna, mas considerar que algo muito mais relevante tem se desvelado no interior da percepção da crise. Trata-se da definição da essência e da teleologia da tarefa educativa: a formação da singularidade e o amor mundi, a partir de onde se estabelece a escolha metodológica e os demais "detalhes pedagógicos particulares".

O enfrentamento da crise na educação, nos diversos modos e peculiaridades como ela se manifesta faticamente, requer pontos de ancoragem para a ação no campo político. Então, sem contrariar ou mitigar a essência mesma da educação com propostas supostamente prontas e limitadoras da espontaneidade (intrínseca à natalidade), em princípio, Arendt assinala dois marcos basilares à luz dos quais os desafios na educação, referentes a educar para a singularidade e para responsabilização coletiva pelo mundo, devem ser efetivamente confrontados: a aplicação do conceito de autoridade na educação e o poder "trans-formativo" da atividade do pensamento. De certo modo, mais que o status de mediações, esses referenciais são fatores transcendentais (no sentido de condições de possibilidade) para

evidencia na sobreposição da preocupação com o método e os possíveis resultados em relação a outros elementos constitutivos da atividade educativa. Assim, passa a viger uma espécie de "fetiche do método", sob a suposição cartesiana que o problema do conhecimento e, nesse caso, da educação dependem da escolha dos métodos mais adequados e bem-sucedidos.

${ }^{645}$ Arendt se empenha no sentido de pensar a inserção do homem como quebra do fluxo unidimensional do tempo e como fator de luta constante contra o passado e o futuro. Nessa linha, concebe que o evento-pensamento deve ter uma dimensão espacial na qual o pensar possa ser exercido sem ser forçado a saltar completamente para fora do tempo humano. A figura do paralelogramo de forças, para ela, constitui a metáfora adequada para descrever a atividade do pensamento: o passado e o futuro representam as duas forças antagônicas e ilimitadas; a força diagonal é o ponto no qual essas forças colidem e, simultaneamente, marca a inserção do homem no tempo. Inserido nessa força diagonal, o homem caminha para frente e para trás, "com movimentos pausados e ordenados", tal como é conveniente à ordem do pensamento, em cujo "lugar no tempo" pode ocupar a "posição de juiz" e julgar com imparcialidade a história. Mediante a atividade do pensamento é o homem quem julga, não a história. Apenas na medida em que realiza essa atividade atemporal enquanto fenômeno mental, o homem concreto vive nessa lacuna (fissura) entre o passado e o futuro (ARENDT, Entre o passado e o futuro, p. 38). 
romper com o aparente estado de paralisia relativo à tarefa educativa. Talvez pareça pouco à primeira vista, mas é por meio deles que se torna possível o enfrentamento da crise na educação, pondo em andamento a factibilidade da tarefa educativa direciona à formação da singularidade e da responsabilidade pelo mundo. Aqui, em um rápido paralelo, é possível supor que Apel está de acordo em relação a esses fatores, porém não se restringindo a eles. Vendo esses fatos desde o ponto de vista de sua crítica semiótico-transcendental como referidos a um campo de fundamentação estritamente fático, típico inclusive do giro pragmático da linguagem, Apel reivindica um passo além, o critério da comunidade ideal de comunicação.

Para Arendt, reabilitar a autoridade na educação tem o sentido de restaurar o fundamento da educação, à medida que a perda da autoridade equivale à perda do fundamento, da permanência e da segurança do mundo. A perda desse fundamento implica em "ser confrontado de novo, sem a confiança religiosa em um começo sagrado e sem a proteção de padrões de conduta tradicionais e, portanto, autoevidentes, com os problemas elementares da convivência humana" ${ }^{646}$. Ao compartilhar a convicção de Aristóteles, Arendt defende a necessidade da autoridade na educação, por julgar que autoridade "é mais plausível e evidente na criação e educação de crianças do que em qualquer outra área" ${ }^{\text {647 }}$. Nessa perspectiva, Arendt preconiza que é necessário estabelecer um divórcio somente na relação entre a educação e a vida pública (e política), a fim de aplicar unicamente - sem postular validade geral para o mundo dos adultos - na esfera educação o conceito de autoridade ${ }^{648}$. Na esfera da educação, a autoridade pode se exorcizar de qualquer conotação que possa indicar aquiescência com ações de dominação e violência. Pois, ela tem sua fonte e expressão na ação responsável pela revelação de uma autoria de seres singulares e pelo cuidado e recriação do mundo. A autoridade, entendida como a ação consentida e assimétrica do educador, seja em razão das experiências de vida e do domínio de conteúdos específicos a serem ensinados, seja em virtude da proximidade com as fontes fundadoras, constitui uma precondição temporária, porém ineliminável, da tarefa educativa.

Arendt assinala ainda que a perda do fundamento da educação, em virtude da perda da autoridade, não acarreta, necessariamente, "a perda da capacidade humana de construir, preservar e cuidar de um mundo que nos pode sobreviver e permanecer em um

\footnotetext{
${ }^{646}$ ARENDT, Entre o passado e o futuro, p. 187.

${ }^{647}$ ARENDT, Entre o passado e o futuro, p. 161.

${ }^{648}$ ARENDT, Entre o passado e o futuro, p. 246.
} 
lugar adequado à vida para os que vêm após" ${ }^{649}$. Na educação, todos estão desafiados a ir além do "leilão de valores" que se instaura com o fim melancólico da tradição ocidental, pois tal não denota o "fim" mesmo da educação. Antes, desdobra-se a partir daí uma nova tarefa à ação formativa, face à perda de plausibilidade em relação ao modo de formular e responder às questões que "coincidem com a aspiração dos homens sobre a terra" ${ }^{650}$. Posto que a crise na educação não é relativa à capacidade de pensar, subsiste sempre a possibilidade de novas trajetórias em direção aos tesouros da tradição. Essa possibilidade implica em resgatar a primeira e grande "reviravolta" em direção à dimensão de profundidade da existência humana, realizada dentro circuitos da tradição, sobre a qual, em última instância, todas as outras se baseiam. Essa primeira reviravolta, análoga à primeira das três descritas na parábola da caverna (Platão, A República), não é uma mera operação mental, senão o revirar de todo ser humano na própria caverna, libertando-se dos grilhões que o acorrenta para ver diante de si as coisas que aparecem, tais como realmente são. Trata-se de um revirar distinto do giro da teoria científica moderna, levado a curso mediante alguma hipótese de trabalho que muda conforme os resultados que produz e cuja validade se mensura, também no plano dos valores, em razão da funcionalização desses resultados na sociedade. De modo peculiar, Arendt parece vislumbrar um caminho "fundacional", inclusive na ordem dos valores humanos, que denota o "regresso" ao princípio, à caverna dos assuntos humanos cotidianos, e aí restaurar a confiança e o espanto face ao que é como é ${ }^{651}$. Essa "via", também relevante à moralidade e à educação dos valores, vai ao encontro da dimensão de profundidade na existência humana, alcançável pela via da recordação ${ }^{652}$.

Face ao "problema em aberto" referente à recusa da autoridade, na educação, cabe aos educadores assumirem a atitude própria do humanista ${ }^{653}$. A meu ver, isso mais que indicar o modus operandi a ser imitado pelos educadores, parece indicar a qualidade da presença educativa que deve ser elevada no mundo. Os educadores, de modo semelhante aos humanistas que se investiram da capacidade de ajuizamento e de gosto, em primeiro lugar, devem se atentar em relação à coerção de verdades absolutas, em quaisquer das espécies de

\footnotetext{
${ }^{649}$ ARENDT, Entre o passado e o futuro, p. 132.

${ }^{650}$ ARENDT, Responsabilidade e julgamento, p. 229.

651 ARENDT, Entre o passado e o futuro, pp. 67-68.

${ }^{652}$ ARENDT, Entre o passado e o futuro, p. 131.

653 "Nem as verdades do cientista, nem a verdade do filósofo, podem ser absolutas; o humanista, portanto, não é um especialista, exerce uma faculdade de julgamento e de gosto que está além da coerção que nos impõe cada especialidade". "O gosto é a capacidade política que verdadeiramente humaniza o belo e cria uma cultura" (ARENDT, Entre o passado e o futuro, respectivamente pp. 280 e 279). Nesse sentido, o humanista encarna um "estilo" de ajuizamento e de presença responsável pelo mundo.
} 
verdade racionais. Em seguida, sob a estilística do humanista, os educadores devem assumir os desafios relativos a cuidarem de si próprios também como parte do cuidado do mundo na educação, buscando por si mesmos deitar suas raízes nas fontes fundadoras e inspiradoras da atividade educativa e, com isso, adquirir condições para mover-se no mundo discursivamente, num vaivém dialógico com os tesouros da tradição. Em certo sentido, tal empreitada parece afigurar uma estética de si, movida pelos próprios educadores, para reencontrar a beleza do mundo e reconstituir sua autoridade legítima pela iniciação dos recém-chegados ao mundo como ele é. Auxiliados pela faculdade de pensar, que é propriedade de todos e não privilégio de $\operatorname{poucos}^{654}$, sempre é possível que os educadores venham a se revitalizar no vigor das raízes da tradição, justamente para avocar novamente a tarefa de "arbitrar", "mediar" e "elevar-se" para-além das especialidades pelo exercício da liberdade no aprender, pensar e agir ${ }^{655}$. Enfim, a convicção de Arendt, quase profética, é que a interrupção dos processos da crise da educação "está ao alcance do poder do pensamento e da ação humana"656.

Tendo como pano de fundo a análise sobre a crise da educação e o conceito de autoridade segundo a ótica de Arendt, explicita-se agora a posição de Apel em relação à dificuldade de conciliar a exigência hermenêutico-transcendental do primado judicativo do sujeito com a exigência de autoridade na educação. Contextualmente, essa dificuldade é tematizada na obra Transformação da filosofia, quando Apel marca sua posição teórica em contraposição à do hermeneuta puro. Só para constar, tópicos anteriores deste trabalho trazem a solução mais geral para essa dificuldade, nos termos da proposta apeliana de uma hermenêutica pragmático-transcendental normativa. Retomando aqui as teses envolvidas nessa oposição, por um lado, Apel defende o pressuposto da simetria linguístico-comunicativa dos interlocutores na situação interpessoal de produção do co-entendimento. Por sua vez, o hermeneuta puro tende a suspender, em favor da superioridade do interpretandum (autor), o pressuposto da simetria idealmente implícita do acordo mútuo no caso da mediação da tradição ${ }^{657}$. Em meio a essa discussão, em uma breve menção e a título de ilustração, Apel

\footnotetext{
${ }^{654}$ ARENDT, Responsabilidade e julgamento, p. 234.

655 "[O humanismo] tem, como tal, a tarefa de servir de árbitro e mediador entre as atividades puramente políticas e puramente fabris, que se opõem uma às outras de um sem-número de modos. Enquanto humanitas (sic!), podemos nos elevar acima desses conflitos entre o político e o artista, do mesmo modo como nos podemos elevar em liberdade acima das especialidades que todos aprendemos e exercemos" (ARENDT, Entre o passado e o futuro, pp. 280-281).

${ }^{656}$ ARENDT, Entre o passado e o futuro, p. 245. Quanto à ação, Arendt considera que o remédio para a irreversibilidade e imprevisibilidade de toda ação já se encontra entre as potencialidades da própria ação: quer pela mediação da faculdade do perdoar que serve para desfazer os atos do passado; quer pela faculdade de prometer e cumprir promessas (cf. ARENDT, A condição humana, p. 295).

${ }^{657}$ APEL, Transformação da filosofia, v. I, p. 64; Transformation der Philosophie, Band I, p. 54.
} 
amplia essa contenda com hermeneuta puro na direção de outros campos do saber, no caso, a psicanálise e a educação. E nisso, emerge uma breve ponderação de Apel em relação à questão da autoridade na educação.

$\mathrm{O}$ ponto principal relativo a essa ponderação concerne à tese de que o uso do "método de semi-elucidação narrativa", segundo Apel, também aplicável à educação, requer uma suspensão temporária da pressuposição da simetria entre os interlocutores na argumentação. Ressalta-se, trata-se da possibilidade de suspensão de um elemento basilar na arquitetura da semiótica transcendental. Na prática, o educador (enquanto autoridade), de modo análogo ao psicanalista ou crítico da ideologia, ao mediatizar o processo de acordo mútuo com o outro por meio de um método de semi-elucidação narrativa (dialógico), vê-se obrigado a suspender a pressuposição de simetria. Apel salienta que essa suspensão ocorre inclusive quando se objetiva apenas a melhora do entendimento sobre algo. Quando ocorre tal suspensão no campo da educação, a pressuposição de simetria da comunicação interpessoal é decidida em favor do "intérprete" do conhecimento, o educador. A simetria é suspensa à custa da competência comunicativa do educando, o que significa o sacrifício da condição de interlocutor do educando. Apel sustenta que é possível admitir essa alternativa estratégica apenas em função das contingências de precarização para a efetivação do diálogo argumentativo. Não obstante, é preciso ter conta que, da perspectiva existencial-hermenêutica, essa suspensão consiste em um escândalo ${ }^{658}$. Pois, problematicamente, essa alternativa implica em suspender a competência comunicativa do aluno, que em sua fragilidade (carência) epistemológica e pedagógica, vê-se rebaixado, parcialmente, a objeto da objetivação científica da educação.

Esse escândalo é ainda mais visível quando a ciência social ligada à crítica da ideologia utiliza o método de semi-elucidação narrativa (modelo da psicanálise). Nesse caso de suspensão da simetria, a crítica da ideologia tende a ser feita por uma parte da sociedade que nega à outra (que detém o poder e é ideologicamente dominante) o diálogo no plano da argumentação, contendo ao menos em parte sua competência comunicativa e, ademais, sua competência objetiva (científica) e política. A suspensão parcial da comunicação é feita em favor de uma parte da sociedade que requer para a si a competência comunicativa. Quanto a esse escândalo, a convicção de Apel é que "enquanto a filosofia, mesmo no tempo da science e technology, tiver que manter desperto o saber acerca da dialética sujeito e objeto no campo das ciências humanas e das ciências sociais crítico-emancipatórias, ela de fato não poderá

${ }^{658}$ APEL, Transformação da filosofia, v. I, p. 65; Transformation der Philosophie, Band I, p. 55. 
tomar como causa sua a trivialização do escândalo"659. Pelo exposto nos tópicos anteriores, depreende-se que a suspensão do pressuposto da simetria entre os interlocutores para mediar o acordo mútuo entre eles denota ainda um atrelamento do campo das ciências humanas ao modelo da lógica da ciência moderna baseada na relação cognitiva entre sujeito e objeto e, além disso, na abstração da dimensão pragmática da linguagem. Desde o prisma da hermenêutica de Gadamer, é possível superar esse escândalo, contanto que ocorra o reconhecimento do cerne das ciências humanas, que é a construção do acordo mútuo mediada pela relação dialógica sujeito-sujeito, em condições de igual competência comunicativa. Daqui se depreende que, caso se pretenda entender e possibilitar a educação (formação como elevação à humanidade, no sentido de Gadamer) como uma ciência social críticoemancipatória, então parece imprescindível, tanto quanto possível, tomar em relevo a pressuposição da simetria entre os interlocutores como princípio fundante do processo educativo (formativo).

Por outra parte, Apel reconhece que há duas situações ${ }^{660}$ perante as quais a ruptura com a pressuposição da simetria entre os interlocutores para mediar o progresso histórico no acordo mútuo entre os homens não é apenas tolerada, mas estrategicamente admissível. A primeira situação se apresenta face à alternativa usual de continuar a política com outros meios. Trata-se da situação em que comunicação e interação imediatas podem se converter em conflito bélico. A segunda situação se apresenta em face da possibilidade da manipulação tácita de uma parte da sociedade por meio da outra, com o claro propósito de impedir a comunicação relevante do ponto de vista prático-político. Frente a essas alternativas, a substituição parcial e temporária da comunicação imediata entre todos os interlocutores por uma objetivação e elucidação quase-naturalista do comportamento humano e da história, na medida em que já significa um avanço na mediação do acordo mútuo, pode se reverter em medida legítima de combate ao referido escândalo. O que respalda essa convicção, segundo Apel, é a ideia de que a história não é a repetição do que "sempre acontece", mas que nela se desenvolve um progresso histórico no acordo mútuo entre os seres humanos. Com base nisso, é possível postular que a substituição parcial e temporária da competência comunicativa de todos por uma parte dos interlocutores pode constituir-se, em face de tais alternativas extremas, em via estratégica para discernir acerca da real possibilidade e necessidade ética e

\footnotetext{
${ }^{659}$ APEL, Transformação da filosofia, v. I, p. 65; Transformation der Philosophie, Band I, p. 56.

${ }^{660}$ APEL, Transformação da filosofia, v. I, p. 66; Transformation der Philosophie, Band I, p. 57.
} 
lógico-transcendental do paradigma do acordo mútuo possível referente ao co-entendimento entre os seres humanos ${ }^{661}$.

Em tese essa solução estratégica pode ser desdobrada para o âmbito da educação. A meu ver, a suspensão parcial e temporária do pressuposto da simetria da competência comunicativa no campo da educação, em favor da autoridade do interlocutor-educador ${ }^{662}$, pode constituir-se em uma alternativa estratégica admissível, contanto que se considere o seguinte: a) o interlocutor-educador, em uma perspectiva teoricamente crítica, deve sustentar sua objeção perante os riscos de uma ciência manipuladora, que tem sua origem na vedação imposta pelo cientificismo positivista à autorreflexividade ${ }^{663}$. Quanto a isso, Apel pondera que nunca é possível haver um acordo puramente hermenêutico entre professor e aluno, sobretudo quando o último é jovem. Por mais que ambos tenham boa vontade, de alguma maneira, é inevitável entre eles alguma objetivação empírico-analítica e manipulação ${ }^{664}$; b) o interlocutor-educador, em uma perspectiva de corresponsabilidade (no sentido ético-político), deve comprometer-se a cooperar na superação das contingências que precarizam a efetivação do diálogo argumentativo em relação aos pressupostos, modelos, programas e práticas da educação; c) a função do interlocutor-educador deve ser compatível filosoficamente com o sentido de uma função emancipadora da ciência ${ }^{665}$. A autoridade atribuída ao interlocutoreducador deve ser exercida no sentido de "uma abordagem metodológica que vincula ciência empírica e reflexão filosófica na 'teoria crítica' com uma intenção prática" (político-ética) ${ }^{666}$. No sentido da tese apeliana da complementaridade dos tipos de racionalidade ${ }^{667}$, presume-se

\footnotetext{
${ }^{661}$ APEL, Transformação da filosofia, v. I, pp. 66-68; Transformation der Philosophie, Band I, pp. 57-59.

${ }^{662}$ Sobre o conceito de autoridade em Gadamer, ver: GADAMER, Verdade e método I, p. 371. Para Gadamer, autoridade não tem a ver com obediência, mas com conhecimento. O reconhecimento da autoridade decorre da ideia que ela não é uma arbitrariedade irracional, mas de algo que "em princípio pode ser compreendido". O verdadeiro fundamento da autoridade é um ato da liberdade e da razão, que concede autoridade ao "superior" (educador, especialista), porque este "sabe melhor".

${ }^{663}$ APEL, Transformação da filosofia, v. II, p. 162; Transformation der Philosophie, Band II, p. 142.

${ }^{664}$ APEL, Transformação da filosofia, v. II, p. 163; Transformation der Philosophie, Band II, p. 142.

${ }^{665}$ APEL, Transformação da filosofia, v. II, p. 149; Transformation der Philosophie, Band II, p. 130

${ }^{666}$ APEL, Transformação da filosofia, v. II, p. 163; Transformation der Philosophie, Band II, p. 142.

${ }^{667}$ Uma ilustração concreta da problemática por trás da tese da complementaridade de Apel é a análise de Goergen sobre os modelos de universidade predominantes na modernidade. Em seu texto "Ciência como emancipação?", Apel faz uma análise da função da ciência (cf. APEL, Transformação da filosofia, v. II, pp. 147-149; Transformation der Philosophie, Band II, pp. 128-129). Entre as abordagens de ambos parece haver um ponto de cruzamento, qual seja a suposição de que o ensino está condicionado pelos distintos interesses cognitivos das ciências (explicativas, hermenêuticas e teoria crítica). Para Goergen, a distinção entre as demandas do mundo do conhecimento e as do mundo do pensamento tem sua raiz em duas vertentes principais da constituição da universidade moderna: a) a que defende o modelo de universidade da ciência que privilegia a investigação especulativa e segue o modelo alemão humboldtiano. É o modelo adotado na Berlin de 1810, orientado filosoficamente por Fichte, Schelling, Schleiermacher e Humboldt; regride ao pensamento de Kant. Esse modelo enfatiza a autonomia especulativa do saber; b) a que defende o modelo francês da universidade napoleônica, responsável pela refundação da Universidade de Paris, em 1806. Esse modelo se liga ao
} 
que o interlocutor-educador, além de constituir-se como autoridade em relação a alguma especialidade relativa ao interesse cognitivo de objetivação e instrumentalização teóricoanalítica do mundo, precisa engajar-se no campo do interesse cognitivo referido à realização da emancipação humana. Como já mencionado, este último interesse, quando dimensionado à educação, pode ser entendido como o interesse hermenêutico-comunicativo referente ao “acordo mútuo engajado dos pedagogos quanto aos objetivos da formação integral e da instrução formal"668; d) o interlocutor-educador, enquanto parte da sociedade autorizada a exercer institucionalmente a tarefa da educação, deve dispor de sua autoridade como um momento em meio à ideia de uma "comunidade educativa" ilimitada, que deve ser construída prioritariamente em meio à concepção do progresso ilimitado do acordo mútuo entre os homens.

É possível pensar que, na filosofia de Apel, o dano hermenêutico relativo à quebra da simetria em favor da autoridade na educação pode ser compensado pela força reflexiva e pelo caráter transpositivo do compreender implícito no postulado de entender o autor melhor do que ele compreende a si mesmo. Esse postulado, igualmente válido para todos os envolvidos na educação e demais âmbitos da vida humana, potencializa da forma mais ampla possível a essência da educação. E faz isso à medida que preconiza que todos nasçam autoralmente (singularidade), de algum modo, em projetos comuns. Se os educadores devem testemunhar, como adultos iniciadores em meio a iniciados no mundo, que a pluralidade dos seres únicos pode nascer continuamente, então jamais poderão se considerar definitivamente prontos para a atividade educativa. Cessar esse nascer é adulterar duplamente a mensagem essencial da qual os educadores são portadores. Educadores que nascem continuadamente, ensinam o já conhecido e educam, por meio de atos e palavras, para a atividade do pensamento. Nesse sentido, é possível depreender que nascer continuamente é, essencialmente, não obstar a natalidade que lhe é intrínseca e resistir à redução da tarefa educativa ao serviço escriba em favor da doutrinação e instrumentalização do conhecimento. Esses educadores, providos de autoridade legítima e responsável pela continuidade do mundo,

pensamento de Condorcet, Taine, Saint-Simon e Comte. Alinhado ao pensamento de Descartes, esse modelo enfatiza o caráter instrumental da universidade como provedora de forças profissionais. Em comum, ambas as vertentes se entendem à serviço da sociedade. Porém, distintivamente, no modelo francês a universidade se submete aos interesses do Estado; no modelo alemão, o Estado deve se orientar pelas verdades estabelecidas nos caminhos reflexivos da razão, ainda que manejada pelo Estado. Para Goergen, esses modelos afiguram os interesses controversos implicados em torno da crise na educação (GOERGEN, Pedro. A universidade em tempos de transformação. Campinas: UNICAMP, [s.d.]. Disponível em: www.prg.unicamp.br/Texto_univ_em_temp_trans_Pedro_Goergen.html. Acesso em 10/06/2013, passim). ${ }^{668}$ APEL, Transformação da filosofia, v. II, p. 162. APEL, Transformation der Philosophie, Band II, p. 141. 
podem introduzir o educando ao desvelamento do mundo como ele é, pela via do diálogo tensionado e amoroso, para que ele possa romper sua condição de estrangeiridade inicial em relação a si mesmo, ao mundo e ao sentido da existência e da história, enfim criar-se singularmente e investir-se da responsabilidade pelo mundo.

Efetivamente, seguindo Arendt ou Apel, não é possível abrir mão da autoridade na educação. A ideia da autoridade na educação não é incongruente com o convívio escolar que exige uma "escola justa", marcada pela construção coletiva e orientada pelos princípios dos direitos de todos, respeito e reciprocidade. Para isso, a educação precisa ajudar a praticar o diálogo argumentativo sobre os interesses universalizáveis, pois eles constituem o fundamento do mundo moral ${ }^{669}$. Ela precisa fazer isso mesmo em face do esquema de negociação estratégico da democracia liberal. Fazendo isso, a educação ajuda a desenvolver a dupla dimensão de cada pessoa: a dimensão de autonomia, pela qual se torna capaz de se conectar com todo ser humano, e a dimensão de autorrealização que convém a cada qual. Nos termos de Cortina, o diálogo e a decisão pessoal são o ponto em que se conciliam comunidade humana (universalidade) e irrepetibilidade pessoal (diferenças) ${ }^{670}$. Decerto, como passo inicial, em vez de abandonar os educadores aos próprios infortúnios, é necessário resgatá-los formativa e politicamente ${ }^{671}$ para que possam reencantar-se pelo mundo, tendo-o como uma

\footnotetext{
669 Aqui, a título de exemplificação de uma educação voltada à prática do diálogo argumentativo sobre os interesses universalizáveis, pode-se citar o texto de Adela Cortina e colaboradores, que contempla uma proposta de educação dos valores a partir dos "mínimos de justiça" (os direitos humanos). Nesse texto, o capitulo 5 trata dos "procedimentos pedagógicos para a busca da norma justa". Esse capítulo traz um conjunto de atividades, visando desenvolver habilidades lógico-argumentativas, a criação de um clima ético na sala de aula, o desenvolvimento da empatia ética, a autocompreensão dos próprios valores, a promoção do pensamento autônomo dos alunos sobre sua moralidade e a orientação para a ação ética correta. O capítulo 6 concerne a uma "proposta de programa para a educação na justiça” (cf. CORTINA, Adela et al.. Educar em la justicia. Valencia: Generalitat valenciana, 1998, pp. 69-111).

${ }^{670}$ CORTINA, Ética aplicada y democracia radical, p. 222.

${ }^{671}$ Para um exemplo de tal intento, ver o relato da experiência de formação continuada de professores das redes públicas municipais de São Paulo, transcorrida nos anos de 2001 a 2008 (cf. CARVALHO, José Sérgio. Uma ideia de formação continuada em educação e direitos humanos. In: Reflexões sobre a educação, formação e esfera pública. Porto Alegre, Penso, 2013, pp. 142-160). Essa experiência é norteada por dois princípios: a) as escolas que devem ser melhoradas e, por isso, "o objeto da formação continuada deve ser a cultura institucional, e não a consciência do professor" (p. 144). Trata-se de desenvolver uma cultura escolar, em que o compromisso da ação educativa com a formação de valores relativos à vida pública tem que ser objeto de debate, compreensão e ação pelos educadores, a fim de impregnar a cultura da instituição e provocar a atualização de suas práticas pedagógicas e de gestão; b) deve-se pressupor que o processo formativo deve visar antes à formação intelectual do educador do que à difusão de recursos técnicos e de procedimentos de ensino. Trata-se, portanto, de ir de encontro à ênfase dada ao desenvolvimento de "competências profissionais". Opõe-se também à pressuposição de que a insatisfação com as práticas educativas resulta da obsolescência dos métodos de ensino e, em contrapartida, a melhoria da qualidade do ensino e o êxito da formação dependem da renovação da abordagem pedagógica (de métodos). À luz dessa experiência, observa-se que essa pressuposição acrítica tem contribuído, em primeiro lugar, para aprofundar o hiato entre as prescrições metodológicas e as práticas escolares, ao passo que as formulações metodológicas soam abstratas e quase inaplicáveis às condições concretas de trabalho dos educadores; e, em segundo lugar, para o empobrecimento teórico da noção de ensino, à medida que o ensinar,
} 
beleza a ser cuidada, conservada, transformada e manifestada na tarefa educativa. Em torno disso, a autoridade na educação interessada na construção de uma sociedade democrática pode cumprir a tarefa de elucidar em que consiste a autêntica democracia, isto é, uma forma de organização social em que os indivíduos podem exercer seu caráter autônomo e participativo, tendo em conta os fins da política e de todas as esferas da sociedade que estão a serviço dos afetados pelas decisões tomadas por eles mesmos ${ }^{672}$. Na linha de uma educação inclusiva ${ }^{673}$, o convívio escolar tem que adotar contornos democráticos, envolvendo análises sobre as necessidades e possibilidades, diálogos entre os atores e decisões coletivas. Mas, no fim, isso não parece mitigar a "autoridade/responsabilidades" dos "adultos/educadores". Antes, exige mais, envolvendo-os diretamente na "teia das relações humanas" implicada na responsabilidade coletiva pelo mundo e na exigência de dar conta do direito de todos ao conhecimento e também à atividade do pensamento.

\footnotetext{
enquanto atividade que visa ao fim da aprendizagem, é reduzido a "um conjunto relativamente padronizável de ações, traduzidas em 'metodologias' e/ou 'procedimentos"' (p. 147). Do ponto de vista político, o predomínio da educação centrada na difusão de métodos e procedimentos significa tratar o trabalho do educador como uma técnica e aliená-lo da sua identidade que se acha engajada em seu trabalho de formação. Assim, o educador é levado a se desincumbir dos resultados de uma proposta que lhe é estranha. Por esse princípio, enfim, visa-se conceber a melhoria da ação docente não como resultado da simples assimilação de procedimentos e saberes, mas "como fruto da formação de intelectuais comprometidos com certos ideais educacionais públicos e comuns" e, ademais, "capazes de pensar e desenvolver formas específicas de traduzir esses ideais em práticas concretas e contextualizadas" (p. 148). E, para tanto, a escola precisa ser um ambiente de estudo sistemático e de debate intelectual.

${ }^{672}$ CORTINA, Ética aplicada y democracia radical, p. 213.

${ }^{673}$ SHILLING, Flávia; SANTOS, Milton Alves. A garantia do direito à educação: aprendizagem, convívio escolar e redes de proteção à criança e ao adolescente. In: Formação de professores: múltiplos enfoques. São Paulo: Editora Sarandi, 2013, pp. 61-89 (passim).
} 


\section{PARTE III - EDUCAÇÃO, EMANCIPAÇÃO E \\ CORRESPONSABILIDADE EM APEL}

\section{Consideração inicial}

Esta parte trata da compreensão da educação no sentido da emancipação, tendo como ponto de partida a concepção do interesse cognitivo emancipador preconizado pela teoria crítica da Escola de Frankfurt e, em um passo seguinte no sentido da contribuição específica de Apel em tal contexto, e a exigência de estabelecer a interface entre a ética do discurso de Apel e a educação direcionada à corresponsabilidade. Essa parte se compõe de dois capítulos.

O primeiro capítulo aborda a compreensão de uma educação voltada à emancipação, em que a educação figura como uma ciência social da mediação entre teoria e práxis impulsionada pela vontade da razão pela autonomia. A referência fundamental desta abordagem é o texto de Apel "Ciência como emancipação?". Seguindo essa abordagem, esse capítulo tematiza os seguintes tópicos: a) o debate sobre a função da ciência e a dimensão antecipativa da filosofia, no sentido de cumprir a função epistemológica de fornecer os princípios da razão ou logos, isto é, os critérios normativos de reconstrução racional dos processos de aprendizagem relacionados à cultura; b) a exposição da concepção de emancipação segundo a teoria crítica; c) a retomada parcial da concepção de emancipação de Habermas; d) o sentido da emancipação em Apel à luz do a priori da comunidade de comunicação.

O segundo capítulo trata da compreensão da educação no sentido da corresponsabilidade no marco da ética do discurso de Apel. Fundamentalmente, esse capítulo põe em questão dois pontos principais: a) em um passo inicial, trata-se da fundamentação e estrutura híbrida da ética do discurso; b) em um passo seguinte, que procura conectar educação e responsabilidade na filosofia moral de Apel, postula-se a possibilidade de uma contribuição recíproca, no sentido de que a educação dos valores públicos possa suplementar a ética do discurso quanto a sua aplicação na história. 


\section{EDUCAÇÃO E EMANCIPAÇÃO EM APEL}

É no texto intitulado Ciência como emancipação? Uma apreciação crítica da concepção de ciência da teoria crítica que aparece o passo inicial de Apel, porém não desenvolvido ulteriormente, no rumo de uma reflexão aparentemente típica de uma filosofia da educação. Esse texto constitui a referência mais elucidativa - e possivelmente mais relevante - na obra de Apel em relação ao âmbito da educação. E chama a atenção o fato de que, na cronologia de Apel, esse texto originariamente concerne a uma conferência proferida por Apel por ocasião dos "Kieler Universitätstage" de 1969, cujo tema geral era "Tarefas da universidade no presente e no futuro". Trata-se de um texto vinculado à função de Apel como catedrático de filosofia em Kiel (Alemanha), portanto, anterior ao início do "despertar político" de Apel e do seu reencontro com Habermas, bem como ao seu ingresso como catedrático de filosofia em Frankfurt am Main, em 1973. Trata-se de um texto posteriormente incorporado à composição da obra Transformação da filosofia, mas que, efetivamente, guarda os limites de sua peculiaridade contextual.

Hipoteticamente, aqui se cogita que o texto "Ciência como emancipação" é possivelmente a referência na obra de Apel mais importante para começar a pensar o campo da educação à luz da semiótica transcendental pelos seguintes motivos. Primeiro, como motivo principal, esse texto faz uma referência à educação que não sistematiza um conceito de educação do ponto de vista semiótico-transcendental, mas indica o foco em relação ao qual, em conformidade com a intuição originária de Apel, a educação precisa ser pensada, ou seja, sob a ótica do a priori da comunidade de comunicação ${ }^{674}$. Ora, mesmo que embrionariamente, nesse texto já aparece a aposta de Apel no sentido de apresentar a fundamentação e os critérios que podem respaldar racionalmente a perspectiva de uma educação à emancipação. Decerto, é preciso ter em conta que, efetivamente, no momento teórico desse texto e da trajetória intelectual de Apel, não existe ainda uma arquitetônica ${ }^{675}$ da semiótica transcendental. Cronologicamente, de 1962 a 1969, Apel se dedica a estudar a obra de Peirce ${ }^{676}$.

\footnotetext{
${ }^{674}$ APEL, Transformação da filosofia, v. II, pp. 171-172; Transformation der philosophie, Band II, p. 150. ${ }^{675}$ A respeito do comentário introdutório de Adela Cortina sobre o caráter arquitetônico da proposta filosófica de Apel, ver: APEL, Teoría de la verdad y ética del discurso, p. 10.

${ }^{676}$ APEL, Antropos, p. 24.
} 
Outro ponto relevante presente nesse texto é que aí Apel enuncia a preocupação de fundo relativa ao propósito de pensar uma teoria crítica capaz de superar o problema da mediação entre teoria e práxis. Para Apel, a educação constitui um caso clássico de ciência que tem a ver com a "mediatização de teoria e práxis" 677 . Este ponto introduz aqui o segundo motivo. Contextualmente, esse texto está enraizado à atividade pedagógica de Apel e, por certo, representa seu esforço no sentido de esboçar uma reflexão filosófica sobre o papel emancipador da ciência (Wissenschaft als Emanzipation) ${ }^{678}$. É precisamente nesse esboço que emerge, ainda que a título de exemplificação, a tentativa apeliana de autocompreensão científica da educação. Essa autocompreensão procura refletir sobre a possibilidade de vinculação entre a compreensão do caráter emancipador do conhecimento, nos termos da matriz teórica da Escola de Frankfurt, e a ciência da educação.

Nesse tópico, em vista de explicitar essa posição sui generis de Apel, desde a qual, reiterando, ele não define um conceito público e intersubjetivamente válido de educação, mas apenas indica a base regulativa para levar adiante discursos fáticos sobre questões atinentes à educação, tratar-se-á dos seguintes pontos: a) a discussão de fundo que motiva o texto "Ciência como emancipação?", a saber, o debate sobre a função da ciência; b) o enfoque do caráter emancipador da emancipação como questão de fundo da tradição da escola de Frankfurt, seja por parte dos seus fundadores, seja por parte dos seus inovadores, tal como é caso de Habermas (possivelmente, a figura mais relevante para Apel); c) a perspectiva crítica de Apel no sentido de desenvolver o lastro teórico, baseado em sua teoria da complementaridade dos tipos de racionalidade, sob o qual é possível conceber que as ciências empírico-hermenêuticas - e entre elas, a ciência da educação - possam se efetivar como mediação à emancipação.

\subsection{O debate sobre a função da ciência e a dimensão antecipativa da filosofia em vista da emancipação na educação}

O ponto de partida da reflexão de Apel, em “Ciência como emancipação?”, sobre o caráter emancipador da ciência - e no caso desta investigação, por ampliação, da ciência da educação - é a controvérsia contemporânea sobre a função da ciência. O núcleo dessa controvérsia é a problemática relativa à autocompreensão acadêmica da ciência, por trás da

\footnotetext{
${ }^{677}$ APEL, Transformação da filosofia, v. II, p. 162; Transformation der philosophie, Band II, p. 141.

${ }^{678}$ APEL, Transformação da filosofia, v. II, pp. 162-166; Transformation der philosophie, Band II, pp. 141145.
} 
qual parece subsistir uma situação paradoxal. Por um lado, vige a compreensão geral de que "entre as tarefas da universidade hoje e no futuro" a prática da ciência ocupa o primeiro lugar. Por outro, apesar dessa suposta compreensão, há a dificuldade de estabelecer (anteriormente) o consenso quanto à compreensão das tarefas da ciência. Isso se agrava, segundo Apel, pois se observa a degeneração do debate direcionado a tal compreensão em uma mera disputa apaixonada entre posições teóricas, ocasionando embaraços no entendimento da ciência ${ }^{679}$. Resta, então, uma situação paradoxal, ao passo que cabe à universidade em primeiro lugar desenvolver a ciência, sem dispor de um claro entendimento público sobre as tarefas inerentes à ciência na práxis social. Por sua vez, Apel entende que a problemática sobre as funções da ciência na contemporaneidade desafia a filosofia a contribuir no questionamento voltado à autocompreensão da ciência. Em positivo, o enfrentamento dessa controvérsia se torna o campo de batalha próprio da filosofia, a partir do qual a reflexão filosófica é desafiada a pensar sobre o interesse cognitivo emancipador.

Para Apel, a disputa relativa às tarefas da ciência reflete, em seu contorno geral, a controvérsia entre os interesses cognitivos diretores das ciências naturais e os das ciências humanas (Geisteswissenschaften, "ciências do espírito"). Na base dessa disputa reside a suposição de que o entendimento de ciência se aplica "em primeiro lugar" às ciências naturais, já que elas, enquanto pesquisa tecnologicamente relevante, representam a força de produção primeira na sociedade industrial. Já no plano das ciências humanas, entende-se que a tarefa primeira da ciência é a prática comunicativa de "unidade entre pesquisa e ensino" (Einheit vor Forschung und Lehre) ${ }^{680}$, em vista da formação de uma opinião pública. $\mathrm{O}$ conflito entre os interesses cognitivos das ciências tem se agravado porque os contemporâneos têm questionado as funções das chamadas "ciências do espírito", inclusive cogitando a possibilidade de excluí-las do conceito de ciência. Há o risco de perder de vista a tarefa que é própria das ciências do espírito; nesse risco reside, por assim dizer, o núcleo do problema em torno dessa controvérsia. No século $\mathrm{XX}$, as ciências sociais, tendo figurado como um "grupo especial" - entre as quais, para Apel, incluem-se as ciências econômicas e a psicologia - incorporaram uma dupla função para a ciência. Nelas, a tarefa primeira da ciência consiste tanto em ampliar e potencializar a força produtiva científico-tecnológica do social-engineering, quanto em promover o aprofundamento crítico do acordo mútuo (öftenlichen Sinnverständigung, entendimento público) acerca do sentido, que deve ser

679 APEL, Transformação da filosofia, v. II, pp. 147 e 149; Transformation der philosophie, Band II, pp. 128-129.

${ }^{680}$ APEL, Transformação da filosofia, v. II, p. 168; Transformation der philosophie, Band II, p. 147. 
desenvolvido a partir da unidade entre pesquisa e ensino nas ciências humanas tradicionais. Em resumo, pode-se afirmar que o núcleo da problemática atual da discussão políticoacadêmica sobre as funções da ciência ontem e hoje resulta da atribuição dessa dupla função à ciência $^{681}$.

Para Apel, o questionamento expresso na pergunta "Ciência como emancipação?" remete não somente à problemática sobre a dupla tarefa da ciência, mas também ao desafio lançado à própria filosofia, que precisa determinar sua tarefa em meio às ciências e, fundamentalmente, perante a exigência de uma função emancipadora da ciência. Em face desse desafio, Apel pensa que, do ponto de vista metodológico, a contribuição da filosofia consiste tanto em tornar inteligíveis, diante de seu pano de fundo histórico, as posições teóricas defendidas na controvérsia relativa ao entendimento de ciência, quanto em reposicionar a função primordial da reflexão filosófica na era da ciência. Neste caminho, o ponto de partida de Apel é a defesa de uma concepção de filosofia como uma "teoria da ciência em potencial” ${ }^{\prime \prime 2}$.

Nesse ponto, é preciso destacar que Apel avança em sua tentativa de reposicionamento da natureza do discurso filosófico. Em "Falibilismo, teoria consensual da verdade e fundamentação última" (1986), texto em que Apel apresenta sua proposta de uma teoria da verdade, ele procura dar uma resposta à problemática do lugar da filosofia na era da ciência. Para tanto, ele desdobra essa problemática em dois problemas: a) o problema da complementação da teoria consensual da verdade das ciências empíricas da natureza, tal como concebida por Peirce, em relação às ciências sociais (hermenêuticas); b) o problema de uma teoria consensual da verdade compatível com os enunciados universais e autorreflexivos da filosofia. A tese de Apel, em relação ao segundo problema, é que é essencialmente próprio dos enunciados da filosofia é a reflexão sobre as pretensões de validade (pretensão de sentido, de verdade, de veracidade e de correção normativa; Reflexion auf Geltungansprüche: Sinn, Wahrheit, Wahrhaftigkeit, Richtigkeitsanspruch). Há que observar, contudo, que a posição de Apel preconiza a distinção desses enunciados em relação aos enunciados das ciências empíricas da natureza, aos da ciência hermenêutica social e, em tal medida, também em relação aos de uma teoria crítica. A posição de Apel representa uma inovação teórica dentro do âmbito da teoria crítica. Essa inovação se refere à concepção da natureza dos enunciados típicos da filosofia. Para Apel, esses enunciados intentam dizer algo verdadeiro

\footnotetext{
${ }^{681}$ APEL, Transformação da filosofia, v. II, p. 148; Transformation der philosophie, Band II, p. 128. ${ }^{682}$ APEL, Transformação da filosofia, v. II, p. 148; Transformation der philosophie, Band II, p. 128.
} 
acerca do sentido da verdade dos enunciados, quer dizer, acerca das pretensões de verdade e condições de realização das diferentes classes de enunciados. Essa reflexão radica sob a compreensão de que os enunciados da filosofia são reflexivos em relação a sua própria pretensão de validade e dotados de pretensão universal de validade. A diferença entre a pretensão universal de validade dos enunciados da filosofia e a pretensão empírico-geral de validade dos enunciados de leis nas ciências da natureza, assim como da pretensão universal a priori de validade dos enunciados matemáticos, é que esses não podem ser autorreflexivos. Autorreflexividade e universalidade são as qualidades típicas dos enunciados da filosofia ${ }^{683}$.

Vale observar que, já em "Ciência como emancipação?”, Apel manifesta a convicção fundamental de que a discussão hoje em voga sobre a função da ciência, no contexto da mediatização entre teoria e práxis, caracteriza um novo ponto culminante para a filosofia. Trata-se de um cume que não havia sido previsto por ninguém, já que - até recentemente, lembrando, Apel escreve sobre isso em 1969 - predominava a opinião dos representantes da "geração cética" ${ }^{684}$, segundo a qual o contexto cooperativo da ciência na práxis social poderia ser assegurado, mesmo prescindindo de qualquer reflexão filosófica sobre seu sentido, em virtude das compulsões objetivas institucionais e tecnológicas. Importa salientar, segundo Apel, que esse cume emerge em contraposição à mentalidade "pósideológica" da "geração cética", quer dizer, como contraponto à preconização do "fim" de uma filosofia engajada direcionada à mediatização entre teoria e práxis. Em vez do "fim da filosofia", a compreensão da filosofia enquanto teoria da ciência denota uma redefinição da filosofia na contemporaneidade, que passa a ser vislumbrada como reflexão metacientífica ${ }^{685}$ sobre as condições de possibilidade da ciência. Vista de tal modo, a contribuição específica da filosofia é refletir sobre as condições de possibilidade transcendentais da constituição objetual das ciências na contemporaneidade.

Nesse sentido, o texto "Ciência como emancipação?" traz uma reflexão bastante enxuta referenciada no legado da teoria crítica da Escola de Frankfurt, particularmente na

\footnotetext{
683 APEL, Teoría de la verdad y ética del discurso, pp. 103-104. APEL, Fallibilismus, Konsenstheorie der Wahrheit und Letztbegründung. In: Philosophie und Begründung, pp. 166-167.

${ }^{684}$ Apel se refere à "geração cética" retratada por Helmut Schelsky como uma "geração silenciosa" em relação a tudo que possa ser chamado de acontecimento da história universal. Caracteristicamente, essa geração se mostra incapaz de reagir às coisas de maneira revolucionária ou com ardorosa paixão coletiva, porém se mostra afeita a investir em projetos que ofereçam segurança e manutenção das conquistas relativas ao bem-estar, à democracia e à privacidade. Os escritos de A. Gehlen, segundo Apel, descrevem o "auge filosófico-antifilosófico de uma autoestabilização análoga aos instintos" que se delineia da "era pós-ideológica por meio de sistemas da técnica marcados pela alienação" (cf. APEL, Transformação da filosofia, v. II, pp. 148-150; Transformation der philosophie, Band II, pp. 129-130).

${ }^{685}$ APEL, Transformação da filosofia, v. II, p. 148. APEL, Transformation der philosophie, Band II, p. 129.
} 
versão de teoria crítica habermasiana, no caso, a teoria dos interesses cognitivos e crítica da razão instrumental. Contudo, vale observar que isso não constitui um atestado de filiação teórica aos fundadores da escola de Frankfurt (a respeito disso o próprio Apel informa em seu relato autobiográfico ${ }^{686}$ ), tampouco um seguimento estrito à reformulação da teoria crítica realizada por Habermas. Em certa medida, é possível afirmar que Apel se filia à tradição da teoria crítica de forma sui generis; na verdade, bem ao estilo das abordagens variadas dos membros da Escola de Frankfurt. A posição de Apel é singular, a meu ver, em decorrência de Apel seguir, em um primeiro momento, a orientação teórica da Escola de Frankfurt no sentido de pensar a educação como emancipação, porém, ao mesmo tempo, delinear um caminho alternativo de teoria crítica, cuja novidade é o delineamento de um marco normativo de fundamentação última (o a priori da comunidade de comunicação ou a racionalidade do discurso argumentativo) para orientar a realização dos consensos fáticos no campo da educação. Peculiarmente, esse caminho segue a via do método transcendental, que, segundo Apel, constitui o modo próprio pelo qual se efetiva a contribuição da filosofia para o conhecimento teórico e para o campo prático (ético-político), bem como, aqui no caso, à educação. Aqui, a meu ver, parece resider a tese fundamental da contribuição de Apel para pensar filosoficamente a educação como emancipação desde um marco criteriológico não meramente contingente, porém de um ponto de ancoragem racional ineliminável, os pressupostos da racionalidade do discurso argumentativo.

Como tal, é relevante observar que essa contribuição trata da dimensão antecipativa relativa aos fatos instranscendíveis da argumentação. No sentido da dimensão $a$ priori da argumentação, a reflexão transcendental se antecipa à experiência empírica. Essa dimensão a priori (antecipativa e intranscendível; vorweggenommen) ${ }^{687}$, contudo, não implica em que a filosofia possa se apartar dos fatos empíricos e, enfim, da história. Efetivamente, marca-se aí um posicionamento específico da própria reflexão filosófica: o de ter em contar os fatos da experiência, mas não os tomar como referência para fundamentar sua própria validade. A missão da filosofia é, precisamente, oferecer uma fundamentação última para a investigação sobre tais fatos, apresentando os pressupostos que tornam essa investigação possível. Por sua vez, essa fundamentação consiste em desvendar as condições antecipáveis de sentido, validade, verdade e correção normativa relativas ao fato ineliminável de que “argumentamos". Nisso, vale reiterar que o projeto da semiótica transcendental de Apel se

\footnotetext{
${ }^{686}$ APEL, Antropos, p. 17.

${ }^{687}$ APEL, Transformação da filosofia, v. II, p. 166. APEL, Transformation der philosophie, Band II, p. 145. CORTINA, Razón comunicativa y responsabilidad solidaria: ética y política em K.-O. Apel, pp. 135-137.
} 
caracteriza como projeto de fundamentação última da argumentação. Com efeito, aí Apel procura elaborar uma perspectiva de reflexão transcendental que guarda uma peculiar relação com a experiência. Nesse projeto, a fixação do sentido e da validade dos argumentos pressupõe já sempre um conceito ideal, o da comunidade ilimitada (contrafática) de comunicação, porém também um conjunto de fatos contingentes vinculados à comunidade real (fática) de comunicação. De tal modo, o sentido de transcendental aí postulado não se desvencilha de tratar dos fatos contingentes, já que o discurso argumentativo empreendido para fundamentar as pretensões de sentido e validade do pensar e agir humanos transcorre no campo da história.

$\mathrm{O}$ ato de fala é um factum universal, porém a argumentação constitui o nível último ineliminável de todo pensamento e comunicação. Com efeito, sem a pressuposição de uma comunidade ilimitada de comunicação e do acontecer fático, carece de sentido atestar o fato de que os homens argumentam e, por isso, podem estar certos a priori de que estão presentes, implicitamente, em qualquer $\operatorname{argumentação~}{ }^{688}$. A argumentação constitui a metalinguagem última e intranscendível, a referência em relação à qual é necessário recorrer inclusive para refletir sobre a própria argumentação. Na pragmática transcendental, a qualificação de transcendental conota a busca de uma evidência infalível, por isso autodenominada por Apel como "fundamentação última", que determine o sentido e a validade dos argumentos. Nela, o transcendentalismo concerne à reflexão transcendental entendida como reconstrução das regras (pressuposições) universais dos atos de fala, em princípio, já reconhecidas implícita e necessariamente pelos interlocutores, cuja eliminação implicaria em converter a tais atos em ações desprovidas de sentido ${ }^{689}$.

Nisso, a contribuição específica da filosofia no sentido de uma interseção com o campo da educação é precisamente fornecer as condições de possibilidade transcendentais da constituição objetual da ciência da educação. Em sua dimensão antecipativa, a semiótica transcendental parece se limitar a fornecer os pressupostos filosóficos últimos dos pressupostos de qualquer filosofia da educação. Vendo por esse prisma, a meu ver, parece se confirmar a hipótese pontuada na primeira parte deste trabalho. A filosofia de Apel representa uma contribuição relevante para a reflexão de natureza filosófica em meio às abordagens das ciências da educação ${ }^{690}$, contanto que se considere que a semiótica transcendental é capaz de fornecer a pressuposição última racional de qualquer outra pressuposição especulativa que

\footnotetext{
${ }^{688}$ CORTINA, Razón comunicativa y responsabilidad solidaria: ética y política em K.-O. Apel, p. 135. ${ }^{689}$ CORTINA, Razón comunicativa y responsabilidad solidaria: ética y política em K.-O. Apel, pp. 132-133. ${ }^{690}$ GILES, Filosofia da educação, pp. 29-31.
} 
funda o campo da educação. A filosofia de Apel não enfoca a discussão concernente ao conteúdo fundamental, às práticas de transmissão e às instituições que a educação representa, e não sistematiza o conceito filosófico da educação à luz da semiótica transcendental. A Apel interessa marcar o que é, no plano filosófico, efetivamente intranscendível para qualquer campo do saber e do agir humano e, em tal medida, para a fundamentação e orientação da educação, em sua dinâmica na sociedade de comunicação real. A estrutura do a priori da comunidade de comunicação fornece os elementos normativos intranscendíveis de todo argumentar para a fundamentação do sentido da educação na direção de uma teoria crítica da "ciência como emancipação" 691 . Ainda a meu ver, os pressupostos filosóficos não tomam o lugar de uma reflexão radical sobre os pressupostos da educação, no sentido de uma filosofia da educação. Mas, antes e implicitamente, os pressupostos filosóficos compõem a base de pressuposição de qualquer filosofia da educação, caso ela se pretenda válida e com possibilidade de promover a emancipação. À medida que fornece a pré-estrutura filosófica (fundamento último) da qual não se pode mais retroceder, em tese, a semiótica transcendental é uma filosofia "interna" da racionalidade do discurso argumentativo que embasa, criteriologicamente, a validade dos pressupostos de qualquer filosofia da educação. É bem mais uma espécie de antecâmara daquilo que é próprio de uma filosofia da educação, se se considera que a semiótica transcendental desnuda o marco normativo a priori da comunidade de comunicação para a construção dos discursos fáticos em relação ao sentido da educação. Nisso, parece residir a contribuição possivelmente mais geral (procedimental) e, ao mesmo tempo, mais profunda da filosofia em vista de ajudar a fundamentar uma perspectiva de educação intencionada na razoabilidade, emancipação e responsabilidade solidária.

\subsection{A questão da emancipação como distintivo da Escola de Frankfurt}

Tendo definido a tarefa da filosofia em meio à controvérsia atual sobre a dupla função da ciência, em um passo seguinte de sua argumentação em "Ciência como emancipação?", Apel trata da questão relativa ao interesse cognitivo emancipador da ciência a partir da concepção da teoria crítica propugnada pela Escola de Frankfurt. O intento preliminar de Apel nesse sentido é mostrar, em uma apreciação histórica, o vínculo genealógico desse interesse com a teoria crítica. Ao caracterizar a teoria crítica em "Ciência como emancipação?", Apel pontua dois aspectos fundamentais que caracterizam a

${ }^{691}$ APEL, Transformação da filosofia, v. II, p. 166; Transformation der philosophie, Band II, p. 145. 
contribuição teórica da Escola de Frankfurt. O primeiro aspecto diz respeito à contribuição da teoria crítica com a reflexão sobre a função emancipadora da ciência. Para Apel, a discussão a respeito do interesse cognitivo emancipador da ciência constitui o transfundo da proposta teórica da Escola de Frankfurt. Apel entende que na defesa da função emancipadora da ciência reside o legado dos teóricos da teoria crítica. Nessa breve caracterização, Apel procura mostrar o vínculo genealógico desse interesse com a teoria crítica. Nesse sentido, ele pontua que a exigência de uma função emancipadora da ciência não resulta do trabalho intelectual dos representantes da teoria da ciência "estabelecida" em nossa epocalidade, mas da atividade de um grupo de "outsiders", um grupo de "sociólogos-filósofos" posteriormente agregados sob a designação de Escola de Frankfurt, cuja concepção de ciência, na ótica dos demais grupos acadêmicos, figura como um meio termo entre filosofia e sociologia. Conforme a ótica desse grupo de "outsiders", essa exigência constitui o viés fundamental do programa de uma teoria crítica enquanto "programa da sociedade a ser modificada" 692 . O segundo aspecto concerne à identificação do programa teórico dos frankfurtianos com a "nova esquerda". A seguir, este tópico procura aclarar esses dois aspectos, mencionados por Apel de forma geral, realçando a compreensão do vínculo genealógico do interesse emancipatório com a teoria crítica da Escola de Frankfurt.

Para Apel, a orientação basilar do programa teórico da teoria crítica é explicitada por Horkheimer, em seu ensaio Teoria tradicional e teoria crítica, publicado em 1937 e reeditado em 1968. A estratégia utilizada para tornar patente tal orientação é a de apresentar a teoria crítica por contraposição à teoria tradicional, mas tendo como pano de fundo que ambas as teorias se entrelaçam em uma perspectiva teórica mais abrangente, a teoria crítica. Para ele, o conceito tradicional de teoria segue a tendência, seja na grande parte da ciência natural, seja nas ciências do homem e da sociedade, que visa a um sistema de sinais puramente matemáticos, cuja possibilidade de aplicação está fora de dúvidas. No quadro atual da ciência, a teoria equivale a uma sinopse de proposições de um campo especializado do saber acumulado que permite caracterizar os fatos tão minuciosamente quanto possível. Desse modo, a essência da teoria reside no manejo da natureza física e dos mecanismos econômicos e sociais determinados ${ }^{693}$.

Para Horkheimer, a teoria tradicional diz respeito à atividade da razão presente na filosofia e nas ciências modernas que segue os moldes do pensamento de Descartes

\footnotetext{
${ }^{692}$ APEL, Transformação da filosofia, v. II, p. 149; Transformation der philosophie, Band II, p. 130. ${ }^{693}$ HORKHEIMER, Max. Teoria tradicional e teoria crítica. In: BENJAMIN, Walter et al. Textos escolhidos. Trad. José Lino Grünnewald et al.. São Paulo: Abril Cultural, 1980, pp. 117-121.
} 
(matemático). Como tal, ela corresponde ao trabalho teórico relativo a um campo delimitado de conhecimento que, pautado pela neutralidade em relação a juízos de valor, pelo respeito às regras gerais da lógica formal e ao princípio de não-contradição e pelo procedimento da dedução ou indução, visa formar sentenças que expressam conceitos universais. No tocante ao método desse trabalho teórico, as manifestações empíricas da natureza e da sociedade são subsumidas nas sentenças, seja por meio da dedução, encaixando-se no sistema teórico montado a priori, seja por meio da indução, de forma a posteriori. Em sua análise, Horkheimer assinala que a teoria, na sua figura tradicional, desempenha uma função social fundamental e positiva, haja vista que as necessidades e fins, as experiências e habilidades, os costumes e tendências do modo de ser humano fazem parte dessa atividade intelectual ${ }^{694}$.

Por contraste à teoria tradicional, segundo Horkheimer, a estrutura lógica da teoria crítica se caracteriza pela pretensão de captar a dimensão histórica dos fenômenos, dos indivíduos e das sociedades. O enfoque analítico-crítico do momento histórico da sociedade burguesa contemporânea representa o núcleo do trabalho intelectual da teoria crítica. No referido ensaio, Horkheimer advoga que o referencial teórico que faculta esse enfoque é o marco conceitual de Marx (conceitos de mercadoria, valor, acumulação, entre outros) ${ }^{695}$. Para Horkheimer, o embasamento da teoria crítica em Marx se justifica pelo fato de que a análise empreendida por ele a respeito do efeito regulador dos processos de troca sobre a organização da economia burguesa se orienta pela dimensão do futuro, pela esperança na emancipação da sociedade. Diferentemente da teoria tradicional apoiada na filosofia de Descartes, a análise de Marx não se prende à discussão entre juízos de fatos e juízos de valor e, além disso, nela, a relação entre realidade e conceitos não é pensada unicamente por meio de dedução ou indução. Então, supondo esses elementos peculiares à análise de Marx, a teoria crítica se projeta como a atividade da razão cuja necessidade se prende a um juízo existencial ${ }^{696}$, a saber, a necessidade de libertar o homem da opressão subjacente ao sistema social vigente.

\footnotetext{
${ }^{694}$ HORKHEIMER, Teoria tradicional e teoria crítica. In: Textos escolhidos, pp. 128-129.

${ }^{695}$ A mudança de posição de Horkheimer em relação a Marx é expressa no ensaio "A teoria Crítica, Ontem e Hoje" (1970). Aí aparece o ceticismo de Horkheimer em relação à validade das teses centrais de Marx, posto que: a) em vez da proletarização progressiva da classe operária e a degradação das condições de vida resultarem na revolução proletária, vê-se que o capitalismo tem utilizado o excedente de riquezas para cooptar as consciências e desativar o conflito de classes; b) não se confirmou a tese das crises cíclicas do capitalismo, decorrentes das alternâncias no processo de produção e consumo (produção excessiva e falta de consumo; falta de produção ou consumo excessivo); c) revelou-se ilusória a expectativa de que justiça poderia se realizar simultaneamente com a liberdade. O capitalismo pode produzir a riquezas que até podem reduzir as desigualdades materiais entre os homens, contudo ao preço da redução sistemática da liberdade, da homogeneização generalizada das consciências, da atrofia da capacidade crítica (FREITAG, Bárbara. $\boldsymbol{A}$ teoria crítica: ontem e hoje. 2. ed., São Paulo: Brasiliense, 1988, pp. 40-41).

${ }^{696}$ FREITAG, A teoria crítica: ontem e hoje, pp. 37-42.
} 
Para Horkheimer, em sua essência, esse juízo existencial preserva o ideal iluminista, qual seja a ideia de usar a razão como instrumento em prol da autodeterminação do homem. Esse ideal, enquanto interesse orientado para a emancipação tendo por meta a transformação radical da sociedade, ainda não "passou" pela prova de sua possibilidade real $^{697}$, porém, assim mesmo, constitui o foco principal do pensamento dialético e da teoria crítica. Trata-se de considerar que esse foco, partindo da visão de Marx, espelha uma preocupação teórica e prática que não é meramente formal, no sentido da atenção dada pela teoria tradicional direcionada às regras metodológicas de acesso à verdade e à objetividade, mas também material (existencial).

Para Horkheimer, a tarefa da teoria crítica é procurar eliminar a oposição entre a atividade intelectual, inerente ao indivíduo, e a realidade social. Isso significa superar a oposição típica do especialista "enquanto" cientista, que tende a ver a realidade social e seus produtos (teorias nos moldes de formulações matemáticas destinadas à aplicação) como algo exterior. É preciso superá-la porque é ela que leva o teórico tradicional a ter uma percepção distorcida de sua atividade científica e função, assim como colaborar na cimentação das relações sociais e de dominação existentes. Isso não implica no rechaço da teoria tradicional; ao contrário, o pensamento crítico pode servir-se sem dúvida do trabalho teórico da ciência ordenadora. A oposição da teoria crítica ao conceito tradicional de teoria não decorre da diversidade dos objetos e dos sujeitos, mas se liga ao esforço que os teóricos críticos empreendem por uma nova organização do trabalho teórico, na qual os fatos percebidos são despojados da condição de mera faticidade ao passo que são compreendidos como produtos controlados pelo interesse humano ${ }^{698}$.

A teoria crítica preconiza uma relação orgânica entre sujeito e objeto (a sociedade e as teorias desenvolvidas para representá-la), em que o sujeito do conhecimento é um sujeito histórico inserido em um processo igualmente histórico que o condiciona e molda ${ }^{699}$. Distintamente do teórico tradicional, presume-se que o teórico crítico sabe de sua condição histórica e social e é ciente da necessidade de investigar "criticamente", sob a base da teoria tradicional $^{700}$, formada pelas ciências especializadas, a sociedade atual com vista a uma sociedade futura organizada racionalmente e orientada para a emancipação. Servindo-se do

\footnotetext{
${ }^{697}$ HORKHEIMER, Teoria tradicional e teoria crítica. In: Textos escolhidos, p. 153.

${ }^{698}$ HORKHEIMER, Teoria tradicional e teoria crítica. In: Textos escolhidos, pp. 131-132.

${ }^{699}$ FREITAG, A teoria crítica: ontem e hoje, p. 42.

${ }^{700}$ Cogita-se aqui, hipoteticamente, que este posicionamento prenuncia a tese defendida por Apel no sentido de uma complementaridade entre as ciências da natureza e as ciências humanas (cf. HORKHEIMER, Teoria tradicional e teoria crítica. In: Textos escolhidos, pp. 131 e 148).
} 
legado da teoria tradicional, mas sem se delimitar metodologicamente à investigação setorial e especializada, a teoria crítica emerge com a pretensão de ser uma investigação dos fatos sociais à luz da totalidade em que cada fenômeno está inserido, tendo em vista a "transformação do todo" (da sociedade) pela efetivação da emancipação. Com essa preconização, Horkheimer delineia o diferencial fundamental do trabalho intelectual a ser desenvolvido pela Escola de Frankfurt ${ }^{701}$.

Pelo expresso anteriormente, por Horkheimer e assinalado por Apel, depreende-se o interesse cognitivo emancipador da ciência caracteriza a especificidade do programa teórico da Escola de Frankfurt. Faz-se necessário explicitar aqui, até para realçar a complexidade que envolve tal compreensão e contextualizar a matriz teórica da qual Apel toma parte, o que vem a ser a Escola de Frankfurt. De forma genérica, tende-se a identificar contemporaneamente o programa da teoria crítica com o termo Escola de Frankfurt. Na interpretação de Bárbara Freitag $^{702}$, esse termo refere-se simultaneamente a um grupo de intelectuais - Horkheimer, Adorno, Marcuse, Benjamin, Habermas, entre outros - e a uma teoria social, cuja institucionalização tem início com a criação do Institut für Sozialforschung (Instituto para a Pesquisa Social), na Alemanha. Segundo essa interpretação, a compreensão da natureza da Escola de Frankfurt exige considerar a peculiaridade das fases que marcam o caminho da teoria crítica, bem como a diversidade de ideias e temas que contornam o conteúdo programático que marca o debate entre teóricos de Frankfurt e seus críticos.

O roteiro de análise das fases e do conteúdo programático da Escola de Frankfurt elaborado por Bárbara Freitag (1986) ilustra a complexidade que envolve o termo Escola de Frankfurt. É interessante assinalar que não consta nesse roteiro nenhuma referência à filosofia de Apel. Para ela, esse termo sugere a ideia de unidade tanto geográfica quanto temática entre os representantes dessa Escola que, na verdade, nem sempre foi efetiva. Com efeito, apesar das variações em relação ao caminho tomado pelos frankfurtianos e aos focos de abordagem teórica, há que se ressaltar que, embrionariamente, subsiste o consenso epistemológico e político entre eles em torno da ideia de que o conhecimento da sociedade, longe de ser um exercício acadêmico asséptico e neutro, deve ser movido pelo interesse que objetiva uma

701 A respeito compreensão da categoria de totalidade para os frankfurtianos, ver: ROVIGHI, Sofia Vanni. História da filosofia contemporânea: do século XIX à neoescolástica. Trad. Ana Pareschi Capovilla. São Paulo: Loyola, 1999, pp. 587-590. HORKHEIMER, Max; ADORNO, Theodor W.. Conceito de Iluminismo. In: BENJAMIN, Walter et al. Textos escolhidos, p. 107. A totalidade, segundo a percepção da dialética adorniana, diz respeito à compreensão "objetiva" de cada fenômeno social singular, reconhecendo os conceitos estruturais como condições dos fatos a eles subsumidos; e, segundo as teorias sistêmicas positivistas, diz respeito à síntese não-contraditória das afirmações sobre o real (cf. FREITAG, A teoria crítica: ontem e hoje, p. 51).

${ }^{702}$ FREITAG, A teoria crítica: ontem e hoje, pp. 09-10. 
sociedade futura como comunidade de homens livres ${ }^{703}$. Isso parece indicar que a defesa da função emancipadora da ciência, no marco de uma teoria social crítica, constitui o ponto em torno do qual se dá a nucleação da "nova esquerda" representada pela Escola de Frankfurt.

O caminho da Escola de Frankfurt segue uma trajetória que abrange três fases e fraturas teóricas. A primeira fase abrange dois momentos: o período da criação e consolidação do Instituto (1922-1932) como centro de pesquisa, caracteristicamente, voltado à análise dos problemas do capitalismo moderno e marcado pelo interesse teórico de integrar a teoria marxista com o freudismo (para investigar o porquê da classe operária não revolucionar a ordem estabelecida); o período de emigração do Instituto, após seu fechamento pelo governo nazista, para os Estados Unidos (1933-1950). Nessa fase, sob a influência decisiva de Horkheimer, a teoria crítica emerge como um novo paradigma (afastado do positivismo e neopositivismo que dominam as ciências naturais e humanas de sua época) para a pesquisa e teorização sociológicas. A segunda fase concerne ao período reconstrução do Instituto em Frankfurt (1950-1970). Nesse momento, sob a direção intelectual de Adorno, a Escola passa a refletir sobre o tema da cultura e desenvolve uma teoria estética (como versão especial da teoria crítica). Habermas é o mais notório representante da terceira fase da Escola, que se estende de 1970 aos dias atuais. Essa fase é marcada pelo propósito de reformular a teoria crítica. A elaboração de uma teoria da ação comunicativa, bem como as reflexões em torno dos problemas da legitimação do Estado moderno, exemplifica os esforços de Habermas para propor uma "nova versão" da teoria crítica, em que postula a substituição da filosofia da consciência por uma teoria da intersubjetividade comunicativa ${ }^{704}$.

No tocante ao conteúdo programático, é preciso considerar que o termo Escola de Frankfurt se liga uma construção teórica não-homogênea e não-uniforme que abrange um feixe eixos temáticos. De fato, a diversificação dentro Escola já aparece em relação ao referencial teórico utilizado pelos autores frankfurtianos para a construção de suas teorias, uma vez que esses autores procuram respaldar suas reflexões pelo diálogo com o pensamento de Marx, Kant, Hegel, Weber, Nietzsche, Freud e outros. Quanto ao conteúdo programático, a Escola aborda assuntos filosóficos (crítica à razão iluminista, dialética, teoria da verdade, ética do discurso), socioculturais (indústria cultural, semiformação, sociedade unidimensional), estéticos (ensaio como forma, racionalidade na obra-de-arte) e psicológicos (anti-semitismo, personalidade autoritária, relação autoridade e família, preconceito).

\footnotetext{
${ }^{703}$ HORKHEIMER, Filosofia e teoria crítica. In: Textos escolhidos, p. 156.

${ }^{704}$ FREITAG, A teoria crítica: ontem e hoje, pp. 9-30.
} 
Segundo o esquema de Bárbara Freitag, tendo presente os teóricos em torno da Escola de Frankfurt até os anos 80 , a teoria crítica tem desenvolvido três eixos temáticos: a dialética da razão e a crítica à ciência (positivista), a dupla face da cultura e a discussão da indústria cultural e a questão do Estado e a dominação tecnocrática ${ }^{705}$. A fim de realçar a apresentação de Apel relativa ao interesse emancipador da teoria crítica, e com isso também situar a inserção da filosofia de Apel no circuito de discussão sobre a concepção de razão subjacente à ciência e sociedade atual, de modo sintético, assinalar-se-á aqui apenas o teor geral do primeiro eixo temático, que trata da interpretação sobre a crise atual da razão segundo os frankfurtianos. No geral, a abordagem do tema da razão esclarecida transpassa a obra de todos os autores da teoria crítica. Contudo, a análise do conteúdo desse eixo faz ver que essa abordagem se eleva, com roupagens variadas, em três momentos nos diferentes trabalhos das gerações dos frankfurtianos.

O primeiro momento do eixo temático sobre a dialética da razão e a crítica à ciência tem seu ponto de partida na confrontação que Horkheimer estabelece entre teoria tradicional, enquanto o pensar de estilo cartesiano, e a teoria crítica, a partir do já mencionado artigo intitulado Teoria tradicional e teoria crítica. Aqui, é interessante assinalar o ensaio que Horkheimer publica também em 1937, intitulado "Filosofia e teoria crítica", no qual ele reforça a distinção entre as teorias tradicional e crítica, enquanto delineia o significado da filosofia no marco da teoria crítica, no sentido de um instrumento de reflexão teórica que mediatiza a prática. Nesse ensaio, ele explicita que a teoria crítica se caracteriza por preservar a herança do idealismo alemão e da própria filosofia. Por isso, o objeto da teoria crítica social não se restringe à constatação e previsão segundo as leis das probabilidades afetas à natureza, tal como ocorre nas ciências especializadas, tampouco intenciona uma mera ampliação do saber que é útil para o funcionamento do sistema dominante. Todavia, supondo o ganho teórico das ciências especializadas, a teoria crítica, na linha de uma filosofia dialética, que parte do princípio de que o desenvolvimento de homens livres depende da

${ }^{705}$ FREITAG, A teoria crítica: ontem e hoje, pp. 31-104.

A título de esclarecimento, o termo "indústria cultural" designa a aparente (falsa) reconciliação, em que a cultura, transformada em mercadoria (e entretenimento), deixa de ter o caráter singular (único) e perde seu ideal de felicidade, de humanidade e de justiça, para ser um valor de troca, um bem de consumo coletivo compatível com as necessidades de acumulação do sistema capitalista, ou seja, um bem avaliado segundo sua lucratividade ou aceitação no mercado e não pelo seu valor estético, literário e filosófico. Segundo Adorno e Horkheimer (no capítulo A indústria cultural: o esclarecimento como mistificação das massas), bem mais que um ramo da produção na diversificada produção capitalista, a indústria cultural é concebida, por sua dimensão anti ou acultural e seu caráter de consumo das massas, para preencher funções sociais específicas: eliminar a dimensão crítica ainda presente na cultura burguesa, perpetuar a produção capitalista e incutir o consumo como caminho da realização pessoal (ADORNO, Theodor W.; HORKHEIMER, Max. Dialética do esclarecimento: fragmentos filosóficos. Trad. Guido Antonio de Almeida. Rio de Janeiro: Zahar, 1985, pp. 99-138). 
constituição racional da sociedade, reflete sobre a atividade humana e o grau de seu poder sobre a natureza. Fundamentalmente, assim afirma Horkheimer, essa reflexão visa "clarificar" e "legitimar" o interesse por uma organização racional da vida humana. Precisamente esse interesse por emancipação, em relação ao qual se espera que "todos" os homens venham a ser reconhecidos como "produtores de todas as suas formas históricas de vida", constitui a tarefa que a teoria crítica confere a si mesma ${ }^{706}$.

Desse primeiro momento, o ponto mais emblemático concerne às reflexões feitas por Horkheimer e Adorno nas obras Dialética do Esclarecimento e Eclipse da razão, ambas lançadas em 1947. Em seu teor geral, Dialética do Esclarecimento descreve a dialética da razão na modernidade, ao delinear o desvio da dimensão crítica e emancipatória da razão em favor de uma razão instrumental que assume o controle técnico da natureza e dos homens. Essa obra reflete a desilusão e o pessimismo de Horkheimer e Adorno perante o atrofiamento da razão iluminista, em virtude de ela ter sido restringida a sua dimensão de funcionalidade no mundo $^{707}$. Na obra Eclipse da razão, uma coletânea de conferências proferidas por Horkheimer em 1944 na Universidade de Columbia, Horkheimer investiga o conceito de racionalidade subjacente à sociedade industrial contemporânea. Em torno desse propósito, ele apresenta sua interpretação acerca da crise atual da razão e do impacto avassalador que essa crise ocasiona nos campos da cultura, da ação ética e política e inclusive da religião, bem como sua visão sobre o papel da filosofia em face do de "eclipse da razão".

Horkheimer e Adorno, em Dialética do Esclarecimento, particularmente, no ensaio intitulado Conceito de Iluminismo, tematizam o caráter paradoxal do programa do Iluminismo $^{708}$. Em uma visão mais ampla, eles entendem que a senha que define o Iluminismo é a "unidade"; na verdade, uma senha que "de Parmênides a Russell" insiste na "destruição dos deuses e das qualidades" "709. Conceitualmente, o Iluminismo enquanto "esclarecimento" designa o processo de racionalização que prossegue na filosofia e na ciência para promover o desenfeitiçamento do mundo - a libertação do medo de uma natureza desconhecida - e fazer dos homens "senhores de si mesmos". Todavia, essa dimensão emancipatória do Iluminismo é atrofiada pela sociedade burguesa, herdeira do Iluminismo, em favor de sua dimensão instrumental, direcionada à subjugação da natureza. Ao assumir a

\footnotetext{
${ }^{706}$ HORKHEIMER, Filosofia e teoria crítica. In: Textos escolhidos, pp. 156-161.

${ }^{707}$ ADORNO; HORKHEIMER, Dialética do esclarecimento, pp. 17-46.

${ }^{708}$ HORKHEIMER; ADORNO, Conceito de Iluminismo. In: Textos escolhidos, pp. 92-105.

${ }^{709}$ HORKHEIMER e ADORNO, Conceito de Iluminismo. In: Textos escolhidos, p. 92.
} 
estrutura da ciência moderna unitária, da qual o positivismo ${ }^{710}$ ocupa o posto de juiz da razão esclarecida, o Iluminismo identifica pensamento e matemática em vista do proceder eficaz, do desempenho ajustado às medidas de calculabilidade e utilidade. Sendo o número o "cânon" do Iluminismo, e a abstração, sua ferramenta, a condição para que possa entender algo como racional é a sua sujeição ao formalismo lógico, isto é, ao esquema de uniformização do mundo ditado pela ciência, caracteristicamente, hostil ao desconexo e ao incomensurável. Para Horkheimer e Adorno, o atrofiamento da razão a esse esquema de uniformização da razão instrumental, peculiar à "teoria tradicional", resulta em uma restrição à pretensão de conhecimento. Nesse esquema, os dados são pensados em suas relações espaço-temporais abstratas e não, como postulam Horkheimer e Adorno de um ponto de vista da teoria crítica, como momentos mediatizados do conceito que só se preenchem no desdobramento de seu sentido social, histórico e humano. E, dramaticamente, à medida que os homens substituem "o conceito pela fórmula, a causa pela regra e pela probabilidade" ${ }^{911}$, eles se despojam da busca pelo sentido da própria existência.

Apontar criticamente a "inverdade" do Iluminismo da razão instrumental é denunciar, segundo Horkheimer e Adorno, a negação da função emancipadora que procede do saber racional. Tal inverdade não diz respeito ao método analítico, mas ao fato de que o Iluminismo, enquanto referência do mundo analítico que espelha como verdade a "eternidade do factual", retrocede à mitologia que pretende superar, isto é, ao problema do saber que está "decidido de antemão". No Iluminismo, o saber se apropria da existência e "a perpetua" como um "esquema" que renuncia à esperança, pois o novo aparece como predeterminado, "que assim é, na verdade, o antigo" ${ }^{, 712}$. O Iluminismo deixa de lado a exigência clássica de pensar o pensamento, perde o elemento de reflexão sobre si, da qual a filosofia de Fichte é a expressão mais radical, precisamente porque ela o desviava do imperativo de comandar a práxis ${ }^{713}$. O Iluminismo restringe a razão a um mero "órgão" voltado à organização e administração do mundo, quer dizer, converte a razão em mero instrumento auxiliar do aparato econômico que tudo abrange, empobrecendo assim tanto a compreensão do pensar quanto da experiência

\footnotetext{
${ }^{710}$ Para Horkheimer, o que torna o positivismo uma filosofia pobre é a sua ausência de autorreflexão, sua incapacidade de compreender suas próprias implicações filosóficas tanto na ética como na epistemologia. $\mathrm{O}$ positivismo tende a substituir a razão autônoma pelo automatismo da metodologia moderna (cf. HORKHEIMER, Max. Eclipse da razão. Trad. Sebastião Uchoa Leite. 7. ed., São Paulo: Centauro, 2010, pp. 89-95.

${ }^{711}$ HORKHEIMER; ADORNO, Conceito de Iluminismo. In: Textos escolhidos, p. 90.

${ }^{712}$ HORKHEIMER; ADORNO, Conceito de Iluminismo. In: Textos escolhidos, p. 106.

${ }^{713}$ HORKHEIMER; ADORNO, Conceito de Iluminismo. In: Textos escolhidos, pp. 104 e 113.
} 
humana ${ }^{714}$. De tal modo, o Iluminismo se efetiva de modo "totalitário", no sentido de uma racionalidade demolidora de cada resistência espiritual, um mecanismo do pensar acorrentado, enfim, "uma nova forma de ofuscamento" que utiliza a "unidade nivelante do abstrato" para negar a possibilidade de "fazer do indivíduo um indivíduo" e favorecer a dominação tecnocrática na sociedade industrial ${ }^{715}$. Para esses pensadores, nesse ensaio, o desmascaramento da ilusão otimista da razão iluminista encontra seu lado mais dramático no fato de que, mesmo existindo a possibilidade do saber contribuir para a dissolução da dominação, efetivamente, "o Iluminismo a serviço do presente transforma-se no total engano das massas"716. Mesmo assim, resta à teoria crítica denunciar essa ilusão e, em uma perspectiva mais ampla, por em discussão o projeto iluminista da modernidade.

Horkheimer principia Eclipse da razão afirmando que, ante a atmosfera de temor e desilusão perante o avanço dos recursos técnicos de informação que se acompanha de um processo de desumanização e redução da autonomia do homem enquanto indivíduo, a investigação do conceito de razão constitui uma tarefa da qual a reflexão filosófica não pode se eximir. A meu ver, na obra, essa tarefa é mais vislumbrada genericamente como um "corretivo da história"717 que delineada sistematicamente. De qualquer modo, essa tarefa é indicativa da necessidade de um contraponto à formalização da razão operada na sociedade industrial, ao passo que essa matematização da razão conduz a própria razão a uma situação paradoxal. Esse paradoxo aparece como crise da própria razão em virtude de sua "dupla face": por um lado, a face instrumental da razão atua no sentido de um antagonismo destrutivo do ego e da natureza; por outro, a face reflexiva (emancipadora) da razão procura atuar no sentido da negação desse antagonismo. À filosofia, utilizando o método da negação, cabe denunciar o caráter destrutivo da razão instrumental, procedendo, seja pela negação das pretensões absolutas da ideologia dominante, seja pela negação das exigências impiedosas da realidade impostas pela formalização da razão. No último ensaio dessa obra (Sobre o conceito de filosofia), Horkheimer expressa o horizonte mais abrangente da tarefa da filosofia na linha de uma teoria crítica, qual seja o de promover a crítica recíproca dos conceitos de razão objetiva (substancial, especulativa) e razão subjetiva (formalizada, funcional) conflitantes na

\footnotetext{
${ }^{714}$ HORKHEIMER; ADORNO, Conceito de Iluminismo. In: Textos escolhidos, p. 108.

715 HORKHEIMER; ADORNO, Conceito de Iluminismo. In: Textos escolhidos, p. 96. HORKHEIMER, Eclipse da razão, pp. 7 e 61.

${ }^{716}$ HORKHEIMER; ADORNO, Conceito de Iluminismo. In: Textos escolhidos, p. 116.

${ }^{717}$ HORKHEIMER, Eclipse da razão, p. 191.
} 
contemporaneidade e, se possível, preparar na esfera intelectual a conciliação dos dois na realidade ${ }^{718}$.

No horizonte dessa crítica recíproca, Horkheimer reflete acerca da crise atual da razão e seu impacto na vida moderna. Para ele, a raiz da crise atual da razão se encontra na mudança do conceito de razão nos tempos modernos, isto é, no processo de substituição da teoria objetiva da razão por uma perspectiva conceitual da razão como faculdade subjetiva da mente, segundo a qual a razão equivale à capacidade de calcular probabilidades e coordenar os meios adequados com um fim determinado. Esse processo reflete a dissolução dos sistemas filosóficos de razão objetiva, em que a razão é concebida como uma faculdade do sujeito individual para perceber a natureza própria das coisas (objetividade em si) e estabelecer a linha de ação no campo ético-político a partir de tal compreensão, para dá lugar a uma epistemologia que reduz a base objetiva do entendimento a um caos de dados nãocoordenados que precisa ser computado e classificado pelo trabalho científico. Graças ao fato de a razão ter deixado de ser um instrumento para compreender e determinar os fins, à medida que liquida a si mesma como "agente de compreensão ética, moral e religiosa" e, em contrapartida, ser remetida à posição de instrumento de ajustamento à realidade e regulação da relação entre meios e fins, a crise atual da razão espelha a situação de "des-razão" da própria razão $^{719}$.

O problema relativo à expurgação da razão especulativa é que o esvaziamento do conteúdo objetivo de todo conceito racional em prol da formalização da razão subjetiva abre espaço para uma concepção de razão essencialmente relativista ${ }^{720}$. Enquanto mecanismo para classificar os fatos e calcular probabilidades, que não reconhece qualquer "sentido" (fundamento último) inerente à realidade, a razão subjetiva se conforma a "qualquer coisa". Para a razão formalizada (instrumental), o que torna uma atividade racional é sua capacidade de servir a outro propósito; a atividade do pensar retira seu significado através de sua ligação com outros fins. Ora, posto que nenhuma realidade particular é racional per se, os conceitos são apenas invólucros formais. A consequência disso é que os conceitos ${ }^{721}$, tais como, justiça, igualdade, felicidade, tolerância, em tempos passados sancionados pela razão e testemunhados pela tradição, perdem as suas raízes intelectuais e a crença numa verdade objetiva. Os conceitos até permanecem como objetivos e fins na sociedade, porém são desprovidos de uma

\footnotetext{
${ }^{718}$ HORKHEIMER, Eclipse da razão, pp. 7, 167, 179 e 191-192.

${ }^{719}$ HORKHEIMER, Eclipse da razão, pp. 16-17 e 23.

${ }^{720}$ HORKHEIMER, Eclipse da razão, pp. 24 e 30.

${ }^{721}$ HORKHEIMER, Eclipse da razão, p. 28.
} 
força racional autorizada para avaliá-los e ligá-los a uma realidade objetiva. Nessa mesma direção, por exemplo, desmorona-se também a fundamentação racional objetiva da democracia e dos direitos humanos, à medida que se dá na sociedade moderna a dissociação entre as aspirações humanas e as potencialidades da ideia de verdade objetiva. Essa dissociação se conecta ao conceito de razão formalizada na medida em que ela, ao postular a objetividade e verdade do conhecimento apenas em função do método, relega o campo da moral e da prática emancipatória a uma esfera de decisão supostamente subjetiva e irracional $^{722}$.

O paradoxo da dupla face da razão impõe uma situação de ambiguidade e crise de sentido à sociedade. A meu ver, essa é uma conclusão mais abrangente que pode ser depreendida da crítica de Horkheimer. Por um lado, o avanço da razão subjetiva tem destruído as bases teóricas das ideias mitológicas, religiosas e racionalistas, ao mesmo tempo em que transforma a razão formalizada em mito. Por outro lado, a sociedade civilizada "até agora" tem sustentado seu poder de convicção nos resíduos dessas ideias, supondo que nelas transparecem elementos de verdade, porque relacionadas com a ideia de logos, quer na forma de Deus ou de um intelecto transcendental, quer na forma da natureza como um princípio eterno. O fato é que a alusão aos princípios - ideias que embasam o sentido pessoal e político da existência - apenas em alguns momentos, assim assinala Horkheimer, acaba sendo um traço esquizofrênico da vida moderna ${ }^{723}$. Problematicamente, o despojamento de qualquer sentido inerente à realidade, decorrente da postura antifilosófica do conceito de razão subjetiva, conduz à reificação da arte, da política e da religião, à transformação de todos os produtos da atividade humana em mercadoria, enfim, a um sistema formalizado de saber e produção de bens que implica na perda da subjetividade e na proibição do pensar que resulta na estupidez subjetiva ${ }^{724}$.

O segundo momento concernente ao eixo temático, que trata da dialética da razão e a crítica à ciência, gravita em torno do debate acerca dos fundamentos epistemológicos do positivismo e da dialética. Esse debate é iniciado em um seminário organizado pela Sociedade de Sociologia alemã (1961) por Popper, apresentando as 27 teses do seu texto-base Sobre a

\footnotetext{
722“'Segundo a razão formalizada, o despotismo, a crueldade e a opressão não são maus em si mesmo; nenhuma operação racional endossaria um veredicto contra a ditadura se os responsáveis por tal operação pudessem dela tirar algum proveito. Frases como 'a dignidade do homem' ou implicam um avanço dialético no qual a ideia do direito divino é preservada e transcendida, ou se transformam em slogans triviais cuja vacuidade se revela assim que busca indagar sobre o seu significado específico" (cf. HORKHEIMER, Eclipse da razão, p. 36).

${ }^{723}$ HORKHEIMER, Eclipse da razão, pp. 38-39 e 44.

${ }^{724}$ HORKHEIMER, Eclipse da razão, pp. 45, 60 e 61.
} 
lógica das ciências sociais, e Adorno, fazendo a contestação dessas teses, e posteriormente ampliado por positivistas (René Koenig, Hans Albert, Ernst Topitsch e outros) e teóricos críticos (Marcuse, Habermas, Albrecht Wellmer). É interessante destacar que Apel amplia esse debate com Popper e, posteriormente, com seu discípulo, Hans Albert. Nesse tópico, sucintamente, importa pontuar os dois aspectos fundamentais que caracterizam o modelo de positivismo proposto por Popper, em relação ao qual Adorno estabelece sua contraposição.

O primeiro aspecto diz respeito ao tipo de método científico preconizado pelo positivismo de Popper, o método científico hipotético-dedutivo. Esse método tem como pano de fundo a concepção de que a ciência progride por tentativa e erro, por conjecturas e refutações, e que as teorias são conjecturas especulativas para superar problemas encontrados por teorias anteriores. Esquematicamente, esse método abrange duas etapas: a) a do contexto de descoberta, a qual compreende o processo pelo qual a ciência começa com o levantamento da dúvida (lacuna, contradição), partindo de um conhecimento prévio (teorias existentes), e estabelece conjecturas (hipóteses falsificáveis; enunciados dedutivos) para solucionar o problema; b) a do contexto da justificação: a qual compreende o processo pelo qual a ciência investiga os possíveis contraexemplos, mediante técnicas de falseabilidade (testagem) e análise dos resultados, para refutar ou corroborar as hipóteses levantadas em relação à teoria. Ao cabo dessas etapas, surge uma "nova" teoria, no sentido do melhor disponível no momento em termos de conhecimento ao passo que mostra uma verdade que elimina tudo que é falso, que conserva, porém, o caráter de conhecimento hipotético (solução provisória), uma que ela constitui, no processo de construção do conhecimento que segue indefinidamente, o ponto de partida de outras possíveis descobertas e tentativas de solucionar problemas. A falsificabilidade serve como critério de clareza e precisão para o progresso da ciência: quanto mais resistente é uma teoria à falsificação, melhor é a teoria. É relevante notar que, o método de Popper privilegia o procedimento dedutivo para a construção de hipóteses explicativas a partir de um problema e não atribui valor especial ao dado empírico; nele, o dado empírico serve ao cientista como possível critério de falsificabilidade de uma "teoria" ou hipótese. Popper se distancia assim dos empiristas clássicos e modernos, precisamente por ter em conta que toda observação é ativa e seletiva, tendo como critério de seleção um conhecimento prévio, as expectativas próprias do contexto de descoberta do conhecimento. Apel entende que o núcleo do falsificacionismo metodológico de Popper, expresso pela máxima: “deixe 
morrer teorias ou hipóteses em lugar de nós mesmos", representa a perspectiva teórica de um prosseguimento (Fortsetsung) da seleção natural no plano da evolução do saber ${ }^{725}$.

Continuando, o segundo aspecto característico do positivismo de Popper se liga à proposta de um método adicional ao da lógica formal para a compreensão objetiva dos fatos relativos às ciências sociais. Divergindo dos positivistas americanos (Nagel, Hempel e outros), Popper defende a diferenciação entre o objeto das ciências naturais, a natureza, e o das ciências sociais, a sociedade e relações humanas. Junto a isso, ele incorpora em sua concepção de positivismo a categoria weberiana da "compreensão". O resultado disso é a idealização de um método científico para as ciências sociais, que ele chama de "lógica situacional". A função da lógica situacional é reconstruir racionalmente os elementos que parecem ser racionalmente psicológicos (tais como desejos, motivos, lembranças, associações) em elementos da situação, que pode ser objeto de reconstruções racionais e teóricas (contanto que a ação seja objetivamente apropriada à situação). A lógica situacional permite "compreender", supondo os homens orientam suas ações de acordo com certos valores e desejos, o comportamento de indivíduos uns em relação aos outros, o mundo físico e o mundo social (instituições). Para além da lógica formal, pela lógica situacional, tudo isso se transforma em objeto das ciências sociais ${ }^{726}$.

Por sua vez, em sua contraposição ao positivismo de Popper, Adorno procura mostrar que a compreensão das ciências formulada por Popper se limita à tematização da "estrutura lógica" da teoria tradicional. No ensaio intitulado Sobre a lógica das ciências

${ }^{725}$ APEL, Fallibilismus, Konsenstheorie der Wahrheit und Letztbegründung. In: Philosophie und Begrïndung. Org. Forum Philosophie Bad Homburg. Frankfurt am Main: Suhrkamp, 1987, p. 120. Em sua crítica a Popper, Apel afirma que a insistência de Popper na tese de que as proposições podem ser fundamentadas apenas mediante proposições (dedutivamente), o que implica em considerar a evidência fenomênica somente como causa psicologicamente relevante para as conclusões de base, constitui uma "falácia abstrativa" em relação à situação do sujeito da fase semanticista da lógica analítica da ciência, a qual configura uma redução lógicosemântica do problema do conhecimento. Na base da argumentação de Popper se encontra, segundo Apel, a diferenciação de Carnap entre a "semântica lógica", pertinente ao problema da verdade, e a problemática do sujeito do conhecimento, cujo caráter é pragmático e tematizável de maneira meramente empírica. Em contrapartida a Popper, seguindo a Peirce, Apel afirma que é insustentável a versão platonizante de Popper acerca de um conhecimento objetivamente válido "without a knowing subject", segundo o qual a problemática do sujeito do conhecimento representa uma problemática relevante só empírico-psicologicamente no sentido do "segundo mundo" (cf. APEL, Fallibilismus, Konsenstheorie der Wahrheit und Letztbegründung. In: Philosophie und Begründung, pp. 132-133). Ver: cap. "Sobre a teoria da mente objetiva": POPPER, Karl. Conocimiento objetivo. Trad. Carlos Solis Santos. Madrid: Tecnos, 1974, pp. 147-179. Sobre o falsificasionismo, cf. os capítulos IV, V e VI in: CHALMERS, A. R. O que é ciência afinal? São Paulo: Brasiliense, 1993, pp. 64-108. A respeito do método das ciências sociais (a sexta tese, considerada como tese principal) e lógica dedutiva do conhecimento (as teses décima quinta a vigésima), ver: POPPER, Karl R. La lógica de las ciencias sociais. In: ADORNO, W. T.; POPPER, K.R., DAHRENDORF, R.; HABERMAS, J.; ALBERT, H.; PILOT, Harald. Karl. La disputa del positivismo en la sociologia alemana. Trad. Jacobo Muñoz. Barcelona-México: Grijalbo, 1973, pp. 103 e 112-116.

${ }_{726}$ Ver as teses vigésima primeira a vigésima sétima, in: POPPER, La disputa del positivismo en la sociologia alemana, pp. 116-119. Ver: FREITAG, A teoria crítica: ontem e hoje, pp. 43-46. 
sociais (1961), Adorno procura mostrar que Popper trata o problema do caráter contraditório (antagonístico) da realidade social ${ }^{727}$ de forma equivocada, precisamente porque vê esse problema apenas em função das regras metodológicas da lógica formal e situacional. O erro de Popper é abordar esse problema como algo de natureza exclusivamente epistemológica, sem considerá-lo como o "motivo constituinte" sociedade que se refere a algo que é ao mesmo tempo um problema epistemológico e "prático", "uma circunstância problemática do mundo"729. O fato de atribuir ao método o papel predominante no processo do conhecimento, supondo que o respeito ao método resulta em "fazer ciência" de forma "neutra" e "objetiva" e traz à tona a verdade, segundo Adorno, é o que qualifica Popper como um "positivista". Em contrapartida, Adorno contesta o privilégio do método explicativo de dar acesso à verdade e à objetividade, afirmando a necessidade de levar em conta a dinâmica da sociedade e a dimensão dialética e crítica que permeia todo processo de conhecimento. Para tanto, ele rejeita a equiparação de crítica e intento de refutação. Enquanto a refutação, no sentido do falsificacionismo de Popper, consiste em uma reformulação de enunciados contraditórios em vista da recuperação da conformidade e harmonia do complexo científico (logicismo), a crítica, no sentido da teoria crítica, segue a direção da permanente autocrítica do conhecimento da sociedade ${ }^{730}$.

Segundo Bárbara Freitag, a contestação de Adorno a Popper, assim como a perspectiva de uma dialética adorniana, é retomada de forma mais aprofundada na obra Dialética negativa $(1970)^{731}$. Nessa obra, a crítica é concebida como o princípio da negatividade constituinte do método dialético e da teoria crítica que se fundem com o

\footnotetext{
${ }^{727}$ Nos termos de Adorno: "Parece innegable que el ideal epistemológico de la elegante explicación matemática, unánime y máximamente sencilla fracasa allí donde el objeto mismo, la sociedad, no es unánime, ni es sencillo, ni viene entregado de manera neutral al deseo o a la conveniencia de la formalización categorial, sino que es, por el contrario, bien diferente a lo que el sistema categorial de la lógica discursiva espera anticipadamente de sus objetos. La sociedad es contradictoria y, sin embargo, determinable; racional e irracional a un tiempo, es sistema y es ruptura, naturaleza ciega y mediación por la consciencia. A ello debe inclinarse el proceder todo de la sociología. De lo contrarío incurre, llevada de un celo purista contra la contradicción, en la más funesta de todas: en la contradicción entre su estructura y la de su objeto. Tan escasamente como la sociedad se sustrae al conocimiento racional y tan evidentes como son sus contradicciones y las condiciones de las mismas, resultan éstas imposibles de escamotear por postulados mentales extraídos de un material indiferente al conocimiento y que no opone resistencia alguna a los usos cientificistas que por regla general se acomodan a la consciencia cognoscente. El tráfico científico-social se ve permanentemente amenazado de errar, por amor a la claridad y a la exactitud, en aquello que se propone conocer (ADORNO, W. T.. Sobre la lógica de las ciencias sociais. In: ADORNO, W. T.; POPPER, K.R.; DAHRENDORF, R.; HABERMAS, J.; ALBERT, H.; PILOT, Harald. Karl. La disputa del positivismo en la sociologia alemana. Trad. Jacobo Muñoz. Barcelona-México: Grijalbo, 1973, p. 122).

${ }^{728}$ ADORNO, Sobre la lógica de las ciencias sociais. In: La disputa del positivismo en la sociologia alemana, p. 137.

${ }^{729}$ Idem, p. 123.

${ }^{730}$ Idem, p. 131.

${ }^{731}$ FREITAG, A teoria crítica: ontem e hoje, pp. 48-52.
} 
objetivo político-social (existencial, material) a ser realizado no futuro. A "dialética" é o método central da produção do conhecimento para uma teoria crítica da sociedade, que não possui, contudo, nenhum "cânone" específico (regras definidas) para produzir um saber prognóstico seguro da realidade. Mas, ao contrário da lógica formal, ela é capaz abarcar o não-idêntico e os elementos da contradição e da transformação em seus conceitos. A "dialética negativa" adorniana consiste no "movimento permanente da razão na tentativa de resgatar as dimensões reprimidas, não concretizadas no presente, transferindo-as para um futuro pacificado em que as limitações do presente se anulem" ${ }^{\text {732 }}$. Marcando a diferença epistemológica entre as perspectivas teóricas confrontadas, Adorno entende que a "dialética negativa” se aproxima da versão emancipatória da razão iluminista, enquanto que o positivismo de Popper, com a razão instrumental.

É importante salientar que, nesse confronto, a conclusão de Adorno é que positivismo e teoria crítica são posições teóricas incompatíveis, pois se ancoram em fundamentos epistemológicos diferentes. Comparativamente, Horkheimer e Adorno chegam a posicionamentos distintos em suas respectivas contraposições, mutatis mutandis, entre as versões de teoria tradicional (positivismo) e teoria crítica (dialética negativa). A conclusão de Horkheimer, já aludida, é que há a possibilidade de convergência entre as duas teorias (os dois momentos da razão), contato que a teoria crítica, sendo entendida como uma teoria mais abrangente, englobe a teoria tradicional ${ }^{733}$. Mais que contrapor a possibilidade de conciliação entre os dois momentos da razão, o instrumental e o crítico, Adorno pensa que, a utilização da razão instrumental pelo positivismo, fazendo-o refugiar-se em subáreas do saber, gera sua contestação e possível autodestruição. Isso porque o positivismo se proíbe de questionar sobre os pressupostos nos quais se assenta a sua "lógica", ao passo que condena esse procedimento como "metafísico". Ocorre que, com essa autorrestrição, a ciência positivista, segundo Adorno, enquanto busca uma suposta verdade dos fatos falsamente neutra e objetiva, não reflete sobre a origem histórica do seu pensamento. Então, ignorando as relações de troca e os interesses de lucro e dominação que condicionam a produção científica das subáreas do saber, a ciência positivista "naturaliza os processos sociais, atribuindo à dinâmica histórica um funcionamento sistêmico, regido por leis absolutas e imutáveis ${ }^{734}$. Para Adorno, essa incompatibilidade é patente, pois o conceito de teoria, segundo a dialética negativa, ao

\footnotetext{
${ }^{732}$ FREITAG, A teoria crítica: ontem e hoje, p. 48.

${ }^{733}$ ADORNO; HORKHEIMER, Dialética do esclarecimento, pp. 17-46. HORKHEIMER, Teoria tradicional e teoria crítica. In: Textos escolhidos, p. 148. FREITAG, A teoria crítica: ontem e hoje, p. 52. HORKHEIMER, Eclipse da razão, p. 179.

${ }^{734}$ FREITAG, A teoria crítica: ontem e hoje, p. 50.
} 
remeter a um futuro melhor, automaticamente, remete à dimensão da prática (campo da ação ética e política); essa dimensão, contudo, é excluída do raciocínio positivista. No sentido do positivismo de Popper, reduz-se a prática à ação do cientista limitada a sua área de especialização, e a crítica, à falsificação de uma hipótese dada, seja via dados empíricos, seja pela descoberta de erros lógicos. Nesse segundo momento, vê-se que a problemática levantada por Horkheimer, é radicalizada pelo confronto entre Popper e Adorno.

O terceiro momento do eixo temático consoante à dialética da razão e crítica à ciência é marcado pela tentativa de reformulação da teoria crítica. O ponto de partida desse momento é o debate entre Habermas e Luhmann, no qual são confrontadas respectivamente as concepções de razão comunicativa (razão como procedimento argumentativo) e razão sistêmica. Luhmann, recorrendo ao modelo da biologia, especificamente a sua distinção conceitual entre sistema (sistema sócio-cultural "aberto") e meio (sistema do organismo vivo “fechado"), afirma que, à proporção que se dá o abandono da dimensão biológica e o avanço em direção a sistemas sócio-culturais, mais aumentam as alternativas de interpretações ou representações do mundo e de orientações comportamentais, resultando na complexidade do sistema. Com efeito, ao institucionalizar papéis sociais específicos, a realidade sistêmica cumpre uma de suas funções centrais, a de "redução da complexidade", exonerando o ator da obrigação de escolher entre as alternativas possíveis. Em sua crítica a Luhmann, Habermas afirma que a categoria de sistema não permite ter opções para escolher entre elas, pois já pressupõe a realidade sistêmica como forma mais adequada. Ademais, a teoria sistêmica não tem condições de explicar como os significados vinculados a valores e normas emergem e passam a regular o sistema. Nela, a existência desses significados não decorre de uma interação dialógica, em que os significados são consensualmente elaborados e reciprocamente respeitados, pois ela é considerada como a priori ao sistema. Nela, os significados já estão estabelecidos e precisam ser, por um lado, internalizados pelos atores e, por outro, institucionalizados em papéis sociais e instituições para que tenham validade. Nesse terceiro momento da discussão sobre a dialética da razão, para os frankfurtianos, aqui representados por Habermas, o conformismo implícito e a dificuldade de explicar os processos históricos, qualifica a teoria sistêmica de Luhmann como uma reformulada da "teoria tradicional". Como tal, ela tem em comum com as versões anteriores de teoria tradicional, que são confrontadas 
por Horkheimer e Adorno, a concepção instrumental da razão, a naturalização dos fenômenos sociais e a tentativa de eliminar a contradição (crítica) do modelo teórico ${ }^{735}$.

A crítica de Habermas a Luhmann toma a direção de um novo paradigma para teoria crítica enquanto teoria da ação comunicativa ${ }^{736}$. Esse paradigma inclui a elaboração de novo conceito de razão, o conceito de racionalidade comunicativa. Peculiarmente, o conceito de razão comunicativa transcende a noção de razão kantiana (subjetiva, transcendental, autônoma) assimilada por Horkheimer e Adorno, em virtude de espelhar "a transparência das relações sociais e a intersubjetividade possível a cada um dos atores nelas envolvidos"737. Esse conceito não se refere a uma faculdade abstrata, mas ao procedimento argumentativo, a partir do qual se espera alcançar o consenso sobre questões relacionadas com a verdade, a justiça e a autenticidade. É a partir desse conceito de razão que ele procura conceituar a sociedade, tendo presente que a modernidade, problematicamente, cria na realidade social uma disjunção e consequente choque entre a esfera do sistema e a esfera do mundo vivido (Lebenswelt). A esfera sistêmica é relativa à atuação da razão instrumental e da técnica nos subsistemas econômico, do dinheiro, e político, do poder. A visão sistêmica se caracteriza pela exclusão do diálogo, na medida em que funciona na base de imperativos automáticos (“integração sistêmica") e encontra no dinheiro uma linguagem universal para a codificação

\footnotetext{
${ }^{735}$ FREITAG, A teoria crítica: ontem e hoje, pp. 52-58 e 63.

${ }^{736}$ A "mudança no paradigma" proposta por Habermas, seguindo a linha crítica comum à Escola de Frankfurt, procura enfrentar os déficits ou aporias da teoria crítica preconizada pelos pensadores da primeira geração de Frankfurt em relação aos conceitos de "razão, verdade e democracia". O déficit da razão se patenteia em face da desconfiança de Horkheimer e Adorno em relação à capacidade emancipatória da razão histórico-filosófica, conduzindo-os a um beco sem saída. Eles se atêm (até os anos 30) a um conceito histórico-filosófico de razão, de inspiração marxista, acreditando em uma razão capaz de objetivar-se na história para emancipar a humanidade. Tal desconfiança, já é notória nos ensaios reunidos na "Dialética do esclarecimento" (1947), leva Adorno a identificar na obra de arte de vanguarda, em especial a música, o último refúgio para cultivar a reflexão crítica e preservar a razão da contaminação instrumentalizadora. Para Habermas, esse impasse reflete o uso ("ultrapassado") do conceito de razão que remonta a Marx, o qual supunha encontrar na categoria do trabalho o substrato material e universal da constituição da razão. Propositivamente, ele pensa que o resgate da concepção emancipatória de razão não ocorre automaticamente com a superação das relações de trabalhos alienadas do capitalismo, mas exige uma nova mediação, que se explicita na categoria da intersubjetividade. O déficit da verdade decorre do fato de que Horkheimer e Adorno, na linha de uma concepção de dialética negativa, foram incapazes de formular um conceito de verdade compatível com os requisitos da ciência e com o conceito integral de razão hegeliana. Na linha da sua teoria crítica, Habermas desenvolve uma teoria consensual da verdade. $\mathrm{O}$ déficit da democracia diz respeito à dificuldade dos "velhos pensadores" de Frankfurt para conceituar democracia. Eles viam a democracia das massas como permanente ameaça à sobrevivência da razão. Isso porque as massas são hostis ao trabalho do conceito e vulneráveis à manipulação; ademais, na massa, o indivíduo perde sua competência reflexiva. Para superar esse déficit, Habermas propõe a substituição da teoria crítica "tradicional" por uma teoria da ação comunicativa, baseada na concepção dialógica da razão e no caráter processual da verdade. Essa teoria não indica uma utopia que aguarda indefinidamente sua concretização social, mas se refere a realidades sociais parcialmente institucionalizadas na linguagem cotidiana, nos procedimentos políticos das democracias ocidentais e nos diferentes "nichos" (arte, ciência, moral, direito) de valor e racionalização das sociedades contemporâneas. Cabe às ciências sociais revelar e fortalecer tais realidades (cf. FREITAG, A teoria crítica: ontem e hoje, pp.106-130).

${ }^{737}$ FREITAG, A teoria crítica: ontem e hoje, p. 60.
} 
das relações sociais, e pelo propósito de "colonizar" as outras esferas da sociedade (arte, direito, ciência, moral, educação) concernentes ao mundo vivido. O "mundo vivido" diz respeito à esfera social e cultural, à visão de dentro da sociedade, ao cotidiano e às vivências que conformam a memória e a história coletiva dos seus membros. Trata-se de uma esfera que é regida pela razão comunicativa.

No entrechoque dessas esferas, o mundo vivido está ameaçado pela interferência do sistema, que quer de impor sua racionalidade instrumental e tecnocrática. Essa interferência ocorre quer pelo subsistema estatal, na forma da burocratização, quer pelo subsistema econômico, na forma da monetarização. A burocratização e a monetarização são as duas usurpações responsáveis pelas patologias do mundo vivido. Em contraposição a essas usurpações do espaço do mundo vivido Então, a tarefa que se apresenta no presente é a “descolonização" do mundo vivido pelo sistema, a fim de reorientar a razão instrumental diga-se, aos limites dentro dos quais é imprescindível, isto é, a organização e reprodução material das sociedades de massa - e reabilitar a capacidade de agir comunicativamente para todos os membros da sociedade. Procurando superar a leitura pessimista sobre o Iluminismo feita por Horkheimer e Adorno, em que "o feitiço se volta contra o feiticeiro", a teoria da ação comunicativa de Habermas postula a reconciliação entre os dois momentos da razão, instrumental e comunicativa. Cabe à racionalidade comunicativa, já preservada e institucionalizada em certos "nichos" do mundo vivido, como, da arte, do direito, da ciência e da moral, por em andamento tal tarefa ${ }^{738}$.

\subsection{A caracterização da teoria crítica como "nova esquerda"}

Feita essa contextualização que realça a apresentação da tese interpretativa de Apel de que a defesa da função emancipadora da ciência constitui o transfundo da proposta da teoria crítica da Escola de Frankfurt, retomar-se-á a exposição das ideias explicitadas em “Ciência como emancipação?”, destacando o que Apel considera ser o legado substancial dos teóricos da Escola de Frankfurt. O programa frankfurtianos, enquanto perspectiva teórica orientada a denunciar o conceito valorativamente neutro de science e o caráter instrumental da razão, ao menos inicialmente, é visto pelos seus contemporâneos como um viés filosóficosociológico tendencialmente da "nova esquerda". Na linha desse viés, segundo Apel, o legado da teoria crítica é ter contribuído para modificar - inclusive por meio da práxis, da exigência

\footnotetext{
${ }^{738}$ FREITAG, A teoria crítica: ontem e hoje, pp. 61-65.
} 
de responsabilidade social e engajamento político - a mentalidade pós-ideológica de uma grande parte da "geração cética", isto é, da geração defensora do modelo tecnocrático da sociedade industrial ${ }^{739}$. O sintoma mais significativo dessa mudança de mentalidade é a guinada na consciência de uma parte significativa do movimento estudantil no tocante à discussão sobre as políticas públicas para o ensino superior na Alemanha.

A crítica da "nova esquerda" representada pela teoria crítica se caracteriza como uma "crítica da razão instrumental" 740 . Conforme Apel, essa crítica, com base no diagnóstico de uma sociedade cientificizada e manipulada por via tecnocrática, procura mostrar que a diluição da práxis política pela tecnocracia dos especialistas já constitui uma realidade perigosa no Leste e no Ocidente. Nesse diagnóstico, há a percepção de que o Estado na era industrial é reordenado como um "corpo técnico universal", tal como um "Estado técnico" ao qual cabe a função de orientar "de fora" (da política) o ser humano na civilização científica a partir de "compulsões objetivas". Ao incorporar esse modelo de "Estado técnico", a sociedade industrial dá início a um tipo de práxis vital que tende a excluir e substituir a política entendida aqui no sentido de decisões que demandam processos comunicativos direcionados à formação democrática da vontade - por decisões técnico-científicas baseadas em um número cada vez maior de informações objetivas, pelo recurso ao saber especializado. Criticamente, a "nova esquerda" entende que tal situação põe em questão a pretensão de equiparar automaticamente conhecimento (ciência) com a produção da liberdade humana na sociedade industrial moderna. Pois, nela, o recurso ao saber especializado disponível e a necessidade de eficiência técnica, no sentido de uma politização da ciência e da técnica como instrumento de dominação, em vez de facilitar a formação democrática da vontade, na linha de uma concepção clássica de democracia como "ser-comum", paradoxalmente, conduz à suspensão da formação dos juízos políticos por parte do entendimento humano normal ou a partir de uma experiência normal de vida. Procedendo de tal modo, o modelo tecnocrático da sociedade industrial realiza a politização da ciência e da técnica mediante a despolitização da política provocada pelo excesso de informação, provocando assim, também por esse excesso, o enfraquecimento da democratização dos cidadãos no Estado. Isso, na análise da teoria crítica, constitui o perigo de uma nova auto-alienação do ser humano ${ }^{741}$.

\footnotetext{
${ }^{739}$ APEL, Transformação da filosofia, v. II, p. 149; Transformation der philosophie, Band II, p. 130.

${ }^{740}$ HORKHEIMER, Eclipse da razão, pp. 28 e 41.

741 APEL, Transformação da filosofia, v. II, pp. 151-152; Transformation der philosophie, Band II, pp. 131132.
} 
Para Apel, o foco da crítica da teoria crítica ao modelo tecnocrático da sociedade industrial é sua contestação à tendência de pensar como imutáveis ou como os únicos possíveis o conceito valorativamente neutro de ciência e o conceito de sociedade industrial. Nesse ponto, a teoria crítica entende que o conceito valorativamente neutro de ciência, sendo relevante em sua referência prática apenas na perspectiva tecnológica (instrumental), funciona como uma perigosa "ideologia da meia razão", justamente porque desativa a reflexão e promove a auto-alienação do ser humano no sistema capitalista de mercado. Enquanto "ideologia", esse conceito científico deixa de refletir "cientificamente" sobre os interesses que estão por trás dos interesses de uma tecnocracia moderna defensora de "compulsões objetivas". Em contrapartida, ao propor uma reflexão sobre esses interesses irrefletidos, a teoria crítica coloca em questão o conceito de uma "sociedade industrial" determinada imutavelmente por "compulsões objetivas". Ao contrário de defender a ligação recíproca entre os conceitos de ciência e sociedade industrial, crítica ao conceito científico de science (conhecimento valorativamente neutro) e ao modelo tecnocrático da sociedade industrial empreendida pela teoria crítica - segundo Apel, desenvolvida por H. Marcuse e depois aprimorada por Habermas - procura revelar o que está por trás da manipulação (regulamentação) da sociedade cientificizada por via tecnocrática. A tese fundamental desses representantes da teoria crítica é que, recorrendo ao prestígio da ciência e à necessidade técnica, o sistema capitalista tardio logra velar ideologicamente o que está por detrás das pretensas "compulsões objetivas", a saber, a "legalidade, não mais refletida, do sistema capitalista tardio da economia de mercado" 742 .

Apel entende que a ênfase da discussão influenciada pela "nova esquerda" é um questionamento acerca do posicionamento "sóbrio-pragmático" da "geração cética" no que tange ao campo da educação. Trata-se de um questionamento que carrega consigo a objeção à expressa exigência de abandonar o ideal acadêmico de uma "formação" universal, por considerá-la inadequada para nossa época, e de fomentar a perspectiva de uma “"educação' profissional eficiente". Nesse questionamento, de um ponto de vista crítico, considera-se que a defesa da entrega do ensino ao "saber especializado orientado" por "compulsões objetivas" é uma perigosa "ideologia da meia razão". Interpreta-se que a mentalidade pós-ideológica é responsável por criar nos estudantes, “em uma universidade conduzida pelas necessidades econômicas do capitalismo tardio e reformada de acordo com princípios de racionalidade próprios à administração empresarial”, "a disposição para serem educados como "idiotas

\footnotetext{
${ }^{742}$ APEL, Transformação da filosofia, v. II, p. 153; Transformation der philosophie, Band II, p. 133.
} 
especializados' arbitrariamente especializados"743. Em consequência a esse questionamento, assim pontua Apel, onde transcorre tal guinada impulsionada pela teoria crítica, a mentalidade pós-ideológica passa a ser vista como uma mentalidade "conformista, oportunista e hostil à reflexão"744.

Há que se assinalar aqui, brevemente, o envolvimento recíproco entre frankfurtianos e movimento estudantil. Em princípio, esse envolvimento é instigado pela pesquisa de temas ligados à educação por parte de alguns frankfurtianos. Um importante registro da vinculação da Escola de Frankfurt com a problemática da educação é a pesquisa de Habermas e Ludwig Friedeburg, realizada no final da década de 50 entre estudantes universitários de Frankfurt e Berlim. O objetivo dessa pesquisa é averiguar o potencial autoritário (ligado ao anti-semitismo) ou democrático da nova geração estudantil do pósguerra, tendo em conta que essa geração é educada por pais em sua maioria vinculados ao regime nazista e, no contexto da reconstrução democrática da Alemanha Ocidental, passa a ser confrontada com um regime liberal-democrático imposto pelos aliados. A conclusão dessa pesquisa indica a situação de uma síndrome autoritária latente na maioria dos entrevistados. Interessantemente, essa investigação é surpreendida, antes de sua publicação em 1961, pela eclosão movimento estudantil em todas as universidades européias, no início da década de 60, trazendo à tona o novo potencial político de uma geração estudantil inconformada com as estruturas autoritárias da universidade e da sociedade ${ }^{745}$.

$\mathrm{O}$ aspecto característico desse envolvimento entre frankfurtianos e movimento estudantil concerne à tentativa empreendida por alguns líderes do movimento estudantil na Alemanha de fundamentar o protesto estudantil nas reflexões de Marcuse, Adorno e Horkheimer ${ }^{746}$. Há registros de que, já nos anos de 1966-1967, a mobilização movimento estudantil em contraposição às estruturas autoritárias da universidade alemã e da sociedade alemãs atinge centros como Berlim, Frankfurt, Heidelberg. Aí, os jovens contestadores, destacadamente Rudi Dutschke, que assume o papel de liderança do movimento na Alemanha, veem no pensamento da teoria crítica uma nova forma de contestação da sociedade. De tal modo, esse envolvimento é permeado pela intenção, por parte do movimento, de transpor a teoria crítica em prática revolucionária, tomando como ponto de partida a democratização da universidade, a destruição da família e do Estado autoritário.

\footnotetext{
743 APEL, Transformação da filosofia, v. II, p. 150; Transformation der philosophie, Band II, p. 131.

${ }^{744}$ APEL, Transformação da filosofia, v. II, p. 150; Transformation der philosophie, Band II, p. 131.

${ }^{745}$ FREITAG, A teoria crítica: ontem e hoje, p. 23.

${ }^{746}$ FREITAG, A teoria crítica: ontem e hoje, pp. 24-26.
} 
A tentativa de incorporação da teoria crítica ao movimento estudantil, segundo Bárbara Freitag, termina com a desilusão e incompreensão de ambas as partes. Os mestres frankfurtianos enxergam na radicalidade do movimento e na imaturidade da grande maioria dos estudantes, em virtude de aderir ao movimento não por motivos racionais, mas pelo impulso de seguir uma liderança carismática (que paralisa a autocrítica de seus adeptos), nítidos traços fascistas e, por isso, passam a combater o movimento, cada qual a seu modo. Adorno chega a equiparar a forma de manifestação do estudantado engajado, por meio da invasão violenta dos prédios, saque de livros, irreverência com os intelectuais e sua produção acadêmica, com a atuação dos nazistas que incineraram os livros “judeus”. Em certa ocasião, ante a ameaça dos estudantes de invadir o Instituto e depredar o prédio e a biblioteca, o próprio Adorno chama a polícia. Habermas cunha a expressão "fascismo de esquerda" para provocar um debate crítico com o movimento, mas, sem a adesão dos estudantes, retira-se para Starnberg (1971-1983), onde se dedica a investigar as condições de vida do homem na civilização técnica e industrial. Friedeburg e Marcuse, partidários de reformas no sistema universitário e educacional, porém rejeitando as propostas revolucionárias e os movimentos de guerrilha urbana, optam pelo embate reflexivo "corpo a corpo" com as massas estudantis. No final, a maioria dos estudantes ligados à teoria crítica abandona seus "ídolos", seguindo rumos diversos, carreira universitária tradicional, adesão a seitas ou partidos políticos, luta armada. E coube a um pequeno grupo desses estudantes - entre outros, Offe, Preuss, Brandt, Senghass, Altvater, Buerger, Sloterdijk ${ }^{747}$ - dá prosseguimento ao debate teórico matizado pela teoria crítica.

Na avaliação de Apel, essa guinada na mentalidade não representa um retorno ao tradicional ideal acadêmico humboldtiano de uma "formação" universal, mas denota a proximidade entre a teoria crítica, ao menos dos seus representantes da primeira geração, e o conceito clássico de ciência e formação propugnado pelo idealismo alemão, de modo particular, pela exigência neo-hegeliana de responsabilidade social e engajamento político. Há que se observar que essa proximidade se manifesta, sobretudo, em sua recusa ao conceito de ciência valorativamente neutro, que domina as ciências hoje ao menos no mundo anglo-saxãoescandinavo, sob o signo de neopositivismo e sua logic of science. Em relação à formação, recusa-se o conceito de educação valorativamente neutro e profissionalizante, como tal apenas referido à práxis social de maneira tecnológica. A recusa propugnada pela teoria crítica lança contra o conceito neopositivista de ciência e contra seu respectivo conceito de educação

\footnotetext{
${ }^{747}$ FREITAG, A teoria crítica: ontem e hoje, pp. 106-139.
} 
profissionalizante a acusação de favorecer a constituição burocrática e tecnocrática da sociedade como um todo e, no plano da formação, de promover a desativação da reflexão (no sentido da "meia razão"), ao colocar em descrédito, por considerá-la não-científica, uma reflexão racional sobre a concatenação entre ciência, educação e referência social prática ${ }^{748}$.

\subsection{A compreensão de emancipação na teoria crítica de Habermas retomada por Apel}

Em seu relato autobiográfico, Apel atesta, a importância de Habermas em sua trajetória intelectual. Essa importância decorre do fato de que a ligação de Apel com a teoria crítica se dá via Habermas. Nesse relato, Apel reconhece que, antes do seu reencontro com Habermas, já conhecido desde os tempos universitários de Bonn, não tinha qualquer conhecimento sobre os fundadores da teoria crítica, Horkheimer e Adorno. A inserção de Apel na Escola se dá por meio da parceria que ele estabelece com Habermas, a partir de 1973, em vista da reformulação da teoria crítica da Escola de Frankfurt. Apel atribui que é graças à interlocução que ele estabelece em torno da discussão das obras de Habermas, juntamente com sua confrontação com o movimento estudantil, que se processa, em grande medida, seu "despertar político"749. Em sua autopercepção intelectual, Apel vê esses dois fatores, o confronto com o movimento estudantil e o reencontro com Habermas, como decisivos em seu processo de abandono da posição de retirada "apolítica", que encarna após o regresso da guerra.

Interessantemente, esses dois fatores são abordados por Apel no texto "Ciência como emancipação?" e, posteriormente, mencionados em seu no relato autobiográfico (1990). Na sequência da exposição desse tópico a partir do texto "Ciência como emancipação?”, verse-á nitidamente a parceria entre Apel e Habermas, em que Apel parte da sistematização dos interesses cognitivos da ciência desenvolvida por Habermas na obra Conhecimento $e$ interesse. Decerto, como bem assinala Apel, essa parceria comporta projetos autorais quanto à tentativa de reformulação da teoria crítica. Para Apel, a diferença entre a versão de reformulação da teoria crítica proposta por ele e Habermas é, respectivamente, a "diferença entre o apriori experimental dos interesses cognitivos constitutivos do sentido e o apriori do discurso argumentativo reflexivamente válido" ${ }^{750}$. Seguindo inicialmente a trilha aberta por Habermas que marca a terceira fase do caminho da Escola de Frankfurt, ao propor a semiótica

\footnotetext{
${ }^{748}$ APEL, Transformação da filosofia, v. II, p. 151; Transformation der philosophie, Band II, p. 131.

${ }^{749}$ APEL, Antropos, p. 17.

${ }^{750}$ APEL, Antropos, p. 18.
} 
transcendental como uma retranscendentalização da filosofia no marco do paradigma da linguagem, Apel representa o esforço no sentido de construir uma "nova" versão da teoria crítica, tendo como pano de fundo o interesse de viabilizar, no plano teórico, a relação entre conhecimento e emancipação.

Na interpretação de Apel, o ponto alto da abordagem da teoria crítica em relação à questão da disponibilização da ciência e do conhecimento em um sistema tecnocrático "quase perfeito" se encontra na concepção propugnada por Marcuse e Habermas de uma crítica ideológica da ciência e da técnica estabelecidas ${ }^{751}$. Em uma perspectiva histórica, essa concepção se define pelo vínculo com a crítica de Marx referente à autoalienação humana no sistema capitalista e, ao mesmo tempo, pelo intento de ultrapassar a crítica românticoexistencialista à modernidade, conforme a qual o mal reside na técnica científica como tal e não na práxis social do ser humano. Em termos de avanço teórico, segundo Apel, essa concepção representa um auge novo e original em relação à reflexão sobre a autoalienação humana no sistema capitalista, na medida em que aborda tópicos que Marx efetivamente não poderia ter previsto. Há que se ressaltar que, diferentemente de Marx, Marcuse e Habermas não supõem uma legalidade objetiva da história, conforme a qual a ciência (conhecimento) relevante enquanto força de produção entra em conflito com as relações capitalistas de produção e, nesse conflito, afirmar-se como precursora do progresso social.

Em uma perspectiva inovadora, segundo Apel, Marcuse e Habermas identificam uma nova situação de perigo para a autodeterminação dos cidadãos e a determinação conjunta entre eles na sociedade industrial moderna, considerando-a como decorrente de um sistema de retroalimentação entre as estruturas de dominação e as possibilidades tecnológicas da ciência. O que não poderia ser previsto por Marx é que, com a politização da ciência e da técnica na sociedade industrial (ambas como ferramenta de domínio dos homens e do mundo), o sistema capitalista tardio regulamento (manipulado) tecnologicamente por intervenções estatais logra alcançar possibilidades de estabilização funcional. Faticamente, nesse sistema de retroalimentação, a força de produção presente no saber disponível, antes presumida por Marx como potencial fonte de emancipação social, no contexto atual se torna mais relevante que a força de produção dos trabalhadores e, de tal modo, logra afirmar-se como instrumento de dominação de uns seres humanos sobre os outros. Para Marcuse e Habermas, o perigo desse sistema reside em sua capacidade de estar muito bem adaptado ao meio social, à proporção que consolida, de um ponto de vista funcionalista, a autoalienação do ser humano mediante

${ }^{751}$ APEL, Transformação da filosofia, v. II, p. 153; Transformation der philosophie, Band II, pp. 133. 
técnicas de manipulação quase imperceptíveis. Na visão de Apel, a divergência intelectual entre os membros da "nova esquerda", em face da quase perfeição técnica desse sistema de retroalimentação, desemboca na pergunta sobre as contradições que poderiam ser postuladas talvez na forma de conflitos sociais - em vista da possível negação ou recusa desse sistema de manipulação. Ilustra essa divergência a concepção semi-anarquista de Marcuse, que preconiza a "negação indeterminada" de uma "recusa absoluta" como única resposta dos cidadãos ainda não integrados ao sistema ${ }^{752}$.

Apel considera que a abordagem da teoria crítica que na contemporaneidade melhor estrutura uma reflexão entre o conceito de ciência, pressuposto em um sistema tecnocrático, e o conceito de "emancipação", no sentido de uma "efetivação" prática da filosofia, é a abordagem epistemológica de J. Habermas. Na ótica de Apel, Habermas é o teórico das ciências de maior destaque atualmente na Escola de Frankfurt. Apel vê na abordagem epistemológica de Habermas, cujo contorno programático inaugural é delineado na obra Conhecimento e interesse, o intento de elaborar uma teoria sobre os interesses condutores do conhecimento subjacentes às ciências possíveis na atualidade, entendendo-os como condições transcendentais da constituição objetual de cada uma dessas ciências. Esses interesses são: o interesse das ciências naturais empírico-analíticas (science), o das ciências humanas hermenêuticas (ciências do espírito) e da teoria crítica $^{753}$.

Apel retoma a teoria do conhecimento proposta por Habermas em "Ciência como emancipação?". Essa retomada, na verdade, atende ao interesse de dupla face do próprio Apel. A fim de destacar seu posicionamento em relação ao binômio conhecimento e emancipação, em um primeiro plano, Apel incorpora em sua proposta filosófica a distinção habermasiana dos três interesses cognitivos subjacentes aos conceitos de ciência. Em um segundo plano, no sentido de um esforço paralelo e próprio, ele procura se afastar da abordagem epistemológica de Habermas, para complementá-la em relação a "um ponto"754. $\mathrm{Na}$ verdade, esse dito "ponto" não diz respeito a algum aspecto secundário da abordagem de Habermas, mas se refere à consideração crítica em relação ao elemento nuclear da teoria do conhecimento de Habermas, diga-se, explicitada em Conhecimento e interesse. Trata-se do veto de Apel à equiparação entre o "interesse emancipatório do conhecimento" e a razão

\footnotetext{
${ }^{752}$ APEL, Transformação da filosofia, v. II, pp. 153-155; Transformation der philosophie, Band II, pp. 133135.

${ }^{753}$ APEL, Transformação da filosofia, v. II, pp. 156-158; Transformation der philosophie, Band II, pp. 136137.

${ }^{754}$ APEL, Transformação da filosofia, v. II, p. 166; Transformation der philosophie, Band II, p. 145.
} 
crítico-reflexiva, portanto, o ponto fundamental da tese de Habermas ${ }^{755}$. Frisando, esse ponto se refere à tese basilar da visão de uma teoria da ciência próxima da teoria crítica que, em Habermas, concerne ao intento de "clarificar o nexo de conhecimento e interesse descoberto no âmbito da metodologia das ciências da natureza e das ciências do espírito" "756. Isso significa que, "para-além” de Habermas, Apel coloca em discussão o núcleo da abordagem epistemológica de Habermas no sentido de uma "crítica" como "unidade de conhecimento e interesse". Supondo esses planos, para expor a posição de Apel "com" e "para-além" de Habermas, faz-se necessário explicitar previamente o teor geral da abordagem epistemológica que defende a tese da equiparação entre interesse emancipatório do conhecimento e razão crítico-reflexiva, a tese de Habermas.

A abordagem epistemológica de Habermas em Conhecimento e interesse se estrutura em torno de dois planos teóricos. Em uma primeira referência histórica à filosofia da reflexão, ele toma em relevo o legado teórico das investigações metodológicas desenvolvidas por Peirce e Dilthey, com vistas a reabilitar a dimensão da autorreflexão nas ciências. Habermas considera que esse legado lhe faculta, em um passo ulterior, refletir sobre os interesses condutores do conhecimento. Nesse passo, ele apresenta sua "crítica" à autocompreensão cientificista das ciências, à marcha pelo positivismo em sua pretensão de reduzir a teoria do conhecimento à teoria da ciência. Em uma segunda referência teórica, ele recorre a Kant e Fichte, a fim retomar a perspectiva teórica que procura fundamentar a relação entre razão teórica e razão prática, sob a perspectiva de que tal relação comporte um interesse da razão pela emancipação. Estruturalmente, a argumentação de Habermas se desenvolve em vista de mostrar que a reabilitação da dimensão de autorreflexão implica em reconhecer que é constitutivo às ciências o nexo entre conhecimento e interesse emancipatório. Em um esforço de compreensão do que está por trás daquilo que Apel retoma de Habermas, tratar-se-á desses dois planos teóricos que estruturam a referida epistemologia de Habermas.

Para Habermas, exemplarmente, Peirce e Dilthey representam um contramovimento teórico em face do programa positivista de redução da teoria do conhecimento à teoria da ciência neutra. Isso ocorre porque, ao desenvolverem a metodologias das ciências da natureza (Peirce) e das ciências hermenêuticas (Dilthey) como lógica da pesquisa, eles fazem isso "com o enfoque" de uma teoria do conhecimento ${ }^{757}$. Para tanto, Peirce, ao analisar o contexto dos modos de inferência nas ciências empírico-analíticas,

\footnotetext{
755 APEL, Antropos, pp. 17-18.

${ }^{756}$ HABERMAS, Jürgen. Conhecimento e interesse. Trad. Luiz Repa. São Paulo: Unesp, 2014, p. 291.

${ }^{757}$ HABERMAS, Conhecimento e interesse, pp. 296-297 e 301.
} 
e Dilthey, ao analisar o andamento da explicação hermenêutica, demonstram os limites da pesquisa científica baseada na lógica formal para explicar como são "possíveis" a indução e o círculo hermenêutico. Interessante, ambos consideram que tal explicação não é algo que possa ser mostrado logicamente, mas apenas nos termos de uma teoria do conhecimento. A implicação básica disso é que o processo de investigação lógica nas ciências empíricoanalíticas e nas ciências hermenêuticas concebido por Peirce e Dilthey passa a pressupor dois elementos: a) que ocorra sob a base de um contexto de vida factual. Essa base para Peirce é a técnica (racionalidade instrumental), para Dilthey, a práxis de vida (ação comunicativa); b) que seja guiado pela busca de uma "resposta à questão sobre as condições a priori do conhecimento possível"758.

O que define a lógica da pesquisa "com o enfoque" de uma teoria do conhecimento é sua orientação de tratar das condições (regras) metodológicas que determinam a organização do processo de pesquisa e a validade do conhecimento nas ciências, para Peirce, empírico-analíticas e, para Dilthey, nas ciências hermenêuticas. Peculiarmente, essa lógica busca compreender as condições não mais referidas ao status de regras transcendentais puras (um a priori em si) relativas à constituição de uma consciência transcendental em geral (Kant), mas tão somente as condições de objetividade da experiência "para o processo de pesquisa" nas ciências. A lógica da pesquisa concebe essas condições como "regras da transformação lógica de proposições, cuja validade só é plausível se as proposições transformadas são referidas a priori a determinadas categorias de experiências"759. Por essa lógica, entende-se que o sentido da validade dos enunciados possíveis nas ciências alcança uma função apenas nos contextos de vida respectivos ao tipo de interesse imanente da investigação, ou seja, no caso das ciências empírico-analíticas segundo Peirce, ao interesse pelo processo de aprendizagem acumulativo voltado à ação instrumental sobre a natureza, no caso das ciências hermenêuticas conforme Dilthey, ao interesse pela interação simbolicamente mediada das tradições ${ }^{760}$. Assim, a investigação dessas condições resulta na explicitação das regras metodológicas que pré-formam o sentido dos modos de conhecimento ligados ao método das ciências. Quanto à compreensão dessas regras, é preciso ter em conta que: essas regras procedem de contextos de vida factuais e funcionam no interior deles, mas ao mesmo tempo possuem um valor posicional transcendental (interesse imanente), em razão do qual determinam a arquitetônica dos distintos processos de pesquisa nas

\footnotetext{
${ }^{758}$ HABERMAS, Conhecimento e interesse, p. 296.

${ }^{759}$ HABERMAS, Conhecimento e interesse, p. 297.

${ }^{760}$ HABERMAS, Conhecimento e interesse, p. 320.
} 
ciências $^{761}$. Na visão de Habermas, o enfoque de Peirce e Dilthey sobre as condições da objetividade da experiência é relevante, do ponto de vista epistemológico, porque ele torna patente, à medida que recupera a dimensão da teoria do conhecimento abandonada pela teoria positivista da ciência, a base de interesses do conhecimento científico ${ }^{762}$.

Há que se salientar que a recuperação da dimensão da teoria do conhecimento operada por Peirce e Dilthey no campo da lógica da pesquisa nas ciências segue caminhos epistemológicos específicos. E a base da distinção entre eles, segundo Habermas, é a diferenciação relativa às condições transcendentais (valor posicional transcendental) das ciências. Em suas investigações metodológicas, Peirce entende sua lógica da pesquisa em conexão com o progresso científico, cujas condições ele investiga dentro do círculo de funções da ação instrumental. Para ele, a lógica é uma disciplina auxiliar que contribui para a institucionalização bem-sucedida do processo de pesquisa e, com isso, para a racionalização progressiva da realidade. Por isso, segundo Habermas, é possível entender que as ciências empírico-analíticas se encontram sob as condições transcendentais da ação instrumental. Em seu sentido (interesse) imanente, essas ciências, mediante uma linguagem "pura" formalizada $^{763}$, medem e geram um saber monológico sobre a realidade da natureza, cuja validade se confirma pelo procedimento da vinculação de teoria e experiência, isto é, em função do que é tecnicamente aplicável ${ }^{764}$.

\footnotetext{
${ }^{761}$ HABERMAS, Conhecimento e interesse, p. 297; esclarecimento a respeito disso, p. 299.

${ }^{762}$ HABERMAS, Conhecimento e interesse, pp. 296 e 301.

${ }^{763}$ Para Habermas, a concepção de linguagem nas ciências empíricas e nas ciências hermenêuticas põe em questão não apenas a distinção entre linguagem "pura" (restringida) e linguagem corrente, se se considera que, além disso, aquela parece caracterizar um "caso limite" desta. A linguagem "pura" se constitui sob as condições transcendentais da ação instrumental como "sumário de todos os nexos simbólicos que podem ser estabelecidos por meio de operações conforme regras" (HABERMAS, Conhecimento e interesse, p. 294). O uso atrelado a essa linguagem atende ao propósito dos enunciados monológicos ("cálculos") das ciências empírico-analíticas, visando assegurar às "proposições teóricas entre si o nexo sistemático que coage segundo regras de derivação" (HABERMAS, Conhecimento e interesse, p. 294). A linguagem formalizada (ou formalizável) é fruto da abstração do material espontâneo das linguagens correntes. Contudo, há que se considerar que a pretensão de ação instrumental relativa à linguagem pura - pretensão de que "todos os mundos de vida historicamente individuados têm de concordar abstratamente" - configura apenas um "caso limite" da própria linguagem, tal como uma variação extrema de mundos de vida (jogos de linguagem) constituídos em termos de linguagem corrente. Trata-se de um caso limite, no qual as condições da ação comunicativa são suspensas e reduzidas "ao ato solitário do emprego de meios racionais com relação a fins" e, finalmente, "a experiência de vida individuada é eliminada em favor de uma experiência repetível dos êxitos da ação instrumental" (HABERMAS, Conhecimento e interesse, p. 295). Isso mostra que o domínio dos objetos das ciências do espírito se constitui somente sob as condições transcendentais da metodologia da pesquisa, mas no plano dos próprios contextos de interações simbolicamente mediadas em geral. No contexto da ação comunicativa, teoria e experiência não se distanciam uma da outra como nas ciências empírica; pois a interpretação é de uma só vez análise linguística e experiência. Aí, "o conteúdo de experiência de um texto transmitido pode ser decifrado ser decifrado pelo intérprete apenas na relação com a estrutura transcendental do mundo ao qual o próprio pertence" (HABERMAS, Conhecimento e interesse, p. 296).

${ }^{764}$ HABERMAS, Conhecimento e interesse, pp. 293-294, 298 e 322.
} 
Por sua vez, Dilthey compreende sua lógica das ciências hermenêuticas em conexão com a hermenêutica. Isso significa, a lógica se conecta com a clarificação de um saber praticamente operante, portanto, já dado como constituído nos processos de consenso entre os oponentes em interações mediadas pela linguagem corrente, cujas condições ele analisa no interior do contexto da ação comunicativa. Na perspectiva da hermenêutica, o que possui valor posicional transcendental é a gramática da linguagem corrente, cujas regras "determinam o solo de uma intersubjetividade refratada entre indivíduos socializados"765. É um solo que é acessível unicamente pela internalização dessas regras, condicionalmente, como colaboradores socializados e não como observadores imparciais. Para Dilthey, a lógica é uma disciplina auxiliar que contribui "para a propagação da consciência histórica e para a

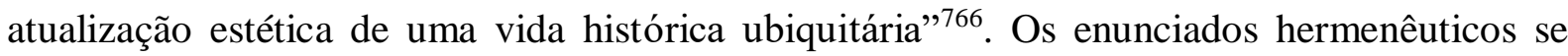
dirigem à "estrutura transcendental de formas de vida factuais e diversas, no interior da qual a realidade é interpretada a cada situação de maneira distinta" e, nisso, abrangem “interpretações da realidade tendo em vista uma intersubjetividade do entendimento orientador da ação, possível para uma situação hermenêutica inicial dada"767. Já que as ciências hermenêuticas procedem no plano da ação comunicativa, a validade do saber hermenêutico é constatada em virtude do que é "praticamente efetivo"768.

De um ponto de vista crítico, além de destacar o mérito, Habermas atesta que o caminho da análise da gênese das ciências trilhado por Peirce e Dilthey tem uma lacuna fundamental. Esse caminho comporta o mérito de analisar a fundação da lógica da pesquisa nas ciências nas condições de vida (contextos de vida factuais), explorando desse modo o enfoque da teoria do conhecimento, sem que tal implicasse em uma recaída na metafísica. A lacuna consiste em que Peirce e Dilthey não concebem as próprias investigações metodológicas na perspectiva de uma autorreflexão das ciências. Eles até se deparam com a base de interesses do conhecimento científico, mas "não formam o conceito de interesse condutor do conhecimento e tampouco apreendem propriamente o que ele intenciona"769. De tal maneira, problematicamente, nenhum dos dois levanta a questão de saber se a metodologia das ciências, enquanto teoria do conhecimento, "reconstrói as experiências profundas da história da espécie, conduzindo assim a uma nova etapa da autorreflexão no processo de

\footnotetext{
${ }^{765}$ HABERMAS, Conhecimento e interesse, p. 295.

766 Idem, p. 322.

${ }^{767}$ Idem, p. 322.

768 Idem, p. 297.

${ }^{769}$ Idem, p. 301.
} 
formação da espécie"770. Então, porque lhes falta tal perspectiva, segundo Habermas, "eles erram o ponto de unidade de conhecimento e interesse" ${ }^{\text {771 }}$.

$\mathrm{Na}$ interpretação de Habermas, Peirce e Dilthey só poderiam identificar as orientações basilares dessas ciências como interesse condutor do conhecimento "em um quadro que lhes era estranho", qual seja o da "concepção de uma história da espécie compreendida como processo de formação" ${ }^{, 772}$. Do contrário, eles não teriam se furtado a considerar a ideia de um processo de formação, unicamente no qual o sujeito da espécie se constitui como tal. Certamente, tal implicaria em levar em conta a experiência da força emancipadora da reflexão, que o sujeito experimenta em si mesmo na medida em que ele se torna transparente em sua autoconstituição, ou seja, dizendo isso nos termos de Fichte, ao passo que o sujeito se torna "consciente de sua autonomia e independência de tudo que lhe é exterior"773. Com esse olhar crítico, para além de Peirce e Dilthey, Habermas preconiza que o caminho legítimo para pensar o nexo entre conhecimento e interesse emancipatório é o da compreensão de que a "razão segue um interesse emancipatório do conhecimento, que objetiva a efetuação da reflexão como tal" ${ }^{\text {774 }}$. Nessa linha, ele entende que a base teórica para pensar acerca da "categoria de interesse do conhecimento", na qual se afigura a força emancipadora da reflexão, é o conceito de interesse da razão, proposto por Kant e desenvolvido por Fichte.

O conceito de interesse da razão, segundo a análise de Habermas, emerge na filosofia transcendental de Kant. Para Kant, no geral, a noção de interesse indica o comprazimento que se vincula à representação da existência de um objeto ou de uma ação. E, por expressar uma relação do objeto interessante com a faculdade de desejar, o interesse visa à existência. Com efeito, sob o propósito da elaboração de uma filosofia da razão prática, Kant introduz a distinção entre interesse empírico, o interesse patológico no objeto da ação, e interesse puro, o interesse prático da ação ${ }^{775}$. É com base nessa distinção que ele estabelece o

\footnotetext{
${ }^{770}$ HABERMAS, Conhecimento e interesse, p. 322.

771 Idem, p. 302.

772 Idem, p. 301.

${ }^{773}$ Neste ponto, Habermas se inspira em Hegel e Fichte. Mas ele esclarece que não visa seguir o propósito da Fenomenologia do espírito com vistas ao saber absoluto e ao conceito de ciência especulativa, tampouco o da Doutrina da ciência de Fichte, a unidade da autointuição de um Eu que produz o mundo e a si mesmo absolutamente. A razão fundamental disso, para Habermas, é que a espécie humana não se constitui apenas sob as condições postas por reflexão. Por isso, não é possível conceber a vida como movimento absoluto (incondicionado) de reflexão. (Ver: HABERMAS, Conhecimento e interesse, pp. 314 e 318 ).

774 HABERMAS, Conhecimento e interesse, p. 302.

$775 \mathrm{O}$ interesse empírico é aquele que pressupõe uma necessidade, surge da carência; indica o interesse patológico dos sentidos no objeto da ação agradável ou útil. Em tal caso, a razão aponta apenas para a regra prática (leis morais) de como remediar a necessidade da inclinação. O interesse puro, enquanto interesse prático
} 
valor posicional do conceito de interesse prático puro da razão, na última seção da Fundamentação da metafísica dos costumes, sob o título de "limite extremo de toda filosofia prática", ao tratar da questão sobre a possibilidade da liberdade ${ }^{776}$. Levando essa distinção em conta, Kant concebe que a ação livre (moral) se funda no interesse factual de realizar o ideal de um reino universal de fins em si mesmos (de seres racionais). Ocorre que, para chegar a essa concepção, ele se vê obrigado a atribuir à razão uma "espécie peculiar de causalidade" estranhamente, indeterminável absolutamente a priori (não pode ser explicado a priori), porém verificável na experiência (um factum contingente que reside na experiência) - para determinar a sensibilidade de acordo com seus princípios ${ }^{777}$. Kant concebe que, para a ação moral, a razão conta com um interesse puro, enquanto efeito subjetivo que a lei da razão exerce sobre a vontade mediante o comprazimento no cumprimento do dever, o qual certifica que a razão pura pode ser prática. Enquanto causa da liberdade, o interesse puro pela observância das leis morais constitui um factum $^{778}$ de ordem superior sobre o qual se apóia a certeza da realidade da razão prática pura. Esse factum não é dado na experiência habitual, mas creditado por um sentimento moral. Esse factum remete a uma base da razão que garante somente as condições da realização da razão. Para Kant, essa base escapa ao conhecimento humano justamente porque não se pode atribuir a ela princípios da razão. É digno de nota que o próprio Kant reconhece que o "interesse puramente moral" constitui um conceito limite que articula uma experiência inconcebível, na qual não é a razão que transgride a experiência, mas é a experiência do sentimento moral que viola a razão. Em tal experiência, o que justifica falar de um interesse especulativo da razão é o fato da razão teórica ser colocada a serviço da razão prática "para um conhecimento", quer dizer, contanto que a razão teórica não seja por isso alienada de sua intenção própria de um conhecimento pelo conhecimento. Então, supondo isso, Kant considera que existe um uso legítimo da razão teórica com propósito prático, ao

na razão no bem e não por interesse, produz uma necessidade (desperta uma carência) e indica o comprazimento pelo bem. Naquele, a faculdade de desejar é excitada por uma inclinação sensível na qualidade de desejo que se tornou hábito; neste, ela é determinada por uma inclinação intelectual livre dos sentidos, que se constitui como uma atitude duradoura. No interesse puro, a vontade age sob a determinação de princípios da razão em si mesma: a razão toma interesse imediato pela ação, somente quando a validade máxima dessa ação é um princípio suficiente de determinação da vontade. Ver: KANT, Immanuel. Fundamentação da metafísica dos costumes. Trad. António Pinto de Carvalho. São Paulo: Nacional, 1964, p. 164 (nota 178) e p. 126 (nota). HABERMAS, Conhecimento e interesse, pp. 302-304.

776 KANT, Fundamentação da metafísica dos costumes, pp. 125-129. HABERMAS, Conhecimento e interesse, pp. 304-307.

777 KANT, Fundamentação da metafísica dos costumes, pp. 126-127.

778 A respeito da aplicação da lei de causalidade à vontade enquanto factum, ver: KANT, Immanuel. Crítica da razão prática. Trad. Valerio Rohden. 4. ed. São Paulo: Martins Fontes, 2016, pp. 80-92. 
mesmo tempo em que o interesse prático puro assume o papel de interesse condutor do conhecimento $^{779}$.

Habermas entende, por seu turno, que o conceito de "interesse puramente moral" estoura o quadro lógico-transcendental do sistema kantiano ${ }^{780}$. A razão disso é que a tarefa de Kant no sentido de explicar a liberdade da vontade se revela paradoxal, já que ele define a liberdade pela independência de forças propulsoras empíricas e, ademais, tal explicação só seria possível recorrendo às leis da natureza. Por conseguinte, segundo Habermas, o questionamento sobre a possibilidade da liberdade dá lugar ao embaraço de saber como a razão pura, isto é, o pensamento que não pode conter nada de sensível em si, pode ser prática. O paradoxo decorre do fato que ele introduz um momento de faticidade na própria razão, que é incompatível com as determinações da razão sob condições transcendentais. Contraditoriamente, por um lado, cogita-se que a razão não pode aparecer sob as condições empíricas da sensibilidade; por outro, admite-se que à razão é inerente um impulso - uma inclinação que infunde um sentimento de prazer, cujo efeito é testemunhado apenas de modo contingente e na experiência - para a realização da razão. $O$ interesse puro, no sentido de uma "afecção da sensibilidade por parte da razão" para que surja um interesse em uma ação sob condições morais, expressa a impensabilidade de uma relação de causalidade entre razão e sensibilidade assegurada pelo sentimento moral $^{781}$.

A conclusão de Habermas é que Kant não consegue livrar sua concepção de uso interessado da razão especulativa inteiramente da ambiguidade ${ }^{782}$. Isso porque o sistema de Kant não resolve o problema da unidade de razão teórica, enquanto faculdade teórica para as finalidades do conhecimento, e razão prática, âmbito da razão consoante à moralidade e liberdade. Nessa ambiguidade, por uma parte, Kant postula a unidade da razão para evitar que a aplicação prática da razão teórica conote uma instrumentalização (refuncionalização) posterior de uma faculdade da razão por meio de outra. Por outra, fica patente a falta de unidade da razão, já que os postulados da razão prática permanecem uma "oferta estranha" para a razão teórica. A possível solução para essa ambiguidade, segundo Habermas, requer que o interesse especulativo da razão seja tomado a sério como interesse prático puro e, nisso,

\footnotetext{
${ }^{779}$ HABERMAS, Conhecimento e interesse, pp. 307-308.

${ }^{780}$ HABERMAS, Conhecimento e interesse, p. 309. KANT, Fundamentação da metafísica dos costumes, pp. 128-129.

${ }^{781}$ HABERMAS, Conhecimento e interesse, p. 306.

${ }^{782}$ HABERMAS, Conhecimento e interesse, p. 311. Sobre o "primado da razão prática pura em sua vinculação com a razão especulativa”, ver: KANT, Crítica da razão prática, pp. 194-197.
} 
que a razão teórica perca sua competência independente do interesse da razão. Esse passo, segundo Habermas, é efetuado por Fichte.

Fichte pensa o conceito de interesse da razão, em sua obra Doutrina da ciência, desdobrando-o no sentido de um interesse emancipatório pela autonomia do Eu, operante na própria razão. É com esse desdobramento que ele postula a realização da unidade especulativa e prática da razão. O caminho pelo qual o conceito de interesse da razão se desdobra de Kant a Fichte passa da compreensão do conceito de um interesse pelas ações da vontade livre, instilado pela razão prática, para a compreensão do conceito de um interesse pela autonomia do sujeito inerente à própria razão agente ${ }^{783}$. A perspectiva concebida por Fichte leva em conta que os interesses imiscuídos na defesa dos sistemas filosóficos remetem a uma oposição fundamental entre, de um lado, o interesse idealista da razão pela emancipação e autonomia do Eu e, de outro, o interesse dogmático, preso à representação do mundo exterior (coisas) e às inclinações empíricas dependentes da natureza. Para Fichte, como o princípio do dogmatismo é a crença na autonomia das coisas, o dogmático tem uma "consciência de si dispersa", concebe-se como produto das coisas ao seu redor, como um produto natural. Em sua contraposição ao dogmatismo, Fichte afirma que o problema da posição do dogmático é que, não encontrando a força para a autorreflexão, ele leva uma existência não livre, precisamente porque não é ciente de sua "autoatividade refletida em si mesmo"784.

Para se desfazer das barreiras do dogmatismo à emancipação, Fichte entende que é necessário "antes fazer que o interesse da razão" se torne interesse próprio, tal como um interesse supremo "por nós mesmos", voltado de uma só vez ao discernimento e à libertação do sujeito ${ }^{785}$. Para isso, ele identifica nas operações da razão teórica o trabalho da prática e designa de intuição intelectual o ponto de unidade de ambas ${ }^{786}$. Na concepção de Fichte, a intuição intelectual não se refere a um "ser", mas a um "agir" no qual o Eu (sujeito) se torna ciente de sua autoatividade refletida em si mesmo. A intuição intelectual é o ato da razão que retorna a si mesma, na forma de uma ação refletida (autorreflexão) e infunde no sujeito o "uso interessado da razão" pela emancipação e pelo transparecer do sujeito para si mesmo em seu autoproduzir. "No interesse pela autonomia do $\mathrm{Eu}$, a razão se impõe na mesma medida em que o ato da razão produz como tal a liberdade. A autorreflexão é intuição e emancipação,

\footnotetext{
${ }^{783}$ HABERMAS, Conhecimento e interesse, pp. 302 e 317.

${ }^{784}$ Idem, p. 316.

${ }^{785}$ Idem, pp. 312-313.

${ }^{786}$ Idem, p. 315.
} 
discernimento e libertação da dependência dogmática de uma só vez"787. É relevante notar que, para Fichte, é o fato de o Eu ser penetrado pelo interesse da razão, no qual ele é apanhado pelo afeto para com a autonomia do Eu e o interesse pela liberdade, que vem à tona o comprazimento prático pela realização do ideal de um reino de seres racionais. É o ato da razão refletida, à medida que estabelece a ligação afetiva entre autonomia do Eu e interesse pela liberdade, que torna o primado da razão prática algo fundamental. Diferentemente de Kant, Fichte não concebe o impulso prático puro, a "consciência do imperativo categórico", como uma produção da razão prática, mas como um ato da própria razão, como autorreflexão que faculta ao Eu suprimir a crença nas coisas e crer em sua autonomia "por inclinação"788.

A solução da problemática referente à unidade teórica e prática da razão se apóia na tese de Fichte de que tal unidade decorre de um interesse prático que pertence à própria razão. Sustenta-se com essa tese, essencialmente, a compreensão de que a razão se apreende como razão interessada na efetuação da autorreflexão ${ }^{789}$. Caracteristicamente, a concepção de uso interessado da razão de Fichte conflita com o sentido tradicional de teoria "pura" como "cópia", enquanto perspectiva contemplativa de conhecimento, que separa o processo do conhecimento e os contextos de vida. Conflita porque a compreensão de "uso interessado da razão", se observada à luz do sentido tradicional de teoria "pura", corresponde a um momento estranho à teoria, que se assoma de "fora" e turva a objetividade do conhecimento. Opondo-se a tal separação, Fichte propugna uma compreensão teórica apoiada na identificação da razão teórica com a prática. Essa identificação é assim entendida: o interesse prático da razão, aparecendo como uma qualidade ética de uma vontade de emancipação e um ato originariamente efetuado da liberdade, constitui o pressuposto de toda lógica (conhecimento), para que o ser humano se eleve ao ponto de vista idealista da maioridade e, assim, possa discernir o dogmatismo da consciência natural. Dessa maneira, como um ato da liberdade, esse interesse antecede à autorreflexão tanto como se impõe na força emancipatória da autorreflexão $^{790}$.

O ponto chave da posição de Fichte se refere à compreensão de que a razão unifica na autorreflexão o conhecimento e o interesse emancipatório. Isso ocorre porque, na autorreflexão, o interesse prático entretecido com a razão teórica perde sua "ulterioridade e se

\footnotetext{
${ }^{787}$ HABERMAS, Conhecimento e interesse, p. 316.

${ }^{788}$ Idem, p. 314.

${ }^{789}$ Idem, p. 321.

${ }^{790}$ Idem, pp. 312-313 e 317.
} 
torna constitutivo para o conhecimento e a ação em igual medida"791. Ele concebe que, na autorreflexão, a organização da razão é imediatamente prática, visto que ela se encontra sob o propósito prático de um sujeito que crê em sua autonomia por inclinação. Na verdade, na forma da autorreflexão, vem à tona a dependência de princípio da razão especulativa em relação à prática, à medida que a prática fornece o "padrão" para a teórica. Fichte chama a atenção para o correto entendimento dessa dependência. Pois, essa dependência não implica na corrupção da força cognitiva da razão pelo interesse emancipatório da razão, tampouco na visão de que esse interesse permanece exterior ao conhecimento (no plano da ação instrumental e da comunicativa). Reiteradamente, Fichte afirma que conhecimento e ação estão fundidos em um único ato. Como no processo de autorreflexão a razão se encontra ao mesmo tempo sob o interesse pela razão, entende-se que um conhecimento em virtude do conhecimento coincide com o interesse pela maioridade (autonomia do sujeito); afinal, a "efetuação da reflexão se sabe como movimento de emancipação" ${ }^{792}$. Um ato de autorreflexão, que "muda uma vida", é de uma só vez um movimento de discernimento e emancipação da crença suportada apenas pelos objetos (dogmatismo) ${ }^{793}$.

Enfatizando, no ato da autorreflexão, o sujeito experimenta em si mesmo a força emancipadora da reflexão. O entrelaçamento de conhecimento e interesse emancipatório coincide com a "atividade" da reflexão, posto que somente o Eu que transparece na intuição intelectual como sujeito e que se põe a si mesmo conquista a autonomia. É o movimento da reflexão que faculta a crítica às estruturas, estejam elas no campo das expectativas cognitivas, morais, estéticas ou da vida social, que intentam fazer-se passar por representações naturais. $\mathrm{Na}$ autorreflexão, já que a razão se encontra sob o interesse pela razão, "um conhecimento em virtude do conhecimento coincide com o interesse pela maioridade; pois a efetuação da reflexão se sabe como movimento de emancipação" ${ }^{\text {"794 }}$. É de tal modo que Fichte concebe que o entrelaçamento de conhecimento e interesse emancipatório coincide com a "atividade" da reflexão, com a atividade que leva o sujeito a um ponto de vista do qual resulta a identidade entre a razão e a vontade de razão.

Do entrecruzamento da compreensão das investigações metodológicas das ciências segundo Peirce e Dilthey e do conceito de interesse da razão conforme Kant e Fichte, em sua abordagem epistemológica, Habermas preconiza o entendimento da "crítica" (teoria

\footnotetext{
${ }^{791}$ HABERMAS, Conhecimento e interesse, p. 318.

${ }^{792}$ Idem, pp. 301-302.

${ }^{793}$ Idem, pp. 316 e 321.

${ }^{794}$ Idem, p. 301-302.
} 
crítica) como unidade de conhecimento e interesse. O núcleo desse entendimento é a categoria denominada por ele de "interesse condutor do conhecimento". Para Habermas, o conceito de "interesse" designa "as orientações basilares que se prendem a determinadas condições fundamentais da reprodução possível e da autoconstituição da espécie humana, a saber, trabalho e interação"795. O conceito de interesse condutor do conhecimento se refere à condição de objetividade da experiência possível que pré-forma, conforme os critérios do contexto de vida objetivo do qual procede a estrutura das direções de pesquisa nas ciências nomológicas ou hermenêuticas, um respectivo sentido (da validade de enunciados) determinado dos próprios modos de conhecimento ligados ao método. A função desse conceito é prevenir a redução naturalista do quadro das ciências a um contexto de vida, ou seja, evitar a acepção de que o conhecimento se reduz a determinações empíricas que só tem função nos contextos da ação instrumental, caso das ciências empírico-analíticas segundo Peirce, ou da interação simbolicamente mediada, caso das ciências hermenêuticas segundo Dilthey. O conceito de interesse condutor do conhecimento faz a "mediação da história natural da espécie humana com a lógica de seu processo de formação",796, mas isso não implica em utilizá-lo, segundo Habermas, para reduzir a lógica da pesquisa a uma base natural qualquer. É importante considerar que essas orientações basilares não miram a satisfação de carências empíricas imediatas, mas vislumbram a solução (no sentido de tentativa) de problemas sistemáticos. Tal é assim, segundo Habermas, porque os interesses condutores do conhecimento não se deixam determinar "como" problemas definidos por eles no interior de um quadro metodológico, mas se medem pelos problemas consoantes à reprodução da vida que são objetivamente levantados e respondidos pela forma cultural da existência ${ }^{797}$.

Em contraposição à tendência positivista de reduzir as ciências a determinações empíricas, Habermas procura reabilitar a dimensão de autorreflexão das ciências, mostrando que os interesses técnico e prático do conhecimento só podem ser concebidos como interesses condutores de conhecimento a partir do nexo com o interesse emancipatório do conhecimento da reflexão racional ${ }^{798}$. Em vista essa reabilitação, Habermas argumenta que os processos de pesquisa metódica não podem caracterizar de modo suficiente a reprodução da vida social sem recorrer às condições culturais dessa reprodução, a um processo de formação que "já

\footnotetext{
795 HABERMAS, Conhecimento e interesse, p. 299.

796 Idem, p. 299.

${ }^{797}$ Idem, pp. 291 e 299-300.

${ }^{798}$ Idem, p. 302.
} 
implica conhecimento em dupla forma" (categorias de saber) ${ }^{799}$, e inclui processos de aprendizagem e de entendimento atravessados pela experiência da reflexão. A rigor, os processos de pesquisa metódica são parte do processo de formação abrangente da história da espécie, somente em relação ao qual a espécie se constitui a si mesma como sujeito. Com isso, ele afirma que os interesses técnico e prático do conhecimento respectivos às ciências empírico-analíticas e hermenêuticas não podem ser concebidos em um quadro de referências biológicas cumprindo a mera função de reprodução e conservação da vida. Bem mais que isso, por estarem presos no plano antropológico às condições existenciais do trabalho e interação, eles devem ser entendidos como interesses condutores do conhecimento que transcorrem no interior de uma história da espécie compreendida como processo de formação, no qual o interesse da razão pela emancipação ("inato à razão"800) antecede o conhecimento, tanto quanto só se realiza por força do conhecimento ${ }^{801}$.

O referido nexo decorre de que a "experiência de reflexão se articula substantivamente no conceito de processo de formação; em termos de método, ele leva a um ponto de vista do qual resulta livremente a identidade entre a razão e a vontade de razão" ${ }^{802}$. Essa reabilitação implica em reconhecer o significado sistemático do conceito de autorreflexão desdobrado por Fichte - a ação interessada da razão pela emancipação que se torna constitutiva do conhecimento e da ação - para a categoria de interesse condutor do conhecimento e para o processo de formação da espécie. $\mathrm{O}$ entrelaçamento de conhecimento (categorias de saber correspondentes ao processo de aprendizagem cumulativo e às interpretações mediadoras das tradições) e interesse (interesses dirigidos à ação instrumental e à comunicativa) se dá com aquela categoria de "ações" emancipatórias que coincidem com a "atividade" da reflexão.

O movimento da reflexão unifica razão e interesse, visto que nele "o processo de conhecimento coincide com um processo de formação" ${ }^{803}$. Para Habermas, não é possível conceber o processo de formação como movimento absoluto de reflexão (incondicionado), pois ele depende das condições contingentes da natureza subjetiva ("condições de uma socialização individuadora de indivíduos em interação") e da natureza objetiva (condições do 'metabolismo' dos que agem comunicativamente com um entorno a ser disponibilizado

\footnotetext{
${ }^{799}$ HABERMAS, Conhecimento e interesse, pp. 300 e 320.

${ }^{800}$ Idem, p. 302.

801 Idem, p. 318.

802 Idem, p. 301.

${ }^{803}$ Idem, pp. 318-319.
} 
tecnicamente" $)^{804}$. Na verdade, segundo Habermas, só é possível certificar-se metodologicamente dos interesses condutores do conhecimento das ciências da natureza e do espírito depois de pisar a dimensão de autorreflexão, na qual transparece a efetuação da reflexão como movimento de emancipação. O nexo fundamental de conhecimento e interesse aparece depois que a metodologia das ciências é desdobrada "à maneira da experiência da reflexão", como "dissolução crítica" da autocompreensão objetivista das ciências que escamoteia o interesse "da atividade subjetiva nos objetos pré-formados do conhecimento possível" ${ }^{\prime 805}$.

Para finalizar essa exposição da abordagem epistemológica de Habermas, baseada na tese da unidade entre interesse emancipatório do conhecimento e razão crítico-reflexiva, cabe apontar o elemento central dessa abordagem que Apel incorpora em sua semiótica transcendental. Fundamentalmente, esse elemento diz respeito à distinção habermasiana dos três interesses condutores do conhecimento subjacentes às ciências possíveis na atualidade. $\mathrm{Na}$ verdade, seguindo a Habermas em Conhecimento e interesse, a princípio, Apel reintera a tese de que o interesse das ciências naturais empírico-analíticas (science), o interesse das ciências humanas hermenêuticas (ciências do espírito) e o interesse da teoria crítica configuram condições transcendentais da constituição objetual de cada uma dessas ciências. Ele concorda inclusive com a observação de que tais interesses se colocam em relação uns com os outros ${ }^{806}$. Então, em conformidade com a distinção habermasiana, em primeiro lugar, Apel reafirma que o elemento que subjaz como contorno transcendental, no tocante à constituição objetual da science empírico-analítica, é o interesse cognitivo diretor pela disposição técnica de processos objetivados e controlados de maneira bem-sucedida. $\mathrm{O}$ aspecto de destaque relativo ao contorno transcendental do interesse cognitivo das ciências da natureza é que, com a possibilidade de checagem experimental, esse interesse garante a um só tempo a continuidade entre saber científico e avaliação técnica ${ }^{807}$.

Em segundo lugar, pensando junto com Habermas, Apel pontua que o interesse cognitivo que subjaz como contorno transcendental às ciências humanas hermenêuticas, é o interesse pelas interpretações da realidade, tendo em vista a conservação e ampliação da intersubjetividade do acordo mútuo possível e orientado para a ação. Para Apel, vale o entendimento de que essas ciências são direcionadas "à abertura possível de sentido e à

\footnotetext{
${ }^{804}$ HABERMAS, Conhecimento e interesse, p. 319.

${ }^{805}$ HABERMAS, Conhecimento e interesse, p. 321.

${ }^{806}$ APEL, Transformação da filosofia, v. II, p. 156; Transformation der philosophie, Band II, p. 136.

${ }^{807}$ APEL, Transformação da filosofia, v. II, pp. 156-157; Transformation der philosophie, Band II, p. 136. HABERMAS, Conhecimento e interesse, p. 298.
} 
checagem de hipóteses de sentido em meio à experiência de comunicacional"808. Nesse ponto, Apel se coloca de acordo com a equiparação estabelecida por Habermas do interesse cognitivo subjacente às ciências hermenêuticas com o "interesse cognitivo prático". Para Habermas, a "práxis" (prático) diz respeito à comunicação e interação político-moralmente relevante entre as pessoas nas formas de vida factuais e diversas; ela se define por oposição às operações valorativamente neutras da técnica, repetíveis por sujeitos cambiáveis. O aspecto fundamental é que a interação político-moralmente, na verdade, já é pressuposta desde o início pela lógica da ciência experimental ${ }^{809}$.

$\mathrm{Na}$ linha da distinção supramencionada, em terceiro lugar, Apel recupera a compreensão habermasiana consoante ao interesse cognitivo diretor da teoria crítica, porém, em um passo subsequente crítico, põe em discussão tal compreensão. Na interpretação de Apel, o programa sintético da "Escola de Frankfurt" visa compatibilizar o intento pósontológico de uma filosofia a um só tempo cognitivo-crítica e engajada (do ponto de vista prático) com o anseio de uma ciência social ideológico-crítica. Ainda segundo essa interpretação, ele entende que, para caracterizar esse programa, Habermas recorre ao “interesse cognitivo emancipador”, intencionando revelar o direcionamento sócio-político e a pretensão de mediatização científica entre teoria e prática que a teoria crítica fomenta ${ }^{810}$. Contudo, ante essa autocompreensão da teoria crítica, Apel julga necessário enfrentar o problema da suspeição que se liga à fundação da concepção da teoria crítica.

Esse problema levanta a dúvida acerca da possibilidade de admitir a identificação do interesse cognitivo emancipador na relação entre filosofia e ciências sociais. Em uma situação diversa a essa suspeita, conforme salienta Habermas, considera-se que é impossível identificar o interesse cognitivo que dirige as ciências naturais empíricas (disponibilização técnica) com o interesse da filosofia, que reflete sobre as condições de possibilidade das ciências. Por seu lado, reforça essa suspeição o fato de que, do ponto de vista de uma autocompreensão meramente cientificista das ciências sociais modernas, há a dificuldade de discernir de que modo as ciências sociais podem ter em comum seu interesse cognitivo diretor

\footnotetext{
${ }^{808}$ APEL, Transformação da filosofia, v. II, pp. 156-157; Transformation der philosophie, Band II, pp. 136137. HABERMAS, Conhecimento e interesse, p. 299.

${ }^{809}$ APEL, Transformação da filosofia, v. II, p. 157; Transformation der philosophie, Band II, p. 137. Para Habermas, "No contexto da ação comunicativa, a linguagem e a experiência não aparecem sob as condições transcendentais da ação. O que tem um valor posicional transcendental é a gramática da linguagem corrente, que ao mesmo tempo regula os elementos não linguísticos de uma práxis de vida exercida. Uma gramática de jogo de linguagem associa símbolos, ações e expressões; ela define esquemas de concepção do mundo e de interações. (...) A realidade se constitui no quadro de uma forma de vida de grupos comunicantes, organizada em linguagem corrente" (cf. HABERMAS, Conhecimento e interesse, pp. 294-295).

${ }^{810}$ APEL, Transformação da filosofia, v. II, pp. 157-158; Transformation der philosophie, Band II, p. 137.
} 
com a filosofia, e tanto mais no sentido de um engajamento emancipador. Em torno dessa suspeita, subsiste a dúvida de saber se o anseio empírico das ciências sociais modernas deve ser abandonado ou não em favor das construções dialéticas de uma filosofia social engajada. Assim, enfrentar essa suspeição, segundo Apel, é um passo primeiro necessário à autocompreensão da teoria crítica ${ }^{811}$.

\subsection{Educação enquanto ciência social da mediação entre teoria e práxis em vista do interesse cognitivo emancipador}

A originalidade da posição de Apel no tocante à relação entre ciência e emancipação política vem à tona em sua tentativa de resposta ao problema da suspeição que se liga à fundação da concepção da teoria crítica. Ante a autocompreensão meramente cientificista das ciências sociais modernas, subsiste a dificuldade de discernir de que modo as ciências sociais podem ter seu interesse cognitivo diretor em comum com a filosofia, sobremaneira no sentido de um engajamento emancipador. A fim de superar a referida suspeição, inicialmente, Apel procura esclarecer o estatuto epistemológico do interesse de disposição das ciências sociais estilizadas de maneira empírico-analítica ${ }^{812}$. Para ele, essas ciências representam o âmbito da ciência social que visa à elucidação das causas (Ursachen) ${ }^{813}$ relativas aos modos de comportamento humano, por exemplo, no campo médico-psicológico, econômico, político e educacional. Em seu anseio empírico, essas conotam uma "elucidação" (Erklären), no sentido do método do "Explicar" das ciências da natureza que trata dos interesses cognitivos dos juízos de objetivação sobre a realidade.

O anseio empírico dessas ciências sociais decorre da necessidade de responder ao problema de uma "elucidação" tecnicamente aplicável do comportamento humano, já que o saber hermenêutico (Verstehen, enquanto método do "Compreender" das ciências do espírito) é inaplicável ${ }^{814}$. De tal maneira, a ciência social empírica se defronta com a difícil tarefa de abordar de modo suficiente a compreensão da experiência sócio-comunicativa através da

\footnotetext{
${ }^{811}$ APEL, Transformação da filosofia, v. II, pp. 157-158; Transformation der philosophie, Band II, pp. 137138.

${ }^{812}$ APEL, Transformação da filosofia, v. II, pp. 158-159; Transformation der philosophie, Band II, p. 138.

${ }^{813}$ APEL, Transformação da filosofia, v. II, p. 160; Transformation der philosophie, Band II, p. 139.

${ }^{814}$ A inaplicabilidade do compreender decorre de que ele, enquanto saber "praticamente efetivo" (cf. HABERMAS, Conhecimento e interesse, pp. 298 e 299), já pressupõe desde o início que todos os seres humanos em um processo de acordo mútuo (entendimento) agem racionalmente; além disso, ao contrário do "elucidar causal-analítico", o compreender não pode ser falsificado, senão evidenciado como inadequado à aplicação (cf. APEL, Transformação da filosofia, v. II, p. 159; Transformation der philosophie, Band II, p. $139)$.
} 
intelecção de símbolos e intenções de sentidos (entrevistas, questionários, coisas do gênero) como se tratasse uma descrição ("elucidação casual”) de processos objetivados. Apel entende que, do ponto de vista do método, a ciência social empírica soluciona o problema da elucidação mediante a estratégia de suspender, na medida do possível, o fenômeno da comunicação e interação subjetiva em favor da relação cognitiva entre sujeito e objeto, pressuposta nas ciências empírico-analíticas. Procedendo assim, à medida que objetificam o ser humano e seu comportamento, no sentido de processos semi-naturais, essa ciência social alcança, segundo Apel, ainda que em proporções limitadas, um entendimento analítico dos modos de comportamento humano de considerável relevância. É relevante porque, como um saber aplicável de maneira prognóstica, a elucidação alcançada nas ciências sociais empírica possibilita, assim como nas ciências naturais, uma disposição técnica do campo objetual elucidável ${ }^{815}$.

Por sua vez, Apel vê a solução adotada pela ciência social empírica como problemática. Desde um olhar ampliado, segundo Apel, é possível presumir que a teoria crítica não vê na possibilidade das ciências sociais empírico-analíticas algo que se deva ampliar ao máximo. E alguns motivos respaldam essa visão ${ }^{816}$. Primeiro, há o receio de que tal ampliação resulte na possibilidade de substituir a dominação da natureza pela dominação do homem sobre o homem. Não se pode menosprezar o fato de que o interesse de disposição técnica dessas ciências abre espaço para a potenciação da dominação do homem sobre o homem. Segundo, a teoria crítica atribui à sociologia outras tarefas, que a colocam em continuidade não com as ciências sociais empírico-nomológicas e sim com a reflexão filosófica em sua intenção prático-social. Por seu turno, essas tarefas concernem à reflexão científica sobre as consequências das ciências sociais empírico-nomológicas, assim como à tentativa de impedir essas consequências. Terceiro, a pressuposição de uma abstração da natureza subjetiva na composição teórica das ciências sociais empiricamente nomológicas que lhe é própria já carece de reflexão crítica. Na prática, essas ciências precisam impedir que os objetos humanos de sua construção teórica tenham reações que tornem a teoria inaplicável. Como resultado, essa ciência social elucida um saber aplicável, porém não capacita para a autorreflexão crítica. No geral, essa visão parece apontar na direção de uma possível incompatibilidade epistemológica entre o interesse de disposição técnica da ciência social empírica e a reflexão filosófica na teoria crítica com uma intenção prática (emancipadora).

\footnotetext{
${ }^{815}$ APEL, Transformação da filosofia, v. II, p. 160; Transformation der philosophie, Band II, p. 139.

816 APEL, Transformação da filosofia, v. II, pp. 160-161; Transformation der philosophie, Band II, p. 140.
} 
Com efeito, a despeito dessa visão, Apel se propõe a superar tal problemática, defendendo a tese da complementaridade entre esses interesses cognitivos.

No entender de Apel, o que parece mais problemático quanto a tal solução é que a abstração das pressuposições pragmáticas da comunicação nas situações de pesquisa potencializa o risco de uma ciência "manipuladora" 817 . É problemático, em primeiro lugar, o fato de que tal solução esteja apoiada sob a proibição imposta pela tradição da semântica lógica de linguagens formalizadas em relação à dimensão hermenêutico-pragmática da linguagem, à dimensão do logos da autorreferência de atos de fala envolvidos numa situação. Ressaltando, tal solução implica no bloqueio daquelas pressuposições que os cientistas hermenêuticos consideram como referência inicial e ponto de chegada de suas operações cognitivas. Na perspectiva da tradição da semântica, a linguagem natural, assim como a dimensão reflexiva do discurso vinculada a ela, com suas metáforas e elementos dependentes de contextos, é a fonte de antinomias e, ademais, apenas conduz a percepções ontológicometafísicas ou de ordem psicológica, consideradas irrelevantes para a teoria filosófica da argumentação. À vista disso, segundo Apel, a solução adotada pela ciência empírica se embasa em estreitamento do conceito de logos a partir de divisão problemática entre as "formas" do logos. Esse estreitamente existe porque a precisão máxima do tipo de racionalidade da ciência da natureza e da técnica axiologicamente neutra depende da suspensão, diferentemente do tipo de racionalidade hermenêutico-pragmática referida ao discurso e à linguagem natural, da autorreflexão referida a uma situação de comunicação ${ }^{818}$. O modo pelo qual algo é convencionado como racional ou irracional, efetivamente, atesta a existência desses dois tipos de racionalidade. Conforme a perspectiva da tradição da semântica lógica de linguagens formalizadas aplicadas à relação técnico-científica entre sujeito-objeto, o irracional indica uma objetivação ou controle técnico "ainda por fazer". Ao mesmo tempo, é racional o que escapa à dimensão subjetivo-pragmática do discurso e da linguagem natural, que constitui, com suas metáforas e elementos dependentes de contextos, a fonte de antinomias ${ }^{819}$.

Em segundo lugar, para Apel, a consequência dessa abstração também é problemática. Pois, ela pode ocasionar, mesmo em proporções limitadas, a objetivação da relação de intersubjetividade nas ciências sociais (como em ciência política, psicologia,

${ }^{817}$ APEL, Transformação da filosofia, v. II, p. 162; Transformation der philosophie, Band II, p. 141.

${ }^{818}$ APEL, O desafio da crítica total da razão e o programa de uma teoria filosófica dos tipos de racionalidade. In: Novos Estudos - CEBRAP, pp. 70-71.

${ }^{819}$ APEL, O desafio da crítica total da razão e o programa de uma teoria filosófica dos tipos de racionalidade. In: Novos Estudos - CEBRAP, pp. 70-71. 
sociologia e economia) $^{820}$. À medida que a dimensão reflexiva da argumentação é suspensa, há o risco de uma manipulação baseada na elucidação, isto é, de uma potenciação da dominação do ser humano sobre o homem, possivelmente imposta por meio de "repressões e tabuizações autoritárias de palavras e ações", em suma, "fixações ideológicas de autoalienação de seres humanos socializados" $" 221$.

Como contraponto à solução nos moldes de uma elucidação encampada pela ciência social, Apel sustenta a tese de que o interesse cognitivo da teoria crítica, com o caráter de um corretivo emancipador, deve complementar hermeneuticamente a composição teórica da ciência social empírica. O significado reparador dessa complementação, em certa medida, equivale uma espécie de antídoto crítico ante a possibilidade de uma ciência social a serviço da tecnocracia, em sua referência prática, convertida em pura tecnologia de adestramento social ${ }^{822}$. Para ele, a combinação de elucidações semi-causais da ciência social empírica com o "Compreender" hermenêutico caracteriza o procedimento metódico da crítica ideológica ${ }^{823}$, enquanto crítica social engajada. Nesse ponto, é preciso ter em conta que, em razão do projeto de retranscendentalização da filosofia vislumbrado por Apel, essa tese não significa apenas o passo metodológico no caminho complementário dos âmbitos do saber, até então separados em função dos seus distintos interesses cognitivos, a saber, o processo de aprendizagem acumulativo em vista da aplicação instrumental (ciências empírico-analíticas) e as interpretações mediadoras da tradição (ciências humanas).

Nesse ponto, para esclarecer o teor relativo à defesa de tal complementaridade, é fundamental considerar o transfundo em relação ao qual essa tese se vincula dentro do programa teórico de "transformação da filosofia" de Apel. Vale salientar que, no texto “Ciência como emancipação?" (de 1969), a argumentação de Apel quanto à tese de uma complementação hermenêutica no sentido de um "movimento corretivo" 824 do ponto de vista prático-social, no âmbito da ciência social empírica, é apenas ligeiramente esboçada. No caso, essa argumentação aí aparece prenunciando o contorno de um projeto filosófico que ele concebe, processualmente, em vista de uma versão de teoria crítica que, pressupondo a complementaridade dos tipos de racionalidade e dos interesses de conhecimento, vislumbra oferecer uma alternativa teórica ao problema da "crítica total da razão". Na arquitetônica da obra de Apel, a tese da complementaridade constitui o núcleo do que Apel denomina de

\footnotetext{
${ }^{820}$ APEL, Transformação da filosofia, v. II, p. 159; Transformation der philosophie, Band II, pp. 138-139.

${ }^{821}$ APEL, Transformação da filosofia, v. II, p. 295; Transformation der philosophie, Band II, p. 262.

${ }^{822}$ APEL, Transformação da filosofia, v. II, p. 162; Transformation der philosophie, Band II, p. 142.

${ }^{823}$ APEL, Transformação da filosofia, v. II, p. 294; Transformation der philosophie, Band II, p. 261.

${ }^{824}$ APEL, Transformação da filosofia, v. II, p. 160; Transformation der philosophie, Band II, p. 139.
} 
"programa de uma teoria filosófica dos tipos de racionalidade", em que visa a oferecer uma alternativa de resposta ao problema da "crítica total da razão".

O ponto de partida de Apel, em sua teoria filosófica dos "tipos de racionalidade", é a análise da tendência atual no campo epistemológico-filosófico de "crítica da razão". Na opinião de Apel, essa tendência de crítica da razão e do logos da ciência se desenvolve em três direções. Em uma primeira, o dístico "crítica total da razão" remete ao fenômeno complexo, em moda, no pensamento contemporâneo sobre um questionamento ou transcender da modernidade pela pós-modernidade. Para Apel, alguns pensadores se destacam dentro dessa perspectiva, tais como, Nietzsche, Heidegger, pós-estruturalistas franceses (Foucault, Derrida), Richard Rorty, Horkheimer e Adorno (por conta do pessimismo em relação à reconstrução da "dialética do Iluminismo"). A segunda direção diz respeito à "autocrítica da razão", exemplarmente representada por Kant, sendo reivindicada como tarefa permanente da filosofia. A terceira é a crítica da forma de racionalidade científica dominante na modernidade, na qual Apel se enquadra. Nessa perspectiva, Apel julga ter alcançado o diferencial de fazer essa crítica partindo de uma filosofia hermenêutico-pragmática, no sentido de uma racionalidade intersubjetivamente prescritiva contida no discurso argumentativo, que permite ampliar o conceito de logos da ciência mediante a suplementação do tipo lógico-formal e matemático de racionalidade (interesses cognitivos dos juízos de objetivação sobre a realidade; "Erklären" qua método do "Explicar" das ciências da natureza) com o tipo de racionalidade do discurso ("Verstehen" qua método do "Compreender" das ciências do espírito). Essa ampliação se baseia, tal como preconizada por Apel, na tese da complementaridade entre os tipos de racionalidade.

Apel concebe a tese da complementaridade dentro de uma relação de especificidade e independência entre os tipos de racionalidade. É importante ter esses aspectos em conta, pois eles desdobram implicações fundamentais à compreensão de Apel, seja em relação à questão da entre teoria e prática, seja em relação ao sentido do interesse cognitivo pela emancipação. Pois bem, para ele, as formas do logos não são redutíveis umas às outras, nem mesmo no futuro; elas devem subsistir umas ao lado das outras ${ }^{825}$. À vista disso, ele concebe essa complementaridade como uma ampliação do conceito de razão, porquanto que incorpora ao logos da ciência a dimensão reflexiva da racionalidade do logos hermenêutico, antes abstraída em prol da objetividade cientificista do programa da ciência nomológica única.

${ }^{825}$ APEL, O desafio da crítica total da razão e o programa de uma teoria filosófica dos tipos de racionalidade. In: Novos Estudos - CEBRAP, p. 79. 
$\mathrm{O}$ viés que marca essa integração reconstrutiva da racionalidade do discurso, amoldada à orientação de retranscendentalizar a reflexão filosófica, é a pretensão de tornar a linguagem natural em uma "metalinguagem pragmaticamente última de toda construção linguística assim como da objetivação lógica e da formalização de argumentos" ${ }^{\text {826 }}$. Nisso, vê-se a peculiaridade da complementação hermenêutica proposta por Apel. Pois, ela ultrapassa o uso factual da linguagem e o autoentendimento factual de formas sociais de vida. Ela se liga ao trabalho da reflexão, enquanto atividade própria da racionalidade do discurso filosófico, interessado em alcançar o jogo de linguagem ideal, que contém os elementos não-contingentes da préestrutura do ser-no-mundo capaz de compreensão ${ }^{827}$. O resultado dessa busca, via reflexão transcendental, é o que Apel designa de racionalidade do discurso argumentativo, uma racionalidade simultaneamente referida à história (sociedade) e à idealização in the long run da vida racional.

A "âncora" da reflexão transcendental de Apel, por assim dizer, é a pressuposição normativa transcendental-hermenêutica do acordo mútuo ilimitado presente na racionalidade do discurso argumentativo. Nesse ponto, faz-se necessário reiterar aqui quanto ao teor dessa pressuposição, equivalente aos "princípios da razão ou logos", e apontar sua implicação no tocante à problemática da mediação entre teoria e prática (ética), pois é por tal viés que Apel trata da educação em “Ciência como emancipação?”. A investigação sobre os critérios de validade do pensar e agir humanos constitui um dos focos temáticos da proposta filosófica de Apel. Na perspectiva dessa investigação, os "princípios da razão ou logos" constituem os critérios normativos de reconstrução racional dos processos de aprendizagem relacionados à cultura $^{828}$. A este tipo de critérios Apel chama "transcendentais". São elementos transcendentais, segundo Apel, as quatro pretensões de validade da fala (sentido, validade, verdade e correção normativa), a situação ideal de fala e o status do discurso em sua relação com a comunicação. Vale ressaltar novamente, na compreensão de Apel, esses elementos são transcendentais, fundamentalmente, porque não podem ser negados sem incorrer em contradição pragmática (performativa), nem podem ser demonstrados sem cair em raciocínio circular (petitio principii). Cumpre à filosofia transcendental antecipar tais elementos (os transcendentais), descobrindo nas regras pragmático-universais da comunicação um núcleo transcendental normativo não empírico, que funcione como base segura do saber. A função

\footnotetext{
${ }^{826}$ APEL, O desafio da crítica total da razão e o programa de uma teoria filosófica dos tipos de racionalidade. In: Novos Estudos - CEBRAP, p. 70.

${ }^{827}$ Idem, pp. 71 e 75.

${ }^{828}$ Idem, p. 71.
} 
"antecipativa" da filosofia se mostra na medida em que ela reconstrói, reflexivamente, o núcleo peculiar do saber que, subtraído ao falibilismo de todo conteúdo da experiência, não se limita a universalizar teorias empíricas ${ }^{829}$. Enfim, essas pretensões perfazem uma ética mínima relativa aos pressupostos do discurso argumentativo. Agrega-se também a esses critérios a pressuposição de que essas exigências de validade, exceto a de veracidade, são passíveis de cumprimento racional, embora raramente de modo fático, mediante o auxílio do discurso argumentativo ${ }^{830}$.

Aclarando um pouco mais, esses critérios, enquanto pressuposições concernentes a toda argumentação, valem como princípios de fundamentação última. Pois eles não podem ser contestados sem autocontradição performativa e, precisamente por isso, não podem ser fundamentados sem círculo (petitio principii) ${ }^{831}$. Nesse marco normativo, Apel defende a ideia de que o critério da não-autocontradição performativa (pragmática), quer dizer, a exigência de evitar enunciados em que o interlocutor simultaneamente nega e suprime as exigências de veracidade e verdade, concerne a um critério de uma fundamentação última da racionalidade do discurso argumentativo ${ }^{832}$. Frisando, Apel caracteriza esses princípios como "pressuposições de fundamentação última da argumentação", peculiarmente, "suficientes

\footnotetext{
${ }^{829}$ CORTINA, Razón comunicativa y responsabilidad solidaria: ética y política em K.-O. Apel, 138-140.

${ }^{830}$ APEL, Semiotica filosófica, p. 258. APEL, O desafio da crítica total da razão e o programa de uma teoria filosófica dos tipos de racionalidade. In: Novos Estudos - CEBRAP, p. 71. HABERMAS, Teorías de la Verdad. In: Teoría de la acción comunicativa: pp. 113-158 (para uma síntese das pretensões de validade, cf. p. 124).

${ }^{831}$ APEL, O desafio da crítica total da razão e o programa de uma teoria filosófica dos tipos de racionalidade. In: Novos Estudos - CEBRAP, p. 71. Em seu texto sobr a teoria da verdade (cf. APEL, Teoría de la verdad y ética del discurso, pp. 46-63. APEL, Fallibilismus, Konsenstheorie der Wahrheit und Letztbegründung. In: Philosophie und Begründung, pp. 125-137), Apel procura compatibilizar o interesse de uma teoria criteriologicamente relevante da verdade (no caso, a teoria consensual da verdade procedente de Peirce) com as posições teóricas do falibilismo e da fundamentação última (defendida por ele). Sobre a tematização das dificuldades metodológicas e criteriológicas da teoria metafísico-ontológica da verdade como correspondência (por supor ingenuamente o ajuizamento externo da relação de conhecimento sujeito-objeto), da limitada relevância criteriológica da teoria fenomenológica da verdade como evidência (por pressupor a interpretação linguística dos fenômenos válida intersubjetivamente como base da fundamentação filosófica última) e, por fim, da teoria semântica da verdade de Tarski ("nova fundamentação da teoria da correspondência").

${ }^{832}$ APEL, O desafio da crítica total da razão e o programa de uma teoria filosófica dos tipos de racionalidade. In: Novos Estudos - CEBRAP, pp. 70-71. Apel alerta reiteradamente quanto aos mal-entendidos em relação à tese da fundamentação última que ele tem proposto Para Apel, essa controvérsia decorre de não distinguir a fundamentação própria do estilo da racionalidade lógica formal-abstrata, em que a exigência de consistência ocorre por derivação de axiomas (derivação de algo a partir de algo, na dedução ou indução) e significa a proibição da contradição proposicional "a e não-a", de uma fundamentação última, decorrente da dimensão reflexiva da linguagem, na qual a exigência de autoconsistência, diferentemente, não deriva da contradição proposicional e sim da proibição de autocontradição performativa. Por autorreflexão, a razão chega a essas condições necessárias do argumentar, aos princípios da própria razão que conduzem à argumentação inteligível enquanto portadora de sentido; procedendo assim, a razão alcança aquilo que é pressuposto em toda fundamentação lógica objetiva, portanto, aquilo que fundamenta ultima e validamente o pensar e agir humanos.
} 
tanto da razão teórica quanto da prática" (ética) ${ }^{833}$. Isso se deve ao fato de que ele atribui a esses princípios a função de realizar a mediação entre teoria e prática, considerando que ao mesmo tempo esses princípios, do lado da razão teórica, constituem o pressuposto transcendental de toda composição teórica da ciência e, do lado da razão prática, perfazem o "aquém" normativo (pressuposição ética intranscendível do discurso) que deve ser respeitado em todo argumentar que pretenda ter sentido e validade intersubjetiva. Para Apel, mesmo o "cientista natural", que no âmbito do seu logos faz do mundo objeto de uma explicação dos fatos valorativamente neutra, à medida que é membro de uma comunidade de compreensão e, de tal modo, trava uma relação "não objetivante com o mundo de um outro (Mitwelt)" -, implicitamente, já tem "reconhecido de antemão determinadas normas morais, como a da formação não-coercitiva de consenso entre membros de iguais direitos" ${ }^{\text {834 }}$.

Nesse ponto, a tese da complementaridade dos tipos de racionalidade chama a atenção para a seguinte circunstância: o $\operatorname{logos}$ da ciência da natureza e da técnica axiologicamente neutra da relação sujeito-objeto "pressupõe o logos hermenêutico da compreensão intersubjetiva e, simultaneamente a este, também o logos de uma ética da comunidade daqueles que investigam a verdade" ${ }^{835}$. Na verdade, Apel desdobra o significado dessa função complementar, porquanto que considera que simultaneamente ao logos hermenêutico, em virtude de sua especificidade referente a conter os critérios normativos de reconstrução racional dos processos de aprendizagem relacionados à cultura ${ }^{836}$, o $\operatorname{logos}$ técnico-científico pressupõe também "o logos de uma ética da comunidade daqueles que investigam a verdade" ${ }^{\prime 837}$. Nessa circunstância transparece a independência e a especificidade do logos hermenêutico como pressuposição e complemento do logos técnico-científico axiologicamente neutro da relação sujeito-objeto, no sentido da compreensão intersubjetiva acerca dos fundamentos e das exigências de validade da argumentação. Aí, reconhecer a função complementar dos pressupostos hermenêuticos das ciências naturais e da técnica significa considerar que a relação de conhecimento sujeito-objeto "tem sempre de pressupor uma compreensão linguística de si e do mundo e, por conseguinte, a relação sujeito-cossujeito complementar à relação sujeito-objeto" ${ }^{\text {838. }}$. Por isso, segundo Apel, ao reconhecer a função

\footnotetext{
${ }^{833}$ APEL, O desafio da crítica total da razão e o programa de uma teoria filosófica dos tipos de racionalidade. In: Novos Estudos - CEBRAP, p. 71.

${ }^{834}$ Idem, p. 79.

${ }^{835}$ Idem, p. 79.

${ }^{836}$ Idem, p. 71.

${ }^{837}$ Idem, p. 79.

${ }^{838}$ Idem, p. 79.
} 
complementar das ciências de compreensão hermenêutica, fica superado a um só tempo distanciamento cognitivo não-axiológico (abstração) do cientificismo pós-cartesiano, assim como sua suposição metódica solipsista do sujeito (solus ipse) $\operatorname{cognoscitivo~}^{839}$.

A implicação possivelmente mais relevante em relação a essas condições necessárias é que elas contêm, como mencionado antes, os critérios normativos da reconstrução racional dos processos de aprendizagem relacionados à cultura. Isso porque, do ponto de vista formal, esses critérios representam a meta (o telos ideal) do cumprimento racional das exigências universais de validade a ser cumprida pelo indivíduo e pela sociedade. Apel assinala que esses critérios consubstanciam não um telos substancial, no sentido da metafísica da vida venturosa ou da filosofia especulativa da história, mas um princípio teleológico, enquanto "princípio regulador da aprendizagem", que tem de ser pressuposto em cada tentativa de "reconstrução racional dos processos da evolução humana". A razão disso é que, para considerar-se como resultado da evolução (progresso da verdade e dos juízos morais $)^{840}$, "toda tentativa nessa direção tem de admitir, como telos possível dos processos de aprendizagem a serem reconstruídos, as pressuposições necessárias de sua própria competência reconstrutiva" ${ }^{841}$, portanto, o logos da racionalidade do discurso. $\mathrm{Na}$ visão de Apel, cabe a esse princípio teleológico desempenhar o papel de um "postulado da autointegração das ciências reconstrutivas" (humanas) ${ }^{842}$, que consiste em mediar "a realização progressiva do equilíbrio entre a formação racional do juízo e a adequação necessária da vida ao ambiente natural e social" ${ }^{\prime 843}$. Com essa compreensão vem à tona uma importante conclusão do programa de uma teoria dos tipos de racionalidade de Apel: "o logos da racionalidade do discurso, pressuposto por toda argumentação, contém também o telos da reconstrução racional de processos culturais de aprendizagem" ${ }^{844}$. Por sua vez, isso significa

\footnotetext{
${ }^{839}$ Analisando a questão da suposta inconciliabilidade da concepção de jogo transcendental de linguagem com a separação de sujeito-objeto do cientificismo, Apel mapeia as abordagens teóricas que, desconsideradas de suas diferenças epistemologicamente relevantes, negaram de forma consciente a separação entre sujeito e objeto proposta pelo cientificismo. Essas abordagens - a filosofia do espírito histórico de Hegel, a fundação das ciências do espírito histórico-hermenêuticas (Schleiermacher, dos representantes da "Escola Histórica", W. Dilthey, Max Weber e Collingwood), o "materialismo histórico" de Karl Marx (no contexto da emancipação da práxis subjetivo-intersubjetiva e enquanto corretivo ideológico-crítico das ciências humanas burguesas) - concebem que "a sociedade é um "sujeito-objeto" - para dizer dialeticamente - com o qual é possível identificar-se intelectivamente, e não um objeto da observação ou elucidação que se dá de acordo com regras apostas de fora" (cf. APEL, Transformação da filosofia, v. II, p. 282; Transformation der philosophie, Band II, pp. 249-250). ${ }^{840}$ APEL, O desafio da crítica total da razão e o programa de uma teoria filosófica dos tipos de racionalidade. In: Novos Estudos - CEBRAP, p. 76.

${ }^{841}$ Idem, p. 75.

842 Idem, p. 75.

${ }^{843}$ Idem, p. 76.

${ }^{844}$ APEL, O desafio da crítica total da razão e o programa de uma teoria filosófica dos tipos de racionalidade. In:
} Novos Estudos - CEBRAP, p. 76. 
que há nesses processos, proporcionalmente ao cumprimento das exigências de validade universal do $\log o s$, a possibilidade de aprender a viver de forma mais razoável, dialógica e solidária. Não há motivo para renunciar à esperança no sentido do avanço da verdade e da ação ética.

Nesse ponto, para reforçar o já afirmado e ousar um pouco em termos de interpretação, parece ser possível afirmar que a tese da complementaridade de Apel encontra seu ponto de ancoragem e justaposição particularmente, dentro do marco da semiótica transcendental, na concepção de comunidade de comunicação. Nessa concepção, essa comunidade tem o status de mediação dialética intersubjetiva simultaneamente histórica e ideal (Kontrafaktisch) que faculta discernir sobre a validação e o sentido do pensar e agir humanos. Com um formato híbrido, comunidade de comunicação se estrutura por uma dimensão histórica, relativa à comunidade real de comunicação (sociedade), e por uma dimensão apriorística (transcendental) relativa à comunidade ilimitada de comunicação, ao jogo ideal de linguagem no qual estão contidos os critérios normativos universais de validade do discurso. Vê-se a complementaridade entre os tipos de racionalidade dentro da estrutura da comunidade de comunicação à medida que se considera que, para chegar a conhecimentos consistentes, não se pode prescindir da experiência empírica e do acordo ilimitado de todos os participantes do "discurso teórico" quanto ao sentido e à validade da verdade da experiência. Aí, quando surge na comunidade real de comunicação a exigência de que o indivíduo possa discernir acerca da necessidade do acordo mútuo quanto à validade da argumentação, ao realizar tal discernimento, concomitantemente, ele já tem antecipado "contrafaticamente" em sua autocompreensão o ponto de vista de uma comunidade ilimitada de comunicação, ou seja, já tem reconhecido os critérios normativos do jogo de linguagem ideal para a formação do consenso na sociedade ${ }^{845}$.

Possivelmente a consequência mais relevante da tese da complementaridade, aqui supondo a contiguidade entre as dimensões da comunidade de comunicação e os tipos de racionalidade, é o reconhecimento do pressuposto transcendental de toda composição teórica da ciência. Reiterando, trata-se do reconhecimento do "aquém" (no sentido de uma fundamentação normativa enquanto ética mínima ${ }^{846}$ ) relativo aos pressupostos da teoria social

\footnotetext{
${ }^{845}$ APEL, Transformação da filosofia, v. I, pp. 69-70. APEL, Transformation der Philosophie, Band I, p. 60. APEL, O desafio da crítica total da razão e o programa de uma teoria filosófica dos tipos de racionalidade. In: Novos Estudos - CEBRAP, p. 75.

${ }^{846}$ APEL, Semiotica filosofica, p. 258. HABERMAS, Teorías de la Verdad. In: Teoría de la acción comunicativa, pp. 113-158 (para uma síntese das pretensões de validade, cf. p. 124). NICOLÁS, Juan A.. Teoría
} 
crítica. Tal significa, do ponto de vista epistemológico, a superação do distanciamento cognitivo não-axiológico (abstração) do cientificismo pós-cartesiano e sua suposição metódica solipsista do sujeito cognoscitivo (pela qual se supõe que o "eu" (solus ipse) está em condição de conhecer algo como algo), ao passo que, no horizonte da comunidade de comunicação, qualquer "evidência" só pode valer como verdade mediante um processo de acordo mútuo linguístico e interpessoal ${ }^{847}$. Apel entende esse reconhecimento como a possibilidade de uma “'Aufklärung' hermenêutica que não deixa tudo como está". Para Apel, tal significa o seguinte: a ciência social empírica precisa levar em conta não apenas as relações "externas" do comportamento humano (as discrepâncias ou contradições subsistentes nas formas de vida históricas, nos jogos de linguagem), elucidáveis por via causal ou estatística, mas também as relações "internas", enquanto relações entendíveis entre ações (intencionais) e conceitos, em que os próprios agentes da ação explicam o sentido de suas ações. Na verdade, mais que isso, Apel pensa que as relações externas não só podem ser "elucidadas com base em hipóteses normativas", mas concomitantemente devem "ser compreendidas também como relações internas" que não puderam ser acolhidas em razão de certas regras de seleção de dados ("Tabuisierungsregeln") ${ }^{848}$. Essencialmente, o objetivo desse "esclarecimento hermenêutico" é fazer a "crítica ideológica" aos jogos de linguagem dessas formas de vida. A convicção de Apel, em relação ao que se pode esperar desse esclarecimento, é que o objetivo da filosofia e das ciências sociais críticas quanto à emancipação nas formas de vida históricas só pode ser "alcançado 'ao logo do tempo' ["in the long run"] em conjunto com a realização prática da comunidade de comunicação ilimitada" 849 .

O ponto chave concernente ao reconhecimento da função complementar dos pressupostos hermenêuticos para a ciência empírica é que, com base nele, Apel reconfigura o sentido do interesse cognitivo pela emancipação, tradicionalmente vislumbrado pela Escola de

de la verdad consenso-evidencial y teoría de la verdad fenomenológico-real. In: Discurso e realidade, pp. 150151.

${ }^{847}$ APEL, O desafio da crítica total da razão e o programa de uma teoria filosófica dos tipos de racionalidade. In: Novos Estudos - CEBRAP, pp. 78-79.

${ }^{848}$ APEL, Transformação da filosofia, v. II, p. 294; Transformation der philosophie, Band II, p. 261.

849 Apel chama atenção para a confusão ideológica entre o ideal e a situação histórica. Para ele, não se pode supor a inteligibilidade ideal justamente onde as circunstâncias históricas apresentam "deformações claras" das funções relativas ao ideal hermenêutico de um acordo mútuo ilimitado. Ao desconsiderar que a contradição é um elemento historicamente inerente aos jogos de linguagem e formas de vida, incorre-se em uma "idealistic fallacy"; como tal, o contraponto à "naturalistic fallacy" da redução cientificista das relações inteligíveis a relações elucidáveis (por via causal e estatística). Ver: APEL, Transformação da filosofia, v. II, pp. 293-297; Transformation der philosophie, Band II, pp. 260-263. Sobre a relação desse tópico com a teoria da verdade consensual de Apel, ver: APEL, Fallibilismus, Konsenstheorie der Wahrheit und Letztbegründung. In: Philosophie und Begründung, pp. 163-164. 
Frankfurt. A meu ver, essa reconfiguração pode ser vista como uma ampliação da compreensão do interesse cognitivo emancipador, provavelmente, em conformidade com o conteúdo da tese da complementaridade dos tipos de racionalidade da dialeticidade da comunidade de comunicação. Assim, enquanto tradicionalmente a Escola de Frankfurt concebe o interesse cognitivo emancipador no plano da faticidade, sob o prisma de uma transformação sócio-histórico, diferentemente, em Apel, esse interesse é vislumbrado a partir da relação dialética entre a comunidade concreta e histórica (realidade fática) e a comunidade ideal de comunicação, a qual antecipa contrafaticamente o "mínimo ético" intranscendível a partir do qual se pode postular a emancipação em um processo nunca definitivo.

$\mathrm{Na}$ prática, Apel entende tal complementação hermenêutica em referência à exigência de que as ciências sociais desenvolvam suas atividades a partir de um consenso sobre um sistema de automanipulação do ser humano, controlado intersubjetivamente e baseado no saber legal. Espera-se que, mediante o acordo mútuo social, no qual (em princípio) todos podem assumir a responsabilidade quanto a uma "manipulação necessária", a objetivação empírico-analítica e a disposição técnica do comportamento humano possam ser sobrepostas e neutralizadas hermeneuticamente. No sentido vislumbrado por Apel, o engajamento sócio-político de uma ciência social crítica funciona como corretivo emancipador de uma manipulação possibilitada pela ciência social ${ }^{850}$. Na perspectiva de uma racionalidade intersubjetiva e dialógica (ampliada), o referido "aquém" fornece o acordo prévio entre os sujeitos do conhecimento quanto ao sentido dos conceitos a serem utilizados pela ciência objetivo-descritiva em suas explicações sobre os fatos e, por isso, ele constitui o "parâmetro dos juízos de valor da ciência empírico-analítica, pelas mãos de uma ciência social crítica, à qual cabe reconstruir a auto-experiência histórica da espécie humana" ${ }^{851}$.

Depois de assinalar a abordagem metodológica que vincula ciência social empírica e reflexão filosófica na teoria crítica com uma intenção prática, delimitadamente, trata-se agora da passagem em que Apel faz uma referência direta à educação. Em "Ciência como emancipação?", para ilustrar as graves consequências de uma ciência manipuladora, ou seja, de uma ciência que não se efetiva por meio da cognição complementar hermenêutica e da reflexão crítica, Apel se refere ao campo da educação. O primeiro deste trabalho menciona essa referência; agora, retoma-se essa referência sob o prisma de que tal ilustração expresssa, colateralmente, uma compreensão geral do campo da educação enquanto ciência social. A

${ }^{850}$ APEL, Transformação da filosofia, v. II, pp. 161-163; Transformation der philosophie, Band II, pp. 141142.

${ }^{851}$ APEL, Transformação da filosofia, v. II, p. 260; Transformation der philosophie, Band II, p. 230. 
meu ver, parece permear essa passagem uma espécie de admoestação (e denúncia) contra o risco de que a tarefa da educação, em vez de potencializar a emancipação, possa se restringir à preponderância do interesse técnico-científico no âmbito do saber e da propagação desse saber no mundo ${ }^{852}$. Nessa passagem, Apel parece avistar a tarefa da educação em consonância com os interesses cognitivos que guiam as funções das ciências (naturais, hermenêuticas e teoria crítica). É no campo de discussão a respeito das funções das ciências humanas no âmbito da ciência que Apel enuncia o papel emancipador da educação. Aí, curiosamente, Apel ultiliza a expressão "pedagogia" (Pädagogik), pelo visto, tomando-a em um sentido supostamente geral, sem se ater a conceituá-la. Com efeito, ao utilizar esse termo, a meu ver, ele indica uma compreensão geral do âmbito da educação, em relação à qual, desde o ponto de vista da semiótica transcendental, existe um problema. Pelo visto, trata-se de uma compreensão que é, efetivamente, problemática. Então, segundo a compreensão de Apel, a educação é uma ciência social "que tem a ver com a mediatização de teoria e práxis" 853 em vista do interesse cognitivo emancipador. Na linha dessa compreensão, ele assinala que, em face da necessidade de "impedir a manipulação elitista por parte dos emancipadores", resta considerar que ela "ainda precisa torna-se um fato político" 854 .

Para aclarar essa compreensão, Apel marca a diferença entre uma ciência social empírico-analítica e uma "ciência social crítica que entende a si mesma como corretivo emancipador de uma manipulação possibilitada justamente pela ciência social"855. De fato, Apel segue mais por uma via negativa, acentuando os traços gravosos de uma compreensão da educação desde a lógica da ciência social empírico-analítica. Esquematicamente, destacam-se os seguintes traços: a) à medida que a educação, partindo do conceito positivista de ciência, estrutura-se como uma ciência social empírico-analítica, por exemplo, baseada nos fundamentos de uma psicologia do condicionamento, ela se torna, em sua referência prática, "puramente tecnológica" 856 ; b) em consequência desse traço, a educação acaba eliminando "qualquer acordo mútuo engajado entre os pedagogos quando aos objetivos da formação

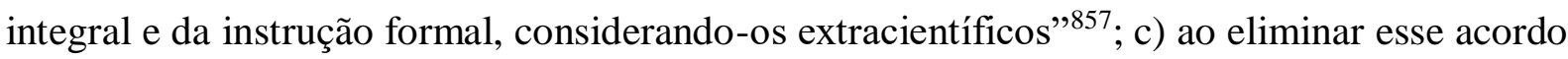
entre os "pedagogos" (mais coerente com o pensamento de Apel, entre educadores e

\footnotetext{
${ }^{852}$ APEL, Transformação da filosofia, v. II, pp. 147 e 149; Transformation der philosophie, Band II, pp. 128 e 130).

${ }^{853}$ APEL, Transformação da filosofia, v. II, p. 162; APEL, Transformation der philosophie, Band II, p. 141: “(...) Die Pädagogik als klassischer Fall einer Wissenschaft, die es mit der Vermittlung von Theorie und Praxis”). ${ }^{854}$ APEL, Transformação da filosofia, v. II, p. 165; Transformation der philosophie, Band II, p. 144. ${ }^{855}$ APEL, Transformação da filosofia, v. II, pp. 162-163; Transformation der philosophie, Band II, p. 142. ${ }^{856}$ APEL, Transformação da filosofia, v. II, p. 162; Transformation der philosophie, Band II, p. 141. ${ }^{857}$ APEL, Transformação da filosofia, v. II, p. 162; Transformation der philosophie, Band II, p. 141.
} 
envolvidos no processo educativo), por conseguinte, corre-se o risco de deixar a demarcação da finalidade da educação para os políticos ligados à área da cultura (por exemplo, comprometidos unilateralmente com interesses estratégicos de disponibilização técnica do saber e com o caráter mercadológico da educação) ${ }^{858}$; d) uma educação entendida como ciência social empírico-analítica, danosamente, elimina também o caráter dialético de todo processo formativo, ao expurgar "toda comunicação não manipuladora e verdadeiramente intersubjetiva entre o pedagogo e os educandos (como objetos da pedagogia), por considerá-la não científica" ${ }^{859}$. Em suma, a educação nos moldes de uma ciência social empíriconomológica é, efetivamente, "pura tecnologia de adestramento" 860 . Longe de constituir um fenômeno útopico (não-lugar), segundo Apel, a função dessa pedagogia se ajusta ao "contexto social de um sistema tecnocraticamente aperfeiçoado de completa manipulação da grande massa por uma elite de manipuladores"

Nessa diferenciação, em relação à pretensão de uma ciência social crítica, no sentido de um corretivo emancipador de uma manipulação possibilitada justamente pela ciência social, Apel pondera que, em virtude da situação de interação e comunicação constituída na sociedade atual, é inevitável algum grau de objetivação empírico-analítica e de manipulação aí fundamentada. Como tratado anteriormente, bem exemplifica tal situação a relação entre professor e aluno. Faticamente, não é possível haver um "acordo mútuo puramente hermenêutico" entre professor e aluno. Nesse caso, é necessário que entre em cena uma "relação de elucidação do comportamento". Quando as motivações essenciais do aluno (criança ou jovem) não são acessíveis a sua capacidade de expressão linguística, por exemplo, é inevitável que ocorra uma objetivação forçada. Em tal situação, essas motivações funcionam como causas de fenômenos que se impingem objetivamente ao professor como dados de uma composição teórica empírico-analítica. Importa que, mesmo nesse caso a objetivação empírico-analítica e a manipulação do parceiro social (o aluno) "não são o objetivo final da abordagem científico-metódica, à medida que esta última se entende a partir do interesse cognitivo emancipador" ${ }^{862}$. A seguir, reitera-se sobre o problema da assimetria e objetivação na interlocução entre professor e aluno já abordado na segunda parte deste trabalho, porém focando agora na alternativa de solução que Apel apresenta para tal.

\footnotetext{
${ }^{858}$ APEL, Transformação da filosofia, v. II, p. 162; Transformation der philosophie, Band II, p. 141.

${ }^{859}$ APEL, Transformação da filosofia, v. II, p. 162; Transformation der philosophie, Band II, p. 141.

${ }^{860}$ SKINNER, $O$ mito da liberdade, cap. 1 (Uma tecnologia do comportamento), passim.

${ }^{861}$ APEL, Transformação da filosofia, v. II, p. 162; Transformation der philosophie, Band II, p. 141.

${ }^{862}$ APEL, Transformação da filosofia, v. II, p. 163; Transformation der philosophie, Band II, p. 143.
} 
Frente à situação de assimetria e objetivação, segundo Apel, a alternativa mais razoável é a de "provocar comunicativamente" (provokative Verständigung), junto com a "objetivação que distancia e a inevitável manipulação" do interlocutor-aluno, um "processo de reflexão", de modo que o aluno tome "consciência dos motivos" que não estão transparentes para ele, "tornando-os acessíveis a uma autêntica discussão intersubjetiva" "863. Nessa linha, para Apel, a abordagem metódica do pedagogo (educador) consiste no procedimento de urdir a parte da objetivação-manipulação com parte do acordo mútuo provocativo, de tal maneira que a primeira parte se torne supérflua "pelo fato de se subtrair o objeto à abordagem objetivadora: o comportamento imaturo da criança, a ser disciplinado por forças externas, deve afinal desaparecer no comportamento autônomo do adulto, graças à educação correta" ${ }^{" 864}$. Com isso, segundo Apel, uma pedagogia emancipadora teria atingido seu objetivo.

Em razão da dialeticidade da comunidade de comunicação, Apel ressalva que esse objetivo "jamais é alcançado por completo". A primeira razão para isso é o fato de que "até mesmo o comportamento comunicacional entre adultos sadios na sociedade humana nunca pode ser puramente intersubjetivo e capaz de levar a um acordo definitivamente válido quanto ao sentido e às normas da práxis social" "865. A segundo razão é que "a um acordo como esse vem interpor-se a ‘auto-alienação do ser humano', que até agora jamais permitiu que os seres humanos fossem plenamente transparentes para si mesmos, em suas palavras e ações" ${ }^{866}$. A

${ }^{863}$ APEL, Transformação da filosofia, v. II, pp. 163-164; Transformation der philosophie, Band II, p. 143. 864 APEL, Transformação da filosofia, v. II, p. 164; Transformation der philosophie, Band II, p. 143. Para Hans Jonas, a educação tem um fim determinado como conteúdo: "a autonomia do indivíduo, que abrange essencialmente a capacidade de responsabilizar-se; ao alcançá-lo (ou supor-se que foi alcançada), ela termina no tempo. O término ocorre de acordo com sua própria lei, e não de acordo com a concordância do educador - nem sequer na medida do seu êxito -, pois a natureza concede apenas uma só vez um determinado lapso de tempo, no qual a educação precisa realizar sua tarefa. Depois disso, o objeto de responsabilidades anteriores se torna, ele mesmo, um sujeito de responsabilidades" (cf. JONAS, O princípio responsabilidade: ensaio de uma ética para a civilização tecnológica, p. 189). Jonas distingue a responsabilidade parental e a responsabilidade política. A responsabilidade paterna tem a ver com o devir individual (com seres que se tornarão homens), especificamente com a tarefa relativa ao crescimento orgânico e pessoal da criança - de modo que historicidade e natureza se interpenetram profundamente nela (criança) - até tornar-se adulto. A responsabilidade paterna cessa quando a criança se torna um adulto autônomo e responsável. Mas, somente com a continuidade da existência emancipada é possível, retrospectivamente, aos pais perguntar se desempenharam bem ou mal sua tarefa. A responsabilidade política pelo devir da história (da humanidade) é distinta dos fenômenos do devir individual, que vai do embrião ao adulto. Pois, "a história das sociedades, nações ou Estados - ou seja, "a História" - não tem nenhum fim predeterminado para o qual tenda ou deva ser conduzida; não faz sentido falar em infância, maturidade ou senilidade da história. Toda comparação orgânica, particularmente com o crescimento, por mais tentadora que seja, está fora de lugar e é enganosa. Desde as origens, todas as sociedades foram formadas por pessoas de diferentes idades, mas os adultos é que sempre exercem o poder e, especialmente nas sociedades mais antigas, os 'mais velhos', que reúnem maior experiência, conhecimento e sabedoria" (cf. JONAS, O princípio responsabilidade, p. 190).

865 APEL, Transformação da filosofia, v. II, p. 164; Transformation der philosophie, Band II, p. 143.

${ }^{866}$ APEL, Transformação da filosofia, v. II, p. 164; Transformation der philosophie, Band II, p. 143. 
terceira razão é que a esse acordo vem interpor-se também a auto-alienação que têm "transformado a história humana muito mais em um resultado de processos causais imperscrutáveis do que no produto de intenções de ação conscientes e responsáveis" ${ }^{867}$. Ora, assim reflete Apel, caso se faça como Marx, considerando que essa auto-alienação não pode ser superada por qualquer esclarecimento ou terapia individual, mas, em vez disso, que a emancipação individual só pode ser mediatizada pela emancipação da sociedade, "então a tarefa de uma ciência social criticamente engajada torna-se visível em toda sua amplitude" $" 868$. E, nesse caso, trata-se de "tomar o modelo" de uma "provocação de processos reflexivos que transformam o comportamento inconscientemente motivado, e por isso manipulável e elucidável, em um agir conscientemente responsável, e de aplicar esse modelo à sociedade como um todo"869. Trata-se de uma ciência social criticamente engajada, voltada à emancipação, e que deve, de sua parte mediatizar-se pelo esclarecimento ou terapia psicológico-individual. Para Apel, isso implica em pensar a "crítica teórica" em uma perspectiva além do pensamento de Marx, tal como Sartre. Pois, a sociedade não pode emancipar-se sem a emancipação dos indivíduos. E, além disso, ela não pode ser emancipada por meio da “manipulação de uma elite partidária que administre os 'interesses objetivos' de todos, sem levar em conta a vontade dos indivíduos" ${ }^{870}$.

A despeito de pontuar a alternativa à objetivação supramencionada, para Apel, quando se trata de impedir a manipulação elitista por parte dos emancipadores no campo da educação (Pädagogik), subsiste o problema da mediação "arriscada" entre teoria e prática. A questão que se impõe a esse respeito é saber de que maneira uma ciência social crítica adequada à ciência social crítico-ideológica pode ser organizada e institucionalizada como uma "práxis politicamente relevante". Em relação a essa questão, em "Ciência como emanciapação?", Apel analisa a resposta do movimento estudantil, cujas palavras de ordem preconizam tanto a delegação de um "mandato político" à ciência ou à universidade quanto a defesa de uma "politização" da ciência e da universidade. Na avaliação de Apel, essa resposta traz consigo exigências e práticas vinculadas a tais exigências de caráter polissêmico, que merecem "algumas reservas". Para Apel, ainda continua valendo a necessidade de fazer um exame crítico mesmo em relação à interpretação da "politização" no sentido de uma “contrapolitização oposta ao entrelaçamento da Big Science com a economia e a política dos

\footnotetext{
${ }^{867}$ APEL, Transformação da filosofia, v. II, p. 164; Transformation der philosophie, Band II, p. 143. ${ }^{868}$ APEL, Transformação da filosofia, v. II, p. 164; Transformation der philosophie, Band II, p. 144. ${ }^{869}$ APEL, Transformação da filosofia, v. II, p. 165; Transformation der philosophie, Band II, p. 144. ${ }^{870}$ APEL, Transformação da filosofia, v. II, p. 165; Transformation der philosophie, Band II, p. 144.
} 
Estados industriais modernos" ${ }^{871}$. A observação de Apel a respeito do contexto social que se liga a essa resposta descortina uma situação de ambiguidade. Por um lado, essa resposta sinaliza o estopim para a discussão de políticas universitárias "atualmente em curso" (contextualmente, aqui se presume a Alemanha na década de 1960), bem como para o debate sobre o conceito de ciência e da relação desta com a práxis e, especialmente, com a política. Por outra, em meio a esse debate, o fato que chama à atenção é o posicionamento da "maior parte dos cientistas já socialmente estáveis". Na ótica de Apel, essa maioria parece tender, “em nome da 'liberdade da pesquisa e do ensino', a rejeitar não apenas a 'ciência politizada', mas também a 'função emancipadora' a ela vinculada, e a se isolar no conceito de uma ciência isenta de valores e isenta de pressupostos sócio-políticos" ${ }^{\$ 72}$.

Como contraponto a esse contexto ambíguo, em "Ciência como emancipação?”, Apel apresenta algumas sugestões - tidas por ele mesmo como insuficientes - para ajudar no debate sobre o problema da mediação entre teoria e práxis. Vale observar, quando se considera o desenvolvimento do pensamento de Apel, parece ser possível enxergar nessas sugestões o esboço das ideias basilares que, paulatinamente, assumem um caráter programático na proposta filosófica apeliano. Aqui, procura-se sintetizar o conjunto dessas sugestões em quatro pontos ou ideias programáticas: a) a apreensão correta do conceito de ciência neutra e sua função emancipadora virtual; b) a contribuição das ciências hermenêuticas (humanas) na mediação da tradição e do acordo cultural e sua implicação no campo da educação, a saber, a exigência de "unidade entre pesquisa e ensino"; c) a ancoragem (fundamentação) do engajamento emancipador no a priori da comunidade ideal de comunicação; d) e, vinculado ao item anterior, a necessidade de complementação, para além de Habermas, da fundamentação filosófica da teoria crítica.

A primeira sugestão concerne à defesa da ideia de que o conceito de ciência isenta de valores deve ser apreendido e praticado, restritivamente, como peculiar à ciência natural e às ciências sociais que transmitem um saber disponível tecnologicamente relevante. Aí, o interesse pelo saber técnico disponível, testável experimentalmente e avaliável do ponto de vista tecnológico, permite "apreender" e "praticar" tais ciências como neutras. Para Apel, o interesse pelo saber técnico científico se vincula a um pré-acordo mútuo irrefletivo, por exemplo, o respeito recíproco pelos cientistas como sujeitos autônomos que manifestam suas opiniões e cujos argumentos devem ser levados a sério. Não obstante, o aspecto determinante

${ }^{871}$ APEL, Transformação da filosofia, v. II, pp. 165 e 172-173 (passim); Transformation der philosophie, Band II, pp. 145 e 151.

${ }^{872}$ APEL, Transformação da filosofia, v. II, p. 165; Transformation der philosophie, Band II, p. 145. 
é que a valoração referenciada à constituição do objeto da ciência natural já está antecipada pelo interesse que a humanidade tem pela disponibilidade técnica do mundo. O interesse pelo saber técnico disponível justifica, segundo Apel, a exigência de neutralidade de toda pesquisa no âmbito dos contornos transcendentais da science. Ao menos em tese, conforme Apel, o interesse pelo saber disponível pode ser visto como um momento do interesse cognitivo emancipador, ao passa que esse interesse representa a libertação do homem da dominação fatídica da natureza. Nisso se encontra o pressuposto de toda emancipação, tal como vislumbrado pelos pensadores do Iluminismo (desde Bacon e Descartes até Kant). Com efeito, Apel pondera que a função emancipadora da ciência natural e da tecnologia é "apenas virtual", pois, no final das contas, tudo depende do que os seres humanos fazem da ciência e da técnica. Ou seja, tal depende de como os seres humanos, em correspondência com o domínio tecnológico sobre a natureza, institucionalizam suas relações sociais. Aí, há sempre o risco de perversão da função emancipadora da ciência; a bomba atômica é um exemplo fático da perversão da razão. $O$ fato é que essa perversão pode ocorrer em um nível mais profundo de sedução, quando os êxitos da science são instrumentalizados em vista de "políticas científicas" do modelo estatal tecnocrático ${ }^{873}$.

A segunda sugestão programática da filosofia de Apel versa sobre a necessidade de uma correção epistemológica no tocante ao reconhecimento da especificidade do âmbito das ciências hermenêuticas (humanas). Essa sugestão, na verdade, é a tese de Apel quanto ao caráter complementar das ciências do acordo mútuo em relação à sciense. Nesse ponto, Apel entende sua crítica ao cientificismo como uma tentativa de sanar a confusão conceitual que procede, ora da absolutização da abordagem metodológica da science (relação sujeito-objeto), ora do intento de ignorar a peculiaridade da referenciação prática das ciências humanas, ou seja, o fato de que aí todas as pessoas são simultaneamente sujeitos e objetos das ciências. Para Apel, o saldo positivo dessa crítica é o reconhecimento de que a função virtualmente emancipadora das ciências naturais e das ciências sociais empíricas requer uma abordagem complementar em relação a elas, no plano das ciências humanas, que trate de um acordo mútuo intersubjetivo quanto a fins e valores. Para isso, é necessário que na abordagem das ciências humanas não ocorra um mero prosseguimento da abordagem objetivadora da science. Isso significa que não se deve substituir um acordo mútuo intersubjetivo metodicamente disciplinado por métodos objetivadores de elucidação ou direcionamento técnico do

${ }^{873}$ APEL, Transformação da filosofia, v. II, pp. 166-167; Transformation der philosophie, Band II, pp. 145146. 
comportamento. Significa também que as tarefas do entendimento mútuo metacientífico, incluídas aí a mediação da tradição e do acordo intercultural, "precisam compor na sociedade não manipulada um contínuo com a formação da assim chamda 'opinião pública" 874 .

Interessantemente, nesse segundo ponto, Apel assinala um aspecto das ciências humanas que se liga, supondo exposto, relevantemente ao campo da educação. Esse aspecto é o caráter essencial da "unidade entre pesquisa e ensino" no âmbito das ciências humanas. Trata-se de um aspecto em relação ao qual se denota uma distinção fundamental, possivelmente relevante do ponto de vista da formação, entre as ciências naturais e as ciências humanas. No caso destas últimas, a unidade entre pesquisa e ensino serve não somente para uma participação o mais precoce possível dos estudantes em pesquisa, mas também representa “a ligação comunicativa do cientista das humanidades com seu público - e isso sob a forma de um apelo ideal (ideale Forderung)" ${ }^{\$ 75}$. Distintivamente, o cientista natural não precisa de público algum, mas apenas da comunidade de especialistas capaz de testar os resultados alcançados por ele e possivelmente dar-lhes continuidade. Exemplificando tal distinção, Apel afirma que retirar o público de um profissional das ciências literárias, significa fazê-lo perder o sentido e a inspiração de sua pesquisa. Pois, nesse caso, "suas conquistas interpretativas, afinal de contas, nada são senão contribuições cientificamente mediatizadas a uma discussão que se dá em meio a um acordo mútuo público e permanente entre as pessoas, sobre normas e estilos possíveis de uma vida que poderia valer a pena ser vivida" ${ }^{\circledR 76}$.

A terceira sugestão, efetivamente programática, concerne à defesa da tese central de Apel segundo a qual a fundamentação filosófica dos parâmetros últimos das normas de valoração pode ser deduzida do a priori da comunidade ilimitada de comunicação $^{877}$. Na concepção de Apel, o engajamento político e social pode ser derivado do a priori da comunidade ilimitada de comunicação, uma vez que aí está contido o princípio regulador que confere o parâmetro mais elevado de valoração às comunidades hermenêuticas de acordo mútuo e das ciências sociais críticas "para a adoção da razão na tradição, e também para a

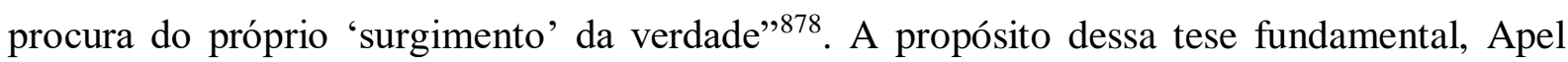
adverte que os problemas de valoração da sociedade humana, que devem ser abordados nas ciências sociais hermenêuticas e críticas, não podem ser reduzidos à avaliação de informações

\footnotetext{
${ }^{874}$ APEL, Transformação da filosofia, v. II, p. 168; Transformation der philosophie, Band II, p. 147.

875 APEL, Transformação da filosofia, v. II, pp. 168-169; Transformation der philosophie, Band II, p. 147.

${ }^{876}$ APEL, Transformação da filosofia, v. II, p. 169; Transformation der philosophie, Band II, p. 148.

877 APEL, Transformação da filosofia, v. II, pp. 170 e 171-172 (passim); Transformation der philosophie, Band II, pp. 148 e 150.

${ }^{878}$ APEL, Transformação da filosofia, v. II, p. 172; Transformation der philosophie, Band II, pp. 150-151.
} 
segundo o interesse de autopreservação de um sistema bem adaptado (decerto, pondera Apel, importante para teorias econômico-políticas de decisão). A razão para tal é que esses problemas implicam mais a "voluntariedade" que a autopreservação de um "sistema adaptativo". A vedação a essa redução é fator que torna ainda mais premente o enfrentamento da exigência de uma fundamentação filosófica das normas de valoração. Desdenhar de tal tarefa, sob a alegação de essas normas não serem científicas, é o mesmo que isentar o acordo mútuo sobre a situação histórica da sociedade e sobre os legítimos interesses de seus membros de qualquer reflexão racional e pública e, por conseguinte, abandonar e submeter a sociedade a uma convenção ad hoc estabelecida entre políticos e especialistas. Tal perspectiva aponta para o caminho de uma constituição social que resulta da combinação entre tecnocracia e decisionismo político ${ }^{879}$.

Em contrapartida a tal caminho, como se tem aludido reiteradamente, Apel concebe que a perspectiva de uma filosofia social intencionada em desenvolver o ideal de uma sociedade emancipada, necessariamente, passa pela confirmação reflexiva e pelo fortalecimento voluntário de uma "comunidade 'ilimitada' de críticos dotados de direitos iguais, já implicitamente antecipada por cada um que argumenta de maneira sensata" ${ }^{\$ 80}$. Reportando à tradição filosófica, Apel relembra que Fichte foi o primeiro a reconhecer que a razão é ao mesmo tempo vontade de realização razão. No entanto, indo com e para além Fichte, Apel preconiza que vontade de realização da razão implica a vontade de modificação das relações políticas e sociais que obstam a realização de uma sociedade emancipada e corresponsável. Como bem observa Apel, a vontade de realização da razão pode ser entendida como uma vontade de emancipação da própria razão, à medida que ela se voltar contra todas as limitações internas e externas da formação de opinião, contra a demagogia e ideologizações do processo de acordo mútuo. Nisso, acrescenta brevemente Apel, por certo, é fundamental à realização de uma sociedade emancipada que haja chances de educação iguais para todos os membros da sociedade ${ }^{881}$.

Por fim, em uma última sugestão contida em "Ciência como emancipação?" a propósito do debate relativo ao problema da mediação entre teoria e práxis, Apel se posiciona em relação à compreensão de Habermas da teoria crítica. Nesse posicionamento, Apel parte de uma questão que julga ser mais difícil de resolver, a questão da transposição da ciência para a práxis política. No tocante a essa questão, a princípio, Apel assinala a seguintes

\footnotetext{
${ }^{879}$ APEL, Transformação da filosofia, v. II, p. 170; Transformation der philosophie, Band II, p. 149.

${ }^{880}$ APEL, Transformação da filosofia, v. II, p. 171; Transformation der philosophie, Band II, pp. 149-150.

${ }^{881}$ APEL, Transformação da filosofia, v. II, p. 171; Transformation der philosophie, Band II, p. 150.
} 
exigências mencionadas anteriormente: se ciência enquanto ciência hermenêutica e como ciência social crítica implica em um engajamento sócio-político contextual, então a ciência precisa "exercer um 'mandato político' a ela delegado, ou ainda 'politizar-se" 882 . Em vista de aclarar essas exigências a partir de um ponto de vista da filosofia da ciência, Apel confronta duas interpretações divergentes: a) a interpretação conservadora do "mandato político" da ciência como um engajamento político individual; b) a interpretação compartilhada por parte dos estudantes que compreende o "mandato político" da ciência como expressão de "politização da ciência" (mediação entre teoria e práxis).

Na primeira interpretação, caracteristicamente conservadora do ponto de vista da ciência política, o "mandato político" da ciência significa o engajamento político individual de cada um dos cientistas enquanto cidadãos. Nesse caso, a competência específica funciona como fator constitutivo de autoridade. Exemplificam essa categoria de engajamento desde o esforço de estudiosos famosos em prol de alguma causa específica até a participação de estudantes em associações estudantis de caráter público. Aos olhos de Apel, esse tipo de engajamento equivale a um "corretivo de um certo posicionamento apolítico" (bastante critica) assumido por muitos intelectuais alemães no passado, que favorece "indubitavelmente a repressão de liberdades democráticas e uma má politização da universidade, a partir de fora" ${ }^{" 883}$. Além de criticável, segundo Apel, essa forma de engajamento político de indivíduos isolados não cumpre a exigência de um "mandato político" da ciência e da universidade. E não só isso, essa forma parece ser insuficiente do ponto de vista epistemológico, pois ela é possível mesmo sob o pressuposto de uma ciência neutra.

Na segunda interpretação, a exigência do "mandato político" da ciência emerge com a expressão "politização da ciência". Trata-se de uma expressão que representa os anseios de parte dos estudantes. Muitas vezes, assim analisa Apel, essa expressão é derivada do conceito de uma teoria crítica compreendido como "mediação entre teoria e práxis". No entanto, segundo Apel, por trás dessa exigência vige a pretensão de suspender a diferença entre ciência e política ${ }^{884}$. Em relação a essa interpretação, por uma parte, Apel concorda com a visão de que as composições teóricas da filosofia e das ciências sociais críticas (cada qual a seu modo) produzem, na abordagem e também nos efeitos alcançados, uma mediação entre teoria e práxis. Por outra, ele julga necessário distinguir a mediação espistemológica (também no sentido de sua institucionalização possível) da mediação entre teoria e práxis a ser

\footnotetext{
${ }^{882}$ APEL, Transformação da filosofia, v. II, pp. 172-173; Transformation der philosophie, Band II, p. 151. ${ }^{883}$ APEL, Transformação da filosofia, v. II, p. 173; Transformation der philosophie, Band II, pp. 151-152. ${ }^{884}$ APEL, Transformação da filosofia, v. II, p. 174; Transformation der philosophie, Band II, p. 152.
} 
realizada por um político ou responsável por políticas científicas, "que com base na educação teórica procura impor um determinado objetivo na prática" ${ }^{\$ 85}$. É precisamente em relação a esse ponto que Apel postula complementar a fundamentação filosófica da teoria crítica apresentada por Habermas em seu livro Conhecimento e interesse.

Para Apel, o interesse emancipador reivindicado por Habermas para as ciências sociais críticas e para a filosofia não conduz a uma identidade pura entre conhecimento e interesse, ou entre reflexão e engajamento prático. Apel entende que tal identidade não é válida, porque o "engajamento" corresponde a uma "tomada de partido arriscada e politicamente efetiva". Nesse ponto, Apel sugere que tal engajamento implica em abandonar a "posição excêntrica" de quem reflete e se identifica com a comunidade ilimitada dos críticos em prol do aqui e agora. Criticamente, Apel pensa que a identidade entre reflexão e engajamento prático postulada por Habermas já pressupõe a "realização efetiva da filosofia". Em vez de tratar tal identidade como como um "princípio regulativo", ao qual, sem prejuízo de sua validação, não pode corresponder nada de empírico (Kant) ${ }^{886}$, em Habermas, segundo Apel, ela já pressupõe a superação da filosofia (exigida por Marx). Nos termos de Apel, "apesar da identidade entre a razão e o interesse racional, reflexão teórica e engajamento prático-material não são idênticos, e voltam a divergir entre si no plano mais elevado da reflexão filosófica, como momentos opostos no interior do interesse cognitivo emancipador" ${ }^{\prime 887}$. No entender de Apel, a versão de teoria crítica de Habermas inclui apenas parte do interesse cognitivo emancipador, qual seja a parte ligada ao interesse pela desdogmatização e crítica de toda convicção, pela dúvida (falibilista do cientista) virtualmente universal, pela possiblidade de revisão de todo engajamento. Em síntese, ela "inclui a parte do interesse cognitivo, da qual a ciência, apesar de todo seu engajamento heurístico, retira sua legitimação enquanto ciência" ${ }^{888}$. Então, segundo Apel, a suposição de que com isso se possa abranger a parte diametralmente oposta do interesse emancipador, isto é, a que se refere à exigência de que o mundo não seja apenas interpretado, mas também transformado (Marx), é uma ilusão idealista. Trata-se de uma ilusão que pode gerar outra ilusão subjetivomaterialista, a saber, a crença de considerar o engajamento na práxis política como ciência, mesmo sendo dogmático e distante da comunidade de comunicação dos cientistas.

\footnotetext{
${ }^{885}$ APEL, Transformação da filosofia, v. II, p. 174; Transformation der philosophie, Band II, p. 152.

${ }^{886}$ APEL, Transformação da filosofia, v. II, p. 174 (ver também nota 41); Transformation der philosophie, Band II, pp. 152-153.

${ }^{887}$ APEL, Transformação da filosofia, v. II, p. 175; Transformation der philosophie, Band II, p. 153.

${ }^{888}$ APEL, Transformação da filosofia, v. II, p. 175; Transformation der philosophie, Band II, p. 153.
} 
Ao finalizar sua análise sobre o problema da mediação, Apel reconhece que o seu resultado pode parecer decepcionante, se se considera que de tal maneira se preconiza uma separação não-dialética entre teoria e práxis. Porém, ao contrário disso, trata-se de considerar que não apenas a composição teórica científica precisa ser mediatizada por um engajamento prático, mas também a práxis política precisa ser mediatizada pela composição teórica científica. Nessa perspectiva, Apel enuncia que a forma estatal da democracia pode ser vista como uma tentativa de efetivar no âmbito político regras fundamentais de funcionamento da comunidade de comunicação crítica e ilimitada, "que se pôde institucionalizar com certo êxito no âmbito da ciência" ${ }^{889}$. Com efeito, precisamente para que se possibilite tal coisa, assim pensa Apel, é necessário manter a diferença conceitual entre ciência e política. Assim, o resultado dessa análise caminha na direção da inadmissibilidade de um "mandato político" da ciência, se se considera por isso a possibilidade de legitimação jurídica da política a partir da ciência, desconsiderando as regras de conduta parlamentares de formação da vontade. Finalmente, para manter a discussão em aberto, Apel sugere um outro ponto de vista para ver a questão do "mandato político" da ciência, que, segundo ele, ultrapassa o viés de um engajamento político particular em nome da ciência. Trata-se de considerar que não se confere um "mandato político" diretamente à ciência, mas a uma universidade organizada democraticamente. Efetivamente, tal não corresponde a um simples mandato político, mas a um mandato concernente a políticas científicas que, em positivo, devem ser ampliadas pelo Estado. No sentido da filosofia de Apel, trata-se de um mandato "destinado à co-participação na realização das condições de possibilidade de políticas da ciência, inclusive de sua função emancipadora de esclarecimento" 890 .

\footnotetext{
${ }^{889}$ APEL, Transformação da filosofia, v. II, p. 176; Transformation der philosophie, Band II, p. 154.
}

${ }^{890}$ APEL, Transformação da filosofia, v. II, p. 176; Transformation der philosophie, Band II, p. 154. 


\section{EDUCAÇÃO E RESPONSABILIDADE NO MARCO DA ÉTICA DO DISCURSO}

Este capítulo trata da compreensão da educação no sentido da corresponsabilidade no marco da ética do discurso de Apel. Fundamentalmente, esse capítulo se norteia por dois pontos principais: a) em um passo inicial, trata-se da fundamentação e estrutura híbrida da ética do discurso; b) em um passo seguinte, que procura conectar educação e responsabilidade na filosofia moral de Apel, postula-se a possibilidade de uma contribuição recíproca, no sentido de que a educação dos valores públicos possa suplementar a ética do discurso quanto a sua aplicação na história.

\subsection{A ética do discurso como ética da responsabilidade: fundamentação e estrutura}

A expressão "ética discursiva" qualifica a tarefa de fundamentação da ética, representada em seus traços essenciais por Habermas e Apel. Essa tarefa, em Apel, toma a direção de um contraponto à situação aporética da ética na época da ciência, em que vige a necessidade e impossibilidade de fundamentar ultimamente uma filosofia prática com validade universal ${ }^{891}$. A versão da ética do discurso em Apel toma o contorno de uma ética da responsabilidade pensada em termos de uma macroética ${ }^{892}$. Essa ética da responsabilidade parte da compreensão segundo a qual a atual situação de crise da humanidade constitui um problema ético, sobremaneira em virtude do risco de extermínio ou destruição da biosfera humana. Tal situação constitui um risco comum (em escala planetária) a toda a humanidade e, em tal medida, requer que a razão prática seja pensada em termos de uma macroética. Frente a essa situação totalmente nova criada pelo homo sapiens com base na ratio técnica, cabe à ética do discurso restituir a "responsabilidade da razão", ou seja, a exigência de fundamentar uma racionalidade da responsabilidade pelo alcance de dimensões planetárias que a ciência e

\footnotetext{
${ }^{891}$ OLIVEIRA, Ética e Racionalidade Moderna, pp. 9-39 (passim).

892 APEL, Estudos de moral moderna, pp. 193-197. Ver VAZ, Escritos de filosofia IV: introdução à ética filosófica 1, pp. 36-40. Para Vaz, o contexto de crise atual traz duas consequiências problemáticas para o bemestar moral da civilização ocidental: a) instrumentalização da forma (feição tecnológica, domínio operatório), em que o predomínio da metaética significa "instrumentalização da lógica e da linguagem éticas, que indiferentes a seu conteúdo real, passam a servir à expressão de um universal relativismo dos valores, de acordo com as necessidades e fins subjetivos ou com os interesses ideológicos dos agentes éticos” (p. 36); b) renúncia da filosofia para fundamentar a conduta ética, o que faz com que a ética, enquanto a explicação do fenômeno ético, passe para a órbita das ciências humanas, isto é, considerada em termos de padrões culturais ou de categorias psicológicas e sociológicas (p. 37).
} 
a técnica estão dando à atividade humana ${ }^{893}$. Com efeito, como bem salienta Cortina, tal intento não concerne a culpabilizar a ciência ou a técnica pelas possíveis consequências negativas de seu desenvolvimento, isto é, por possíveis catástrofes - por exemplo ecológicas, bélicas ou alimentícias. Isso porque não compete à razão técnica a responsabilidade pelos seus efeitos e sim à razão prática. Cortina compartilha a opinião que esse problema não se origina da incompetência científica, da insuficiência de educação, da falta de informação ou recursos para a pesquisa, senão do estilo de vida do homem moderno fundado em suas crenças básicas. Para Cortina, os sintomas dessa crise se enraízam na ideia equivocada do progresso, à medida que ele não é entendido como adequação do homem ao meio natural, mas como adequação do meio às necessidades humanas, fomentadas pelo crescimento econômico. O caso concreto da possibilidade de destruição da ecosfera, que envolve a discussão das ideias de progresso e fim, não é um problema de meios, mas de fins. Como tal, ele não é um assunto da razão técnica, mas um problema lançado pela ciência e técnica à razão prática, que deve se responsabilizar por esse desafio universal ${ }^{894}$.

Nos termos de uma macroética, cabe à filosofia prática ${ }^{895}$, além de pautar a responsabilidade pessoal de cada um perante seu próximo, a função de levar a humanidade a

${ }^{893}$ HERRERO, F. Javier. A ética do discurso de K.-Otto Apel. In: HERRERO, F. J. e NIQUET, Marcel (Ed.). Ética do discurso: novos desenvolvimentos e aplicações. Minas Gerais: FAFICH-UFMG, 2000, p. 10. Ante o desafio de conciliar lei (universal/necessidade) e liberdade (particular/contingência), os paradigmas éticos se classificam em: a) convencionalismo (séc. V a.C.): ressalta a oposição entre natureza e convenção, primando pela última. É o caso de Protágoras, para o qual vigora o pacto social implícito que, imemorialmente ligado à origem do ethos, é o seu universal particularizado nas diversas tradições e costumes; b) o naturalismo: preconiza a necessidade da natureza, a tirania dos desejos (cinismo e hedonismo); c) o normativismo que, na figura de Sócrates, aparece como o paradigma que propõe a questão de compatibilizar a universalidade cega do destino com a universalidade luminosa da razão e, desse modo, superar os obstáculos relativos ao autodomínio da liberdade, fora da qual não há lugar para o pensamento ético, e o determinismo da physis, vinculado ao atomismo de Demócrito e à imprevisibilidade da fortuna (cf. VAZ, Escritos de filosofia IV: introdução à ética filosófica 1, pp. 61-65). A princípio, é possível equiparar a semiotica filosofica de Apel a uma versão contemporânea do normativismo, na medida em que ela explicita as condições transcendentais da validade intersubjetiva implícitas na racionalidade da argumentação.

${ }^{894}$ CORTINA, Razón comunicativa y responsabilidad solidaria, pp. 26-27.

${ }^{895}$ Sobre a estrutura conceitual da ética (filosofia prática), ver: VAZ, Escritos de filosofia IV: introdução à ética filosófica 1, pp. 67-76 (passim). Para Vaz, a ética é um saber distinto, tanto da ciência da natureza quanto do saber técnico, capaz de elevar ao nível do logos da ciência, metódico e demonstrativo, a racionalidade implícita do ethos. No sentido propugnado por Sócrates, Platão e Aristóteles, a ética concerne a um saber de natureza filosófica, que tem por objeto a práxis que se exerce na esfera do ethos. A definição do objeto da ética, dada por Tomás de Aquino ao comentar Aristóteles, ilustra essa distinção: "o sujeito (= objeto) da filosofia moral é a operação humana ordenada a um fim ou então o homem enquanto age voluntariamente em vista de um fim" (cf. p. 68). O objeto é a práxis humana e a sua ordenação a um fim; nessa linha, a antropologia (operar) e a metafísica (fim) constituem condições de possibilidade de uma ética filosófica. Práxis e techne são dois modos distintos do operar humano, delimitando os campos respectivos da ética e da técnica. Ainda que ambos sejam modos do operar humano dirigido para a produção de uma obra e obedecendo a normas ou regras, a natureza da práxis se diferencia da techne, segundo Aristóteles, porque o finalismo da práxis é voltado para a perfeição do sujeito operante e o finalismo da techne, para a perfeição da obra a ser produzida. A práxis concerne a uma atividade que tem o seu fim em si mesmo, cujo movimento se completa na imanência (no permanecer em) do sujeito que o 
assumir e organizar coletivamente a responsabilidade moral ante os efeitos principais e colaterais de suas ações coletivas em medida planetária. A resposta responsável a uma demanda universal é uma ética universalmente válida, uma normativa comum a toda espécie humana ameaçada. Para tanto, em seu ponto de partida, a ética do discurso enfrenta o paradoxo da necessidade de uma ética universal e a simultânea dificuldade de uma fundamentação da ética na época da ciência. Isso ocorre porque, na modernidade, o mesmo conceito de "ratio" científica que, em decorrência de suas implicações tecnológicas, determina a situação atual de desafio da razão prática, por exemplo, a necessidade de uma responsabilidade solidária da humanidade para salvar a ecosfera planetária, bloqueia a priori a mobilização da razão prática, por considerá-la carente de status epistemológico, isto é, sem validade intersubjetiva ${ }^{896}$. A impossibilidade de uma fundamentação racional da ética é impossibilitada por conta da adoção das seguintes premissas fundamentais por parte do conhecimento científico: a) exclusivamente a partir de fatos (proposições descritivas sobre o que é) não é possível derivar nenhuma norma (prescrição), sob pena de incorrer em "naturalistic fallacy"; b) somente podem ser objetiva e intersubjetivamente válidas as constatações empíricas valorativamente neutras da ciência e as inferências lógicas; c) a fundamentação filosófica de validade deve ser equiparada a dedução lógica de proposições a partir de proposições, tal como um cálculo proposicional semanticamente interpretado ${ }^{897}$. Fundamentalmente, esse paradoxo se liga ao fato de que a lógica científica moderna, que

causa. A techne é, por sua vez, um ato de produzir que se completa na exterioridade do produto, daí que seu movimento seja transiente (passar além). Para Vaz, o desaparecimento dessa distinção na cultura contemporânea implica a perda da especificidade ética de nossas ações e a submissão à tirania do produzir nas relações humanas. Ainda no tocante à definição da práxis como objeto próprio do saber prático ou da Ética, segundo Vaz, as concepções propostas por Platão e Aristóteles se tornaram paradigmas para toda a história do pensamento ético. Para Platão, "a Ética é primeiramente uma "ciência teórica e, enquanto tal, passa a ser derivadamente (ou pedagogicamente, segundo a República) uma ciência prática. Platão adota, pois, uma concepção unívoca da razão científica, na qual a ciência da prática é igualmente, por definição, uma ciência prática, ou seja, à ciência cabe reger inteiramente a prática" (p. 71). Distintamente, Aristóteles preconiza uma "divisão analógica da razão científica, na qual a práxis recebe seu estatuto próprio de objeto de um saber específico, designado justamente como ethike pragmateia, disciplina ética ou hoje simplesmente Ética" (p. 71). A ética é uma teoria da práxis que é, ao mesmo tempo, uma teoria prática: "é a prática que produz sua própria teoria tendo em vista não apenas o conhecimento (teoria) do Bem mas igualmente o propósito de tornar bom o seu praticante" (p. 71). A partir dessas concepções, o problema epistemológico fundamental de uma ciência da práxis passa a ser o de encontrar um saber no qual teoria e prática estejam intrinsecamente articulados na unidade do mesmo processo cognoscitivo. Aqui se cogita, hipoteticamente, que a estrutura híbrida da ética do discurso tem a pretensão de enfrentar o problema da mediação entre teoria e prática, mutatins mutandis, em que a fundamentação do princípio é "cognitivista, formal, universal, deôntico e pós-convencional" (cf. HERRERO, A ética do discurso de K.-Otto Apel. In: Ética do discurso: novos desenvolvimentos e aplicações, pp. 19-20).

${ }^{896}$ APEL, Necesidad, dificultad y posibilidad de una fundamentación filosófica de la ética en la época de la ciência. In: Estudios éticos, p. 115.

${ }^{897}$ Idem, p. 127. 
traduz discursivamente a regularidade causal dos fenômenos da natureza, não pode ser aplicada à ordem dos costumes.

Segundo a análise de Apel, a raiz da dificuldade relativa à fundamentação filosófica da ética se encontra na distinção estabelecida por David Hume entre fatos (ser) e normas (dever-ser). Na modernidade, a cisão entre leis fáticas da natureza oriundas de uma racionalidade cientificista e tecnológica valorativamente neutra e leis normativas do agir humano, supostas como oriundas da razão prática subjetiva estabelece um abismo logicamente insuperável entre a ideia da razão prática e a ideia de uma racionalidade científica e tecnológica. Esse abismo orienta o novo (moderno) paradigma ético, em substituição à unidade metafísica do ens e do bonum, seja no sistema aristotélico, seja no logos heraclitiano-estóico. Nesse contexto, Apel vê a ética de Kant como exemplo desse novo paradigma, posto que ele define o "simplesmente bom" não através do pressuposto ontológico de uma perfeição do ser, mas do pressuposto transcendental de uma vontade boa e autônoma. Kant explicita a lei do dever-ser postulando como critério para a legalidade das máximas da vontade a possibilidade da unidade e identidade da lei natural e lei ética, a ser realizada por todos os homens ${ }^{898}$. No século XX, essa distinção se converte em paradigma da metaética analítica, no sentido da análise valorativamente neutra e científico-objetiva dos discursos normativo-prescritivos em sua diferenciação com relação aos discursos explicativodescritivos da ciência. A distinção linguístico-analítica desses dois tipos de discursos, enquanto correlatos de ser e dever-ser e do fundamento da crítica à naturalistic fallacy, por um lado, equipara os predicados de "objetividade" e "verdade" às proposições descritivoexplicativas da ciência e, por outro, segrega o campo da ética à esfera da fundamentação subjetiva. Posto que as proposições prescritivo-normativas da ética são tidas como não objetivamente válidas e verdadeiras, elas podem apenas funcionar como fundamento válido somente para as decisões subjetivas, instaurando assim o modelo do decisionismo ético.

Como resultado da distinção entre ser e dever-ser, na época da ciência e no contexto do liberalismo tardio, a possibilidade da filosofia prática é aventada nos termos de um sistema ideológico de complementaridade entre a racionalidade processual valorativamente neutra da ciência no âmbito público e a decisão valorativa pré-racional no âmbito privado da vida. Segundo Apel, esse sistema de complementaridade das filosofias "standards" ocidentais do século XX, em que um existencialismo subjetivista-irracionalista se

\footnotetext{
${ }^{898}$ APEL, Necesidad, dificultad y posibilidad de una fundamentación filosófica de la ética en la época de la
} ciência. In: Estudios éticos, pp. 112-113. 
converte em complemento filosófico da ratio cientificista-tecnológica, cumpre a função ideológica de legitimar a separação e complementação da vida pública e da vida privada. Com base nesse sistema, vige a seguinte situação dilemática nas sociedades industriais e democracias ocidentais: "ou liberdade pessoal e ciência livre, porém sem compromisso intersubjetivo com normas éticas, valores e fins; ou uma mediação institucionalizada e fixada dogmaticamente entre teoria e práxis, porém sem oportunidade de mediação baseada na livre decisão da consciência individual" ${ }^{\text {"99. }}$. Apel traduz essa situação afirmando que na vida pública vigora o monoteísmo racional. Nele, as justificações morais são substituídas por argumentos pragmáticos de peritos baseados em regras científicas objetiváveis. Ao mesmo tempo, ele afirma que na vida privada reina um politeísmo axiológico, posto que as decisões éticas ou religiosas decorrem da hierarquia de valores do reduto da consciência privada ${ }^{900}$. $\mathrm{O}$ problema de fundo, segundo Apel, é que esse sistema de complementaridade ideológica, que atualmente funciona no liberalismo tardio, não prevê uma fundamentação ético-racional das convenções públicas válidas, tampouco uma interpretação substancial ético-normativa das decisões de consciência pré-racionais dos indivíduos, que nas convenções são pressupostas como constitutivas ${ }^{901}$. Ademais, as convenções e os consensos fáticos, como tentativa de síntese entre as decisões subjetivas e as pretensões de normas objetivas, resultam racionalmente inadequados para o sustento último da validade das normas éticas e jurídicas, tal como se verifica quando se analisa o solipsismo metódico. O esforço de Apel é o de mostrar, frente ao irracionalismo ético e ao silêncio público quanto à ética, que as normas morais são racionais contanto que argumentáveis e, além disso, que é possível construir uma ética não neutra, porém cognitiva e normativa ${ }^{902}$.

$\mathrm{Na}$ análise desse paradoxo, Apel identifica três correntes filosóficas, a saber, o solipsismo metódico, o cientificismo positivista e o racionalismo crítico. Apel entende que essas posições teóricas colaboram na desmobilização da fundamentação racional e última de uma ética universal de responsabilidade solidária exigida pelas consequências das ações coletivas da humanidade. O que torna esse quadro de desmobilização ainda mais dramático é

\footnotetext{
${ }^{899}$ CONILL apud CORTINA, Razón comunicativa y responsabilidad solidaria, na p. 34.

${ }^{900}$ APEL, Necesidad, dificultad y posibilidad de una fundamentación filosófica de la ética en la época de la ciência. In: Estudios éticos, pp. 114-115. CORTINA, Razón comunicativa y responsabilidad solidaria, pp. $38-42$.

${ }^{901}$ APEL, Necesidad, dificultad y posibilidad de una fundamentación filosófica de la ética en la época de la ciência. In: Estudios éticos, pp. 111-115.

${ }^{902}$ CORTINA, Razón comunicativa y responsabilidad solidaria, p. 40-43.
} 
que os sistemas filosóficos imperantes que legitimam ideologicamente os sistemas políticos, nem no Ocidente nem no Oriente fomentam a responsabilidade da razão prática ${ }^{903}$.

O principal adversário da filosofia de Apel é o "modo de pensar monológico", denominado por ele de solipsismo ou individualismo metódico ${ }^{904}$. O solipsismo metódico consiste na postura metodológica impregnada na tradição do liberalismo e na filosofia Ocidental, de Descartes a Husserl, que concebe que o indivíduo, no campo teórico como no prático, é anterior à constituição da sociedade. O indivíduo recorre a esta, em último caso, para satisfazer suas necessidades, interesses e desejos mediante ações instrumentais e estratégicas. Mesmo reconhecendo que o homem possui uma dimensão social, esse modo de pensar defende que o critério último da moralidade é o bem subjetivo. Nesse modo de pensar monológico, a moralidade é um produto da consciência individual e, por isso, uma resposta solidária às ameaças éticas em escala planetária não é prescritível incondicionalmente, senão que aconselhável na medida em que produz benefício ao próprio indivíduo. Para Apel, o individualismo metódico é perigoso por causa de suas consequências práticas, pois a partir dele é possível legitimar ideologicamente o egoísmo social. Com base nele, a razão prática corre o risco de se degenerar em uma racionalidade estratégica de cálculo de benefícios e satisfações individuais que, consequentemente, impossibilita uma resposta ética universal. Aqui, a ética do discurso de Apel se serve da superação do solipsismo metódico por meio do "socialismo pragmático", tal como exposto em capítulo anterior deste trabalho. Nesse rumo, a objeção de Apel ao solipsismo metódico, partindo da semiótica trivalente de Charles S. Peirce, é no sentido de demonstrar que ele é produto de uma falácia abstrativa. Ele é expressão do erro da filosofia moderna da consciência e da análise da linguagem reduzida às dimensões sintática e semântica, do erro da abstração da dimensão pragmática da linguagem. Na raiz desse erro está a suposição de que o homem é capaz de forjar seu pensar e agir sem já estar sempre inserido em uma comunidade comunicação; ou seja, não considerar que "nós somos um diálogo" (Hölderlin). Resumidamente, isso significa que a ética do discurso se estrutura pelo dialógico em contraposição ao monológico ${ }^{905}$.

\footnotetext{
${ }^{903}$ CORTINA, Razón comunicativa y responsabilidad solidaria, p. 31.

${ }^{904}$ CORTINA, Razón comunicativa y responsabilidad solidaria, p, p. 33.

905 CORTINA, Razón comunicativa y responsabilidad solidaria, p. 52-66. Para Kuhlmann, o a priori de comunicação representa uma clara objeção ao solipsismo ("eu não posso levantar com meu pensamento uma pretensão de validade e compreendê-la ao mesmo tempo como privada"), cf. KUHLMANN, Wolfgang. Problemas de fundamentação da ética do discurso. In: HERRERO, F. J. e NIQUET, Marcel (Ed.). Ética do discurso: novos desenvolvimentos e aplicações. Minas Gerais: FAFICH-UFMG, 2000, pp. 45-48.
} 
O cientificismo positivista, ao passo que parte da separação epistemológica entre teoria e dever-ser práxis, atribui racionalidade ao discurso sobre fatos e deixa na penumbra do irracional o discurso sobre normas (valoração). Em uma perspectiva mais abrangente, a escola do racionalismo crítico ${ }^{906}$ de $\mathrm{K}$. Popper defende a tese da a impossibilidade de uma fundamentação última, seja da ação ou do conhecimento. Essa impossibilidade deriva da equiparação da ideia de fundamentação filosófica e científica com o procedimento de dedução lógica de proposições a partir de proposições. Trata-se da equiparação da validade intersubjetiva com a objetividade das constatações empíricas valorativamente neutras e das inferências lógicas, tornando assim impossível uma fundamentação última das normas éticas. Essa impossibilidade ocorre em duas situações: a) quando somente podem ser intersubjetivamente válidas as constatações empíricas isentas de valoração; b) à medida que é impossível a derivação lógica de normas exclusivamente a partir de constatações empíricas ${ }^{907}$. Nessa ideia logicista de fundamentação está implicado que as proposições normativas e prescritivas não podem ser fundamentadas por meio de evidências quaisquer, que não sejam as da lógica dedutiva. Da ideia popperiana da fundamentação decorre que todo intento de fundamentação última conduz ao trilema de Münchhausen: a) ou o intento de derivação de orações a partir de orações conduz a um regresso ao infinito, b) ou a uma pressuposição das orações que tem que fundamentar, caindo em um círculo lógico (petitio principii); c) ou a uma interrupção do intento de fundamentação, adotando determinadas premissas como $\operatorname{dogmas}^{908}$.

H. Albert, discípulo de Popper, propõe uma estratégia substitutiva para a impossibilidade da fundamentação última das normas éticas, em que se vislumbra aplicar ao mundo moral, político, religioso e econômico o modelo da racionalidade crítica, regida pelo princípio do falibilismo. Ou seja, semelhantemente às hipóteses da ciência empírica, as teorias éticas e suas vivências devem ser submetidas à prova crítica de plausibilidade através da

\footnotetext{
906 APEL, Necesidad, dificultad y posibilidad de una fundamentación filosófica de la ética en la época de la ciência. In: Estudios éticos, pp. 128-133. CORTINA, Razón comunicativa y responsabilidad solidaria, p. 32.

907 APEL, Necesidad, dificultad y posibilidad de una fundamentación filosófica de la ética en la época de la ciência. In: Estudios éticos, p. 128. CORTINA, Razón comunicativa y responsabilidad solidaria, p. 31.

908 APEL, Necesidad, dificultad y posibilidad de una fundamentación filosófica de la ética en la época de la ciência. In: Estudios éticos, p. 129. Aqui se marca a reformulação pragmático-transcendental da problemática da fundamentação: não se trata de uma fundamentação por derivação, mais por estrita reflexão; concerne à seara da racionalidade filosófica, cuja tarefa é uma reflexão transcendental enquanto explicitação dos pressupostos irrecusáveis de toda argumentação. A respeito da questão concernente à fundamentação, ver: OLIVEIRA, Sobre a fundamentação, pp. 68- 78; KUHLMANN, Problemas de fundamentação da ética do discurso. In: Ética do discurso: novos desenvolvimentos e aplicações, pp. 61-61, especificamente a "objeção 5" (impossibilidade de uma fundamentação suficiente de uma ética normativa) e a "objeção 6" (discussão sobre o status e o valor posicional dos argumentos reflexivos).
} 
experiência, com o fim de superar o dogmatismo e facultar o surgimento de uma "sociedade aberta" (crítica) frente às sociedades fechadas, regidas pela irracionalidade. Em contrapartida, Apel entende que a estratégia compensadora dos popperianos, na direção da permanente crítica e seleção através da falsificação, sob a suposição de que as teorias éticas devem morrer semelhantemente às espécies que não se adaptam à natureza, em lugar da fundamentação suficiente, não soluciona o problema de uma fundamentação última, no caso de uma norma ética básica da sobrevivência a qualquer preço, que já é pressuposta como um a priori ético não falseável. Segundo Apel, a analogia entre o exame de teorias ou hipóteses da ciência empírica e o exame de sistemas morais é equivocada. Na verdade, os homens não podem deixar morrer as normas morais como se fossem hipóteses da ciência empírica, porque não é possível supor que, em nome da vida, possam distanciar-se por algum tempo da "vida boa". Isso é reconhecido por Descartes quando conserva a "moral provisória" como condição de possibilidade da dúvida metódico-científica ${ }^{909}$.

De todo modo, Albert pensa que a ideia de fundamentação filosófica última da ética deve dá lugar ao decisionismo. Para ele, já que a opção por uma ou outra normatividade ética é, em último caso, inargumentável, em vista de imunizar a vida social dos dogmatismos e totalitarismos e dotar a decisão de racionalidade, é necessário adotar alguns procedimentos. O primeiro é propor diversos sistemas éticos hipotéticos e revisáveis, para serem submetidos ao crivo do princípio do falibilismo. Esse procedimento se embasa no princípio da realizabilidade, em que as ciências determinam o que pode ser feito e, por conseguinte, os sistemas morais submetem suas normas à crítica científica. $\mathrm{O}$ conhecimento científico dá a primeira palavra no âmbito da moral: "o que não se pode, não se deve”. O segundo é averiguar a coerência interna dos sistemas propostos à luz do princípio de não-contradição. Aqui, o postulado da congruência exige que a decisão por um sistema de valores deve contar com o conhecimento científico disponível. O terceiro passo é extrair as consequências previsíveis (critério metaético) de cada sistema moral coerente e congruente em prol de sociedades regidas pela racionalidade política, econômica e ética. Assim, conforme a tese do racionalismo crítico, a decisão última substitui a fundamentação última ${ }^{910}$. Em contraposição a Albert, Apel afirma que os argumentos, por mais contundentes, não obrigam ninguém a aceitar uma opção; a negativa é sempre possível e a vontade tem a última palavra. É imprescindível contar com a vontade autônoma dos indivíduos e inclusive com o

\footnotetext{
909 APEL, Necesidad, dificultad y posibilidad de una fundamentación filosófica de la ética en la época de la ciência. In: Estudios éticos, pp. 130-133.

${ }^{910}$ CORTINA, Razón comunicativa y responsabilidad solidaria, p. 43-47.
} 
compromisso existencial para se falar de ética. No entender de Apel, a necessidade de uma fundamentação filosófica última das normas e dos fins últimos se justifica como uma opção racional, porque nela "razão" e "vontade" se identificam" 911.

Em face de esses obstáculos à legitimação da moralidade e ao mesmo tempo da necessidade uma macroética para a nossa epocalidade, a ética do discurso de Apel subsume a perspectiva de uma proposta de filosofia moral que assume, em seu ponto de partida, a tarefa de fundamentação última da ética. Para Cortina, a "ética do diálogo" de Apel se consubstancia como uma ética contemporânea próxima às motivações e à consciência da vida cotidiana, visando fundamentar uma proposta ética com validade intersubjetiva para um ethos responsável e solidário, o que demonstra sua resistência a reconhecer no fim das imagens do mundo o fim da moralidade ${ }^{912}$. Ao esboçar sobre a compreensão pragmático-transcendental da ética do discurso, Apel assinala os dois traços principais que caracterizam sua proposta de teoria moral como "ética do discurso": a) a ética discursiva "remete a uma forma especial de comunicação, o discurso argumentativo, como medium de fundamentação concreta das normas"; b) a ética do discurso "remete à circunstância segundo a qual o discurso argumentativo, e não outra forma de comunicação no mundo da vida, contém o a priori racional de fundamentação para o princípio da ética" ${ }^{913}$. Esses traços característicos se estruturam sob a base do tipo de reflexão que Apel considera ser especificamente filosófica, a reflexão transcendental ${ }^{914}$, isto é, uma reflexão sobre as condições de possibilidade e validade da constituição do conhecimento no mais amplo sentido.

Os traços supramencionados decorrem do caminho adotado por Apel em sua trajetória com vistas à transformação da filosofia transcendental pelo paradigma da linguagem. A segunda parte deste trabalho enfoca essa trajetória. Aqui, para aclarar o pano de fundo desses traços, reitera-se delimitamente sobre a situação da filosofia transcendental na era da ciência. Essa situação se caracteriza pelo fato de que a filosofia não pode reclamar um objeto como seu objeto, isto é, nem a consciência, nem a linguagem, nem a sociedade enquanto comunidade de comunicação. Em contrapartida, ela pode e deve investigar

\footnotetext{
${ }^{911}$ CORTINA, Razón comunicativa y responsabilidad solidaria, p. 48-52.

${ }^{912}$ CORTINA, Razón comunicativa y responsabilidad solidaria, p. 12. Sobre a questão do fundamento ver: RÖD, W.. O problema da fundamentação última na filosofia contemporânea: o debate entre racionalismo crítico e pragmática transcendental. In: CARVALHO, Maria Cecília de (Org). Paradigmas Filosóficos da Atualidade. Campinas: Campus, 1989, pp. 127-144 (passim). Cf. também: OLIVEIRA, Ética e racionalidade moderna, p. 939.

${ }^{913}$ APEL, Teoría de la verdad e ética del discurso, p. 147-148.

${ }^{114}$ Sobre o sentido de transcendental, cf. APEL, Transformação da filosofia (v.1), introdução, p. 84, nota de rodapé 115 .
} 
virtualmente todos os objetos do conhecimento, tanto pré-científico como científico, em virtude de seu valor transcendental como condições de possibilidade e validade do conhecimento. É desse "valor transcendental”, segundo Apel, que surge a posição peculiar do discurso teórico da filosofia como administradora da reflexão transcendental sobre a validade. No sentido desse tipo de reflexão, os enunciados estritamente filosóficos se caracterizam pela autorreflexividade e universalidade.

Esse caminho toma a direção da descoberta da linguagem como medium constitutivo de todo sentido e validade. A linguagem é a instância que, estando presente em toda comunicação humana, implica um "entendimento humano" (acordo) acerca do sentido de todas as palavras usadas e do sentido das coisas mediadas pelos significados das palavras e, assim, mediatiza toda relação significativa entre sujeito e objeto. Ela constitui a condição de possibilidade e validade do conhecimento objetivo, do autoconhecimento e do agir com sentido. Na visão de Apel, a humanidade alcança no século XX a consciência de que a palavra "linguagem" aponta para um problema de fundamentos da ciência e filosofia. A linguagem se torna uma preocupação comum a quase todas as disciplinas e escolas teóricas. Então, supondo isso, o caminho de Apel é o de mostrar a linguagem, em sentido kantiano, como um medium intranscendível de todo sentido e validade.

Concebendo em termos kantiano, Apel define a linguagem como uma grandeza transcendental (transzendentale Grösse) ${ }^{915}$. Tal transformação considera que, fundamentalmente, não há uma "astúcia da razão", mas fora da linguagem não há razão. Na compreensão de Apel, os homens como seres de linguagem, em oposição aos animais, estão condenados a "entender-se" sobre os critérios de sentido e validade do agir e conhecer. Nesse caminho, a tarefa de fundamentação é marcada pelo abandono do paradigma monológico da razão centrada na consciência (gnosiologias centradas na subjetividade e na evidência) e, em contrapartida, pela adoção do paradigma da linguagem, da razão centrada no fato "objetivo" e público do diálogo (discurso argumentativo). Apel aplica o método transcendental sobre esse factum de caráter intersubjetivo, que serve de pedra angular de toda sua reflexão filosófica: o campo da intersubjetividade linguisticamente mediada. A argumentação expressa o traço específico da razão humana, bem como a esfera que diz respeito à constituição de validade. Como traço peculiar desse caminho, Apel entende que o objeto da reflexão transcendental não é a estrutura sintático-semântica da linguagem, ou seja, não é a verdade da proposição, mas a

915 APEL, Transformação da filosofia, v. II, p. 379; Transformation der philosophie, Band II, pp. 333. A concepção do conceito transcendental-hermenêutico de linguagem de Apel constitui o pano de fundo do segundo capítulo deste trabalho. 
relação hermenêutico-pragmática presente na atividade humana, por meio da qual se articula a validade intersubjetiva dos argumentos. E, em razão disso, ele desenvolve uma hermenêutica transcendental e uma pragmática transcendental enquanto aspectos complementares de uma semiótica transcendental ${ }^{916}$.

Supondo o caráter intranscendível da linguagem, Apel concebe a ética do discurso como uma perspectiva de filosofia prática articulada em duas dimensões ${ }^{917}$. Em sua dimensão exotérica, a ética do discurso conota que o discurso argumentativo é o medium intranscendível para a fundamentação das normas consensuais da ética e do direito. Em sua dimensão esotérica, especificamente própria do tipo de discurso filosófico, ela remete à circunstância em que o discurso argumentativo contém também o a priori racional de fundamentação para o princípio de universalização dos interesses da ética. Na dimensão exotérica, a ética do discurso evoca o apecto referente a uma perspectiva normativa de uma ética da corresponsabilidade $^{918}$. Por trás desse aspecto subsiste a situação, pela primeira vez na história, em que se observa a insuficiência de uma moral dos costumes (moral convencioanal) ${ }^{919}$ para regular as relações intersubjetivas, cujas normas seriam supostamente evidentes para todos os indivíduos. Ocorre que, como destinatário de uma moral convencional, o indivíduo não pode assumir a responsabilidade solidária pelas consequências e subconseqüências em escala mundial das atividades coletivas dos homens - por exemplo, quanto à aplicação industrial da ciência e da técnica - e organizar a corresponsabilidade como práxis coletiva. Ainda é preciso considerar que, em meio a essa insuficiência, a alternativa no sentido do burocratismo despótico-totalitarista, além de despojar o sujeito de sua corresponsabilidade, não é compatível com a liberdade e autonomia moral do indivíduo.

Disso, para resolver o problema de uma ética pós-convencional da responsabilidade, segundo Apel, resta a alternativa da ética do discurso. É a alternativa pelo fato de pressupor a cooperação solidária dos indivíduos já por meio da participação no discurso argumentativo, tanto quanto possível, já na fundamentação das normas morais e jurídicas susceptíveis de consenso. Nesse sentido, também a institucionalização política dos discursos práticos constitui uma tarefa vinculada à cooperação solidária dos indivíduos corresponsáveis e, por conta disso, sujeita à crítica de “opinião pública” por meio de

\footnotetext{
${ }^{916}$ APEL, Le problème de l'évidence phénomenologique à la limière d'une sémiotique transcendantale. In: Critique, p. 80-81.

917 APEL, Teoría de la verdad e ética del discurso, pp. 148 e 150. Cf. HERRERO, F. Javier. O problema da fundamentação última. In: Kriterion, Belo Horizonte, v. XXXV, n. 91, pp. 7-16, Jan/95-Jul/95, cf. pp. 8-10.

${ }^{118}$ APEL, Teoría de la verdad e ética del discurso, p. 149.

919 APEL, Teoría de la verdad e ética del discurso, p. 148.
} 
discursos. Nesse ponto, é importante ter em conta que a "libertação" dos indivíduos mediada pelas instituições não pode conduzir à situação em que a comunidade de comunicação das pessoas capacitadas para o discurso venha a se distanciar de sua responsabilidade e competência comunicativa frente às instituições. Na avaliação de Apel, a regulamentação normativa, mais ou menos vinculante, na forma de entendimentos, conclusões e pactos que regulamentam os planos de política local, nacional e internacional, parece atestar o reconhecimento da perspectiva normativa de uma ética da corresponsabilidade, tal como sugere a dimensão exotérica da ética do discurso. Segundo Apel, os discursos no sentido de uma macroética contemporânea se caracterizam como mediação de organização cooperativa da responsabilidade solidária, bem como da fundamentação ou justificação das normas jurídicas e sociais ${ }^{920}$.

O segundo traço da ética do discurso é a dimensão esotérica, propriamente filosófica. Essa dimensão consiste na pressuposição que o discurso argumentativo, em razão do seu caráter intranscendível (Nichthintergehbarkeit) por parte de qualquer pensamento com pretensão de validade, deve "possibilitar a fundamentação última do princípio ético que deve conduzir já sempre todos os discursos argumentativos, enquanto discursos práticos de fundamentação de normas" ${ }^{\prime 921}$. A respeito dessa pressuposição, os representantes de uma ética de princípios comprometida com Kant têm indicado que a exigência de discursos práticos de fundamentação de normas por parte da ética do discurso já pressupõe, ele mesmo, um princípio ético, que pode funcionar como critério formal para o procedimento e os resultados pretendidos desses discursos. No entanto, salienta Apel, o problema é que não se pode equiparar todas as conversações (negociações) em vista de acordos normativos obrigatórios como discursos práticos (no sentido da ética do discurso). O que define esses discursos práticos é, fundamentalmente, sua capacidade de consensuar as soluções para os problemas por parte de todos os envolvidos, ou seja, a capacidade de consenso por parte dos afetados na negociação. Diferentemente do discurso de negociação estratégica, que tende a apoiar-se no cálculo de riscos e vantagens e na violência declarada, os discursos práticos (éticos) necessitam se basear em argumentos racionais válidos. Apel responde enfaticamente: o consenso à custa de terceiros ou chantagem não enreda os resultados eticamente pleiteados pelos discursos práticos de valor ético desejado ${ }^{922}$.

\footnotetext{
${ }^{920}$ APEL, Teoría de la verdad e ética del discurso, pp. 148-149.

${ }^{921}$ APEL, Teoría de la verdad e ética del discurso, p. 150.

922 APEL, Teoría de la verdad e ética del discurso, pp. 150-151.
} 
Também diferentemente do que se pode pressupor em uma antiga ética de princípios, no sentido de que a pergunta pelo princípio criteriológico dos discursos seja respondida por meio de uma fundamentação pré-comunicativa e referida ao sujeito autárquico (Kant), a ética do discurso se caracteriza por descobrir, mediante o discurso reflexivoargumentativo no próprio discurso, um a priori ineliminável para todo pensamento filosófico, o qual inclui o reconhecimento de um princípio criteriológico da ética. Nisso reside o caráter estritamente filosófico-transcendental da ética do discurso, na linha de uma transformação semiótico-transcendental da filosofia de Kant que visa a fornecer uma fundamentação transcendental última da lei moral ${ }^{923}$. Para Apel, Kant não realiza tal fundamentação porque, ao estabelecê-la como um factum evidente da razão prática, baseia-se em um princípio subjetivo da razão (princípio do "eu penso"), no sentido do solipsismo metódico. Com efeito, segundo Apel, o princípio do "eu penso" (Descartes, Kant, Husserl) não permite, desde si mesmo, nenhuma fundamentação transcendental da ética. Sendo mais enfático, Apel assinala que esse princípio não proporciona sequer o fundamento para a constituição do sentido da pergunta pela lei moral, porque a pergunta pela lei moral (diferentemente da lei natural) só encontra seu sentido na regulação das relações intersubjetivas de uma pluralidade de sujeitos. Em sua crítica, Apel salienta que Kant recorre ao "reino dos fins" metafísico para pensar a "autonomia da vontade moralmente boa como 'ratio essendi' da lei moral". Nisso, Kant pressupõe uma liberdade metafísica - apenas “pensável”, mas que não é cognoscível nem demonstrável - das entidades inteligíveis puramente racionais para tornar compreensível a autonomia moral do homem ${ }^{924}$.

No tocante à fundamentação, Apel entende que a semiótica transcendental alcança uma compreensão até então não alcançada pela filosofia do sujeito moderno. Nela, a frase não-falseável do "eu penso" não pode ser expressa e entendida como transcendentalmente solitária e autárquica no sentido do solipsismo metódico, mas somente como "eu argumento no discurso". O "eu argumento no discurso" expressa o reconhecimento da dimensão transcendental da intersubjetividade, ou seja, a necessidade da comunicação como condição de possibilidade da compreensão linguística com os outros. Ao mesmo tempo, "eu argumento no discurso" implica em reconhecer-se a um só tempo membro de uma comunidade real de comunicação e de uma comunicação ideal de comunicação (contrafaticamente pressuposta na

\footnotetext{
923 APEL, Teoría de la verdad e ética del discurso, p. 151.

${ }^{924}$ APEL, Teoría de la verdad e ética del discurso, pp. 151-152.
} 
situação da argumentação) ${ }^{925}$. Para Apel, a possibilidade efetiva de uma fundamentação última da ética depende de uma transformação pragmático-transcendental da filosofia transcendental, a ser realizada mediante a substituição do princípio do "eu penso" pelo princípio "eu argumento". A tese fundamental da ética do discurso, em sua dimensão esotérica (filosófica), é que na argumentação pública, assim como no pensar solitário, já se pressupõe as condições normativas de possibilidade de um discurso argumentativo ideal como única condição possibilidade para resolver sem violência as pretensões de validade em situação de disputa. Esse discurso ideal, enquanto discurso propriamente filosófico, não constitui um jogo de linguagem "autossuficiente", pois sua função pressupõe que todos os participantes no discurso estejam a priori comprometidos - de forma ilimitada e sem reservas - na solução de todas as questões relativas à validade. Ele também não se confunde com um discurso limitado estrategicamente, pois, mediante ele, importa alcançar soluções para os problemas que são susceptíveis de consenso para todos os membros de uma comunidade ilimitada e ideal de argumentação ${ }^{926}$.

Para Apel, a pergunta rigorosa pelas condições transcendentais do sentido e validade do discurso requer uma atitude estritamente reflexiva. Isso significa descobrir e explicitar o que já está necessariamente contido no discurso argumentativo. Em conformidade com essa fundamentação por autorreflexão, essa pergunta pelo pressuposto inclui já implicitamente as condições de possibilidade de sua resposta. Nisso consiste, segundo Apel, o aspecto mais importante da fundamentação reflexiva última da ética ${ }^{927}$. Apel entende que as condições de possibilidade de uma fundamentação racional última da ética dizem respeito a todos os pressupostos da argumentação que cumprem a condição de não poderem ser mais discutidos por nenhum oponente sem uma real autocontradição performativa e de não poderem ser demonstrados sem petitio principii" ${ }^{, 28}$. As condições explicitadas por autorreflexão não podem ser negadas sem cair em autocontradição performativa, posto que elas estão presentes como condição de possibilidade dessa negação; disso decorre que elas não podem "ser provadas dedutivamente sem envolver círculo vicioso, porque elas são inobjetiváveis, i.é, estão necessariamente presentes como condição de possibilidade de toda

\footnotetext{
925 APEL, Teoría de la verdad e ética del discurso, p. 152. CORTINA, Razón comunicativa y responsabilidad solidaria, pp. 66-70.

926 APEL, Teoría de la verdad e ética del discurso, pp. 154-155.

927 APEL, Teoría de la verdad e ética del discurso, p. 156.

${ }^{928}$ APEL, Necesidad, dificultad y posibilidad de una fundamentación filosófica de la ética en la época de la ciência. In: Estudios éticos, p.154.
} 
prova objetiva" ${ }^{929}$. O ponto arquimédico da fundamentação última, ou seja, o caráter especificamente pragmático-transcendental, reside não em uma premissa contingente, empírica ou metafísica, mas no a priori da situação (detrás da qual não se pode retroceder mais) do pressuposto cognoscível somente por autorreflexão ${ }^{930}$. Nesse a priori, o "eu argumento no discurso" significa argumentar como membro de uma comunidade real de comunicação e como membro de uma comunidade de comunicação ilimitada e necessariamente antecipada contrafaticamente ${ }^{931}$. Em sua dimensão fática (comunidade real de comunicação), o argumentar "sério" implica em tomar em relevo as condições iniciais para qualquer discurso concreto, que são tematizadas pela hermenêutica filosófica e pela pragmática linguística a respeito da pré-compreensão do mundo e do acordo. Trata-se aqui dos pressupostos - descritos por neopragmatistas e hermeneutas, tais como Gadamer, MacIntyre, Williams e Rorty - que pertencem a uma "base histórica e contingente de consenso", delineando uma eticidade concreta e condicionada sociocultural e historicamente ${ }^{932}$. Em sua dimensão contrafática, o pressuposto da comunidade ideal de comunicação é "quase ignorado" 933 pela hermenêutica e pela pragmática procedentes de Heidegger e Wittgenstein. Aí, o argumentar implica em reconhecer os pressupostos ideais e universalmente válidos da comunicação em uma comunidade ideal de comunicação. Por sua vez, essas condições se equiparam a normas ideais universalmente válidas ${ }^{934}$.

Para aclarar sobre a fundamentação pragmático-transcendental da ética por autorreflexão, retoma-se aqui a exposição de Herrero, a qual tem o mérito de distinguir, esquematicamente, "os pressupostos transcendentais do discurso argumentativo", "os pressupostos reais do discurso argumentativo" e o "telos do princípio moral para a práxis histórica" da sociedade ${ }^{935}$. Tratar-se-á sobre este último item no tópico seguinte, relacionadoo particularmente à parte $\mathrm{B}$ da ética do discurso. Conforme esse esquema de desdobramento das ideias de Apel, a autorreflexão referida à situação da argumentação descobre e explicita os

\footnotetext{
${ }^{929}$ HERRERO, F. Javier. A ética do discurso de K.-Otto Apel. In: HERRERO, F. J. e NIQUET, Marcel (Ed.). Ética do discurso - novos desenvolvimentos e aplicações. Minas Gerais: FAFICH-UFMG, 2000, pp. 16-17.

${ }^{930}$ APEL, Necesidad, dificultad y posibilidad de una fundamentación filosófica de la ética en la época de la ciência. In: Estudios éticos, p. 160.

${ }^{931}$ APEL, La ética del discurso ante el desafío de la filosofía latinoamericana de la liberación in: Isegoría, p. 112.

${ }^{932}$ APEL, Teoría de la verdad e ética del discurso, p. 157.

${ }^{933}$ Este "quase ignorado" parece refletir uma imprecisão, pois, pelo exposto na segunda parte deste trabalho consoante aos giros hermenêutico-linguístico e pragmático-semiótico, não é possível depreender, por exemplo, de Heidegger ou Wittgenstein a defesa de uma fundamentação racional última.

${ }^{934}$ APEL, Teoría de la verdad e ética del discurso, pp. 157-158.

${ }^{335}$ HERRERO, A ética do discurso de K.-Otto Apel. In: Ética do discurso: novos desenvolvimentos e aplicações, pp. 17-25 (passim).
} 
pressupostos (condições) transcendentais do discurso argumentativo, bem como o princípio moral implicado nele. Para Herrero, as condições que devem ser preenchidas para que a ação argumentativa possa em geral ter sentido e ser válida intersubjetivamente são as seguintes: a) do ponto de vista sintático, exige-se que as proposições cumpram regras intersubjetivas do uso linguístico de uma determinada comunidade linguística; b) do ponto de vista semântico e pragmático, exige-se, primeiro, que as proposições sejam compreensíveis para os cossujeitos, para que possam mediatizar o significado do objeto da argumentação; segundo, que a argumentação seja válida intersubjetivamente, ou seja, que justifique com razões as pretensões de sentido e validade levantadas; terceiro, que essa justificação venha a ser responsavelmente aceita por todos ${ }^{936}$.

Conforme Herrero, desdobrando a autorreflexão desses pressupostos, depreendese que, se toda argumentação já contém esses pressupostos, então quem argumenta já está pressupondo implícita e necessariamente os seguintes elementos instranscendíveis da comunicação. Ou seja, quem argumenta está pressupondo: a) que toda argumentação levanta pretensões intersubjetivas (verdade, correção e veracidade) para a validade das proposições; b) "que toda pretensão intersubjetiva é resolúvel discursivamente por razões"; c) "que toda resolução discursiva é responsável pela argumentação"; d) "que toda argumentação justificada discursiva e responsavelmente visa ao entendimento consensual, i.é, supõe a racionalidade do entendimento"; e) "que toda argumentação consensualmente válida implica a reciprocidade dialógica universal"; f) que a reciprocidade dialógica pressupõe que todo sujeito argumentante é livre e autônomo para levantar pretensões e tomar posição sobre as pretensões levantadas pelos outros, tem igualdade de direitos na argumentação e em todos os âmbitos do mundo da vida, enfim, é livre para se expressar e participar nos discursos sobre todas as questões do mundo da vida; g) que todos são corresponsáveis pelo reconhecimento da liberdade e direitos de todos, pela resolução dialógica dos conflitos passíveis de consenso, pelas ações e consequências dessas ações, pela organização da sociedade e pela conservação, crítica e renovações de suas instituições; h) que, pelo simples fato de argumentar, já tem

\footnotetext{
${ }^{936}$ HERRERO, A ética do discurso de K.-Otto Apel. In: Ética do discurso: novos desenvolvimentos e aplicações, pp. 17-18. Em consequência à descoberta da linguagem como campo de interesse comum de investigação (reviravolta linguística), surge três grandes âmbitos de pesquisa da linguagem: a) sintática, investigando a relação dos sinais linguísticos entre si; a) a semântica, investigando a relação dos sinais com o significado, ou seja, a dimensão referencial com os objetos significas; c) pragmática, investigando a relação dos sinais com os sujeitos e com o uso que estes fazem dos sinais e das proposições (p. 11).
} 
reconhecido que participa de uma comunidade ideal de comunicação e de argumentação contrafaticamente antecipada ("no fato de argumentar e mesmo contra os fatos") 937 .

Dado que a argumentação supõe as condições supramencionadas, então quem argumenta já tem reconhecido o princípio moral implicado em sua argumentação, ou seja, a reciprocidade dialógica universal. Na argumentação surge o dever recíproco de considerar como válido exclusivamente o que pode ser fundamentado discursiva e responsavelmente por argumentos racionais, quer dizer, "o dever de resolver dialógica e argumentativamente todas as pretensões à validade da vida humana”, em princípio, capaz de consenso ${ }^{938}$. Como já mencionado, esse princípio moral (meta-norma) é a transformação discursiva do princípio kantiano da autonomia da vontade como fundamentação da ética, em que a vontade todo ser racional como universalmente legisladora dá lugar ao princípio dialógico normativo. Ao passo que atua como norma procedimental da argumentação teórica ou prática a partir do “imperativo moral de abrir-se ao diálogo como o único modo de resolver racionalmente os conflitos nas relações inter-humanas e de fundar normas", esse princípio traz consigo a superação do solipsismo metódico ${ }^{939}$.

Conforme a análise de Herrero, é possível atribuir ao princípio dialógico normativo da ética do discurso as seguintes características. Esse princípio moral é: a) cognitivista, porque se funda ultimamente na intelecção racional da validade obrigatória de um princípio do bom enquanto princípio do dever-ser; b) formal e universal, porque sua fundamentação exige, em um primeiro momento, a abstração da fundamentação de normas materiais vinculadas à situação; c) pós-convencional, porque supera os critérios da moral convencional, já que se responsabiliza pelas consequências da aplicação do princípio moral na situação concreta; d) deôntico, pois coloca o problema do dever-ser previamente ao problema do "telos" (problema do bem viver e da felicidade platônico-aristotélico e utilitarista). E procede assim em razão de três motivos. Primeiro, enquanto ética crítica, a ética do discurso deixa em aberto a questão do telos-felicidade. Ela não "prescreve (como Platão e criadores de utopias) uma forma total de vida no sentido da unidade da justiça, da virtude e felicidade, nem a concebe (como Hegel) como a necessária "realidade da eticidade substancial'" 940 . Segundo, enquanto ética crítico-universalista, por um lado, ela não pode admitir o relativismo moral; por outro, tendo descoberto o princípio moral na discursividade e supondo que ele precisa ser

\footnotetext{
${ }^{937}$ HERRERO, A ética do discurso de K.-Otto Apel. In: Ética do discurso: novos desenvolvimentos e aplicações, p. 18.

${ }^{938}$ Idem, pp. 18-19.

${ }^{939}$ Idem, p. 19.

${ }^{940}$ Idem, p. 19.
} 
realizado nas diversas formas de vidas, a ética do discurso julga que as formas de vida devem subordinar seus projetos às condições universais do princípio moral. Terceiro, enquanto ética deôntica (Kant), a ética do discurso não garante a compatibilidade entre justiça e felicidade, caso do estado ideal de Platão, mas assinala a possibilidade da concordância entre a dignidade de ser feliz e a felicidade de fato em dependência dos discursos práticos. "Enquanto cognitivista, formal, universal, deôntica e pós-convencional, a ética do discurso fornece um procedimento de formação da vontade" e, de tal modo, "abre o espaço para que os afetados busquem por eles mesmos uma resposta para os problemas práticos-morais e prático-políticos do mundo da vida"941.

A descoberta dos pressupostos reais do discurso argumentativo, seguindo a explanação de Herrero, traz à luz a faticidade existencial do ser-no-mundo e a historicidade da razão. Quando se argumenta, junto com o a priori transcendental da argumentação, não se parte de um ponto zero da história e da razão moral, pois a argumentação ocorre numa situação histórica determinada do mundo da vida. No tocante a esses pressupostos, isso significa que a argumentação implica em reconhecer: a) uma comunidade real de comunicação, ou seja, uma realidade de costumes e instituições presente que, entre seu passado historicamente irreversível e determinante (o "de onde" ela provém) e seu futuro possível e incerto (o "para onde"), dá-se conta do dever de assumir o seu passado e, ao mesmo tempo, de ser corresponsável pelos projetos futuros; b) uma comunidade já constituída no seu meio natural (rico e devastado) e na sociedade organizada como estado de direito (a um só tempo observado e desrespeitado de fato), com seus costumes e instituições (racionais e irracionais), com suas tradições (variadas e maltratadas), com sua ética convencional e irresponsabilidade; c) uma comunidade, na qual se dá a formação da identidade pessoal e a integração (e também marginalização) social, que já realiza um entendimento consensual sobre o sentido da forma de vida, assim como sobre a verdade objetiva e correção intersubjetiva em vista de superar os desentendimentos (dissensos); d) uma comunidade que reconstrói sua história à luz das ciências naturais, humanas, hermenêuticas e culturais, o que mostra um certo grau de reconhecimento de uma racionalidade do entendimento, à medida que defende que todo sujeito humano é livre e tem igualdade de direitos, assim como a exigência da racionalidade comunicativa crítica para a reconstrução crítica da sociedade. Por esses pressupostos constituírem um fato, na argumentação está implícita o reconhecimento de

${ }_{941}$ HERRERO, A ética do discurso de K.-Otto Apel. In: Ética do discurso: novos desenvolvimentos e aplicações, p. 20. 
pertença a uma comunidade real de comunicação com seu agir ético e político convencional e seus consensos e dissensos fáticos, em boa medida sob pretensões arbitrárias e interesseiras, portanto, a uma comunidade que envolve a todos e os condiciona na argumentação. Desse reconhecimento se depreende a exigência da corresponsabilidade pela solução racionalmente consensual dos problemas que emergem em cada situação histórica determinada, seja em razão das contradições da comunidade real - a um só tempo racional-irracional, justa-injusta, mal integrada porque deficiente na socialização, seja porque na comunidade real a personalização é autônoma só em algumas ocasiões, seja porque a omissão quanto à responsabilidade abre espaço para a irresponsabilidade dos outros ${ }^{942}$.

É no reconhecimento desses pressupostos da argumentação, que não podem ser negados sem autocontradição performativa, que vem à tona a transformação pós-metafísica do princípio de universalização (“imperativo categórico") da ética. No horizonte dessa transformação, considera-se que a argumentação racional, isto é, que respeita as pretensões de sentido e validade do discurso, nolens volens ("querendo ou não querendo", que não se pode negar sem autocontradição performativa), pressupõe tanto a antecipação das relações ideais da comunicação, quanto o reconhecimento da igualdade de direitos e da corresponsabilidade, em princípio, de todos os participantes da comunicação. Considera-se que no argumentar está presente a pressuposição, enquanto finalidade do discurso, da capacidade universal de alcançar o consenso (acordo) para todas as soluções vinculantes dos problemas de fundamentação de normas. "O pensar só tem sentido e validade porque toda pretensão levantada com o conteúdo pensado é, em princípio, intersubjetiva e, em princípio, resolúvel discursivamente" ${ }^{, 943}$. O ponto principal dessa transformação é o seguinte: em lugar da aptidão legal das máximas de ação - segundo Kant, que os indivíduos precisam querer -, põe-se a ideia reguladora da consensualidade de todas as normas válidas por parte de todos os afetados, porém tendo em conta que a factibilidade delas depende de serem realizadas aproximativamente no campo do discurso real ${ }^{944}$. Na perspectiva da ética do discurso, a implementação e concretização da determinação kantiana da aptidão como lei no plano da intersubjetividade reside na capacidade de consenso universal, isto é, na idéia reguladora da comunicação humana que exige para a sua realização a obrigação da mediação dos interesses de todos os possíveis afetados. No sentido da fundamentação última pragmático-

\footnotetext{
${ }^{942}$ HERRERO, A ética do discurso de K.-Otto Apel. In: Ética do discurso: novos desenvolvimentos e aplicações, pp. 21-22.

${ }_{943}$ HERRERO, F. Javier. O problema da fundamentação última. In: Kriterion, Belo Horizonte, v. XXXV, n. 91, pp. 7-16, Jan/95-Jul/95, p. 8.

${ }_{944}$ APEL, Teoría de la verdad e ética del discurso, p. 158.
} 
transcendental do princípio de universalização da ética, o factum evidente da razão consiste em considera que quem argumenta, contanto que com a razão comunicativa enquanto racionalidade discursiva, já tem reconhecido a validade da lei moral na forma de princípio ético do discurso ${ }^{945}$.

\subsection{A educação para a corresponsabilidade como complemento necessário para superar o problema da aplicação referenciada à história da ética do discurso}

Feita a exposição no tópico anterior sobre a fundamentação da ética do discurso, este tópico trata de questões que se vinculam à possibilidade de aplicação do princípio da ética do discurso como ética da responsabilidade, qua ética referida à história. Aqui, essas questões se concentram em torno de dois pontos fundamentais. O primeiro ponto concerne a expor o ponto de vista de Apel a respeito da caracterização da ética do discurso, em primeiro lugar, como não-abstrata e referida à história e, em segundo lugar, como ética da responsabilidade, no sentido de uma ética pós-weberiana. Esse ponto assinala, fundamentalmente, o intento apeliano de demonstrar que a ética do discurso realiza a passagem de uma ética convencional para uma ética pós-convencional. A esse ponto parece ser possível pensar que tal passagem implica a formação da responsabilidade solidária (corresponsabilidade). Por conseguinte, essa possibilidade indica aqui um segundo ponto, que corresponde, de certo modo, a uma ideia original deste trabalho. Essa ideia preconiza o caráter suplementar da esfera da educação na parte B da ética do discurso, ou seja, no que tange a sua dimensão de ética da responsabilidade referida à história. Fundamentalmente, postula-se que a educação possa figurar, transversalmente aos subsistemas coercitivos da responsabilidade ligados à política, ao direito e à economia, como uma mediação institucional contraestratégica responsável pela formação à emancipação e à corresponsabilidade.

Para iniciar o primeiro ponto supramencionado, é importante reiterar que Apel concebe a ética do discuro não apenas como uma ética de princípios (parte A), mas também como uma ética de responsabilidade de referência histórica (parte B) ${ }^{946}$. Abreviando, a "parte A" da ética do discurso diz respeito a sua fundamentação; a "parte B" concerne ao significado teleológico do princípio moral para a práxis histórica. A exigibilidade de uso do princípio moral da consensualidade próprio do discurso argumentativo na situação real traz consigo o

\footnotetext{
945 APEL, Teoría de la verdad e ética del discurso, pp. 158-159.

946 Sobre o caráter híbrido da ética do discurso, ver: NIQUET, Ética do discurso como teoria moral realista. O que isso significa? In: Ética do discurso: novos desenvolvimentos e aplicações, pp. 75-76.
} 
problema da responsabilidade histórica pelas consequências do uso desse princípio na história real. Aí, a questão de fundo é se é responsável agir moralmente num mundo amoral, no qual parece predominar o comportamento estratégico dos homens. Essa questão remete ao dilema de, por uma parte, “confiar (como Hegel) à 'astúcia do Espírito do mundo' a realização das condições históricas e sociais para poder agir moralmente e, até lá", por outra, "confiar à razão estratégica e neutra a ação política como Maquiavel e Lenin" ${ }^{947}$. Na linha desse dilema, Max Weber opôs à moral de princípios a ética da responsabilidade. Para ele, o "desencantamento do mundo" operado na passagem para a sociedade moderna trouxe consigo a exigência de abandono da moral de princípios em favor de uma ética da responsabilidade. $\mathrm{Na}$ tradição do pensamento Ocidental, Hegel, o utilitarismo anglo-saxão e também Hans Jonas fazem uma crítica ao formalismo kantiano. No caso de Hans Jonas, ele faz essa crítica a partir do que ele denomina de "princípio responsabilidade". Na linha desse princípio, Jonas afirma que “o 'primeiro dever' da ética do futuro é visualizar os efeitos de longo prazo" daquilo que "ainda não foi experimentado e talvez não possua analogias na experiência do passado e do presente" "948. Afirma ainda que "o 'segundo dever' é mobilizar o sentimento adequado à representação", ou seja, a adoção de um temor de tipo espiritual, como resultado de uma atitude deliberada, para deixar-se afetar pela salvação ou pela desgraça das gerações vindouras $^{949}$.

Frente ao referido dilema, o passo inicial de Apel é mostrar que a ética do discurso é uma ética não-abstrata, ao passo que se define como uma ética de princípios também referida à história. Aqui, a tese fundamental é a seguinte: a ética do discurso procede do a priori da comunidade ideal de comunicação antecipada contrafaticamente e, ao mesmo tempo, do "a priori da faticidade" da comunidade real de comunicação ${ }^{950}$. Esse último $a$ priori é a forma sociocultural de vida a qual pertencem, já sempre, cada um daqueles que aceitam a ética, desde a base de sua identidade contingente, isto é, de seu nascimento e socialização. Considerando o duplo dimensionamento da ética do discurso e, particularmente, sua referência à história, segundo Apel, a semiótica (pragmática) transcendental se caracteriza como uma teoria pós-metafísica ${ }^{951}$. À vista disso, assim pensa Apel, a suposição de um $a$ priori da intersubjetividade, pensado por Kant como "reino dos fins" de caráter metafísico,

\footnotetext{
947 HERRERO, A ética do discurso de K.-Otto Apel. In: Ética do discurso: novos desenvolvimentos e aplicações, p. 23.

948 JONAS, O princípio responsabilidade, p. 72.

949 JONAS, O princípio responsabilidade, pp. 72-73.

${ }^{950}$ APEL, Teoría de la verdade e ética del discurso, pp. 163-164.

${ }^{951}$ APEL, Teoría de la verdade e ética del discurso, p. 164.
} 
faz-se valer no “"entrecruzamento' pragmático-transcendental do a priori da comunidade ideal de comunicação, antecipada contrafaticamente, e a comunidade real, historicamente condicionada" 952 . Isso significa "proceder desde um ponto de vista mais aquém do idealismo e do materialismo metafísicos, tendo que considerar os a priori da idealidade e da faticidade, bem como sua situação histórica" 953 . Dessa forma, a ética discursiva se fundamenta no $a$ priori dialético da comunidade de comunicação, isto é, no a priori da faticidade e historicidade do ser-no-mundo humano (Heidegger) pertencente a uma "forma de vida" sociocultural (Wittgenstein) e, simultaneamente, no a priori não-contigente dos pressupostos universais da racionalidade do discurso argumentativo, que comporta, "qua 'factum da razão', o status de um parâmetro teleológico-normativo na reconstrução da história da cultura e da sociedade humanas" ${ }^{954}$. Para Apel, atualmente é possível compreender que o a priori nãocontigente do discurso argumentativo constitui a condição de possibilidade mesma da filosofia e da ciência e, por isso, ele representa um factum histórico que pertence ao legado cultural ${ }^{955}$.

A tarefa que se coloca para a ética do discurso, em virtude de ela não partir da suposição de um um ideal normativo dos entes puramente racionais ou uma comunidade separada da história puramente racional, é a reconstrução da história da cultura e sociedades humanas. E tal reconstrução deve tornar visível o pressuposto normativo (o a priori do discurso) de sua reconstrução, o qual pertence à faticidade do ser-no-mundo, como resultado da história. Para Apel, tal diz respeito a uma reconstrução "interna” (racional noromativa) que, sob a idéia regulativa de estabelecer ao menos parcialmente o princípio do discurso (consenso), tem primazia em relaçao à explicação "externa" da história (que procede de forma complementária e causal) e à explicação sistêmico-funcional da racionalidade humana ${ }^{956}$. Nessa tarefa transparece, segundo Apel, a consequência metodológica que expressa o motivo da divisão arquitetônica da ética em "parte A" e "parte B". O a priori dialético da ética do discurso se assenta sob duas premissas. De um lado, vale a premissa de que, diferentemente de uma ética deontológica de princípios (Kant), a ética do discurso não parte de um ponto zero da história. Antes, ela considera que a fundamentação de normas concretas e a sua aplicação às situações se conectam, desde o início, à eticidade construída historicamente nas correspondentes formas de vida, tendo em vista a conservação das condições naturais de vida

\footnotetext{
${ }^{952}$ APEL, Teoría de la verdade e ética del discurso, p. 164.

${ }^{953}$ APEL, Teoría de la verdade e ética del discurso, p. 164.

954 APEL, Teoría de la verdade e ética del discurso, p. 166.

955 APEL, Teoría de la verdade e ética del discurso, p. 166.

956 APEL, Teoría de la verdade e ética del discurso, pp. 166-167.
} 
e dos avanços histórico-culturais da comunidade real de comunicação existente. Ela se vincula à eticidade que procura conservar os avanços culturais que possibilitam incorporar discursos argumentativos de fundamentação consensual de normas. De outro, vale a premissa segundo a qual a ética do discurso não pode renunciar ao ponto de vista universal do dever ideal, sistematizado por Kant ${ }^{957}$.

Do a priori dialético da ética do discurso se deriva a dupla tarefa da ética do discurso. No tocante sua "parte A", a tarefa é oferecer um princípio procedimental formal ("metanorma") para a fundamentação discursiva das normas que possam ser consensuadas universalmente. No que se refere à "parte B", a tarefa é urdir a fundamentação consensual das normas com as relações fáticas dadas nas situações, no sentido de uma ética da responsabilidade referida à história. Ressalta-se, tal tarefa não corresponde ao problema tradicional da aplicação das normas morais, ou seja, ao problema da "phonesis" ou do "juízo" como em Aristóteles e Kant, pois, respectivamente, não se trata de recorrer aos costumes convencionais de aplicação das normas éticas, na perspectiva da eticidade convencional da polis, tampouco deixar a cargo do juízo do homem comum a aplicação responsável de uma moralidade de princípios abstrata ${ }^{958}$. Para Apel, o problema da conexão com a história assinala uma tarefa a ser resolvida, "dentro do possível", mediante discursos reais. Tais discursos devem ser, eles mesmos, expressão do princípio de universalização dos interesses. E, além disso, eles precisam incorporar a soma das contribuições oriundas das ciências da natureza e das ciências sociais ou da história. Para Apel, parece certo que a resolução do problema do passo histórico à moral pós-convencional reside em uma ética discursiva informada cientificamente. Nisso reside o desafio de viabilizar a possibilidade de cooperação da ética filosófica: a) com as ciências da natureza, que podem proporcionar um "saber prognosticamente relevante e orientativo para o futuro" (tais como, prognósticos das consequências e subconseqüências previsíveis de medidas, resoluções legais, cálculos de situações simuladas); b) com as ciências sociais, que podem contribuir para reconstruir a situação histórica concreta à qual se conectará uma "aplicação politicamente responsável" da ética do discurso num contexto de uma forma de vida particular. Em suma, no âmbito dos discursos práticos vem à tona o desafio de uma ética do discurso informada cientificamente,

\footnotetext{
957 APEL, Teoría de la verdade e ética del discurso, pp. 167-168.

958 APEL, Teoría de la verdade e ética del discurso, p. 168.
} 
no sentido de uma cooperação com instituições, sobremaneira a do direito, e com dados sóciohistóricos reconstruíveis da consciência moral ${ }^{959}$.

Para Apel, um modelo que exemplifica a tentativa de estruturar uma ética informada cientificamente pelas ciências sociais é a teoria dos graus de desenvolvimento da consciência moral de Piaget e Kohlberg. Essa teoria, ao estruturar tanto a "ontogénesis" (evolução do individuo) quanto a "filogénesis" (evolução da espécie, segundo a biogenética de Haeckel) da consciência moral, segundo Apel, tematiza o problema da passagem da moral convencional para uma moral pós-convencional ${ }^{960}$. Segundo essa teoria, o problema da dependência da "ontogénesis" da moralidade individual em relação à "filogénesis" da eticidade humana se mostra de duas maneiras. Em uma primeira forma de dependência, Kohlberg pensa que o grau de desenvolvimento moral alcançado pelo indivíduo depende do processo de socialização e do do grau filogenético de desenvolvimento da eticidade coletiva. Vendo por esse prisma, em uma sociedade tribal que não tem a forma de organização do Estado, não se pode esperar a competência moral do tipo 4 (Law and Order). Para Apel, vale observar que essa dependência, relevante do ponto de vista pedagógico, não é decisiva para o problema em questão da passagem para uma moral pós-convencional. O fato é que, nas sociedades pós-iluministas, parte alcança os graus de moralidade pós-convencional, mesmo quando a maioria permanece em graus 3 e 4 de convencionalidade moral, conforme a classificação de Kohlberg ${ }^{961}$.

Nesse ponto, também para tornar claro o caráter pedagogicamente relevante dessa teoria, na forma de esquema, apresenta-se os seis níveis da competência de juízo moral de Kohlberg. Esses níveis correspondem, segundo Kohlberg, a uma "hierarquia de formas da integração moral" no sentido da crescente justiça ${ }^{962}$. Trata-se, pois, de uma "estrutura de justiça” composta em seis níveis. O nível 1 pré-convencional se caracteriza pela falta de compreensão da "justiça" como reciprocidade concreta da permuta entre indivíduos diferentes. No caso das crianças, a falta de condições para executar operações de pensamento no sentido da reciprocidade lógica ou reversibilidade, impede a compreensão da reciprocidade do juízo moral. Elas entendem a justiça como uma ordem social, na qual a desobediência dos

\footnotetext{
959 APEL, Teoría de la verdade e ética del discurso, pp. 169-170.

960 APEL, Ética e responsabilidade: o problema da passagem para a moral pós-convencional, pp. 211-217. APEL, Teoría de la verdade e ética del discurso, p. 170. ABBAGNANO, Dicionário de Filosofia, verbete Biogenética, p. 110.

961 APEL, Teoría de la verdade e ética del discurso, pp. 170-171.

962 APEL, Ética e responsabilidade: o problema da passagem para a moral pós-convencional, p. 218.
} 
fracos tem como consequência um castigo pelos fortes ${ }^{963}$. O nível pré-convencional 2 se caracteriza por um entendimento ingênuo-instrumental da essência da justiça. Aqui, a "regra de ouro" da Biblia é entendida no sentido da reciprocidade da permuta de amabilidades ou de retaliação por atos maus. Nesse nível, a criança é capaz de executar operações de pensamento no sentido da reciprocidade ou reversibilidade e, por isso, define a justiça no sentido da "reciprocidade concreta da permuta de dádivas ou realizações"964. O nível convencional 3 corresponde ao entendimento da justiça no sentido de uma reciprocidade ideal. Tal corresponde ao correto entendimento da "regra de ouro", ou seja, tratar os outros do mesmo que gostaria de ser tratado. Nesse nível as crianças ou jovens são capazes de "transpor-se ao mesmo tempo para dois papéis diferentes que estão relacionados um ao outro"965. Comparativamente, na situação hipotética de uma criança bater na outra, a criança do nível 2 tende a "bater de volta", valendo-se da ideia de que se deve fazer o memo que a outra criança fez a ela. A criança do nível 3 avalia que "bater de volta" pode levar a uma nova relação de reciprocidade; nisso, ela está em condições de colocar o perdão acima da vingança. Não há ainda no nível 3 convencional condições para a universalização da "regra de ouro", tampouco uma "precisão das obrigações e deveres de um papel no sentido de sistema de funções sociais: uma ordem societária, que fixa os papéis atráves de regras ou normas respectivas do comportamento correto" 966 .

Continuando a exposição, o nível 4 convencional, correspondente a "Law and Order", diz respeito a uma ordem estatal da sociedade e do direito. Para Kohlberg, é nesse nível que se encontra a maioria dominante dos adultos nos estados industriais da civilização ocidental. A relação de reciprocidade dos direitos e deveres é aí intermediada e limitada pelo sistema social. Diferentemente do nível anterior, em que a reciprocidade positiva da justiça consiste numa permuta interpessoal de bens e realizações, no nível 4, essa permuta diz respeito a realizações e recompensas entre pessoas singulares e o sistema. A reciprocidade negativa da justiça consiste não na vingança e represália entre pessoas (famílias), mas na obrigação, conforme com o princípio da igualdade perante a lei, de pagar a "dívida à sociedade" 967 . No nível 4, "a justiça é para o indivíduo uma questão de defesa da própria ordem social ("law, nation, and God") contra os seus inimigos: criminosos, dissidentes, e

\footnotetext{
${ }^{963}$ APEL, Ética e responsabilidade: o problema da passagem para a moral pós-convencional, p. 218.

${ }^{964}$ Idem, pp. 218-219.

965 Idem, p. 219.

966 Idem, p. 220.

${ }^{967}$ Idem, p. 220.
} 
inimigos exteriores" ${ }^{968}$. A definição chave do nível 5 pós-convencional é a perspectiva de produzir lei (“orientação legalista do contrato"). Nesse nível, recorre-se "ao direito natural dos indivíduos de fundamentar a ordem social na qual eles querem viver por meio de contratos segundo o ponto de vista da utilidade e, em caso de necessidade, de os alterarem" 969 . O ponto de vista da utilidade (regra do utilitarismo) funciona como um princípio de legitimação racional para o direito e para os contratos subjacentes. Se no nível 4 as leis são pressupostas como sacrossantas, distintamente, no nível 5 pós-convencional, elas são fundamentadas em comparação com outras regras, em vista do mais útil para o indivíduo. No nível 5, quanto à justiça, "a atenção transfere-se da defesa de lei e ordem para o problema da legitimação que é necessária para maximizar o bem-estar dos indivíduos" ${ }^{\text {"970 }}$. Nesse sentido, o respeito pela lei procede de sua função, que é mediar - analogamente a um "juiz de partida" - os interesses de grupos diversos e conflitantes. Os arranjos processuais da democracia constitucional que precedem as leis e a ordem social, qua representação igual dos interesses de todos os indivíduos para a formação do consenso, são atitudes que exemplificam esse nível 5 pósconvencional. Caracteristicamente, o princípio moral que rege o nível 5 não orienta a ação do indivíduo para o questionamento da lei e do direito. Mais precisamente, é típico desse nível o conflito entre a legalidade (direito vigente) e o "moral point of view". Nesse conflito, o "moral point of view" se fundamenta apenas no "direito da consciência subjetiva"; é importante ressaltar, o "moral point of view" não se fundamenta em um princípio intersubjetivo válido. Em tal nível, é possível pensar em uma desobediência civil baseada na “decisão de consciência”, porém à margem da sociedade ${ }^{971}$.

Por seu turno, o nível 6 pós-convencional representa o autêntico princípio moral da autonomia. O fator que caracteriza o princípio moral desse nível é sua universalidade. $\mathrm{O}$ fundamento para a obrigação não decorre de uma "ponderação utilitarista do proveito ou prejuízo do modo de ação ou de um implícito contrato social" ${ }^{972}$, mas da lei suprema universalmente válida de nunca tratar um ser humano meramente como um "meio" e sim como um como um “fim” em si mesmo. Nesse nível, mais que legitimar as leis do Estado, é necessário comprovar que tais leis são manifestações imperfeitas de uma lei suprema. Esse nível supõe, além dos princípios da regra do utilitarismo e do contrato social, "uma lei moral superior" composta de dois princípios: a) o princípio que "pessoas enquanto seres com

\footnotetext{
${ }^{968}$ APEL, Ética e responsabilidade: o problema da passagem para a moral pós-convencional, p. 221.

${ }^{969}$ Idem, p. 220.

970 Idem, pp. 221-222.

${ }^{971}$ Idem, p. 221.

${ }^{972}$ Idem, p. 225.
} 
finalidade própria possuem um valor moral incondicional"; b) o "princípio da igualdade de direitos formal de todas as reivindicações de pessoas em todas as situações" ${ }^{\prime 973}$. Esses princípios, independentemente dos papéis sociais e dos contratos sociais, valem para qualquer "ser racional" qua "ator moral ideal". Para Kohlberg, esses princípios são mais imparciais e universalmente válidos do que aquilo que deve ser exigido para todas as normas jurídicas (perspectiva legisladora do nível 5).

Para além de Kohlberg, Apel preconiza a necessidade de um nível 7 da consciência moral para solucionar o problema da aplicação de princípios morais pósconvencionais. Para Apel, subsiste na teoria kohlbergiana de níveis ideais um um "déficit de concretude metodologicamente condicionado" 974 , na medida em que ela se refere ao nível supremo com as éticas de princípios de Kant e Rawls. Apel destaca que, segundo Kohlberg, na sociedade pós-iluminismo (caso da sociedade norte-americana) apenas cerca de cinco por cento dos adultos alcançam o nível 6 pós-convencional da competência de juízo moral. O problema da aplicação relativa à situação da moralidade pós-convencional resulta do fato de que as condições sociais de aplicação da moralidade pós-convencional de nível 6 ainda não existem de todo. O nível 7 da competência de juízo moral conota a tarefa da realização das condições sociais de aplicação da moralidade de nível 6. Para Apel, a realização dessa tarefa significa desenvolver uma "competência de juízo específica"975, que pode ser qualificada como nível 7 ético-responsável da consciência moral. Destacadamente, Apel pensa que essa tarefa pode ter como ponto de partida duas áreas de problemas moralmente relevantes, em virtude da influência da moral universalista sobre as instituições: a) as áreas das relações internacionais, que necessita de uma "ideia reguladora" para a estratégia moral a longo prazo da realização progressiva da substituição da regulação de conflitos puramente estratégica por uma regulação de conflitos consensual-comunicativa; b) as áreas ligadas à "crise ecológica", em que se faz necessário organizar a corresponsabilidade dos seres humanos pelos efeitos e consequências secundárias das ações humanas coletivas. Faz parte das condições constitutivas da competência de nível 7 , a capacidade de colaborar na realização progressiva da comunidade ideal de comunicação. Nisso, na linha da perspectiva de uma responsabilidade orientada para o concreto-universal da humanidade (Hans Jonas), o nível 7 implica na

\footnotetext{
${ }^{973}$ APEL, Ética e responsabilidade: o problema da passagem para a moral pós-convencional, p. 226.

${ }^{974}$ Idem, p. 251.

${ }^{975}$ Idem, p. 255.
} 
responsabilidade pela conservação das condições de vida para uma continuidade da humanidade nas gerações futuras ${ }^{976}$.

Tomando em consideração esses níveis, Apel trata da segunda forma de dependência da "ontogénesis" da moralidade individual em relação à "filogénesis" da eticidade humana. Para a ética do discurso é fundamental investigar a forma de dependência das condições de aplicação e também da competência moral pós-convencional relativa ao nível de eticidade coletiva já alcançada por parte da população mundial, especialmente, no âmbito das instituições jurídicas e sua aceitação social ${ }^{977}$. Na prática, trata-se de investigar aqui, por exemplo, se se um político deve renunciar à racionalidade estratégico-instrumental em suas negociações para transformar a conversação no sentido da ética do discurso e de suas normas sobre a formação puramente argumentativa do consenso acerca das normas de validade. A resposta de Apel é que, procedendo de tal modo, o político tende a fracassar como sujeito da ação. Porém, mais importante que isso é o fato de que não se deve exigir moralmente do indivíduo, sem uma ponderação responsável dos resultados e subconsequências possíveis de sua ação, que deva comportar-se segundo um princípio moral incondicionalmente válido. Não se pode imputar ao indivíduo a responsabilidade por um sistema de auto-afirmação, isto é, família, grupos de interesses, Estado ${ }^{978}$. A resposta de Apel circunscreve o aspecto fundamental da distinção entre "ética da convicção" ("ética incondicionada") e "ética da responsabilidade" (pelas consequências) weberiana, na qual Weber se contrapõe à ética do sermão da montanha e contra Kant. Para Apel, essa distinção reflete a problemática da mediação entre a ética de princípios e a história, que "surge sempre quando não estão ainda construídas as condições sociais de aplicação para um determinado grau de competência judicativa moral ${ }^{979}$.

No entender de Apel, Weber marca nitidamente a distinção entre ética da convicção e ética da responsabilidade. Segundo Apel, essa distinção se baseia na investigação que Weber realiza sobre os tipos de racionalidade que fundamentam a ação social e, com isso, o processo de racionalização do Ocidente. Weber opõe a racionalidade teleológica (meio-fim) à racionalidade valorativa. A racionalidade teleológica se caracteriza por utilizar a racionalidade valorativa, como pressuposto para a seleção dos seus fins, e estabelecer meios adequados para alcançá-los, bem como responsabilizar-se pelas consequências previsíveis de

\footnotetext{
976 APEL, Ética e responsabilidade: o problema da passagem para a moral pós-convencional, pp. 255-258.

977 APEL, Teoría de la verdade e ética del discurso, p. 171.

978 APEL, Teoría de la verdade e ética del discurso, p. 172.

${ }^{979}$ APEL, Teoría de la verdade e ética del discurso, p. 172.
} 
sua ação ${ }^{980}$. Na racionalidade valorativa, sob a suposição de que os valores são supremos e expressam um dever incondicional para o agir humano, no sentido do imperativo categórico kantiano, a seleção dos fins e meios acontece sem qualquer preocupação com as consequências da ação. Tal como caracteriza Weber, a racionalidade valorativa se sujeita ao estatuto de fé pré-racional ou irracional e, em termos de valores, configura-se como uma ética da convicção. O problema é que essa ética, ao passo que prescinde de qualquer referência em relação ao lugar e situação, acaba desprovendo o sujeito de responsabilidade. Por sua vez, à medida que considera os efeitos da humana, a racionalidade teleológica preconiza uma ética da responsabilidade. Em razão disso, pontua Apel, mesmo considerando a ética da convicção indispensável, Weber concede à ética da responsabilidade um maior grau de racionalização que a ética da convicção ${ }^{981}$.

Na sua obra Ciência e Política: duas vocações, Weber analisa os contornos que marcam as diferenças entre a ética da convicção e a ética da responsabilidade. Aqui, exemplifica-se essa diferença a partir da análise de Weber da "política como vocação". Nessa análise, Weber assinala as três qualidades determinantes que legitimam o político a exercer o seu ofício com soberania: paixão pela causa ("propósito a realizar” e devoção a uma causa), sentimento de responsabilidade e senso de proporção (serenidade) ${ }^{982}$. Para Weber, o político só pode reger-se pela racionalidade estratégica, pois ele, quando se põe apaixonadamente a serviço de uma causa, move-se com o correspondente sentimento de responsabilidade em relação aos efeitos da sua ação. À medida que estabelece a ação correta e estratégica a ser executada, o político estabelece, mediante seu ato, a relação com a ética da responsabilidade. Nisso, segundo Weber, é possível optar entre duas maneiras de fazer política: viver "para" a política ou viver "da" política ${ }^{983}$. Na primeira, o político transforma a política em "fim de sua vida" e se coloca a serviço do bem público. A atividade política, seja pelo gozo na posse do poder, seja pela expressão de um valor pessoal, dá significação à vida do político. $\mathrm{Na}$ segunda, a atividade política é uma fonte de vantagens econômicas e prestígio social. Por isso, segundo Weber, é indispensável que o político tenha uma vida econômica independente de qualquer atividade política ou social, para não usufruir do bem público. Efetivamente, o político não pode regular-se por uma ética da convicção, tal como a preconizada nos

\footnotetext{
${ }^{980}$ WEBER, Max. Ciência e Política: duas vocações. Trad. Leonidas Hegenberg e Octany Silveira da Mota. São Paulo: Cultrix, [s.d.], p. 113.

${ }^{981}$ APEL, Estudios Éticos, p. 32-34.

982 WEBER, Max. Ciência e Política: duas vocações. Trad. Leonidas Hegenberg e Octany Silveira da Mota. São Paulo: Cultrix, p. 106.

${ }_{983}$ WEBER, Ciência e Política, pp. 64-67.
} 
ensinamentos do sermão da montanha (abandonar tudo, dar a outra face, não resistir ao mal com a força e dizer a verdade), pois tal conduziria a política à violência e à decepção diplomática. Com efeito, para Weber, "a ética da convicção e a ética da responsabilidade não se contrapõem, mas se completam e, em conjunto, formam o homem autêntico, isto é, um homem que pode aspirar à "vocação política", ${ }^{984}$. O fato é que, isoladamente, essas éticas são problemáticas. O problema da ética da responsabilidade é definir o limite da racionalidade estratégica, para evitar o risco de reduzir a ética da responsabilidade em puro utilitarismo ${ }^{985}$. O grave problema da ética da convicção é que ele, visando atender normativas absolutas (pela simples execução de normas) não pressupõe a vontade do sujeito, que pode obstruir a qualidade da ação. Na verdade, o ato da vontade do sujeito força um limite para essas duas perspectivas éticas. Pois, "a ética da intenção não experimenta hesitação alguma, senão que condena toda ação que utilize meios moralmente perigosos, enquanto que a ética da responsabilidade permite utilizar meios duvidosos, sempre que com isso se persiga consequências boas" $" 986$.

Com a pretensão de marcar a ética do discurso como uma ética da responsabilidade pós-weberiana, Apel afirma que o problema da responsabilidade histórica da ética do discurso já está implicitamente posto na situação da argumentação. Pois, toda argumentação, pelo fato de antecipar contrafaticamente as condições ideais de uma comunidade ilimitada de comunicação e supor as condições históricas e contingentes da situação real da comunidade de comunicação, já pressupõe a diferença radical entre tais condições, bem como o telos moral da práxis histórica. Isso significa que, na argumentação, já se pressupõe a obrigação a ser alcançada em longo prazo de transformar as condições reais existentes, as quais correspondem à perspectiva de uma moral convencional, e de criar as condições sociais suficientes para possibilitar a efetivação do princípio moral na sociedade, na direção de uma moral racional pós-convencional ${ }^{987}$. A fundamentação do princípio moral, ao se confrontar com a situação real, recebe um alargamento normativo na forma de um telos (fim) regulador formal da práxis histórica. Esse telos emerge como um princípio da ação para guiar a práxis histórica dos sujeitos perante a exigência de aproximar progressivamente às condições sócio-políticas reais das condições ideais.

\footnotetext{
${ }^{984}$ WEBER, Ciência e Política, p. 122.

${ }^{985}$ CORTINA, Razón comunicativa y responsabilidad solidaria: ética y política em K.-O. Apel, p. 198.

${ }^{986}$ CORTINA, Razón comunicativa y responsabilidad solidaria: ética y política em K.-O. Apel, p. 194.

987 HERRERO, A ética do discurso de K.-Otto Apel. In: Ética do discurso: novos desenvolvimentos e aplicações, p. 23.
} 
Em Apel, esse telos não projeta uma utopia social concreta ${ }^{988}$, mas funciona como um fim moral estratégico para a superação da irracionalidade existente e criação das condições de aplicação do princípio moral de consensualidade. Esse telos regulador da ação, na medida em que funciona como um mediador entre o princípio moral (a racionalidade discursivo-consensual) e a responsabilidade com a situação (a racionalidade políticaestratégica), exige: em primeiro lugar, a corresponsabilidade pela sobrevivência da comunidade real, seja em relação às condições de existência de todos os seres, seja em relação à conservação das condições naturais (por exemplo, em face da crise ecológica), sem a qual nem é possível pensar no princípio moral; em segundo lugar, a corresponsabilidade pela preservação da "realidade racional" das instituições e tradições, ou seja, das condições culturais que podem valer como conquistas no caminho da efetivação da racionalidade consensual. Por isso, esse princípio mediador preconiza a rejeição moral de todos os meios e estratégias que possam pôr em perigo os ganhos da evolução cultura ("o já transformado" da realidade atual naquilo que ela tem de irracional) $)^{989}$.

O princípio moral formal-universal não permite prescrever a priori normas concretas de eticidade substancial, mas é por meio de ele que surge a necessidade de realizar discursos práticos. Esses discursos cumprem a função de tentar resolver o problema da mediação entre a racionalidade comunicativo-consensual e eticidade da sociedade real ${ }^{990}$. O princípio moral fornece para discursos práticos uma norma procedimental de decisão para todas as questões substanciais do mundo da vida. Tal norma, sob a pressuposição da reciprocidade dialógica universal, prescreve a resolução dos conflitos do mundo da vida por meio de argumentos consensuais. Essa norma estabelece como válido o discurso no qual a argumentação é racional e responsavelmente aceita sem coação por todos os participantes. Por sua vez, isso requer a criação das condições que permitam a aplicação desse princípio na história, ou seja, a diversificação de níveis e de diferentes mediações que possam transformar

\footnotetext{
${ }^{988}$ APEL, Teoría de la verdade e ética del discurso, pp. 164-165. Em virtude de sua vinculação à identidade contigente, segundo Apel, a ética do discurso evita o dualismo kantiano da doutrina de dois mundos e da concepção antropológica de "cidadão do mundo". Ela evita inclusive a equiparação do a priori da comidade de comunicação a um utopismo, considerado por Apel como perigoso. Essa equiparação é sugerida por pragmáticos que renunciam ao projeto de uma ética de princípios em favor de uma eticidade com base meramente históricocontigente de consenso, isto é, de uma ética neoaristotélica ou neohegeliana que se liga à tradição regional e particular. Contrapondo a crítica de utopismo direcionada à ética do discurso, Apel salienta que o ponto de partida da ética do discurso é o "homem finito", portanto, um ser que não é um ser racional puro, nem meramente sensitivo ou instintivo, como os animais.

989 APEL, Teoría de la verdade e ética del discurso, p. 166. HERRERO, A ética do discurso de K.-Otto Apel. In: Ética do discurso: novos desenvolvimentos e aplicações, pp. 24-25.

${ }^{990}$ HERRERO, A ética do discurso de K.-Otto Apel. In: Ética do discurso: novos desenvolvimentos e aplicações, p. 25.
} 
os costumes, a organização da sociedade e de suas instituições, o Estado de direito existente e a ética específica da comunidade real. De tal maneira, a ética do discurso vincula os cossujeitos à participação em discursos reais, para que possam alcançar o maior acordo possível sobre os interesses reais e a melhor orientação empírica sobre os efeitos colaterais em virtude do seguimento de normas. Os discursos práticos respondem à necessidade de validar o marco normativo a ser utilizado pelos afetados nas situações reais, os interesses ou necessidades efetivos dos afetados pelas normas e o saber especializado (científico) dos fatos e das consequências previsíveis das ações para a avaliação adequada da situação em que se deve $\operatorname{agir}^{991}$.

Efetivamente, em vista de solucionar o problema da mediação entre a racionalidade comunicativo-consensual e a eticidade da sociedade real, em publicações mais recentes $^{992}$, Apel procura suplementar a dimensão de corresponsabilidade exigida pela ética do discurso com a dimensão de responsabilidade fática exigida pelos subsistemas coercitivos da política, do direito e da economia de mercado. É em relação a essa solução vislumbrada por Apel que se preconiza aqui, com certa originalidade, a possibilidade de uma suplementação na parte B da ética do discurso por meio da inserção da esfera da educação. Para tratar disso, apresenta-se aqui a solução de Apel e, em seguida, a sugestão de suplementação da educação junto ao rol das mediações (subsistemas) incubidas de realizar as condições sociais de aplicação da racionalidade consensual-comunicativa.

No tocante à relação entre discursos práticos e direito, Apel vê o direito como um subsistema de coerção social que, apesar de só exigir um comportamento externo em conformidade com as leis, permite privilegiadamente criar as condições históricas para a realização da racionalidade discursivo-consensual ${ }^{993}$. A necessidade da moral para a fundamentação do direito decorre da dificuldade, não considerada relevantemente pelos positivistas, de justificar a validade fática da ordem jurídica e de responder ao porquê uma ordem política deve ser justa. Em geral, atribui-se que o direito positivo vale porque está em vigor; e que ele consegue força jurídica por conta dos procedimentos jurídicos considerados

\footnotetext{
${ }^{991}$ HERRERO, A ética do discurso de K.-Otto Apel. In: Ética do discurso: novos desenvolvimentos e aplicações, pp. 26-28.

${ }_{992}$ APEL, The response of discourse ethics, pp. 95-115. APEL, Ética do discurso e as coerções sistêmicas da Política, do Direito e da Economia: uma reflexão filosófica sobre o processo de globalização. In: Ética do discurso: novos desenvolvimentos e aplicações, pp. 201-223.

${ }^{993}$ APEL, The response of discourse ethics, pp. 109-113. APEL, Ética do discurso e as coerções sistêmicas da Política, do Direito e da Economia: uma reflexão filosófica sobre o processo de globalização. In: Ética do discurso: novos desenvolvimentos e aplicações, pp. 218-220. HERRERO, A ética do discurso de K.-Otto Apel. $I n$ : Ética do discurso: novos desenvolvimentos e aplicações, pp. 25-26 e 28-30.
} 
válidos. A dificuldade de fundar ultimamente o direito põe a nu a questão da legitimidade dos procedimentos jurídicos. Ora, para Apel, a questão referente à fundamentação do direito pode ser respondida, sem reivindicar argumentos metafísicos, se o direito remeter a fundamentação procedimental de suas normas ao "princípio da formação consensual argumentativa entre sujeitos de iguais direitos e de igual responsabilidade, legisladores e destinatários do direito, fundamentado de modo pragmático-transcendental" ${ }^{994}$. Na verdade, assim pensa Apel, a "meta-norma" moral da consensualidade está sempre pressuposta na fundamentação do direito positivo, contanto que sejam tidas como válidas as leis jurídicas que, sendo derivadas de um processo de argumentação, contam com o assentimento de todos os membros da comunidade do direito.

No tocante à relação entre discursos práticos e política, Apel vê a necessidade de fundamentar o poder de sansão monopolizado pelo Estado ${ }^{995}$. Em relação à política, os discursos práticos cumprem a função de mediatizar a ação comunicativa com os interesses estrategicamente defendidos pelos grupos sociais e com o poder de coerção do Estado de direito. Aí aparece o problema de justificar eticamente a coação das normas jurídicas que se baseia no poder monopolizado pelo Estado e no domínio; normas essas que se baseiam não na convicção por argumentos ("livre de domínio"). Aparentemente a exigência de fundamentação da coação parece contradizer o princípio fundamental da formação do consenso "pela coação não coercitiva dos argumentos". Para Apel, aqui vale a seguinte distinção: a) no domínio do "discurso liberado de ação" (da ideia reguladora), presume-se a exclusão do domínio e da violência em todo discurso argumentativo e nos discursos práticos (na fundamentação das normas situacionais); b) já no domínio "fora do discurso ideal” não se pode postular que a vida humana em comum possa ser liberada de domínio.

Para Apel, mesmo o discurso filosófico, ao passo que é institucionalizado, não está isento de certas funções de domínio e coação. Ora, importa que tal domínio concorra em favor da maior liberdade possível de domínio e de violência para fazer valer os argumentos racionais. "Em situações de interação ou de comunicação estrategicamente distorcidas, pode ser até moralmente prescrito praticar estratégia contra estratégia, violência aberta ou oculta

\footnotetext{
${ }^{994}$ HERRERO, A ética do discurso de K.-Otto Apel. In: Ética do discurso: novos desenvolvimentos e aplicações, p. 30.

${ }_{995}$ APEL, The response of discourse ethics, pp. 106-109. APEL, Ética do discurso e as coerções sistêmicas da Política, do Direito e da Economia: uma reflexão filosófica sobre o processo de globalização. In: Ética do discurso: novos desenvolvimentos e aplicações, pp. 217-218. HERRERO, A ética do discurso de K.-Otto Apel. In: Ética do discurso: novos desenvolvimentos e aplicações, pp. 26-27 e 30-32.
} 
(por ex. engano) como violência-anti-violência"996. O alargamento da ética do discurso numa ética de responsabilidade histórica e a fundamentação da validade da coerção das normas jurídicas, ao passo que causam a autolimitação do princípio do discurso, facultam uma base de justificação do poder de sanção do Estado de direito. O Estado de direito representa a mais eficaz forma de limitação da violência política contra a violência, pois, em seu poder público de sanção ele descarrega e alivia o indivíduo de sua aplicação do poder com responsabilidade moral. A aquisição moral relevante do Estado de direito não é apenas a segurança da paz, a proteção do corpo e da vida, tal como suposto por Hobbes, mas reside também no fato de que o Estado exerce a mediação responsável entre os âmbitos da moral e da política. Decerto, o monopólio da violência pelo Estado de direito não elimina a responsabilidade histórica dos indivíduos, sobremaneira porque ele regula apenas âmbitos da vida que permitem uma coação jurídica. Em muitos âmbitos essenciais da vida permanece o problema da ética da responsabilidade política. Isso também porque, para além das instituições existentes, permanece a exigência de corresponsabilidade pelas consequências das ações coletivas, o que parece implicar a corresponsabilidade pela institucionalização de uma ordem jurídica mundial.

A fundamentação das normas do direito e do poder de coerção do Estado de direito permitem desenvolver a mediação com a economia de mercado ${ }^{997}$. A realização de discursos práticos referidos à economia de mercado visa salvaguardar a independência e a liberdade de negociação e de contrato de todos os participantes no mercado, evitando assim as desfigurações da livre concorrência. Nesse ponto, Apel postula que o poder político de negociação deve ser limitado por normas deônticas, fundadas no princípio moral que exige processos públicos de entendimento consensual envolvendo os interesses de todos os afetados. Isso supõe, idealmente, que a economia não seja regida única e predominantemente pelos interesses de lucro do mercado.

Para contextualizar a sugestão mencionada anteriormente, faz-se aqui um apontamento sintético do teor geral da concepção de ética do discurso em Apel. Ele fundamenta sua proposta de filosofia moral num a priori dialético entre o princípio fundamental ideal, concernente a uma fundamentação final pragmático-transcendental da

\footnotetext{
${ }^{996}$ HERRERO, A ética do discurso de K.-Otto Apel. In: Ética do discurso: novos desenvolvimentos e aplicações, p. 32.

${ }_{997}$ APEL, The response of discourse ethics, pp. 112-115. APEL, Ética do discurso e as coerções sistêmicas da Política, do Direito e da Economia: uma reflexão filosófica sobre o processo de globalização. In: Ética do discurso: novos desenvolvimentos e aplicações, pp. 220-223. HERRERO, A ética do discurso de K.-Otto Apel. In: Ética do discurso: novos desenvolvimentos e aplicações, pp. 26 e 32-33.
} 
ética derivada da antecipação contrafática das condições de interação de uma comunidade de comunicação ideal, e o a priori da faticidade, referente às formas vida históricas da comunidade de comunicação real ${ }^{998}$. É característico desse a priori dialético a diferença entre a ideia regulativa, representando o "racional moral como real", e o fato de que as condições de aplicação reais e ideais da ética do discurso nunca estão inteiramente realizadas. Apel intenta desdobramentos de sua filosofia moral no sentido de viabilizar a realização das condições históricas que possam factibilizar uma ética da comunicação da corresponsabilidade. Apel pensa que exigir o cumprimento do princípio ideal de uma ética do discurso sem tratar do problema das condições de aplicação da ética à história pode resultar em uma irresponsabilidade. O problema da aplicação responsável da ética do discurso não se equipara ao conhecido problema da aplicação de normas universais a situações concretas, mas ao problema da passagem da moral convencional para a pós-convencional. O problema da aplicação relativa à história da ética do discurso implica na perspectiva de uma ética pósconvencional, que concerne a realização de "discursos práticos" que colaboram na aproximação entre a comunidade real de comunicação e a comunidade ideal de comunicação. A responsabilização pelas consequências das ações humanas requer o auxílio de subsistemas de coerção objetiva institucional da política, do direito e da economia. Ocorre que, problematicamente, ele não tematiza o que se supõe como fundamental, a educação em vista da corresponsabilização pelas ações humanas coletivas no mundo. É estranho que Apel não tenha se aplicado a vincular de modo sistemático sua filosofia com o campo da educação, justamente quando preconiza a conexão entre teoria e prática (ética). Daí, faz-se necessário uma reparação, no sentido de uma possibilidade de contribuição recíproca entre a filosofia de Apel e a educação.

Tratanto do assunto ligado à sugestão mencionada a pouco, o fato de Apel não privilegiar a tematização da questão da educação no contexto da discussão sobre os "discursos práticos" parece indicar que a esfera da educação "ocupa", no programa filosófico apeliano, uma posição de relevância minoritária. Ela é quase invisível para Apel, se se considera que ele toma como mais premente a discussão de outras demandas da sociedade, tais como questões políticas, econômicas, jurídicas, ecológicas, desportivas. Nisso, parece existir algum contrassenso, pois a efetivação da formação da moralidade para a vida pública, que é o objeto do problema referente à parte $\mathrm{B}$ da ética do discurso enquanto ética da responsabilidade, não

\footnotetext{
${ }^{998}$ NIQUET, Ética do discurso como teoria moral realista. O que isso significa? In: Ética do discurso: novos desenvolvimentos e aplicações, pp. 75-76.
} 
pode prescindir de uma abordagem teórica prioritária do processo educativo. Em tese, é preciso pôr em primeiro plano a instituição ou instância à qual caberá "transformar didaticamente" a urdidura da normatividade ideal da comunidade de comunicação com a normatividade fática dos subsistemas da política, do direito e da economia, e conduzir a atividade educativa para a responsabilidade, seja em nível de uma macroética qua formação ética intencionada na corresponsabilidade intersubjetiva pelas consequências das ações humanas coletivas, seja em nível institucional, respondendo junto com os subsistemas funcionais de coerção social da política, do direito e da economia pela responsabilidade fática na sociedade. Parece que esta lacuna produz, em certa medida, a suspeita quanto à possibilidade de uma efetiva contribuição da ética do discurso à fundamentação filosófica de uma educação dos valores.

Pois bem, Apel concebe sua filosofia moral como uma ética ao mesmo tempo de princípios e referida à história, mas não desdobra essa concepção sistematicamente no sentido da educação, de modo a delinear uma filosofia da educação. A princípio, é possível afirmar que a questão acerca da possível contribuição da filosofia Apel, em termos de especificidade e alcance, para o campo da educação precisa ser suscitada, tal como se propõe neste trabalho. Aqui, ao cabo desse trabalho, resulta uma sugestão interpretativa inical a respeito dessa compreensão. Ela diz respeito à consideração de que a esfera da educação somente aparentemente constitui um tema invisível na filosofia de Apel. À primeira vista, sobremaneira em sua proposta de filosofia prática, parece valer o contrário. Pois, Apel não inclui a educação na discussão do problema de uma aplicação referenciada à história da ética do discurso (parte B) qua ética da responsabilidade, precisamente quando defende a tese de que a responsabilização pelas consequências das ações humanas requer o auxílio dos subsistemas de coerções objetivas da política, do direito e da economia ${ }^{999}$. Disso, é possível suspeitar que a esfera da educação subsuma uma função instrumental secundária a serviço de subsistemas de coerção institucional da política, do direito e da economia de mercado. É estranho que Apel não tenha estendido de modo sistemático sua arquitetônica filosófica para o campo da educação, já que preconiza a conexão entre teoria e prática. Entretanto, das poucas alusões diretas à educação feitas por Apel, é possível depreender que a educação constitui uma condição necessária e ineliminável (transcendental) da formação da racionalidade do entendimento humano que faculta a emancipação e a responsabilidade solidária.

\footnotetext{
999 APEL, Ética do discurso e as coerções sistêmicas da Política, do Direito e da Economia: uma reflexão filosófica sobre o processo de globalização. In: Ética do discurso: novos desenvolvimentos e aplicações, pp. 201-223. APEL, The response of discourse ethics, pp. 95-115.
} 
Mas, para isso, faz-se necessário uma reparação, no sentido de uma tentativa de esclarecimento teórico acerca da possibilidade de contribuição recíproca entre a filosofia de Apel, especificamente em relação à parte $\mathrm{B}$ da ética do discurso, e a esfera da educação. No sentido de uma contribuição recíproca, cogita-se: a) a possibilidade de que a esfera da educação possa incorporar a compreensão de corresponsabilidade intrínseca à ética do discurso. Hipoteticamente, vislumbra-se que a esfera da educação, à luz da transformação da filosofia proposta por Apel, possa figurar como uma esfera institucional transversal aos subsistemas da política, do direito e da economia de mercado, atuando responsavelmente pela formação para a corresponsabilidade histórica do homem pelo mundo. Presume-se o caráter transversal dessa esfera, posto que sem a formação para a responsabilidade histórica do homem pelo mundo parece improvável subsistir as próprias pretensões levantadas na política, no direito e na economia de mercado; b) a possibilidade de que ética do discurso possa ser suplementada pelo caráter programática de uma educação em direitos humanos, no sentido do discurso prático próprio da esfera da educação vinculado aos mínimos de justiça, e assim viabilizar uma mediação estratégica e contraestratégica complementar para a factibilidade do princípio deôntico da universalização dos interesses na história (princípio U). Nessa direção, a educação em direitos humanos pode funcionar, teleologicamente, como uma instância institucional direcionada ao entretecimento das pretensões concernentes à racionalidade consensual-democrática e a responsabilização pelas consequências tomadas nos âmbitos da política, do direito e da economia.

De tal modo, a esfera da educação pode preencher a lacuna da "transformação pedagógica" no projeto de transformação semiótico-transcendental da filosofia, especificamente quanto ao problema de uma ética aplicada à história. A educação, enquanto atividade própria da faticidade existencial do ser-no-mundo e da historicidade da razão, concerne à ação formativa de caráter teórico-prático. Ao mesmo tempo, sob o marco da racionalidade comunicativa e suas condições ideais de comunicação, a educação pode incorporar a contraestratégia teórica e moral da razão para a práxis intersubjetiva e responsável em relação à transformação das condições históricas ainda marcadas pela racionalidade político-estratégica ou pela irracionalidade existente na comunidade real de comunicação. Quer dizer, fundamentada nos pressupostos da racionalidade discursivoconsensual e no intento do uso consequente do princípio moral de universalização dos interesses, cabe à educação formar sujeitos dialógicos e responsáveis capazes de empenhar-se, de modo processual e falível, na criação das condições históricas suficientes que possibilite a transformação (emancipação) da realidade, naquilo que ela ainda tem de irracional e injusto. 
Nessa perspectiva dialética, a educação pode constituir-se como mediação institucional imprescindível para a práxis histórica entre a racionalidade político-estratégica e a racionalidade discursivo-consensual, entre o princípio moral de universalização dos interesses e a responsabilidade na e com a situação histórica. A educação, no sentido de uma formação que eleva à humanidade embasada em mínimos éticos universais e na dignidade do homem, pode converter-se em uma via fundamental para reduzir paulatinamente a diferença radical entre as condições ideais de uma comunidade ilimitada de comunicação e as condições históricas e contingentes da situação da comunidade real de comunicação e, nisso, criar condições sociais suficientes para possibilitar a efetivação da resolução consensualargumentativa dos problemas teóricos e práticos na sociedade. 


\section{CONCLUSÃO}

Preliminarmente, é importante ressaltar que estas considerações finais, mais que destacar protocolarmente os tópicos e as conclusões que se ligam a este processo de pesquisa ao redor do entrelaçamento entre os conceitos de educação, emancipação e corresponsabilidade na filosofia de Karl Otto Apel, gravitam em torno de uma observação somente agora possível. Essa observação concerne à percepção do caráter inconcluso dessa investigação. Verazmente, afirmar isso aqui não é um mero truque de retórica. À luz do percurso dessa investigação, é possível depreender que tal observação se vincula, coerentemente, à lógica do princípio epistemológico do falibilismo e ao caráter assintótico que acompanha a dialeticidade do a priori da comunidade de comunicação. Com efeito, neste caso, além desse transfundo epistemológico-filosófico, o aspecto fático determinante de tal inacabamento é a resposta insuficiente à problemática que essa pesquisa procura suscitar. Os saltos e reiterações que aparecem nesse texto em busca de transparecer o possível salto de Apel à educação, no campo da razão teórica (semiótica transcendental) e no campo razão prática (ética do discurso), em certa medida, denotam mais o fluxo argumentativo de retorno ao contexto da problemática que ao contexto de descobertas e conclusões, decerto, hipotéticas e provisórias. Posto isso, à guisa de considerações finais deste trabalho acadêmico, explicitam-se sinteticamente quatro pontos de destaque concernentes a esse contexto de descobertas dessa pesquisa e, em seguida, uma ponderação sobre o teor dessa observação.

O primeiro ponto, que é o principal, diz respeito à questão de fundo dessa pesquisa: saber em que medida a proposta filosófica de Apel empreende o "salto" da filosofia à educação e, por conseguinte, se tal salto consiste em uma contribuição substancial para pensar o horizonte da educação pelo viés da emancipação e da responsabilidade solidária. Diretamente, essa pergunta é o foco nuclear dos capítulos 1 e 2 deste trabalho; porém, para além daí, ela é o elemento constitutivamente transversal do interesse cognitivo que impulsiona a elaboração desta tese. Na primeira parte desse trabalho, essa questão visa verificar uma possível interseção entre a problemática da proposta filosófica de Apel e a problemática da educação. O primeiro capítulo esboça uma interpretação da problemática da filosofia de Apel em torno de três interesses que se alinham à pretensão da transformação semióticotranscendental da filosofia: a retranscendentalização da filosofia no marco do paradigma da linguagem, a recuperação da dimensão pragmática da linguagem na semiótica transcendental de Apel e a pretensão de superação do solipsismo metódico pressuposto na concepção de 
ciência unitária. A problemática da educação é mirada desde uma compreensão ampliada que, ultrapassando a função de transmitir conhecimentos, projeta-se na perspectiva da tarefa de capacitar a pessoa para que possa assumir um papel ativo e responsável dentro da coletividade. O núcleo da problemática da educação é a tensão entre a responsabilidade pela formação da singularidade e a responsabilidade pela conservação e transformação do mundo comum. É possível depreender da análise realizada em vista do entrecruzamento dessas problemáticas que Apel dá um passo inicial, em seu texto "Ciência como emancipação?", no sentido de "pensar a educação", mas, efetivamente, não rompe com sua situação de intelectual que se manifesta de "fora da educação".

A despeito do afirmado acima, a filosofia de Apel não se esquiva de uma compreensão da teleologia essencial da educação no sentido da autonomia, socialização e responsabilidade do sujeito pelo mundo. Isso se mostra por meio de algumas escassas e ocasionais referências feitas à educação em suas publicações, delimitadamente nos textos principais que se ligam à organização teórica da semiótica transcendental e da ética do discurso. Nessas referências, ele pontua o que considera ser o aspecto central da problemática da educação: as dificuldades e riscos decorrentes de uma ciência manipuladora e de uma educação que não desenvolve a capacidade crítica. Em seu relato autobiográfico, Apel chama a atenção para a função pública ético-política da educação e, quase em tom de denúncia, para o perigo de uma educação a serviço da irreflexão, que obstaculiza a autonomia e a corresponsabilidade pelos efeitos das ações coletivas. O capítulo 6 deste trabalho procura transpor, especulativamente, a hermenêutica de Apel, que normatiza por via do método transcendental o primado judicativo do sujeito (crítico e responsável), no sentido de uma contribuição direta da semiótica transcendental para o campo da educação. Entrevê-se aí que a hermenêutica normativa de Apel pode cumprir a função de alicerçar metodicamente a educação, para que ela possa se desenvolver na direção de um propósito fundamental: desenvolver o reflexivo como antídoto para evitar a repetição de Auschwitz.

Ainda a respeito desse primeiro apontamento, vale ponderar acerca da constatação hipotética que se levanta quanto à invisibilidade da educação na filosofia de Apel. Não se pode negar a pertinência dessa suposição. Ao longo desse texto, aqui e ali se reitera o teor dessa constatação, por exemplo, no contexto da ética da responsabilidade de Apel. Nesse contexto, Apel incorpora suplementarmente os âmbitos do direito, da política e da economia de mercado em sua solução para o problema da aplicação da ética do discurso na história, porém não trata sobre a produção das condições para a realização de discursos práticos especificamente relacionados ao campo da educação. Como dito, não se observa uma 
referência direta e sistemática a respeito de qual instância social compete a função de "transformar didaticamente" a trama da normatividade ideal da comunidade de comunicação com a normatividade fática dos subsistemas da política, do direito e da economia. Igualmente, nota-se que não se trata aí acerca de qual instância social cabe a função de conduzir a formação para a corresponsabilidade, seja em nível de uma macroética (corresponsabilidade), seja em nível institucional (responsabilidade fática fundada nas coerções dos subsistemas da sociedade). Ao mesmo tempo, aqui e ali também se duvida da consistência dessa hipótese, por exemplo, no contexto do texto "Ciência como emancipação?".

De todo modo, parece valer o teor geral do esquema analítico de verificação dessa lacuna na obra de Apel, aqui proposto em dois níveis: o da pedagogia e o da filosofia da educação. No nível referido à pedagogia, a obra de Apel não desenvolve uma tematização hermenêutico-conceitual da problemática concernente ao processo pedagógico. Ela não desenvolve uma reflexão filosófica específica correlacionada à problemática que subsume a significação, em um sentido amplo, da expressão pedagogia qua âmbito que cuida dos critérios, conteúdos, práticas e processos de transmissão dos saberes pela escola. Em um segundo nível, Apel não desenvolve também um “discurso teórico" característico da filosofia da educação. Nisso, falta à semiótica transcendental autoaclarar-se quanto a uma concepção de educação. Apesar de propor-se a "transformar" filosoficamente o modelo de teoria do conhecimento para a produção de verdades científicas e universais, o que afeta, por exemplo, a fundamentação da educação dos valores na era das ciências, efetivamente, Apel não se detém na tarefa de tematizar, de modo direto e aprofundado, a correlação e as possíveis implicações entre a semiótica transcendental e a fenomenologia da educação.

Positivamente, nesse segundo nível, Apel esboça o viés de fundamentação de uma possível "intervenção filosófica na educação", a ser possibilitada à luz do a priori da comunidade ilimitada de comunicação. Com isso, ele prenuncia o traço fundamental de um questionamento radical e crítico acerca dos pressupostos intranscendíveis e do sentido "último" da educação no tocante à singularidade, à intersubjetividade e à conservação do mundo, na linha de uma discussão teórica própria da filosofia da educação. Não obstante, ainda parece mais razoável supor que o salto reflexivo da semiótica transcendental, como uma nova versão de Teoria Crítica, no rumo da sistematização de uma proposta de educação comprometida com a emancipação e a responsabilidade solidária - constitui um passo ulterior, só possível por meio da cooperação da filosofia (teórica e prática) com as instituições, sobremaneira com a do direito, e com outras ciências, no sentido de uma filosofia informada cientificamente. Isso é defendido por Apel como um recurso para a resolução do 
problema do passo histórico à moral pós-convencional (parte B da ética do discurso). Cogitase a cooperação da ética filosófica com as ciências da natureza, pois podem fornecer um saber prognosticamente relevante e orientativo para o futuro; e com as ciências sociais, que podem contribuir para reconstruir a situação histórica concreta à qual se conectará uma "aplicação politicamente responsável" da ética do discurso numa forma de vida particular. Quanto a isso, não se pode esquecer que a semiótica transcendental preconiza a tese da complementaridade hermenêutica como "corretivo emancipador" da composição teórica da ciência social empírica, justamente como uma espécie de antídoto crítico ante a possibilidade de uma ciência social a serviço da tecnocracia, em sua referência prática, convertida em pura tecnologia de adestramento social. De todo modo, vale observar que o princípio moral formaluniversal não permite prescrever a priori normas concretas de eticidade substancial. Ele obriga a todos os portadores de competência comunicativa a procurar na comunidade real de comunicação - aí inclusa a comunidade educativa - um acordo recíproco para alcançar a formação solidária da vontade. Com isso, parece valer que esse salto não pode ser confundido com a defesa de uma utopia com conteúdo, por exemplo, uma utopia formativa social concreta.

Nesse "salto" contributivo entre a filosofia e as ciências, Apel se propõe a delinear a contribuição específica da racionalidade da filosofia. Essa contribuição consiste em explicitar os "princípios da razão ou logos", isto é, os critérios normativos de reconstrução racional dos processos de aprendizagem relacionados à cultura. Na medida em que explicita os "princípios da razão ou logos”, a filosofia cumpre a função de antecipar os critérios normativos para qualquer atividade linguística humana. Nessa cooperação, o paradigma da semiótica transcendental tem o mérito de descobrir nas regras pragmático-universais da comunicação um núcleo ineliminável normativo não empírico, que funciona como uma base segura do saber, subtraída ao falibilismo de todo conteúdo da experiência. Na ótica de Apel, tais elementos são transcendentais, fundamentalmente, porque não podem ser negados sem incorrer em contradição pragmática (performativa), nem podem ser demonstrados sem cair em raciocínio circular (petitio principii). Assim, a contribuição específica da semiótica transcendental se amolda no sentido de fornecer as condições de possibilidade transcendentais da constituição objetual da ciência da educação. Agora, em sua dimensão antecipativa, a semiótica transcendental parece limitar-se a fornecer a racionalidade filosófica última por trás do discurso sobre os pressupostos de qualquer filosofia da educação. Contanto que se considere que a semiótica transcendental é capaz de fornecer a pressuposição última racional de qualquer pressuposição especulativa que funda o campo da educação, então o paradigma 
da semiótica transcendental representa uma contribuição relevante para a reflexão de natureza filosófica em meio às abordagens das ciências da educação. Aqui se presume que o que é, no plano filosófico, efetivamente intranscendível para qualquer campo do saber e do agir humano, em tal medida, pode ser desdobrado para a fundamentação e orientação da educação, em sua dinâmica na sociedade de comunicação real.

A estrutura do a priori da comunidade de comunicação fornece os elementos normativos intranscendíveis de toda argumentação para a fundamentação do sentido da educação na direção de uma teoria crítica da ciência como emancipação. Com efeito, os pressupostos filosóficos não tomam o lugar de uma reflexão radical sobre os postulados da educação, que é típica de uma filosofia da educação. Antes e implicitamente, os pressupostos filosóficos compõem a base de pressuposição ineliminável de qualquer filosofia da educação, caso ela se pretenda válida e com possibilidade de promover a emancipação. À medida que transparece o marco normativo a priori da comunidade de comunicação para a construção dos discursos fáticos em relação ao sentido da educação, do qual não se pode mais retroceder, a semiótica transcendental parece ser uma filosofia "interna" da racionalidade do discurso argumentativo que embasa, criteriologicamente, a validade dos pressupostos de qualquer filosofia da educação. Aqui se presume que a semiótica transcendental é uma espécie de antecâmara daquilo que é próprio de uma filosofia da educação. Nisso, parece residir a contribuição possivelmente mais geral (procedimental) e, ao mesmo tempo, mais profunda da filosofia em vista de ajudar a fundamentar uma perspectiva de educação intencionada na razoabilidade, na emancipação e na responsabilidade solidária.

O segundo ponto de destaque deste trabalho se refere aos exercícios especulativos de desdobramentos da arquitetônica da semiótica transcendental na direção da educação. Esses exercícios, desenvolvidos no último capítulo da segunda parte deste texto, refletem o esforço de provocar alguma interlocução entre a filosofia teórica de Apel e o campo da educação. É imperioso reconhecer a complexidade que o intento relativo a esses exercícios envolve, pois a dificuldade imediata é a intelecção da concepção de semiótica transcendental como paradigma de filosofia primeira. Para edificar essa concepção, Apel estabelece interlocução com várias correntes teóricas do pensamento Ocidental e uma diversidade de autores. Destacadamente, a trajetória de Apel se cruza com o movimento de reviravolta linguística da hermenêutica e da pragmática. Aqui não se intenciona resumir tal trajetória, já explicitada nos capítulos 3, 4 e 5 desse trabalho. Antes, ressalta-se que, mesmo onde parece não haver quase referência explícita à educação, tal como é campo da filosofia teórica de Apel, daí vem à tona, particularmente do giro hermenêutico-transcendental realizado por 
Apel, a possibilidade de conceber a educação como formação à elevação humanidade, bem como de discutir sobre vários assuntos relevantes à educação. Parece ser um resultado interessante dessa pesquisa os tópicos tematizados no capítulo 6 desse texto. Esses tópicos, , a título de exemplificação, abordam assuntos variados: educação e a capacidade de pensar; a autonomia do sujeito (autoria) na educação; o binômio simetria e autoridade na educação.

O terceiro ponto concerne à reconfiguração da concepção de teoria crítica em Apel. Enquanto tradicionalmente a Escola de Frankfurt concebe o interesse cognitivo emancipador no plano da faticidade, sob o prisma de uma transformação sócio-histórica, diferentemente, em Apel, esse interesse é vislumbrado a partir da relação dialética entre a comunidade concreta e histórica (realidade fática) e a comunidade ideal de comunicação, a qual antecipa contrafaticamente o "mínimo ético" intranscendível a partir do qual se pode postular a emancipação em um processo nunca definitivo. Essa reconfiguração pode ser vista como uma ampliação da compreensão do interesse cognitivo emancipador, provavelmente, em conformidade com o conteúdo da tese da complementaridade dos tipos de racionalidade da dialeticidade da comunidade de comunicação. Apel concebe que a perspectiva de uma filosofia social intencionada em desenvolver o ideal de uma sociedade emancipada, necessariamente, passa pela confirmação reflexiva e pelo fortalecimento voluntário de uma comunidade ilimitada de críticos dotados de direitos iguais, já implicitamente antecipada por cada argumentante. Para Apel, a vontade de realização da razão implica a vontade de modificação das relações políticas e sociais que obstam a realização de uma sociedade emancipada e corresponsável. A vontade de realização da razão é uma vontade de emancipação da própria razão, à medida que ela se voltar contra todas as limitações internas e externas da formação de opinião, contra a demagogia e ideologizações do processo de acordo mútuo. Nisso, é fundamental à realização de uma sociedade emancipada que faculte chances de educação iguais para todos os membros da sociedade.

O quarto ponto se refere à sugestão feita no último capítulo. Como dito, Apel concebe sua filosofia moral como uma ética ao mesmo tempo de princípios e referida à história, mas não desdobra essa concepção sistematicamente no sentido da educação, de modo a delinear uma filosofia da educação. A propósito disso, apresenta uma sugestão de reparação, a qual aponta para a possibilidade de contribuição recíproca entre a filosofia de Apel, especificamente em relação à parte $\mathrm{B}$ da ética do discurso, e à esfera da educação. Nesse sentido, entende-se que a educação pode incorporar a contraestratégia teórica e moral da razão para a práxis intersubjetiva e responsável em relação à transformação das condições históricas ainda marcadas pela racionalidade político-estratégica ou pela irracionalidade existente na 
comunidade real de comunicação. Isso parece exigir, por sua vez, a compreensão da esfera da educação como uma esfera institucional transversal aos subsistemas da política, do direito e da economia de mercado, atuando responsavelmente pela formação para a corresponsabilidade histórica do homem pelo mundo.

Por fim, retornemos agora à observação que introduz essas considerações finais relativa ao caráter inconcluso desse trabalho. Antes de mais, tal se deve ao reconhecimento dos limites dos resultados desta pesquisa. Agora, vê-se possibilidade de continuidade desta pesquisa em duas perspectivas. No plano da semiótica, na linha da segunda parte deste texto, parece possível conjecturar-se sobre a possibilidade de tematizar dois tópicos: a) educação e diálogo em Apel: o consenso como ideia regulativa par a resolução dos problemas afetos à educação; b) o desafio de pensar a educação a partir da complementaridade entre as ciências do "explicar" e do "compreender". No plano da ética do discurso, a tarefa que foi anunciada no final do último capítulo: a possibilidade de que ética do discurso possa ser suplementada pelo caráter programático de uma educação em direitos humanos, no sentido do discurso prático próprio da esfera da educação, vinculado aos mínimos de justiça, e assim viabilizar uma mediação estratégica e contraestratégica complementar para a factibilidade do princípio deôntico da universalização dos interesses na história. Ademais, circunstancialmente, esse trabalho não realiza o caminho de um manual de filosofia da educação, nem produz o roteiro de uma possível prática pedagógica a partir da filosofia de Apel. E por não se autoproduzir de tal modo, fica a impressão de que talvez valha aqui uma transposição do significado que o poeta Manoel de Barros atribui à poesia: esse texto "é antes de tudo um inutensílio". Na verdade, é difícil escapar à tentação que se liga a uma vontade de verdade invertida, aquela que clama por um resultado que dispensa o pensamento de pensar contínua e ulteriormente.

Por outro lado, parafraseando Apel, parece existir algum grau de conforto em relação à impotência da própria atividade de reflexão, ao passo que ela faculta, reversamente, a dinâmica da natalidade do próprio pensar e do vaivém argumentativo. Assim, ao término desta fase de travessia investigativa, o que parece ficar de mais substancial é a própria tentativa de espiar pelas frestas o alcance de tal problemática, provocada inicialmente na primeira parte, porém presente ao longo de todo o trabalho. No fundo, essa observação é um chamamento para reiniciar a "Aufklärung hermenêutica que não deixa tudo como está". 


\section{REFERÊNCIAS}

\section{Fontes referidas a Karl Otto Apel}

APEL, Karl Otto. A Ética do discurso em face do desafio da filosofia da libertação latinoamericana. In: SIDEKUM, Antônio (org.). Ética do discurso e filosofia da libertação: modelos complementares. Trad. Ilson Kayser. São Leopoldo: UNISINOS, 1994.

El camino del pensamiento de Charles S. Peirce. Trad. Ignacio Olmos \& Gonzalo de Puerto y Gil. Madrid: Visor, 1997.

El problema de la fundamentación última desde una pragmática transcendental del lenguaje. In: Estudios Filosóficos. Trad. Noberto Smilg. N. 102, pp. 251-299, 1987.

Estudios Éticos. Trad. Carlos Santiago. México: Distribuciones Fontamara, 2004.

. Estudos de moral moderna. Trad. Benno Dischinger. Petrópolis: vozes, 1994.

Ética do discurso e as coerções sistêmicas da Política, do Direito e da Economia: uma reflexão filosófica sobre o processo de globalização. Trad. F. Javier Herrero. In: HERRERO, F. J. e NIQUET, Marcel (Ed.). Ética do discurso: novos desenvolvimentos e aplicações. Minas Gerais: FAFICH-UFMG, 2000, pp. 201-223.

Ética e responsabilidade: o problema da passagem para a moral pós-convencional. Trad. Jorge Telles Menezes. Lisboa: Instituto Piaget, 2007.

Fallibilismus, Konsenstheorie der Wahrheit und Letztbegründung. In: Philosophie und Begründung. Org. Forum Philosophie Bad Homburg. Frankfurt am Main: Suhrkamp, 1987.

Husserl, Tarski oder Peirce? Für eine transzendentalsemiotische Konsentheorie der Wahrheit In: Manuscrito Inédito, Frankfurt am Main, pp. 1-12, 1995

- Le problème de l'évidence phénomenologique à la limière d'une sémiotique transcendantale. In: Critique, n. 464-465, 1986, pp. 79-113.

O desafio da crítica total da razão e o programa de uma teoria filosófica dos tipos de racionalidade. Trad. Márcio Suzuki. In: Novos Estudos - CEBRAP, n. 23, pp. 67-84, março de1989.

Paradigmas de filosofía primera. Trad. Andrés Crelier e Miguel Mailluquet. Buenos Aires: Prometeo Libros, 2013.

Processo de análisis e investigación - autopercepción intelectual de un processo histórico, retrospectiva autobiográfica. In Antropos: Karl Otto Apel - uma ética del discurso o dialógica, Barcelona, n. 183, pp. 12-19, marzo-abril 1999, cf. pp. 15-18. 
APEL, Karl Otto. Semiotica filosofica. Trad. Julio de Zan, Ricardo Maliandi e Dorando Michelini. Buenos Aires: Editorial Almagesto, 1994.

Sprachliche Bedeutung, Wahrheit und normative Gültigkeit. Die Soziale Bindekraft der Rede im Lichte einer transzendentalen Sprachpragmatik. In: Archivio di Filosofia, v. 55, n. 1-3, pp. 51-88, 1987.

Ibérica, 1991.

Teoría de la verdad y ética del discurso. Trad. Norberto Smilg. Barcelona: Paidós

Transformação da filosofia: filosofia analítica, semiótica, hermenêutica. Trad. Paulo Astor Soethe. São Paulo: Loyola, 2000, v. I.

Transformação da filosofia: o a priori da comunidade de comunicação. Trad. Paulo Astor Soethe. São Paulo: Loyola, 2000, v. II.

Transformation der Philosophie: Sprachalytik, Semiotik, Hermeneutik. 5. Aufl., Frankfurt am Main: Surhkamp, 1994, Band I.

Transformation der Philosophie: das Apriori der Komnunikationsgemeinschaft. 5. Aufl., Frankfurt am Main: Surhkamp, 1993, Band II.

The response of discourse ethics: to the moral challenge of the human situation as such and especially today. Louvain: Peeters, 2001.

\section{Fontes complementares}

ABBAGNANO, Nicola. Dicionário de filosofia. Trad. Alfredo Bosi. 2. ed., São Paulo: Martins Fontes, 1998.

ADORNO, Theodor W. Educação e emancipação. Trad. Wolfgang Leo Maar. 4. Ed., Rio de Janeiro: Paz e Terra, 1995.

Sobre la lógica de las ciencias sociais. In: ADORNO, W. T., POPPER, K.R., DAHRENDORF, R., HABERMAS, J., ALBERT, H., PILOT, Harald. Karl. La disputa del positivismo en la sociologia alemana. Trad. Jacobo Muñoz. Barcelona-México: Grijalbo, 1973.

ADORNO, Theodor W.; HORKHEIMER, Max. Dialética do esclarecimento: fragmentos filosóficos. Trad. Guido Antonio de Almeida. Rio de Janeiro: Zahar, 1985.

ANDRADE, Marcelo. A banalidade do mal e as possibilidades da educação moral: contribuições arendtianas. In: Revista Brasileira de Educação, Rio de Janeiro, v. 15, n. 43, pp. 109-125, jan./abr. 2010.

A banalidade do mal e as possibilidades da educação moral: contribuições arendtianas.

In: Revista Brasileira de Educação, v. 15, n. 43, pp. 109-125, jan./abr. 2010. 
APARISI, Juan Carlos Siurana. Consenso. In: VILLA, Mariano Moreno [coord.]. Diccionario de pensamiento contemporâneo. San Pablo, Madrid: 1997.

APARISI, Juan Carlos Siurana. Una brújula para la vida moral: a idea de sujeto en la ética del discurso de Karl Otto Apel. Granada: Editorial Comares, 2003.

AQUINO, Tomás de. Questões Discutidas Sobre a Verdade. Trad. Luiz João Baraúna. São Paulo: Abril Cultural, 1973, (col. Os Pensadores).

AQUINO, José Moacir de. O problema da verdade: a aporia criteriológica da teoria metafísico-ontológica da verdade como correspondência segundo Karl Otto Apel. In: AQUINO, J. M. de; NUNES, Marcelo A.; MELO, Ricardo Pereira (orgs.). Filosofia contemporânea em debate. Campo Grande: UFMS, 2013.

ARENDT, Hannah; WEIL, Eric; RUSSELL, Bertrand; ORTEGA y GASSET. Quatro textos excêntricos. Trad. Olga Pombo. Lisboa: Relógio D’Água Editores, 2000.

2011.

Entre o passado e o futuro. Trad. Mauro W. Barbosa. 7. ed., São Paulo: Perspectiva,

Responsabilidade e julgamento. Tradução de Rosaura Eichenberg. São Paulo: Companhia das Letras, 2004.

A condição humana. Trad. Roberto Raposo. 11. ed., Rio de Janeiro: Forense Universitária, 2010.

Homens em tempos sombrios. Trad. Denise Bottmann. São Paulo: Companhia das Letras, 2008.

A vida do espírito: o pensar, o querer, o julgar. Trad. Antonio Abranches, César Augusto R. de Almeida, Helena Martins. 3. ed., Rio de Janeiro, Relume Dumará, 1995.

Responsabilidade e julgamento. Trad. Rosaura Eichenerg. São Paulo: Companhia das Letras, 2004.

BAZARIAN, Jacob. O problema da verdade - teoria do conhecimento. SP: Alfa-Omega, 1985.

CARVALHO, José Sérgio. Uma ideia de formação continuada em educação e direitos humanos. In: Reflexões sobre a educação, formação e esfera pública. Porto Alegre, Penso, 2013

CÉSAR, Maria R. de Assis; DUARTE, André. Hannah Arendt: pensar a crise da educação no mundo contemporâneo. In: Educação e Pesquisa, São Paulo, v. 36, n. 3, p. 823-837, set./dez. 2010.

CHALMERS, A. R. O que é ciência afinal? Trad. Raul Filker. São Paulo: Brasiliense, 1993.

CHEDIAK, Karla. O problema da falácia naturalista para o projeto de uma ética evolucionista. In: Kriterion, Belo Horizonte, n 113, Jun/2006, p. 147-157. 
CONILL, Jesus. El crepúsculo de la metafísica. Barcelona: Anthropos, 1988.

CORREIA, Adriano. O pensamento pode evitar o mal? In: Revista Educação: Hannah Arendt pensa a educação. São Paulo: Segmento, n. 4, 2006, p. 46-55.

O pensamento pode evitar o mal? In: Revista educação: Hannah Arendt pensa a educação, (Ed. Segmento - especial biblioteca do professor), São Paulo, n. 4, [201-], pp. 4655.

Natalidade e amor mundi: sobre a relação entre educação e política em Hannah Arendt. In: Educação e Pesquisa, São Paulo, v.36, n.3, p. 811-822, set./dez. 2010.

CORTINA, Adela et al.. Educar em la justicia. Valencia: Generalitat Valenciana, 1998.

CORTINA, Adela. Razón comunicativa y responsabilidad solidaria: ética y política em K.O. Apel. 2. ed., Salamanca: Ediciones Sígueme, 1988.

Ética aplicada y democracia radical. Madrid: Editorial Tecnos, 1993.

CUPANI, A crítica de Karl Otto Apel ao modelo analítico do conhecimento. In: CARVALHO, Maria C. M. de. A Filosofia analítica no Brasil. Campinas: Papirus, 1995.

DELACAMPAGNE, Christian. História da filosofia no século XX. Trad. Lucy Magalhães e Carlos Nelson Coutinho. Rio de Janeiro: Zahar, 1987.

DUSSEL, Enrique D.. Ética da libertação: na idade da globalização e da exclusão. Trad. Ephraim F. Alves et al.. Petrópolis: Vozes, 2000.

Filosofia da libertação: crítica à ideologia da exclusão. Trad. Georges I. Maissiat. São Paulo: Paulus, 1995.

Para uma ética da libertação latino-americana III: erótica e pedagógica. Trad. Luiz João Gaio. São Paulo: Loyola \& Ed. UNIMEP, [s.d; original de 1977].

FREITAG, Bárbara. A teoria crítica: ontem e hoje. 2. ed., São Paulo: Brasiliense, 1988.

GADAMER, Hans-Georg. Verdade e método I: traços fundamentais de uma hermenêutica filosófica. Trad. Ênio Paulo Giachini.14. ed., Petrópolis, RJ: Vozes e Ed. Universitária São Francisco, 2014.

GADOTTI, Moacir. Concepção dialética da educação: um estudo introdutório. 10.ed., São Paulo: Cortez, 1997.

GILES, Thomas Ransom. Filosofia da educação. São Paulo: EPU, 1983.

GOERGEN, Pedro. A universidade em tempos de transformação. Campinas: UNICAMP, [s.d.]. Disponível em: Disponível em: <www.prg.unicamp.br/Texto univ em temp trans Pedro_Goergen.html>. Acesso em 10/06/2013. 
GRONDIN, Jean. Introdução à hermenêutica filosófica. Trad. Benno Dischinger. São Leopoldo: UNISINOS, 1999.

HABERMAS, Jürgen. Teorías de la Verdad. In: Teoría de la acción comunicativa: complementos y estudios previos. Trad. Manuel Jiménez Redondo. Madrid: Ediciones Cátedra, 1989.

. Conhecimento e interesse. Trad. Luiz Repa. São Paulo: Unesp, 2014.

HEIDEGGER, Martin. Ser e tempo. Trad. Márcia de Sá Cavalcante Schuback. 2. ed., Petrópolis: Vozes e Ed. Universitária São Francisco, 2007.

A caminho da linguagem. Trad. Marcia Sá Cavalcante SchubackPetrópolis, RJ: Vozes e Ed. Universitária São Francisco, 2014.

. Sobre a essência da verdade: a tese de Kant sobre o ser. Trad. Ernildo Stein. SP: Duas Cidades, 1970.

HERRERO, F. Javier. Desafios éticos no mundo contemporâneo. In: Síntese, Belo Horizonte, v. 26, n. 84, pp. 5-11, 1999.

A ética do discurso de K.-Otto Apel. In: HERRERO, F. J. e NIQUET, Marcel (Ed.). Ética do discurso: novos desenvolvimentos e aplicações. Minas Gerais: FAFICH-UFMG, 2000 .

O problema da fundamentação última. In: Kriterion, Belo Horizonte, v. XXXV, n. 91, pp. 7-16, Jan/95-Jul/95.

HORKHEIMER, Max. Eclipse da razão. Trad. Sebastião Uchoa Leite. 7. ed., São Paulo: Centauro, 2010.

Teoria tradicional e teoria crítica. In: BENJAMIN, Walter et al. Textos escolhidos. Trad. José Lino Grünnewald et al.. São Paulo: Abril Cultural, 1980, (col. Os Pensadores).

HORTA, José S. Baia. Planejamento educacional. In: MENDES, Durmeval Trigueiro (coord.). Filosofia da educação brasileira. 6. ed., Rio de Janeiro: Civilização Brasileira, 1998.

HUSSERL, Edmund. Investigações lógicas: sexta investigação (elementos de uma elucidação fenomenológica do conhecimento). Seleção e trad. Zeljko Loparié e Andréa M. A. de C. Loparié. São Paulo: Abril Cultural, 1975, (col. Os Pensadores). 1962.

La filosofia como ciencia estricta. Trad. Elsa Tabernig. Bueno Aires: Editorial Nova,

KUHLMANN, Wolfgang. Problemas de fundamentação da ética do discurso. In: HERRERO, F. J. e NIQUET, Marcel (Ed.). Ética do discurso: novos desenvolvimentos e aplicações. Minas Gerais: FAFICH-UFMG, 2000.

JAEGER, Werner. Paidéia: a formação do Homem Grego. Trad. Artur M. Parreira. São Paulo: Herder, [s.d.]. 
JONAS, Hans. O princípio responsabilidade: ensaio de uma ética para a civilização tecnológica. Trad. Marijane Lisboa e Luiz Barros Montez. Rio de Janeiro: Contraponto - Ed. PUC-Rio, 2006.

JONES, Peter. Hume, in: BUNNIN, Nicholas, TSUI-JAMES (org.). Compêndio de filosofia. Trad. Luiz Paulo Rouanet. São Paulo: Loyola, 2002.

KANT, Immanuel. Crítica da razão pura. Trad. Alexandre F. Murujao. 8. ed., Lisboa: Fundação Calouste Gulbenkian, 2013.

Fundamentação da metafísica dos costumes. Trad. António Pinto de Carvalho. São Paulo: Nacional, 1964. 2016 .

Crítica da razão prática. Trad. Valerio Rohden. 4. ed. São Paulo: Martins Fontes,

KOYRÉ, Alexandre. Do mundo fechado ao universo infinito. Trad. Donaldson M. Garschagen. Rio de Janeiro: Forense-Universitário. São Paulo: Editora USP, 1979.

KUHN, Thomas. A estrutura das revoluções científicas. Trad. Beatriz Vianna Doeira e Nelson Boeira. 2. ed., São Paulo: Perspectiva, 1978.

MACHADO, Nilson José. Educação e autoridade: responsabilidade, limites, tolerância. Petrópolis, RJ: Vozes, 2008.

MORENO, Arley R.. Introdução a uma pragmática filosófica: de uma concepção de filosofia como atividade terapêutica a uma filosofia da linguagem. Campinas, SP: Unicamp, 2005 .

NICOLA, Abbagnano. ABSURDO. In: Dicionário de Filosofia. 5. ed., SP: Martins Fontes, 2007.

NICOLÁS, Juan A. Teoría de la verdad consenso-evidencial y teoría de la verdad fenomenológico-real. In: FERNÁNDEZ, Domingo Blanco et al. (Ed.). Discurso y realidad: en debate con K. - O. Apel. Madrid: Editorial Trotta, 1994.

NIQUET, Marcel. Ética do discurso como teoria moral realista. O que isso significa? In: HERRERO, F. J. e NIQUET, Marcel (Ed.). Ética do discurso: novos desenvolvimentos e aplicações. Minas Gerais: FAFICH-UFMG, 2000.

OLIVEIRA, Manfredo A. de. Reviravolta lingüístico-pragmática na filosofia contemporânea. São Paulo: Loyola, 1996.

. Sobre a fundamentação última. Porto Alegre: Edipucrs, 1994.

Ética e Racionalidade Moderna. São Paulo: Loyola, 1993.

A filosofia na crise da modernidade. São Paulo: Loyola, 1989. 
PEIRCE, Charles S. Sanders. Escritos coligidos. Trad. Armando M. D’Oliveira e Sérgio Pomerangblum. São Paulo: Abril Cultural, 1974, (col. Os Pensadores).

. Ilustrações da lógica da ciência. Trad. Renato R. Kinouchi. São Paulo: Ideias \& Letras, 2008.

PLATÃO, Mênon. Trad. Maura Iglesias. Rio de Janeiro: PUC-Rio - Loyola, 2001.

PLATÓN. Gorgias. Disponível em: <http://www.dominiopublico.gov.br/download/texto/ bk000468.pdf $>$. Acesso em 10/09/2015

POPPER, Karl. Conocimiento objetivo. Trad. Carlos Solis Santos. Madrid: Tecnos, 1974.

. La lógica de las ciencias sociais. In: ADORNO, W. T., POPPER, K.R., DAHRENDORF, R., HABERMAS, J., ALBERT, H., PILOT, Harald. Karl. La disputa del positivismo en la sociologia alemana. Trad. Jacobo Muñoz. Barcelona-México: Grijalbo, 1973.

PUNTEL, Lorenz Bruno. Wahrheitstheorien in der neueren Philosophie. 3. ed., Darmstadt: Wiss. Buchgesellschaft, 1993.

REALE, Giovanni. História da filosofia antiga. Trad. Henrique Cláudio de Lima Vaz e Marcelo Perine. São Paulo: Loyola, 1984, v. II.

RESCHER, Nicolas. Die Kriterien der Warhheit In: Wahrheitstheorien. Gunnar Skirbekk (Org.). Frankfurt am Main: Suhrkamp, 1996.

RÖD, W.. O problema da fundamentação última na filosofia contemporânea: o debate entre racionalismo crítico e pragmática transcendental. In: CARVALHO, Maria Cecília de (Org). Paradigmas Filosóficos da Atualidade. Campinas: Campus, 1989.

ROVIGHI, Vanni Sofia. História da filosofia contemporânea do século XIX à neoescolástica. Trad. Ana Pareschi Capovilla. São Paulo: Loyola, 1999.

SANTAELlA, Lucia. O Papel da Mudança de Hábito no Pragmatismo Evolucionista de Peirce. In: Cognitio, São Paulo, v. 5, n. 1, p. 75-83, jan./jun. 2004.

SHILLING, Flávia; SANTOS, Milton Alves. A garantia do direito à educação: aprendizagem, convívio escolar e redes de proteção à criança e ao adolescente. In: Formação de professores: múltiplos enfoques. São Paulo: Editora Sarandi, 2013.

SILVEIRA, Lauro Frederico Barbosa da. O caráter dialógico do signo e do pensamento em Peirce. In: Trans/Form/Ação, São Paulo, v. 11, p. 23-29, 1988.

SKINNER, B.F. O mito da liberdade. Trad. Elisane Reis Barbosa Rebelo São Paulo, Summus, 1983.

STEGMÜLLER, Wolfgang. A Filosofia Contemporânea. São Paulo: Ed da Universidade de São Paulo, 1977. 
TANGUY, L. Racionalização pedagógica e legitimidade política. In: ROPÉ, F.; TANGUY, L. Saberes e competências. Campinas: Papirus, 1997.

VAZ, Henrique C. de Lima. Escritos de filosofia IV: introdução à ética filosófica 1. São Paulo: Loyola, 1999.

VÁZQUEZ, Adolfo Sanchez. Ética. Trad. João Dell'Anna. 25. ed., Rio de Janeiro: Civilização Brasileira, 2004.

WEBER, Max. Ciência e Política: duas vocações. Trad. Leonidas Hegenberg e Octany Silveira da Mota. São Paulo: Cultrix, [s.d.].

WITTGENSTEIN, Ludwig. Tractatus logico-philosophicus. Trad. José Arthur Giannotti. São Paulo: Companhia Editora Nacional \& Editora da Universidade de São Paulo, 1968.

Investigações filosóficas. Trad. José Carlos Bruni. São Paulo: Abril Cultural, 1975 (col. Os Pensadores). 